Szegedi Tudományegyetem

Történettudományi Doktori Iskola

Modernkori képzési program

\title{
Ideológia és propaganda a Franco-diktatúra filmpolitikájában
}

Doktori (Ph.D.) értekezés

Szerző: Lénárt András

Témavezető: Dr. habil. Alessandro Rosselli, PhD, DEA. lektor

Szeged

2013 


\section{Tartalomjegyzék}

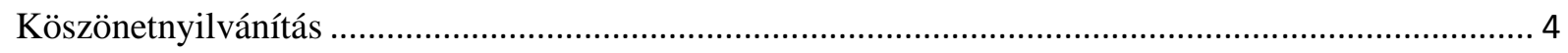

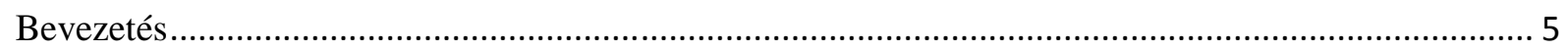

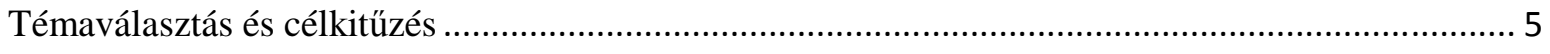

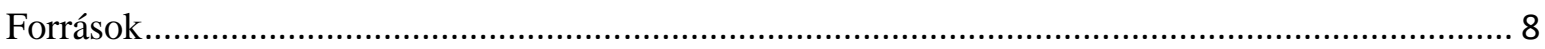

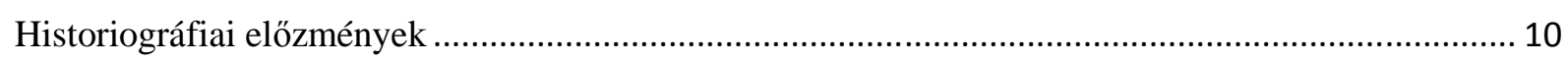

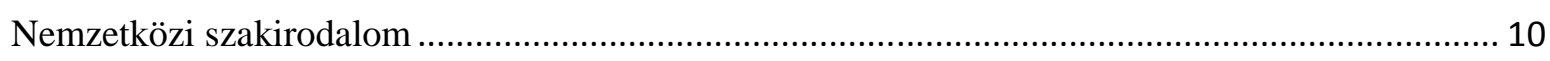

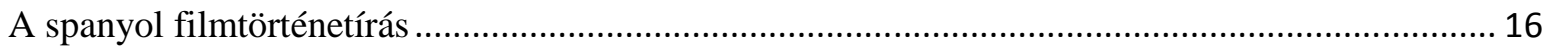

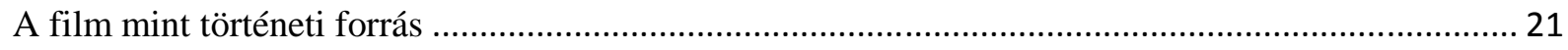

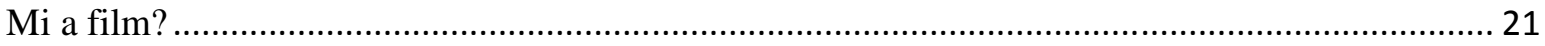

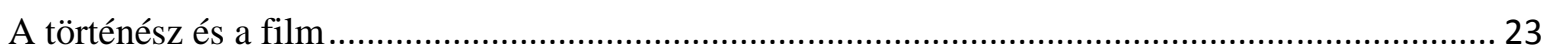

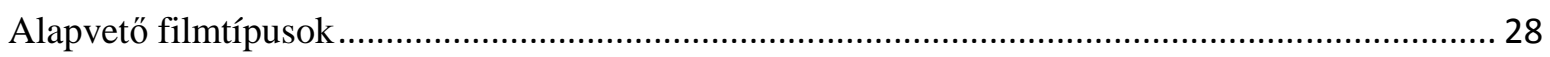

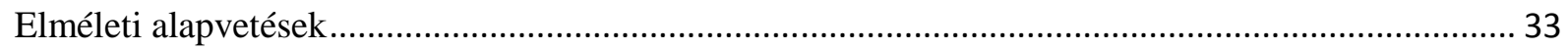

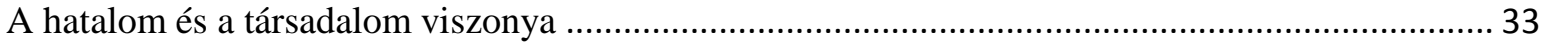

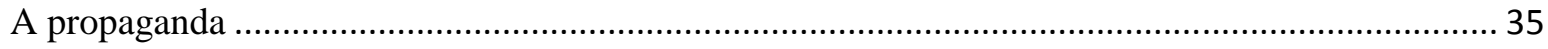

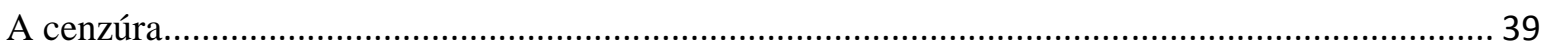

Filmpolitikák és filmpropagandák - nemzetközi kitekintés ............................................................ 43

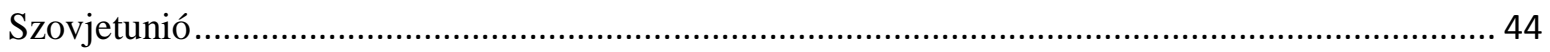

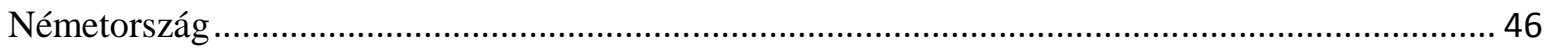

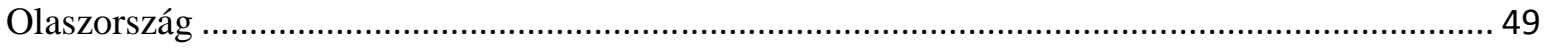

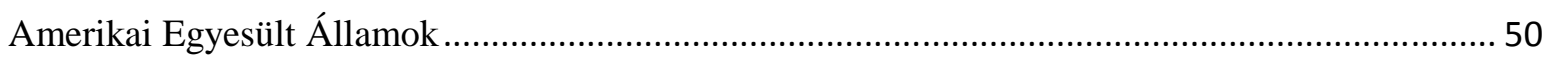

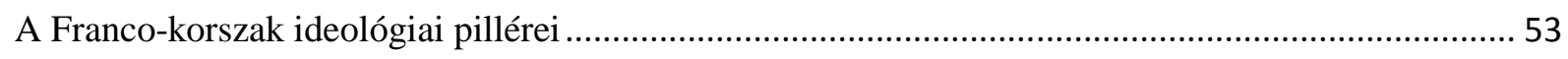

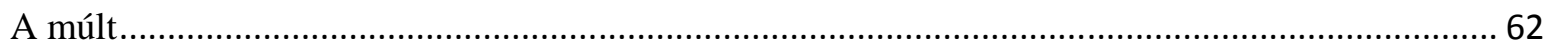

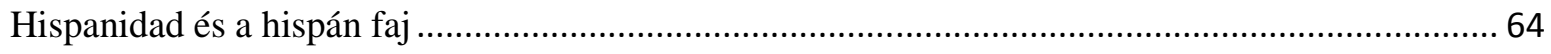

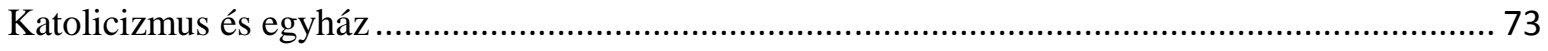

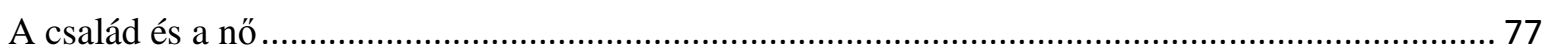

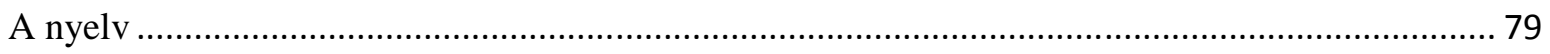

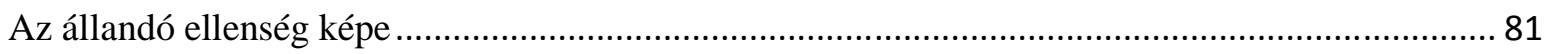

Kultúra, társadalom és propaganda a Franco-rendszerben ................................................................. 85

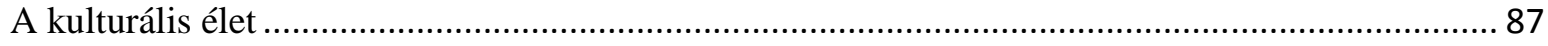

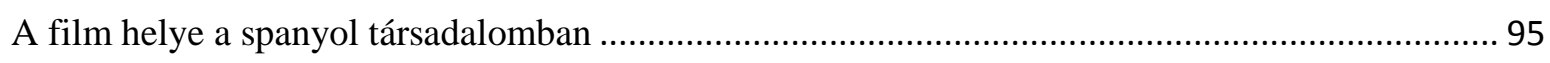

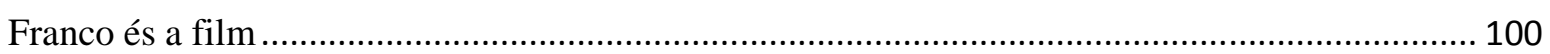

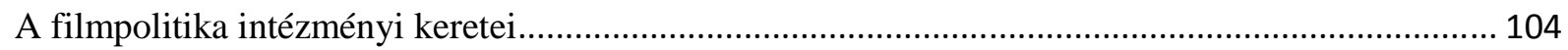

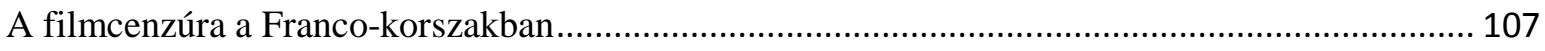

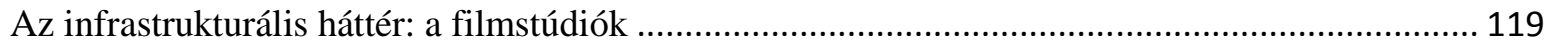

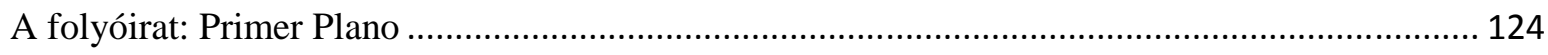




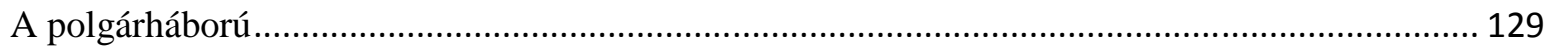

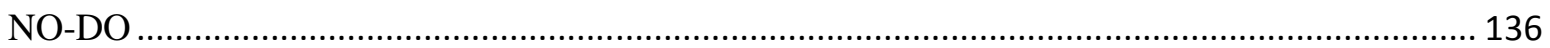

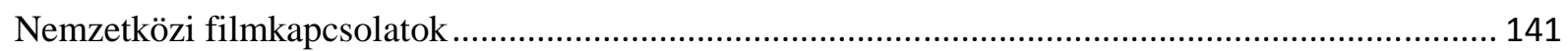

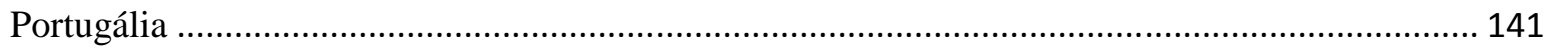

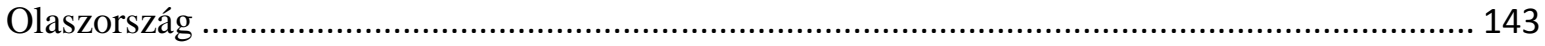

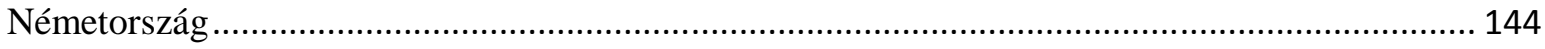

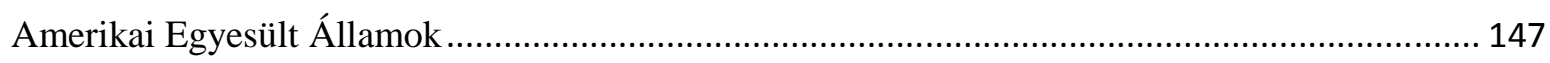

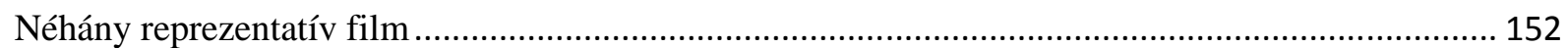

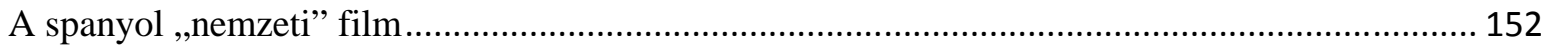

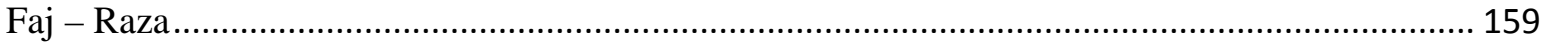

A polgárháború

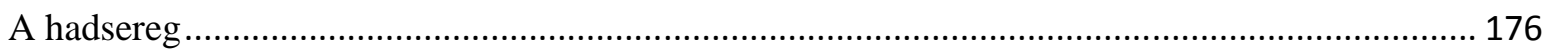

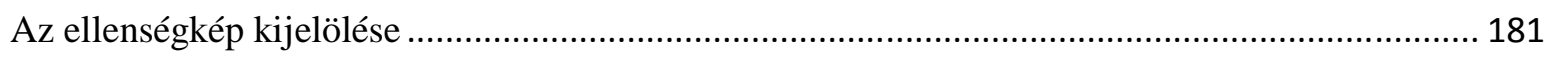

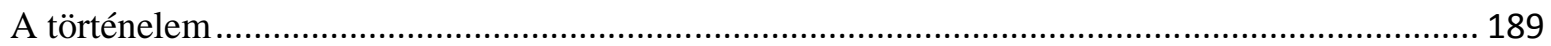

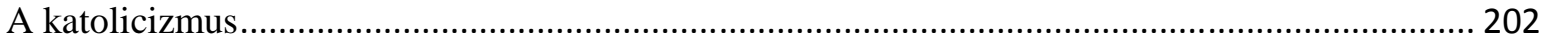

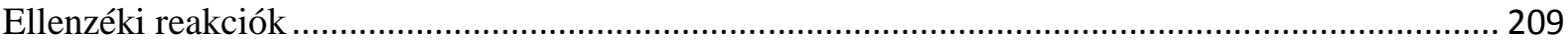

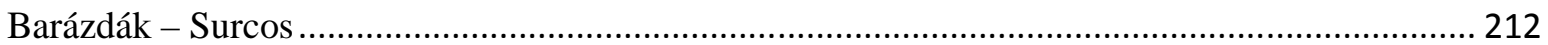

Isten hozta, Mr. Marshall! - ¡Bienvenido, Míster Marshall!....................................................... 215

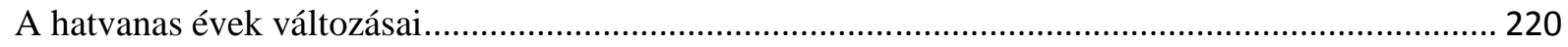

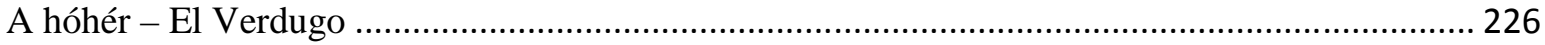

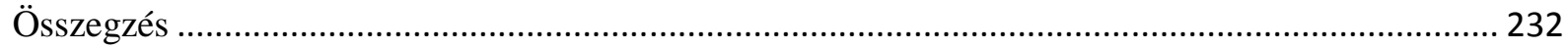

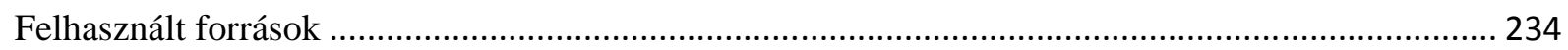

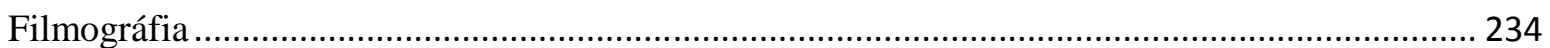

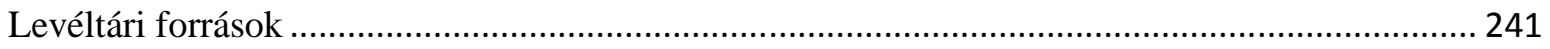

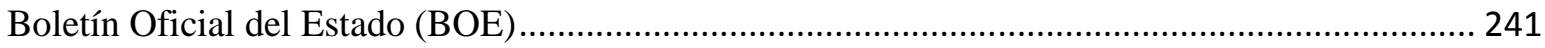

A tárgyalt időszakban megjelent könyvek és a kapcsolódó személyek írásai, önéletrajzai, naplói 242

A tárgyalt időszakban megjelent folyóirat- és újságcikkek .......................................................... 242

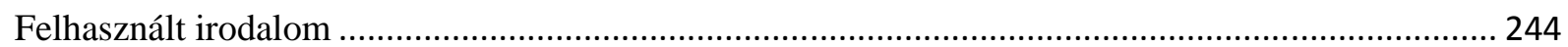

Könyvek és monográfiák spanyol film és filmtörténet témában ................................................... 244

Tanulmányok és könyvfejezetek spanyol film és filmtörténet témában ........................................ 248

Folyóirat-, újság- és online cikkek spanyol film és filmtörténet témában........................................ 253

Spanyol politika, történelem, kultúra és társadalom témájú könyvek, monográfiák, tanulmányok,

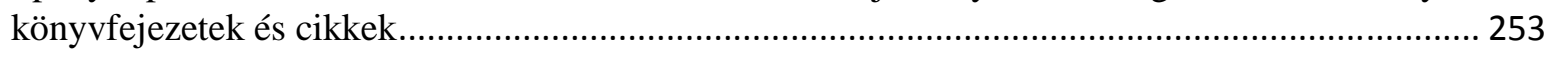

Egyéb hivatkozott könyvek, monográfiák, tanulmányok és cikkek .............................................. 256

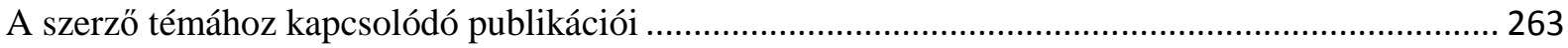

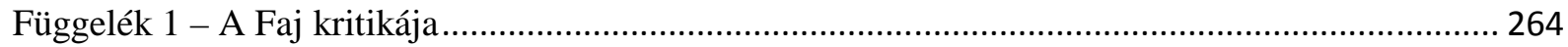

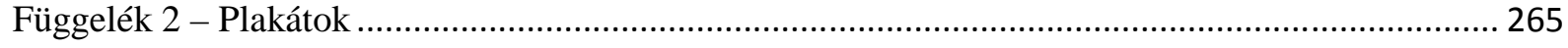




\section{Köszönetnyilvánítás}

Köszönettel tartozom témavezetőmnek, dr. Alessandro Rossellinek, amiért kutatásaim során mindvégig támogatott, és az elmúlt hét évben bármikor fordulhattam Hozzá, ha bíztatásra volt szükségem.

Hálámat fejezem ki a Szegedi Tudományegyetem Történettudományi Doktori Iskolája Modernkor (Új- és Legújabbkor) Programjának, amiért lehetővé tették, hogy PhD-képzésem során elmélyítsem történettudományi ismereteimet. A Szegedi Tudományegyetem Hispanisztika Tanszékének és Történeti Intézetének munkatársai támogatói légkör megteremtésével segítették munkámat.

Az Oviedói Egyetemen José Girón Garrote és a madridi Carlos III Egyetemen Matilde Eiroa de San Francisco az évek alatt folyamatosan ösztönöztek, hogy tartsak ki céljaim mellett. Első írásaim és további terveim megismerése után az alábbi történészek, filmtörténészek és egyetemi munkatársak bátorító szavai és tettei sokat segítettek abban, hogy ne térjek le a már megkezdett utamról: Vajda Zoltán, José María Caparrós Lera, Dornbach Mária, Kaczúr Ágnes, Magí Crusells, Asier Aranzubia Cob, María del Mar Díaz González, Szajbély Mihály, Gergely András, Kökény Andrea, Révész Éva, Csikós Zsuzsanna, Gyáni Gábor, Hahner Péter, Schubert Gusztáv és Jeney Zsuzsanna. Külön köszönettel tartozom azon tanulmánykötetek és folyóiratok főszerkesztőinek, akik az elmúlt évek alatt publikálásra érdemesnek találták a kutatási témámhoz kapcsolódó írásaimat.

A disszertáció elkészítéséhez alapos kutatómunkára volt szükség külföldi intézményekben. A Spanyol Külügyminisztérium „MAEC-AECI” ösztöndíja jóvoltából négy hónapot tölthettem el Spanyolországban, doktori munkám megalapozását és a forrásaim felkutatását ez az ösztöndíj tette lehetővé. Az azt követő években önálló utak alkalmával végeztem kiegészítő vizsgálódásokat. Sokat segítettek azon intézmények dolgozói, amelyekben kutatásaimat folytattam Madridban és Alcalá de Henaresben: Filmoteca Española, Archivo General de la Administración, Archivo del Ministerio de Asuntos Exteriores, Consejo Superior de Investigaciones Científicas - Centro de Ciencias Humanas y Sociales, Biblioteca Nacional de España, valamint számos film- és könyvkereskedés.

A legnagyobb hálával Édesanyámnak tartozom, fenntartás nélküli szeretete és állandó, önzetlen és önfeláldozó támogatása nélkül ma sehol sem lennék. Köszönet mindenért! 


\section{Bevezetés}

\section{Témaválasztás és célkitüzés}

A nemzetközi történetírásban napjainkban már elfogadott módszernek számít, hogy a filmtörténet elemeit, kutatási eredményeit is hasznosítják a történeti vizsgálódás során. Számos szempontból megindokolható, miért lehet egy film értékes kiegészítője a történelemtudományi forrásbázisnak. ${ }^{1}$

Munkámban megvilágítom, hogy a spanyol Franco-rendszer (1939-1975) ideológiája mennyiben tükröződött vissza a korszak filmpolitikájában, a fennálló eszmerendszer és történelemszemlélet hogyan állíthatta szolgálatába a mozgóképkultúrát, hogyan válhatott az állami propaganda egyik zászlóvivőjévé. Bemutatom, honnan táplálkozott és milyen elemeket foglalt magában a diktatúra ideológiai rendszere, majd azt vizsgálom, hogy az irányító hatalom által preferált témák hogyan jelentek meg a korszak filmjeiben és ahhoz kapcsolódó intézményrendszerében. A hatalommal szembenálló, azt kritizáló filmesek munkásságából azokat az elemeket emelem ki, amelyek politikai szempontból fontosak voltak az adott korszakban, és talán még ma is azok.

Disszertációm elsősorban történelmi tárgyú, egyik célja, hogy a filmtörténetet beemelje Magyarországon is a történeti segédtudományok közé, a filmet történeti forrásként kezelje. Minderre az elmúlt években már tettek szórványos kísérleteket, munkámmal ehhez a vonulathoz szeretnék kapcsolódni. Dolgozatomban csak a szükséges mértékben folyamodom a müvek esztétikai és mủvészeti szempontú elemzéséhez, a konkrét munkákat, tendenciákat, müfajokat és témákat történeti-politikai nézőpontból közelítem meg.

Fontos kiemelni, hogy elsősorban játékfilmekre koncentrálok, mert azok szakmai megvalósítása, a bennük elrejtett üzenetek összetettebbnek és elemezhetőbbnek bizonyulnak, mint a közvetlenebb dokumentumfilmek esetében. Utóbbi müfaj a közönség körében soha nem volt igazán népszerű, mivel ritkábban tud betölteni szórakoztatói funkciót, így a társadalomra kifejtett hatása is kevésbé erőteljes. Filmpolitika kapcsán diktatúrákban leginkább az élőszereplős filmeket érdemes vizsgálat alá vonni, én is ezt teszem; dokumentumfilmeket csak akkor említek, ha valamilyen okból megkerülhetetlenek, esetleg egy adott időszakban (mint a spanyol polgárháború) szinte kizárólag azok készültek.

\footnotetext{
${ }^{1}$ Erről lásd bővebben „A történész és a film” című alfejezetet.
} 
Kristin Thompson és David Bordwell filmtörténészek öt fő típusát különböztetik meg a filmtörténeti értelmezésnek ${ }^{2}$ :

1. Életrajz: egy alkotó életét dolgozza fel

2. Ipar- vagy gazdaságtörténet: a gyártási és üzleti eljárásokat ismerteti

3. Esztétikai szempontú történeti elemzés: a filmművészet elemeit (formát, stílust, müfajt) vizsgálja

4. Technikatörténet: a filmkészítés alapanyagait és berendezéseit állítja középpontba

5. Társadalom-, kultúr-, és politikatörténet: nagyobb társadalmi összefüggésben vizsgálja a film szerepét

Egy konkrét film alapos elemzéséhez a fent említett kategóriák mindegyikét be kell vonni, hogy teljes képet kaphassunk a müről. Jelen esetben, történelmi tárgyú disszertációról lévén szó, az utolsó típust részesítem előnyben, mivel nem célom az adott filmek kimerítő analízise.

A nemzetközi hispanisztikai kutatások nyitását a szigorúan vett filológiai, irodalmi és történelmi vizsgálódásokon túllépő területek irányába a 90-es évekre tehetjük: ekkortól Nyugat-Európában, Latin-Amerikában és az Amerikai Egyesült Államokban beemelnek olyan, addig csak önállóan vett tudományágakat is a hispanisztika kötelékébe, mint, többek között, a hermeneutika, a pszichoanalízis, a feminizmus, a társadalmi nemre irányuló kutatások (gender studies), a kultúrtörténet, a másság filozófiája, a néprajz, az antropológia és a filmtörténet. A logocentrikus kultúrkép vizuális kultúrképpé változik, ahol az adott nemzet kulturális öröksége integráns részét képezi a kutatásoknak. Mindezek közül az audiovizuális reprezentáció, vagyis a film lesz az, amely multidiszciplináris vonatkozásai miatt egyre szélesebb körben lesz használható és a többi tudományterülettel is kombinálható. ${ }^{3}$

A magyarországi hispanisztikai kutatások számára érdekes és mindenképpen újdonság lehet az értekezésem, valamint a spanyolországi kutatásokat is gazdagíthatja új szempontokkal. Esetenként olyan kérdések is felmerülnek, amelyek a Franco-korszak társadalma, politikai és ideológiai önmeghatározása szempontjából új, az eddigi ismereteket kiegészítő információkkal szolgálhatnak.

Magyarországon a Franco-rendszerhez a filmpolitikáján, hivatalos filmjein keresztül közelítő, tudományos kutatásokra alapuló munka még nem született, így itthoni közegben

\footnotetext{
${ }^{2}$ Thompson, Kristin - Bordwell, David: A film története. Budapest, Palatinus, 2007. 25.

${ }^{3}$ Erről lásd az alábbi tanulmánykötet bevezető fejezetét: Herrera, Javier - Martínez-Carazo, Cristina (szerk): Hispanismo y cine. Madrid - Frankfurt am Main, Iberoamericana - Vervuert, 2007. 9.
} 
disszertációm új eredményeket adhat. Nemzetközi (mindenekelőtt spanyol) viszonylatban is új megközelítéseket nyújthat a dolgozatom; bár jelentek már meg olyan könyvek spanyol nyelven, amelyek a Franco-rezsim filmpolitikájának bizonyos elemeit, szegmenseit, témáit bemutatták ${ }^{4}$, olyan szintézis-jellegü írás még nem került publikálásra, amely a diktatúra főbb ideológiai komponenseiből kiindulva vizsgálná azok közvetlen hatását a filmpolitika intézményi és törvényi alakítására, majd mindezeket konkrét példákon keresztül is szemléltetné. Értekezésemmel e hiány pótlására teszek kísérletet, a már létező szakirodalom felhasználása, eredményeinek bemutatása mellett saját következtetéseimet és az összefüggéseket is közlöm.

A fentiekből következik, hogy nem spanyol filmtörténetet készítek. A disszertációm megírásában nem cél, hogy a spanyol filmtörténet legjelesebb darabjai és filmesei az őket megillető súllyal legyenek jelen az elkövetkező oldalakon. Mind a munkák, mind az alkotók aszerint kerülnek említésre, hogy a történeti, politikai, ideológiai és propagandisztikus szempontok alapján milyen jelentőséggel bírtak.

Még egy pontosítást szükségesnek tartok. A Franco-rendszer egésze időben igen tág, a disszertáció terjedelmi korlátai nem teszik lehetővé, hogy a kérdéses harminchat év során minden, az állam és a filmpolitika kapcsolatában beálló változást részletesen bemutassak, de ez nem is feltétlenül szükséges. A Franco-korszak hivatalos ideológiájának formálódása a spanyol polgárháborúra és az azt követő évekre datálódik, csúcspontját pedig a 40-es és 50-es évekre éri el. ${ }^{5}$ Természetesen a lényeges és meghatározó filmpolitikai döntéseket is ebben az időszakban hozták, az 50-es évek végétől a diktatúra lezárultáig az alapelvek módosulásának, esetenként „puhulásának” lehetünk tanúi, összhangban a rendszer, valamint a bel- és külpolitika változó mechanizmusaival. Mindezeket figyelembe véve a disszertációban nagyobb hangsúlyt fog kapni a polgárháborútól az 50-es évek végéig tartó korszak, amikor a témám szempontjából leginkább releváns döntések és filmek születtek, a későbbi korokból pedig azokat a folyamatokat, személyeket és munkákat emelem ki, amelyek az állami politika kapcsán valóban idevágó mozzanatok.

Értekezésemben mindenekelőtt szükségesnek tartom megindokolni, miért is érdemes egy történésznek a filmmel, filmtörténeti kérdésekkel foglalkoznia, ugyanis ez a szempont Magyarországon, ahogyan már említettem, ritkán müvelt tudományterület. Majd áttérek a hatalom, az állami propaganda, a cenzúra és a film összefüggéseire. Egy nemzetközi

\footnotetext{
${ }^{4}$ Ezekről bővebben „A spanyol filmtörténetírás” című alfejezetben szólok, illetve a disszertáció későbbi oldalain hivatkozásokban tüntetem fel őket.

${ }^{5}$ A történetírás ezt az 1959-ig tartó időszakot nevezi első francóizmusnak (primer franquismo).
} 
áttekintés után érkezem el az értekezés központi témájához, hogy bemutassam előbb a Franco-rendszer ideológiai elemeit, annak kapcsolatát a kultúrpolitikához, majd a hivatalos filmpolitikához, filmiparhoz, filmművészethez és a konkrét alkotásokhoz. Elsősorban olyan témacsoportokra helyezem a hangsúlyt, amelyek a politika és a film viszonyának leginkább ingergazdag környezetét jelentik.

\section{Források}

Kutatásaim során primer és szekunder forrásokat egyaránt használtam. A Spanyol Filmarchívumban és az Alcalá de Henares-i Főlevéltárban cenzori jelentésekhez, rendeletekhez, hivatalos utasításokhoz, nagyköveti beszámolókhoz jutottam hozzá. Ugyanitt filmpolitikai célzatú állami kiadványokat is vizsgáltam. A spanyol filmtörténészek által kevéssé látogatott Külügyminisztériumi Levéltárban is találtam releváns iratokat. A Filmarchívum és a kutatóközpontok könyvtáraiban és dokumentumgyüjteményeiben, valamint a Nemzeti Könyvtárban megtalálható, az 1923 és 2012 között született, film-témájú könyvek áttanulmányozása után kiválogattam és elemeztem azokat, amelyek mérvadónak bizonyultak. Értékes forrásként tekintettem a korabeli folyóiratok, napilapok és filmes szaklapok vonatkozó cikkeire, valamint a tárgyalt korszakban alkotó és befolyásos filmesek és filmpolitikusok írásaira, életrajzaira, memoárjaira, publikált naplóira. Internetes forrásokat akkor vontam be munkámba, ha az azokban található információt más források is alátámasztották, vagy ha a szerző személye és a megjelenés helye garanciát jelentettek az adatok megbízhatóságára; leginkább az online változatban is elérhető (vagy kizárólag így megjelenö) folyóiratok és digitális publikációk filmtörténeti témájú tanulmányaival foglalkoztam, Spanyolországban ezek mérvadónak számítanak. Írott forrásként szolgáltak továbbá a Boletín Oficial del Estado (Állami Hivatalos Közlöny - BOE) számai is, amelyekben a törvényeket és törvényerejü rendeleteket hozza nyilvánosságra a mindenkori spanyol kormány.

Legfontosabb primer forrásaim a filmek voltak: munkám során közel kétszáz, 1936 és 1976 között készült játékfilmet, dokumentumfilmet és filmhíradót tekintettem át, ezekből válogattam ki azokat, amelyekkel részletesen is foglalkozom. A filmek keletkezési ideje és műfaja rendkívül szerteágazó, igyekeztem minden olyan anyagot bevonni, amely valamilyen szempontból fontos munka lehet. A kérdés nemzetközi dimenzióinak megvilágítása céljából említés, esetenként egy rövid bemutatás erejéig néhány olyan, nem Spanyolországban készült mozgóképet is vizsgálat alá vetettem, amely témám szempontjából relevánsnak mutatkozik. 
Az értekezés lapjain a filmek megtekintése és kategorizálása, valamint az írott anyagok áttanulmányozása után levont következtetésekről is számot adok.

Vannak olyan kérdések, amelyeket már bőségesen feldolgozott a szakirodalom, jelen dolgozat nem tudna érdemben sok új adatot hozzátenni. Ezeket az információkat a disszertáció során kevésbé részletgazdagon tárgyalom, a már meglévő bibliográfia segítségével összegzem a legfőbb pontokat, kiegészítve azokat saját következtetéseimmel. Minden esetben hivatkozásokban jelzem, milyen szakirodalom látott már napvilágot a témában.

Az értekezésben szereplö spanyol filmek többségét nem mutatták be Magyarországon, ezért nem rendelkeznek hivatalos magyar címmel. Azonban az elmúlt öt-hat évben megszaporodott külföldi központú, de hazánkba is sugárzó tematikus filmcsatornák jóvoltából számos olyan film volt látható Magyarországon feliratos vagy szinkronizált változatban, amelyet a magyar adatbázisok nem tartanak nyilván, mert nincs hivatalos magyar forgalmazójuk (a 60-as évek elött készült müvek esetében ez ritka, de elöfordul). Mivel számos film kapcsán nem lehet egyértelmüen kijelenteni, hogy Magyarországon ismert-e a szükebb vagy szélesebb közönség körében, ezért minden mü esetében első előforduláskor közlöm a szó szerinti, vagy jelentésében megközelítőleg azonos tartalmú, esetleg magyarázó fordítást (ha létezik hivatalos magyar címe, akkor azt használom), az eredeti címet, a rendező nevét és a készítés évét. A késöbbiekben már csak a magyar címet említem. Minden hivatkozott film a dolgozat „Filmográfia” részében is megtalálható különbözö kategóriákba sorolva. 


\section{Historiográfiai előzzmények}

\section{Nemzetközi szakirodalom}

A témaválasztásnál már jeleztem: a nemzetközi történetírásban elfogadott tény, hogy a film és a történelem kapcsolatát vizsgálni hasznos és produktív kutatói tevékenység. Ebből adódóan idegennyelven rendelkezésre áll olyan szakirodalom, amely kijelöli a kutatás követendő útját. Az alábbiakban azokat a főbb müveket ismertetem, amelyek a film és a történelem kapcsolatával foglalkoznak, a következő alfejezetben pedig a spanyol filmtörténetről szóló munkákat tárgyalom.

Általánosságban elmondható, hogy elsősorban az eredetileg filmesztétikával, filmművészettel foglalkozó szakemberek ismerik fel, hogy a film műfaja hasznos adalékokkal szolgálhat a világtörténelem kérdéseihez, a különböző politikai - ideológiai vonulatok alakulásához, azonban az említett kutatók eredményei legtöbbször nem lépnek túl a filmtörténeti - filmesztétikai tematikájú könyvek és tanulmánykötetek lapjain, a történészekhez nem jutnak el. Ezért szükséges a fordított megközelítés is: egy történész, egy elsősorban a történelemmel és a politikával foglalkozó kutató mozduljon el a filmkultúra irányába, nyíljon meg az audiovizuális reprezentáció ezen formája felé, és fogadja el, hogy ez a nem tisztán történeti müfaj is tud számára hasznos eredményeket nyújtani. Egyes történészek megtették ezt a lépést, filmes szakemberekkel együttműködve elindították azt a folyamatot, amely követendő példaként állhat a jelen és a jövő történészei előtt. A legfontosabb személyeket és müveket kiemelve bemutatható, hogyan és kiknek a részvételével született meg ez az irányzat.

Az elismert filmesztéta és kritikus Siegfried Kracauer a Dr. Caligari (Das Kabinett des Doktor Caligari, Robert Wiene, 1920) című film apropóján írta meg 1947-ben a Caligaritól Hitlerig: a német film pszichológiai története ${ }^{6}$ című könyvét, amely klasszikus munkává vált ebben a témában. A szerző szerint a kor német filmjei pontos leírást adtak a weimari köztársaság mindennapjairól, a korabeli német ember lelkületéről, és mintegy előrevetítették a hitleri hatalomátvételt. Úgy véli, általánosságban minden filmes munka legyen az megtörtént eseményeken alapuló film vagy fikció - bemutatja egy ország és a lakosság pillanatnyi életét, lelkiállapotát. A filmben látható nemzetről, mely a háttérben akkor

\footnotetext{
${ }^{6}$ Kracauer, Siegfried: From Caligari to Hitler. A Psychological History of the German Film. New York, Princeton University Press / London, Dennis Dobson Ltd, 1947. Magyar nyelvủ kiadás: Caligaritól Hitlerig: a német film pszichológiai története. Budapest, Magyar Filmintézet, 1993.
} 
is felfedezhető, ha a filmnek egy abszolút főszereplője van, látleletet nyújtanak a filmrendezők. Ez különösen igaz a Dr. Caligarira, ennek megtekintésével megérthetjük, miért tehetett szert később olyan nagy népszerüségre a hitleri ideológia, és hogyan kerülhetett egy egész nemzet egyetlen ember befolyása alá. Kracauer munkája megvilágítja, milyen kapcsolat áll fenn a nemzeti filmgyártás és egy korszak társadalma között.

A filmet történeti forrásanyagként is kezelő személyek közül első helyen a francia Marc Ferro említhető, aki azóta is hivatkozási alapként szolgál minden, a témában dolgozó kutató számára. Ferro úttörőnek számít a filmművészet és a történelem, mint két egymástól elkülönülő diszciplína összekapcsolásában. Végzettségét tekintve történész, szakterülete a Szovjetunió és Oroszország története, társszerkesztője a francia Annales folyóiratnak és a Journal of Contemporary Historynak, tanulmányi igazgatója a párizsi École des Hautes Études en Sciences Sociales-nak ${ }^{7}$. Első ilyen témájú könyve a számos nyelven megjelent és alapmünek számító Cinéma et Historie ${ }^{8}$. A ma is aktív Ferro ebben a munkájában megfogalmazta, miért kell és hogyan lehet a filmet bevonni a történelemtudomány által vizsgált területek körébe. Ferro szerint a film egy történelmi dokumentumként is értelmezhető, ő maga is a történelem forrásának nevezi a filmet, és didaktikai eszközként is tekint rá. Külön hangsúlyt fektet a különböző diktatúrák idején forgatott dokumentumfilmekre és játékfilmekre: ugyanolyan fontos, hogy mit láthatunk a filmen, mint az, amit nem láthatunk. Egy totalitárius állam, még ha igyekszik is teljes kontrollt gyakorolni a filmek felett, nem tudja megakadályozni, hogy a képek segítségével felszínre kerüljenek olyan információk a rendszerről, amelyeket valójában el akart titkolni. Több konkrét példán keresztül (háborús propagandafilmek, dokumentumfilmek, szovjet alkotások stb.) mutatja be, milyen többletet nyújthat a mü áttanulmányozása a kort vizsgáló személy számára, elsősorban a nácizmus, a kommunizmus, illetve a diktatúrák társadalmának főbb jellegzetességeit beazonosítva, de az Amerikai Egyesült Államok politikai és társadalmi berendezkedésére is kitér egyes filmekkel összefüggésben. Tudományos munkássága mellett Ferro rendezőként és narrátorként részt vett Leninről és a Szovjetunióról szóló televíziós dokumentumfilmek készítésében is.

Ferro nagy tisztelöje és az általa kijelölt út folytatója Pierre Sorlin, aki a már szintén klasszikusnak számító műveiben igazolta és füzte tovább kollégája gondolatait. Szerinte a múltat nem csak ábrázolja, de az arról való gondolkodásunkat akár át is formálhatja egy film,

\footnotetext{
${ }^{7}$ Ferro szakmai életútjáról lényegretörő vázlatot ad José María Caparrós Lera a Ferro könyvének spanyol, kibővített és aktualizált fordításához írt előszavában: Ferro, Marc: Historia Contemporánea y Cine. Barcelona, Editorial Ariel, 2000. 7-11.

${ }^{8}$ Ferro, Marc: Cinéma et Historie. Paris, 1977. Több nyelvre, így angolra és spanyolra is lefordították.
} 
amennyiben készek vagyunk arra, hogy forrásnak tekintsük a vizuális anyagokat ${ }^{9}$; később a filmek szociológiáját, valamint elemeinek egymásra építkezését vizsgálta, bevonva a társadalmak szemrevételezését is. ${ }^{10}$ Újabb keletü, a 90-es években íródott munkájában ${ }^{11}$ az európai társadalmakra koncentrál: hogyan jelenik meg egy adott ország (Franciaország, Olaszország, Németország, Nagy-Britannia) filmtermésében a nemzeti jelleg, mi különbözteti meg egymástól a müveket, és hogyan mutatják be a munkák a néző számára az adott társadalmat és annak jellegzetességeit. A szerző szerint ugyanis egy idegen kultúra egyedi vonásait kiválóan érzékelteti a film; pontosabban, a film erre a legtökéletesebb eszköz. Sorlin tanulmányai napjainkban is gyakran feltünnek a történelem és a film viszonyát elemző kötetek lapjain.

Angol nyelvterületen Paul Smith számít úttörőnek The Historian and Film címü tanulmánykötetével $^{12}$, ahol a zömében angol történészek és filmtörténészek (de jelen van Marc Ferro is) a fentiekben említett vonalat már a 70-es években elkezdték. Míg egyes szerzők a filmtípusok és a filmarchívumok jellegzetességeit vizsgálják, mások a filmhíradókhoz és fikciós játékfilmekhez közelítenek történészi szemmel. William Hughes tanulmánya ${ }^{13}$ különösen figyelemre méltó, történelmi eseményeket és konkrét filmeket hoz fel érvként arra, hogy a filmet valódi bizonyítékként lehet és kell felhasználni a történeti kutatásokban. A könyv több fejezete a film használatáról értekezik egyetemi és középiskolai közegben. A megállapítások egybehangzóak: mind a felsőoktatásban, mind az alacsonyabb fokú oktatási szinteken helye van a filmnek a történelemórán, mivel a diákok sokkal fogékonyabbak egy ismeret elsajátítására, amennyiben vizuális támogatást is kapnak hozzá.

A témában elmélyülni kívánó történészek néhány további érdekességgel is találkozhatnak. A Robert C. Allen és Douglas Gomery szerzőpáros több nyelvre is lefordított Film history. Theory and Practice ${ }^{14}$ címü könyve kikövezi a történész számára követendő utat. Alapmunkának számító írásukban, miután végigveszik, tudományosan milyen módon lehet megközelíteni a történelmet és a filmtörténetet, a két tudományterületet összekapcsolják, miközben bemutatják a filmtörténet esztétikai, technikai, gazdasági és társadalmi vetületeit is. Az erre épülő, szintén több nyelven is elérhető francia De l'Histoire du Cinema. Méthode

\footnotetext{
${ }^{9}$ Erről szól: Sorlin, Pierre: The Films in History. Restaging the Past. Oxford, Basil Blackwell, 1980.

${ }^{10}$ Uö: Sociologie du Cinéma. Párizs, Aubier Montaigne, 1977.

${ }^{11}$ Uö: European Cinemas, European Societies, 1939-1990. London, Routledge, 1991.

${ }^{12}$ Smith, Paul (szerk.): The Historian and Film. Cambridge University Press, 1976.

${ }^{13}$ Hughes, William: „The evaluation of film as evidence” in: Smith, Paul: The Historian and Film. Id. mü. 4979.

${ }^{14}$ Allen, Robert C. - Gomery, Douglas: Film history. Theory and Practice. McGraw-Hill, 1985.
} 
historique et historie du cinema ${ }^{15}$ pedig módszertani segítséget nyújt a kutatóknak: többek között Lucien Febvre, Marc Bloch, Pierre Bourdieu, Fernand Braudel, Alain Boureau és Michel Foucault történeti és történetfilozófiai téziseinek és megállapításainak felhasználásával igazolják, hogy a film történeti segédtudományként kezelhető.

A fenti könyveket mind tizenöt - húsz évvel ezelőtt, vagy még korábban adták ki, de napjainkban is ezek számítanak a legalapvetőbb szakirodalomnak a témában. Emellett természetesen folyamatosan, szinte minden nyelven jelennek meg munkák ebben a tárgykörben, amelyek színesítik a palettát. Ezek közül az egyik legérdekesebb és leghasznosabb az izraeli történész, Shlomo Sand munkája, a huszadik század történelmét a filmtörténet tükrében vizsgáló Le XX siécle á l'écran ${ }^{16}$. Kiemelendő továbbá Robert $\mathrm{A}$. Rosenstone három könyve ${ }^{17}$, amelyek az ókortól napjainkig elemzik a különböző korok filmes ábrázolását és annak hitelességét, valamint a társadalmak ezek hatására változó történelemszemléletét. Marnie Hughes-Warrington legfontosabb müve ${ }^{18}$ a történelmi eseményeket és azok filmvásznon való megjelenítését taglalja, kiegészítve hasznos módszertani megfigyelésekkel, míg Hannu Salmi tanulmányában a történelmi filmek narratíváját vizsgálta. ${ }^{19}$ A madridi Carlos III egyetem neves európai történészek és filmtörténészek (köztük Pierre Sorlin) részvételével tanulmányozta ${ }^{20}$, napjainkban milyen témakörökben (történelmi emlékezet, kiemelkedő személyek, nemzeti identitás stb.) érdemes egymáshoz közelíteni a történelem és a film müfaját. A könyveken kívül az adott országok filmmüvészeti és filmtörténeti tárgyú folyóirataiban jelennek meg olyan tanulmányok, amelyek nemcsak egy ország filmmüvészetének, de az adott nemzet történetének és filmkultúrájának kapcsolatát is nagyító alá veszik. Szintén hasznos vállalkozás, amikor egy történelemhez és filmtörténethez egyaránt értő személy összegyüjti a nemzeti történelem egy adott korszakát vizsgáló mozgóképes munkákat. ${ }^{21}$

\footnotetext{
${ }^{15}$ Lagny, Michele: De l'Histoire du Cinema. Méthode historique et historie du cinema. Párizs, A Colin, 1992.

${ }^{16}$ Sand, Shlomo: Le XX $X^{e}$ siécle á l'écran. Seuil, 2004.

${ }^{17}$ Rosenstone, Robert A. (szerk.): Revisioning History. Film and the Construction of a New Past. Princeton, Princeton University Press, 1995; Visions of the Past. The Challenge of Film to Our Idea of History. Cambridge, Harvard University Press, 1995; History on Film / Film on History. London, Pearson Education Ltd, 2006.

${ }^{18}$ Hughes-Warrington, Marnie: History Goes to the Movies: Studying History on Film. Abingdon, Routledge, 2007.

${ }^{19}$ Salmi, Hannu: „Film as Historical Narrative” in: Film-Historia, Vol. V, No. 1. 1995. 45-54. Elérhetö: http://www.publicacions.ub.es/bibliotecadigital/cinema/filmhistoria/Art.Salmi.pdf $\quad$ (letöltés ideje: 2012-11-29)

${ }^{20}$ Camarero, Gloria - Heras, Beatriz de las - Cruz, Vanessa de: Una ventana indiscreta. La historia desde el cine. Madrid, Ediciones JC, 2008.

${ }^{21}$ Spanyolországban ezt Miguel Juan Payán tette meg La historia de España a través del cine (Madrid, Cacitel, 2007) címü könyvében, de a már említett országok többségében megfigyelhetó ugyanez a törekvés.
} 
Magyarországon kisebb próbálkozások történtek csak arra nézve, hogy a filmet bevonják a történészek által kezelt forrásbázisba, esetenként konkrét filmek elemzése kapcsán merülnek fel ilyen szempontok. Elsősorban a filmesztétikával és filmtörténettel foglalkozó személyek közelítettek a történelemtudomány felé, a fordított irányú elmozdulás még ritka. Néhány átfogó mü ${ }^{22}$ publikálása mellett leginkább a különböző országok filmgyártásáról

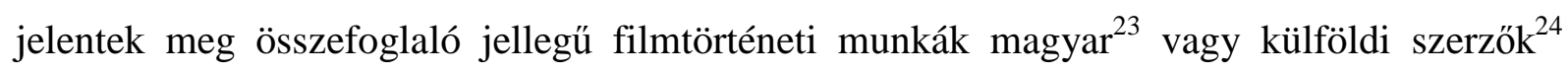
tollából, illetve színészportrék és rendezői életrajzok, filmelméleti kötetek. Spanyol témában csak Luis Buñuel, Pedro Almodóvar és kisebb mértékben Carlos Saura életművére koncentráltak a kiadók, az önéletrajztól a forgatókönyveken keresztül a rendezők fikciós írásainak megjelentetéséig, a munkásságukat elemző könyvekkel egyetemben ${ }^{25}$. A 80-as évektől napvilágot látott néhány összefoglaló, ismeretterjesztő jellegü cikk a Filmvilág folyóiratban a spanyol filmtörténet egy-egy szegmenséről. ${ }^{26}$ Bíztató jel, hogy publikáltak már átfogó, általános magyar játékfilmtörténeteket, amelyek az egyes munkákat és tendenciákat történeti kontextusban is vizsgálják ${ }^{27}$, így ezek kiindulópontjául szolgálhattak további, magyar

\footnotetext{
${ }^{22}$ Berkes Ildikó - Nemes Károly: A filmmüvészet fejlödési vonala. Budapest, Uránusz, 2011; Gregor, Ulrich Patalas, Enno: A film világtörténete. Budapest, Gondolat, 1966; Kovács András Bálint: A film szerint a világ: tanulmányok. Budapest, Palatinus, 2002; Kovács András Bálint: A modern film irányzatai: Az európai müvészfilm 1950-1980. Budapest, Palatinus, 2005; Nemes károly: A nyugati filmmüvészet konfliktusa. Budapest, Kossuth Kiadó, 1971.

${ }^{23}$ Például: Berkes Ildikó - Nemes Károly: A japán film világa. Budapest, Magyar Filmintézet, 1997; Berkes Ildikó - Nemes Károly: A német filmmüvészet története. Budapest, Uránusz, 2006; Berkes Ildikó - Nemes károly: A kelet-európai filmmüvészet. Budapest, Uránusz, 2007; Berkes Ildikó: Az orosz-szovjet film: a szovjet filmmüvészet mint a Szovjetunió tükre. Budapest, Uránusz, 2008; Bikácsy Gergely: Bolond Pierrot moziba megy. A francia film ötven éve. Budapest, Héttorony - Budapest Film, 1992; Győri Zsolt (szerk.): Fejezetek a brit film történetéből. Eger, Líceum Kiadó, 2010; Magyar Bálint: Az amerikai film. Budapest, Gondolat Kiadó, 1974; Varga Anna: Az 1910-es évek orosz némafilm-kultúrája. Budapest, L’Harmattan, 2011.

${ }^{24}$ Elsaesser, Thomas: A német újfilm. Budapest, Palatinus Kiadó, 2004; Lizzani, Carlo: Az olasz film története. Budapest, Gondolat, 1981; Rosselli, Alessandro: Amikor a Cinecittà magyarul beszélt. Szegedi Tudományegyetem, 2005.

${ }^{25}$ Almodóvar, Pedro: Patty Diphusa. Budapest, Palatinus, 2006; Bikácsy Gergely: Buñuel-napló. Budapest, Osiris Kiadó, 1997; Buñuel, Luis: Odalenn [forgatókönyv]. Szeged, Szukits Kiadó, 2001; Buñuel, Luis: Az andalúziai kutyától Az öldöklö angyalig - Forgatókönyek 1. Budapest, L'Harmattan, 2006; Buñuel, Luis: Utolsó leheletem. Budapest, L'Harmattan, 2006; Buñuel, Luis: Az Egy szobalány naplójától a Tristanáig Forgatókönyek 2. Budapest, L”Harmattan, 2008; Hollós Adrienne: Carlos Saura. Budapest, Magyar Filmtudományi Intézet és Filmarchívum, 1983; Nemes Károly: Luis Buñuel. Budapest, Magyar Filmtudományi Intézet és Filmarchívum, 1979; Strauss, Frédéric (szerk.): Pedro Almodóvar. Budapest, Osiris Kiadó, 2005; Szabó Z. Pál: Lázadás a halál ellen. Salvador Dalí, Luis Buñuel: Andalúziai kutya. Budapest, Áron Kiadó, 2003.

${ }^{26}$ Bikácsy Gergely: „Lábadozók (A spanyol film Franco után. Négy évtized)” in: Filmvilág, 1982/01. 36-40; Dés Mihály: „Spanyolország messzire van (A spanyol film Franco nélkül)” in: Filmvilág, 1985/07. 3-9; Tanner Gábor: „Filmtörvény Spanyolországban” in: Filmvilág, 2001/07. 25-26; Tanner Gábor: „Mondd, hogy félsz (A spanyol thriller)” in: Filmvilág, 1997/08. 38-41; Tanner Gábor: „Torreádorsirató” in: Filmvilág, 2000/11. 46-48; Todero Frigyes: „Furkósbot és mézesmadzag (A spanyol film a Franco-rendszerben. Négy évtized)” in: Filmvilág, 1981/12. 28-30.

Jelen disszertáció szerzője az elmúlt évek során több témához illeszkedő cikket és tanulmányt publikált folyóiratokban és kötetekben, ezek listája a bibliográfiai részben található.

${ }^{27}$ Balogh Gyöngyi - Gyürey Vera - Honffy Pál: A magyar játékfilm története a kezdetektöl 1990-ig. Budapest, Müszaki Könyvkiadó, 2004; Gyürey Vera - Lencsó László - Veress József (szerk.): A magyar filmtörténet képeskönyve. Budapest, Osiris Kiadó, 2003; Magyar Bálint: A magyar némafilm története. Budapest, Palatinus,
} 
vonatkozású kutatásoknak. A Kádár-korszak filmjeinek, filmeseinek és politikájának összefüggésével foglalkozik Gervai András két könyve ${ }^{28}$, amelyek új színben tüntetik fel a hatalom és a müvészek közötti kapcsolatokat. Kutatásai alapját kulcsfontosságú személyekkel készített interjúk, valamint a Magyar Országos Levéltárban és az Állambiztonsági Szolgálatok Történeti Levéltárában megvizsgált források jelentették. Murai András munkája ${ }^{29}$ a rendszerváltás után készült magyar filmek Kádár-korszak ábrázolását mutatja be szemléletesen, Kelecsényi László könyvei ${ }^{30}$ pedig a magyar filmtörténet egyes korszakait és szempontjait veszik górcső alá. Jakab György nyomtatásban is megjelent előadása ${ }^{31}$ a film és a történelem kapcsolatát mutatja be röviden, Varga Balázs ilyen jellegü kutatásai ${ }^{32}$ a Kádárkorszakra koncentrálódnak. Sárközy Réka könyve ${ }^{33}$ precízen ismerteti a magyar történelmi tárgyú dokumentumfilmek történetét, kitérve az intézményi háttérre, valamint a történész filmmel kapcsolatos feladataira is. Néhány tanulmány és esszé erejéig pedig már megjelent egy adott történelmi kor, személy, intézmény vagy esemény filmeken keresztül történő szemléltetése, elemzése, elsősorban észak-amerikai témában, történészek tollából. ${ }^{34} \mathrm{~A}$ Filmvilág, a Metropolis, a Filmkultúra, a Prizma és az Apertúra filmmüvészeti folyóiratok sokat tesznek a hiány pótlásáért.

2003; Nemeskürty István: A képpé varázsolt idő: a magyar film története és helye az egyetemes kultúrában, párhuzamos kitekintéssel a világ filmmüvészetére. Budapest, Magvetö Kiadó, 1984.

${ }^{28}$ Gervai András: A tanúk: film - történelem. Budapest, Saxum, 2004; Uő: Fedőneve: „szocializmus”Müvészek, ügynökök, titkosszolgák. Pécs, Jelenkor, 2010.

${ }^{29}$ Murai András: Film és kollektív emlékezet. Magyar múltfilmek a rendszerváltozás után. Szombathely, Savaria University Press, 2008.

${ }^{30}$ Kelecsényi László: Vászonszerelem - A magyar hangosfilm krónikája 1931-töl napjainkig. Budapest, Noran Kiadó, 2007; Uő: Álmodozók és megszállottak.Bevezetés a magyar filmtörténetbe. Budapest, L'Harmattan, 2010.

${ }^{31}$ Jakab György: „Tükör vagy ecset? Avagy történelem a filmen, film a történelemórán” in: http://www.tte.hu/toertenelemtanitas/toertenelemtanarok-orszagos-konferenciaja/6740-tukor-vagy-ecset (201211-29)

${ }^{32}$ Például: Varga Balázs: „Türéshatár. Filmművészet és cenzúrapolitika a hatvanas években” in: Kisantal Tamás - Menyhért Anna (szerk.): Müvészet és hatalom - A Kádár-korszak müvészete. Budapest, József Attila Kör L'Harmattan, 2005. 116-138.

${ }^{33}$ Sárközy Réka: Elbeszélt múltjaink. A magyar történelmi dokumentumfilm útja. Budapest, 1956-os Intézet L'Harmattan Kiadó, 2011.

${ }^{34}$ Például: Lévai Csaba: „Hollywood és az Amerikai Egyesült Államok történelmi küldetése Mel Gibson $A$ hazafi címü filmjének tükrében" in: Tóth Zsófia Anna - Vajda Zoltán (szerk): Amerikanisztika és vizualitás. Metszéspontok az információs társadalom horizontján. Szeged, Americana eBooks, 2012; Szélpál Lívia: „Sommersby, avagy Martin Guerre visszatérése a történelem és film kapcsolatának tükrében” in: Aetas, 2010/3. 159-171. Szintén ide sorolhatóak Hahner Péter a Filmvilág folyóiratban megjelent ismeretterjesztő jellegű cikkei egy-egy filmpremier vagy filmmüfaj és a hozzájuk köthető amerikai törénelmi események kapcsolatáról, összefüggéseiről, illetve a szerző személyes véleményéről. 


\section{A spanyol filmtörténetírás}

A dolgozatban tárgyalt téma a történelem és a filmtörténet határán mozog. Az ország filmtörténetét vizsgáló monográfiák és tanulmánykötetek elszórtan tartalmaznak olyan információkat, kutatási eredményeket és elemzéseket, amelyek a témához illeszkedő historiográfia részeként értékelhetőek. Csak néhány általános müvet emelek ki, mert a dolgozat lapjain lábjegyzetben felsorolásra kerülnek azon írások, amelyeket az adott témákhoz és résztémákhoz felhasználtam. 1993-ban jelent meg Spanyolországban egy filmtörténeti témájú könyveket összefoglaló mü ${ }^{35}$, ennél újabb bibliográfia csak interneten érhető $\mathrm{el}^{36}$. Disszertációm elkészítéséhez a fenti két bibliográfiai gyüjteményben feltüntetett müvek mellett újabb, illetve ott nem említett írásokat is használtam, minden esetben szem előtt tartva, hogy azokat történelemtudományi szempontból is kiértékelhessem. Az alábbiakban azokat a jelentősebb, átfogó munkákat helyezem előtérbe, amelyek értekezésem központi témáját valamilyen mértékben érintik.

A Franco-korszak filmtörténetével foglalkozó müvek igen régiek, napjainkban leginkább egyes alkotókra, műfajokra koncentráló írások látnak napvilágot. Természetesen a tárgyalt időszakban is jelentek meg ilyen témájú könyvek ${ }^{37}$, ezek többsége azonban az objektivitás teljes hiányáról árulkodik, elsősorban konkrét filmek és alkotók ismertetésével tölti meg lapjait, valamint egyes szempontokat (mint a köztársasági filmgyártás a polgárháború alatt) nem is említ. Propagandatörténet szempontjából azonban értékes művek; mind közül leginformatívabb az 1949-ben kiadott El cine español ${ }^{38}$, amely az olvasók számára 150 oldalban összefoglalta, mit érdemes tudniuk a spanyol filmről: a számos statisztikai- és számadatot felvonultató kiadvány megfogalmazta a film céljait, felvázolta a spanyol filmtörténet fontosabb állomásait, a film születésének fázisait, a mozitermek számát és befogadóképességét, a technikai és stilisztikai tudnivalókat, a szakemberek feladatát, a nemzetközi kapcsolatokat, bemutatta a vonatkozó törvényeket és intézményeket, felsorolta az

\footnotetext{
${ }^{35}$ Delgado Casado, Juan: La bibliografía cinematográfica española. Madrid, Arco/libros, 1993.

${ }^{36}$ Martínez-Carazo, Cristina: Bibliografía cine español. Alicante, Biblioteca Virtual Miguel de Cervantes, 2008. Elérhető: http://www.cervantesvirtual.com/obra/bibliografia-cine-espanol--0/ (2012-11-20)

37 A legfontosabbak: Cabero, Juan Antonio: Historia de la cinematografía española (1896-1948). Madrid, Gráficas Cinema, 1949; Méndez-Leite, Fernando: Historia del cine español. Madrid, Ediciones Rialp, 1965. Carlos Fernández Cuenca, akiről a dolgozat lapjain több alkalommal is lesz szó, a Franco-rendszer utolsó évtizedeiben, valamint a demokratikus átmenet idején is számos spanyol és nemzetközi filmtörténettel foglalkozó könyvet adott ki. Bár rá is jellemző az alapvető Franco-szimpátia, műveiben reális és objektív filmmüvészeti elemzéseket is olvashatunk.

${ }^{38}$ El cine español. Madrid, Oficina Informativa Española, 1949.
} 
addig odaítélt filmes díjakat, valamint függelékben megadta a stúdiók és filmvállalatok jegyzékét azok pontos címével együtt.

A diktatúra bukásakor látott napvilágot két, filmhistoriográfiai szempontból számottevőnek mondható monográfia ${ }^{39}$ elismert szerzők tollából, forrásmegjelölést azonban alig tartalmaznak, levéltári hivatkozást pedig egyáltalán nem. Dolgozatom megírásához ezeket csak kis mértékben használtam, mivel leginkább általános, ismeretterjesztő áttekintésként értékelhetőek, szemléletük pedig esetenként markánsan szélsőbaloldali ${ }^{40}$; az itt fellelhető információkat a későbbi évtizedekben más kutatók tudományosan is alátámasztották vagy cáfolták újabb keletü publikációikban.

Név szerint kell kiemelni két spanyol filmtörténészt, akik meghatározó egyéniségei a spanyol filmtörténetírásnak. Mindketten ma is aktívak és a legtöbbet tették Spanyolországban a film és a történelem közös nevezöinek megtalálásáért.

Román Gubern ${ }^{41}$ a Barcelonai Autonóm Egyetem Audiovizuális Kommunikáció Tanszékének oktatója, több európai és észak-amerikai felsőoktatási intézmény vendégprofesszora. 1965 óta publikál a nemzetközi és a spanyol filmvilág történetéröl, hazájának elsőszámú filmtörténésze. Munkáiban felfedezhető, hogy élénken érdeklődik a film és a történelem kapcsolata iránt, de a kérdéshez ő is többnyire filmesztétikai nézőpontból közelít, interdiszciplináris megközelítésű müveiben újradefiniálja a film és a tömegkommunikációs eszközök elméletét és történetét, valamint nagyító alá veszi a filmtörténet apróbb mozzanatait is. Napjainkban leginkább a film mint médium vizsgálata foglalkoztatja.

José María Caparrós Lera ${ }^{42}$ katalán filmtörténész szintén a Barcelonai Egyetem professzora és külföldi egyetemek előadója, a mértékadó Film-Historia folyóirat (2001-től

\footnotetext{
${ }^{39}$ Gubern, Román - Font, Doménec: Un cine para el cadalso. Barcelona, Editorial Euros, 1975; Font, Doménec: Del azul al verde. Barcelona, Editorial Avance, 1976.

${ }^{40}$ Doménec Font a szélsőbaloldali-maoista Organización Comunista de España (Bandera Roja) párt tagja volt a tardofranquismo és a demokratikus átmenet idején, filmes tárgyú müveiben a francói filmtörténetet ilyen ideológiai megközelítésből szemléli, többek között a spanyol osztályharc és a burzsoázia történetével párhuzamba állítva.

${ }^{41}$ Spanyol filmtörténethez kapcsolódó müvei (az első megjelenés kronológiai sorrendjében): Historia del cine. Barcelona, Ed. Danae, 1969 (számos újabb kiadást is megért); Cine contemporáneo, Barcelona, Salvat, 1974; Un cine para el cadalso (társszerzö: Doménec Font). Id. mü.; Cine español en el exilio. Barcelona, Editorial Lumen, 1976; El cine sonoro en la II República (1929-1936). Barcelona, Lumen, 1977; Raza: un ensueño del general Franco. Madrid, Ediciones 99, 1977; Carlos Saura. Festival Iberoamericano de Cine de Huelva, 1979; La censura. Función política y ordenamiento jurídico bajo el franquismo (1936-1975). Barcelona, Ediciones Península, 1981; 1936-39: La guerra de España en la pantalla. Madrid, Filmoteca Española, 1986; Proyector de luna. La Generación del 27 y el cine. Barcelona, Anagrama, 1999; Val de Omar, cinemista. Granada, Diputación Provincial de Granada, 2004; Los años rojos de Luis Buñuel (társszerző: Paul Hammond). Madrid, Editorial Cátedra, 2009. Számos kötetét többször is kiadták.

${ }^{42}$ Fontosabb, spanyol filmtörténethez kapcsolódó művei (az első megjelenés kronológiai sorrendjében): $E l$ cine republicano español, 1931-1939. Barcelona, Dopesa, 1977; El cine político visto después del franquismo.
} 
FilmHistoria Online ${ }^{43}$ néven) alapító főszerkesztője, az előző fejezetben már említett Marc Ferro és Pierre Sorlin követője. Rendkívül termékeny író mind a spanyol, mind a nemzetközi filmtörténet és filmmüvészet témájában. Mủvei nagy népszerüségnek örvendenek ma is, mivel nézeteit, elemzéseit olvasmányos és közérthető stílusban tárja az olvasóközönség elé. Az egyik legolvasottabb filmkritikai és filmtörténeti internetes blog is a nevéhez füződik. ${ }^{44}$ 1983-ban alapította meg a Barcelonai Egyetem Legújabbkori Egyetemes Történeti Tanszékén belül az első Film - Történeti Kutatóközpontot (Centre d'Investigacions Film-Història), amely a film és a történelem kapcsolatát vizsgáló nemzetközi konferenciák, kutatócsoportok, monográfiák, enciklopédiák világszerte ismert és elismert mühelyévé vált; a hozzá kapcsolódó doktori iskolában számos értékes disszertáció született az elmúlt két évtizedben.

Caparrós Lera közvetlen munkatársai, Magí Crusells ${ }^{45}$ (a FilmHistoria Online jelenlegi főszerkesztője) és Rafael de España ${ }^{46}$ filmtörténészek szintén kulcsfontosságú alakjai a filmtörténetírásnak, ők hárman a film és a történelem összefüggéseinek legfőbb spanyol

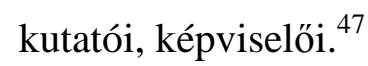

A fent említett szerzőkben közös, hogy értékes kutatási területként tekintenek a film és a történelem kapcsolatára, az általuk kitaposott ösvényen számos történész és filmtörténész indult el az elmúlt két évtizedben.

Barcelona, Dopesa, 1978; Arte y política en el cine de la República (1931-1939). Barcelona, Universidad de Barcelona, 1981; El cine español bajo el régimen de Franco, 1936-1975. Barcelona, Edicions de la Universitat de Barcelona, 1983; The Spanish Cinema: A Historical Approach (társszerző: Rafael de España). Barcelona, Centre for Cinematic Research "Film-Historia", 1987; El cine español de la democracia. Barcelona, Anthropos, 1992; Cine Español. Una historia por autonomías, Vols. I-II (szerk.). Barcelona, PPU, 1996-1998; Historia crítica del cine español. Barcelona, Ariel, 1999; Estudios sobre el cine español del franquismo (1941-1964). Valladolid, Fancy Ediciones, 2000; La Pantalla Popular. El cine español durante el Gobierno de la derecha, 1996-2003. Tres Cantos, Akal, 2005; Las grandes películas del cine español (társszerzők: Magí Crusells és Rafael de España). Madrid, Ediciones JC, 2007; Historia del cine español. Madrid, T \& B, 2007; Cinema en temps de guerra, exili i repressió (társszerző: Magí Crusells). Barcelona, Memorial Democrátic, D.L. $2010 ; 100$ documentales para explicar historia (társszerzők: Magí Crusells és Ricard Mamblona). Madrid, Alianza Editorial, 2010.

${ }^{43}$ FilmHistoria Online: http://www.pcb.ub.edu/filmhistoria/ $\quad$ (2012-11-20)

${ }^{44}$ CaparrósCinema: www.caparroscinema.blogspot.com (2012-11-20)

${ }^{45}$ Főbb müvei: La Guerra Civil española: cine y propaganda. Barcelona, Editorial Ariel, 2000; Las Brigadas Internacionales en la pantalla. Universidad de Castilla La Mancha, 2002; Cine y Guerra Civil Española: imágenes para la memoria. Madrid, Ediciones JC, 2006; Directores de cine en Cataluña. Barcelona, Universitat de Barcelona, 2009. Társszerzőként: Caparrós Lera, José María - Crusells, Magí - España, Rafael de Las grandes películas del cine español. Id. mü; Caparrós Lera, José María - Crusells, Magí: Cinema en temps de guerra, exili i repressió. Id. mü; Caparrós Lera, José María - Crusells, Magí - Mamblona, Ricard: 100 documentales para explicar historia. Id. mü.

${ }^{46}$ Főbb müvei: Directory of Spanish and Portugese Film-Makers and Films. Westport, Greenwood, 1994; El cine de Goebbels. Barcelona, Editorial Ariel, 2002; De la Mancha a la pantalla. Aventuras cinematográficas del ingenioso hidalgo. Barcelona, Publicacions i Edicions UB, 2007. Társszerzőként: Caparrós Lera, José María España, Rafael de: The Spanish Cinema: A Historical Approach. Id. mü; Caparrós Lera, José María - Crusells, Magí - España, Rafael de: Las grandes películas del cine español Id. mü.

47 Caparrós Lera és Crusells profeszorokkal, ahogyan a Köszönetnyilvánításban említettem, személyes kapcsolatban is állok. Jelen disszertációval szeretnék kapcsolódni az általuk megkezdett úthoz. 
A Julio Pérez Perucha által szerkesztett filmantológia ${ }^{48}$ a legjelentősebb múvek között említhető, Spanyolország legkiemelkedőbb filmtörténészei és filmesztétái írtak két-három oldalas ismertetőket, rövid elemzéseket Spanyolország filmtörténetének alapvető darabjairól. Az eredmény egy 303 tanulmányból álló, rendkívül informatív és gondosan megszerkesztett munka. Carlos F. Heredero 1993-ban megjelent monográfiájában ${ }^{49}$ az 50 -es évek filmjeiről ad kimerítő áttekintést, a José Luis Castro de Paz és kollégái által összeállított spanyol filmtörténet $^{50}$ pedig szintén szintézis jellegű munka, minden korszak jelentősebb alkotóit, filmjeit, müfajait és tendenciáit mutatja be néhány mondatban, sok esetben vitatkozva más szerzőkkel. A Spanyol Filmakadémia kötete ${ }^{51}$ húsz tanulmányban foglalja össze röviden a spanyol filmtörténet legfontosabb aspektusait Román Gubern szerkesztésében.

A spanyol filmtörténet és a spanyol történelem közötti találkozási pontok három legtöbbet tárgyalt területe a polgárháború ${ }^{52}$, a Franco-korszak szimbólumává vált NO-DO filmhíradó $^{53}$, valamint a cenzúra ${ }^{54}$; az elmúlt tizenöt évben mindhárom témában rendkívül gazdag szakirodalom született.

A ma is létező folyóiratok közül a már említett FilmHistoria Online, a Secuencias, a francia eredetü Cahiers du Cinema spanyol változata, a Caimán Cuadernos de Cine, valamint az Archivos de la Filmoteca ${ }^{55}$ a legszínvonalasabbak, ezek gyakran vizsgálják a film és

\footnotetext{
${ }^{48}$ Pérez Perucha, Julio (szerk.): Antología crítica del cine español, 1906-1995. Flor en la sombra. Madrid, Ediciones Cátedra - Filmoteca Española. 1997.

${ }^{49}$ Heredero, Carlos F.: Las huellas del tiempo. Cine español 1951-1961. Valencia/Madrid, Filmoteca Valenciana/Filmoteca Española, 1993.

${ }^{50}$ Castro de Paz, José Luis (és mások, szerk.): La nueva memoria. Historia(s) del cine español, (1939-2000). A Coruña, Vía Láctea Editorial, 2005.

51 Gubern, Román (szerk.): Un siglo de cine español. Madrid, Academia de las Artes y las Ciencias Cinematográficas de España, 1997.

${ }^{52}$ Amo García, Alfonso del (szerk.): Catálogo general del cine de la Guerra Civil. Madrid, Cátedra - Filmoteca Española, 1996; Álvarez Berciano, Rosa - Sala Noguer, Ramón: El cine en la zona nacional, 1936-39. Bilbao, Mensajero, 2000; Crusells, Magí: La Guerra Civil española: cine y propaganda. Barcelona, Editorial Ariel, 2000; Fernández Cuenca, Carlos: La guerra de España y el cine. Madrid, Editora Nacional, 1972; Sala Noguer, Ramón: El cine en la España republicana, 1936-39. Bilbao, Mensajero, 1993; Sánchez-Biosca, Vicente: Cine y Guerra Civil Española. Madrid, Alianza Editorial, 2006; Sánchez-Biosca, Vicente: España en armas: El cine de la Guerra Civil Española. Diputación de Valencia, 2007; Sánchez-Biosca, Vicente - Tranche, Rafael R.: El pasado es el destino: Propaganda y cine del bando nacional en la guerra. Madrid, Cátedra, 2011.

${ }^{53}$ Tranche, Rafael R - Sánchez-Biosca, Vicente: NO-DO. El tiempo y la memoria. Madrid, Ediciones Cátedra Filmoteca Española, 2006; Abella, Rafael - Cardona, Gabriel: Los años del NO-DO. Barcelona, Destino, 2008.

${ }^{54}$ Gubern, Román - Font, Doménec: Un cine para el cadalso. Id. mü; Gubern, Román: La censura. Función política y ordenamiento jurídico bajo el franquismo (1936-1975). Id. mü; Afinoguénova, Eugenia: „La censura cinematográfica en el territorio nacional durante la Guerra Civil y la consolidación del <Nuevo Estado>" in: Herrera, Javier - Martínez-Carazo, Cristina (szerk): Hispanismo y cine. Id. mü. 119-141; Gil, Alberto: La censura cinematográfica en España. Barcelona, Ediciones B, 2009; González Ballesteros, Teodoro: Aspectos jurídicos de la censura cinematográfica en España. Madrid, Editorial de la Universidad Complutense, 1981; Neuschafer, Hans-Jörg: Adiós a la España eterna. Madrid - Barcelona, Ministerio de Asuntos Exteriores Editorial Anthropos, 1994.

${ }^{55}$ Bár a FilmHistoria Online, a Secuencias és az Archivos de la Filmoteca hivatalos besorolása folyóirat, ezek valójában évente két-három alkalommal megjelenő tanulmánykötet-sorozatok, amelyek Spanyolország és a világ legelismertebb filmtörténészeinek írásait közlik.
} 
történelem kapcsolatát mind spanyol, mind nemzetközi viszonylatban. A Dirigido por a filmrendezőket helyezi középpontba és rajtuk keresztül közelít egy adott ország filmtörténetéhez. A spanyol filmipar és filmmüvészet jelenlegi állapotáról a Spanyol Filmakadémia havonta megjelenö lapja, az Academia. Revista del cine español közöl adat- és részletgazdag tanulmányokat, portrékat és részben tudományos, részben ismeretterjesztő jellegü írásokat. A már megszünt Contracampo, valamint a közel 200 oldalas tematikus számaival megjelenő, 2003-ban felszámolt Nickel Odeon szintén értékes tanulmányokkal járultak hozzá a filmtörténet elemzéséhez.

Értekezésem témája miatt nem szólok azokról a könyvekről és monográfiákról, amelyek döntően nem filmtörténeti, hanem filmesztétikai és filmelméleti szemszögből közelítenek a film mint médium kérdéséhez, valamint a nemzetközi filmtörténetet (mindenekelőtt az amerikait) tárgyalják. Mindkét területen rendkívül szerteágazó szakirodalom áll rendelkezésre spanyol szerzők tollából, többet közülük a világ egyetemeinek filmelméleti képzésein kötelező tananyagként használnak.

A disszertáció további oldalain, egyes filmpolitikai intézkedések, törvények, témák (mint a cenzúra, a filmhíradók vagy a polgárháborús filmek) és filmek kapcsán más jelentős és értékes müvekre is hivatkozom.

A spanyol filmtörténet szakirodalma igen gazdag. Ezek általában az egész filmtörténetre vonatkoznak, vagy konkrét periódusokat vesznek nagyító alá, mindenekelőtt filmmüvészeti és filmtörténeti szempontú értekezések. Esettanulmányként használhatóak azok a munkák, amelyek egy-egy város, régió vagy autonóm közösség kapcsán mutatják be, milyen konkrét jelenségekkel találkozott a társadalom a mindennapok során egy adott korszakban mind a filmkészítés, mind a filmnézés terén. ${ }^{56}$

\footnotetext{
${ }^{56}$ Ilyen témájú, általam ismert és használt könyvek az Albacete esetét vizsgáló García Rodrigo, Jesús Rodríguez Martínez, Fran: El cine que nos dejó ver Franco. Toledo, Junta de Comunidades de Castilla-La Mancha, 2005; az Asztúria filmtörténetét tárgyaló Lorenzo Benavente, Juan Bonifacio: Asturias y el cine. Gijón, Mases Ediciones, 1984 és Caparrós Lera idézett könyve, amely autonóm közösségenként mutatja be két kötetben a spanyol filmgyártás fejlődését: Cine Español. Una historia por autonomías, Vols. I-II. Id. mü.
} 


\section{A film mint történeti forrás}

\section{Mi a film ${ }^{57}$}

A mozgókép a 19. század végén az ipari forradalom szülötteként jött létre. Elterjedéséhez szükséges előfeltétel volt, hogy a modern civilizációban megjelenő technikai újdonságokat megfelelő módon tudja hasznosítani a társadalom.

Ami 1895-ben, a Lumière testvérek első filmvetítésén csak szórakoztató, általános kikapcsolódást szolgáló új találmánynak tűnt, az a 20. században már jóval többnek bizonyult. A filmfelvevőgép újdonsága, a vetítés „csodája” a nézőket lenyügözte, de az értelmiségi réteget eleinte taszította. Hosszú időnek kellett eltelnie, amíg mủvészeti ágként kezdtek közeledni a filmkészítéshez, annak termékére pedig értékes, érdekes, nem lebecsülendő produktumként tekintettek. A 20. század elejétől napjainkig terjedő időszakban a film hosszú utat járt be: a kezdeti vélekedésből, mely szerint a film nem több, mint kizárólag az alsóbb néprétegek számára szórakozást nyújtó eszköz, mára általánosan elfogadottá vált, hogy a filmmüvészet egyike a sokak által tisztelt és elemzett müvészeti ágaknak. Része lett a kulturális életnek, a művészeti kánonnak, a mindennapoknak, és már messze nem csak szabadidős tevékenységnek számított egy film megtekintése. Az elmúlt évtizedekben az úttörő kinyilatkoztatások után (Ricciotto Canudo már 1911-ben „hetedik művészetként” aposztrofálta a filmet: az építészet, a szobrászat, a festészet, a zene, a tánc és a költészet összeolvadásaként és tökéletesedéseként létrejött művészeti formaként ${ }^{58}$; ez a kijelentés akkoriban még nem aratott osztatlan sikert) lassan beszivárgott a magas kultúra (high culture) szféráiba is a mozgókép művészete.

A modern civilizáció kialakulásának egyik velejárója volt az egyetemes filmkultúra megszületése és elterjedése. A mozgókép rohamtempóban hódította meg a társadalmakat Európában és az amerikai kontinensen is. Egy olyan új, szórakozásra és kikapcsolódásra kiváló alkalmat nyújtó eszközt láttak a kamera teremtette illúzióban, amely bővíti a mindennapok elől búvóhelyet kereső emberek lehetőségeit. Az 1910-es és 20-as évektől a mozi egyre népszerübbé vált minden réteg számára.

\footnotetext{
${ }^{57}$ Az alfejezet címe a filmelméletek egyik atyja, André Bazin eredetileg négy kötetben kiadott francia nyelvü monográfiájának címére utal. Bazin, André: Qu'est-ce que le cinéma ? Éditions du Cerf, Collection "Septième Art", 1958-1962. ( magyarul: Bazin, André: Mi a film? Budapest, Osiris Kiadó, 2002.)

${ }^{58} \mathrm{Az}$ 1911-ben írt és olasz nyelven első ízben 1914-ben publikált A hét müvészet kiáltványa címü röpirata magyar nyelven megtalálható a Magyar Filmtudományi Intézetben. Filmelméleti munkásságának kifejtése: Canudo, Ricciotto: A hetedik müvészet esztétikája. Budapest, MFI, 1961.
} 
Az alcímben feltett kérdésre nem lehet egyértelmü választ adni, mindenki számára mást jelent a film fogalma. Nem csak attól függően különböznek az értelmezések, hogy technikai, esztétikai, müvészeti, vagy esetleg ipari szempontból közelítjük-e meg a kérdést. Dolgozatomnak nem célja elméleti fejtegetésekbe bocsátkozni, ezért inkább csak olyan alapvető megállapításokat teszek, amelyek a mozgókép mibenlétének legfőbb vonásait emelik ki, egyszersmind előzetesen megindokolják annak a társadalomra gyakorolt hatását.

A film olyan müvészeti forma, amely dinamikussá teszi a megjelenítendő személyt, tárgyat, eseményt, azt önnön mozgásában képes visszaadni, szemben a vele rokonságban álló fényképészettel. Így adja meg az életszerüség és a valósághü mozgásformák illúzióját. A korai teoretikusok felfedezték a film és a valóság közötti szoros kapcsolatot, a mozi védelmezői arra hivatkoztak, hogy a film az összes korábban kialakult müvészeti formánál hívebben tudja leképezni a körülöttünk lévő világot, és nem csak másolja azt, vagy reflektál a történésekre. A későbbi évtizedekben a hangosfilm megjelenésével vizualitásból audiovizualitássá fejlődött. A filmvászon alakjai már verbális kapcsolatba is kerültek a közönséggel, kialakítva egy olyan új világot, amely még a korábbiaknál is nagyobb eséllyel vonta hatása alá a közönséget.

Mindennek alapját a kép jelenti. A film képe azonban nem egy önmagában álló izolált egység, több kép egymásutánisága, azok egysége adja a folyamatosságot és a mozgás illúzióját. Nem kimondja vagy leírja a szóban forgó tárgyat, hanem megmutatja, és ehhez felhasználja a rendelkezésére álló összes elemet: kép, hang, beszéd, zene, felfüzve az irodalom világából adaptált cselekményvezetésre, narratív struktúrákra. A konkrét, beszélt nyelven kívül a film saját nyelvezetével van jelen térben és időben. Társadalmi kommunikációt kezdeményez a nézővel, miközben az alkotók személyes önkifejezését valósítja meg. A legáltalánosabb - kevésbé tudományos, inkább közönségbarát - vélekedés szerint pedig a néző ébren álmodhat, azonosulhat a film hősével, úgy érezheti, mintha ő maga élné át a látott kalandokat, történeteket. A film világába menekülhet a igazi valóság elől.

Pier Paolo Pasolini olasz rendező filmesztétikai tárgyú írásaiban fejti ki, hogy a filmekben a valóságot magával a valósággal ábrázolhatja, és nem a nyelv áttételével reprezentálja. Szerinte a képeknek azért nincsen szótára, mert az végtelen mü, mint az élet és a világ. A képek szótárát lehetetlen összeállítani, helyette inkább filmeket kell készíteni. ${ }^{59}$

A filmet sok tényező alakítja. Az 1910-es évektől kezdve egész iparág épült köré, amely tekintélyes gazdasági hatalommá fejlődött. Ahhoz, hogy a filmvilág létrejöhessen,

\footnotetext{
${ }^{59}$ Idézi: Dobai Péter - Pintér Judit - Szkárosi Endre: „Szenvedély és ideológia. Dialógus Pier Paolo Pasoliniről” in: Filmvilág, 2010/12. 6.
} 
szükség volt jól szervezett stúdiókra, a tőkét adó, a piaci viszonyokat jól ismerő és megfelelő kapcsolatokkal rendelkező üzletemberek bevonására, a publicitás megszervezésére, a szükséges infrastruktúra felállítására. A filmeket gyártó profitorientált cégek kezdettől fogva fogyasztásra szánt terméket készítenek. A gyártás, terjesztés és bemutatás adja egy film „élettörténetének” három fó állomását, és minden ilyen fázisban anyagi szempontok játsszák a föszerepet, alárendelve céljaiknak a müvészeti aspektust.

A jelenség összetettségét mutatja, hogy a fentiekből kiindulva a filmet értelmezhetjük művészeti megnyilvánulásként, ipari szektorként, kommunikációs eszközként és nyelvi formaként is.

A film elsődleges szerepe a szórakoztatás, de kezdettől fogva hozzáadódik az informálás és a meggyőzés célrendszere is. A színház, a varieté müsorok, a cirkusz, és a különböző müvészeti előadások, esetleg sportesemények közül választhattak korábban az emberek, ha szabadidejüket könnyed szórakozással szerették volna eltölteni. A filmvetítés megjelenésével egy új lehetőség nyílt meg az előbbiek mellett, amely idővel a legfelsőbb réteget is vonzotta, az arisztokráciának magánvetítéseket rendeztek, és a legalsóbb osztályok is érdeklődni kezdtek iránta, mert a szerényebb anyagi körülmények között élők is meg tudták fizetni ezt a szórakozási formát. Végül az egész társadalomra nagy hatást fejtett ki. Douglas Gomery átfogó monográfiájában megosztott élvezetnek nevezi azt a jelenséget, amely kezdettől fogva a filmvetítések egyik vonzereje: a közönség együtt vesz részt az eseményen, közösen válnak részeseivé, és a megtekintés után még sokáig visszatérő téma lehet a megtekintett alkotás beszélgetéseikben, levélváltásaikban, vitáikban ${ }^{60}$. Egy adott ország mozibajárási szokásait ezek mentén tökéletesen meg lehet vizsgálni.

\section{A történész és a film}

A film huszadik századi találmány, amely huszadik századi eszközökkel ábrázolja a jelen vagy a régmúlt idők történéseit. A módszer azonban ma is vitatott. A realista filmelméletek hívei (többek között Hugo Münsterberg, Szergej Eizenstein, Rudolf Arnheim) szerint a film hủen tükrözi a valóságot, objektíven közelít, részleteiben képes visszaadni a való világban történt dolgokat, akár múltbéli, akár egyidejủ eseményekről is legyen szó. Ezzel szemben a formalista elméletek követői (mint André Bazin vagy Siegfried Kracauer) úgy vélik, bármit is rögzít a kamera, az már a valóság egyéni értelmezése, minden a rendező, a forgatókönyvíró és az operatőr saját kreációja, a realitás csak háttérként és kiindulópontként

\footnotetext{
${ }^{60}$ Gomery, Douglas: Shared Pleasures: A History of Movie Presentation in the United States. Madison, The University of Wisconsin Press, 1992.
} 
szolgál; amit látunk, az maga a művészet. ${ }^{61}$ Bármelyik nézőponttal is értünk egyet, a filmet mindkét esetben tekinthetjük egy adott korból hátramaradt forrásnak, amely sokat elárul mind az ábrázolt korról, mind a film forgatásának időszakáról. Ahogyan más források esetében, úgy a film kapcsán is szükséges, hogy a kutató kritikai szemlélettel közelítsen a vizsgálandó anyaghoz, felismerje, mely részletek relevánsak a cél elérése érdekében, tudjon szelektálni a vizuális anyagok között, és eldöntse, milyen forrásértékkel bír a kérdéses dokumentum.

A filmeket ugyanakkor nem szabad a benne ábrázolt kor és események tükörképeként kezelni, ahogyan a hagyományos történészi forrásokat sem. Minden, amit jelenkori és múltbeli eseményekről vetünk papírra (vagy adaptálunk filmvászonra), már csak szubjektív értelmezése a tényeknek.

A film és a történelem kapcsolatát tárgyaló könyvek és kötetek ${ }^{62}$ tanulmányai mind megfogalmazzák a legfőbb kételyeket is: a film az esetek többségében talán manipulálja, elferdíti, súlyosabb esetben meghamisítja a történelmet. Lehet egyáltalán megbízható forrásként kezelni a mozgóképet? A válasz egyszerünek tünik: amennyiben a kutató rendelkezik a szükséges tudással ahhoz, hogy el tudja választani a tényeket a történelemhamisítástól, akkor a film, mint a képekkel és hangokkal operáló reprezentáció eszköze, segítheti a történész munkáját. A filmet még nem forrásként használó történészek részéről nem fogalmazódott meg egyértelmű ellenérv a film használata ellen, mindössze a fent említett szubjektivitás és manipuláció (vagy hazugság) veszélyeire figyelmeztetnek. ${ }^{63} \mathrm{Az}$ ilyen nem hangsúlyos, de tetten érhető pesszimizmus miatt fordulhat elő, hogy a film egyes országokban még nem tölt be fontosabb szerepet a történeti kutatásokban.

Marc Ferro tette fel a kérdést, vajon meg lehet-e írni a történelmet filmek segítségével? Vagyis: felruházható-e a kamera azokkal a tulajdonságokkal, amelyekkel egy írószerszám? Ő maga is részben nemleges választ adott a felvetésre. Minden történelmi tárgyú film ugyanis egy mások által korábban már kifejtett történeti vízió újraértelmezése, a történelmi tényeket bemutatni szándékozó filmesek saját nézőpontjukat ültetik át a filmvászonra, míg más

\footnotetext{
${ }^{61}$ A két szemlélet közötti alapvető különbségeket összegzi: Arnold, Brandon: „Realism, Formalism and Classicism" in Les Cahiers du East Hollywood Cinema

Elérhető: http://filmhistory.wordpress.com/2007/08/31/realism-formalism-and-classicism/ (2012-11-20)

A föbb filmelméletekkel és teoretikus állásfoglalásokkal foglalkozik, többek között: Andrew, Dudley: The Major Film Theories: An Introduction. Oxford University Press, 1976; Stam, Robert: Film Theory. An Introduction. Oxford, Blackwell Publishers, 2000; Cristian Réka Mónika - Dragon Zoltán: Encounters of the Filmic Kind: Guidebook to Film Theories. Szeged, JATE Press, 2008.

Magyar nyelven lásd, többek között: Bíró Yvette: A hetedik müvészet. A film formanyelve, a film drámaisága. Budapest, Századvég, 1994 (és későbbi kiadások).

${ }^{62}$ Lásd a korábbi „Historiográfiai előzmények” című fejezetet.

${ }^{63}$ Erről is értekezik Ormos Mária: Van-e történelem? címü előadásában, amely a Mindentudás Egyeteme keretében hangzott el 2003-ban.

Megtekinthető: http://mindentudas.hu/elodasok-cikkek/item/49-van-e-történelem?.html (2012-11-20)
} 
valószínűleg eltérő aspektusból közelítene. Ugyanakkor ez nem azt jelenti, hogy a filmművészet nem segíthet a múlt feltérképezésében, megnyitásában a jelen embere felé. Bizonyos rendezők képesek arra, hogy nem ítélkeznek a múlt felett, inkább csak enyhe részrehajlással orientálnak, új távlatokat nyitnak meg a néző előtt, segítenek neki új látásmódokat felfedezni. A történelmi tény tehát a filmek segítségével még inkább relatívvá válik. Ferro szerint ebbe a kategóriába kevesen tartoznak, ő Andrej Tarkovszkijt, Luchino Viscontit és Ousmane Sembènét sorolja ide. ${ }^{64}$ Véleményem szerint Theodoros Angelopoulos és a Taviani testvérek is beilleszthetők ebbe a sorba, de bizonyos megkötésekkel Andrzej Wajda is.

Minden történelmi eseményre több reakció is lehetséges. A filmes személye, politikai meggyőződése, az alkalmanként objektivitásnak beállított elkerülhetetlen szubjektivitása, intelligenciája, az éppen fennálló politikai berendezkedés mind befolyásolják, hogyan jelenik meg az ábrázolás tárgya a vásznon. Ritka, hogy egy filmrendező legalább két nézőpontot is figyelembe vegyen, inkább az adott nemzethez vagy ideológiához tartozó filmesek készítik el a saját változataikat. ${ }^{65}$

Nem hagyhatjuk figyelmen kívül azt sem, hogy az írott történelemmel szemben a filmes történelem egyáltalán nem teljes, a világtörténet meghatározó eseményei nem részei még a filmes kánonnak. Az alkotók (vagy megrendelőik) személyes döntésén múlik, mely mozzanatokat tartják megörökítésre érdemesnek múltjukból vagy jelenjükből. Pierre Sorlin szavaival élve: ,,a képernyő nem azt mutatja meg, hogy milyen a világ, hanem azt, hogy egy adott korszakban milyennek látják, láttatják azt." ${ }^{, 66}$ Ez a megállapítás, véleményem szerint, a hagyományos történetírásra is teljes mértékben igaz.

A film, hasonlóan a többi tömegkommunikációs eszközhöz, nagy hatással van az egyén érzékelési mechanizmusaira. Viselkedési normákat, hiedelmeket, az addigitól eltérő életstílust, teljesen új világlátást képes kialakítani a nézőkben. Ez a mindennapok során is megmutatkozott az Amerikai Egyesült Államokban, amikor a 40-es és 50-es évek csillagai, valamint a 70-es és 80-as évek tévésztárjai igazi személyiségformáló erővel bírtak. A történelem kapcsán ugyanez elmondható: ha eléggé karizmatikus személyiséggel és meggyőző erővel bíró filmesek próbálják elhitetni a nézővel, hogy a múlt értelmezése csak az

\footnotetext{
${ }^{64}$ Ferro, Marc: Cinema and History. Detroit, Wayne University Press, 1988. 162-163.

${ }^{65}$ A kivételek közé tartoznak a közelmúltból Clint Eastwood „testvérfilmjei”, A dicsőség zászlaja (Flags of Our Fathers, 2006) és a Levelek Ivo Dzsimáról (Letters from Iwo Jima, 2006). Mindkét mủ a második világháború egyik elhíresült csatáját, az Ivo Dzsima szigetén lezajlott ütközetet mutatja be Eastwood rendezésében, előbbi amerikai, utóbbi japán szemszögböl. A rendező eredeti szándékát, amely szerint semleges nézőpontot képviselve közelíti meg a témát, viszonylag sikeresen teljesítette, nem mentesülve a kötelező hollywoodi pátosztól.

${ }^{66}$ Sorlin, Pierre: Sociologie du Cinéma. Id. mü. 33-34.
} 
általuk kifejtett módon történhet, véleményüket hajlamosak lehetnek széles körben is megkérdőjelezhetetlennek vélni, még akkor is, ha sok elem csak a fantázia szüleménye. ${ }^{67}$ Így tehát az is egyre gyakrabban megesik, hogy egy film módosítja a történelmet, pontosabban, bizonyos személyek történelemről vallott elképzeléseit.

A filmes önálló döntése, hogy mi kerül a vászonra. Nem csak az események között szelektál, de azokon belül is csak rajta múlik, hogy milyen momentumokat emel ki, hallgat el, esetleg értelmez újra (vagy hamisít, szélsőséges esetben). Az ilyen bizonytalansági tényezők miatt fontos kiemelni, hogy egy történelmi film, vagy egy konkrét történelmi korban készült munka nem helyettesíti az írott anyagokat, hanem kiegészíti, esetleg színesíti azokat. Szükséges a korszak ismerete ahhoz, hogy el tudjuk választani a valóban megtörtént eseteket a kitalációtól.

A történetírás analógiája használható a filmkészítésre is. Két kort különböztethetünk meg: azt, amelyet a film ábrázol, valamint a film elkészítésének idejét. Játékfilmek esetében a két kor a legtöbbször megegyezik, de számos alkalommal, például történelmi, háborús, vagy western filmek esetében, egy letünt kort próbálnak ábrázolni több-kevesebb hitelességgel. Dokumentumfilmeknél gyakrabban nyúlnak vissza a készítők múltbéli eseményekhez. A két idősík számos kérdést vet fel, több értelmezési lehetőséget biztosít az érdeklődő történésznek, kutatónak.

A legtöbb esetben megállapítható: egy film leginkább azt a kort tükrözi vissza, amelyben a forgatás lezajlott, és nem azt, amit ábrázol. A múlthoz a jelen perspektívájából közelít. Egy film elsősorban arról mesél nekünk, hogy a forgatás idején az alkotó stáb mit tartott fontosnak elmesélni a múlt történéseiből, hogyan, milyen módszerrel, nézőpontból és eszközökkel tette azt, és hogyan viszonyul egy filmmüvészet keretein belül dolgozó csoport a saját vagy egy más nemzet történelméhez. Ez leginkább akkor lehet érdekes, ha az alkotó a saját nemzeti történelme egy epizódjához nyúl vissza. A demokráciákban alkotó filmkészítőknek általában nem áll szándékukban „történelmet csinálni”, csak elmesélni, lefesteni akarnak egy adott korszakot. Az elkövetkezendő évek-évtizedek számára mégis fontos lesz ez a végtermék, amely az ország társadalmáról vagy a világ egyes szegmenseiről adhat röntgenképet, és akár a történelmi emlékezet értékes részévé is válhat.

Tágabban értelmezve a film müfaját, annak környezetét vizsgálva is fontos következtetésekre juthatunk a kor társadalmát illetően. Társadalmi elhelyezkedésüket tekintve mely réteg járt moziba a vizsgált időszakban? Milyen volt a közönség nemek szerinti

\footnotetext{
${ }^{67}$ Oliver Stone filmrendező amerikai történelemről, társadalomról, elnökökről szóló művei talán legjobb példáját adják ennek a kategóriának.
} 
megoszlása? Ezek a kérdések több tekintetben is fontosak lehetnek. Egyrészt megmutatják, mely rétegeknek milyen mértékben volt lehetősége moziba menni anyagi helyzetük függvényében. Másrészt arra is választ kaphatunk, hogy a felsőbb, a középső vagy az alsóbb társadalmi rétegek voltak-e fogékonyabbak a filmben látottakra. Az ország gazdasági helyzetét vizsgálva is adalékként szolgálhatnak a filmszínházakra vonatkozó adatok, azok elhelyezkedése (tömegek által frekventált belváros vagy szegényebb külváros), illetve a mozijegyek ára. ${ }^{68}$

A gazdaságtörténet mellett más történeti ágak is hasznosíthatják a filmgyártás nyújtotta információkat. Az eszmetörténet számára például igen gazdag a lehetőségek tárháza: egy adott kor és társadalom eszmeiségét, uralkodó ideológiáját tükrözik vissza a filmes produktumok, és mindez kiegészül a high culture - popular culture (magas és populáris kultúra) szembenállását vizsgáló irányzatokkal, amelyek egyes filmeket, filmes irányzatokat besorolnak saját kategóriájukba. ${ }^{69}$ Howard Hawks és Billy Wilder amerikai komédiái, Claude Chabrol pszichológiai esettanulmányként is értelmezhető francia társadalomrajzai, Mario Camerini az olasz fasizmus idején készült vígjátékai, az amerikai Spike Lee korai filmjei mind hü képet adnak az adott nemzet vagy társadalmi-etnikai csoport pillanatnyi állapotáról, problémáiról.

A 70-es évektől kezdve vált egyre inkább elfogadottá, hogy a filmnek helye van a történész által felhasznált források között. Számos intézményben bizottságok, kutatócsoportok jöttek létre, ezek közül úttörő volta miatt kiemelkedik az Amerikai Egyesült Államokban a Történész Filmbizottság (Historians Film Committee) 1970-töl. Az elkövetkezendő években más országok egyetemei és történész társaságai is hoztak létre hasonló kutatócsoportokat.

\footnotetext{
${ }^{68}$ A legtöbb ország filmgyártására vonatkozóan készültek már ilyen munkák, amelyek a nemzet anyanyelvén vagy angol nyelven íródtak. Néhány példa angolul: Richards, Jeffrey - Aldgate, Anthony: Best of British: Cinema and Society from 1930 to Present. London, I.B. Tauris, 1999; Kenez, Peter: Cinema and Soviet Society from the Revolution to the Death of Stalin. London, I.B. Tauris, 2001; Shafik, Viola: Arab Cinema: History and Cultural Identity. Cairo, American University in Cairo Press, 2007; Tegel, Susan: Nazis and the Cinema. Hambledon Continuum, 2008; Ricci, Steven: Cinema and Facism. Italian Film and Society, 1922-1943. University of California, 2008.

Globális szempontból a film és a társadalom kölcsönhatását vizsgálja: Jarvie, Ian: Towards of Sociology of the Cinema: A Comparative Essay on the Structure and Functioning of a Major Entertainment Industry. London, Routledge \& Paul Kegan, 1970 és Shiel, Mark - Fitzmaurice, Tony: Cinema and the City: Film and Urban Societies in a Global Context. Oxford, Blackwell Publishers, 2009.

Magyar nyelven Thompson-Bordwell: A film története (id. mü) ad betekintést a nemzetek társadalma és filmgyártása közötti viszonyrendszerbe.

${ }^{69}$ Alapvető megközelítést ad: Storey, John: Cultural Theory and Popular Culture. An Introduction. London, Longman, 2009 (és korábbi kiadások). A legtöbb magas és populáris kultúrával foglalkozó mü megvizsgálja adott filmek ebben a dimenzióban való elhelyezkedését, Storey könyve a lényegi kérdéseket tárgyalja.
} 
Ugyanebben az évtizedben született meg az első próbálkozás olyan módszertan kialakítására, amely segítségével a történész hasznos forrásként kezelheti a filmet. ${ }^{70}$

\section{Alapvetö filmtípusok}

Egy történész számára számos aspektusból szolgálhat a film forrásként. A különböző filmmüfajok, filmtípusok (filmhíradó, dokumentumfilm, játékfilm) rávilágíthatnak egy adott ország történelmének bizonyos mozzanataira, fontosabb eseményeire vagy személyeire, kiegészítve a történeti vizsgálódást végző kutató addig elért eredményeit.

\section{A filmhíradó}

Az egyidejűség legjobb példája a filmhíradó műfaja. A korabeli közönség számára készült híradó elsősorban informatív célokat szolgált, a nézőket tájékoztatta bel- és külpolitikai, társadalmi kérdésekről. Közvetlenül az emberekhez szólt, tudósította őket a legfontosabb eseményekröl. A közönség privilegizált helyzetben érezhette magát, mintha ő maga is részt vett volna a megidézett eseményen. A legfőbb cél az volt, hogy a filmhíradót megtekintő polgár informálva érezze magát, mintha az állam fontosnak tartaná, hogy tájékoztassa őt a világban történtekről.

A demokráciákban is alkalmazták a manipuláció eszközét ebben a müfajban, a befolyásolás azonban szélsőséges méreteket öltött, ha a diktatúrák filmhíradóit tekintjük. Diktátorok és állampárti vezetők, különböző mértékben, de hasonló hatékonysággal használták fel a tájékoztatás szóban forgó eszközét. Leginkább Hitler és Mussolini esetében lehet ismert a híradókból visszaköszönő kép: mindketten igazi „színészként” viselkedve, mozdulataikat előre megtervezve, az operatőröknek elözetesen kiadott utasítások nyomán valódi előadásokat mutattak be a filmfelvételeken, amelyeket a nép elsősorban a moziban tekinthetett meg. Ezek föleg a nagyközönség előtt elmondott beszédek rögzített változatai voltak, később hivatalos események, például avatóünnepségek, diplomáciai látogatások felvételeit továbbították. És éppen ebben áll történeti forrásértékük. Könyvekből, tanulmányokból, írott forrásanyagok közzétételéből a történésznek viszonylag világos képe van a fent említett személyek politikai döntéseinek természetéről, azok mozgatórugóiról, a világpolitika eseményeiről, de az állami vezető mint individuum kevéssé ismert számára. A filmhíradó tanúsítja, hogyan viselkedett a vezér a publikum elött, milyen gesztusokkal közvetítette mondanivalóját, és a nép hogyan reagált erre. A filmfelvétel mindent megmutat: a

\footnotetext{
${ }^{70}$ Jackson, Martin A.: „Film as a Source Material: Some Preliminary Notes Toward a Methodology” in: The Journal of Interdisciplinary History, Vol. IV. 1973. 73-80.
} 
szónokot körülvevő díszlet, a rögzítés technikai elemei (például alulról történő fényképezés, hogy a személy nagyobbnak, jelentősebbnek tünjék) mind a személyi kultuszról vagy éppen az azt kialakítani segítő részletekről árulkodnak. Szintén hasznos adalékként szolgálhatnak azok a híradórészletek, amelyek a mindennapi élet valamelyik területére vonatkoznak, a boltokban történő sorban állástól a munkával töltött hétköznapok visszaidézéséig. Mindez persze csak a felszínt láttatta: a filmhíradónak semmi köze sem volt a későbbiekben divatossá vált tényfeltáró riportokhoz, és az elméletileg összetartozó híreket sem kapcsolta egymáshoz, mert fennállt a veszélye, hogy a néző esetleg összeillesztheti a mozaikokat. A történész számára értékes információkat tartalmaz a híradó: a valóság mely részét engedte nyilvánosságra hozni a belföldi vagy külföldi közönség számára, illetve milyen üzeneteket akart közvetíteni a hivatalos politika. ${ }^{71}$

\section{A dokumentumfilm}

A dokumentumfilm sok szempontból rokonítható müfaj volt a filmhíradóval, ez utóbbi megszűnése után, a tévéhíradó megszületésével különültek el igazán két különböző zsánerré. Eredeti szándéka szerint a dokumentumfilm dokumentumértékű, vagyis a valóságot objektív módon, a tényekhez ragaszkodva, az igazság oldaláról mutatná be, szemben a játékfilmmel. Ez a kitétel azonban szintén vitatott, mert a dokumentumfilmnek is van rendezője, a legtöbb esetben forgatókönyvírója is, de mindenképpen rendelkezik operatőrrel, aki megválasztja, mit, hogyan, milyen szögböl, milyen hosszan rögzítsen. Különösen igaz ez a diktatúrák hivatalos dokumentumfilmjeire, amelyek a manipuláció legfontosabb eszközévé léptek elő. John Grierson, a brit dokumentumfilm-gyártás egyik megalapozója úgy definiálta ezt a müfajt, mint a „valóság kreatív kezelése”72. Egy állami megrendelésre készült dokumentumfilm bemutatja, hogyan is vélekedik az adott nemzet politikai vezető rétege az országról, mit tart érdemesnek kiemelni, hangsúlyozni, ugyanakkor mi hiányzik, miről nem beszélnek: a történész ezek alapján közelebb kerülhet az adott korszakhoz és az azt uraló és irányító ideológiához. Legkiemelkedőbb példaként említhető Leni Riefenstahl munkája, a Nemzetiszocialista Párt kongresszusát megörökítő Az akarat diadala (Triumph des Willens, 1935). Dokumentumértéke elvitathatatlan: Adolf Hitler felmagasztalása, a rajongó tömeg bemutatása, mindez korszakalkotó technikával megvalósítva, a tökéletes propagandafilm

\footnotetext{
${ }^{71}$ Filmhíradókkal foglalkozó, általam is ismert munkák: Bartels, Ulrike: Die Wochenschau Im Dritten Reich: Entwicklung Und Funktion Eines Massenmediums Unter Besonderer. Frankfurt am Main - Berlin - Bern Brüsszel - New York - Oxford - Wien, Peter Lang, 2004; Fielding, Raymond: The American Newsreel: A Complete History, 1911-1967. Jefferson, McFarland \& Company, 2006; Tranche, Rafael. R . Sánchez Biosca, Vicente: NO-DO: El tiempo y la memoria. Id. mü. Egy adott ország filmgyártásával, filmtörténetével foglalkozó könyv az esetek többségében kitér a nemzeti filmhíradók elemzésére, bemutatására.

${ }^{72}$ Evans, Gary: John Grierson: Trailblazer of Documentary Film. Montréal, Dundurn, 2005. 11.
} 
modellje. A történész számára Riefenstahl filmjei kötelező darabnak számítanak, mint az értékes filmforrás prototípusai.

Egy államhoz nem kötődő magánszemély vagy bizonyos mértékben független produkciós cég dokumentumfilmje abba engedhet bepillantást, hogy egy kívülálló mit mutathatott be az adott korból, az élet mely szegmensei juthattak át a cenzúra szürőjén.

További információkkal szolgálhat az olyan típusú dokumentumfilm, amelyet egy elnök vagy diktátor saját magáról készíttet egy megbízható rendező segítségével, mint Spanyolországban a Franco, ez az ember (Franco, ese hombre, José Luis Sáenz de Heredia, 1964). Az ilyen dokumentumfilm szembeállítható a hasonló tematikájú, de ellentétes politikai meggyőződésű filmes mühelyből kikerülő munkákkal, mint a szintén spanyol Caudillo (Basilio Martín Patino, 1973); ez utóbbi még a diktatúra idején, a legnagyobb titokban készülhetett csak el. A későbbiekben még mindkettőről ejtek szót.

A filmek „értékes” tulajdonságai mellett olyat is találhatunk, amely egyenesen nélkülözhetetlen egy kutató számára. Ez akkor fordulhat elő, amikor a film mint bizonyíték, az egyetlen hasznosítható forrás szerepét tölti be. Ilyen a Kennedy-gyilkosságot megörökítő rövidfilm, a Zapruder Film (Zapruder Film, Abraham Zapruder, 1963); a merénylet körülményeit vizsgáló Warren-bizottság is elsődleges bizonyítékként használta fel, és azóta is a témával foglalkozó történészek egyik fontos segítsége. Ehhez kapcsolódnak azok a merényleteket, katasztrófákat megörökítő rövid dokumentumfilm-értékü felvételek, amelyek a szemtanú szerepét tölthetik be a későbbi vizsgálatok során. A filmek és dokumentumfilmek esetenként tehát nem csak érdekes, de szükséges forrásként is kezelhetőek. Vannak olyan történelmi helyzetek, amelyek megítélésekor döntő lehet a vizuális bizonyíték. Jó példa erre a spanyol polgárháborúban Guernica bombázása és annak filmes bizonyítékai. ${ }^{73}$

\section{A játékfilm}

Akár megtörtént eseményeken alapul, akár teljes mértékben fikciós elemekből építkezik egy játékfilm, a történész számára ez a müfaj szolgál az egyik leghasznosabb, ugyanakkor legellentmondásosabb forrásbázisként. A sokszor száraz stílusú dokumentumfilmekkel ellentétben a játékfilm, a színészek segítségével előadott történetmesélés mindig is sokkal közelebb állt a nézőközönséghez, jobban és könnyebben befogadták azt.

Jelentős forrásértékkel bír az a film, amelyben a forgatás időszaka és az ábrázolt kor egybeesik. Totalitárius vagy autokratikus rendszerekben a film mondanivalója és a közönség felé közvetített üzenet nem térhet el jelentősen a hivatalos ideológiától, ugyanis a cenzúra ezt

\footnotetext{
${ }^{73}$ A témáról a polgárháborús alfejezetben lesz szó.
} 
nem engedné meg. Minden diktatúrából számtalan példa hozható arra, hogyan próbálták meg népszerüsíteni az állami politika által vallott nézeteket. A szovjet Patyomkin páncélos (Броненосеи Потёмкин, Szergej Mihajlovics Eizenstein, 1925) és az Október (Октябрь, Szergej Mihajlovics Eizenstein, 1928), a német A zsidó Süss (Jud Süß, Veit Harlan, 1940) vagy a spanyol Faj (Raza, José Luis Sáenz de Heredia, 1942) mind igazi klasszikusnak számítanak ebben a kategóriában, de a demokrácia is kitermelte a maga hatásos, a történelmi - társadalmi jelenségeket nagyban befolyásoló filmjeit. Ezek közül leghíresebb az Egy nemzet születése / Amerika höskora ${ }^{74}$ (The Birth of a Nation, David W. Griffith, 1915), amely a kor társadalmi hangulatának lett tükörképe, és nagy szerepet játszott az USA-ban a Ku-Klux-Klan modernizálódásában és népszerüvé válásában. Külön érdekesség történészi szemmel vizsgálni azokat a munkákat, amelyek szintén azonos korban készültek, de érezhető rajtuk az ironikus, a fennálló rend visszásságait érzékeltető hangvétel. Ez lehet „,belső ellenállás”, mint $A$ tanú (Bacsó Péter, 1969) és A hóhér (El verdugo, Luis García Berlanga, 1963), vagy kívülről érkező kritika, mint A diktátor (The Great Dictator, Charles Chaplin, 1940).

A játékfilm konkrét helyzeteket középpontba állítva rekonstruálni próbál eseményeket, a rendező szubjektív látásmódját közvetíti a beállítások és a montázstechnikák segítségével. A történésznek tisztában kell lennie azzal, hogy a film készítője milyen céllal forgatta munkáját. Pusztán szórakoztatni kívánt, és az ábrázolt kor csak díszítőelemként szolgál a cselekményhez, vagy hiteles kordokumentumot akart készíteni. Tévútra viheti ugyanis a kutatót, ha mindent valóságosnak vesz, amit a filmen lát, szükséges tehát a „kritikai szem”, amellyel meg tudja különböztetni a tényeket a forgatókönyvíró fantáziájának szüleményétől. A történész ebben az esetben előnnyel indul az átlagos filmnézővel szemben, mivel ideális esetben eléggé jártas a korban, ismeri az eseményeket és a felsorakoztatott főbb szereplők egy részét, de még számára is újdonsággal bírhat a Hitler és a nácizmus végnapjait bemutató $A$ bukás (Der Untergang, Oliver Hirschbiegel, 2004), a Mussolini rezsimjére koncentráló Mussolini és én, Galeazzo Ciano (Mussolini and I, Alberto Negrin, 1985), a második világháború egy kulcsfontosságú eseményét felrajzoló A normandiai partraszálláshoz vezető út (Ike: Countdown to D-Day, Robert Harmon, 2004), vagy a kubai történelemhez értők is új információkkal gazdagodhatnak a Che $-A z$ argentin (Che: Part One, Steven Soderbergh, 2008) és a Che - A gerilla (Che: Part Two, Steven Soderbergh, 2008) címü életrajzi filmek segítségével. $^{75}$ A napjainkban divatossá vált, „szappanoperásított” történelmi

\footnotetext{
${ }^{74}$ Magyarországon két hivatalos címmel is rendelkezik.

${ }^{75}$ Azért ezeket a címeket emeltem ki, mert az adott korszakokkal és országokkal foglalkozó történészek többsége általában elismerően nyilatkozik ezekről a filmekről, megjegyezve azok hibáit is.
} 
játékfilmsorozatok időnként már történészeket is alkalmaznak tanácsadóként, ugyanakkor a dramaturgiai hatás kedvéért ezek sokszor meg is hamisítják a történelem egyes részeit, így a szériákat a szakemberek nem igazán tartják mérvadónak. Ismeretterjesztő, a közönséghez bizonyos történelmi korokat közelebb hozó alkotásokként azonban kiválóan funkcionálnak. Ilyenre példák, többek között, az ír-kanadai-amerikai Tudorok (The Tudors, 2007-2010), a IV. Fülöp korába kalauzoló spanyol kalandfilmsorozat, a Vörös sas (Águila roja, 2009- ), valamint a Magyarországon forgatott kanadai-ír széria, a Borgiák (The Borgias, 2011- ). Szociológiai szempontból adalékokkal szolgálhat két spanyol teleregény, a Szeretni zavaros idökben (Amar en tiempos revueltos, 2005-2012) és a Meséld el, hogyan történt (Cuéntame cómo pasó, 2001- ): előbbi a spanyol polgárháború és a Franco-korszak első két évtizedét, utóbbi a diktatúra végét és a demokratikus átmenet periódusát mutatja be, mindkettő egy-egy család és ismerőseik, barátaik szemszögén keresztül önmagukat alakító politikusok (mint Santiago Carrillo) szerepeltetésével.

A történész számára a történelmi film müfaja az egyik legérdekesebb, leghasznosabb anyag. José María Caparrós Lera három alapvető típusát különíti el ennek a zsánernek. Az első kategóriába azok az alkotások tartoznak, amelyek az ábrázolt társadalom életéről és helyzetéről „történelmi tanúsítványt” állítanak ki, vagyis feltett szándékuk, hogy müvészi eszközökkel történeti értékkel bíró művet készítsenek. Ide tartoznak az olasz neorealizmus és a szovjet iskola kiemelkedő darabjai, utóbbiak közül mindenekelőtt A sztrájk (Стачка, Szergej Mihajlovics Eizenstein, 1924). A második típus filmjei szintén történelmi tényeket mutatnak be főbb eseményeken és szereplőkön keresztül, de a témakezelés túlságosan romantikus, mintha a regényeket egy az egyben átültették volna a filmvászonra. A hollywoodi szuperprodukciók, mint az Elfújta a szél (Gone with the Wind, Victor Fleming, George Cukor, Sam Wood, 1939) vagy a Gandhi (Gandhi, Richard Attenborough, 1982) lehetnek ennek példái. A harmadik csoportba azok a müvek tartoznak, amelyek többé-kevésbé szem előtt tartják a történelmi hüséget, de a megvalósítás a rendező szubjektív szemléletét adja vissza. Eizenstein legtöbb alkotása, illetve az amerikai háborús filmek sorolhatók ide. Caparrós Lera szerint a totalitárius államok a második és harmadik kategóriához vonzódnak, mert az első esetében fennáll a veszélye annak, hogy a nézők a müvészi önkifejezés eredményét látva a rezsim eredeti szándékától eltérő következtetésekre jutnak. ${ }^{76}$

\footnotetext{
${ }^{76}$ Caparrós Lera, José María: „El cine como documento histórico” in: Paz Rebollo, María Antonia - Montero Díaz, Julio (szerk.) Historia y Cine: Realidad, ficción y propaganda. Madrid, Editorial Complutense, 1995. 4245.
} 


\section{Elméleti alapvetések}

Kiindulópontként szükségesnek tartom három terület elméleti hátterének megvilágítását. A hatalom, a propaganda és a cenzúra olyan fogalmak, amelyek a társadalomra kifejtett hatásukat tekintve alapvető jelentőséggel bírnak, éppen ezért a filmpolitikák, mindenekelőtt a totalitárius filmpolitikák vizsgálatakor is figyelembe kell venni azok jellegét és tulajdonságait. Ezekkel is magyarázható, hogy a filmek miért játszanak olyan fontos szerepet egy diktatúra idején, miért kell mind az adott kornak, mind az utókornak foglalkoznia velük.

\section{A hatalom és a társadalom viszonya}

Minden rezsim, amely hatalma fenntartására törekszik, befolyása alatt kell tartsa a kommunikáció csatornáit. Napjainkban a 21. századi tömegkommunikációs eszközök világában egy ilyen szándék egyre kevésbé garantálja a sikert, elsősorban az internetnek köszönhetően. A kommunikáció és az információ feletti teljes vagy részleges kontroll teszi lehetővé, hogy a vezető réteg ideológiája, a nép és a külvilág felé vetített kép megfeleljen az azt kialakító személyek elvárásainak, még azelőtt kiküszöböljék a lehetséges anomáliákat, mielőtt azoknak egyáltalán esélyük lenne kapcsolatba kerülni a célszemélyekkel. A hatalmat kezükben tartók az őket körülvevő környezet felett uralkodva próbálják elérni céljaikat, az ehhez vezető úton pedig sokszor nem válogatnak az eszközökben.

Minden hatalmat gyakorló entitás alapvető szándéka, hogy hatással legyen az emberi elmére. A minket körülvevő események érzékelése és az általuk bennünk ébresztett gondolatok döntően befolyásolják, milyen válaszreakciókat is adunk majd mind az egyén, mind a közösség szintjén. Az állami struktúra legfelsőbb szintjén elhelyezkedő erőknek el kell érniük, hogy minden, náluk alacsonyabb társadalmi státusszal rendelkező állampolgár nyíltan vagy hallgatólagosan elfogadja az éppen zajló folyamatokat. Végső esetben megelégedhetnek azzal is, ha a társadalom csak passzív szemlélője a történteknek. Amit nem sikerül egyszerü fogalmazással, a bürokráciában használatos bonyolult nyelvezettel, vagy a dezinformáción és félrevezetésen alapuló diszkurzív stratégiákkal elérni, azt megvalósíthatják más kényszerítő eszközökkel. Elsődleges szempont a fentről jövő szabályok és utasítások maradéktalan érvényesülése. Ha a rájuk erőltetett normákban számos olyan pont van, amely potenciális konfliktusforrásként is megnyilvánulhat a jövőben, az állami kommunikációért felelős intézmény feladata, hogy azt semlegesítse. Amennyiben erre nincsen lehetőség, egy sokkal 
komplexebb folyamatot kell beindítani. Ennek lényege, hogy az állampolgárt hüségre, lojalitásra és egyetértésre nevelje, ellenkező esetben megerősödnek az ellenzéki erők, a hatalom eddigi birtokosa könnyen alávetetté válhat, és a korábban kisebbségben lévő gyakorolhatja a kontrollt. ${ }^{77}$

A fent említett megállapítások ugyanúgy igazak a demokratikus államberendezkedésekre, mint a legszélsőségesebb diktatúrákra. Természetesen minőségi különbség áll fenn. Az első esetben a befolyásolás és kényszerítés mechanizmusai, optimális helyzetben, akár nem is érzékelhetőek az egyének számára, ők maguk is elhiszik, hogy szabad akaratukból cselekszenek, saját meggyőződésükből osztják a hatalom által vallott nézeteket. A második esetben a népnek nincs más választása, mint engedelmeskedni, a direkt befolyásolás pedig a mindennapok részévé válik.

Mindkét helyzetben a „fentről” érkező kommunikációs stratégiák győzelmeként fogható fel, ha nincsenek elsöprő erejü ellenzéki megmozdulások (demokrácia) vagy az állami ideológiával nyíltan szembemenő különvélemények (diktatúra). Régebbi korokban a regnáló hatalomnak kevesebb munkájába került mindent ellenőrzés alatt tartania. Az autokratikus berendezkedésű államokban még könnyebb volt a vezetők dolga: az ideológia szent és sérthetetlen, az irányadó normák egyértelmüek, aki mindezeknek ellenszegül, az szankciókban részesül.

Egy ideológia követői sokszor hamis információt közölnek a befogadókkal, ugyanakkor Werner Stark szerint az ideologikus gondolkodás nem egyenlő a hazugsággal, bár mindkettő a valótlanság dimenziójában mozog. A hazug a mások gondolkodását igaztalan információkkal igyekszik befolyásolni, viszont a saját elméje teljes mértékben tisztában van azzal, hogy hazugságot terjeszt, az igazságnak ö maga tudatában van. Egy adott ideológia hüséges terjesztője azonban az esetek többségében már önmaga is befolyás alatt áll, ha másokat félrevezet, azt sokszor nem feltétlenül rosszindulattal teszi, mert talán ő is hisz az információ igazságtartalmában. ${ }^{78}$

A társadalmi konstrukciókban saját kultúra alakul ki, amely visszatükrözi a szóban forgó nemzet vagy népcsoport identitását. Egyik a másiktól nem vonatkoztatható el: a szociális állapotokra hatással lévő folyamatok nem hagyják érintetlenül a kulturális közeget, amelyben a múltból eredő tradíciók vegyülnek az új struktúrákkal. Ez az újdonság azonban

\footnotetext{
77 A hatalom és a társadalom viszonyát elemző müvek száma igen nagy. Három alapvető, általam is használt munka: Arendt, Hannah: The Human Condition. Chicago, University of Chicago Press, 1958; Castells, Manuel: Comunicación y poder. Madrid, Alianza Editorial, 2009; Zaller, John: The Nature and Origins of Mass Opinion. Cambridge, Cambridge University Press, 1992.

${ }^{78}$ Stark, Werner: The Sociology of Knowledge. London, Routledge, 2001. 48-49.
} 
sok esetben arra irányulhat, hogy a korábbi beidegződéseket megmásítsa, újraértékelje, esetleg teljesen megsemmisítse, helyette pedig új, a hatalmon lévő elitnek tetsző tartalmakat honosítson meg.

Az emberi elmében lejátszódó folyamatoknak nagy szerepe van a hatalom és a társadalom viszonyában jelentkező módosulásokban, mert az egyénben müködő pszichológiai mechanizmusok már predesztinálják a népet arra, hogy könnyen befolyásolható legyen. A szociológiai és pszichológiai kutatások mindennek a társadalmi vetületét is magyarázzák, dolgozatom témája miatt azonban nem térek ki bővebben ezekre a faktorokra. ${ }^{79}$

$* * * * * * * * * * * * * *$

Ahhoz, hogy egy hatalmon lévő csoport eredményesen tudja befolyásolni az uralma alatt élő népet, szükséges a saját nézőpont állandó fenntartása, hirdetése, valamint az ellentétes vélemények elhallgattatása. Diktatúrákban mindkét tevékenység központi szerepet játszik, előbbivel a propaganda, utóbbival a hozzá szorosan kapcsolódó cenzúra foglalkozik, de a kettő át is fedi egymást. Szükségesnek tartom mindkettő rövid elméleti áttekintését, mert így nyerheti el létjogosultságát az a megközelítés is, hogy egyes csoportok a filmet politikai, ideológiai és hatalmi játszmák eszközeként használhatják fel.

\section{A propaganda}

A propaganda egyik magyar nyelvü definíciója így hangzik: „eszméknek, tanoknak, nézeteknek, politikai elméleteknek különféle eszközök (élőszó, nyomtatás, művészet, technika stb.) útján történő módszeres terjesztése" ${ }^{80}$ Bár eredetileg pozitív jelentéssel bírt a szó, a 20. századtól kezdődően szinte kizárólag negatív értelmet társítanak hozzá. Elméleti és gyakorlati tanulmányozása az első világháború után kezdődött el, amikor rájöttek, hogy mekkora erőt képvisel. Ekkor állították fel az első propagandaelméleteket. 1927-ben jelent meg Harold D. Lasswell máig klasszikusnak számító könyve az első világháború propagandatechnikáiról ${ }^{81}$, amelyben elöször teszi egyértelművé, hogy a modern világban a propaganda az egyik legnagyobb hatalommal bíró eszköz. A 30-as évektől kezdve egyre többen fordultak a propaganda tanulmányozásához, ehhez kapcsolódóan pedig a pszichológia, a szociológia, a történettudomány és a különböző müvészeti ágakkal foglalkozó tudományterületek is vizsgálni kezdtek olyan kérdéseket, amelyek érintették ezt a problémát.

\footnotetext{
${ }^{79}$ Erről lásd, többek között: Damasio, Antonio R.: The Feeling of What Happens, Body and Emotion in the Making of Consciousness. New York, Harcourt Brace \& Company, 1999.

${ }^{80}$ Bakos Ferenc: Idegen szavak és kifejezések szótára (9. kiadás). Budapest, Akadémiai Kiadó, 1989. 688.

${ }^{81}$ Lasswell, Harold D.: Propaganda Technique in World War I. New York, Knopf, 1927 (későbbi, szélesebb körben, általam is ismert kiadás: MIT Press, 1971.)
} 
A század második felében, elsősorban az amerikai és nyugat-európai egyetemeken a propagandakutatás a kommunikáció tanszékek egyik népszerü irányává vált, Lasswell nyomdokain számos történelemben és kommunikációs stratégiákban jártas személy indult $\mathrm{el}^{82}$

A propaganda egy kommunikációs folyamat eredménye. Fő célja, hogy elősegítse a kibocsátó és a befogadó közötti kölcsönös megértést: adatokat közöl, eszméket oszt meg, magyaráz. Ezzel szembeállítható egy másik kommunikációs folyamat, a meggyőzés. Ebben az esetben a kulcs a befogadó válaszreakciója, vagyis a lényeg abban áll, hogy a közlő hatással legyen a befogadóra. A meggyőzés lényege - és ezért nagyon fontos a propaganda szempontjából -, hogy a kibocsátó hatására a befogadó belátja, saját érdeke, hogy magáévá tegye az ötletet, véleményt, ideológiát. Egy válaszreakció megalkotását célozza meg, logikai és pszichológiai tényezőket is figyelembe véve: a racionális érvek felsorakoztatása mellett szükséges pszichésen is közelíteni a célszemélyek felé, értelem és érzelem együtt adják a „meghódítandó” területet. A sikeres propagandista eléri, hogy a befogadó akár önmaga elveinek ellentmondva viselkedjen, akár azt is megtegye, ami hátrányára szolgál.

Fontosnak tartom részletesen is megvizsgálni ezt a kérdést, mivel disszertációm fő témájának ez adja egyik alapvető elméleti hátterét.

A meggyőzés során a kibocsátó pszichológiai mechanizmusok alkalmazásával a befogadót megpróbálja integrálni saját eszmerendszerébe. Az ehhez használt szavak és verbalitáson alapuló technikák azonban kétélü fegyvernek bizonyulhatnak, ugyanis jelentésük az adott kontextustól függ. A hatalom szempontjából egy érvelés önigazolásként értelmezhető, míg a másik oldal szintén ugyanezt a retorikát alkalmazhatja, de már negatív előjelű jelentéstartalommal. A nézőpont megváltoztatásával a diskurzus jelentése is változik. ${ }^{83}$ Jean-Marie Domenach hat alapvető propagandatechnikát különböztet meg ${ }^{84}$, ezeket a propagandista sokszor tudat alatt, együttesen veszi figyelembe és használja. Mindegyik

\footnotetext{
${ }^{82}$ Néhány fontosabb, általam is használt és a felsőoktatásban alkalmazott, alapvető szakirodalomként kezelt példa: Domenach, Jean-Marie: La propagande politique. Párizs, Presses Universitaires de France, 1950; Thomson, Oliver: Mass Persuasion in History: a Historical Analysis of the Development of Propaganda Techniques. Edinburgh, Paul Harris Publishing, 1977; Lasswell, Harold D - Lerner, Daniel - Speirer, Hans (szerk.): Propaganda and Communication in World History, Vols. I-III, Honolulu, 1979-1980; Jowett, Garth O'Donnell, Victoria: Propaganda and Persuasion. London, Sage Publications, 1986. Az általános propagandatörténeteken kívül adott nemzetek propagandájáról írott számos monográfia is napvilágot látott, elsősorban a világháborúkban és az azokat követő nemzetközi konfliktusokban fontos szerepet játszó országok vonatkozásában. Spanyolországban Alejandro Pizarroso Quintero munkásságát érdemes kiemelni.

${ }^{83}$ Rodríguez González, Félix: „Eufemismo y propaganda política” in: Revista Alicantina de Estudios Ingleses 1. 1988. 165-167.

84 Domenach, Jean-Marie: La propagande politique. Id. mü. 45-83. A későbbiekben született propagandatörténetek mind átveszik ezt a kategorizációt, kibővítik és módosítják azt.
} 
esetben fennáll a veszélye, hogy a szándékával ellentétes hatást ér el. Domenach kategorizációját használja a kapcsolódó szakirodalom is ${ }^{85}$ :

1: Egyszerűsítés. A propagandisztikus üzenet legyen rövid, világos, akár elég egy szlogen, szimbólum, metafora, hasonlat, megszemélyesítés is. Ehhez kapcsolódó megállapítás, hogy a propagandának egy konkrét célra kell koncentrálnia, egy kijelölt ellenségre (személy, csoport, ország) fókuszálnia, valamint egy konkrét személy vagy csoport felmagasztalására. Veszélye, hogy túlságosan leegyszerüsítenek, a népet együgyünek és gyermetegnek nézik, az emberek pedig ezt akár észre is vehetik. A túlságosan racionális érvelés akár érthetetlenné is teheti az üzenetet, tehát figyelembe kell venni a korábban már említett pszichológiai faktort is.

2: Túlzás. A szintén az ehhez a fogalomkörhöz kapcsolódó lekicsinylés és torzítás segítségével a propagandista kijelöli a célt, amire koncentrálni akar. Veszélye, hogy a túlzás a befogadó számára már hihetetlen méreteket ölt.

3: Hangszerelés. Fontos az ismétlödés, de nem monoton módon, hanem különböző formákban és különböző csatornákon keresztül érkezve, vagyis folyamatosan áthangszerelve. Ebben a hangszerelt ismétlődésben fellelhető belső fejlődési ritmusnak növekvő tendenciát kell mutatnia, mindig felsőbb szintre lépni az üzenet tartalma és közvetítése terén. A hangszerelt ismétlés veszélye, ha továbbra is túlságosan egysíkúnak és változatlannak tủnik a befogadó számára.

4: Transzfúzió. A kibocsátó és a befogadó között létre kell hozni egy kapcsolódási pontot. A propagandistának meg kell találnia azt a konkrét kulturális vagy tradicionális csatornát, amellyel azonosulhat, és amelyen keresztül kapcsolatba léphet közönségével, így keresztülviheti az üzenetet. Domenach szerint mindig van egy már eleve létező közös pont, amellyel egymáshoz kapcsolódhatnak: nemzeti mitológia, szokások, közös félelmek, fóbiák. Ez a technika rengeteg veszélyt rejt magában, egy helytelen helyzetfelméréstől kezdve az apróbb elszólásokig bármi meghiúsíthatja a cél elérését.

5: Fertőzés. Amikor az üzenet megérkezik, működésbe lépnek terjesztési, „fertőzési mechanizmusok". A szociológiából ismert jelenség, hogy minden társadalmi csoport konformizmusra törekszik, tagjai igyekeznek a lehető legjobban hasonlítani egymásra, ugyanis a másoktól való eltérést a többség abnormálisnak ítéli. Ha a társadalmi csoport egy részét sikeresen megfertőzzük egy ideológiával vagy véleménnyel, akkor ez idővel hatással

\footnotetext{
85 Domenach eredeti, hosszan kifejtett és komplex magyarázatokkal társított elképzelésének egy általam leegyszerüsített változatát közlöm itt, amelyet az egyetemi oktatásban is használok, kiemelve azokat a szempontokat, amelyek a filmpropaganda esetében jelentősek lesznek, a szerző ugyanis a filmet még nem kezelte súlyának megfelelően 1950-ben.
} 
lesz a többiekre, nem tudják magukat kivonni alóla. A „vírus” önálló életre kell, terjedni kezd. Akkor a leghatékonyabb, ha elöször a társadalom elit rétegét célozzuk meg, onnan ugyanis könnyebben terjed „lefelé”. Éppen ezért vigyázni kell arra, hogy az üzenet kellően kimunkált legyen, nehogy az értelmiség gyanakvóvá váljon.

6: Ellenpropaganda. Minden propaganda szükségszerüen kiprovokálja az ellenpropagandát, egy propagandistának ezzel tisztában kell lennie, és tudnia kell semlegesítenie azt. Az ellenpropaganda nem támadhat frontálisan, az eredeti propaganda elemeit egyenként kell célba vennie, kezdve a legkönnyebben támadhatóval. Akkor éri el a legjobb hatást, ha a forrást tudja hitelteleníteni, vagy nevetségessé tenni. Veszélye egyértelmü: ha nem sikerül érvényesíteni az ellenpropaganda céljait, akkor az eredeti propaganda üzenete ettől felerősödik.

Más szempontokat is figyelembe kell venni. Vajon egy korábbi, azonos ideológiából vagy pártból érkező propaganda nem mondott-e élesen ellent a mostaninak? Ha az orientáción változtatni kell, akkor azt fokozatosan lehet csak megtenni, és nem hirtelen. A propagandával ugyanis együtt járhatnak olyan járulékos veszteségek, mint a fásultság, a szkepticizmus megnövekedése, és idővel az emberek belefáradhatnak a hatalom üzeneteibe. Ez utóbbinak köszönhető a diktatúrákban a nyílt propagandisztikus üzeneteket hordozó filmek fokozatos népszerüségvesztése.

Minél szélsőségesebb egy ideológia, annál hangsúlyosabb lesz az azt képviselő propaganda, ugyanis egy demokráciához szokott, vagy arra vágyó népcsoporttal nehezebb lesz elfogadtatni, hogy egy fentről jövő, exkluzivista eszmerendszert érezzen magáénak.

A müvészeti alkotások az állami propaganda egyik elsődleges megnyilvánulásai. Az ideológia szellemében született munkák és a vezetéssel közösséget vállaló művészek támogatása, azok állami és művészeti díjakkal való kitüntetése egy domináns kultúra kialakítását célozzák meg, ez a kultúra pedig természetesen a fennálló eszméket közvetíti a befogadóknak.

Az audiovizuális eszközökkel operáló propaganda és a reklám közös jellemzője, hogy ugyanabból indulnak ki: a képek és hangok együttese elementáris hatással van a befogadó személyre. A film jelentősége és a filmműfajok jellegzetességei kapcsán már felmerültek azok a kérdések, amelyek a hatalom számára fontossá, a nép számára pedig vonzóvá tehetik a mozgóképeket. Mindezekből következik, hogy a néző szeme előtt pergő események valódinak tűnnek, amit a híradókban, dokumentumfilmekben és játékfilmekben lát a közönség, azt reálisnak értékeli. Számára az így kapott információ párosul az újdonság varázsával és a szórakozással, a film játékideje alatt átkerül a mozgó (ál)valóságba. Ha a film készítője 
professzionális módon viszonyul a propaganda mechanizmusaihoz, akkor könnyen elérheti a kívánt hatást.

A diktatúrák keletkezésével és müködésével foglalkozó Hannah Arendt értelmezése ${ }^{86}$ szerint a totalitárius propaganda egy fikciós világot épít fel a társadalom köré, amely önmagába foglal minden, később születő direktívát is. Az irányítási hierarchia és a centralizált döntéshozás áll a középpontban. Amikor a totalitárius eszközökkel irányító csoport hatalma teljessé válik, elveszíti a kapcsolatot a realitással, és kizárólag az általa konstruált fiktív világot tekinti valódinak, a benne létező egyetemes törvények legitimálják az adott mozgalom későbbi rendelkezéseit, esetleges pozícióváltásait is. A propaganda feladata, hogy a tömegek számára ezt a fiktív világot igazinak, és egységesnek mutassa, ugyanakkor ne látszódjon a fennálló rend teljesen stabilnak és megbonthatatlannak, mert csak így lehet igazolni, hogy a továbbiakban is szükség van a hatalmat gyakorló párt vagy csoport egyeduralmára. A társadalom számára olyannak kell tűnjön ez a világ, mint amelyet egyértelmű, józan ésszel is felfogható döntések irányítanak, minden szándék építő jellegü (oktatás, építkezések, kultúra egységesítése), az ellenség pedig mindezeket le akarja rombolni. Arendt ebben jelentős szerepet tulajdonít a filmnek.

\section{A cenzúra}

A Larousse enciklopédia értelmezése szerint a cenzúra „müvészeti alkotások, sajtótermékek, tömegkommunikációs eszközök stb. tartalmát politikai, vallási stb. szempontból (előzetesen) ellenőrző intézmény". 87 A cenzúra egyidős az írásbeliség kialakulásával. A különböző történelmi korokban hatalmon lévő politikai és társadalmi csoportok, valamint a hozzájuk eleinte szorosan kötődő, később tőlük elváló egyházak egyik elsődleges célja volt, hogy kontroll alatt tartsák a társadalmat. Nem szükséges előfeltétel, hogy mindez diktatórikus berendezkedésen belül történjen, a demokráciákban is megfigyelhető mindez. A propagandát szükségszerủen mindig kiegészítette a cenzúra. Megakadályozni az információ szabad áramlását, a napvilágra kerülő adatok szelektálása, a fő irányelveknek és ideológiának ellentmondó eszmék külvilágtól történő elzárása, ezek mind a propagandisztikus manipuláció egyik fő eszközének számítanak. A cenzúra akadályoz, formál, generál, megszabja, milyen információ, milyen formában jut el a befogadóhoz.

\footnotetext{
${ }^{86}$ Ezt összefoglalja: Aprea, Gustavo: „¿Existe un cine totalitario?” in: Block de Behar, Lisa - Rinesi, Eduardo (szerk.): Cine y totalitarismo. Buenos Aires, La Crujía Ediciones, 2007. 93-94.

${ }^{87}$ Magyar Larousse (Bakos Ferenc és Szávai János főszerk.). Akadémiai Kiadó, Budapest, 1991. 451.
} 
A cenzori beavatkozás során szövegeket vagy bármely más, egyéni kreatív folyamat kapcsán létrejövő végterméket vizsgálat alá vonnak, majd eltávolítanak, módosítanak benne részeket, esetleg teljes egészében be is tiltják azt.

A téma egyik szakértője, Héctor Borrat négy kategóriába sorolja a politikai hatalom által gyakorolt cenzúrát, vagyis külső cenzúrát, és ezeken belül összesen nyolc fajtát különböztet meg: ${ }^{88}$

1. a hatalom által alkalmazott módszer alapján: közvetlen és közvetett cenzúra;

2. a beavatkozás időbeni elhelyezkedését illetően: előzetes és utólagos cenzúra;

3. a cenzúrázott üzenet tartalma alapján: információ- és véleménycenzúra;

4. a cenzúrázott médium alapján: egyénre szabott és általános cenzúra;

A fentieket a hatalom közvetlen beavatkozással erőlteti rá a müre. Az ezzel szemben álló öncenzúra során viszont maga az alkotó igyekszik eltávolítani munkájából minden olyan elemet, amelyröl gyanítja, hogy a cenzori hatóság nem fogja majd engedélyezni a közzétételét.

A filmcenzúrát két részre bonthatjuk. Az egyik a bírálóbizottságok által szükségesnek tartott cenzúra, amelyet a kiskorúak védelmében alkalmaznak, illetve az olyan személyeket akarják megóvni bizonyos tartalmaktól, akik bántónak érezhetik a látottakat. Az ilyen típusú, a filmekbe iktatott vágásokkal operáló cenzúra behelyettesíthető az 50-es és 60-as években létrejövő, ma is létező korhatár-besorolással, illetve annak jelzésével, hogy a film bizonyos jelenetei sérthetik a nézőket. Ez utóbbi nem megsemmisítő erejü, a jelenetek a filmben maradnak, mindössze egy figyelmeztetést csatolnak hozzá.

Ezzel szemben áll a fentről megszabott, kötelező érvényü cenzúra, amikor egy hatóság szabja meg, hogy a nézők nem fogják látni az adott jelenetet vagy hallani néhány mondatot. Nem bízza a választást a közönségre, helyette dönt. Ennek oka többféle lehet. Eredhet szimplán abból a szándékból, hogy a túlságosan brutális, naturális jelenetekkel ne sokkolják a közönséget; ezt elsősorban a demokráciákban alkalmazzák a horrorisztikus, erotikus jeleneteket vagy trágár kifejezéseket tartalmazó szekvenciáknál. Ennél összetettebb kérdés, amikor a cenzori aktusban egy ideológiai elhatározás ölt testet. A felsőbb hatalom (állam, stúdió, producer, bizonyos országokban az egyház) úgy dönt, nem fogja megengedni, hogy a

\footnotetext{
${ }^{88}$ Borrat, Héctor: „Los múltiples recursos del poder para implantar censuras” in: Bezunarten, D. - Canga Laregui, J. (szerk.): Los límites de la información política. Universidad del País Vasco, San Sebastián, 1989. 159.
} 
kérdéses jelenettel szembesüljön a néző, mert az esetleg ellentmond a társadalom felett uralkodó ideológiának, sértheti a nemzeti büszkeséget, más országok állampolgárait, valami olyat ábrázolna, ami összezavarná, esetleg kritikai gondolkodásra késztetné a nézőt. Vagy egyszerüen csak kérdések vetődnének fel benne az aktuális állapotokra vonatkozóan.

Ha a cenzúra az állami irányítás hivatalos eleme lesz, akkor a mindennapok részévé válik, az emberek megtanulnak együtt élni vele. Idővel elfogadják és természetesnek veszik a létét, kevesen próbálnak szembeszállni. A hivatalos állami cenzúra önmagában hordozza annak a lehetőségét, hogy túlzásokba esik, a tiltás és szabályozás szélsőséges méreteket ölt, de a törvényben foglaltak értelmében mindenhez joga van.

A filmcenzúra számos módon megvalósítható. Amennyiben totális cenzúráról beszélünk, megtiltható egy film elkészítése már a forgatás megkezdése előtt, leállíthatják a munkálatokat menet közben, de később is betilthatják a forgalmazást és bemutatást. Ezek a filmek tehát hivatalosan nem is léteznek. Részleges cenzúra esetén a film nem tủnik el, csak egyes részei. A tartalomra vonatkozó beavatkozás során módosításokat iktatnak be, jeleneteket kivágnak vagy megváltoztatnak, szereplőket távolítanak el, dialógusokat törölnek, esetleg utószinkronizálással teljesen új értelmet adnak nekik. Ez minden esetben előzetes cenzúra, vagyis még a bemutató előtt valósítják meg, elsősorban különböző diktatúrákban, illetve a volt szocialista országokban jellemző metódus. Nem tudhatjuk azonban, hogy demokráciákban milyen mértékben alkalmazzák ezt; hivatalosan ott nem létezik cenzúra, a valóságban azonban a forgatókönyvek és a kész filmek is több kézen mennek át. A néző - az esetek többségében - nem értesül a cenzori beavatkozásról, mivel az utómunkálatoknak köszönhetően nem látszik a filmen, hogy milyen manipulációkat hajtottak végre rajta. Általában az alkotók későbbi nyilatkozatai és filmtörténészek feltáró kutatásai alapján tudhatunk róla, hogy egy filmet korábban cenzúráztak. ${ }^{89}$

Természetesen a filmeket érintő cenzúra sem csak a diktatúrákra volt jellemző a múltban, az Amerikai Egyesült Államokat hozhatjuk fel erre példaként. ${ }^{90}$ A „Hollywoodi Álomgyár”-nak fénykorában, az 1930-as években szintén megvoltak a maga normái, méghozzá rögzített formában. 1927-től Hollywood bigottan katolikus, a politikában és az üzleti életben befolyásosnak számító, az utókor által ideológiailag reakciósnak minősített szektorai egy kódex megalkotását szorgalmazták, amely egyértelműen kimondja, hogy mit

\footnotetext{
${ }^{89}$ A filmcenzúra különböző típusairól ír részletesen: Alsina Thevenet, Homero: El libro de la censura cinematográfica. Barcelona, Editorial Lumen, 1977. 10-29. Közel 350 oldalon keresztül számos érdekes és értékes példát is hoz cenzori beavatkozásra a nemzetközi filmművészetből kiemelt alkotásokon keresztül.

${ }^{90}$ Mint a későbbiekben látni fogjuk, a jelzett korszakban a filmekkel kapcsolatos amerikai álláspont a spanyol francói filmpolitika bizonyos szegmenseire is hatással lesz.
} 
tilos bemutatni a filmvásznon, és mivel kell nagyon óvatosan bánni. Az Amerikai Filmproducerek és Forgalmazók Szövetsége (Motion Pictures Producers and Distributors Association), későbbi nevén Amerikai Filmszövetség (Motion Picture Asscociation of America) 1930-ben hozta nyilvánosságra a Filmprodukciós Kódexet (Motion Picture Production Code, ismertebb nevén Hays Kódex, a Szövetség elnöke, Will H. Hays után), amelynek értelmében minden bemutatásra szánt filmet engedélyeztetni kellett az arra kijelölt bizottsággal. A szabályozás szerint tiltott, többek között, bármiféle szexualitásra utaló jelenet vagy párbeszéd, a vulgáris kifejezések használata, a faji keveredésre való utalás, az egyház negatív színben való feltüntetése és más nemzetek állampolgárainak megsértése. Ezen felül ajánlásokat fogalmazott meg további 26 pontban, köztük a kiskorúakra, a fegyverek használatára, a bünözés ábrázolására és a házastársi kapcsolatokra vonatkozóan. ${ }^{91}$ Áttekintve a szabályozást, egyértelműnek látszik, hogy a Katolikus Egyház erkölcsre vonatkozó tanításainak gyakorlatba ültetéséről van szó. A filmek betiltása ellen csak úgy tudtak védekezni a stúdiók, hogy a forgatókönyveket elözetes kontrollra küldték, a forgatásokon jelen voltak a cenzori hatóság illetékesei, a bemutató előtt pedig újfent ítélkezhettek a film felett. A Tisztesség Nemzeti Ligája (National Legion of Decency), melynek tagjait hívő katolikus pénzemberek és politikusok adták, vezetője pedig egy szélsőjobboldali nézetekkel szimpatizáló jezsuita pap volt, a 30-as évektől kezdődően minden bemutatandó filmet kategorizált, és ha egy nekik nem tetsző film került bemutatásra, akkor a film, a stúdió és a mozi elleni bojkottra szólított fel. Ez a tevékenység sok esetben elérte célját, hatalmas anyagi veszteséget okozva a hollywoodi moguloknak. A Kódex hivatalosan még a 60-as években is fennállt, de egyre kevesebb jelentőséget tulajdonítottak neki. ${ }^{92}$ A későbbiekben szintén a filmvilágba való beavatkozásként lesz értékelhető az Amerika-ellenes Tevékenységet Vizsgáló Bizottság (House on Un-American Activities Committee - HUAC) Hollywoodot is érintő müködése.

\footnotetext{
${ }^{91}$ Black, Gregory D.: Hollywood Censored: Morality Codes, Catholics and the Movies. Cambridge University Press, 1996. 36-38; 42-43; Byrd, Cathy - Richmond, Susan (szerk.): Potentially Harmful: The Art of American Censorship. Athens, The University of Georgia Press, 2006. 45-49.

${ }^{92}$ A témában számos jelentős mủ született, elsősorban amerikai filmtörténészek és szociológusok tollából. Ezek közül az általam használtak (az előző lábjegyzetben feltüntetetteken kívül): Bernstein, Matthew (szerk.): Controlling Hollywood: Censorship and Regulation in the Studio Era. Rutger, Rutgers University Press, 1999 és Jeff, Leonard L. - Simmons, Jerold L. The Dame in the Kimono: Hollywood, Censorship, and the Production Code. The University Press of Kentucky, 2001.
} 


\section{Filmpolitikák és filmpropagandák - nemzetközi kitekintés}

A spanyol filmpolitika tárgyalása előtt egy rövid, vázlatos képet adok más totalitárius államok filmpolitikájáról, ezek ugyanis sok olyan elemet tartalmaztak már, amelyek később Spanyolországban is felbukkantak. Azt is mutatják, hogy nem Francisco Franco tábornok volt az első vezető, aki a filmet fontos tényezőként vette számításba. Az alapokhoz a Szovjetunióig kell visszanyúlni, majd kitérek Németországra és Olaszországra, mint a spanyol eset közvetlen előzményeire. Végül a demokratikus filmpropagandára is hozok példát az Amerikai Egyesült Államok kapcsán.

Előzetes megállapításként elmondható, hogy a diktátorok és állampárti vezetők többsége kedveli a filmmüvészetet, de legalábbis tiszteli és értékeli erejét. Ugyanakkor tisztában vannak vele, hogy kontroll alatt kell tartani a filmpolitikát, mert a legártatlanabbnak tünő munka is súlyos veszélyeket hordozhat magában: akár az egyes részletek, akár az összkép, bizonyos alkotók részvétele, idézetek és utalások, a zene, a szereplők közelében látható könyvek, képek, szobrok mind olyan üzeneteket sugallhatnak, amelyeket a rezsim támadásként értékelhet. A rendezők azonban sokszor mégis keresztül tudták vinni elképzeléseiket. A tökéletlenül müködő spanyol filmcenzúrát több rendező is sikeresen megkerülte az 50-es évektől, ahogyan az olasz esetre sem mondható, hogy a tiltás totális lett volna. Ivan Passer cseh filmrendező a Prágai Tavasz következményei kapcsán kifejtett megállapításai minden autoriter rendszerre jellemzőek: „A kontrollnak vagy cenzúrának, akár politikai, akár anyagi, mindig ugyanazok a következményei: tönkreteszik mind a jellemet, mind a tehetséget. Az anyagi kontroll valószínüleg kicsit következetesebb, mert fillérre össze lehet adni a számokat. Természetesen a politikai ellenőrzés fizikailag veszélyesebb: a kontroll alá vont személyt meg is ölhetik - ami gyakran meg is történt. Furcsamód mégis könnyebb repedést találni rajta. Sokkal valószínübb ugyanis, hogy egy ideológiai könyvelö kövessen el hibát, mint olyasvalaki, aki a filléreket számolgatja."93

A totalitárius államok propagandájának egyik fő tengelyét adja a filmpolitika, ahol nem elsősorban müvészetként tekintenek rá, hanem egy gondosan megtervezett politikai eszközként, amelynek csak egy része, hogy szórakoztatói funkciót is ellásson. A hatalmat gyakorlók politikai igényeinek rendelik alá a mozgóképet még olyan esetekben is, amikor magát a filmgyártást magántulajdonban lévő stúdiók és vállalatok végzik: a végső szó és a teljes kontroll az állam kezében van. A Hannah Arendt által felvázolt, általam korábban már

\footnotetext{
${ }^{93}$ Idézi: Zalán Vince: „Kisvárosi víkendek. Ivan Passer másfél cseh filmje - 1. rész” in: Filmvilág, 2010/10. 32.
} 
említett totalitárius fikciós világon belül helyezkedik el mind a szórakoztató, mind a tisztán propagandaszándékkal készült film.

Minden diktatúrában általános jelenség, hogy a rendszerrel szembenálló, vagy az eleinte azt támogató, de később attól valamelyest eltávolodott művészek elnyomásban részesültek, betiltották, bebörtönözték őket, emigrációra kényszerültek, rosszabb esetben az életuikkel fizettek.

\section{Szovjetunió}

Lev Tolsztoj 1910-ben megjegyezte: „A filmfelvevő számára kell írni, mert azt hatalmas tömegek és minden egyes nép is megérti.",94

1919-től figyelhető meg először, milyen kiemelkedő fontossággal bír a film ebben a térségben. Ekkor jelent meg az agitka, a szovjeteket támogató rövid propagandafilm. Ehhez kapcsolódtak az agitációs járművek (teherautók, gőzhajók, vonatok), amelyek segítségével a legtávolabbi falvakba is eljuttathatták a filmeket és vetítőberendezéseket. Lenin 1922 elején meghatározta nemcsak a Szovjetunió, de szinte minden későbbi, diktatórikus vonásokkal felruházott ország filmhez való viszonyát, tekintet nélkül ideológiai hovatartozására. A későbbi, nem szovjet vezetők természetesen nem hivatkoztak Leninre, de egyértelmü, hogy az általa deklarált elképzeléseket mindannyian hasznosították. Egyrészt, letette a filmgyártás lenini irányának alapját, amely szerint a filmeknek mind szórakoztató, mind oktatói funkciót is el kell látniuk, ezáltal a műveltebb és az írástudatlan tömegekre is rendkívül nagy hatást gyakorolhatnak. Másrészt, megszületett az a kijelentés, amely később sok más diktátor szájából is elhangzik kisebb módosításokkal: „minden müvészet közül számunkra a film a legfontosabb". 95 A filmgyártás irányítását egy megbízható testület hatáskörébe helyezte, vezetőjének pedig feleségét, Nagyezsda Krupszkaját tette meg; ez az intézmény alapította meg a világ első filmiskoláját. ${ }^{96}$ Ezzel a film első helyet szerzett a nép befolyásolására szánt eszközök rangsorában, természetesen a mindenre kiterjedő állami ellenőrzés alatt. Hasznos eszköz volt: a Szovjetunió hatalmas területén élő népek száznál is több különböző nyelven beszéltek, és a (néma)film volt az egyetlen, nagy népszerüségnek örvendő médium, amely közös, mindenki számára érthető „,nyelven”, a képek nyelvén szólt a nagy százalékban

\footnotetext{
${ }^{94}$ Az idézetet szovjet források alapján közli: Gómez Bermúdez de Castro, Ramiro: Evolución de la producción cinematográfica española (con especial estudio del periodo 1975-1985). Doktori értekezés. Madrid, Universidad Complutense de Madrid, Facultad de Ciencias de la Información, Departamento de Comunicación Audiovisual, 1989. 18.

${ }^{95}$ Taylor, Richard - Christie, Ian (szerk.): The Film Factory: Russian and Soviet Cinema in Documents 18961939. New York, Routledge, 2002. 53.

${ }^{96}$ Taylor, Richard: The Politics of the Soviet Cinema, 1917-1929. Cambridge University Press, 1982. 43-44.
} 
analfabéta közönségéhez. Bár Oroszország előbb az első világháború, majd a belső viszályok miatt igencsak elszigetelődött a világ többi részének filmjeitől (korábban elsősorban import filmeket vetítettek), éppen ez tette lehetővé, hogy megszülessen a szovjet filmipar, amelyet technikai és esztétikai újításait tekintve - mai napig a filmtörténet egyik legkiemelkedőbb vívmányaként tartanak számon világszerte. A korszak jelentős szovjet filmesei (mindenekelőtt Eizenstein, Vertov, Pudovkin és Kulesov) tették lehetővé, hogy a lenini ideológia eluralja a vásznakat, és ezek, valamint a módszer továbbfejlesztése szolgáltak mintaként és hivatkozási alapként a propagandafilmek készítésének nemzetközi téren is.

Sztálin kezdeményezésére született meg a szocialista realizmus, ez az irányelv 1935-től egészen a Szovjetunió összeomlásáig határozta meg a müvészetek feladatát és fosztotta meg azokat, sok esetben, az innovatív és művészetközpontú elképzelések megvalósításától. Az avantgárd müvészetek üldözötté váltak. A szocialista mü nevelt és példaképeket, pozitív hősöket állított középpontba, az egyszerüségre törekedett, áthatotta a pártszellem (partijnoszty) és a népi szellem (narodnoszty), célkitüzései azonban évröl-évre változtak, megnehezítve a filmesek munkáját. ${ }^{97}$ A változó célrendszernek egyik szemléletes példája Eizenstein Október címü munkája: a filmet sorozatos utócenzúrák érték, mivel a benne ábrázolt Trockij fokozatosan kikerült Sztálin bizalmasainak köréből, így a rendezőnek kockáról kockára ki kellett őt vágnia filmjéből, majd más szovjet vezetők, elsőszámú politikusok is áldozatául estek előbb a sztálini önkénynek, majd a vágóasztalnak. A diktátor minden vágást személyesen ellenőrzött. ${ }^{98}$ Sztálin természetesen nem csak a filmeken keresztül retusálta a történelmet, a müvészeti ágak mindegyikébe beavatkoztak.

Sztálin, akár csak elődje, rendkívül fontosnak tartotta a film szerepét a társadalom formálásában. Szerinte a film egy kivételes eszköz, amely segít megértetni a munkásosztállyal a Párt céljait, növelheti kulturális javaikat és politikai éleslátásukat. ${ }^{99} \mathrm{Az}$ eltérő megfogalmazás is mutatja: míg Lenin müvészeti formaként tekintett a filmre, addig Sztálin egyszerűen eszközként aposztrofálta azt. Mindez abból adódott, hogy a sztálini rendszer elítélően nyilatkozott a legtöbb müvészeti formáról, mivel azok többértelmüsége, bonyolultsága okot adhatott számukra a gyanakvásra, a szovjet nép esetleg olyan következtetéseket is levonhatott a müvekböl, amelyek kellemetlenül érintették volna a legfelsőbb vezetést.

\footnotetext{
${ }^{97}$ Thompson, Kristin - Bordwell, David: A film története. Id. mü. 287.

${ }^{98}$ Bergan, Ronald: Sergei Eisenstein: A Life in Conflict. Boston, Overlook, 1999. 114-117.

${ }^{99}$ Chiarini, Luigi: El cine, quinto poder. Madrid, Taurus, 1963. 16.
} 
Sztálin személyes viszonyt is ápolt a filmmüvészettel. Alakja számos korabeli játékfilmben feltünt (kizárólag egy bizonyos színész alakíthatta őt), természetesen mitikus, hatalmas vezérként ábrázolták; ezekből a munkákból mindig küldött egy-egy ajándékpéldányt más országok vezetőinek is. A fontos filmeket a forgatás különböző fázisaiban többször is magához kérette, és belső körének tagjaival (mint Berija vagy Molotov) jelenetről jelenetre kielemezte azokat, majd egy jegyzéket küldött a rendezőnek arról, hogy mit kell megváltoztatni. Életének utolsó éveiben maratoni vetítéseket rendezett privát vetítőtermében a meghívottak számára, ekkor már föleg az amerikai filmekért rajongott. ${ }^{100}$

A szovjet filmpropaganda leghüségesebb követőjét a politikai spektrum éppen ellenkező oldalán kell keresni.

\section{Németország}

A nemzetiszocialista német mủvészet a germán mítoszok, a görög-római klasszicizmus grandiózus megjelenítéséhez folyamodott. Albert Speer és kollégái építményei, a degeneráltnak tartott müvészeti formák számüzése, valamint az árja faj nagysága elött tisztelgő nagyszabású tömegrendezvények (mint az 1936-os Olimpiai Játékok Berlinben vagy a Nemzetiszocialista Párt kongresszusa) a monumentalizmus, a felsőbbrendűség példái.

Az 1920-as években a német filmgyártás mind minőség, mind mennyiség tekintetében előkelő helyen szerepelt nemzetközi viszonylatban, a 30-as évek elejére pedig már csak Hollywood vetekedhetett vele. Az expresszionizmus és a realizmus filmvásznon történő ábrázolása külföldön is ismertté tette Fritz Langot, Georg Pabstot és Friedrich Murnaut, mindehhez az UFA (Universum Film $A G$ ) stúdió adta a professzionális infrastrukturális hátteret. Adolf Hitler hatalomra kerülésével azonban mindez megszakadt, részben a filmesek emigrációjának, részben az ideologizált filmgyártásnak köszönhetően. Minimálisra csökkent a korábban nagy bevételeket jelentő exportképes alkotások száma, az új rendszer egyre szélsőségesebbé válásával pedig néhány demokratikus ország, mint Franciaország és az Amerikai Egyesült Államok, teljes bojkottot hirdetett a német filmekre, Csehszlovákia és Lengyelország pedig azért vezetett be behozatali tilalmat a német művekre, mert félt a nácizmus terjeszkedésétől. ${ }^{101}$

\footnotetext{
${ }^{100}$ Diez Puertas, Emeterio: Historia social del cine en España. Editorial Fundamentos, Madrid, 2003. 295-296. Sztálin filmekhez füződő kapcsolatáról érzékletes képet ad A legbelsőbb körök (The Inner Circle, Andrej Koncsalovszkij, 1991) címü film.

${ }^{101}$ España, Rafael de: El cine de Goebbels. Id. mü. 20.
} 
A Führer szintén tudatában volt a filmben rejtőző erőnek. Nem bízta azonban saját emberei kreativitására, hogy milyen módon használják fel a mozi kínálta lehetőségeket. Az UFA stúdió részvényeinek többségét már 1927-ben felvásárolta Alfred Hugenberg, a Nemzetiszocialista Párthoz közel álló üzletember és korabeli „médiamogul”, üzlettársai és politikus barátai pedig folyamatosan átvették az irányítást a stúdió infrastruktúrája felett. ${ }^{102}$ Így az 1933-as hatalomátvétel után már nem volt szükség tisztogatásra sem, a náci propagandafilmek gyártása akadályok nélkül megkezdődhetett, az új rendszerrel egyet nem értő filmesek pedig elhagyták az országot.

Joseph Goebbels és emberei tanulmányozták a legfontosabb szovjet propagandafilmeket, értelmezték és elemezték a jeleneteket és a mondanivalót, majd igyekeztek azokat a nemzetiszocialista közeghez adaptálni. A propagandaminiszter bevallottan rajongott a hollywoodi és a szovjet alkotásokért, szívügyének tekintette, hogy a náci Németország filmnagyhatalommá váljon: 1935-ben még egy húsz országból származó, összesen közel kétezer személy részvételével megrendezett nemzetközi filmkongresszust is szervezett Berlinben, amelyet az általa megfogalmazott, mind Németországra, mind a világ filmgyártására érvényesnek vélt tudományos előadással zárt. ${ }^{103}$ A heroikus német múlt és a dicsőséges német jelen volt a legfőbb témája a kötelezően forgatandó és vetítendő német propagandafilmeknek. Hitler és Goebbels között azonban konfliktus támadt: míg a propagandaminiszter az észrevétlen meggyőzés mellett érvelt, valamint előnyben részesítette a tisztán szórakoztató, ideológiailag semleges vagy csak enyhén náci szellemiségü filmtermékeket, addig Hitler a közvetlen propagandát nevezte meg a német filmipar elsőszámú feladataként. Kettősség alakult ki: a külföldre is exportált filmeknél elsősorban Goebbels elvei érvényesültek, a német nép számára készült művek esetében azonban arra törekedtek, hogy minél egyszerübb módon juttassák el a közönséghez az egyértelmü üzeneteket, igazodva a Gleichschaltung ${ }^{104}$ irányelveihez. ${ }^{105}$

A hollywoodi stúdiórendszerrel, amely Európára is kiterjesztette hegemóniáját, a Harmadik Birodalom saját filmkészítéssel próbált szembeszállni, de rontotta helyzetüket, hogy 1933 júniusában megtiltották a zsidók filmgyártásban való részvételét (az országot

\footnotetext{
${ }^{102}$ Kreimeier, Klaus: The UFA Story: A History of Germany's Greatest Film Company, 1918-1945. Berkeley Los Angeles - London, University of California Press, 1999. 129-131.

${ }^{103}$ España, Rafael de: El cine de Goebbels. Id. mü. 16.

${ }^{104}$ A Gleichschaltung (egységesítés, uniformizálás) magában foglalja minden, a nácizmus szellemiségével ellentétes tudomány és müvészet tagadását és a náci értékek magasztalását.

${ }^{105}$ Schulte-Sasse, Linda: Entertaining the Third Reich: Illusions of Wholeness in Nazi Cinema. Duke University Press, 1998. 17-46. A könyv bemutatja a náci filmgyártás fö témáit és alkotóit is.

Lásd még német nyelven: Heinzlmeier, Adolf: Nachkriegsfilm und Nazifilm. Anmerkungen zu einem deutschen Thema. Frankfurt am Main, Frankfurter Bund für Volksbildung, 1988.
} 
elhagyó zsidó filmesek jelentős része később éppen Hollywoodban futott be fényes karriert), sok német filmes pedig, bár nem voltak zsidó származásúak, a körülmények kedvezőtlen alakulása miatt inkább az emigrációt választotta. A náci vezetés célul tűzte ki, hogy az ideológiájuk terjesztésének szolgálatába állított német nemzetiszocialista filmipar befolyási övezete alá vonjon minél több európai, majd latin-amerikai országot. A legújabb kutatások szerint a nácik már sikerrel készítettek 3D-technológiájú kísérleti filmeket is ${ }^{106}$, megelőzve ezzel az Egyesült Államokat. Lengyelország lerohanása után az összes német filmhíradót egyesítették az UFA-hoz tartozó Deutsche Wochenschau $(D W)$ égisze alatt, amely felett Goebbels szigorú irányítást gyakorolt; az UFA ezzel a német Propagandaminisztérium egyik elsőszámú eszközévé vált. Minden országba más, az adott környezetre adaptált változatot küldtek, és mindegyik más elnevezést viselt: Spanyolországban a polgárháború és a második világháború alatt az UFA Aktualitásokat (Actualidades UFA) láthatta a moziközönség.

Hitler magas szinten müvelte a propaganda művészetét. Meggyőződése volt, hogy az első világháborúban Németországot nem a harctéren, hanem a propaganda terén győzték le. Gustave Le Bon téziseit ${ }^{107}$ alapul véve a tömeget nyájnak tekintette, ostoba emberek összességének, amelynek csak egyféle dolgot szabad mondani, elzárva őket minden választási lehetőségtől $^{108}$ (ezt később a Mein Kampfban fejti ki részletesen). Vezetni kell őket, és erre a nézőhöz közvetlenül elérő film a legalkalmasabb eszköz. A Führer kedvelte a filmesek társaságát, gyakran adott partikat, ahová kizárólag a filmvilág képviselői nyerhettek bebocsátást, a filmiparban dolgozók jövedelmét pedig egy olyan adókategóriába sorolta, hogy fizetésük szinte teljes összegét megtarthatták. Estéit általában egy film megtekintésével zárta, ahol, amennyiben német filmről volt szó, kötelezően meg kellett jelenniük a film készítőinek is. A legfőbb cenzor szerepét is betöltötte: a propagandafilmeket - akárcsak Sztálin kockáról kockára kommentálta, saját kezüleg javított bele a forgatókönyvekbe is. ${ }^{109}$ Magas szintre emelte a személyi kultuszt, tudatosan alakítva imázsát.

Ahogyan a szovjet film kapcsán Eizenstein és kollégái esetében meg kell említeni azt az újdonságot és előrelépést, amellyel hozzájárultak a filmtörténet fejlődéséhez, úgy a náci filmiparban is szükséges kiemelni Leni Riefenstahl Az akarat diadala címü propagandafilmjét. Ezt a müvet, témája ellenére, filmmüvészeti szempontból az egyik legkiemelkedőbb alkotásként tartjuk számon ma is.

\footnotetext{
${ }^{106}$ Child, Ben: „Nazi 3D films from 1936 discovered” in The Guardian, 2011. február 16. Elérhetö: http://www.guardian.co.uk/film/2011/feb/16/nazi-3d-films-discovered (2012-11-21)

${ }^{107}$ Magyarul: Le Bon, Gustave: A tömegek lélektana. Budapest, Hatágú Síp Alapítvány, 1993.

${ }^{108}$ Ormos Mária: Hitler élete és kora, Budapest, Pannonica Kiadó, 2003. 15.

${ }^{109}$ Diez Puertas, Emeterio: Historia social del cine en España. Id. mü. 292-295.
} 


\section{Olaszország}

Az olasz fasizmus művészetfelfogásában a római múlthoz nyúlt vissza, festészete és építészete szimbólumrendszerében megjelentek a Római Birodalomból ismert alakzatok és jelképek aktualizált változatai. A Fasiszta Kulturális Intézet (Istituto Fascista di Cultura) a belföld, a Dante Alighieri Intézet (Istituto Dante Alighieri) a külföld irányába terjesztette a fasiszta kultúrát.

Az első világháborúig az olasz történelmi filmek és melodrámák biztosították a kiemelkedő itáliai jelenlétet a világ filmművészetében. A Mussolini ösztönzésére létrehozott LUCE Intézet (L’Unione Cinematografica Educativa) tartotta kézben a filmhíradók és dokumentumfilmek készítését, valamint minden filmgyártó tevékenységet végző vállalat csak az intézet engedélyével müködhetett.

A propaganda típusa és a fentről megszabott kultúra azonban Olaszországban bizonyos szempontból különbözik a többitől: míg a szovjet és a náci esetben a vezető ideológia kizárólagossága figyelhető meg, addig a fasiszta Olaszország esetében helyet kap egy kis bizonytalansági faktor, megjelennek az egyensúlytalanság tényezői, és az olasz elemeket vegyíti némi európai és amerikai felhanggal. Ennek persze megvolt a célja: a Duce elérte, hogy a nép azt higgye, szabadon dönt, így nem felsőbb parancsra, hanem önként alávetve magukat alkalmazkodnak az ideológiához, önállóan felfogják, hogy nekik „ez a jó”. 110 Ellentétben a többi diktatúrával, Itáliában nem sikerült teljesen összhangba hozni a politika vonulatát a filmipar termékeivel, mindig voltak müfajok, „,kiskapuk”, amelyeken keresztül az igazi filmmüvészet is megmutatkozhatott (a fasiszta tematika valamilyen szinten itt is jelen volt, de sokszor csak másodlagos módon). Ez részben tudatos volt: a Duce és propagandistái úgy vélték, a közönség elutasítaná a hitleri közvetlen propagandát, így nyitottabbnak mutatkoztak. ${ }^{111}$ Mussolini filmjei olyannyira különböztek Hitler mozijaitól, hogy Goebbels egy alkalommal megjegyezte a Vaskorona (La corona di ferro, Alessandro Blasetti, 1941) kapcsán: „Ha ezt egy német rendező csinálta volna, falhoz kellene állítani és lelőni”. ${ }^{112} \mathrm{~A}$ hangosfilm megérkeztével a fasiszta ország filmjei rendkívüli népszerüségnek örvendtek a lakosság körében. A rendszerhez hü, ugyanakkor bizonyos fokú szabadsággal rendelkezö alkotók, nem titkoltan, a korabeli hollywoodi munkákat próbálták imitálni

\footnotetext{
${ }^{110}$ Lengyel László: „Tömegpropaganda és buborékpolitika” in: Mozgó Világ, 2006/1, 36-37.

${ }^{111}$ Aristarco, Guido: Il cinema fascista: il prima e il dopo. Edizioni Dedalo, Bari, 1996. 73; Arnone, Karen: The Cinema under Mussolini in: http://ccat.sas.upenn.edu/italians/resources/Amiciprize/1996/mussolini.html (201211-21)

${ }^{112}$ Thompson, Kristin - Bordwell, David: A film története. Id. mű. 303.
} 
történetvezetésükben és rendezési stílusukban, méghozzá nagy sikerrel. A magyar filmesek olaszországi tevékenysége is hozzájárult a korszak itáliai filmmüvészetének felvirágoztatásához. ${ }^{113}$ Kimondottan a fasiszta ideológiát népszerüsítő film kevés készültt.

Mussolini szerint a film a leghatékonyabb és legkifejezőbb müvészeti forma, amely a modern korban az emberiség rendelkezésére áll. Személyesen felügyelte a Cinecittà filmstúdió létrehozását és müködését, valamint a Velencei Filmfesztivál megalapítását, mindkettő létezik ma is. Az Olaszországban vetítendő fontosabb filmeket előzetesen megtekintette magánvetítőtermében, személyesen engedélyezte bemutatásukat. Az általa betiltott filmeket megőrizte magángyüjteménye számára. ${ }^{114}$

Hitlert megelőzően ő tökéletesítette a személyi kultuszt, ennek kiépítéséhez elsősorban a filmművészetre támaszkodott. Mindig pontosan megtervezte, hogyan áll majd kamera elé, a felvevőgép milyen szögből rögzítse beszédeit, a tükör előtt előre elpróbált gesztikuláció és testtartás pedig a lehető legnagyobb tiszteletet ébressze nézőiben.

Az olasz neorealizmus, Roberto Rossellini és kortársai filmmüvészeti tevékenysége nem jöhetett volna létre, ha az alkotók müvészi fejlődésére nem nyomja rá bélyegét az olasz fasizmus. A Mussolini-érában megtapasztalt korlátok és elnyomás, amelyek a relatív alkotói szabadság mellett is jól tapinthatóak voltak mindenki számára, egyik legfőbb kiváltó okaiként említhetőek annak, hogy az olasz filmesek valami újat, valami mást kerestek, és így létrehozták az európai filmművészet egyik mérföldkövének számító új irányzatot.

\section{Amerikai Egyesült Államok}

Demokráciákban is bírhat a diktatúrákhoz hasonló jelentőséggel a mozgóképes müvészet. Már Winston Churchill is brit filmesek, mindenekelőtt a magyar származású Korda Sándor (Alexander Korda) segítségével próbált meg közvetlen kapcsolatot kialakítani a társadalommal, önmagáról és politikájáról kedvező képet bemutatva. ${ }^{115}$ A legfrissebb filmtörténeti kutatások szerint a Lady Hamilton (That Hamilton Woman, 1941) címü Kordafilmben a Lord Nelson szájából elhangzó németellenes mondatokat valójában Churchill írta és küldte el a forgatókönyvírónak, hogy illessze be azokat a párbeszédbe; nem véletlen, hogy a brit miniszterelnöknek, saját bevallása szerint, ez volt a kedvenc filmje. ${ }^{116}$

\footnotetext{
${ }^{113}$ Erről lásd: Rosselli, Alessandro: Amikor a Cinecittà magyarul beszélt. Id. mű.

${ }^{114}$ Diez Puertas, Emeterio: Historia social del cine en España. Id. mü. 290-291.

115 Paris, Mike: „La industria británica de cine y el problema de la descolonización” in: Montero, Julio Rodríguez, Araceli (szerk.): El cine cambia la historia. Madrid, Ediciones Rialp, 2005. 50.

116 „Lady Hamilton” in: Imágenes, 2008/12. 23.
} 
A demokratikus filmpropaganda legtökéletesebb példája az Amerikai Egyesült Államok. Ahogyan Carmen Martín Gaite spanyol írónő fogalmazott: „filmvetítőjén keresztül az Egyesült Államok rendelkezik a világ leghatalmasabb szellemi birodalmával". ${ }^{117}$ Hollywood mindig azonnal reagált a világpolitika eseményeire. A spanyol polgárháborúban az amerikai filmeseknek nagy szerepük volt abban, hogy nemzetközi szolidaritási mozgalom indult meg a spanyol köztársaságiak mellett, Franco ellen. A filmek cselekményének szerves részét képezte a spanyol konfliktus. ${ }^{118}$ A második világháború alatt mindez fokozódott: hős amerikaiak lepték el a vásznakat, akik senkit és semmit nem kímélve harcoltak a tengelyhatalmak ellen a demokrácia védelmében. A közönséget szabadidejében is hazafiasságra nevelték, a világháborús amerikai filmpropaganda máig az egyik legjelentősebb audiovizuális propagandának számít, amelyet hol együttműködve, hol egymással párhuzamosan fejtett ki a kormány és a filmstúdiók. Az ezt követő hidegháború különleges helyzetet teremtett. A nagypolitika szüntelenül napirenden tartotta a kommunista veszélyt, minden sarkon szovjet kémeket vizionáltak, a nép rettegett a szovjet támadástól. Megszülettek az úgynevezett „,paranoia filmek”. Egyik fajtája a konkrét kémkedéssel, szovjet ügynökökkel operáló munkák, szép számmal találni ilyet a filmkánonban ${ }^{119}$. A másik csoportba tartoznak a közel száz darabot számláló inváziós filmek, amelyek áttételes szovjetellenes propagandát képviseltek: földönkívüliek, testrablók, szörnyek, óriáspolipok, óriáshangyák és ezekhez hasonló lények lepték el a vásznakat, de az első látásra csak alacsony színvonalú horrornak és fantasztikus filmnek elkönyvelt művek elkészítését is az idegen erőtől, többnyire a Szovjetuniótól való félelem motiválta. A szörnyeket könnyen be lehetett helyettesíteni a megszálló kommunista ügynökökkel. ${ }^{120}$ Ugyanígy reagáltak a későbbiekben kirobbanó tényleges háborúkra is: Korea, Vietnam, Öböl-háború, Irak, Afganisztán. Ezek a filmek azonban nem magáról a háborúról szólnak, hanem olyan történeteket mesélnek el, amelyek az amerikai hazafias érzést táplálják. A konkrét háborúról készülő filmek általában háborúellenes

\footnotetext{
${ }^{117}$ Martín Gaite, Carmen: Usos amorosos en la posguerra española. Barcelona, Anagrama, 1987. 30.

${ }^{118}$ Lásd a „Nemzetközi filmkapcsolatok” fejezetben az „Amerikai Egyesült Államok” címü alfejezetet.

${ }^{119}$ Néhány emblematikus alkotás: A vasfüggöny (The Iron Curtain, William A Wellman, 1948), A vörös Duna (The Red Danube, George Sidney, 1949), a Pekingi expressz (Peking Express, William Dieterle, 1951) vagy A fiam, John (My Son John, Leo McCarey, 1952). Több amerikai film más országokban mutatja be a szovjetek tetteit, ilyen a magyar 1956-os forradalom utáni időszakba helyezett antikommunista kalandfilm, A budapesti rém (The Beast of Budapest, Harmon Jones, 1958) is.

${ }^{120}$ Legismertebb pédák: Földönkívüli jövevények (It Came from Outer Space, Jack Arnold, 1953), Hódítók a Marsról (Invaders from Mars, William Cameron Menzies, 1953), A testrablók támadása (Invasion of the Body Snatchers, Don Siegel, 1956). A számtalan sci-fi mellett a kultikus Star Trek - Ürszekerek (Star Trek, 19661969) című televíziós sorozat is egyik vezérfonalaként használta a szovjet-amerikai szembenállást, de a világürbe helyezve, emberek és idegen fajok háborújaként ábrázolva azt, majd a 80-as évek második felében indult Star Trek: Az új nemzedék (Star Trek: The Next Generation, 1987-1994) már a békés egymás mellett élésre törekvés szellemében készült.
} 
nyílt vagy áttételes propagandák, ahol a traumát és az elhibázott döntéseket hangsúlyozzák $\mathrm{ki}^{121}$. A középutat a semleges hangvétel jelenti, ahol bemutatják a háborúk tragédiáit, de nem ítélik el egyértelműen az amerikai hadba lépést, esetleg csak utalnak rá, hogy az okok és szándékok nem feltétlenül elfogadhatóak. ${ }^{122}$ A Szovjetunió összeomlása után Hollywood szerint az USA egyedül maradt, mint a világ képét meghatározó nagyhatalom és a demokrácia védelmének egyetlen letéteményese. Az amerikai létpropaganda egyik huszonegyedik századi eleme ez, az ellenség pedig általában nem amerikai, vagy ha mégis az, akkor is külföldi szálak mozgatják annak megfelelően, hogy éppen mely nemzet testesíti meg az adott korszakban a fö ellenfelet.

$* * * * * * * * * * * * * * *$

Bármilyen filmről is legyen szó, a mű egy, az alkotók által vallott ideológiát közvetít felénk. A néző pedig nem tudja magát kivonni a hatása alól, akár egyetért az abban látottakkal, akár nem, részesévé válik annak a kollektívának, amelyből az alkotás valamilyen válaszreakciót vált ki.

\footnotetext{
121 Például: M.A.S.H. (M.A.S.H., Robert Altman, 1970), Apokalipszis most (Apocalypse Now, Francis Ford Coppola, 1979), A szakasz (Platoon, Oliver Stone, 1986), A háború áldozatai (Casualties of War, Brian DePalma, 1989), Született július 4-én (Born on the Fourth of July, Oliver Stone, 1989).

${ }^{122}$ Egyik legfrissebb példa A bombák földjén (The Hurt Locker, Kathryn Bigelow, 2008), illetve az amerikaiak szándékait már sötétebb tónussal ábrázoló Zöld zóna (Green Zone, Paul Greengrass, 2010). Ide sorolhatóak azon akciófilmek is, amelyekben amerikai katonák és kommandósok külföldön védik a haza érdekeit. Különböző müfajú televíziós sorozatok is készültek háborús témákról amerikai szemszögből (vígjátékok is), ezek segítségével ugyanis tartósan jelen lehet az üzenet a családok nappalijában mind az USA-ban, mind külföldön. Ilyen a klasszikus film folytatásaként készült M.A.S.H. (M.A.S.H., 1972-1983), valamint a China Beach (China Beach, 1988-1991), Az elit alakulat (Band of Brothers, 2001), az Irak (Over There, 2005), a Gyilkos megszállás (Generation Kill, 2008) vagy A hös alakulat (The Pacific, 2010).
} 


\section{A Franco-korszak ideológiai pillérei}

Egy rezsim által kialakított ideológiai környezet alapvetően befolyásolja a megszülető kulturális és mủvészeti termékek tartalmát, formáját. Az ideológia összetett fogalom. Werner Stark szociológus úgy vélte, minden gondolatot befolyásol a társadalmi környezet és a dolgok természete, mindezekből pedig egy sajátos pszichológiai deformáció révén születik meg az ideológia, amelyet olyan szubjektív, személyes érzelmek befolyásolnak, mint a gyülölet, a félelem és a vágy. Az ideológiát kialakító és arra jelentős befolyással bíró személyek igazságérzete ezáltal teljes vagy részleges mértékben eltorzul. ${ }^{123}$

A spanyol esetben nem beszélhetünk mértani pontossággal megalkotott ideológiáról, bár történt több kísérlet is, hogy Franco politikai gondolkodását összegezzék. ${ }^{124}$ A korszak egyik szakértője, Stanley G. Payne szerint Franco soha nem alkotott világos elméletet arról, még önmaga számára sem, milyen ideológia vezérli őt, és ez nagymértékben megkülönbözteti a spanyol utat a huszadik század többi politikai vonulatától. Egységes és kiforrott eszmerendszer helyett inkább olyan fajsúlyos, egymáshoz sok esetben szorosan, máskor lazábban kapcsolódó elemekről beszélhetünk, amelyek együttesen adnak egy ideológiai hálózatot. ${ }^{125}$ Ilyen volt, többek között, a nacionalizmus, az egységre törekvés, a katolicizmus és a politikai pártok nélküli erős kormányzás. Juan Pablo Fusi úgy véli, a francói ideológia egy korábban már létező gondolkodás újabb, naprakészebb változata: a tradicionalizmus vezetőjének számító Víctor Pradera gondolatvilága adja a Caudillo számára az alapvető értékeket, a jelszavak pedig a vallás, az Állam, a tulajdon és a család. ${ }^{126}$ Matilde Eiroa friss, részletgazdag és átfogó tanulmánya a diktatúra főbb szövegeit és Franco beszédeit elemezve mutatja ki, hogy mely témák milyen rendszerességgel fordultak elő a francói retorikában. ${ }^{127} \mathrm{~A}$ Francót támogató erők mindannyian hozták magukkal a saját értékrendjüket, ezeket

\footnotetext{
${ }^{123}$ Clifford Geertz antropológus és kultúrtörténész 1964-ben megjelent, az ideológiát mint kulturális rendszert jellemzö, azt egyetemes történeti és történetfilozófiai kontextusban is vizsgáló tanulmányában Starké mellett a téma elismert nemzetközi szakértőinek eredményeit összegzi: Geertz, Clifford: „Ideology as a cultural system” in: Apter, David Ernest (szerk.): Ideology and Discontent. New York, The Free Press of Glencoe, 1964. 47-76. Online változat: http://xroads.virginia.edu/ DRBR/geertz.html (2012-12-04)

${ }^{124}$ Lásd: Solís Ruiz, José: Pensamiento político de Franco. Vols. I-II. Madrid, Ediciones del Movimiento, 1975. Különösen érdekes Manuel Vázquez Montalbán könyve, aki Franco beszédeit és interjúit vette nagyító alá, hogy abból kialakítson egy koherens ideológiai hátteret, vajon milyen eszmei erők, „démonok” vezérelték a Caudillo gondolkodását: Vázquez Montalbán, Manuel: Los demonios familiares de Franco. Barcelona, Random House Mondadori, 2004.

${ }^{125}$ Payne, Stanley G.: Franco. El pérfil de la historia. Madrid, Alianza, 1992. 258.

${ }^{126}$ Fusi, Juan Pablo: Franco: Autoritarismo y poder personal. Madrid, El País, 1985. 93-94.

${ }^{127}$ Eiroa San Francisco, Matilde: „Las fuentes doctrinales: pensamiento y lenguaje de la represión sistemática (1936-1948)" in: Aróstegui, Julio (szerk.): Franco: La represión como sistema. Barcelona, Flor del Viento Ediciones, 2012. 107-143.
} 
esetenként könnyen össze tudták hangolni egymással, máskor azonban konfliktusokat szültek. A csoportok sokfélék voltak: falangisták, carlisták, monarchisták (alfonzinisták és juanisták), valamint külön eszmei világot képviselt a hadsereg és az egyház.

Dolgozatomnak nem feladata a különböző frakciók ideológiai alapon történő megkülönböztetése, kizárólag olyan részleteket emelek ki, amelyek témám szempontjából relevánsak, együttes jelenlétük pedig döntő hatást gyakorolt a filmpolitikára.

A Franco-korszak magyar szakértője, Harsányi Iván úgy véli, a háború idején és a diktatúra első éveiben a falangisták és a konzervatívok eszmerendszere áthatotta egymást, a konzervatív ideológiákból eltüntek a liberalizmus nyomai, a falangizmus nemzetiszocializmusa pedig szinte államvallássá vált. A különböző csoportok egymástól gyakran eltérő elveket képviseltek, a halmazok metszete maga Franco tábornok volt: ő egyesítette magában a csoportok hitvallását és vált az összeütközéseket megakadályozó legföbb vezérré. ${ }^{128}$ Szervezetileg a FET y de las JONS (Falange Española Tradicionalista y de las Juntas de Ofensiva Nacional-Sindicalista - Tradicionalista Spanyol Falange és Nemzeti-Szindikalista Offenzíva Juntái) fogta össze a különböző irányzatokat. Az említett szerző a polgárháborút lezáró évre vonatkozóan írja, amit magam a 40-es évekre is alkalmazhatónak vélek: „1939 tavaszán valamennyi áramlat teljes ideológiai egysége elsősorban a legyőzött demokratikus tábor hatalmas és sokszínű gondolatkincsének merev tagadását jelentette."129 A diktatúra végéig (1975) a különböző, egymáson felülkerekedni próbáló csoportok, családok vetélkedései határozták meg a rendszer poltikai-ideológiai fő irányait.

A Második Köztársaság idején kialakult konzervatív, jobboldali és szélsőjobboldali csoportok lesznek föszereplöi az 1936-ban kirobbanó polgárháborúnak. Az említett körök eszmei találkozóhelyévé vált az 1931-ben alapított Acción Española címü folyóirat, ahol megosztották gondolataikat, formálták is egymást, így kezdett lebomlani a határvonal a jobb és a szélsőjobb között, és vált egy heterogén masszává. ${ }^{130}$ A folyóirat célja „olyan egységes platform kimunkálása volt, melyet liberalizmus- és parlamentellenes, korporatív, katolikus, monarchista szellem jellemzett". ${ }^{131}$

\footnotetext{
${ }^{128}$ Harsányi Iván: A Franco-diktatúra születése. Budapest, Kossuth Könyvkiadó, 1988. 153-154. A könyv alábbi oldalain részletes és világos leírást ad a szerző arról, hogy a különböző csoportok milyen elvek köré gyültek a polgárháború alatt és a diktatúra első éveiben, melyek voltak a közös és az eltérő pontok: 151-175.

129 Uo. 161.

${ }^{130}$ Harsányi Iván: „A spanyol politikai konzervativizmus a 20. században” in: Uő: A félperifériától a centrum felé. Spanyolország és Portugália a „hosszú 19.” és még hosszabb 20. században. Pécs, Publikon Kiadó, 2011. 193-194.

${ }^{131}$ Anderle Ádám: Megosztott Hispánia. Budapest, Kossuth Könyvkiadó, 1985. 156. Anderle Ádám könyvében az alábbi oldalakon olvashatunk először magyar nyelven az Acción Españoláról: 156-160.
} 
A Falange megalapítója, a polgárháború első évében a köztársaság elleni szervezkedés vádjával kivégzett José Antonio Primo de Rivera mint állandó, karizmatikus vezér, egyszersmind mártírrá vált nemzeti hős kapott helyet a nemzeti oldal panteonjában. A falangista vezér halála után Franco vette át szerepét, José Antonio egy mindenki felett álló védőszentté vált a nacionalisták szemében, az iránta tanúsított kultusz hasonlatos volt a vallási fanatizmushoz. A halála után készített Jelen! José Antonio Primo de Rivera temetésén (;Presente! En el enterramiento de José Antonio Primo de Rivera, Departamento Nacional de Cinematografía, 1939) címü rövid dokumentumfilmben a német és olasz propagandafilmek hagyományait és technikai, filmnyelvi eszközkezelését követve bemutatják az alkotók, milyen fájdalmat és ürt hagyott maga után a hős halála. José Antonio testét átszállítják a spanyol vidéken, majd a főváros után az Elesettek Völgyébe érkeznek; az út során a nép is tisztelettel adózik az elhunytnak. Eközben a narrátor kommentálja is az eseményeket, a meglévő mítoszt táplálja és nagyítja tovább, összekapcsolva mindezt a jelennel. „A nép átérzi José Antonio drámáját és képes áhítattal adózni az új cézárnak, az új Állam doktrínája megalkotójának, amelyet Franco a fegyveres győzelmével nyert el”, említi a narrátor. A képek és a szöveg együttese büszkeséget és fájdalmat egyaránt próbál közvetíteni. A polgárháború utolsó évében, valamint a posguerra periódusában készült filmhíradók visszatérő alakja lesz José Antonio Primo de Rivera, a vezér, a szent és a mártír hármas szerepkörét betöltve. ${ }^{132}$

Hitler egyik spanyol csodálója és követője, Ramiro Ledesma Ramos 1931-ben megalapította a JONS-t (Juntas de Ofensiva Nacional-Sindicalista - Nemzeti-Szindikalista Offenzíva Juntái), amely a korabeli spanyol politikai csoportok közül a legtisztább változatát mutatta be a fasizmusnak. 1934-ben történik meg a Falange és a JONS egyesítése FE de las JONS (Falange Española de las Juntas de Ofensiva Nacional-Sindicalista-Spanyol Falange és Nemzeti-Szindikalista Offenzíva Juntái) néven. Módszerük a szisztematikusan alkalmazott erőszak volt, a nácizmus és fasizmus alapeszményeit próbálták spanyol környezetre adaptálni a nemzeti-szindikalizmus keretein belül egy totalitárius államban, erőteljes katolikus fundamentummal.

José Antonio Primo de Rivera halála és minden potenciális rivális eltủnte (egyesek elhunytak, mások kiszorultak a hatalomból) után Franco 1937-ben egyesítette a különbözö csoportokat a Spanyolország nacionalista kézre kerülő területeit irányító, már említett FET y de las JONS-ban, majd, kiegészülve a vertikális szakszervezetekkel és az államot támogató csoportokkal, a Nemzeti Mozgalom (Movimiento Nacional) már az egész országot

\footnotetext{
${ }^{132}$ Erről bővebben: Sánchez-Biosca, Vicente: „El ausente, ¡Presente!: el carisma cinematográfico de José Antonio Primo de Rivera, entre líder y santo" in: Archivos de la Filmoteca, No. 46. 2004. 66-87.
} 
kormányozta. A FET y de las JONS müködéséről szóló szervezeti szabályzat kifejezte, milyen célok lebegnek az új Spanyolországot vezető Caudillo szeme előtt: „,... azt a feladatot kell betöltenie, hogy Spanyolországnak, mint a Történelem szereplöjének visszaadja lerombolhatatlan sorsközösségének, katolikus és birodalmi elhivatottságának mélységes tudatát, hogy olyan gazdasági rendszert építsen föl, amely fölülemelkedik az egyén, a csoport, az osztály érdekein, s így megsokszorozza az Állam szolgálatában álló javak mennyiségét, megvalósítva a társadalmi igazságosságot és a személyiség keresztény szabadságát". ${ }^{133}$ A fasizmushoz legközelebb álló Falange-csoport a Nemzeti Mozgalomnak csak egy szegmensét adta. A polgárháború alatt és közvetlen utána túlsúlyban voltak, 1939-ben még 650 ezer férfi tagja volt, 1943-ra ez a szám 932 ezerre emelkedett. Az adminisztrációs és irányító testületekben is számbeli fölénnyel rendelkeztek, 1945-ig a Nemzeti Tanács tagjainak 88\%-át és a Nemzeti Mozgalom irányítóinak többségét is a Falange adta. ${ }^{134}$ A társadalom átnevelése és az új Spanyolország politikai berendezkedésének megreformálása a Falange kezébe került. A hozzájuk tartozó sajtó független volt még a központi cenzúrától is.

A második világháború utolsó éveiben, amikor már láthatóvá vált, hogy a tengelyhatalmak lesznek a vesztes fél, a Franco-rezsim számára is egyre kényelmetlenebbé vált a fasiszta retorikát alkalmazó csoportok nagy súlya. Egyértelmünek tủnt, hogy a győztes országok nem fogják eltürni egy fasizmussal szimpatizáló rendszer fennmaradását Európában, sem szövetségesként, sem baráti országként nem tekintenek majd rá. Ezzel párhuzamosan, az egyház és a polgárság bizonyos szektorai féltékenyen szemlélték a Falange hatalmát, a Caudillo is korlátozva érezte egyeduralmát. A gyökeres bel- és külpolitikai fordulattal az irányító testületekben a Falange és társszervezetei ezért veszítettek erejükből, a 40-es évek második felétől pedig a falangista eszmék és személyek (a Nemzeti Mozgalom korábban egyik alapkövének számító karlizmussal és alfonzinista monarchizmussal egyetemben) egyre inkább már csak integrált áramlatokként funkcionáltak, súlyuk pedig csökkenőben volt. ${ }^{135}$ 1945-től a Propagandisták Nemzeti Katolikus Szövetsége (Asociación Católica Nacional de Propagandistas - ACN de P), 1957-től pedig az Opus Dei körébe tartozó politikusok (utóbbi esetében technokraták) foglaltak el kulcspozíciókat, a Falange mozdulatlan (inmovilista) szektorai a 70-es évek elején kerülnek majd ismét előtérbe, de csak rövid időre. Állandó tényezőként - Franco mellett - csak a hadsereg és az egyház voltak jelen a rezsim

\footnotetext{
${ }^{133}$ Idézi: Harsányi Iván: „A spanyol politikai konzervativizmus...”. Id. mü. 198.

${ }^{134}$ Moradiellos, Enrique: La España de Franco (1939-1975). Política y sociedad. Madrid, Editorial Síntesis, 2000. 70-71.

${ }^{235}$ A Falange szerepéről a polgárháború alatt és után számos könyv került publikálásra. Az általam használt: Rodríguez Jiménez, José Luis: Historia de la Falange Española de la JONS. Madrid, Alianza Editorial, 2000.
} 
irányításában. Ez a megállapítás a filmpolitika terén is igazolható: tisztán falangista, karlista vagy monarchista eszmekörben készült filmet csak elvétve tudunk felmutatni a diktatúra időszakából, egyértelmủen a katonai morálra és a klerikális témára épülő alkotást viszont több tucatot.

A közelmúltban számos, az adott korszakkal foglalkozó művet kiadó José Javier Esparza úgy véli, olyan személyeken múlott a diktatúra sikere, akik egyszerre több ilyen frakcióhoz is tartoztak. Egyik példaként Carrero Blanco admirálist hozza, aki a katonai szabálykövetés, a politikai katolicizmus és a szocioökonómiai haladásra való készség „olvasztótégelyét” adta, de ide sorolható szerinte Alfredo Sánchez Bella is, aki elvakult falangista propagandistából a részleges nyitást sem elutasító tájékoztatási és idegenforgalmi miniszter lett a korszak végére. Ök és kulcspozíciót elfoglaló társaik érzékelték a változások szükségét, és - bár csak lassan és kis mértékben - belülről próbálták meg a rezsimet más utakra terelni. ${ }^{136}$ A fejlődést pedig, szerinte, maga a Caudillo is támogatta. Stanley G. Payne és más szerzők, a Franco-időszakra vonatkozó korszakolását kiegészítve Esparza három különböző, egymásból kifejlődő és egymással tökéletesen harmonizáló Francoszerepfelfogást különböztet meg: a Katona, a Misszionárius és a Fejlesztő. Ez a három szerep Esparza szerint a változó idők, a társadalom szükségletei és a világpolitika változásai miatt alakult ki, alapvetően egymást követték, de ha a szükség úgy hozta, a három párhuzamosan volt jelen, a Caudillo bármikor tudott váltani egyikről a másikra. ${ }^{137}$ A Katona és a Misszionárius nem voltak összetett személyiségek, inkább a háború által megtépázott nép szükségleteire adtak azonnali reakciót, és közelíteni akartak az egyszerü polgárokhoz. A Fejlesztő már bonyolultabb karakter, döntően elitista: olyan tudás birtokában van, amelyében senki más, csak ő képes átlátni a bonyolult folyamatokat, éppen ezért egyértelmü, hogy ő vezeti a tömegeket. ${ }^{138}$ Mindhárom típus jelen van a korszak filmjeinek karaktereiben is.

Az 1939-ben a harmadik kiadását megélt és az iskolákban kötelező oktatási anyaggá vált Catecismo patriótico español ${ }^{139}$ összefoglalja, milyen ideológiai alapokon nyugszik az új Spanyolország. Franco áll a társadalom csúcsán, ő a legfőbb vezér (Caudillo), a tábornokok

\footnotetext{
${ }^{136}$ Esparza, José Javier: Juicio a Franco. Madrid, LibrosLibres, 2011. 75. Bár Esparza ezt nem említi, de fontos megjegyezni: a nyitás periódusát követően az 1969-ben a Tájékoztatási és Idegenforgalmi Minisztérium élére kerülő Alfredo Sánchez Bella visszatérést jelentett a konzervatívabb politika felé, nevéhez füződik a 40-es éveket idéző szigorúbb cenzori és sajtópolitika.

${ }^{137}$ Uo. 76. Az alábbi oldalakon részletesen is kifejti a szerepfelfogások mibenlétét és jellemzőit: 76-115.

${ }^{138}$ Uo. 113-114.

139 González Menéndez-Reigada, Ignacio: Catecismo patriótico español. Salamanca, 1939. Mivel az eredeti szöveghez nem volt hozzáférésem, összegzésemhez egy, a Catecismo bizonyos részeit szemantikai szempontból elemző, angol-spanyol szinkronnal és fordítással foglalkozó doktori disszertációt használok: Camino Gutiérrez Lanza, María del: Traducción y censura de textos cinematográficos en la España de Franco: Doblaje y subtitulado inglés-español (1951-1975). Universidad de León, Secretariado de Publicaciones, 2000. 35-37.
} 
tábornoka (Generalísimo), aki a spanyol nemzet ura. A többiek (mint Mola vagy Queipo de Llano) csak utána következhetnek. Isten választotta ki őt Spanyolország felemelésére, a nép tehát az Úrnak engedelmeskedik azáltal, hogy elfogadja Francót vezérének. A katolikus vallás egységbe fogja a hispán fajt, ezért az egyház a hatalom egyik legfőbb támasza. A kasztíliai spanyol lesz a civilizáció nyelve, maga mögé utasítva az angolt és franciát. Miután oldalakon keresztül sorolja a nemzet történelmi eredményeit, elérkezik a jelenhez, amelyben hét fő ellenséget nevez meg: liberalizmus, demokrácia, judaizmus, szabadkőművesség, kapitalizmus, marxizmus, szeparatizmus. A nemzeti csapatok által vezetett Keresztes Hadjárat átmenetileg legyőzte ezeket, de nem tudta elérni a tényleges megsemmisítésüket. Továbbra is lesben állnak, támadásra készek. Spanyolország a Nyugat egyetlen reménysége, hogy fennmaradjon a civilizáció.

A rövid- és hosszú távú politikai célkitüzések területén könnyen kiéleződhettek a nézeteltérések a Nemzeti Mozgalom csoportjai között, ezért vált kulcsfontosságúvá Franco személye, mint összetartó erő és egyensúly a különböző érdekek között. Voltak azonban olyan szegmensei a rendszernek, ahol többé-kevésbé egységes teoretikai bázison alapuló értékrendszerek találkoztak. Ilyen volt a diktatúra filmpolitikája is, ahol a művek tematikájában nem láthatunk egymással élesen szembenálló vetületeket, inkább a rezsim általános felfogását képviselik szintetizáló módon. Ebben az esetben is megállapítható lesz azonban, hogy mely elvek bizonyultak dominánsnak.

Egységes kiindulópontként megemlíthetjük, hogy a hatalom két fő pillérének tartott hadsereg és egyház értékrendszere minden esetben alapvető szempontként jelent meg. A Nemzeti Mozgalom mellett ezek két olyan tényezőt jelentettek, amelyek fontos szerepet kaptak a döntések meghozatalában. Az akkori spanyol berendezkedés gerincét alkotó katonaság érzékenynek mutatkozott minden kis rezdülésre, amely a rendszer stabilitását megingathatta. A katolikus klérus a rezsim másik fő támaszát adta; missziójuk a katolikus lelkek védelme minden káros, őket esetlegesen tévútra terelő hatástól.

A Franco-korszak megteremtette a Gerő András által szimbolikus politikának nevezett gyakorlatot, amely részben egy politika-, gazdaság- és társadalomtörténettel összefüggő identitás- és kultusztörténet, részben azonban különbözik is tőle. A szimbolikus politika akár kijelölheti a reálpolitika útját is, utóbbi intézkedései az előbbi ideológiai nyomvonalán haladhatnak. ${ }^{140}$ A polgárháború utáni Spanyolországban éppen erről volt szó. Gerő arról a lehetőségről is beszél, amikor a szimbolikus politika a reálpolitikától eltérő alternatívát

\footnotetext{
${ }^{140}$ Gerő András: Képzelt történelem. Budapest, Eötvös Kiadó - PolArt Kiadó, 2004. 7.
} 
képvisel: a spanyol esetben ez az 50-es évek közepétől tapintható ki, de csak kisebb mértékben, amikor a változó bel- és külpolitika ellenére bizonyos rezsimhez hủ személyek továbbra is megpróbálták a merev és elvakult ideológiát képviselni. Erre a filmpolitikában is látunk majd példát.

Mielőtt áttérnék a diktatúra általam kulcsfontosságúnak vélt ideológiai összetevőire, még érinteni kell egy kérdést: fasizmus volt-e a spanyol rendszer? Manuel Vázquez Montalbán, Togliatti és Poulantzas munkáiból kiindulva, az európai fasizmusok tíz legfőbb ismérvét az alábbiakban jelöli meg: nacionalizmus, jogi önkény, az elit kultusza, militarizmus, a család tisztelete, az oktatási és információközlő apparátus feletti kontroll, értelmiség-ellenesség, korporativizmus, rasszizmus és antiklerikalizmus. Véleménye szerint a spanyol esetben is felfedezhetőek mindezek, azzal a különbséggel, hogy az utolsó előtti elem másként, az utolsó pedig egyáltalán nem jelenik meg. A vallásban a nemzetikatolicizmus (Montalbán szavaival élve: szuperkatolicizmus) vált mindenható tényezővé. ${ }^{141}$ A rassz kérdése nem faji üldözésként, hanem a kiemelkedő hispán faj felmagasztalásaként jelentkezett, a Hispanidad felfogásából kiindulva nem faji alapú kirekesztésről (antiszemitizmus) beszélhetünk, hanem mérsékelt volumenü vallási alapú megvetésről (antijudaizmus); ismertek már a rezsim zsidómentő akciói ${ }^{142}$, egyes zsidó művészek feltétlen támogatása (Vajda László filmrendező esete), míg a zsidó nép iránt tanúsított ellenérzések leginkább a retorika szintjén maradtak.

A legtöbb szerző úgy ítéli meg, hogy a spanyol Franco-rendszert túlzás lenne fasizmusnak nevezni, inkább csak „fasizmus-szerünek.” Edward Malefakis, az egyik legelismertebb amerikai hispanista az erre vonatkozó vélekedések összegzéseként hosszú tanulmányában kifejti, mik a fasizmusok legfőbb jellemzői, majd ezek után tételesen elemzi, miért is nem feleltethető meg ezeknek a Franco-rendszer. Szerinte a Caudillo, a fasiszta diktátorokkal ellentétben, nem akart egy új társadalmi struktúrát létrehozni, hanem restaurálni igyekezett egy idealizált múltbéli Spanyolország-képet, méghozzá az általa totalitáriusnak nevezett Katolikus Királyok államának mintájára. A premodern korszakot preferálta a modern korral szemben. Fontos különbségnek véli Malefakis, hogy Mussolinivel és Hitlerrel szemben

\footnotetext{
141 Vázquez Montalbán, Manuel: Los demonios familiares de Franco. Id. mű. 14.

${ }^{142}$ A magyar esetről lásd részletesen: Harsányi Iván: „Meggyőződés vagy kötelességteljesítés. Ángel Sanz Briz szerepe az üldözött magyar zsidók életében (1944)” in: Anderle Ádám (szerk.): Zsidóság a hispán világban. Szeged, SZTE Hispanisztika Tanszék, 2004. 95-108. A mai spanyol társadalom büszke a korabeli zsidómentő tettekre, a Sánz Briz életéről szóló Budapest angyala (El ángel de Budapest, Luis Oliveros, 2011) címü tévéfilm 2011-ben az állami televízióban az év legnézettebb spanyol filmjévé vált, 3 és fél millióan látták és számos nemzetközi díjjal tüntették ki. Az említett adatokról lásd: „'El ángel de Budapest', la película española más vista en televisión en 2011" in: http://www.europapress.es/chance/tv/noticia-angel-budapest-pelicula-espanola-masvista-television-2011-20120103183718.html (2011-11-21)
} 
Franco külpolitikai és terjeszkedési ambíciói visszafogottabbak voltak (mindössze Marokkó, a Nyugat-Szahara és Gibraltár kérdése említhető), a birodalomépítési terv csak szellemi síkon, a Hispanidad keretein belül született meg. A fasiszták a tömeget mobilizálni akarták, hogy egyfajta mitikus együttműködésben, közösen építsék a fasiszta jövőt; ezzel szemben Franco inkább demobilizálni igyekezett a népet, a rendszer stabilizálódása után igyekezett a társadalom nyugodtan és szorgalmasan dolgozó részének tekinteni azt. Bár bizonyos évfordulókon vagy kivételes alkalmakon Spanyolországban is szerveztek az állam iránti szimpátiát kifejező tömegdemonstrációkat, azok volumene nem ért fel a fasizmusokban tapasztalhatókéval. A spanyol rezsim grandiózus müvészi megnyilatkozásai (építészet, festészet) és propagandagépezete is jóval visszafogottabb volt, mint a fasizmusok esetében. A vezérközpontú irányítás ellenére Franco karizmája nem vetekedhetett Hitlerével és Mussoliniéval, nem emelkedett isteni magasságokba, a Caudillo soha nem lett Duce vagy Führer. Hitler és Mussolini még az irányító csoportok között sem türtek meg semmiféle pluralizmust, szemben Franco a hatalmi apparátusban kulcsszerepet betöltő családjaival. Malefakis szerint az egyik legfontosabb szempont az egyház: a németek és olaszok inkább mellőzték az egyházzal való együttmüködést, esetenként kifejezetten meg is romlott köztük a viszony, Franco azonban államának szerves részévé tette azt. A szerző végkövetkeztetése, hogy Franco nem akart létrehozni utópikus társadalmat, bár egyes elemeit átvette, de összességében meg sem próbálta adaptálni az olasz fasizmust. A zsidósághoz is máshogy viszonyult Franco. Malefakis hangsúlyozza, nem akarja kisebbíteni a spanyol diktatúra büneit, a halottak számának közlésével még azt is állítja, hogy Franco rendszere részben kegyetlenebb volt a másik kettőnél. Mindössze a fogalmak tisztázását szerette volna elérni. ${ }^{143}$

Ormos Mária is úgy vélte, hogy a Franco-rendszer különbözött a német és olasz esettől, ugyanis a fasiszta elit részese volt a hatalomnak, de, ellentétben a másik két országgal, nem vált azonossá vele. Szintén fontos különbség, hogy a spanyol nacionalisták a hadsereg vezette és a nagybirtokosság által támogatott felkelés útján szerezték meg a hatalmat. ${ }^{144}$

A tömegekhez való viszonyulást egy újságcikkben leírt okfejtéssorozat határozta meg, amely egyértelműen alapjául szolgált a propagandaértékü filmeknek is. 1937-ben egy névtelen szerző publikálta $A$ tömegek esztétikája ${ }^{145}$ című cikkét egy falangista folyóiratban, ez

\footnotetext{
${ }^{143}$ Malefakis, Edward: „La dictadura de Franco en una perspectiva comparada” in: García Delgado , José Luis (szerk.): Franquismo. El juicio de la historia. Madrid, Ediciones Temas de Hoy, 2005. 11-68.

${ }^{144}$ Ormos Mária: Nácizmus - fasizmus. Budapest, Magvető Kiadó. 1987. 432-433.

${ }^{145}$ Ismeretlen szerző: „Estética de las muchedumbres” in: Vértice, No. 3. 1937. június. Az eredeti szöveg nem áll rendelkezésemre, de a Franco-korszak társadalmát és müvészetét vizsgáló könyvek közül több is részletesen ismerteti azt. Az általam használt mü: Llorente, Ángel: Arte e ideología en el franquismo (1936-1951). Madrid, Visor, 1995. 27.
} 
alapján kijelölhető, hogyan is próbálták meg szisztematikusan befolyásuk alá vonni a tömegeket. Kiindulópontjuk: az első világháború után a bolsevik propaganda hatására Európa országainak népe elveszítette képességét a józan gondolkodásra, a nemzeti pártok pedig széttöredeztek, nem képesek a vezetésre. Ekkor születik meg a hazafias erők és lelkületek összefogásából egy új ideológia és egy új állam, amelyeket egy erős, magabiztos és megingathatatlan vezér, egy caudillo irányít. Ez a vezér messianisztikus módon emelkedik a nép fölé, és vezeti őt a helyes irányba. Franco megnyilatkozásai, minden lefilmezett hivatalos esemény azt a tényt vette alapul, hogy a tömegeket döntően befolyásolja a heroikus tettek ábrázolása, az ünnepi események és vallási ceremóniák pedig hatásuk alá vonják az embereket. A nézőnek éreznie kell, hogy fontos részét képezi az Új Államnak, az állam érte van, érte dolgozik, és minden, ami a vászonról visszaköszön, az ő érdekében történik. Ugyanakkor, mindennek csak akkor van hatása, ha tudatosul a közönségben: ők nem egyének, nem individuumként lettek megszólítva, hanem a közösség, a tömeg részei. Ez a tömeg pedig feltétel nélkül a Franco-rendszer kiszolgálója kell, hogy legyen, amennyiben szereti hazáját, hiszen a Caudillo által megteremtett berendezkedés a spanyol állam jólétét és üdvözülését akarja elérni. A cikk szerint a náci Németország és a fasiszta Olaszország adják a tökéletes modelljét ennek az új esztétikai rendszernek, de még a szovjet viszonyokban is felfedezhető használható elem. Ök, a spanyolok tökéletesítik a tömegek esztétikáját.

A Franco-rezsim konstruált szimbólumrendszere is építőeleme a korszak kulturális és társadalmi reprezentációinak. Az egyenruhák, zászlók, himnuszok és indulók, építmények, emlékművek, személyek ikonográfiája a diktatúra berendezkedésének alapvető részeivé váltak, azok megjelenése általános volt a mindennapokban, a társadalmi élet és az ünnepek során, valamint a müvészetek, így a film területén is.

$$
* * * * * * * * * * * * * * *
$$

Az alábbiakban néhány olyan ideológiai komponenst vizsgálok meg, amelyeket a filmek kapcsán kiemelkedően fontosnak nevezhetünk, kezdve a korszakot döntően jellemző történelemszemlélettel. A filmpolitikában és filmmüvészetben való megjelenésükre is kitérek most röviden, az ezekhez kapcsolódó konkrét műveket pedig a későbbi fejezetekben mutatom be bővebben. 


\section{A múlt}

Az említett Catecismo... nyolc olyan nagy történelmi eseményt nevez meg, amelyek a spanyol nép nagyságát hivatottak alátámasztani:

„1. a Római Birodalmat emberségesebbé és spirituálisabbá tették;

2. áttérítették és civilizálták a barbárokat;

3. kiüzték Európából a mór seregeket;

4. legyőzték a törököket Lepantónál;

5. megvédték a keresztény civilizációt és a görög-római lelkiséget a protestantizmustól;

6. Amerika felfedezése, meghódítása és civilizálása;

7. megdöntötték Napóleon hamis alapokon nyugvó birodalmát;

8. elsöpörték az eurázsiai bolsevizmust."146

A hivatalos filmpolitika által támogatott filmekben - ahogyan a későbbiekben néhány példán keresztül látni fogjuk - a jelölt témák egy része különösen nagy hangsúlyt kap, míg mások kevésbé tünnek majd fontosnak.

A rezsim kulturális beágyazottságának szimbólumai azokat a tételeket idézték vissza, amelyek a 16. századi, birodalmi létet jellemezték a maga vallásos, klasszikus és humanista mủveltségével. A középiskolai oktatásban kiemelt hangsúlyt kapott a birodalmi Spanyolország történelme és a Hispanidad ideológiai alapjainak magyarázata. Mindezzel az egyre elterjedtebbé váló fekete legenda tételeit ${ }^{147}$ akarták cáfolni, rávilágítva arra, hogy a spanyol nemzet erkölcsileg feddhetetlen nép, a Hispanidad birodalmi szellemisége pedig még magasabb szintre emeli őket. ${ }^{148}$ A 17 . század végétől kezdődő, mindenekelőtt az örökösödési háborút követő Bourbon-periódus nézeteik szerint a hanyatlás kora, a dicső Spanyolország elveszejtése.

A spanyol dicsőséges múlt központja Kasztília, értelmezésük szerint innen indult ki a nemzeti egység létrehozása (egybekötve a reconquistával) és a birodalomépítés. A polgárháborús győzelem számos alkalommal párhuzamba kerül a középkori győzelmekkel és a 19. századi spanyol erényekkel, ezek mindegyike Kasztíliára koncentrálódik. Juan de

\footnotetext{
${ }^{146}$ Camino Gutiérrez Lanza, María del: Traducción y censura de textos... Id. mü. 36-37.

${ }^{147}$ A fekete legenda a Spanyolország elleni negatív elöítéletek ,gyüjteménye”, amely különböző elemekből táplálkozik. Minderről magyar nyelven lásd: Farkas Pálma: Fekete legenda, hispanoamericanismo és az Egyesült Államok Miguel Primo de Rivera diktatúrája idején (1923-1930). Doktori értekezés. Szeged, 2012. 22-64.

${ }^{148}$ Delgado Gómez-Escalonilla, Lorenzo: Imperio de papel: acción cultural y política exterior durante el primer franquismo. Madrid, Consejo Superior de Investigaciones Científicas, 1992. 122-123.
} 
Orduña 1939-es Jön már a kíséret (Ya viene el cortejo) címü dokumentumfilmje ezt a film nyelvén is összefoglalja.

A francói történelemszemlélet egyik fundamentuma, hogy a Spanyolország egységét megteremtő Katolikus Királyok periódusát veszi a nemzeti nagyság sarokkövének - ez a megállapítás azonban máris hamis, ugyanis Kasztíliai Izabella és Aragóniai Ferdinánd házasságával nem következett be egyesülés, csupán összekapcsolódás. Kasztília és Aragónia relatív önállósága továbbra is fennállt, a királyságokon belül is megmaradtak a kisállamok. A korszak azonban mindvégig hivatkozási alap lesz az új hatalomnak - Franco egy Don Juannak $^{149}$ 1942-ben írt levelében ki is fejti, hogy Spanyolországban csak akkor lenne elképzelhető a monarchia restaurációja, ha az a Kasztíliai Izabella királyságát megidéző autoriter monarchia lenne. ${ }^{150}$ A felkelők számára minden olyan történelmi esemény, amely az általuk egységesnek vélt ország fennmaradását szavatolta vagy kiállt amellett, bekerülhetett a nemzeti kánonba, így szintén a Katolikus Királyoknak adóztak hálával Granada visszahódítása, a zsidók kiüzése, valamint az Új Világ felfedezése miatt. A hanyatlás periódusának számító Bourbon-korszak éppen ezért nem tartozik bele a francói nemzeti történelembe, a 19. század eleje azonban igen, mert az idegen (napóleoni) megszállókkal szembeszegülő spanyol nép éppen a nemzeti önrendelkezés érdekében lázadt fel. Innen pedig egyenes út vezet az 1936-39-es polgárháború igazolásához, ahol, értelmezésük szerint, szintén az idegen hatalmak összeesküvésétől kellett megvédenie Spanyolországot a hazafiaknak.

A Katolikus Királyok korszakának jellegzetességei képezték a Franco-rendszer alapját, így a kettő közötti párhuzam a rezsim számára a spanyol nemzet egyik fő alkotóelemének számított: az egységes nemzet (a 16. században Kasztília központtal), a katolicizmus hegemóniája, a fegyveres erők garantálta fegyelem és védelem, valamint a külső és belső ellenséggel vívott állandó harc.

A Franco-rendszer által dicsőséges múltnak tartott idők további elemeire a későbbi alfejezetekben és a konkrét filmek kapcsán térek ki, mivel úgy vélem, a kapcsolódási pontok miatt nagyobb létjogosultsága van ott értekezni róluk.

\footnotetext{
${ }^{149}$ Az utolsó spanyol uralkodó, XIII. Alfonz fia, aki önmagát tekintette a spanyol trón jogos örökösének. Később fia, Juan Carlos lesz Spanyolország királya..

${ }^{150}$ Preston, Paul: Juan Carlos. El Rey de un pueblo. Barcelona, Debolsillo, 2004. 32.
} 


\section{Hispanidad és a hispán faj}

Mivel földrajzilag és politikailag lehetetlen volt Spanyolország és a volt latin-amerikai gyarmatok egyesítése, szellemi síkon próbáltak erre törekedni. A tettek és a retorika alapján egy olyan, az utókor által elképzelt közösségnek nevezett formáció létrehozása volt a cél, amelynek résztvevőit nem feltétlenül köti össze direkt hatalom, a kapocs a múltban és a jelenben egyaránt keresendő. ${ }^{151}$

A Falange által megtestesített birodalmi akarat (voluntad de imperio) mutatta, hogy, bár Latin-Amerika volt gyarmatai már elszakadtak az anyaországtól, ismét bekövetkezhet az egyesülés spirituális síkon. Véleményük szerint valódi szeparáció igazából nem is történt, mert a hispán faj mindig is egy volt, semmilyen földi hatalom nem szakíthatja szét népeit. Az egykoron nagy és legyőzhetetlen hispán birodalom szellemi téren továbbra is fennáll, a Nemzeti Mozgalom hivatott őrködni az egység felett. A közös múlt, a nyelv, a szokások, a kultúra, a vallás és a spanyolokban és latin-amerikaiakban egyaránt csörgedező hispán vér mindörökké összeköti az óceán két oldalán élő népeket.

Az összetartozás gondolatát leghangsúlyosabban a 19. század végétől kereshetjük. A kolóniák elvesztésével már a századfordulón jelentőssé vált az egység kiemelése, szembeállítva mindezt a félszigeti nacionalizmusok törekvéseivel. A hispán faj ünneplését 1918-tól kezdődően október 12-én nemzeti ünnepként tartják számon (Día de la Raza - A Faj Napja). Primo de Rivera diktatúrája is az egység mellett tette le a voksát, retorikájában a hispanismo és a pánhispán gondolatkörök megjelenése volt hangsúlyos ${ }^{152}$, de a Második Köztársaság idején az összetartozás kisebb hangsúlyt kapott. Többek között a régiók autonomista törekvései, az ország megbonthatatlan egységének esetleges feltörése tette szükségessé a nacionalista oldal szemében az 1936-os felkelést, így már a fegyveres konfliktus első pillanatától kiemelt szerepet kapott az összetartozás. A Franco-diktatúra egy centralista hispán nacionalizmust állított nemzeti politikája középpontjába, amelyből kizárt mindent, ami nem az általuk vallott, a régi kasztíliai hagyományokhoz visszanyúló egységet hirdette, így a kis nemzetek önállósodási törekvései is nemkívánatossá váltak.

A volt kolóniákkal való harmonikus kapcsolat a spanyol nacionalizmus szerves részét képezte. Egy Argentínában élő spanyol pap, Zacarías de Vizcarra javasolta először, hogy a

\footnotetext{
${ }^{151}$ Benedict Anderson 1983-ban fejtette ki elöször az elképzelt közösségek elméletét, amelyeket a történelem különböző korszakaiban kialakuló és fenntartható nacionalizmusok egyik alapfeltételeként jelöl meg. Az erröl szóló monográfia: Anderson, Benedict: Imagined Communities: Reflections on the Origin and Spread of Nationalism. London-New York, Verso, 1991.

${ }^{152}$ Erröl lásd: Farkas Pálma: Fekete legenda ... Id. mü. 81-98.
} 
„Raza” helyett a „Hispanidad” szót használják, erről számol be Ramiro de Maeztu 1931-ben megjelent híres írásában, a La Hispanidadban ${ }^{153}$. Maga Maeztu is a Hispanidad kifejezés mellett érvel, amely az összes hispán népet magában foglalja, eröteljes katolikus töltettel (1958-tól már a Faj Napját is Hispanidad Napjának nevezik). Későbbi munkájában, a Defensa de la Hispanidadban ${ }^{154}$ már bővebben kifejti gondolatait, a spanyol fajt teszi meg a legfejlettebb keresztény civilizáció képviselöjévé, részletes történelmi okfejtéssel alátámasztva. Kimondja: „A Hispanidad teremtette az egyetemes történelmet, és nincsen a világon semmi, a Kereszténységen kívül, ami hozzá lenne fogható”, ${ }^{155}$... „A közösségünk nem faji és nem földrajzi, hanem szellemi”" ${ }^{156}$... „A Hispanidad birodalma azon a reményen alapul, hogy hozzánk hasonlóan az ismeretlen területek népei is megmenekülhetnek"157. Maeztu a spanyol történelem olyan korszakait emeli ki, amelyek szerinte a Hispanidad eszméjéhez pozitív elemeket tettek hozzá. Spanyolország létét attól a időponttól számítja, amikor a vizigótok felvették a kereszténységet (586), a csúcsidőszak a 16. századra tehető, a hanyatlásért pedig a Bourbon-dinasztia a felelős, karöltve az országot (szellemileg és katonailag is) folyamatosan támadó idegen országok nemzetközi összeesküvésével és az idegenszívű spanyolok árulásával. Csodálja a korabeli Németország és Olaszország fejlődését és politikai berendezkedését, szerinte ezek mintáját követve kellene visszanyúlni a spanyol múlt dicső korszakaihoz, hogy a nemzet ismét megtalálhassa önmagát. Csejtei Dezső szavaival élve a maeztui érvelésben ,...a még inkább múlt századi hangvételü populista exkluzivizmus átnő egy - minden archaizációja ellenére - „modernebb” hangszerelésű katolikus totalitarizmusba”. ${ }^{158}$ Anderle Ádám szerint „haza, vallás, fasizmus a hispanidad közös fogalmába integrálódott a jobboldali ideológiában. Ez a pánhispanizmus erősen konzervatív, történeti érvelésű, birodalmi-imperialista változata volt, mely Spanyolország nagyságának visszaállítását ígérte. Enyhe kapitalizmusellenssége ekkor antiszemitizmussal társult." 159

Szintén a dicsőséges hispán múltra építené az ország jövőjét Ernesto Giménez Caballero, a Falange egyik alapítója és fö ideológusa. Elméleti okfejtései rokonságot

\footnotetext{
${ }^{153}$ Maeztu, Ramiro de: „La Hispanidad” in: Acción Española, 1/I, 1931. 8-16.

Elérhetö: http://www.filosofia.org/hem/193/acc/e01008.htm (2012-11-21)

${ }^{154}$ Maeztu, Ramiro de: Defensa de la Hispanidad. Madrid, 1934.

Elérhetö: http://guardiadelahispanidad.files.wordpress.com/2009/09/defensa-de-la-hispanidad.pdf 21)

${ }^{155}$ Uo. 14

${ }^{156}$ Uo. 15

${ }^{157}$ Uo. 69.

${ }^{158}$ Csejtei Dezső: „A 98-as nemzedék és a spanyol történelem” in: Aetas, 1998/4. 26.

${ }^{159}$ Anderle Ádám: Megosztott Hispánia. Id. mü. 158.
} 
mutatnak a fentiekben vázoltakkal, ám ő messzebbre megy, a fasizmus spanyol változata mellett teszi le voksát, annak lesz egyik ideológiai megalapozója. Számára már a Katolikus Királyok időszaka is a spanyol fasizmus előfutára, így a nemzeti történelemben ez a periódus a követendő példa. Nézetei szerint Spanyolországnak Latin-Amerikával karöltve kell felemelkednie, mert testvérnemzetek. Giménez Caballero és ideológiája nem ért el akkora népszerüséget, mint Maeztu Hispanidad-koncepciója, nem valósult meg a valódi spanyol fasizmus. ${ }^{160}$

A hispán faj felsőbbrendűségét más, igen szélsőséges érvekkel is magyarázták. Antonio Vallejo Nájera a nemzeti oldal legbefolyásosabb pszichiátere, a Nemzeti Hadsereg Pszichiátriai Szolgálatának vezetője, Franco egyik bizalmasa tanulmányokban és elemzésekben értekezett e témáról. ${ }^{161}$ Nézeteinek ismertetése általában nem jelenik meg a Franco-korszakkal foglalkozó spanyol és külföldi történészek müveiben, én azonban fontosnak vélem kiemelni néhány szempontját, ugyanis a későbbiekben visszaköszönnek alapvetéseinek egyes elemei mind a politikában, mind a filmkészítésben. A Caudillóhoz füződő viszonya és a rezsimben betöltött szerepe miatt valószínüsíthető, hogy érvelései hatással voltak a döntéshozókra.

Vallejo Nájera szerint a hispán fajnak meg kell szabadulnia azoktól a káros hatásoktól, amelyek az elmúlt évszázadokban az erkölcsi értékrendszer összeomlásához és a faj degenerálódásához vezettek. A spanyoloknak igényt kell támasztaniuk arra, hogy biológiailag és társadalmilag a legfejlettebb osztályokhoz tartozzanak. A mentálisan alsóbbrendűnek tekinthető emberek nem vehetnek részt a döntések meghozatalában, és rá kell ébredni, hogy nem ér ugyanannyit mindenkinek a szavazata. Az évszázadok során több különböző fajból alakult ki a jelenlegi hispán faj, amelyet már csak a hit és a gondolkodás fog egybe. A 17. századi értékeknek kell visszatérniük: a miszticizmus, a lovagiasság, a becsület kultusza, a bátorság, a józanság, az anyagi javak megvetése, a szemérem, az őszinteség, a szenvedélyes elkötelezettség és a büszkeség értékrendszerének együttese szavatolhatja, hogy a hispán faj ismét naggyá válik. Szükséges, hogy az emberek alávessék magukat a vezetőjük akaratának, a fiatalok pedig azonosuljanak a Caudillóval, mint legfőbb vezérrel. A kulturális életet is új alapokra kell helyezni, a vallás és a hazafias érzés adja az új nemzet fundamentumait. Ha

\footnotetext{
${ }^{160}$ Giménez Caballero ehhez kapcsolódó elméleti okfejtéseit lásd: Giménez Caballero, Ernesto: Genio de España. Exaltaciones a una resurrección nacional y del mundo. Madrid, Ediciones La Gaceta Literaria, 1932 (és további kiadások). Eszmerendszeréről magyar nyelven ad összefoglalást: Virágh Anna: „Európa és a spanyol identitás Ernesto Giménez Caballero történelemszemléletében” in: Ferwagner Péter Ákos - Kalmár Zoltán (szerk.): Az átmenet egyensúlya. Szilágyi István 60 éves. Budapest, Áron Kiadó, 2010. 69-77.

${ }^{161}$ Két legfontosabb müve: Eugenesia de la Hispanidad y regeneración de la Raza. Burgos, 1938 és Política racial del Nuevo Estado. San Sebastián, Editorial Española, 1938.
} 
mindez teljesül, megteremtődnek az ideális feltételei annak, hogy a kiválasztott faj, a hispán rassz ismét terjeszkedni kezdjen. Ehhez viszont meg kell tagadni mindent, ami a demokratikus és a marxista országokra jellemző, ugyanis azok az alsóbbrendü, a középszerü egyedeket favorizálják. Csak egy totalitárius államban valósulhat meg, hogy a felsőbbrendü faj kifejlődik (egyes érvelései rokonságot mutatnak a nácizmus fajelméletével), és elérkezik az igazságos társadalom. ${ }^{162}$ A fentieken kívül Vallejo Nájera értekezik az alkoholizmus, a szexuális devianciák, a prostitúció és az erkölcstelenség veszélyeiről, a munka- és átnevelő táborok, valamint elmegyógyintézetek megsokszorozódásának szükségességéről is, mivel kizárólag ez utóbbi intézmények szavatolhatják, hogy az alsóbbrendủ személyek nem jelentenek majd veszélyt a felsőbbrendűekre.

Gyakori jelenség volt a polgárháború idején, hogy a legitim kormánnyal nem szimpatizáló, esetleg a baloldali pártokban halálos veszélyt látó értelmiségiek is mintha egy isteni küldöttet láttak volna Franco tábornokban. Ahogyan Manuel Machado költő írta 1937ben: „A gondviselés szülötte, győzedelmes Caudillónk, kit Isten választott ki, hogy véghez vigye a hatalmas munkát. A háború és a béke embere ő. Spanyolország férfiúja. Franco, Franco, Franco."163 Bár körülötte nem alakult ki olyan mértékủ személyi kultusz, mint ami Hitlert vagy Sztálint övezte, alakja mindenkié felett állt.

A Hispanidad fogalmának egy másik megközelítését nyújtja Rafael Gil Serrano, aki 1938-ban publikált (majd később még több ízben kiadott) müvében, A Hispanidad új felfogása címü könyvében háromféle Spanyolországot különböztet meg ${ }^{164}$ :

- „Igen-Spanyolország”: azok a lovagias, hősi, katolikus spanyolok, akik országuk üdvéért tevékenykednek, és nem bocsátanak meg azon ellenségeiknek, akik nem téríthetők jó útra.

- „Nem-Spanyolország”: a tudatlan és szolgalelkü Spanyolország, akik mindent feláldoznak önmaguk boldogulása érdekében.

- „Anti-Spanyolország”: A másik két Spanyolország esküdt ellensége, felforgató és áruló tevékenységével megmételyezi a spanyol hazát.

Gil Serrano kifejti, hogy Igen-Spanyolország a kormányzó csoportokat foglalja magában, míg Nem-Spanyolország a dolgozókat. Anti-Spanyolországként pedig azokat a csoportokat azonosítja, amelyek ellen a könyv írásakor a polgárháború folyt: kommunisták,

\footnotetext{
${ }^{162}$ A fenti a Vallejo Nájera könyvei alapján készített összegzés, valamint az alábbi írás következtetése: González Duro, Enrique: El miedo en la posguerra. Madrid, Oberon, 2003. 50-53.

${ }^{163}$ Idézi: Esparza, José Javier: Juicio a Franco. Id. mü. 86.

${ }^{164}$ Gil Serrano, Rafael: Nueva visión de la Hispanidad. Buenos Aires, Espasa-Calpe, 1938.

A kategóriákat magyar nyelven ismerteti: Anderle Ádám: Megosztott Hispánia. Id. mü. 162-164.
} 
marxisták, szabadkőművesek, köztársaságiak, és mindenki, aki ezek befolyása alatt áll. IgenSpanyolország maga a spanyol nemzet, a másik kettő ellen ádáz küzdelmet kell folytatni.

Spanyolország a Franco-korszakban megpróbálta továbbra is egyfajta anyaország szerepét betölteni, amely őrködik a volt kolóniák felett, paternalista módon óvja a tőle elszármazott népeket. Intézményes keret is épült az ideológia köré, az 1940-ben létrejött Hispanidad Tanácsa (Consejo de la Hispanidad) a kulturális kapcsolattartás, és egyben a másik kontinens felé irányuló nemzetikatolikus propaganda fő felelősévé lép elő - 1946-tól a Hispán Kultúra Intézete (Instituto de Cultura Hispánica) néven müködik, latin-amerikai országokban is megjelennek kihelyezett intézetei. A kultúra pedig hosszabb távon hídként funkcionálhat a két térség politikai összefonódása szempontjából is. Ez azonban nem csak a felkelők soraiban merült fel: korábban a köztársasági kormányok is úgy vélték, hogy a közös nyelv, eredet, történelem és kultúra alapvetően összekapcsolja Spanyolországot a hispánamerikai köztársaságokkal. $^{165}$

Már a polgárháború idején hivatalos körökben is megfogalmazódott, és nyomtatott formában is megjelent a vezető erők kinyilatkoztatása a spanyol civilizációs szándékról. Érvelésük szerint Spanyolországot, mint a hispán világ spirituális tengelyét, történelmi okoknál fogva megilleti a latin-amerikai kontinens feletti őrködés joga, a spanyol technika és a kultúra segítségével vissza kell hódítani a régi területeket. Missziójuk, hogy 200 millió hispánt megvédjenek a dollár és a font képében megjelenő gazdasági imperializmustól. Eltérően tehát a maeztui Hispanidad-felfogástól, a felkelés alatt politikai és katonai alapon elképzelt újraegyesítés is komolyan szóba került. Értelmezésük szerint a Hispanidad megmentése egyet jelent a katolicizmus és a spanyol nyelv védelmével. Hamar világossá vált azonban, hogy a latin-amerikai nemzetek - érthető módon - nem fogadták lelkesedéssel a totális spanyol hegemóniára való törekvést, így a francói megközelítés a későbbiekben már csak politikai és kulturális indíttatásúvá redukálódott. ${ }^{166}$

A Falange hivatalos programjában világosan megmutatkozott, hogyan tekintettek a távoli kontinensre. ${ }^{167}$ A harmadik cikkely szerint Spanyolország csak birodalmi állapotában lehet teljes, ezért kulturális, gazdasági és hatalmi egyesülésre törekednek. Spanyolország lesz a hispán világ szellemi vezetője, Európában kiemelkedő hely illeti meg, és nem fogadják el sem a nemzetközi elszigetelődést, sem a külföldi közvetítést. A Hispanidad Tanácsa megalapításának célja, ahogyan a falangista napilap, az Arriba ír róla, hogy megtestesítse az

\footnotetext{
${ }^{165}$ Delgado Gómez-Escalonilla, Lorenzo: Imperio de papel. Id. mü. 56.

${ }^{166}$ Uo. 124-125.

${ }^{167}$ Los XXVI puntos del estado español.
}

Elérhetö: http://www.generalisimofranco.com/descargas/26\%20puntos.pdf (2012-11-21) 
egységes spanyol külpolitikát, különösen ügyelve a kulturális elemekre. Az irányítás a Tanács elnöki pozícióját is betöltő Ramón Serrano Súñer és döntően falangista kötődésű bizalmasai kezében volt. ${ }^{168}$ A Tanácson belül számos szekció jött létre, a politikai, gazdasági, társadalmi, jogi és kulturális osztályok a saját hatáskörükbe tartozó ügyek abszolút felelősévé váltak. Alapvető feladatuk volt, hogy az ország külpolitikáját a maguk módján érvekkel igazolják. A kulturális szekció felelt a tudományos, irodalmi, művészeti, oktatási, könyvtáralapítási, sajtóügyi témákért, beleértve a propagandát megvalósító anyagok terjesztését is. ${ }^{169}$ Ezen a területen a Faj (Raza, José Luis Sáenz de Heredia, 1942) címü film lesz kiemelkedő, amelynek elkészítéséről és bemutatásáról, mint a Tanács által támogatott „első nagy filmről”, hivatalosan is szóltak a szekció feladatait kijelölő állásfoglalásban. ${ }^{170}$ A Hispán Kultúra Intézete pedig az Amerika hajnala (Alba de América, Juan de Orduña, 1951) kapcsán alkot maradandót a mozgókép terén. Mindkét filmről részletesen szólok a későbbi fejezetekben.

A Caudillo már a polgárháború éveiben több alkalommal is egyértelmü kijelentést tett arra nézve, hogy Spanyolországnak vezető szerepet szán a hispán világ életének irányításában. Saját szavai szerint: „,.. erős a vágyam, hogy újjáélesszem mindazt, amit hispano-amerikanizmus név alatt ismer a világ" , és hozzátette, Spanyolországnak fontos feladata van „,... azzal a földrésszel szemben, amelyet a spanyol géniusz tárt fel az emberiség elött". ${ }^{171}$

A „Hispanidad” kifejezésről 1941 májusában egy miniszteri rendeletben határoztak:

\begin{abstract}
„A hispán világot alkotó fogalmak összességét jelenti, valamint kifejezi különleges szellemiségét és életfelfogását, közös történelmi tradícióját és legfelsőbb egyetemes végzetét. Tilos a Hispanidad szó szabad használata, nem alkalmazhatják azt ipari megfontolásból, például kereskedelmi márkaként vagy egy létesítmény elnevezéseként”. 172
\end{abstract}

\footnotetext{
168 Delgado Gómez-Escalonilla, Lorenzo: Imperio de papel. Id. mü. 269. és 281.

${ }^{169}$ Uo. 279-280. A néhány hónappal korábban megalakult Hispán-Amerikai Kulturális Egyesület (Asociación Cultural Hispano-Americana) hasonló feladatköröket látott el. Ez a szervezet hivatalosan nem állt állami irányítás alatt, ténylegesen azonban a spanyol kormány ezen keresztül igyekezett kulturális elemekkel is alátámasztani a Latin-Amerikába irányuló külpolitikáját. Erről lásd: Uo. 248-252.

${ }^{170}$ Uo. 299 . Nem nevezik meg a film címét, de a mü forgatásának körülményei és az előkészítési fázis pontos ismeretében egyértelmü, hogy Sáenz de Heredia filmjéről van szó.

${ }^{171}$ Idézi: Harsányi Iván: A Franco-diktatúra születése. Id. mü. 106-107.

${ }^{172}$ Idézi: Gil Pecharromán, Julio: La política exterior del franquismo (1939-1975). Barcelona, Flor del Viento Ediciones, 2008. 42.
} 
A diktatúrában a fent említett elemek az állami ideológia szintjére emelkedtek. Alfredo Sánchez Bella falangista politikus, a korabeli propaganda egyik legfőbb alakja (és a Hispán Kultúra Intézetének igazgatója) az alábbi módon értékelte az eszmét 1953-ban:

„A 'Hispanidad a Pireneusokban kezdödik' mondat nem lehet pusztán csak egy frázis, egy olyan realitássá kell válnia, amelyet érezhetővé kell tenni, el kell kezdenünk azt érezni Spanyolországban, mert ma hiányzik belöle az amerikai dimenzió, és meg kell neki ezt adnunk, ugyanis csak abban a dimenzióban válhat lehetôvé, hogy elérjük a mindannyiunk által vágyott nagyhatalmi rangot”. ${ }^{173}$

A Külügyminisztérium költségvetésében egyre nagyobb súllyal jelent meg a kulturális diplomáciának elkülönített keret: míg a második világháború éveiben körülbelül csak a büdzsé 6\%-át fordították erre, addig 1946-ban már 20,7 \%-ot szántak rá, és 1950-ig az összeg évente 3-4 \%-kal növekedett (az ezt követő években pedig 1-1 \%-kal csökkent). Ezen belül a latin-amerikai kultúrmisszióra szánt anyagi kiadások a fenti összegek 10-12\%-át adták. ${ }^{174} \mathrm{~A}$ polgárháború után alapított Tudományos Kutatások Legfelsőbb Tanácsa (Consejo Superior de Investigaciones Científicas - CSIC) ténykedése politikailag és anyagilag is szorosan kapcsolódott a fentiekhez, az egyház érdekszférájába tartozó testület, erőteljes opusdeista befolyással, a tudományos kutatásokat igyekezett ötvözni a katolicizmus szellemében. Ennek kötelékében született meg az Arbor címü folyóiratuk is.

A spanyol birodalmi érzés szorosan összefüggött a korábbi kolóniákkal fenntartott kapcsolattal. Kezdettől fogva megfogalmazódott az igény arra, hogy a Falange alakítson egy külföldre irányuló szervezetet, amely Latin-Amerikát állítja a középpontba és kijelöli a követendő utat, szolgálva a birodalmi ügyet. Még a Brit Birodalom spanyol változatának képe is felmerült. Így született meg a Falange de Exterior, a Falange külföldi hálózata. Ennek a fokozott kapcsolattartásnak az ,egyek vagyunk” típusú, szellemi síkon értelmezendő összetartozáson kívül gazdasági okai is voltak, az új spanyol állam számított a latin-amerikai országok, valamint az ott élő spanyol emigránsok pénzügyi együttmüködésére is. ${ }^{175}$ LatinAmerikában a francói eszmével egyetértő spanyol emigránsok és az adott országban velük szimpatizáló állampolgárok segítségével szerveződtek kulturális egyesületek, amelyek a spanyol nacionalista propaganda meghosszabbított karjaként müködtek. A latin-amerikai

\footnotetext{
${ }^{173}$ Archivo del Ministerio de Asuntos Exteriores (továbbiakban: AMAE), R-11626. 23-as számú jelentés

${ }^{174}$ Pérez Herrero, Pedro - Tabanera, Nuria (szerk.): España / América Latina: Un siglo de políticas culturales. Madrid, AIETI/Síntesis-OEI, 1993. 130-131.

${ }^{175}$ Harsányi Iván: A Franco-diktatúra születése. Id. mü. 108-109.
} 
kontinensen, elsősorban Mexikóban és Chilében nagy aktivitást mutató köztársasági emigránsok hasonló tevékenységet folytattak saját ügyük érdekében.

Az 1948-ban útjára indult Cuadernos Hispanoamericanos folyóirat hasábjain spanyol és latin-amerikai szerzők fejtették ki véleményüket, meglátásukat a két régió közötti kapcsolatokról, azok lehetséges fejlesztési irányairól. Az orgánum egyik újdonsága, hogy lapjain nem kizárólag a rezsim elveihez elvakult módon ragaszkodó szerzők és cikkek kaptak helyet, hanem találkozhatunk nemzetközileg is elfogadott, liberálisabb szemléletü szerzőkkel és témákkal is, melyek célja egy kulturális aspektusú dialógus felállítása. ${ }^{176}$

A rezsim Hispanidad-felfogása többször is módosult az évtizedek folyamán. A második világháború után, amikor a Falange tagjai elveszítették kulcspozícióikat, helyükre az Acción Católica körébe tartozó politikusok léptek (Alberto Martín Artajo a külügyminiszteri, José Ibáñez Martín az oktatási miniszteri poszton), akik saját területüket a Hispanidad szellemében formálták át; míg a Falange Hispanidad-értelmezése, bár csak retorika szintjén, de szellemi és területi expanzionizmust is magában foglalt, addig a konzervatív-katolikus hozzáállás visszatért a maeztui elvekhez, ahol a Hispanidad legfőbb feladata a régi hódítás (conquista) evangelizációs értelemben történő folytatása. Az egyértelmü spanyol ideológiai imperializmusra való törekvés mellett egy nosztalgikus komponense is volt szándékaiknak, ahol a jelen birodalomépítő céljait párhuzamba állították a régi, mitikus Spanyol Birodalom képével, kizárva az elmúlt kétszáz év történelmének jelentős részét, mint az általuk károsnak ítélt modernizmus gyökereit. Egyetlen hit és egyetlen nyelv alatt akarták egyesíteni a hispán világot - ez azonban már nem feltételezett politikai-területi egyesítést. ${ }^{177}$

Spanyolország és Latin-Amerika filmmüvészeti kapcsolatának jelentőségét már az 1931-ben Madridban megrendezett Hispán-Amerikai Filmmüvészeti Kongresszus mutatta. Itt azonban az összefogás oka elsősorban a hangosfilm megszületése után egyre gyorsabban terjeszkedő észak-amerikai filmek benyomulása volt a közép- és dél-amerikai országokba; a pánhispán jellegü, a spanyol nyelven beszélő művek népszerüsítését és az ehhez szükséges politikai-gazdasági előfeltételek megteremtését célzó tudományos összejövetel nem hozott számottevő eredményt. ${ }^{178}$ Az egymás iránti érdeklődés azonban megélénkült, a polgárháború alatt és után számos spanyol filmes emigrált Latin-Amerikába, a Franco-korszak pedig

\footnotetext{
${ }^{176}$ A Cuadernos Hispanoamericanos profilját magyar nyelven röviden felvázolja: Virágh Anna: „A független Spanyol-Amerika és a Hispanidad eszméje" in: Anderle Ádám (szerk.): Latin-Amerika: A függetlenség útjai. Szeged, 2012.

177 Juan-Navarro, Santiago: „Una sola fe, una sola lengua: La Hispanidad como coartada ideológica en el pensamiento reaccionario español" in: Hispania, 89.2. 2006. 395-397.

${ }^{178}$ Gubern, Román: „El cine sonoro (1930-1939)” in: Gubern, Román (és mások): Historia del cine español. Madrid, Cátedra, 2009. 130-131.
} 
kiemelt figyelmet fordított a hispán országok közötti filmkapcsolatokra. Hogy kihangsúlyozzák a közép- és dél-amerikai országok szoros kötődését az Ibériai-félszigethez, a 40-es évektől a legtöbb filmes szaklapban az addig megszokott cine latino (latin film) elnevezés helyett a cine ibérico (ibér film) használatát szorgalmazták. ${ }^{179}$

Az elméleti alapokat igyekeztek átültetni a filmmüvészet területére is, célul tủzték ki a Hispanidad erényeit visszatükröző új filmmủvészet kialakítását. Jóslatuk szerint a spanyol nyelven beszélő filmek hamarosan felülkerekednek a világ összes mozgóképes termékén, az amerikai kontinensen pedig már korán abszolút többségbe kerülnek majd a müvészi és technikai értelemben is tökéletesnek mondható hispán alkotások, maguk mögé utasítva a hollywoodi műveket. A nyelv és az összetartozás-érzés pozitív hatást fog kifejteni, és Latin-Amerika közönsége kizárólag a Hispanidad értékeit tükröző mestermüveket fogja fogyasztani. ${ }^{180}$ A 40-es és 50-es évek folyamán a rezsimhez hü filmes szaklapok cikkei, tudósításai és filmkritikái folytatták ezt a vonalat, újabb és újabb érveket felhozva a hispán nagyság filmeken történő megjelenítése mellett.

1948-ban egy újabb nemzetközi filmes eseményt rendeztek meg, ezúttal a Falange kötelékébe tartozó Nemzeti Szórakoztatóipari Szakszervezet (Sindicato Nacional de Espectáculo - SNE) égisze alatt. A Hispán-amerikai Filmszemlén (Certamen Cinematográfico Hispano-americano) a Spanyolországból és a latin-amerikai kontinens különböző régióiból érkezett filmek vetítése mellett konferenciákat szerveztek, ahol megvitatták, milyen lehetséges együttmüködéseket tartanak a felek elképzelhetőnek. ${ }^{181}$ Kiindulási alapként Ernesto Giménez Caballero egy könyve szolgált, amelyben a szerző Mexikót mutatta be filmeken keresztül, és a legmagasztosabb hispán értékek megvalósulásaként azonosította a latin-amerikai országot, amely a vallás és lovagi erények mindenható tiszteletében mutatkozik meg. Az elfelejtett Spanyolországot látta itt viszont, amelyet ismét meg kell teremteni az Ibériai-félszigeten is. ${ }^{182}$ Ennek eredménye számos

\footnotetext{
${ }^{179}$ Ezt egy cikkben alapozták meg: „A propósito de un cine latino” in: Primer Plano, No. 19. 1941. április 13. A továbbiakban számos alkalommal hivatkozom majd a Primer Plano címủ folyóirat cikkeire. A pontos adatok megadásakor azonban nem tüntetek fel oldalszámot, mert a folyóirat példányainak többségében nem történt számozás, az oldalak egyszerűen csak „egymás után következtek”, így a kezembe került példányoknál én sem éltem az oldalak beszámozásának lehetöségével, ahogyan a spanyol filmtörténészek sem szoktak. Az adott kiadás sorszáma, illetve a megjelenés pontos dátuma utal a konkrét lapszámra.

${ }^{180}$ Centeno, Félix: „El cine español en América” in: Primer Plano, No. 102. 1942. szeptember 27.

${ }^{181}$ Borau, José Luis: „Certamen Cinematográfico Hispanoamericano” in: Borau, José Luis - Heredero, Carlos F. (szerk.): Diccionario del cine español. Madrid, Alianza Editorial - Academia de las Artes y las Ciencias Cinematográficas de España, 1998. 207-208.

${ }^{182}$ Giménez Caballero, Ernesto: Amor a México (a través de su cine). Madrid, Seminario de Problemas Hispanoamericanos, 1948. 13-16.
} 
koprodukció $^{183}$ lett, valamint filmmüvészeti folyóiratok terjesztése, közös filmtéka és celluloidgyártó vállalatok létrehozása. Mexikó aktív részvétele meglepő volt, mivel a köztársasági emigráns kormányt támogatta; ugyanakkor, a Spanyolországba érkezett mexikói delegációban helyet kaptak emigráns baloldali spanyol politikusok is, akik a baráti kapcsolatok jegyében biztonságban részt vehettek a madridi szemlén, majd velük együtt ismét elhagyhatták az országot. Szintén gyakorivá vált, hogy rendezőket, forgatókönyvírókat és színészeket „adtak kölcsön” egymásnak az érintett országok. A két legjelentősebb filmstúdió, a Cifesa és a Suevia Films leányvállalatokat is kitelepített Latin-Amerikába, a 60-as évektől pedig, mindenekelőtt az orosz-amerikai Samuel Bronston Spanyolországba érkezésével, a nemzetköziség új értelmet fog nyerni (a későbbiekben ezekről is részletesebben szólok). Összességében azonban elmondható, hogy a koprodukciók gyártása mellett a többi terv nem valósult meg: a résztvevő országoknak nem állt szándékában saját törvényeik és szokásaik megváltoztatása a spanyol igényeknek megfelelően (mint a kötelező szinkron és a cenzúra), ez pedig a másik félnek elfogadhatatlan volt. Így a madridi székhellyel tervezett Hispán-Amerikai Filmegyesület (Unión Cinematográfica Hispanoamericana) müködése már a megalapításakor kudarcba fulladt. 1950-ben egy újabb filmszemlét szerveztek, de ekkor már Spanyolország nem Latin-Amerikára, hanem egyre inkább az USA-val kialakítandó (1953-ban pedig egyezmény szintjén is megvalósuló) baráti kapcsolatokra fókuszált, ahol a filmes egyezményeknek nagy jelentőséget tulajdonítottak. ${ }^{184}$

\section{Katolicizmus és egyház}

A polgárháborúban a felkelő csapatok saját állításuk szerint Isten nevében fogtak fegyvert a demokratikus kormány ellen, harcukat kezdettől fogva támogatta a katolikus egyház, Spanyolország püspökei sorban a lázadók mellé álltak, majd Divini Redemptoris... kezdetű enciklikájában XI. Pius pápa is védelmébe veszi a Keresztes Háborút, amelyet a „,nemzetiek” az egész világot veszélyeztető kommunista túlkapások ellen folytatnak. ${ }^{185} \mathrm{Az}$ egyházi személyek köztársaságiak iránt táplált ellenérzése nem volt alaptalan, a katolikus

\footnotetext{
${ }^{183}$ Elsősorban Mexikó és Argentína társult be az 50-es évektől egy-egy filmes projektbe a spanyol filmstúdiók oldalán.

${ }^{184}$ Caparrós Lera, José María: „Imágenes de América Latina del siglo XX en el cine de la autarquía” in: Uő: Estudios sobre el cine español del franquismo. Id. mü. 34-36.

${ }^{185}$ XI. Pius: Divini Redemptoris ...

Elérhetö: $\quad$ http://www.vatican.va/holy father/pius xi/encyclicals/documents/hf_p-xi_enc_19031937_diviniredemptoris_en.html (2011-11-21)
} 
egyházat privilégiumaitól megfosztó köztársasági időszakban számos kolostort és templomot felgyújtottak, papokat és apácákat zaklattak és gyilkoltak meg antiklerikális csoportok. ${ }^{186}$

Állam és Egyház ismét összefonódott, a kialakult estado confesionalban az egyház szerves részét képezte az államnak, de nem egyenrangú módon; a katolikus szervezetek alárendelt szerepet játszottak, ugyanakkor kétségtelenül főszerepet. Franco cserébe a katolikus vallást tette meg rendszere alapkövévé. Az egyház döntő szót kapott a társadalmi élet számos területén, így az oktatásban és a karitatív tevékenységben is. A magyar pap-teológus tanár, Tóth Tihamér spanyol nyelvre lefordított, aktuális témákat feldolgozó müvei az iskolai katolikus erkölcsi nevelés alapmüveivé váltak. ${ }^{187}$ A nemzetikatolicizmus lett a rezsim egyik legfőbb jellemzője. Megkezdődött a lerombolt templomok újjáépítése, a megrongált kolostorok renoválása, a katolikus egyház szervezeteket alapított karitatív céllal, valamint megsokszorozódott a vallási sajtótermékek és rádióadók száma.

A társadalom mindennapi életét katolikus szellemben szervezték újjá, nőtt a csodák és jelenések száma, mindezekről a napilapok címoldalon tudósítottak. A papok jelen voltak minden társadalmi intézményben, állandó konzultánsként segítették a helyesnek ítélt útra terelést. Az egyház munkáját, és egyben a rezsim társadalom- és kultúrpolitikáját támogatta a már említett ACN de P. ${ }^{188}$ Az 1909-ben jezsuiták által alapított szervezet célja, hogy az országot a katolicizmust irányelvként követő, mélyen vallásos személyek irányítsák, a lakosságot pedig vallási szellemben neveljék át. Hatalmas anyagi és szellemi holdudvar állt mögötte, idővel már saját napilapokkal, folyóiratokkal, oktatási intézményekkel, kiadókkal, országos hálózattal rendelkezett. A Falange második világháborút követő háttérbe szorulásával az $\mathrm{ACN}$ de $\mathrm{P}$ kötelékébe tartozó politikusok kulcsszereplőivé váltak az új kormányoknak, kezdve a külügyminiszteri tárcával (Alberto Martín Artajo). A rezsim kommunikációs folyamataiban és propagandatevékenységében döntő szerepet játszottak az 50-es évek végéig, amikor az Opus Dei vált a legbefolyásosabb erővé.

A nacionalista győzelem után kizárólag az egyházi esküvőt tartották legálisnak, a köztársaság idején végbement polgári házasságkötéseket és válásokat visszamenőleg is érvénytelenítették (így sok elvált személy hirtelen ismét házassá vált, a házasok egy része pedig egyedülállóvá). A keresztelőkön adható neveket csak az egyház által szentesített

\footnotetext{
${ }^{186}$ Erről is ír, többek között: Esparza, José Javier: El terror rojo en España. Madrid, Ed. ALTERA, 2007.

${ }^{187}$ Anderle Ádám: A magyar-spanyol kapcsolatok ezer éve. Szeged, Szegedi Egyetemi Kiadó - Juhász Gyula Felsőoktatási Kiadó, 2005. 142-143. Tóth Tihamér munkásságáról szóló átfogó tanulmány: Posztós Ildikó Piroska: „A spanyol Tóth Tihamér-jelenség” in: Magyar Egyháztörténeti Vázlatok, 2006/3-4. 17-34.

${ }^{188} \mathrm{Az}$ ACN de P történetét bemutatja (a Franco-korszakra koncentrálva): Montero, Mercedes: Cultura y comunicación al servicio del régimen, Historia de la ACN de P entre 1945 y 1959. Ediciones Universidad de Navarra, 2001.
} 
jegyzékböl választhatták ki. Az istenkáromlás üldözendő cselekedet volt. A házasságtörés Isten ellen való vétek, az egyházi cenzorok szigorúan vették a filmek elbírálása során is a megcsalásra utaló jeleket. A fiatalok társasági élete és megjelenése felett is igyekeztek szigorú kontrollt gyakorolni, püspökök és alacsonyabb rangú egyházi személyek újságcikkeket vagy akár egész könyveket írtak az elvárt viselkedésről, öltözködésről: a párok mit tehetnek és mit nem tehetnek az utcán, nyilvános helyeken, mozikban, a strandon milyen típusú fürdőruhákat viselhetnek, és a férfiak és nők egymástól milyen távolságban helyezkedhetnek el, milyen táncokat illeszthetnek be a táncestekbe. ${ }^{189}$ Az 50-es évek végétől megélénkülő, Spanyolországba irányuló turizmus azonban legyőzte a társadalmon őrködő egyházi méltóságokat, a külföldiek tettei felett a hatalom rendszerint már szemet hunyt, a papok azonban folyamatosan felháborodott panaszleveleket tettek közzé a sajtóban.

Természetesen a filmekre is felügyeltek, nem csak a hivatalos cenzoriális úton. Alapvetően a mozgóképet elítélendőnek tartották, egy spanyol püspök szavaival élve: „,.. a film a legnagyobb sorscsapás, amely a világot érte". ${ }^{190}$ Pamplona püspöke hozzátette, a mozi az oka annak, hogy az emberiség alámerült az erkölcsi fertőben, ezért hatalmas szolgálatot tennének az emberiség számára, ha kétnaponta legalább egy filmszínházat porig égetnének; ez a megváltó tủz szabadítaná fel a lelkeket. ${ }^{191} \mathrm{Ha}$ egy olyan művet mutattak be a moziban, amely valamilyen szempontból kifogásolható volt az egyház számára, a vasárnapi mise részeként felszólaltak ellene, leendő nézőit isteni büntetéssel fenyegették, a katolikus ifjúsági szervezetek tagjai pedig a vetítésre érkező nézőket a mozik ajtajában fenyegették kiátkozással. Gyakran előfordult, hogy a vetítőteremben a vallásos szervezetek képviselői vagy a jegyszedők előadás közben hirtelen villanyt gyújtottak, leleplezve így a sötétben esetleg más tevékenységet folytató ifjú párokat. ${ }^{192}$ 1948-ban egy katolikus hetilapban közzétettek egy teljes imát, amely Jézushoz könyörög azon eltévelyedett, beteg lelkű, müveletlen emberekért, akiket rabul ejtett a mozi sátáni ereje, és akiket „,szarkasztikus eufóriában tart ez a szellemi tuberkulózis". ${ }^{193}$ Az 50-es években is született olyan újságcikk a filmről egy püspök tollából, amely szerint ,,az erkölcstelenség közvetítője, a bűnhöz rendkívül közel eső tevékenység, sok olyan betegség legfőbb kiváltója, amelyek a fiatalságot sújtják és

\footnotetext{
${ }^{189}$ Abella, Rafael: La vida cotidiana bajo el régimen de Franco. Madrid, Ediciones Temas de Hoy, 1996. 50-51.

${ }^{190}$ Idézi: Tejada, Luis Alonso: La represión sexual en la España de Franco. Barcelona, Caralt, 1977. 124.

${ }^{191}$ González Duro, Enrique: El miedo en la posguerra. Id. mü. 224.

192 Tejada, Luis Alonso: La represión sexual... Id. mü. 124

193 Idézi: Salvador Marañón, Alicia: De ¡Bienvenido, Mr. Marshall! a Viridiana. Historia de UNINCI, una productora cinematográfica española bajo el franquismo. Pozuelo de Alarcón, Egeda, 2006. 80.
} 
mindenekelőtt a szemre és az idegrendszerre fejtenek ki káros hatást". ${ }^{194}$ A későbbiekben szelídültek a vélemények, bár 1967-ben Las Palmas püspöke még nyilatkozatot tett közzé arról, hogy meg kell tagadni a feloldozást mindenkitől, aki részt vesz a Las Palmasi Filmfesztivál erkölcstelen vetítésein (ugyanis az itt bemutatott filmek egyikében egy ruhátlan nő is látható volt). ${ }^{195}$ A Gilda (Gilda, Charles Vidor, 1946) című amerikai film egy teljesen ártalmatlan jelenetét az egyházi cenzor pedig azért vágatta ki a spanyol bemutatóra szánt kópiából, mert úgy vélte, hogy amikor a női főszereplő, Rita Hayworth leveszi a kesztyüjét, azzal valójában egy sztriptíz első mozdulatait teszi meg, ami végül csak szándék szintjén $\operatorname{marad}^{196}$ (ez már csak azért is képtelenség, mert az akkoriban érvényben lévő hollywoodi Produkciós Kódex sem engedett volna meg ilyenfajta sugalmazást).

Idővel azonban az egyház is ráébredt, hogy nem lehet megkerülni a filmet, ezért inkább azon keresztül kell hatni az emberekre. A szokásos körlevelek és újságcikkek mellett két katolikus szellemben született és az egyház áldásában részesített filmes folyóirat (Film Ideal, Revista Internacional del Cine) is elindult az 50-es években, amely figyelmeztetett a veszélyekre, morális és filozófiai kérdéseket tárgyalt, valamint most már az olvasók figyelmébe is ajánlott olyan müveket, amelyeket helyénvalónak gondolt. Mivel a tiltás nem volt megvalósítható, igyekeztek orientálni a közönséget.

Mindez alkalmazkodott a katolikus egyház nemzetközi szinten is megfigyelhető, filmhez történő viszonyulásához. Michel Lagrée vallástörténész a francia esetre vonatkozóan négy fázisról beszél; úgy vélem, hogy ez a felosztás kisebb időbeni eltérésekkel Spanyolországra is alkalmazható. Az első fázisban (a kezdetektől 1914-ig) veszélytelen szórakoztatási formának tartották, majd a másodikban (1914-1925) kifejezetten káros médiumnak. A harmadik szakaszban (1925-1940) átértékelték a filmet, és igyekeztek a közönséget irányítani, majd a negyedik fázisban (1945-1960) már megpróbálták azt a saját hasznukra fordítani, és a katolikus filmklubok mellett megjelent a katolikus filmgyártás is. ${ }^{197}$ Ugyanakkor, az alapvetően negatív viszonyulás a második világháború után is fennmarad, XII. Pius pápa 1949-ben is kifejti, hogy a fiatalok esetében a filmek a szellemi hanyatlás okozói. ${ }^{198}$

\footnotetext{
${ }^{194}$ Eslava Galán, Juan: Coitus interruptus. La represión sexual y sus heroicos alivios en la españa franquista. Barcelona, Editorial Planeta, 1997. 322-323.

${ }^{195}$ García Escudero, José María: La primera apertura. Diario de un director general. Barcelona, Editorial Planeta, 1978. 49.

${ }^{196}$ Gubern, Román - Font, Doménec: Un cine para el cadalso. Id. mü. 57.

${ }^{197}$ A Lagrée által francia nyelven felvázolt kategorizációt spanyolul összegzi: Bonafoux, Corinne: „Los católicos franceses ante el cine: ensayo de una historia del público católico" in: Montero, Julio - Rodríguez, Araceli (szerk.): El cine cambia la historia. Id. mü. 213.

${ }^{198}$ Uo. 216.
} 
1941-ben publikálták Spanyolországban A film és a katolikusok címü 270 oldalas kötetet ${ }^{199}$, amelyben egyházi személyek és katolikus írók tanulmányokban vizsgálják meg a kérdést. Kitérnek a filmek lehetséges veszélyeire, üzeneteire, müvészeti és technikai oldalára, annak potenciális hasznára az oktatásban és a katolikus propagandában. Függelékekben közlik a pápák, különböző nemzetiségű bíborosok és püspökök véleményét a filmekről, valamint mellékelik a spanyolországi filmterjesztő vállalatok listáját és a filmről értekező, katolikus szellemiségü könyvek és folyóiratok bibliográfiáját öt nyelven. Aprólékosan foglalkoznak a témával, lehetőségeket és veszélyeket vázolnak fel, nemzetközi példákat elemeznek, és nem határolódnak el egyértelműen a mozgóképtől, hanem megpróbálják kijelölni a követendő utat.

Az egyház és az állam közötti együttmüködés nem volt teljes mértékben harmonikus a rezsim folyamán: a társadalmi egyenlőtlenségeket látva, az 50-es évek második felétől, mindenekelőtt a fiatalabb papi rétegek egy része (a Katolikus Akció Munkástestvériségein keresztül) és a baszkföldi újjáéledő nacionalizmushoz kapcsolódó helyi egyháziak az emberek felé fordultak, felemelték szavukat a diktatúra néhány intézkedése ellen, szolidaritást és együttérzést kértek a szegény rétegekkel, közvetlen párbeszédet a hatalom és a társadalom között - megelőzve ezzel és helyenként erőteljesebben kifejezve az 1962-es II. Vatikáni Zsinat hasonló jellegü ajánlásait. Mindez párhuzamos volt a 60-as években hangsúlyossá váló, az egész rendszert jellemző nyitási politikával.

\section{A család és a nö}

Franco államában a spanyol nemzet alapeszménye a család, a már említett Tóth Tihamér könyvei is nagy hangsúlyt fektetnek rá. Az apa a haza érdekében bármilyen áldozatra kész, és ilyen szellemben neveli gyermekeit is. Hogy ez biztosan a kívánt módon történjen, a diktatúra létrehozta ennek intézményeit is. Mindenekelőtt gondoskodni kellett arról, hogy a legaktívabb korosztály, a fiatalság egy, a rezsimhez hủ és általa ellenőrzött csoportba tömörüljön. A német és olasz mintára megalakult, a FET y de las JONS kötelékébe tartozó Ifjúsági Szervezetek (Organizaciones Juveniles), későbbi nevén Ifjúsági Front (Frente de Juventudes) fogta össze és oktatta a fennálló eszmék szellemében az Új Spanyolország fiataljait. A Front megalakulását kihirdető, 1940. december 6-ára datált törvény ${ }^{200}$ értelmében az Ifjúsági Front felelős, többek között, a fiatalok politikai, szellemi, fizikai oktatásáért, a katonaságra felkészítő előneveléséért, mindent a Nemzeti Mozgalom doktrínáival

\footnotetext{
${ }^{199}$ El cine y los católicos. Madrid, Editorial Aldecoa, 1941.

${ }^{200}$ Boletín Oficial del Estado (a továbbiakban: BOE), 7-XII-1940.
} 
összhangban, valamint együttmüködik a kulturális szervezetekkel. Összesen 29 cikkelyben rendelkezik a Front müködéséről és feladatairól.

A család középpontjában azonban a nő legalább olyan hangsúlyos szerepet tölt be, mint a férfi. Ahogyan a filmekben is láthatjuk, az asszony erős jellemü, áldozatkész, fiatal korában is mindent megtesz azért, hogy a társadalom hasznos tagja legyen, majd családanyaként a gyermekei és a família fenntartása lesz életének fő célja. A Falange Női Szekciója (Sección Femenina) a hölgyeket integrálta szervezetbe. Markánsan katolikus szellemben és jelszavakkal karitatív, szociális, kulturális tevékenységet végzett, feladata az ideális asszony és feleség kinevelése. Kulturális téren legnépszerübb a Kórusok és táncok (Coros y danzas) részleg munkája volt. Szervesen kapcsolódott ehhez a hasonló feladatkört betöltő, Carmen Polo (Franco felesége) elnökölte Növédelmi Patronátus (Patronato de Protección a la Mujer), amelynek legföbb funkciói a következők voltak: az állam tájékoztatása a közerkölcs állapotáról, javaslattétel a nők védelmére hozandó intézkedésekről, segítségnyújtás a káros szenvedélyek áldozatául esett asszonyok, otthonról elszökött lányok és egyedülálló anyák részére, a bünelkövető (elsősorban prostitúciót gyakorló) nők átnevelése, a katolikus egyház megváltó tevékenységének segítése, a közerkölcsöt sértő társadalmi események felügyelete, aktív részvétel a filmcenzúra bizottságaiban, öltözködés és fürdőruha-viselet ellenőrzése, pornográf tartalmú anyagok betiltatása és más szociális feladatok ellátása. ${ }^{201}$

A nők központi jelentőséggel bírnak a rezsim filmjeiben, a fontosabb mủvekben egyenesen főszerepet kapnak. A későbbiekben tárgyalandó Aragóniai Agustina (Agustina de Aragón, Juan de Orduña, 1950), a Szerelmi örület (Locura de amor, Juan de Orduña, 1948), valamint az Ursino hercegnöje (La princesa de Ursinos, Luis Lucia, 1947) és a Kasztília bátor asszonya (La leona de Castilla, Juan de Orduña, 1951), többek között, mind elsősorban a női karakterekre épül. A Franco-korszakban készült történelmi filmek és a nők megjelenítését a gender studies keretében vizsgáló kutató szerint kettősség figyelhető meg: míg a vásznon a nő jelenléte soha nem volt ennyire hangsúlyos, mint a rezsim idején, addig az ország társadalmi és politikai újjáépítésében az asszonyokat éppen másodvonalbeliként kezelték, ugyanis semlegesíteni akarták azt a potenciális veszélyforrást, hogy a független női akarat szembeszállhat a férfiak hegemóniájával. Ugyanakkor a nőket a modern társadalom még nem rontotta meg, a spanyol nemzeti nagyság letéteményesei, helytállásuk és ösztönzésük alapfeltétele annak, hogy a férfiak harcba bocsátkozhassanak hazájuk

\footnotetext{
${ }^{201}$ González Duro, Enrique: El miedo en la posguerra. Id. mű. 188, 192-193, 220.
} 
megmentéséért, valamint a hispán tradíciók és a folklór is rajtuk keresztül élnek tovább. ${ }^{202} \mathrm{~A}$ társadalmi nem történetével foglalkozó kutatók szerint az európai nacionalizmusokban az Anya és a Haza szorosan összefügg, előbbi biztosítja az utóbbi biológiai és ideológiai utánpótlását és fenntartását, közvetíti az utókor számára a nemzeti örökséget. Az anyaság a nők fő feladata, ezzel járulnak hozzá a Haza és a Faj fenntartásához. Mindez a Francorendszerben odáig fajult, hogy a feminista kritika szerint az Állam kisajátította az asszonyfigurát, önmagának rendelte alá, saját tulajdonaként kezelte őt. A legfőbb tekintély azonban a családfőé, az apáé és férjé (mindenekelőtt pedig a Haza Atyjáé, vagyis a Caudilloé). ${ }^{203}$

\section{A nyelv}

Az egységes nemzeti öntudatra való nevelés egyik eszközének a diktatúra a castellano, mint kizárólagosan használható spanyol nyelv hegemóniáját tartotta. A kisnemzetek nyelveinek nyilvános használatát betiltották, ideértve az oktatást, a hivatalos ügyintézést és az írott nyelvet (sajtó, irodalom) is. Egy polgárháború után megjelent újságcikkben egy katalán pap a következőt írta a Solidaridad Nacional címü lapban, védelmébe véve az ilyen irányú rendelkezéseket: „Tilos megjelentetni minden olyan publikációt, könyvet, brosúrát, újságot, folyóiratot és napilapot, amely nem Spanyolország hivatalos nyelvén íródott, a faj és a hispán világ minden gyermekének nyelvén". ${ }^{204}$ A 60-as évekig érvényben lévő törvénykezés értelmében az újszülötteknek adható keresztnevek közül eltávolították a kisnemzetekre jellemzőket (mint a Jordi és az Iñaki, bár ez a törekvés nem járt sikerrel). Igyekeztek számüzni a spanyol nyelvből az idegen szavakat és valamilyen kasztíliai megfelelővel helyettesíteni azokat. ${ }^{205} 1939$ és 1945 között a katalán, baszk és gallego nyelvű színházak müködése tiltott volt, ám a 40-es évek második felétől már kevésbé szigorú az ellenőrzés. Arra azonban várni kell a 60-es évek nyitásra ösztönző periódusáig, hogy a kisnemzetek saját identitásukat visszatükröző darabokat tűzhessenek mủsorra. ${ }^{206}$

\footnotetext{
${ }^{202}$ Ballesteros, Isolina: „Mujer y nación en el cine español de posguerra” in: Herrera, Javier - Martínez-Carazo, Cristina (szerk): Hispanismo y cine. Id. mü. 368-371.

${ }^{203}$ Uo. 376-377.

204 Idézi: Gómez, Luis: „Españolizar ya lo hizo Franco ... y fracasó” in: El País, 2012. október 14. Elérhetö: http://sociedad.elpais.com/sociedad/2012/10/14/vidayartes/1350243756_004204.html (2012-11-21) 205 Abella, Rafael: La vida cotidiana bajo el régimen de Franco. Id. mü. 51.

${ }^{206}$ Kiss Tamás Zoltán: „Csend! Csend, ha mondom! Csend! A spanyol színház a Franco-korszakban (19361945)" in: Lengyel György (szerk.): Színház és diktatúra a 20. században. Budapest, Corvina Kiadó - Országos Színháztörténeti Múzeum és Intézet, 2011. 111.
} 
1941-ben lép életbe a kötelező szinkronról szóló törvény. ${ }^{207}$ A külföldi, más nyelven forgatott filmeket spanyolosították: csak olyan film kerülhetett bemutatásra, amely kasztíliai nyelven szólt közönségéhez. A spanyol szinkront kihirdető rendelkezés megszabta még a munkálatok körülményeit is: a szinkronizálást spanyol tulajdonban lévő, spanyol területen fekvő stúdiókban kellett végezni, és a munkálatokban részt vevő személyzet is kizárólag spanyol lehetett. Ezen kívül rendelkezett a szinkronizálási engedélyről, arról az összegről, amelyet a film külföldi gyártója részére kellett kifizetni, hogy ne legyen nemzetközi törvénybe ütköző a nyelvváltoztatás.

Mindazonáltal, a kötelezően spanyol nyelven beszélő filmeknek volt egy velejárója, amely nagymértékben károsította az ország filmgyártását, rövid és hosszú távon egyaránt. Erre már 1949-ben egy Franco-rendszerhez hü filmtörténész is figyelmeztetett, aki szerint hatalmas hibát követtek el a külföldi filmek szinkronizálásával, ezzel ugyanis nyomorba döntötték a nemzeti filmgyártást, nagyjából minden lehetőséget megvonva tőle, hogy sikeres legyen saját hazájában. ${ }^{208}$ Megfosztották a spanyol nemzeti filmipart attól az egyetlen előnyétől, amivel felülkerekedhetett volna a külföldi fillmdömpingen: anyanyelvén szólt a néphez (ahogyan Fernando Vizcaíno Casas író fogalmazott: „Valószínűleg a kötelező szinkron volt a spanyol filmgyártásra mért halálos ütés”209). A spanyol szinkronnal ellátott idegennyelvű produkciók így hasonló vonzerővel bírtak, mint az otthoniak, sőt, ahogyan az szinte minden országban lenni szokott, felül is kerekedtek rajtuk. A Primer Plano folyóirat hasábjain folyamatosan vitáztak egymással a filmkritikusok és filmművészek a szinkron hatásáról, gyakori volt a rendelettel szembeni állásfoglalás is. ${ }^{210} \mathrm{Nem}$ a filmgyártásban érdekelt, vagy ahhoz értő szakemberek hozták ezt a döntést, hanem a minden körülmények között nyelvi azonosságot erőltető vezetői kar; a kötelező szinkronról szóló törvényt 1947-ben vissza is vonták, miután felismerték negatív oldalait, de gyakorlati alkalmazása megmaradt. ${ }^{211}$ Szintén megjegyzendő, hogy a filmiparban érdekelt három terület (gyártás, forgalmazás, bemutatás) közül csak az első károsodott a törvény által, mert a másik két szektornak a

\footnotetext{
${ }^{207}$ A rendelet, érdekes és megmagyarázhatatlan módon, soha nem került publikálásra az Állami Közlönyben, de utasításait minden stúdió kötelezö törvényerejü rendeletként kezelte. Mindenki tudott róla és igyekezett azt betartani, későbbi törvényekben hivatkoztak is rá. Lásd: Castro de Paz, José Luis: Un cinema herido. Los turbios años cuarenta en el cine español (1939-1950). Barcelona, Paidós, 2002. 29.

${ }^{208}$ Cabero, Juan Antonio: Historia de la Cinematografía Española. Id. mü. 662.

${ }^{209}$ Vizcaíno Casas, Fernando: Historia y anécdota del cine español. Madrid, Adra, 1976. 86.

${ }^{210}$ Például az alábbi vezércikkben: „Contra el doblaje de las películas” in: Primer Plano, No. 154. 1943. október 26.

${ }^{211}$ Monterde, José Enrique: „El cine de la autarquía”. in: Gubern, Román (és mások): Historia del cine español. Id. mü. 191-192. o.
} 
bemutatható filmek megsokszorozódásával és az azokra kíváncsi nézők számának növekedésével egyenes arányban emelkedett a bevételi forrása.

A későbbi filmművészeti főigazgató, José María García Escudero teljesen elfogadhatatlannak tartotta a szinkront, müvészeti merényletnek tartotta azt, Balázs Béla magyar filmesztéta megállapítását is idézte: „lehetséges például angolul beszélni és közben olaszul gesztikulálni?” 212 Ám ő is elfogadta, hogy a nézők és a terjesztők már annyira hozzászoktak a spanyol nyelven hallgatott filmekhez, hogy elutasítanák az eredeti nyelvü, feliratos müveket.

A kisnemzetek nyelvei, bár csak minimális mennyiségben, de felbukkantak a fösodorbeli filmekben: a már említett Aragóniai Agustina egyes jeleneteiben a köznép tagjai esetenként katalánul szólnak egymáshoz. A két változatban, spanyol és katalán hanggal is felvett A Júdás (El Judas, Ignacio F. Iquino, 1952) című film utóbbi változatát azonban azonnal betiltották, mert még egy vallási témájú, az erkölcsöt és az erényeket hirdető film számára sem volt megengedhető, hogy döntően ne kasztíliai nyelven forduljon a közönséghez. ${ }^{213}$

Ugyanakkor a szinkron egy másik, társadalmi célú szerepet is betöltött. A spanyol nyelven beszélő filmek vetítése volt ugyanis az egyetlen módja annak, hogy a jelentős létszámú analfabéta tömegekhez eljusson a mozgókép által nyújtott élmény, kiküszöbölve ezzel az idegen nyelv okozta nehézségeket.

\section{Az állandó ellenség képe}

A győztesek és legyőzöttek Spanyolországában az áldozatok száma ma is vitatott. A legújabb becslések szerint ${ }^{214}$ összesen 433 ezer áldozattal jártak a harcok, ebből 165 ezren betegségben hunytak el, erőszakos halált 268 ezer személy halt. A csatatéren körülbelül 137 ezren vesztették életüket, a későbbi terror áldozatai 130 ezren lehettek. A polgárháború halottainak összesített száma 625 ezerre tehetö, beleértve a háború és a diktatúra minden áldozatát. Ezek a számok azonban eléggé képlékenyek, főleg a háború utáni elnyomás, a bosszúhadjárat eredményeként történt kivégzések és börtönbüntetések adatai emelhetnek a végső becsléseken. ${ }^{215}$ A tömeges szegénység, a lakás-, ruha- és élelmiszerhiány, valamint a jegyrendszer is számos áldozatot követelt.

\footnotetext{
${ }^{212}$ García Escudero, José María: Cine español. Madrid, Ediciones Rialp, 1962. 97-98.

${ }^{213}$ Gubern, Román - Font, Doménec: Un cine para el cadalso. Id. mü. 71-72.

${ }^{214}$ Esparza, José Javier: El terror rojo en España. Id. mü. 360-361.

215 Nincs két olyan történeti munka vagy statisztika, amely azonos számokat mutatna. Éppen ezért nem vállalkozom pontos adatok közlésére, a fent hivatkozott Esparza becsléseit azért emeltem be, mert egyfajta
} 
Az 1939-ben hozott Politikai Felelösségre Vonás Törvénye (Ley de Responsabilidades Políticas) ${ }^{216}$ értelmében gyakorlatilag bárkit meg lehetett vádolni azzal, hogy együttműködött a „hazaáruló” köztársasági erőkkel, ez alapján kezdtek a győztesek tisztogatásokba. Az ezt kiegészítő, 1940-es a Szabadkőmüvesség és Kommunizmus Elnyomásának Törvénye (Ley para la Represión de la Masonería y del Comunismo) ${ }^{217}$ preambulumában pedig történelmileg próbálják igazolni a jelen ellenségképét:

„A spanyol gyarmatbirodalom elvesztésében, a véres függetlenségi háborúban, a Spanyolországot az elmúlt évszázadban ostorozó polgárháborúkban és az alkotmányos monarchia bukását felgyorsító, valamint a diktatúra időszakát aláaknázó felfordulásokban mindig felfedezhető a szabadkömüvesek és az anarchizmust hirdetö erök együttes ténykedése, melyeket rejtőzö nemzetközi erök mozgatnak."

Mindkét törvény képviseletében különleges bíróságok álltak fel, a büntetés általában halál, börtön, munkatábor. Ez a rendkívül gyors ütemben zajló ítélethozatal-sorozat 1943-44ig tartott, a második világháború utolsó éveiben már tömeges szabadon bocsátások, enyhítések történtek a politikai bűnökért elítéltek körében, több tucat börtönt is bezártak, mert a fogvatartottak száma csökkent. ${ }^{218}$ Nem szüntek meg az igazságtalan kivégzések és elzárások, de a változó nemzetközi helyzet (mindenekelőtt a fasizmus közeledő bukása) hatására mérséklődő tendenciát mutattak.

A keresztes hadjárat fogalma a nemzetikatolikus Spanyolországban, elsősorban a Falange hatására, magasztos értékkel bírt. Ahogyan évszázadokkal korábban a reconquista alatt a katolikus nemzet megszabadult a kártékonynak ítélt idegen elemektől, úgy a polgárháború során Franco és csapatai ugyanezt tették: eltávolították a hatalomból és a közéletből az általuk nemzetellenesnek tartott csoportokat. Sok fenyegető árnyat látott a spanyol nép fölé tornyosulni a nacionalista tábor, de ezek közül is a legveszélyesebbnek a kommunizmust vélte. A fegyveres harccal azonban nem oldódtak meg a problémák, a nemzetközi kommunizmust, a marxizmust és a szabadkőművességet minden gonosz forrásaként jelölték meg, és az ellenük folytatott harc vált a nemzeti összefogás egyik elsőszámú indokává. Franco polgárháború alatt és után elmondott beszédeinek központi

középutat képviselnek. Napjainkban is számos könyv és tanulmány közöl hitelesnek mondott számokat ebben a témában, de mindegyik eltérő adatokat említ.

${ }^{216}$ BOE, 18-II-1939.

${ }^{217}$ BOE, 2-III-1940.

218 A Franco-korszak történetével és az elnyomással foglalkozó művek mindegyike részletesen tárgyalja a megtorlások mértékét és tendenciáit. A legfrissebb kutatási eredményeket közli: Aróstegui, Julio (szerk.): Franco: La represión como sistema. Id. mü. 
témája a kommunizmus veszélye, ebben a szellemben írtak cikkeket a sajtótermékek is. Spanyolország ellenfelei továbbra is a marxizmus, a szabadkőmủvesség és a judaizmus. A háború után azonban változás történt: a retorikában nem kizárólag marxizmusról beszélt, a kapitalizmus is ellenféllé vált, mintegy egyenlőségjelet téve a kettő közé. A beszédekben és a sajtóban a marxizmus, bolsevizmus, kommunizmus, szabadkőművesség, kapitalizmus, judaizmus, liberalizmus szavak jórészt egymás szinonimáiként funkcionáltak; a propaganda szerint az idegen hatalmak ügynökei beszivárogtak a nemzeti Spanyolország minden társadalmi szférájába, és a fenti eszmék szolgálatában belülről próbálják szétbomlasztani az új rendet. A polgárháború alatt a felkelők oldalán álló sajtóban, a harcok után pedig minden Spanyolországban megjelenő újságban találunk számos cikket ebben a témában. Ezeket egészítik ki a Caudillóval készült interjúk, beszédeinek leiratai. Mindez érvényes a rádióra is. A kommunizmus gyűjtőnév alatt csoportosított a fentieken kívül mindenkit, aki - Franco szerint - a múltban a szociális reformok és a kisnemzetek autonómia-törekvésének támogatásával megkérdőjelezte Spanyolország egységét, vagy gyengíteni akarta a katolikus egyház hatalmát. ${ }^{219} \mathrm{Az}$ 50-es évektől egyre gyakoribbá váló sztrájkok, majd az évtized második felében megjelenő egyetemi tiltakozó mozgalmak a Generalísimo szerint mind a külföldről beszivárgó kommunista ügynökök lázító akcióinak eredményei voltak.

Az egyház is támogatta az állandósuló harcot. Az irányításuk alá tartozó közoktatásban terjesztették nézeteiket a démonizált liberalizmusról, szocializmusról, pozitivizmusról, naturalizmusról és szabadkőmüvességröl, a tankönyvek és iskolai olvasókönyvek is ezek ellen irányuló szövegeket tartalmaztak. A kötelező tankönyvként funkcionáló, már említett Catecismo patriótico is a zsidó-szabadkőmüves csoportokat és a nemzetközi kommunizmust nevezte meg a legfenyegetőbb veszélynek, amelyekkel egyetlen igaz katolikus sem vállalhat közösséget. A velük való múltbeli együttműködést Spanyolország fő bűnei közé sorolja, ezt a foltot pedig csak vérrel lehet kitörölni. ${ }^{220}$

Franco nemzetközi elismertsége részben ennek köszönhető. Mivel ö már mindenkinél korábban figyelmeztette a világot a kommunista veszélyre, amikor kiéleződött a konfliktus a Szovjetunió és az Egyesült Államok (és más nyugat-európai országok) között, akkor a spanyol tábornok egy, a fenyegetettséget már jó előre érzékelő hadvezér szerepét vehette fel. Külpolitikájában mindvégig a tántoríthatatlan antikommunista álláspontjára helyezkedett, így

\footnotetext{
${ }^{219}$ Erről lásd: Vázquez Montalbán, Manuel: Los demonios familiares de Franco. Id. mü.

${ }^{220}$ Camino Gutiérrez Lanza, María del: Traducción y censura de textos cinematográficos... Id. mü. 37.
} 
a hidegháború eseményei ${ }^{221}$ valamint a Szovjetunió agresszivitása is az ő igazát támasztották alá. Az 1956-os magyar eseményekre adott spanyol reakció szervesen illeszkedett ehhez a felfogásához.

A kommunistákkal kapcsolatban is felállította elméletét a rezsim már idézett pszichológusa, Vallejo Nájera, aki Franco megbízásából 1938-ban egy pszichológiai kutatóintézetet is létrehozott, hogy a „vörös” pszichopata bünözőket, valamint a marxizmus biofizikai gyökereit tanulmányozza. Vizsgálatait és kísérleteit a San Pedro de Cárdenában létesített koncentrációs táborban fogva tartott, marxistának bélyegzett köztársaságiakon és nemzetközi brigadistákon végezte. Eredményeit az akkoriban hitelesnek és mérvadónak tekintett spanyol orvosi szaklapokban publikálta, majd azokat a napilapok is átvették. Arra a következtetésre jutott, hogy egyes személyek biológiailag predesztináltak arra, hogy a marxizmust és kommunizmust magukba fogadják. Ezek az ideológiák annyira leegyszerüsítettek és primitívek, hogy a szellemileg alsóbbrendủ és mentális degenerációban szenvedő személyek könnyen magukévá teszik, mert segítségükkel alapvető állati ösztöneiket elégítik ki. Vizsgálatai alapján úgy vélte, a „vörösök” intelligenciája alig mérhető, vallási áhítatra képtelenek, a kultúrában járatlanok, antiszociálisak, elidegenedett személyek, politikai fanatikusok, összességében degeneráltnak minősíthetőek. ${ }^{222}$ Vallejo Nájera kutatásait a rezsim más pszichiáterei tovább folytatták (kiemelkedik közülük is Marco Merenciano) annak érdekében, hogy a társadalomban beazonosíthassák a bujkáló marxistákat. A Francorendszer antikommunista retorikáját tehát a 40-es és 50-es években a fentiekből kiinduló és ahhoz nagyon hasonló, tudományosnak látszó eredményekkel is alátámasztották ${ }^{223}$, a rezsim egyes politikusai pedig alkalmanként hasonlóan képtelen véleményeket hangoztattak. ${ }^{24}$

\footnotetext{
${ }^{221}$ A korabeli spanyol sajtóban és Franco beszédeiben ezek közül legtöbbször a Truman-doktrína, az Amerikaellenes Tevékenységet Vizsgáló Bizottság, a Koreai-félszigeten és Kínában zajló események, valamint az 56-os magyar forradalom jelentek meg.

${ }^{222}$ González Duro, Enrique: El miedo en la posguerra. Id. mü. 53-55, 60-61.

${ }^{223}$ A téma egyik mai szakértője részletesen megvizsgálta mindezeket: González Duro, Enrique: Los psiquiatras de Franco: los rojos no estaban locos. Barcelona, Ediciones Península, 2008.

${ }^{224}$ Gabriel Arias Salgado, a rezsim első tájékoztatási és idegenforgalmi minisztere egy interjúban komoly hangvételben fogalmazta meg irreálisnak tünő gondolatait, amely szerint Sztálin azért utazik olyan gyakran Azerbajdzsánba, mert ott a Sátán személyesen ad neki instrukciókat egy, a Föld mélyével kapcsolatot teremtő olajfúrókúton keresztül. Erről lásd: Abella, Rafael: La vida cotidiana... Id. mü. 173.
} 


\section{Kultúra, társadalom és propaganda a Franco-rendszerben}

Egy embercsoporttal elfogadtatni egy új eszmerendszert rendkívül nehéznek bizonyulhat, amennyiben az ellenállásba ütközik a társadalom részéről. A szélsőjobboldali diktatúrák, elsősorban Mussolini és Hitler rendszere a tömegek mobilizálását, az ideológia aktív támogatását kívánta meg, ezért propagandájuk erre irányult. A rendszer felállításához szükséges erőszakot a konszolidáció periódusában a hatalom és a társadalom közötti, fentről irányított konszenzussá próbálták változtatni, a társadalmi kommunikációs eszközöket és a kultúrát használták fel annak érdekében, hogy a nép számára úgy tűnjön, az ő véleményét is kikérték, az ő beleegyezésével valósul meg az új állam. A „tömegek államosítása” és ,a nemzet közösségének" kialakítása kifejezésekkel írhatóak le azok a folyamatok, amelyeket a német és az olasz rezsim alkalmazott: éreztetni akarták a társadalommal, hogy mindenki részese a politikai rendszer alakításának, az egész társadalom közösen formálja a nemzeti politikát; ezt szem előtt tartva szervezte meg a hatalom a felvonulásokat, tömegrendezvényeket, valamint kezdett monumentális építkezésekbe. Maga az állam vált egyfajta vallássá, amelynek minden polgár behódolni kényszerült, így vált a propaganda is az erőszak egyik fajtájává. A Duce és a Führer köré felépített mítoszok adták mindezek motorját. $^{225}$

Francisco Franco tábornok rendszere, ahogyan erről már korábban szóltam, számos eltérést mutat a fasiszta rezsimektől, esete mégis rokonítható a fentiekkel a propaganda terén, de egy másik aspektust is figyelembe kell venni. Mindezt talán Juan Pablo Fusi történész fogalmazza meg legvilágosabban, hipotézisét azóta is sokan idézik és tartják elfogadottnak. Szerinte a felkelők hatalomra kerülése Spanyolország történelméből, értékeiből és tradícióiból egyenesen következik, ezek pedig az emberekbe már jóval korábban, szinte már genetikusan beidegződtek. Az emberek nem érzelmileg azonosultak a nacionalistákkal, hanem egyszerüen csak természetesnek vették az új állapotot, alkalmazkodtak hozzá, mert nem volt annyira idegen tőlük és felmenőik hozzáállásától. Az esetek többségében ehhez nem volt szükség kényszerre sem. Franco számított arra, hogy aktiválódnak a spanyolokban a régi elvek, esetleg felszínre hozza a bennük szunnyadó tradíciókat: a hagyományos családcentrikusság, a

\footnotetext{
${ }^{225}$ Olasz, német, francia és angolszász szerzők megállapításait foglalja össze és rendszerezi: Sevillano Calero, Francisco: Propaganda y medios de comunicación en el franquismo (1936-1951). Alicante, Universidad de Alicante, 1998. 43-47.
} 
katolikus hit fenntartás nélküli tisztelete, a rend és fegyelem tekintélye, valamint a hagyományos politikai pártok iránt érzett megvetésük. ${ }^{226}$

A tömegek befolyásolása természetesen kulcsfontosságú volt a Caudillo számára. A falangista és a hagyományos konzervatív tömegfelfogás ötvözeteként olyan csoportot tartott ideálisnak, amelyet jelszavak és ideálok segítségével, felülről vezérelten lehet mozgásba hozni és egy hierarchikusan felépített társadalom alkotóelemei; mindez alkalmazkodott a már idézett A tömegek esztétikája címü cikk alapvetéseihez. Ez leginkább az alsó osztályokra vonatkozott, őket a falangista „szociális demagógia” vette célba, a rendszerrel egyet nem értő értelmiséget úgysem tudták megváltoztatni, ezzel ők is tisztában voltak: velük szemben a megtorlás és az elnyomás eszközeit használták. ${ }^{227}$

Az oktatási rendszer segítségével megkezdődött a történelem át- és újraértelmezése, amely a múltra való hivatkozással a jelent is a hatalomra került csoportok érdekei szerint tudta pozitív színben feltüntetni.

A nemzetikatolikus diktatúra fenntartása erőteljes propagandatevékenységet igényelt. Az állami és magánkézben lévő rádiók, sajtóorgánumok, vetítőtermek és hírügynökségek a Nemzeti Mozgalom szócsöveivé váltak. Az 1938 és 1944 között fennállt, a Belügyminisztériumhoz tartozó és a Falange irányítása alatt álló Nemzeti Sajtó- és Propagandaügyi Hivatal (Delegación Nacional de Prensa y Propaganda) végezte az ehhez kapcsolódó tevékenységet, majd az ezt követő években folyamatosan átkerült más osztályok, hivatalok hatáskörébe. ${ }^{228} 1945$ és 1951 között az Oktatási Minisztériumhoz tartozó Propaganda Főigazgatóság (Dirección General de Propaganda), végül az 1951-ben megalakult Tájékoztatási és Idegenforgalmi Minisztérium (Ministerio de Información y Turismo) lett felelős a propaganda irányításáért.

A polgárháború után az új rend fenntartása mellett egy másik területen is létfontosságúvá vált az erőteljes propaganda kifejtése: a második világháború kitörésével Spanyolország ismét egy fegyveres konfliktus kapujában találta magát. Mind a semleges, mind a nem hadviselő fél státusza idején erőteljes tengelybarát propaganda indult meg a spanyol sajtóban Németország és Olaszország mellett, mintegy előkészítve a közvéleményt a két szélsőjobboldali hatalom oldalán történő hadba lépésre. Ezzel megágyaztak a Kék Hadosztály frontra küldésének társadalmi elfogadottsága előtt is. A sajtópropaganda

\footnotetext{
${ }^{226}$ Fusi, Juan Pablo: „Para escribir la biografía de Franco” in: Claves de Razón práctica, 27/1992. 8-15.

${ }^{227}$ Harsányi Iván: A Franco-diktatúra ... Id. mü. 171-175.

${ }^{228}$ Tranche, Rafael R - Sánchez-Biosca, Vicente: NO-DO. Id. mü. 31-34.
} 
egyöntetủen a tengelyhatalmak mellett foglalt állást, a szövetségeseket, bár a társadalom számos csoportja inkább velük szimpatizált, kizárólag negatív színben ábrázolták.

A film a kultúra szerves részét képezi minden társadalomban, így a Franco-rendszer kultúrpolitikájának többi szegmensét is szükségesnek tartom röviden bemutatni ahhoz, hogy a filmművészetet is be tudjam illeszteni az őt megillető helyre.

\section{A kulturális élet}

Politikai és kulturális viszonylatban egy új rezsim elsődleges céljai között szerepel, hogy háttérbe szorítsa, vagy teljesen megsemmisítse az előző vezetés főbb intézményeit. A spanyol esetben is létezett egy szervezet, amely különösen veszélyesnek tünt az új hatalom számára.

A felsőoktatás szabadságát hirdető és a Krause filozófiáján alapuló Oktatás Szabad Intézete (Institución Libre de Enseñanza - ILE) 1876-ban született meg Francisco Giner de los Ríos ösztönzésére, reakcióként Cánovas del Castillo az oktatás sokszínüségét hátrányosan érintő reformjaira. ${ }^{229}$ Az ILE oktatói, vendégelőadói és publikációinak szerzői között nemcsak a korabeli Spanyolország, de a fejlett világ több vezető értelmiségije is megtalálható volt, mindannyian a haladó pedagógiai és tudományos nézetek képviselői. Számukra a gondolat, az oktatás, a kutatás és az ismeretterjesztés szabadsága mindennél fontosabb volt, ezt a nézetet népszerüsítették hallgatóik körében. Az Intézethez, a hozzá kapcsolódó Diákotthonhoz (Residencia de Estudiantes), a Történeti Tanulmányok Központjához (Centro de Estudios Históricos), a Tanulmányi Bövítés Juntájához (Junta para la Ampliación de Estudios), valamint a Természettudományok Nemzeti Intézetéhez (Instituto Nacional de Ciencias FísicoNaturales) kötődő diákok pedig hamarosan Spanyolország új generációs értelmiségét adták. 1931-től a Második Köztársaság kezdeményezésére mindez kiegészült az elsősorban madridi egyetemi hallgatókból és oktatókból álló Pedagógia Missziók (Misiones Pedagógicas) tevékenységével, amelyek a döntően analfabéta vidéki lakossághoz juttatták el a kultúra eredményeit mozgó könyvtárak, színházi előadások és filmvetítések formájában. Ahogyan a nevük mutatja, nem csak szórakoztatói és kulturális, hanem pedagógiai feladatuk is volt: oktatófilmjeik segítségével részletesen bemutatták a közönségnek, hogyan lehet gazdaságos módon kenyeret elöállítani, illetve milyen új technikával megvalósítható öntözési formákat alkalmazhatnak a földeken. A spanyol agrárrégiókban élők sokszor e misszióknak

\footnotetext{
${ }^{229}$ Az ILE és kapcsolódó intézményei történetéről lásd: Rodríguez de Lecea, Teresa (és mások): La Institución Libre de Enseñanza. Madrid, Información y Revistas S.A., 1985. Az ILE örökségét jelenleg a Francisco Giner de los Ríos Alapítvány kezeli.
} 
köszönhetően láttak filmet életükben először. ${ }^{230}$ Kulturális szempontból a Diákotthon bírt legnagyobb jelentőséggel: falai között az évek során állandó vagy átmeneti jelleggel megfordult Luis Buñuel, Federico García Lorca, Salvador Dalí, José Ortega y Gassett, Rafael Alberti és Unamuno is. 1939-1940 folyamán azonban a háború győztesei megszállták ezeket az intézményeket, elkobozták vagyonukat, tagjait számüzetésre kényszerítették, bünösként elítélték, vagy elhallgattatták.

Általánosan kijelenthető, hogy a Caudillo államában a fogyasztói kultúrát előnyben részesítették a hivatalos kultúra mindenhatóságával szemben. Felismerték ugyanis azt a realitást, hogy a nagy népszerüségnek örvendő, szórakoztató és a mindennapok gondjaitól elvonatkoztató megnyilatkozási formák sokkal jobban lekötötték, és egyúttal passziválták a nép figyelmét, mint azok a kulturális termékek, amelyek gondolkodásra késztették az embereket a fennálló politikai, társadalmi és gazdasági helyzetükkel, lehetőségeikkel kapcsolatban. Ez nem spanyol sajátosság: ugyanez megfigyelhető Mussolini Olaszországában is, valamint a demokráciák is élnek a figyelemelterelés ezen válfajával. Éppen ezért, bár a propaganda - mint minden autokratikus berendezkedésben - rendkívül fontos szerepet töltött be az állam életében, Spanyolországban (és Olaszországban, szemben például a hitleri Németországgal és a sztálini Szovjetunióval) sok esetben nagyobb hangsúlyt helyeztek a pusztán szórakoztató, ártalmatlanabb alkotásokra. A szovjet érdekszférához tartozó országok szinte mindegyikében működő, Magyarországon Aczél György nevéhez füződő 3T-elv (Támogat, Tür, Tilt) a Franco-korszak kultúrpolitikájában is beazonosítható. Bár a témával foglalkozó szakirodalom nagy része általánosságban totális kontrollról beszél, ez a megállapítás kiigazításra szorul: valóban szigorú szabályozást vezettek be a kultúra területén, nem beszélhetünk azonban áthatolhatatlan korlátokról. A rendszer egyik ellentmondása, hogy nem valósították meg a hegemón, egyeduralkodó kultúrát. Még 1959-ben is irányelvként fogalmazták meg, hogy a spanyol állam külpolitikáját is elsősorban kulturális alapokra kell helyezni, mert erő, pénz és presztízs hiányában csak így lehet esélye nemzetközi színtéren is a hangsúlyos jelenlétre. ${ }^{231}$

Kulcsszó a változás, illetve a puhulás: párhuzamosan a rendszer politikai evolúciójával, a polgárháborút követő évtized merev szabályai után az 50-es évek második felétől, de mindenekelőtt a 60-as évektől kezdődően már megfigyelhetőek a lazulás jelei, több mindent volt szabad kimondani, leírni, bemutatni.

\footnotetext{
${ }^{230}$ García Maroto, Eduardo: Aventuras y desventuras del cine español. Barcelona, Plaza \& Janes Editores, 1988. 70-71.

${ }^{231}$ AMAE, R-10208/66; „Funciones políticas de la Dirección General de Relaciones Culturales”, 2/II/1959
} 
Kezdetben az ellenkultúra, a vesztes Spanyolország ideológiai megnyilatkozásainak megsemmisítése volt a cél, ezt látványos propagandisztikus eseményekkel támasztották alá. 1939. április 30-án a madridi Központi Egyetemen a Falange szervezésében, a sajtó munkatársainak meghívásával és az új oktatási államtitkár részvételével történt az első nagyszabású autodafé, a Spanyolország ellenségeinek nyilvánított szerzők és gondolkodók (mint Marx, Gorkij, Freud, Rousseau, Voltaire és Sabino Arana) könyveinek elégetése, elítélve ezzel a marxista, liberális, modernista és szeparatista eszméket. Ahogyan az Arriba napilap fogalmazott egy későbbi, hasonló típusú esemény kapcsán: „Ezzel a könyvégetéssel hozzájárulunk az Egy, Nagy és Szabad Spanyolország építéséhez. Tủzre vetjük a szeparatizmus, liberalizmus, marxizmus, a fekete legenda, a katolicizmus-ellenesség, a beteges romanticizmus, a pesszimizmus, az extravagáns modernizmus, az ízléstelenség, a gyávaság, az áltudományosság ... könyveit.” ${ }^{232}$

A spanyol közoktatás, a tudományos élet és kultúra teljes átszervezése már a felkelés alatt megkezdődött, ennek első lépéseként mindenre és mindenkire kiterjedő tisztogatásba kezdtek a lázadó erők. A köznevelésbe bevezették az új, hazafias nevelést célzó tartalmakat, mint a Nemzeti Szellem Alakítása (Formación del Espíritu Nacional) címü tantárgy. ${ }^{233} \mathrm{Az}$ 1943-as egyetemi törvény ${ }^{234}$ szinte teljes mértékben a katolikus egyház hegemóniáját valósította meg a felsőoktatásban, fontos katedrákat töltöttek be papok és vallási szervezetek (ACN de P, majd Opus Dei) képviselői, valamint kötelezővé vált a katolikus vallás oktatása az egyetemisták számára. A liberálisnak, köztársaságinak, vagy egyszerűen csak a Nemzeti Spanyolország ellenségének vélt értelmiségieket, oktatókat, irodalmárokat, történészeket és művészeket száműzték a közéletből. A már említett CSIC mellett a különböző szekciókra osztott és a FET y de las JONS Politikai Juntájának alárendelt Politikatudományi Intézet (Instituto de Estudios Políticos) volt a szellemi élet egyik irányítója. ${ }^{235}$ Az egyetemi hallgatók azonban 1956-tól folyamatos tiltakozó megmozdulásokat, egyetemfoglalásokat szerveztek; ezeket a hatalom eleinte kemény kézzel leverte, azok idő- és térbeli megsokszorozódásával azonban már nem tudta felvenni a harcot, az oktatási tárca engedményekre kényszerült. Ezek a hallgatók már egy új nemzedéket képviseltek: nem voltak személyes emlékeik a polgárháborúról, és sok esetben a rezsimet hủen kiszolgáló, a győztesek csapatában helyet

\footnotetext{
${ }^{232}$ Rodríguez, Joaquín: „Libros en llamas, ideas ignífugas” in: Los futuros del libro. Elérhetö: http://www.madrimasd.org/blogs/futurosdellibro/2008/05/14/91803 (2012-11-21)

${ }^{233}$ Gómez, Luis: „Españolizar ya lo hizo Franco ... y fracasó” Id. mü.

${ }^{234}$ BOE, 31-VII-1943.

${ }^{235}$ Harsányi Iván: A Franco-diktatúra születése. Id. mü. 142-148.
} 
foglalók gyermekei voltak, akik nem értettek egyet szüleik ideológiai meggyőződésével. A letartóztatott egyetemisták mellett pedig számos jobboldali értelmiségi és politikus is kiállt.

Bár a szellemi élet feletti teljes kontrollra törekedett az új hatalom, nem sikerült ezt maradéktalanul megvalósítani. Tiltólistára kerültek művészek, írók, politikusok, nevüket még csak említeni sem volt szabad, az újszülötteknek sem adhattak olyan egyre népszerübbé váló keresztneveket, mint a Dolores Ibárrurira utaló Pasionaria, vagy az Unificación (Egyesülés), Octubre (Október), illetve az oroszos hangzású, vagy a baloldaliakkal szimpatizáló híreshírhedt személyekre emlékeztető nevek. ${ }^{236}$ Az új nemzeti kultúrát igyekeztek új alapokra helyezni, külső kapcsolatokat pedig csak a velük szimpatizáló országokkal kerestek.

A polgárháború előtt és alatt a köztársasággal szimpatizáló művészek és értelmiségiek a Franco-rendszerben általában hallgatásra, gyakran emigrációba kényszerültek (mint Américo Castro, Rafael Alberti, Joan Miró, Luis Buñuel, Juan Ramón Jiménez), esetleg még tragikusabb sors várt rájuk (ahogyan Federico García Lorcára). Sokan azonban a felkelőkkel vállaltak ideológiai közösséget (Torrente Ballester, Camilo José Cela ${ }^{237}$, Eugenio d'Ors, Azorín, Ernesto Giménez Caballero, Salvador Daliín ${ }^{238}$.

Franco alapvetően igyekezett távol tartani az értelmiségieket. Beszédeiben soha nem használt irodalmi idézeteket, interjúiban többször is említette, hogy a 98-as nemzedékből sugárzó pesszimizmust és rezignáltságot tartotta a spanyol társadalmat lelkileg megnyomorító erők kiindulópontjának, az értelmiségieket pedig úgy általában liberálisnak és szabadkőművesnek vélte, akik hajlamosak a kommunizmus felé fordulni. ${ }^{239}$ A Falange-ban propaganda és kultúra területén kulcspozíciókat betöltő Dionisio Ridruejo deklarált célja volt, hogy visszaállítsák a katolikus dogmát és a nemzeti idealizmust a katonai erényekkel vegyítve. $^{240}$

A polgárháború kitörésekor létrejött Nemzeti Sajtó- és Propagandaügyi Hivatal Millán Astray tábornok felügyelete alatt müködött, majd rövidesen ezt a tevékenységet kiegészítette egy rendelkezés a sajtócenzúráról. Az 1938. április 22-én kihirdetett Sajtótörvény (Ley de

\footnotetext{
${ }^{236}$ Uo. 150-151.

${ }^{237}$ Bár Celát nem minden irodalom- és kultúrtörténet sorolja a nacionalista szimpatizánsok közé, a diktatúra alatt kifejtett besúgó és cenzori tevékenysége miatt indokoltnak tartom ebben a csoportban megemlíteni.

${ }^{238}$ Giménez Caballero és Dalí korábban szorosan együttműködtek Luis Buñuellel, előbbi Spanyolország első filmklubjának létrehozásában, utóbbi az Andalúziai kutya (Un chien andalou, Luis Buñuel, 1929) elkészítésében. Az ideológiai nézeteltérések azonban ellentétes táborba sodorták őket és egymást rágalmazó, szidalmazó, feljelentő ellenségekké váltak. Különösen Dalí és Buñuel kapcsolata mérgesedett el.

${ }^{239}$ Fusi, Juan Pablo: „La cultura” in: García Delgado, José Luis (szerk.): Franquismo. El juicio de la historia. Madrid, Ediciones Temas de Hoy, 2005. 223-224.

${ }^{240}$ Uo. 226-227. Ridruejo a 40-es évektöl távolodni kezdett a rendszertől, egyre hangsúlyozottabban állt ki a szabadságjogok mellett, és erőteljesen kritizálta a rezsimet.
} 
Prensa $)^{241}$ írásba foglalta, hogy a sajtószabadság liberális felfogása káros, kizárólag az új Állam kiépítését támogató sajtó lehet szabad. A sajtószabadság csak addig terjedt, amíg nem kérdőjelezte meg a haza és az állam egységét. Főszerepet nyertek az újonnan alapított vagy már korábban is létező, szélsőjobboldali vagy monarchista irányultságú és nemzetikatolikus hangvételü újságok: Arriba, Ya, Madrid, $A B C,{ }^{242}$, valamint a Vértice, Escorial, vagy a legolvasottabb napilap, a Marca nevü sportlap. A sajtó az állam szolgálatába állított intézménnyé vált, a Nemzeti Sajtószolgálat (Servicio Nacional de Prensa) felügyelte az információközlést, a lapok alapítását és az előzetes cenzúrát, újságíróként pedig kizárólag az államilag fenntartott nyilvántartásba vett személyek dolgozhattak. Az EFE és Pyresa hírügynökségek önállósága is megszünt. Azonban a kontroll nem volt, nem lehetett teljes: számos alkalommal a rezsim családjai, mindenekelőtt az egyház és a Falange vitába keveredett egymással és az állammal, mivel saját akaratát kívánta érvényesíteni. Már 1941-től megjelenhetett a La Codorniz címü szatirikus folyóirat, amely a grafikai humor kategóriájában görbe tükröt tartott a hatalom és társadalom elé; természetesen eleinte rendkívül óvatosan, később már egyre nyíltabban. Fennállása során számos alkalommal sújtotta a hatalom büntetésekkel és felfüggesztéssel. A sajtó mind a külföld, mind a belföld számára a nemzeti Spanyolország legyőzhetetlenségét és értékeit hirdette. ${ }^{243}$ A sajtótörvény szigora természetesen függött attól, hogy éppen melyik szerv, vagy melyik miniszter hatáskörébe tartozott. Az 1966. március 18-án hozott, Manuel Fraga Iribarne tájékoztatási és idegenforgalmi miniszter nevéhez füződő új Sajtó- és Nyomtatási Törvény (Ley de Prensa e Imprenta ${ }^{244}$, más néven Fraga-törvény (Ley Fraga) lazított a kereteken, és a nyugat-európai értelemben vett sajtószabadság felé tett néhány lépést, többek között az előzetes cenzúra eltörlésével.

A szabadidő felett is igyekeztek irányítást gyakorolni: a Falange kötelékébe tartozó szervezetek foglalkoztak minden sportintézmény müködtetésével és hivatalos sportrendezvény megszervezésével, míg az iskolai és egyetemi sportéletről az Ifjúsági Front, a Falange Női Szekciója és a vertikális szakszervezetek oktatási és szabadidős bizottságai gondoskodtak.

A képzőművészetek szintén a győztes csapatok üzenetét közvetítették. Az építészetben a monumentális formák és grandiózus tömbök domináltak, a festészetben is a vallási témáké

\footnotetext{
${ }^{241}$ BOE, 24-IV-1938.

${ }^{242}$ Harsányi Iván: A Franco-diktatúra születése. Id. mü. 146-148.

${ }^{243}$ Eiroa de San Francisco, Matilde - Carrera Álvarez, Pilar: España, voz en off. Teoría y praxis de la prensa española en el contexto de la Guerra Fría. Valencia, Editorial Tirant lo Blanch, 2008. 26-32.

${ }^{244}$ BOE, 19-III-1966.
} 
és a nemzeti történelemé lett a főszerep. A háborúban elesett nacionalisták tiszteletére emlékmüveket, kegyhelyeket, kereszteket emeltek, emléktáblák tanúsították, hogy az elhunytak Isten és a Haza érdekében áldozták fel életüket. José Antonio Primo de Rivera, a Falange alapítójának neve minden ilyen listán feltünt az első helyen, az alatta sorjázó személyek mind az ő útját követték. Már a polgárháború lezárulta után hoztak egy rendeletet, melynek értelmében a Felszabadítás Keresztes Hadjárata ügyéért elesettek emlékét az utókornak meg kell őriznie, ehhez pedig egy hatalmas és méltóságot sugárzó emlékmü felállítása szükséges, hogy példaként szolgáljon az eljövendő nemzedékek számára. ${ }^{245}$ Ennek eredménye az 1940 és 1958 között épült, mai árfolyamon számolva 338,06 millió eurót és számos emberéletet felemésztett Elesettek Völgye. ${ }^{246}$

$\mathrm{Az}$ irodalom terén két tendencia figyelhető meg. Egyrészt, előtérbe került az Aranykor és a reneszánsz irodalma, valamint a klasszikus katolikus költészet. Másrészt, megszülettek a polgárháború és a posguerra kötetei, természetesen mindent a győztesek szemszögéből interpretálva: a költészet, a dráma, a regény, a novella, az önéletrajz és életrajz, valamint külön kategóriaként a történetírás publikációi az új Spanyolország nagyságát a múltbéli dicsőséggel hasonlították össze, ahol kizárólag a győztes félnek van létjogosultsága önmagát spanyolnak nevezni, mindenki más az árulók kategóriájába tartozik. A preferált történelmi korok és témák szorosan illeszkedtek a rezsim általános attitűdjéhez ${ }^{247}$, új elemként a 40-es évektől beillesztve a polgárháború nacionalista megközelítését közvetítő regényeket, visszaemlékezéseket. Külön kategóriát képviselnek a vallási jellegű művek, amelyek a katolikus lelkiségről, szentek életéről, és az egyház által kijelölt követendő útról szólnak. Mindezek azonban kisebbségben voltak a már említett „semleges” tematikájú művekkel szemben, ahol a lektür és a ponyvairodalom is nagy népszerüségnek örvendett, fokozatosan pedig a rezsim által hallgatásra ítélt szerzők is visszatértek különböző álneveken. ${ }^{248}$

Bár a filmművészet háttérbe szorította, a színház továbbra is fontos szórakoztatási és kulturális színtérnek bizonyult. A polgárháború idején, hasonlóan a filmgyártáshoz, itt is kettős színjátszásról beszélhetünk: mind a köztársasági csoportok, mind a felkelők saját

\footnotetext{
${ }^{245}$ Ezt foglalja össze az a törvényerejü rendelet, amely létrehozza a Santa Cruz del Valle de los Caídos Alapítványt: BOE, 05-IX-1957.

${ }^{246}$ Calleja, José María: El Valle de los Caídos. Madrid, Editorial Espasa Calpe, 2009. 45.

Magyar nyelven a hely történetéről és a jelenlegi vitáról lásd: Lénárt András: „Az Elesettek Völgye” in: Egyenlítö, 2012/5. 18-21.

${ }^{247}$ Lásd „A Franco-korszak ideológiai vizsgálata” címü fejezetet és annak alfejezeteit, mindenekelőtt a Catecismo patriótico español által részletezett nyolc fő történelmi eseményt, valamint a Hispanidad eszméjére vonatkozó megállapításokat.

${ }^{248}$ Alvar, Carlos - Mainer, José Carlos - Navarro, Rosa: A spanyol irodalom rövid története. Budapest, Nemzeti Tankönyvkiadó, 2002. 416-427.
} 
színházakat üzemeltettek, ám a müsorra tủzött darabok ideológiai hatása enyhe volt, a politikai befolyás nem hangsúlyos. A cenzúrára, engedélyezésre és betiltásra vonatkozó szokások $^{249}$ megegyeztek a filmmüvészetet érintő hasonló intézkedésekkel, amelyekről később lesz szó. Az előadások többsége a zarzuela, a sainete, és más könnyedebb műfajokba sorolható, majd megjelentek komolyabb hangvételü melodrámák és a nagy spanyol klasszikusok is. Polgárháborús témákhoz ritkán nyúltak, ha mégis, akkor természetesen a győztesek oldaláról nézve. ${ }^{250}$ Itt is jelen volt a korábban említett elv: inkább szórakoztasson a darab, mintsem gondolkodásra késztessen.

1945-ig a kultúrában a Falange igyekezett hegemón szerepre törni, az ezt követő öt-hat évben pedig a különböző családok próbálták meg érvényesíteni akaratukat. Ezalatt az oktatást az egyház lényegében monopolizálta. Az 1950-es évektől kezdve vált egyértelművé, hogy nincsen egységes állami (állampárti) kultúra, hiányoznak a müvelődéspolitikai irányelvek. A rezsim családjaihoz hü értelmiségiek, írók, filozófusok mellett továbbra is jelen voltak azok a személyek, akik a liberális vonulatot képviselték, de mindenképpen a Franco-ellenes csoportokkal szimpatizáltak, esetleg vállalták is baloldali elkötelezettségüket. A rezsim által leginkább gyülölt marxizmus vált az ellenzéki kultúra egyik „divatirányzatává”: sokan nem azért lettek marxisták, mert hittek annak elveiben, hanem azért, mert így egyértelmüen részesévé váltak a rendszerellenességnek. Mivel nyíltan ellenzéki álláspontot fejthettek ki, műveikben elvont ábrázolásra és kettős értelmezésre alkalmat adó leírásokra törekedtek, a társadalom és az egyén ellentmondásait vizsgálták, új témákat emeltek be a kánonba, majd fokozatosan megjelent a kritikai hangnem is. ${ }^{251} \mathrm{Az}$ említett 3T modell spanyol változatában a Tür kategória vált döntővé, a 20. századi spanyol kultúra (mindenekelőtt az irodalom, a színház és a film) legkiemelkedőbb, mindmáig időtálló darabjainak tekintélyes része a diktatúra éveiben született.

A historiográfiában is megjelent a többszólamúság, az állami ideológiát képviselő hivatalos történetírók nyílt fórumokon és publikált írásokban vitatkoztak a velük egyet nem értő kollégáikkal: mind közül legismertebb az Américo Castro és Claudio Sánchez Albornoz közötti vita a spanyol nemzetet alkotó csoportokról és a spanyol múltról. ${ }^{252}$

\footnotetext{
${ }^{249}$ Szándékosan használom a „szokás” szót a „szabály”, a „,norma” vagy a „törvény” helyett, „A filmcenzúra a Franco-korszakban" címü alfejezetben fejtem ki ennek okát.

${ }^{250}$ A korszak színjátszásáról áttekintést ad: Kiss Tamás Zoltán: „Csend! Csend, ha mondom! Csend!” Id. mű. 108-125.

${ }^{251}$ Alvar, Carlos - Mainer, José Carlos - Navarro, Rosa: A spanyol irodalom rövid története. Id. mü. 408-437.

${ }^{252}$ A két vonatkozó mü: Castro, Américo: España en su historia. Buenos Aires, 1948 és Sánchez Albornoz, Claudio: España: un enigma histórico. Buenos Aires. 1957.
} 
Az ellenzéki kultúra és kritika már az 50-es évek közepétől számottevővé vált, de egyelöre csak a szubkultúra és a titkos összejövetelek szintjén mutatkozhatott meg. Hangsúlyos véleménykülönbség, illetve már rendszerellenesnek tekinthető müvészi megnyilatkozás esetén természetesen a cenzúra szava volt a döntő. A régiók kulturális életét a rezsimnek, bár megpróbálta, mégsem sikerült megsemmisítenie. Mindenekelőtt a katalán és baszk identitások tudták megőrizni sajátosságaikat, íróik, gondolkodóik, filozófusaik és történészeik az 50-es évek második felétől folyamatosan publikáltak kasztíliai spanyol nyelven, nemzeti kultúrájukat és tradícióikat fenntartották az utókor számára.

Az egyre több háztartásba elérő rádióban az egész társadalomra hatást gyakorló folytatásos rádiójátékokat, vetélkedőket és zenés müsorokat hallgathattak, a spanyolok napi szintü szórakoztatásáról a bikaviadalok és a sport, elsősorban a futball is gondoskodtak. A spanyol labdarúgóklubok győzelmei és a csapatokban játszó sztárok (Kubala, DiStefano) a nemzet büszkeségeivé váltak, a futball terén aratott győzelmek az állami propaganda hangsúlyos részét alkották, a meccsek megtekintése kohéziós erőt jelentett a spanyol társadalom számára. Akkora vonzóerővel bírt egy-egy mérkőzés, főleg a 40-es évek végétől, hogy új stadionokat kellett építeni a több ezres közönségnek, a futballt pedig a legkedveltebb szabadidős tevékenységként tartották számon, lekörözve bármely más kulturális eseményt. A spanyol válogatott sikeresen szerepelt a nemzetközi megmérettetéseken is, az 1964-es Európa-bajnokságon pedig éppen legnagyobb ideológiai ellenfelét, a Szovjetuniót legyőzve szerezte meg a bajnoki címet. $^{253}$ Nem véletlen, hogy a futball számos népszerü, közönségkedvenc film központi témájává vált. A Bajnokok! ( ¡iCampeones!!, Ramón Torrado, 1943), a Tizenegy pár futballcipö (Once pares de botas, Francisco Rovira Beleta, 1954), A jelenség (El fenómeno, José María Elorrieta, 1956) vagy Az angyal a csúcson van (El ángel está en la cumbre, Jesús Pascual, 1958), többek között, népszerü focisták főszereplésével forgatott részben fikciós, részben dokumentarista-jellegü játékfilmek, vagy színészek által eljátszott futball-központú történetek. Mind közül azonban a legnagyobb sikert a Kubala László főszereplésével készült Az ászok békére törekszenek (Los ases buscan la paz, Arturo Ruiz-Castillo, 1954) érte el, amelyet ma is kultuszfilmként tartanak számon. Erről a későbbiekben még lesz szó.

Az 50-es évek közepétől egyre inkább elérhető ellenzéki kultúra a társadalom számára szelepként funkcionált, a fentről rájuk erőltetett hivatalos ideológiát kritizáló, azt részben kioltó eszmék tették az emberek számára elviselhetővé a mindennapokat. Az élet minden

\footnotetext{
${ }^{253}$ A spanyol futballtörténet különbözö korszakairól lásd a Museo del Juego honlap különböző periódusokat feldolgozó tanulmányait: http://www.museodeljuego.org/contenidos.asp?menu id=133 (2012.11.21.)
} 
területén jelen voltak ezek kisebb-nagyobb mértékben, egyik leghangsúlyosabb módon majd a filmmüvészetben láthatjuk a megjelenését. 1962-től, Manuel Fraga Iribarne tájékoztatási és idegenforgalmi miniszterré történő kinevezésével megindult az apertura periódusa, a kultúra nyíltabbá, liberálisabbá vált, ebben a szellemben tevékenykedő felelösök töltöttek be a kulcspozíciókat (színház- és filmmüvészeti főigazgatóként például José María García Escudero). A későbbi években történtek kísérletek a bunker csoport $^{254}$ által túlságosan megengedőnek tartott intézkedések mérséklésére (részben sikerrel), a 60-as és 70-es évek Spanyolországa azonban már csak nyomokban emlékeztetett az azt megelőző évtizedek Franco-rezsimére.

\section{A film helye a spanyol társadalomban}

A 20-as évek közepéig az értelmiségi körök nem tulajdonítottak nagy jelentőséget a filmnek, alsóbbrendủ szórakozási formának tartották azt, művészetnek pedig csak néhányan nevezték. Regény- és esszéírók öltötték magukra a filmkritikus szerepét, az újságok hasábjain általában lekicsinylő és megvető véleménnyel illették a műveket. A mértékadó személyek álláspontja egészen a 40-es évek elejéig nem változott, a Primer Plano folyóirat első számában megjelent körkérdésre adott válaszokból ${ }^{255}$ kiderült, hogy a legtiszteletreméltóbbnak vélt gondolkodók, különböző okokból kifolyólag, egyáltalán nem jártak moziba, mégis volt róla véleményük, méghozzá rendkívül negatív. Bár Azorín az említett körkérdés kapcsán egyenesen károsnak és erkölcstelennek nevezte a filmet, később két könyvet is írt ${ }^{256}$, amelyekben esztétikai szempontból, a színház viszonylatában foglalkozott a filmmel, de továbbra is másodrangú művészeti formának titulálta azt; majd, főleg idősebb korában, állandó mozibajáró értelmiségiként, számos cikket és elemzést írt ebben a témában, ekkor már sokkal pozitívabb hangnemben. ${ }^{257}$ Rafael Alberti verset is költött egy amerikai színészre összpontosítva (Buster Keaton busca por el bosque a su novia, que es una verdadera vaca), valamint a polgárháború első évében szerepelt a Madrid védelmében (En Defensa de Madrid, Alianza de Intelectuales para la Defensa de la Cultura, 1936) címü

\footnotetext{
254 A bunker csoport azokra a mozdulatlan (inmovilista) személyekre vonatkozik, akik még a nyitás periódusában is ragaszkodtak a régi elvekhez, elfogadhatatlannak tartottak bármiféle liberalizációt. Az elnevezés utalás Hitler bunkerére, ahol a Führer a haláláig kitartott meggyőződései mellett..

${ }^{255}$ „Los académicos españoles y el cine” en: Primer Plano, No. 1. 1940. október 20.

256 Azorín: El cine y el momento. Madrid, Biblioteca Nueva, 1953 és El efímero cine. Madrid, Afrodisio Aguado, 1955.

${ }^{257}$ Az Azorín munkásságával foglalkozó tíz kötetes évkönyvsorozat minden darabjában található elemzés filmes írásairól, gondolatairól: Anales azorinianos. Fundación Cultural de la Caja de Ahorros del Mediterráneo, 19832007.
} 
dokumentumfilmben is. ${ }^{258}$ A 98 -as nemzedék minden tagjának volt mondanivalója a mozgóképes művészetről ${ }^{259}$, az olasz Benedetto Croce-hoz és Giovanni Gentile-hez hasonlóan pedig egyes spanyol filozófusok (Ortega y Gasset, Eugenio D’Ors, Gregorio Marañón) is értekeztek a filmről.

A Falange egyik fő ideológusa, Ernesto Giménez Caballero 1935-ben úgy vélte, Spanyolország képes lesz megteremteni az egyetemes erkölcsiséget képviselő filmgyártást, amely felülmúlja mind az individualista és kapitalista nyugati, mind a társadalmilag felforgató és tömegekre építő szovjet filmkészítést. Szerinte Olaszország ugyanerre törekszik most, de ha elbukna, akkor valószínủleg a spanyol géniuszra hárulna ez a missziós feladat. ${ }^{260}$ Giménez Caballero nevéhez számos dokumentumfilm és rövidfilm kötődik rendezőként és forgatókönyvíróként, ezek döntően kulturális és turisztikai témákat ölelnek fel, elenyésző köztuik az ideológiai töltettel rendelkező darab. A La Gaceta Literaria címü folyóiratában pedig művészek, filozófusok, gondolkodók, későbbi falangisták (mint Ramiro Ledesma Ramos) és maga a főszerkesztő foglalkoztak először érdemben filmmüvészeti témájú írásokkal és filmkritikákkal már a 20-as évek végén.

A nagypolgárság és a politikai és gazdasági arisztokrácia néhány tagja, akik a filmhez inkább üzleti szempontból közelítettek, már 1919-ben megalapították Madridban az Atlántida részvénytársaságot, amely szilárd anyagi és szervezeti háttérrel próbálta meg összefogni a spanyol filmgyártást néhány korábban már létező stúdió fúziójával. Az egyik ilyen stúdió, a Cantabria Films förészvényesei között megtalálható volt XIII. Alfonz uralkodó is, aki így az új társaság első részvényesévé is vált. ${ }^{261}$ Az Atlántida nem került monopolhelyzetbe, más filmstúdiók is aktív tevékenységet folytattak a 20-as évektől kezdődően. A későbbiekben az iparban, kereskedelemben és politikában is érdekelt gazdasági elit egyre fokozottabban jelent meg befektetőként a filmiparban.

XIII. Alfonz film iránti vonzódása köztudott volt, hatalmas összegeket fordított filmkészítésre, Európában egyedülálló filmfelvevőgép-gyüjteménnyel rendelkezett, magánfilmtára pedig szintén említésre méltó, megtalálható volt benne kedvenc müfaja, a pornográf filmek szinte minden akkoriban elérhető darabja. Mecénási tevékenysége ennél is tovább ment: megbízást adott két korabeli elismert rendezőnek, Ricardo de Bañosnak és

\footnotetext{
${ }^{258}$ Gubern, Román: Cine español en el exilio. Id. mü. 47-48.

259 Erről lásd: Utrera Macías, Rafael: Modernismo y 98 frente a Cinematógrafo. Sevilla, Secretariado de Publicaciones de la Universidad, 1981.

${ }^{260}$ Idézi: Guarner, José Luis: 30 años de cine en España. Barcelona, Editorial Kairós, 1971. 13.

${ }^{261}$ Cánovas Belchí, Joaquin T.: „La Atlántida S.A.C.E. y otros estudios madrileños en los años veinte” in: García de Dueñas, Jesús - Gorostiza, Jorge (szerk.): Los estudios cinematográficos españoles. Madrid, Academia de las Artes y las Ciencias Cinematográficas de España. 2001. 25-26.
} 
testvérének, hogy más európai országok mintájára készítsenek olyan munkákat, amelyek pornográf tartalommal telítettek. Ezek közül három ismert, pontos gyártási évüket máig nem sikerült meghatározni, csak annyi biztos, hogy A gyóntató (El confesor), A ministráns (El ministro) és a Hölgyek rendelöje (Consultorio de señoras) mind a 20-as években készültek, rendezőik pedig a Baños-testvérek. ${ }^{262}$ III. Viktor Emánuel olasz uralkodó hasonló vonzalmat mutatott a felnőtt filmek iránt, valamint a spanyol arisztokrata körök kiemelkedő tagjai is osztoztak királyukkal ebben a szenvedélyben; mind anyagilag, mind kreatív ötletekkel hozzájárultak a pornográf filmek készítéséhez. Mindez jelzi: bár az elit réteg már a filmgyártás kezdetén jelen volt ebben az iparágban, az önmagukat konzervatív értékrendünek valló személyek hitvilágukkal kevéssé összeegyeztethető alkotások megszületéséhez is asszisztáltak. A későbbiekben alakuló filmvállalatok pedig már egyre nagyobb politikai és társadalmi érdeklődésre tartottak számot, az 1933-ban megszülető CEA (Cinematografía Española Americana, S.A.) stúdió megnyitását maga a köztársasági elnök, Alcalá Zamora vezényelte le ünnepélyes keretek között. ${ }^{263}$

A Diákotthon szervezésében számos filmvetítésre és alkotói beszélgetésre került sor, az események egyik főszereplője Luis Buñuel volt; 1928-tól avantgárd-témájú előadásokat és vetítéseket tartott, ezeken a korabeli madridi társasági élet krémje vett részt, a filmek között pedig feltüntek a legfontosabb külföldi alkotások is. Ortega y Gassettet a vetítések állítólag annyira lenyügözték, hogy azt mondta a rendezőnek, ha fiatalabb volna, ő is a filmművészet felé fordulna. ${ }^{264}$ A 40-es évektől ellepték a fontosabb spanyol városokat a filmklubok, amelyek alternatívát nyújtottak a mozimüsorokkal szemben: a tematikus programok, müvészfilmek, esetleg máshol cenzoriális okok miatt nem látható filmek (mint a szovjet alkotások vagy Ingmar Bergman munkái), a félhivatalos vetítések megszervezése a városi filmszerető értelmiség és az egyetemi hallgatók egyik kedvelt tevékenységévé vált. Idővel a parókiák, kolostorok, egyházi szervezetek szintén megalapították saját filmklubjaikat, itt azonban a különböző csoportok (Opus Dei, Acción Católica, katolikus közösségek) között rivalizálás indult, hogy melyikőjük képviselje a fő katolikus vonalat. A 40-es évek végétől alakuló egyetemi filmklubok már próbáltak kikerülni az állami ellenőrzés alól, és ez részben sikerült is nekik: az illegális klubok mellett itt fordult elő legnagyobb számban, hogy a rendszernek nem tetsző filmeket is levetítették titokban, majd az 50-es évek közepétől az

\footnotetext{
${ }^{262}$ Solís Krause, Rubén: La cultura de Eros. Antología ilustrada del libertinaje. Barcelona, Robinbook, 2007. 202. A Valenciai Filmarchívum restaurációs munkájának köszönhetően ma teljes egészében megtekinthetőek ezek a korábban elveszettnek hitt darabok, 1997-ben VHS-kazettán kiadásra is kerültek Spanyolországban.

${ }^{263}$ Tranche, Rafael R.: „CEA: Los intereses creados” in: García de Dueñas, Jesús - Gorostiza, Jorge (szerk.): Los estudios cinematográficos españoles. Id. mü. 140.

${ }^{264}$ Buñuel, Luis: Utolsó leheletem. Id. mü. 89.
} 
egyetemi vezetőség ehhez hallgatólagos beleegyezését is adta. 1957-től a korábbi (és egyben leendő) filmmüvészeti föigazgató, José María García Escudero elnökletével létrejött a Filmklubok Föderációjának Juntája (Junta de la Federación de Cine Clubs), és ezzel a filmklubok is az állami rendszer részeivé váltak. ${ }^{265}$

1925-ben már összesen évi 27 filmet készítettek Spanyolország-szerte, ezeket közel 1400 moziteremben vetítették. ${ }^{266}$ A 20-as években a nagyvárosokban mindennapos tevékenységnek számított moziba menni, a színház, a bikaviadal és a varieté müsorok mellett szokássá vált a filmnézés is, népszerüségét tekintve időnként meg is előzte azokat. 1927-től egyre gyakoribbá váltak a filmvetítés céljából kialakított termek, moziépületek, ezek nagy részét más célt szolgáló helyiségekből alakították át. Madridban 1920-ra már összesen 31 mozi állt, ezek egy része a forgalmas bevásárló negyedekben, más része a szórakozóhelyekkel is rendelkező zónákban helyezkedett el. 1935-re ez a szám eléri a 62-őt. A legolcsóbb jegyeket szinte bárki meg tudta fizetni, míg az elegánsabb ülöhelyekért, páholyokért többet kértek; attól is függött az ár, hogy mely napokon és mely napszakban volt az előadás. A vidéki helyzet azonban különbözött ettől: sem az állandó vetítések, sem a mozibajárás szokása nem honosodott meg oly mértékben, mint a nagyvárosban, inkább csak a nyári hónapokban, ünnepségek vagy vásárok alkalmával tekintettek meg egy-két filmet a falusiak. Ezen igyekeztek segíteni a vándormozisok, akik vetítőgéppel és filmtekercsekkel járták a falvakat. $^{267}$

A Primo de Rivera-korszakban a mozi vált a legnépszerübb, legtöbb nézőt vonzó szórakozássá, mindezt azonban a történetek egyszerüségével, bárki számára érthető cselekményvezetéssel magyarázzák, a müvészet szó fel sem merült a filmek kapcsán a napi sajtó erre vonatkozó híreiben. ${ }^{268}$

1935-re Spanyolországban 3500 moziterem állt a nézők rendelkezésére; ugyanebben az évben Franciaországban ez a szám 4100, Olaszországban 4800, Németországban 5237, NagyBritanniában 4950, az Egyesült Államokban 16 192, a Szovjetunióban pedig kiemelkedően magas, 34490 volt. A 40-es és 50-es években az egy före jutó mozis férőhelyek számában Spanyolország első lett Európában. ${ }^{269}$

\footnotetext{
${ }^{265}$ Hernández-Marcos, José Luis - Ruíz Butron, Eduardo A: Historia de los Cine Clubs en España. Madrid, Ministerio de Cultura, Dirección General de Cinematografía, 1978. 37; 46-49; 71-72.

${ }^{266}$ García Maroto, Eduardo: Aventuras y desventuras del cine español. Id. mü. 25.

${ }^{267}$ Montero, Julio - Paz, María Antonia: „Ir al cine en España en el primer tercio del siglo XX” in: Pelaz, JoséVidal - Rueda, José Carlos (szerk.): Ver cine. Los públicos cinematográficos en el siglo XX. Madrid, Ediciones Rialp, 2002. 130-132.

${ }^{268}$ Uo. 135-136.

${ }^{269}$ Adatokat közli: Gómez Bermúdez de Castro, Ramiro: Evolución de la producción... Id. mü. 18.
} 
A polgárháború alatt a film nagy presztízsre és erőre tett szert, nem csak a művészeti ágak között. A mozik és vetítőtermek a társasági élet egyik központjává váltak, ezért fontos volt, hogy a tulajdonosaik is hitet tegyenek a Nemzeti Mozgalom mellett. A harcok után (főleg 1939-ben, a Győzelem Évében) meghonosodott szokást, amely szerint az üzletek tulajdonosai a kirakatban táblákon, feliratokon nyilvánították ki a győztes csapatok és Franco iránt érzett teljes szimpátiájukat, a mozik és filmgyártók is gyakorolták. A mozitermekben nem csak a filmhíradó és a vetített film, de maga a hely is közvetítette az ideológiát. Több forrásból is ismerjük, milyen volt egy átlagos madridi mozielőadás 1939 és 1943 között (vagyis a polgárháború után és a második világháború alatt, amikor a rezsim ideológiai megalapozása történt meg). A vetítés kezdete elött a közönségnek állva, felemelt karral tisztelegve kellett végighallgatnia a spanyol, német, olasz és portugál nemzeti himnuszokat, valamint a karlisták (Oriamendi), a Falange, a Légió és a Katonai Akadémia himnuszát; néha mindet egymás után, néha csak a legjelentősebbeket. Ezután a tömegből valaki „spontán” módon felkiáltott, „Franco, Franco, Franco, Éljen Spanyolország!” Az ezt követő egységes taps után kezdődött a vetítés. Minden mozinak spanyol nevet kellet adni (így lett a barcelonai Spring (Tavasz) filmszínházból Murillo), egészen 1943-ig pedig a müsorfüzetekben és a köztéri filmplakátokon az évszám mellett feltüntették, hogy ez a Győzelem Első, Második stb. évének felel meg. ${ }^{270}$ A spanyol külpolitikát is módosító tengelyhatalmi veszteségsorozat után a fasiszta országok himnuszai kikerültek a repertoárból, majd a 40-es évek végére általában megelégedtek egy himnusszal is.

A spanyol nép egyre inkább természetes szórakozási formának vélte a filmszínházat. A vásznakon önmagukat, a győztes Spanyolország társadalmát látták viszont, a legyőzöttekkel csak a polgárháborús tematikájú, vagy a hispán faj ellen nemzetközi összeesküvést szövő csoportokat is ábrázoló filmekben találkozhattak, természetesen negatív viszonylatban. Az utánjátszó mozikban alacsony árakon két vetítést is megnézhettek egymás után (doble sesión), így egész estéket tölthettek elzártan a külvilág valóságától. A városokban rendszeres kikapcsolódási formának számított, a 40-es évek közepétől pedig vidéken is a mindennapok részévé vált, amennyiben a falu vagy kisváros rendelkezett állandó vetítőgéppel. Egy házaspár így írta le mozibajárási szokásait az 50-es évek közepén: „Vasárnap reggelenként templomba jártunk, utána megittuk a vermutot, majd ettünk, kávéztunk, és utána moziba mentünk. Egy igazi társadalmi esemény volt. A hét folyamán

\footnotetext{
${ }^{270}$ Bardem, Juan Antonio: Y todavía sigue. Memorias de un hombre de cine. Barcelona, Ediciones B, 2002. 97; Ripoll, Xavier: „Cataluña” in: Caparrós Lera, José María (szerk.): Cine Español. Una historia por autonomías, Vol.1. Id. mü. 222.
} 
mindenkinek a moziról kellett beszélgetnie, témává vált. Ha valaki nem járt moziba, azt jellemgyengeségnek vették, mintha nem lenne eléggé müvelt, megvetően néztek rá mifelénk". ${ }^{271}$

Mint arról már írtam, a katolikus egyház - bár korábban a mozi ellen foglalt állást fokozatosan ráébredt, hogy fontos kapcsolatot veszítene el így a társadalommal; az egyre nagyobb számban megjelenő katolikus filmklubok már erre utaltak. Az 1958-tól több alkalommal is megrendezett Albacetei Filmorientációs Hét (Semana de Orientación Cinematográfica) létrehozását a helyi püspök kezdeményezte, azzal az indoklással, hogy a film a kulturális élet megkerülhetetlen részévé vált, így a mozgóképes médium fő feladata, hogy az ember személyiségének kiteljesedését segítse. ${ }^{272}$ Természetesen a célkitűzéshez illeszkedő műveket válogattak be. Spanyolország minden régiójában és nagyobb városában tartottak már filmheteket, filmciklusokat, fesztiválokat, ahol bizonyos téma köré csoportosították az alkotásokat.

A polgárháború és a diktatúra legsötétebb éveiben a közönség valóban arra használta a mozit, hogy elvonatkoztasson a valóságtól, egy olyan világba meneküljön, ahol nem kell szembenéznie a realitással. Ahogyan egy asztúriai filmtörténész írja: „A szavazatnélküli emberek igennel szavaztak egy másik életre". ${ }^{273}$

\section{Franco és a film}

Franco közvetlen részvétele a spanyol kultúra alakításában ${ }^{274}$ négy alkalommal nyilvánult meg. Legismertebb ezek közül a $R a z a^{275}$ címü filmregény szerzőisége, amelyet Jaime de Andrade álnéven jegyzett, erről később részletesen szólok a film tárgyalása során. 1922-ben írta a Marruecos: diario de una bandera ${ }^{276}$ címủ könyvet, amelyben az 1920 és 1922 között a marokkói Légióban szerzett személyes tapasztalatai olvashatóak érzékletes tájleírással és részletes információközléssel egybekötve; bár a történetírás általában elfogadja,

\footnotetext{
271 Martínez, Amparo: „Aragón” in: Caparrós Lera, José María (szerk.): Cine Español. Una historia por autonomías, Vol.1. Id. mü. 63.

${ }^{272}$ A püspök erre vonatkozó körlevelét idézi: García Rodrigo, Jesús - Rodríguez Martínez, Fran: El cine que nos dejó ver Franco. Id. mü. 321-322.

${ }^{273}$ Lorenzo Benavente, Juan Bonifacio: Asturias y el cine. Id. mü. 34.

${ }^{274}$ Franco intellektuális fejlősédéről, az öt ért hatásokról ír: Merino, Julio: El otro Franco. El Franco intelectual y el Franco de la República. Madrid, Albor Libros, 2010. A könyv megemlíti a tábornok álnéven folytatott forgatókönyvírói tevékenységét is, de arról nem szól, hogy mikor és miért kezdődött el élénken érdeklődni a filmek iránt.

${ }^{275}$ Andrade, Jaime de: Raza. Anecdotario para el guión de una película. Madrid, Numancia, 1942.

276 Franco Bahamonde, Francisco: Marruecos, diario de una bandera. Madrid, Pueyo, 1922. A könyvet a későbbiekben újra kiadták 1939-ben, 1956-ban, 1976-ban és 2008-ban, valamint elérhető elektronikus formában is: http://es.scribd.com/doc/37918004/Diario-de-una-Bandera (2012. 11. 21.)
} 
hogy a könyvet Franco írta, Stanley G. Payne történész felemlegeti annak a lehetőségét, hogy a valódi szerző egy katalán újságíró. ${ }^{277}$ Az évek során a falangista Arriba címủ folyóiratban megjelent cikkeit gyüjtötte össze 1952-ben a Masonería ${ }^{278}$ kötetben Jakim Boor írói álnév alatt, ebben kifejti nézeteit arról a több száz éve tartó nemzetközi szabadkőmüves összeesküvésről, amely szerinte a kommunizmussal karöltve állandó fenyegetést jelent mind Spanyolországra, mind az egész világra. Ezeken felül Franco tábornok alakja számos képzőmüvészeti és szépművészeti alkotásban megjelenik. ${ }^{279}$

Bár a diktatúra idején a filmhíradók és dokumentumfilmek többségében Franco központi szerepet töltött be, első mozgóképes megjelenése sokkal korábbra datálódik: 1926ban a korszak számos kiemelkedő személyiségével együtt részt vett $A$ nö, aki rosszul ment férjhez (La malcasada) címü, Francisco Gómez Hidalgo újságíró rendezésében és forgatókönyve alapján készült némafilmben, ahol a szereplők - önmagukat alakítva, de mégis egy fikciós történetbe helyezve - egy romantikus komédia jeleneteit elevenítik meg. A stáblista valóban impozáns, a hivatásos színészek és a leendő Caudillo mellett feltünik a szereplök között egy-egy jelenet erejéig a testvére, Ramón Franco, valamint Millán Astray, Alejandro Lerroux, Azorín, Miguel Machado, Eugenio D’Ors, Ramón del Valle-Inclán és a hivatalban lévő diktátor, Miguel Primo de Rivera is. Aktuális témát, a válás lehetőségének törvénybe iktatásáról szóló kérdést járt körbe a film, egyszersmind trivializálva is ezt a problémát, illeszkedve a konzervatív állásponthoz. A korabeli kritikák méltatták a film magas esztétikai színvonalát, a megvalósítás és a színészi játék profizmusát, valamint a megjelenő hírességek magával ragadó erejét; ezzel szemben a mai filmtörténetírás nem értékeli nagyra ezt a müvet, a nézők valószínűleg csak azért özönlöttek nagy számban a film vetítéseire, mert ez volt az egyik első munka, amelyben a stúdióbelsők mellett a közönség számára jól ismert külső helyszíneket is használtak, valamint valóban vonzotta őket Primo de Rivera és a többi valós személy részvétele. José María Caparrós Lera úgy véli, ez volt az első alkotás a spanyol filmtörténetben, amely propagandisztikus szándékkal deklaráltan foglalkozott egy társadalompolitikai kérdéssel, egyértelműen kinyilvánítva az alkotók véleményét, a végeredmény azonban egy gyengén kivitelezett produktum. ${ }^{280}$

\footnotetext{
${ }^{277}$ Payne, Stanley G.: The Franco Regime. 1936-1975. Madison - London, The University of Wisconsin Press, 1987. 72 .

${ }^{278}$ Boor, Jakim: Masonería. Madrid, 1952. Online változat: http://es.scribd.com/doc/8111216/Jakim-BoorFranco-Masoneria (2012-11-21)

${ }^{279}$ Llorente Hernández, Ángel: „La construcción de un mito. La imagen de Franco en las artes plásticas en el primer franquismo (1936-1945)" in: Archivos de la Filmoteca, No. 43-44. 2002-2003. 46-75.

${ }^{280}$ Caparrós Lera, José María: Arte y política en el cine de la República. Id. mü. 75-77.
} 
Franco alakja számos alkalommal megjelent a filmvásznon, életében azonban játékfilmen csak rövid jelenetekben alakították őt színészek. Kiemelkedő szerepet játszott évtizedeken keresztül a $N O-D O$ filmhíradóiban, erről egy későbbi fejezetben szólok. A diktatúra során két mü készült róla. A Fajt is rendező José Luis Sáenz de Heredia a Caudillo kérésére forgatta a Franco, ez az ember (Franco, ese hombre, 1964) című dokumentumfilmet, amelynek forgatókönyvét a Manuel Fraga Iribarne által elnökölt miniszteri bizottság állította össze. A Caudillo életének legfőbb állomásait mutatja be az elkészült mü és viszonyát a 20. század legföbb eseményeihez és személyeihez. Már rendelkezésre álló archív felvételeket használtak fel, összeállítva így egy audiovizuális életrajzot, majd kiegészítették azt kizárólag a film kedvéért készülő felvételekkel, ahol a tábornok és családja a kamera kedvéért „színészkedett” is. A polgárháború utáni spanyol társadalom viszontagságait korabeli dalokon keresztül bemutató Dalok egy háború utánra (Canciones para después de una guerra, 1971) című művét kísérő botrány és betiltás ${ }^{281}$ miatt Basilio Martín Patino teljes titokban, archív anyagok felhasználásával készítette el a Caudillo (1974) című dokumentumfilmjét, elsősorban a polgárháborúhoz vezető útra koncentrálva és megvizsgálva a Franco körül kialakult ikonográfiát minden lehetséges szemszögböl. Látható a filmen eredeti felvételeken a polgárháború néhány kiemelkedő alakja (Sanjurjo, Durruti) és döntő ütközetei, elhangoznak a témához illeszkedő versek és dalok, látleletet kapunk az 1920 és 1939 közötti Spanyolország mindennapjairól. A vezérfonál Francisco Franco előmenetele a ranglétrán, valamint beszédei, látogatásai. Mivel nem állami megrendelésre készült, ezt az alkotást majd csak 1977-ben mutatják be hivatalosan ${ }^{282}$ a rendező többi filmjével együtt. Patino filmjei föleg a korabeli felvételek, a Franco-korszakot jellemző életképek, archív anyagok, eredeti újságcikkek felhasználása miatt értékes forrásként kezelhetőek a történész számára.

Csak sejteni lehet, hogy maga Franco milyen müfajokat vagy konkrét filmeket kedvelt. A történelmi tematikájú művek bizonyosan közel álltak hozzá, de más müfajokban is talált élvezhető alkotást. Több, egymással megegyező anekdota szerint a Nászút (Viaje de novios, León Klimovsky, 1956) címü könnyed vígjáték kapcsán a tábornok megjegyezte: „Na, ilyen filmeket kell csinálni Spanyolországban”. ${ }^{283}$ A filmben számos olyan, mai szemmel ártalmatlannak látszó jelenet található, amely az akkori cenzorok számára károsnak tűnhetett (csókjelenet, fürdőruhás nő, érzelmes pillanatok), a cenzori jelentésben az egyik bíráló ezt

\footnotetext{
${ }^{281}$ A film létezését olyannyira rejtve akarta tartani a hatalom a közönség elöl, hogy hivatalos cenzori jelentés nem is található róla.

${ }^{282}$ Korábban titkolták a film létezését, elöször csak 1977-ben szerepel hivatalos jelentés a film elkészültéröl: Archivo General de la Administración (továbbiakban: AGA), Cultura, 36/05261-es doboz, 87854-es köteg

${ }^{283}$ Taibo I, Paco Ignacio: Un cine para un imperio. Madrid, Oberon, 2002. 177-178.
} 
mégis csak lehetséges problémás pontként említi, mások még csak ki sem térnek rájuk. ${ }^{284}$ Felmerülhet a kérdés, vajon köze lehet-e ennek a ténynek ahhoz, hogy a Caudillo, ahogyan sok más mủ esetében is, a hivatalos cenzori vizsgálatot megelőzően tekintette meg a filmet.

Franco, a többi diktátorhoz hasonlóan, rendelkezett magánfilmtárral, José María Caparrós Lera filmtörténész ehhez kapcsolódó legújabb kutatási eredményei a közelmúltban láttak napvilágot. Az El Pardo vetítőtermének adatai szerint 1946-tól haláláig Franco tábornok 2094 vetítést rendezett családja és barátai számára, átlagosan heti kettőt. A filmhíradók mellett filmtárának 3/4 részét hollywoodi darabok tették ki, csak közel 500 volt a spanyol alkotás. Ezek között megtalálhatóak a korabeli közönségkedvencek, valamint a Walt Disney stúdió számos rajzfilmje is. Többet a cenzúra nem engedett bemutatni Spanyolországban, vagy csak drasztikus módosítások után; Franco filmtára a vágatlan változatokat őrizte. A filmekhez tartozó dokumentáció igazolja, hogy a müveket közvetlenül az amerikai filmterjesztői hálózatok juttatták el az El Pardo palotába. ${ }^{285} \mathrm{Az}$ amerikai filmek spanyolországi forgatása során pedig Franco több hollywoodi sztárral is közös programokat szervezett, többek között Sophia Loren, Audrey Hepburn, Mel Ferrer, Omar Sharif, Gene Kelly és Ava Gardner társaságában fotózták le őt a korabeli lapok. John Wayne-nel baráti viszonyt ápolt, a westernhős többször is vendégeskedett a Caudillo palotájában. ${ }^{286}$

Halála után számos filmrendezőt megihletett Franco személye, több színvonalas produkció született alakjáról, amelyek egy része megtörtént eseményeket dolgozott fel, míg mások fikciós történeteket vittek vászonra. ${ }^{287}$

\footnotetext{
${ }^{284}$ AGA, Cultura, 36/03570-es doboz, 14899-es köteg

${ }^{285}$ Geli, Carles: „Sesión de tarde con Franco” in: El País, 2011. augusztus 21.
} Elérhető: http://elpais.com/diario/2011/08/21/revistaverano/1313877601_850215.html (2012-11-21)

${ }^{286}$ A filmek iránt egy másik családtag is érdeklődött, leginkább üzleti megfontolásból: a tábornok unokája, Francisco Franco y Martínez-Bordiú a 70-es években tanácsadóként vett részt Luis García Berlanga Nemzeti vadászat (La escopeta nacional, 1978) címü filmjében, majd a 80-as években bérbe adta Valdefuentest, nagyapja kedvenc birtokát és az azon álló kápolnát, hogy erotikus, pornográf és horrorfilmeket készítsenek ott, összesen tizenötöt. Sánchez Soler, Mariano: Los Franco, S.A. Madrid, Oberon - Grupo Anaya, 2003. 58-59.

${ }^{287}$ Előbbi kategóriából az 1936-os felkelést megelőző hetek történéseit bemutató Dragon Rapide (Dragon Rapide, Jaime Camino, 1986), utóbbiból két szatíra, a Fernando Vizcaíno Casas regényéből készült, a demokratikus átmenet éveiben Franco tábornok feltámadását vizionáló ... És a harmadik évben feltámadt (... Y al tercer año, resucitó, Rafael Gil, 1980), valamint az egy Franco-hasonmás kalandjait elmesélő, Román Gubern forgatókönyvét felhasználó Várj rám az égben (Espérame en el cielo, Antonio Mercero, 1988) aratott sikert mind a közönség, mind a kritika körében. A tábornok agóniáját és halálát a November 20: Franco utolsó napjai (20-N: los últimos días de Franco, Roberto Bodegas, 2008) címü, nagy nézettséget elért tévéfilm mutatta be.

Franco alakjának mozgóképes megjelenéseiről ír: España, Rafael de: „Franco después de Franco” in: FilmHistoria, Vol V, No. 2-3, 1995.

Elérhető: http://www.publicacions.ub.es/bibliotecadigital/cinema/filmhistoria/Art.Rafael.pdf (2012-12-01) valamint: Pingree, Geoffrey B.: „Franco and the filmmakers: critical myths, transparent realities” in: FilmHistoria, Vol. V, No. 2-3. 1995.

Elérhetö: http://www.publicacions.ub.es/bibliotecadigital/cinema/filmhistoria/Art.\%20pingree.pdf (2012-12-01) 


\section{A filmpolitika intézményi keretei}

A Második Köztársaság idején a filmipar krízishelyzetben találta magát. A hazai filmgyártás volumene csökkent, a terjesztők és a közönség inkább a külföldi müveket részesítették előnyben, amelyek a Hollywoodban szokássá vált dupla változatoknak (dobles versiones $)^{288}$ köszönhetően azonnal be tudtak lépni a spanyol piacra is. A korszak filmgyártását a szólásszabadság szempontjából vizsgáló alkotmányjogász professzor adatai szerint 1931 és 1932 folyamán a Spanyolországban bemutatott 840 filmből mindössze hat volt spanyol alkotás. ${ }^{289}$ A némafilmből a hangosfilmbe történő átmenet technikai feltételei sem voltak adottak. A spanyol szakírók és kritikusok lázadni kezdtek a hollywoodi filmek ellen, cikkeikben valódi nemzeti filmkészítést követeltek, mert szerintük az Amerikai Egyesült Államok nem képes megragadni a hispán életszemléletet, és nem is szabad engedni, hogy ezzel próbálkozzon. Spanyolországnak kell készítenie a spanyol nyelvü, spanyol közönségnek szánt, spanyol tematikájú filmeket. ${ }^{290}$ Ezek pedig természetesen exportálhatóak lesznek LatinAmerikába is.

Általánosságban megállapítható, hogy a köztársasági baloldal, bár a kultúrára is igyekezett időt és energiát fordítani, a filmmel kevéssé törődött, míg a jobboldal a Cifesa stúdión keresztül elöretört. Ahogyan Román Gubern fogalmaz a korszak filmgyártásáról született monográfiájában: „A filmet a magántőke ellenőrzésére hagyták és a konzervatívklerikális jobboldal ideológiai érdekeinek nyújtották át”. ${ }^{291}$

1933-tól három éven keresztül kezd kiépülni a valódi spanyol filmgyártás, amely 1935re éri el azt a pontot, amikor már mind müvészeti, mind technikai szempontból valódi modern

\footnotetext{
${ }^{288}$ Az 1920-as évek második felétől kezdve a hollywoodi filmexport egyik elsődleges piacává a latin-amerikai országok váltak, elnyomva, esetenként teljesen ellehetetlenítve a helyi filmkultúrák kibontakozását. A hangosfilm megszületésével még intenzívebbé vált az észak-amerikai behatolás, a spanyol és latino forgatókönyvírók, rendezők és színészek közreműködésével az USA-sikerfilmekből rögtön készítettek egy spanyol nyelvü verziót is, vagyis dupla változatokat forgattak számos angol nyelvü alkotásból. Ezek a változatok nem csak Latin-Amerikát árasztották el, hanem Spanyolországba is jutott belőlük nagy számban. A kezdeti sikerek után ez a szokás a 30-as évek végére kifulladt, mivel a készítők nem fordítottak elég figyelmet a különböző országokban természetes dialektusbeli különbségekre, igyekeztek egy „,semleges spanyolt” használni, minden dialektusból átvenni bizonyos elemeket. A nézők idővel lázadni kezdtek a nemtörődömség ellen. Ezekből a kettős változatokból nem sok maradt fenn az utókornak, de az egyik leghíresebb igen: a klasszikus, Lugosi Béla főszereplésével készült Drakulából (Dracula, Tod Browning, 1931) készült egy spanyol változat is George Melford rendezésében, a címszerepet ebben Carlos Villarías alakította. A spanyol stáb az amerikaiak által forgatott jeleneteket még aznap éjjel újraforgatta ugyanabban a díszletben, többnyire lemásoltak és tökéletesítettek minden kamerabeállítást, de a szereplők már spanyol anyanyelvüek voltak. Szintén jelentős volt az olasz és francia nyelvü dupla változatok készítése, de a spanyolénál kisebb számban.

${ }^{289}$ Martínez-Bretón, Juan Antonio: Libertad de expresión cinematográfica durante la II República Española. Madrid, Editorial Fragua, 2000. 27.

${ }^{290}$ Santos, Mateo: „Resurrección de Don Quijote” in: Film Popular, No. 291. 1932. március 10. 3.

${ }^{291}$ Gubern, Román: El cine sonoro en la II República (1929-1936). Id. mü. 223-224.
} 
filmiparról beszélhetünk. Kormányzati segítséggel, magántőke bevonásával, Madrid és Barcelona központtal állnak fel a hollywoodi stúdiórendszer mintájára kreált, modern infrastruktúrával rendelkező, első jelentős spanyol filmstúdiók, mint a CEA, az Orphea Films, a Ballesteros Tona Films, a Chamartín, az Iberia Films, a Buñuelhez kötődő Filmófono vagy a Franco-rendszerben nagy jelentőségre szert tevő Cifesa. ${ }^{292}$ Román Gubern szerint 1935 és 1936 között Spanyolországban forgott a legtöbb dokumentumfilm, lekörözve ezzel a világ két legfontosabb dokumentumfilm-gyártó műhelyének tartott Nagy-Britanniát és Szovjetuniót. ${ }^{293}$ 1931 és 1936 között összesen 185 film készült, ebből 261936 első félévében. ${ }^{294}$ Az újonnan felállt filmgyártó vállalatok azonban már nem tudtak kibontakozni. ${ }^{295}$

1938-ban Burgosban alakul meg a Nemzeti Filmszakosztály (Departamento Nacional de Cinematografía) Manuel Augusto García Viñolas vezetésével, amely ismert, korábban köztársasági érzelmü filmrendezőket (mint Edgar Neville és Eduardo García Maroto) is felvett soraiba, akik ezután a felkelők számára készítettek propagandafilmeket. A Nemzeti Szórakoztatóipari Szakszervezet (SNE) 1942 áprilisában közzétett rendelkezése szerint a nemzeti filmvédelmi terv kiegészítéseként az állam filmstúdiók létesítését ösztönzi, mert ezek elengedhetetlenek az erős filmipar megteremtéséhez, a hispán-amerikai piacok megszervezéséhez és a nemzeti ügyet szolgáló producerek munkájának megkönnyítéséhez. ${ }^{296}$ 1940 és 1955 között már évente átlagosan 40 film készült. ${ }^{297}$ A filmstúdiók elhelyezkedése mutatja, hogy míg korábban Katalónia vezető filmipari központ volt, addig a Franco-diktatúra megszilárdulása idején a fővárosra koncentrálódott az irányítás: 1944-ben Madrid 55 filmstúdiónak adott otthont, míg Barcelonában csak 18 müködött, és azok sem voltak nagy jelentőségűek. ${ }^{298}$

1947-ben alakult meg a Filmmüvészeti Kutatási és Kísérleti Intézet (Instituto de Investigaciones y Experiencias Cinematográficas - IIEC), amely, félrevezető neve ellenére, valójában filmiskola volt, ahol a következő évtizedek legjelentősebb filmrendezői tanultak.

\footnotetext{
${ }^{292}$ A spanyol stúdiórendszer történetéről, annak kialakulásáról és működéséről a kezdetektől a 2000-es évekig átfogó képet nyújt a Spanyol Filmakadémia gondozásában megjelent tanulmánykötet: García de Dueñas, Jesús Gorostiza, Jorge (szerk.): Los estudios cinematográficos españoles. Madrid, Academia de las Artes y las Ciencias Cinematográficas de España. 2001.

${ }^{293}$ Gubern, Román: Cine español en el exilio. Id. mü. 216-217.

${ }^{294} \mathrm{Az}$ adatokat közli: García Rodrigo, Jesús - Rodríguez Martínez, Fran: El cine que nos dejó ver Franco. Id. mü. 32 .

${ }^{295}$ A Második Köztársaság filmygyártásával foglalkozik három monográfia: Caparrós Lera, José María: El cine republicano español, 1931-1939. Barcelona, Dopesa, 1977; Uö: Arte y política en el cine de la República (19311939). Barcelona, Universidad de Barcelona, 1981; Gubern, Román: El cine sonoro en la II República (19291936). Barcelona, Lumen, 1977.

${ }^{296}$ Gómez Alonso, Rafael: „Diagonal: Una segunda vida para los estudios Lepanto” in: García de Dueñas, Jesús - Gorostiza, Jorge (szerk.): Los estudios cinematográficos españoles. Id. mü. 226.

${ }^{297}$ García Rodrigo, Jesús - Rodríguez Martínez, Fran: El cine que nos dejó ver Franco. Id. mủ. 32.

${ }^{298}$ Ripoll, Xavier: „Cataluña”. Id. mü. 224.
} 
Sokan közülük ellenzéki filmesek lesznek. A 40-es évek közepétől egyre több napi- és hetilapban (Arriba, Ateneo, Ínsula, La Hora, Juventud) volt filmes rovat, majd specifikusan filmművészeti és filmkritikai lapok is megjelentek: Primer Plano, Cinema Universitario, Cinestudio, a már idézett egyházhoz kötődő folyóiratok, illetve az UNINCI stúdió disszidens $^{299}$ filmeseit tömörítő, a legfontosabb és legszínvonalasabb filmelméleti és filmkritikai műhellyé váló Objetivo. Utóbbinak a baloldali (sok esetben kommunista) érzelmü szerkesztőbizottsága és az itt közölt írások miatt sok problémája akadt a hatóságokkal, de máig a Franco-rendszerben megjelent legszínvonalasabb, igazi értelmiségi filmmüvészeti folyóiratként tartják számon. Rövid életet ért meg, mindössze kilenc számot publikáltak 1953 és 1955 között, közben egyszer fel is függesztették. Ennél sikeresebb volt a Nuestro Cine, amelyet szintén baloldali értékrendet valló személyek szerkesztettek. ${ }^{300}$

1951-ben alakult meg a Tájékoztatási és Idegenforgalmi Minisztérium, első vezetője Gabriel Arias Salgado, a Falange egyik fő alakja és Franco odaadó híve, az úgynevezett neototalitárius információkontroll atyja. Különböző minisztériumokban és szakosztályokon szerzett tapasztalatait tudta felhasználni saját tárcája irányításában. Az általa bevezetett információ doktrínája elsősorban a sajtót vette ellenőrzés alá, de fontosnak tartotta a film szigorú felügyeletét is. Értelmezése szerint a sajtószabadság és a véleménynyilvánítási szabadság nem egyéni, hanem a közjó érdekében alkalmazható kollektív jogok, ezért az államnak kell azokat gyakorolnia. ${ }^{301}$ Már pozícióba lépése évében létrehozta a Színház-és Filmmüvészeti Főigazgatóságot (Dirección General de Cinematografía y Teatro), amely vezetésére José María García Escuderót kérte fel, aki először mindössze hat hónapig töltötte be ezt a posztot ${ }^{302}$, majd tíz évvel később visszatért. Először 1954-ben a Salamancai Egyetemen került be a tananyagba a filmmüvészet, konferenciákat is szerveztek, ahol egy-egy előadást tartott Ramón Menéndez Pidal („A film és a történelem” címmel) és Enrique Tierno Galván („A film és a társadalom”) is. ${ }^{303}$ García Escudero második mandátuma alatt és az ő aktív részvételével alakult meg 1963-ban az első Filmtörténeti és Filmesztétikai Tanszék a Valladolidi Egyetemen; García Escudero szerint a 16. században a költészet, a 17. században

\footnotetext{
${ }^{299}$ A disszidens filmesek az országon belül képviselték az ellenzéki vonulatot. Ezt természetesen nem tehették meg nyíltan, ezért az UNINCI stúdiót létrehozva igyekeztek olyan filmeket gyártani, amelyekben megjelenik a társadalom- és rendszerkritika. A cenzúrával állandó harcot folytató alkotók tevékenységét nevezi a spanyol filmtörténetírás disszidens mozinak (cine de disidencia).

${ }^{300}$ Heredero, Carlos F.: Las huellas del tiempo. Id. mü. 150-153.

${ }^{301}$ Eiroa de San Francisco, Matilde - Carrera Álvarez, Pilar: España, voz en off. Id. mű. 49-55.

${ }^{302}$ Lemondásának okai és körülményei a disszertáció fő témájának szempontjából is fontosak, mindezekről későbbi fejezetekben szólok részletesebben.

${ }^{303}$ Hernández-Marcos, José Luis - Ruíz Butron, Eduardo A: Historia de los Cine Clubs en España. Id. mü. 5052.
} 
a festészet, a 18. században a zene, a 19. században a színház képviselte az igazi, élő müvészetet, a 20. században pedig a film. „Hogyan is lehetne tanulmányozni a marxista dialektikát Eizenstein, a janzenizmust Bresson, az egzisztencializmust pedig Bergman nélkül?"304, tette fel a költői kérdést.

\section{A filmcenzúra a Franco-korszakban}

A Franco-korszak cenzúráját, konkrét filmekre vonatkozó vizsgálatát és a cenzúra módszertanának értelmezését számos spanyol szerző tárgyalja monográfiájában. ${ }^{305} \mathrm{Az}$ alábbiakban ezek lényegét, témám szempontjából releváns vetületeit foglalom össze és egészítem ki azokat újabb adalékokkal.

\section{Elözmények}

1912 novemberében jelenik meg az első olyan királyi rendelet, amely szabályozza a filmek bemutatását és bevezeti a cenzúrát. Utóbbit azzal indokolják, hogy a Spanyol Higiéniai Társaság és Spanyol Gyermekgyógyászok Társasága figyelmeztetett a filmekből áradó, gyermekeket fenyegető erkölcsi veszélyekre, mert büncselekmények elkövetésére ösztönözhetik őket. A kiskorúak testi és szellemi védelme állt a középpontban, ennek érdekében korlátozták a vetítőtermekbe történő bejutást is. Az erőszakos és pornográf jeleneteket tartalmazó filmek mellett azokat is betiltották, amelyek sérthették más nemzetek szuverenitását és állampolgárait. Minden bemutatandó filmet előzetesen véleményeztetni kellett a helyi polgári kormányzó irodájával és az általa kijelölt cenzori juntával. ${ }^{306}$

A fenti intézkedések bővített változatai, évröl évre más intézmények hatáskörébe kerülve, fennmaradtak Primo de Rivera idején is. ${ }^{307}$ A szovjet filmek bemutatását azonban, „,veszélyes ideológiai tartalma” miatt, erőteljesen korlátozták, Eizenstein és Pudovkin alkotásai tilalom alá estek Spanyolországban, miközben azok filmművészeti jelentőségét a

\footnotetext{
${ }^{304}$ García Escudero, José María: La primera apertura. Id. mü. 56.

${ }^{305}$ A legfontosabb mủ az 1975-ben született Gubern, Román - Font, Doménec: Un cine para el cadalso. Barcelona, Editorial Euros, 1975. Gubern öt évvel később önállóan kiadta ennek frissített, általa átdolgozott változatát: Gubern, Román: Régimen jurídico y función política de la censura cinematográfica bajo el franquismo. Barcelona, Ediciones Península, 1981. Az elmúlt évek során számos tanulmány és könyv látott napvilágot, amelyek összegezték, esetleg új adatokkal egészítették ki a korábbiakat. Néhány általam is használt példa: Afinoguénova, Eugenia: „La censura cinematográfica en el territorio nacional durante la Guerra Civil y la consolidación del <Nuevo Estado〉" in: Herrera, Javier - Martínez-Carazo, Cristina (szerk): Hispanismo y cine. Id. mü. 119-141; Gil, Alberto: La censura cinematográfica en España. Barcelona, Ediciones B, 2009; a cenzúra intézményét közjogi és nemzetközi jogi szempontból vizsgálja: González Ballesteros, Teodoro: Aspectos jurídicos de la censura cinematográfica en España. Id. mü. A Franco-korszak filmművészetét, színházát és irodalmát vizsgálja cenzori szempontból: Neuschafer, Hans-Jörg: Adiós a la España eterna. Madrid - Barcelona, Ministerio de Asuntos Exteriores - Editorial Anthropos, 1994.

${ }^{306}$ González Ballesteros, Teodoro: Aspectos jurídicos de la censura... Id. mü. 109-111.

${ }^{307}$ Uo. $112-114$.
} 
spanyol írók is magasztalták. Míg tehát az orosz filmtörténetet is tárgyaló, a 20-as évek második felében megjelent könyvek részletesen szóltak a szovjet müvek esztétikai újításairól és lenyügöző megvalósításairól, addig magukat az alkotásokat nem láthatták a nézők. A helyzet a Második Köztársaság idején csak részben változott, újabb szovjet alkotások kerültek tiltólistára, politikai tartalmukra hivatkozva nem voltak bemutathatóak a mozikban. Azonban a valódi művészeti értéket felmutató szovjet mủvek (mint a Patyomkin páncélos) cenzúrázott változata megjelenhetett az értelmiségiek által szervezett filmklubok programjában. 1936-ban, a Népfront győzelmével születtek meg az első, szovjet filmekre vonatkozó spanyol forgalmazói engedélyek, de a rövidesen elkezdődő polgárháború miatt csak a köztársasági területen élők tekinthették meg azokat, majd a Franco-korszakban ismét teljes lesz a tiltás. ${ }^{308}$

Az 1930 áprilisában megjelenő királyi rendelet a madridi Biztonsági Főigazgatóság (Dirección General de Seguridad) kizárólagos hatáskörébe utalta a játékfilmeket érintő cenzúrát, míg híradók esetében a madridi intézmény mellett Barcelona Polgári Kormányzata is eljárhatott. Mindez azonban csak egy évig maradt érvényben, mert a monarchia eltünésével felálló köztársaság 1931-ben eltörölte azt, ugyanis szerinte semmilyen eredményt nem ért el, viszont önkényes cenzori tevékenységével helyrehozhatatlan károkat okozott a filmterjesztöi vállalatok számára. Az új törvény szerint minden régióban a helyi polgári kormányzó döntése alapján kellett a filmeket véleményezni, megszünt tehát a központi, egész országra kiterjedő cenzúra. A betiltott filmek engedélyeztetését ismét kérni lehetett, ha végrehajtották rajtuk a szükséges változtatásokat (ilyen pontot sem a korábbi, sem a későbbi cenzúratörvények nem tartalmaztak). Az is a helyi testületek döntése volt, hogy milyen bizottságokat állítanak fel ebből a célból. 1935-ben azonban visszatér a központosítás, ismét a madridi Biztonsági Főigazgatóságé a végső szó, kivéve Katalóniát, ahol a Generalitat kompetenciája a filmpolitika. Négy latin-amerikai országgal (Mexikó, Chile, Nicaragua és El Salvador) kötött kétoldalú megállapodások alapján mindkét fél betiltja saját területén azokat a filmeket, amelyeket a másikra nézve sértőnek találnak. A cenzori tevékenység azonban igen passzívnak bizonyult, mivel a köztársasági kormányok kevés figyelmet fordítottak a filmpolitikára. ${ }^{309} \mathrm{~A}$ korszakból két mozgóképhez kapcsolódó eseményt tartok szükségesnek megemlíteni.

Luis Buñuel Föld, kenyér nélkül (Las Hurdes - Tierra sin pan, 1932) címü rövid dokumentumfilmje Cáceres (Extremadura) térségében mutatja be a rendkívüli méretü szegénységet, a központi hatalom és az egyház által elhanyagolt elmaradott régiót, a

\footnotetext{
${ }^{308}$ Martínez-Bretón, Juan Antonio: Libertad de expresión cinematográfica ... Id. mü. 64-68.

${ }^{309}$ Erről részletesen: Uo. 39-61. Martínez-Bretón könyve a köztársasági filmcenzúrát vizsgálja példákkal gazdagon illusztrálva.
} 
kegyetlen mindennapokat és a lakosok reménytelen helyzetét, egyértelműen állást foglalva a fennálló társadalmi helyzet igazságtalanságai ellen. A Lerroux vezette köztársasági kormány már az első vetítés után betiltotta a mủvet, indoklása szerint a film tiszteletlen a spanyolokkal szemben és szégyent hoz az egész országra - a tiltást a későbbi köztársasági kormányok is fenntartották, a Népfont azonban 1936-ban engedélyezte a bemutatását, majd éppen a köztársasági oldal használta fel azt propagandaként: a rövidfilmben látható borzalmas állapotok felszámolását ígérik, ha sikerül legyőzni a fasisztákat. ${ }^{310}$ Bár hivatalosan a valódi helyzetet bemutató dokumentumfilmként tartják számon, Buñuel alkotása inkább egy valódi felvételeket a montázstechnikák segítségével ötvöző, azokat rendkívüli mértékben manipuláló, hatásvadásznak és polgárpukkasztónak értékelhető mü, amely a szürrealizmushoz való vonzódásának terméke.

A másik jellemző példa szélesebb nemzetközi vonatkozással bír. 1935-ben José María Gil Robles hadügyminiszter felháborodott a Paramount stúdió által forgalmazott, Marlene Dietrich föszereplésével készült Az asszony ördög (The Devil is a Woman, Josef von Sternberg, 1935) címü filmen, ugyanis szerinte a Spanyolországban játszódó történetben az egyik spanyol katonatiszt az egyenruhához méltatlan, erkölcstelen módon viselkedett. Mivel Gil Robles korábban a hollywoodi Metro Goldwyn Mayer és Paramount stúdiók európai filmterjesztési hálózatát képviselő ügyvédként is dolgozott, könnyen tudott intézkedni: régi kapcsolatai révén elérte, hogy a Paramount visszavonja a filmet előbb a spanyol piacról, majd minden országból, valamint azt is, hogy a film negatívját elégessék a washingtoni spanyol nagykövetségen a diplomaták jelenlétében. Von Sternberg rendező azonban ellopta az eredeti negatívot, így csak egy kópia égett el, amit Gil Robles persze nem tudott; egészen 1961-ig kellett várni, hogy a film világszerte bemutatásra kerüljön, Spanyolországban pedig először egy Dietrich-nek szentelt filmciklusban került tévéképernyőre 1986-ban. ${ }^{311}$

\section{A polgárháború és a diktatúra}

1938 novemberétől Ramón Serrano Súñer belügyminiszter (Franco tábornok sógora) elrendelte a cenzúra szigorítását, és létrehozta az azt felügyelő Filmcenzúra Bizottságot (Comisión de Censura Cinematográfica) és a Filmcenzúra Legfelsőbb Juntáját (Junta Superior de Censura Cinematográfica ${ }^{312}$. A két testület között megosztották a hatásköröket és a cenzúrázandó produkciókat (játékfilm, dokumentumfilm, filmhíradó, elsődleges cenzúra,

\footnotetext{
${ }^{310}$ Rodrigo Mora, Félix: „Tierra sin pan, ¿obra artística surrealista o panfleto liberal-proletarista?” Elérhető: http://felixrodrigomora.net/Tierra\%20sin\%20panII.pdf (2012-11-22)

${ }^{311}$ Martínez-Bretón, Juan Antonio: Libertad de expresión cinematográfica ... Id. mü. 90-91.

${ }^{312}$ BOE, 5-XI-1938.
} 
másodlagos cenzúra stb.). Kizárólag ezek jóváhagyásával lehetett megkezdeni a forgatást, majd bemutatni a kész müvet. A belügyminiszter szerint, „figyelembe véve, milyen befolyással rendelkezik a film a gondolatok szabad áramlása és a tömegek nevelése felett”, a Spanyol Államnak minden szükséges intézkedést meg kellett tennie, hogy a potenciális veszélyforrásokat ellenőrzése alá vonja. ${ }^{313}$ A polgárháború lezárultával az intézmények kiegészültek a Propaganda Nemzeti Szakszolgálatának Vezetösége (Jefatura del Servicio Nacional de Propaganda) keretein belül 1939-ben felálló Cenzúra Szekcióval (Sección de Censura $)^{314}$, amely újabb szempontok alapján a sajtó, a színház, a film és a zene terén vezet be cenzúrát. A későbbiekben sok gondot okoz majd, hogy a különbözö testületek nem azonos módon ítéltek meg egy-egy anyagot. 1939 végén az Ipari és Kereskedelmi Minisztérium (Ministerio de Industria y Comercio ) rendeletben ${ }^{315}$ fejtette ki, hogy az államnak kell gondoskodnia a filmiparról, mert az mind a nemzetgazdaság, mind a szellemi és anyagi propaganda szempontjából létfontosságú terület. 1940-től a Sajtó, Propaganda és Turisztikai Altitkárság (Subsecretaría de Prensa, Propaganda y Turismo) alá tartozó, a Propaganda Föigazgatóságtól (Dirección General de Propaganda) függő Nemzeti Filmszakosztály (Departamento Nacional de Cinematografía) ${ }^{316}$ engedélye szükséges minden forgatáshoz.

A szakosztály irányelvei:

„1. A filmgyártás soha nem tartozhat kizárólagosan az Állam tevékenységi körébe.

2. Az Államnak ösztönöznie kell a magánkezdeményezést a nemzeti filmmüvészet fejlödése céljából.

3. Az Állam gyakorolja a filmek feletti felügyelet és irányítás jogát abból a célból, hogy méltó legyen hazánk szellemi értékeihez.

4. Az Állam minden esetben fenntartja magának a filmhíradók és a propagandisztikus célú dokumentumfilmek gyártásának jogát." 317

A cenzúra intézményéhez szorosan kötődik a korábban már tárgyalt kötelező szinkronizálás. Az egységes nyelvhasználatra való törekvés mellett a szinkron hatékony cenzori eszköznek is bizonyult, mivel a spanyol szinkronban önkényesen megváltoztathatták az eredeti szöveg dialógusait.

\footnotetext{
${ }^{313}$ Uo.

${ }^{314}$ BOE, 30-VII-1939.

${ }^{315}$ BOE, 21-X-1939.

${ }^{316}$ BOE, 25-II-1940.

${ }^{317}$ Uo.
} 
Egy amerikai film spanyol szinkronizálásához kapcsolódik a francói filmcenzúra legnagyobb, nemzetközi visszhangot kiváltó botránya is, amelyet a pap-cenzorok döntése okozott. Mivel a rezsimmel összefonódó katolikus egyház nem nézte tétlenül, hogy a filmvásznon házasságtörésre utaló jelek mutatkozzanak, a Mogambo (Mogambo, John Ford, 1953) című film kapcsán a Grace Kelly és Donald Sinden alkotta házaspárt a spanyol szinkron segítségével, többszöri intézkedés során, testvérpárrá változtatták ${ }^{318}$, így már kevésbé volt botrányos, hogy a feleség és a vadászt alakító Clark Gable karaktere vonzódott egymáshoz. Az azonban nem keltette fel az erkölcsi ítészek figyelmét, hogy ebben az új változatban számos, Kelly és Sinden között játszódó jelenet erőteljesen a két személy (eredetileg házaspár, most testvérpár) között fennálló intim viszony meglétére utalt. A külföldi sajtó azonnal, a spanyol újságok csak a 70-es évektől kezdődően reagáltak az esetre, és a teljes spanyol cenzúrát jellemző visszatérő megállapítássá vált, hogy a katolikus egyház számára elfogadhatóbb a vérfertőzés, mint a házasságtörés.

Nem beszélhetünk ugyanakkor egységes cenzúráról, a beavatkozásnak nem léteztek központilag meghatározott normatív keretei. Irányadó direktívák hiányában, minden mü megítélése külön döntést igényelt, „testre szabott” eljárások határozták meg, mi maradhat egy filmben és mit kell belőle eltávolítani. Ez sok esetben a pillanatnyi közhangulattól, a cenzorok szeszélyétől és a rezsimben betöltött pozíciójától (katonatiszt, egyházi személy, politikus) függött, valamint attól, hogy az erkölcsiség és a valóságábrázolás mely oldalára mutatkozott érzékenynek, mire helyezte a hangsúlyt, amikor a „helyes” fogalmához próbálta igazítani a forgatókönyvben leírtakat vagy a már filmszalagra vett képkockákat. Az egyértelmüen elfogadhatatlan tartalmak (meztelenség, pornográfia, extrém erőszak, Spanyolország és a Franco-rezsim nyílt becsmérlése, vallás- és kereszténység-ellenes szólamok) mellett minden jelenet egyéni elbírálás alá esett. Ezért használtam korábban a cenzúra kapcsán a „szokás” kifejezést a „,szabály” vagy a „,norma” helyett, mert tényszerűbb így tekinteni rá.

A filmirányítási és a cenzori testületekben helyet foglaló politikusok, katonatisztek, papok és katolikus szervezetek képviselöi változó számbeli összetétellel voltak jelen, saját véleményezést készítettek a forgatókönyvről, vagy a már kész filmről, majd ezeket összesítve adta ki a bizottság a végső határozatot. A filmek korhatár-besorolását is ők szabták meg. A cenzori jelentések alapján szembetűnő, hogy a legszigorúbb ítéletet mindig az egyháziak adták, számos esetben előfordult, hogy minden cenzor bemutatásra alkalmasnak ítélt egy filmet, ám a pap-cenzornak fenntartásai voltak. Az említett Mogambo példája is ezt mutatja.

\footnotetext{
${ }^{318}$ AGA, Cultura, 36/03489-es doboz, 12723-as köteg és 36/03500-ás doboz, 13015-ös köteg.
} 
Az egyik legaktívabbnak számító, az erkölcsi cenzúra mindenhatójának tartott Peyró atya például büszkén állította, hogy élete során hatezernél is több filmet ellenőrzött, másfél kilométernyi celluloidot vágatott ki ezekböl, így közel tízezer erkölcsromboló csókjelenettől kímélte meg a közönséget. ${ }^{319}$ Ugyanakkor, a Junta egyik egyházi cenzora 1951-ben felhívta a figyelmet, hogy mindig igyekeztek úgy beiktatni a vágásokat, hogy a néző ne vegye észre, valami hiányzik. Azt is állította, hogy a legtöbb jelenetet nem azért kell kivágni, mert valami erkölcsi problémát vélnek benne felfedezni, hanem azért, mert a játékidőt hozzá kell igazítani a rendelkezésre álló vetítési időhöz, és ezt a hálátlan feladatot is nekik kell elvégezniük. ${ }^{320}$ 1950-ben a spanyol katolikus egyház felállította az Elöadómüvészeteket Osztályozó Nemzeti Hivatalt (Oficina Nacional Clasificadora de Espectáculos) is, amely a Junta döntése után saját szempontrendszere alapján sorolta be hívei számára a filmeket az alábbi kategóriákba:

1 (mindenki számára engedélyezett)

2 (fiatalok számára engedélyezett)

3 (csak idösebbek számára)

3R (idösebbek számára kifogásokkal)

4 (rendkíviul veszélyes). ${ }^{321}$

1942-től a Közoktatási Helyettes Államtitkárságtól (Vicesecretaría de Educación Popular) függö Nemzeti Színház- és Filmmüvészeti Hivatal (Delegación Nacional de Cinematografía y Teatro) alá tartozik a két fö cenzori testület ${ }^{322}$, 1945-től pedig a Nemzeti Oktatási Minisztériumban (Ministerio de Educación Nacional) felállt Közoktatási Altitkárságon (Subsecretaría de Educación Popular) belül működő Színház és Filmmüvészeti Főigazgatósághoz (Dirección General de Cinematografía y Teatro) kerül a filmmüvészet ügye. A későbbiekben ez a főigazgatóság marad a főszereplő a mozgóképek ügyében, mellé azonban felállítanak egy, a katolikus szektor tagjai által alkotott Filmirányítói Legfelsőbb Juntát (Junta Superior de Orientación Cinematográfica), ahol az alapító rendelet szerint az egyház által delegált személyek vétója minden esetben felülírja más tagok döntéseit. ${ }^{323} 1952$ ben történik egy jelentős lépés, minden addigi cenzúratestületet összefognak a Filmirányítói Intézetben (Instituto de Orientación Cinematográfica) létrehozott Filmmüvészeti Cenzúra és Osztályozó Juntában (Junta de Clasificación y Censura de Películas Cinematográficas). ${ }^{324} \mathrm{Az}$

\footnotetext{
${ }^{319}$ Taibo I, Paco Ignacio: Un cine para un imperio. Id. mü. 55.

320 „La censura cinematográfica, tema palpitante” in: Espectáculo, No. 50.1951 május. 2-3.

${ }^{321}$ Salvador Marañón, Alicia: De iBienvenido, Mr. Marshall! a Viridiana. Id. mü. 46-47.

${ }^{322}$ BOE, 26-XI-1942.

${ }^{323}$ BOE, $11-\mathrm{X}-1947$.

${ }^{324}$ BOE, 31-III-1952.
} 
osztályozással foglalkozó részleg döntötte el, hogy milyen kategóriába kerülnek a spanyol és külföldi filmek technikai, művészeti és kereskedelmi szempontból, kontrollálta a támogatásokat és a filmexportot.

Külön kategóriát képviselt a még megmaradt spanyol kolóniák esete. A Spanyolországban érvényes cenzori rendelkezések alapvetően ezekre a területekre is vonatkoztak, de 1942-ben olyan kiegészítések születtek, amelyek nem egyeztek a félszigeten érvényben lévő, homogénebb szabályozással. Ezek értelmében a Magreb térség spanyol érdekeltségü területein csak olyan filmek bemutatása volt engedélyezett, amelyek nem sértik a területen élő őslakosok vallását, szokásait, hitet tettek a vallási és társadalmi sokszínűség mellett és elősegítették „az arabok, izraeliták és európaiak együttélését”. A bemutatandó alkotásokból ki kellett vágni minden olyan jelenetet és párbeszédet, ami az említett szempontok alapján problémásnak bizonyulhat. A helyi cenzori testület a Tetuáni Öslakos Ügyek (Asuntos Indígenas en Tetuán) kompetenciájába került, ahol az őslakos cenzor (censor indígena) vétójoggal rendelkezett. Megelőzve a lehetséges félreértéseket, valamint az Amerika hajnala marokkói bemutatója kapcsán felmerült nézői reakciókból okulva (a közönség rosszul fogadta, hogy Boabdilt nevetséges figuraként ábrázolták) nem engedélyezték olyan spanyol és más külföldi filmek és filmhíradók bemutatását Marokkóban, amelyekben hangsúlyos szerepet kap az arab nép, az idegenlégió és a zsidóság témája. ${ }^{325}$

Átvizsgálva száznál is több cenzori jelentést, megállapítható néhány általánosság. Az két legfontosabb szempont minden esetben az erkölcs és a hispán faj védelme. Szintén beavatkozások történtek az alábbi esetekben: képi vagy verbális utalások a szerelmespár intim együttlétére, társadalmi kritikaként felfogható párbeszédek vagy jelenetek (lakáshiányra, ételhiányra, munkanélküliségre utaló szekvenciák), a rendőri beavatkozás képei, a szereplők életébe akadályt gördítő bürokrácia, valamint az állam, a hadsereg és az egyház szatirikus ábrázolása. Spanyol filmek esetében már a forgatás előtt a cenzorok megváltoztatták a munkacímeket is, amennyiben az eredeti kapcsán felmerülhetett utalás kétséges értelmezésre. A film cselekményét is áthelyeztethették más korszakba, hogy a negatív cselekedetek okát ne a polgárháború utáni, hanem még a köztársasági időszakban azonosíthassák be. ${ }^{326}$ A cenzorok tevékenysége leginkább az ilyen, utalások vagy félmondatok erejéig jelenlévő részletekre korlátozódott, mivel nyíltan rendszerellenes hangvételü, a hatalmat támadó filmterveket a

\footnotetext{
${ }^{325}$ Diez Puertas, Emeterio: „La censura cinematográfica en las colonias españolas” in: Film-Historia, Vol. IX, No. 3. 1999.

Elérhetö: http://www.publicacions.ub.edu/bibliotecadigital/cinema/filmhistoria/art.diez.pdf (2012-11-22)

${ }^{326}$ Például A bosszú (La venganza, Juan Antonio Bardem, 1957) esetében, ahol a filmet még számos más cenzori csonkítás is érte. AGA, Cultura, 30/03648-as boboz, 17635-ös köteg
} 
spanyol alkotók nem is mertek előterjeszteni. Ennek oka a már többször említett öncenzúra: az alkotók maguk is tudták, mi lehet az, ami miatt a tervük fennakad a cenzúra rostáján, ezért már igyekeztek önmagukat korlátok közé szorítani. ${ }^{327}$ Más taktika is rendelkezésére állt a filmrendezőknek: olyan jeleneteket hagyni a filmekben, amelyek szinte cenzúráért kiáltanak, biztosra vehető, hogy az ítészek eltávolíttatják a filmből. A kirívó szcénák és párbeszédek olyannyira lekötötték a cenzor figyelmét, hogy az ennél visszafogottabb, de alapvetően szintén problémás elemeket esetenként már észre sem vették, megelégedtek azzal, hogy találtak valami egyértelmúen elfogadhatatlant. Antonio Lara író ezt a taktikát az „elégedett hiéna" kifejezéssel illette. ${ }^{328}$ Mindez a már említett helyzetnek volt köszönhető, amely szerint nem léteztek a cenzúrának hivatalos szabályai.

A központi cenzúra után jött a helyi szint: bár törvényileg csak a Junta vizsgálata volt kötelező, mégis ajánlott volt a városi testületek cenzori bizottságának is megtekinteni a filmet a bemutatás előtt, ugyanis a vidéki lakosság esetleg másra volt érzékeny, mint a fővárosiak; utóbbiakat az előbbiek általában túlságosan szabadelvünek tartották. Sok esetben a jelenetek és a párbeszédek is újabb ellenőrzés alá kerültek, majd a vetítés előtt még egyszer végignézték a filmet, hogy a helyi bizottság által parancsba adott változtatásokat valóban beiktatták-e. ${ }^{329}$

A külföldi filmeket olyan cenzori beavatkozások is érték, amelyek a mü egészét károsították meg. Sokat közülük még az importálás előtt betiltottak, valamelyiket csak a cenzorok számára tartott elővetítés után. A bemutatható filmek esetében a vallásra és egyházra, a családra, a szegénységre, mindenféle politikai meggyőződésre, mindenekelőtt a kommunizmusra utaló jelenetek kerültek a cenzúra célkeresztjébe. Számos érdekes, helyenként nevetséges vagy irreális, a Mogambo esetéhez hasonló döntéssel találkozhatunk. A változtatások oka nem minden esetben egyértelmü, így csak találgatni lehet például, hogy $A$ palást (The Robe, Henry Koster, 1953) címü Jézus-történet spanyol változatában az eredeti, „, a tanítványa, aki a balján ült” mondatot miért kellett megváltoztatni „,a tanítványa, aki az asztalánál ült”-re ${ }^{330}$; talán túlzás itt is a Franco-rendszer baloldaliságot megvető ideológiáját keresni, de a döntésre nem kínálkozik ésszerü magyarázat. Bőségesen őriz a spanyol levéltár olyan cenzori anyagokat, ahol a motiváció már egyértelműbb. Három ilyet emelek ki illusztrációként:

\footnotetext{
${ }^{327}$ Juan Antonio Bardem Kellemes húsvétot (Felices Pascuas, 1954) címü filmjében a házasságtöröket az eredeti terv szerint valamilyen isteni erkölcsi büntetés sújtotta volna; egy barátnője tanácsára azonban a rendező inkább megváltoztatta a film végét, a szereplők büntetése halál lett, ugyanis szerinte csak ezzel elégedett volna meg az egyházi cenzor. Igaza lett. Bardem, Juan Antonio: Y todavía sigue. Id. mü. 203-204.

${ }^{328}$ Taibo I, Paco Ignacio: Un cine para un imperio. Id. mü. 133-134.

${ }^{329}$ Erről Albacete város egyik cenzora számolt be a hely filmtörténetéről szóló könyv íróinak. García Rodrigo, Jesús - Rodríguez Martínez, Fran: El cine que nos dejó ver Franco. Id. mü. 389.

${ }^{330}$ AGA, Cultura, 36/03475-ös doboz, 12359-es köteg
} 
- Az olasz-brit koprodukcióban készült Rómeó és Júlia (Romeo and Juliet, Renato Castellani, 1954) végén az egyik cenzor szerint a vágások és a szinkron segítségével „minden áron meg kell akadályozni, hogy Júlia öngyilkos legyen”. 331

- A filmtörténet egyik leghíresebb amerikai musicalje, az Egy amerikai Párizsban (An American in Paris, Vincente Minnelli, 1951) az alábbi cenzori utasításokat kapta a spanyol bemutató előtt: „A nyolcadik, kilencedik, tizedik és tizenegyedik tekercsen mérsékeljék a csókjelenetet. Ez utóbbi tekercsen töröljék a tivornyán a túlságosan bujálkodó táncjelenetet. A tizennyolcadik tekercsen töröljék a kán-kánról készült közelképeket”. 332

- A német Kereslek tégedhez (Ich suche Dich, O.W. Fischer, 1956) a következő megjegyzést füzték: „El kell távolítani az arra utaló megjegyzéseket, hogy Gaby egy protestáns lelkész lánya (lehetne inkább orvos), illetve minden olyan vallási utalást is, amelyet tévesen lehet értelmezni. Vagyis: a lány esetében ne legyen egyértelmü a missziós tudat vagy a buzgó vallásosság, hanem egyszerüen csak legyen a jó leány, aki beleszeret az ateista főszereplőbe és megpróbálja őt megmenteni. Így nem tűnhet a tevékenysége túlzásnak." 333

A Casablanca (Casablanca, Kertész Mihály, 1942) képsoraiból teljes dialógusokat és párbeszédrészleteket vágtak ki, mert a szereplők valamelyike utalást tett arra, hogy korábban harcolt a spanyol polgárháborúban. ${ }^{334}$ A legtöbb feljegyzés amerikai filmeket ért politikai és erkölcsi töltetű cenzúráról maradt hátra, mivel a külföldi filmek döntő többsége hollywoodi alkotás. A Szovjetunióból és a kelet-európai országokból származó mủvekkel a cenzúrának nem volt feladata, ugyanis azokat, összhangban a Franco-rendszer a szóban forgó régióhoz füződő viszonyával, eleve tilos volt Spanyolországba importálni.

Spanyol filmek esetében kevesebbszer kellett beavatkozni az öncenzúra miatt; a 60-as évektől azonban a filmesek is megkezdték a nyitás fázisát, ezért a hatóság már több figyelmet szentelt nekik. A producerek egyik hatásos eszköze volt az apertura periódusában, hogy két változatot készítettek filmjeikből: egyet a belföld, egyet pedig a külföld számára. Utóbbi változatban előfordultak erotikus jelenetek is - Ignacio F. Iquino producer vált az ilyen kettős

\footnotetext{
${ }^{331}$ AGA, Cultura, 36/03535-ös doboz, 13868-as köteg

${ }^{332}$ AGA, Cultura, 36/03437-es doboz, 11370-es köteg

${ }^{333}$ AGA, Cultura, 36/03621-es doboz, 16675-ös köteg

${ }^{334}$ A Casablanca esetében az eredeti angol nyelvü, illetve a spanyolra szinkronizált változat között markáns különbségeket találhatunk egyes dialógusokban. Alább egy példa, hogyan hangzott két mondat a két változatban: Eredeti angol: „Ön fegyvereket szállított Etiópiába és harcolt a fasiszták ellen Spanyolországban. Hát nem érdekes, hogy Ön mindig az elnyomottak mellett áll?"

Spanyol szinkron:'Fegyvereket vitt Etiópiába, harcolt az ausztriai Anschluss ellen. Hát nem furcsa, hogy Ön mindig az igaz ügyet védelmezi?"

Más országokban is éltek a manipuláció ilyen típusú eszközével, a Casablanca eredeti nyelvü és magyar szinkronos változata közötti különbségről lásd: Hahner Péter: „Rick háborúba megy (A Casablanca és a politika)" in: Filmvilág, 2012/09, 10-11.
} 
filmek egyik mesterévé már az 50-es évek közepén, majd mindezt Jesús Franco rendezö 335 tökéletesítette a 60-as évektől, aki gyakorlatilag minden filmjéböl készített egy csak enyhén korhatáros verziót a spanyol közönségnek, valamint egy erotikával és horrorjelenetekkel bőségesen füszerezett változatot a külföld számára; ennek ellenére, a cenzúrával még így is sok gondja akadt. A más országok számára készült verziót nem nyújtották be a spanyol cenzori hivatalnak, nem kértek rá bemutatási engedélyt, egyszerüen kivitték azt külföldre, és ott gond nélkül vetíthették. ${ }^{336}$ Jesús Franco a 60-as évek végétől a koprodukcióiban részt vevő országok jogi segítségének köszönhetően forgalmazhatta saját elképzeléseit világszerte.

Azok a filmek, amelyeknek végső változatában a cenzúra semmilyen kivetnivalót nem talált és a Franco-korszakot jellemző ideológia tükröződését is látták benne, megkaphatta az 1944-ben létrehozott nemzeti érdek (interés nacional) titulust. A kategóriát létrehozó rendelet szerint az ide tartozó filmek magasztalják a faji értékeket, valamint példázzák a rezsim morális, társadalmi és politikai elveit, ezért a legkedvezőbb időszakban mutatják be őket a mozikban, és mindaddig kötelesek lesznek ezeket müsoron tartani, amíg a vetítéseken a terem befogadóképességének több mint 50\%-át igénybe veszik a nézők. ${ }^{337}$ Ezek a filmek 40\%-os, majd később 50\%-os állami támogatást élveztek. A nem nemzeti érdek kategóriába tartozókat az 1952-ben felállt Osztályozási Junta öt kategóriába sorolta, és mindegyiknél megszabta, hogy visszamenőleges hatállyal a költségvetés hány százalékát térítik meg: 1A (40\%), 1B (35\%), 2A (30\%), 2B (25\%), 3 (nem támogatják). A későbbiekben már nem százalékokat, hanem konkrét összegeket rendeltek minden egyes csoport mellé, illetve annak függvényében is növekedhetett a támogatás, hogy a filmek külföldi forgalmazása mennyi bevételt jelentett a spanyol államnak. ${ }^{338}$ A forgatáshoz szükséges költségeket a stúdió tőkéjéből, bankhitelekből, állami kölcsönökből, a forgalmazói vállalatok által adott előlegekből és a filmgyártó cég előző

\footnotetext{
335 Jesús (Jess) Franco a spanyol és nemzetközi filmművészet egyik ikonja, nevéhez füződik például Bram Stoker klasszikus regényének egyik leghitelesebb feldolgozása, a Drakula gróf (El conde Drácula, 1970). Egyedi jelensége ő a spanyol filmgyártásnak, nemzetközileg elismert filmes, Quentin Tarantino amerikai filmrendező egyik példaképe, Luis Buñuel is tisztelte öt merészségéért és filmnyelvi újításaiért. Karrierje elején Luis García Berlanga és Orson Welles rendezőasszisztenseként is dolgozott. Közel kétszáz filmjével abszolút rekorder Spanyolországban. Műveiben az eleinte enyhén erotikus és horrorisztikus elemek jelenléte a 60-as évek végétől egyre hangsúlyozottabbá vált. Az ösztön, a szexus, az emberi lélek mélyéről fakadó különbözö perverziók adták és adják ma is a Jesús Franco-filmek fő vezérfonalát, a kontextus pedig gyakran az évezredes mitológiák által kreált vámpírok és zombik univerzuma. A rezsim alatt a cenzúra nagy figyelmet szentelt munkásságának, és betiltották, vagy felismerhetetlenre szabdalták a nevéhez füződő celluloidtermékeket, de külföldi barátainak és producertársainak köszönhetően más országokban a közönség csorbítatlanul nézhette munkáit. Személye a spanyol demokratikus átmenet egyik jelképévé vált, 2009-ben a Spanyol Filmakadémia munkássága elismeréseként Tiszteletbeli Goya-díjjal tüntette ki.

${ }^{336}$ Gubern, Román: La censura. Id. mü. 140.

${ }^{337}$ BOE, 23-VI-1944.

${ }^{338}$ Caparrós Lera, José María: Historia Crítica del Cine Español. Id. mủ. 82-83; Pérez Bastías, Luis - Alonso Barahona, Fernando: Las mentiras sobre el cine español. Barcelona, Royal Books, 1995. 51-57.
} 
munkái után kapott visszatérítésekből oldották meg. Ezen kívül, a filmgyártó vállalatok egy spanyol film előállításáért cserébe importálási és szinkronizálási engedélyekhez jutottak, amelyek nélkül nem lehetett behozni Spanyolországba külföldi filmeket; minél jobb besorolást kapott az általuk előállított film a Juntától, annál több importengedélyt adtak ki a stúdiónak. A sikervárományos amerikai filmek forgalmazásához tehát szükség volt saját filmek előállítására is. Az importálási és szinkronizálási engedélyek olyan fontossá, sok esetben életbevágóvá váltak egy stúdió számára, hogy korrupciós hálózat is kialakult körülöttük: valóságos feketepiac jött létre, ahol a stúdiók egymás között adták-vették, esetleg cserélgették ezeket, így a spanyol filmek váltópénzként vagy készpénzként is funkcionáltak. ${ }^{339}$ Fernando Fernán Gómez színész-rendező egy interjúban megerősítette, hogy számos olyan film forgatásán vett részt, amely kizárólag az importálási engedélyek megszerzése miatt zajlott, ennek a rezsim döntéshozói tudatában voltak, de semmit sem tettek ellene. Így biztosították, hogy a film elég jó értékelést kapjon ahhoz, hogy cserébe behozhassanak amerikai filmeket. $^{340}$

Bár már erőteljesen érződtek a közeledő nyitás jelei, a cenzúra egyik legnevezetesebb beavatkozása mégis a 60-as évek elejéhez kötődik. 1960-ban Juan Antonio Bardem kérésére és intézkedései nyomán visszatért hazájába Luis Buñuel, hogy legújabb filmjét otthon forgassa az UNINCI stúdió keretein belül. A Viridiana (Viridiana, 1961) volt az első spanyol film, amely a Cannes-i Filmfesztiválon elnyerte az Arany Pálma-díjat. Az erőteljesen antiklerikális és vallásellenes film azonban botrányt váltott ki a vatikáni sajtó körében, és Spanyolországot vádolták, amiért egy ilyen filmet engedett leforgatni, ráadásul benevezni egy külföldi fesztiválra. A Szentszék egyenesen blaszfémiát kiáltott. ${ }^{341}$ A film végső üzenete, hogy a keresztény irgalom és könyörület mit sem ér; a jelenetek valóban támadást intéznek a vallási intézmények és szentségek ellen, mindenekelőtt a koldusok orgiája, valamint a Leonardo da Vinci Utolsó vacsora című mủvét átértelmező beállítás. A reakció nem maradt el, José María Muñoz Fontán filmfőigazgatót azonnal leváltották ${ }^{342}$, a filmet pedig végérvényesen betiltották ${ }^{343}$, és visszamenőleges hatállyal még a korábban ellenvetés nélkül kiadott forgatási engedélyt is megtagadták. Az UNINCI stúdió a Franco-rezsim kereszttüzébe

\footnotetext{
${ }^{339}$ Salvador Marañón, Alicia: De ¡Bienvenido, Mr. Marshall! a Viridiana. Id. mü. 72. és Castro de Paz, José Luis: Un cinema herido. Id. mü. 30-31.

340 „Entrevista a Fernando Fernán Gómez” in: Nickel Odeon, No. 9. 1997. 68.

${ }^{341}$ A botrány részleteiről, valamint az olasz és spanyol sajtó reakciójáról lásd: Salvador Marañón, Alicia: De ¡Bienvenido, Mr. Marshall! a Viridiana. Id. mü. 496-502; a film értelmezéséröl és mondanivalójáról: Neuschafer, Hans-Jörg: Adiós a la España eterna. Id. mü. 226-242.

${ }^{342}$ Cerón Gómez, Juan Francisco: El cine de Juan Antonio Bardem. Universidad de Murcia - Primavera Cinematográfica de Lorca, 1998. 15.

${ }^{343}$ AGA, Cultura, 36/03835-ös doboz, 22650-es köteg
} 
került, az anyagi ellehetetlenülést csak Santiago Carrillo és az illegálisan tevékenykedő Spanyol Kommunista Párt néhány tagjának segítsége tudta átmenetileg megakadályozni, de hamarosan csődöt kellett jelentenie. ${ }^{344}$

A nyitás periódusában is számos külföldi filmet tiltottak be, amelyet hivatalosan nem lehetett látni a mozitermekben; nem hivatalosan vagy illegálisan azonban a müvészmozikban és filmklubokban felbukkantak.

Egy több helyen is megtalálható becslés szerint 1940 és 1974 között összesen hetvenezer méternyi filmet vágtak ki az alkotásokból, a cenzúrázott negatívok száma és hossza azonban továbbra is ismeretlen, mivel a nem kívánt részeket sokszor nem csak kiszedték, hanem el is égették. A 90-es években háromezer méter filmanyag porosodott a filmarchívumok raktáraiban, amelyek esetében azt sem sikerült beazonosítani, hogy vajon melyik müből kerültek eltávolításra. ${ }^{345}$

1976 februárjában szűnt csak meg a forgatókönyvek előzetes átvizsgálásának kötelezettsége, önkéntesre változtatva azt ${ }^{346}$; a cenzúra végleges eltörlésére az 1977-es szólásés sajtószabadságot garantáló törvényig ${ }^{347}$ kellett várni. A cenzúra azonban a demokratikus átmenetben sem tünt el véglegesen. Bár az erőszakos és erotikus filmek előtt megnyílt a lehetőség, voltak témák, amelyeket nem lehetett teljes szabadsággal kezelni: emlékezetes maradt a spanyol társadalom számára A cuencai büntény (El crimen de Cuenca, Pilar Miró, 1980) esete, amelyet egy évre betiltott Adolfo Suárez kormánya, a film rendezőnőjét pedig a Katonai Törvényszék fogta perbe a fegyveres intézmények megsértése vádjával. ${ }^{348}$

\footnotetext{
${ }^{344}$ Bardem, Juan Antonio: Y todavía sigue. Id. mü. 304-309.

${ }^{345}$ García Rodrigo, Jesús - Rodríguez Martínez, Fran: El cine que nos dejó ver Franco. Id. mü. 33.

${ }^{346}$ BOE, 24-II-1976.

${ }^{347}$ BOE, 12-IV-1977.

${ }^{348}$ A film büne az volt, hogy nyíltan, realista-naturalista módon bemutatta azokat az igazságtalanságokat és kegyetlenkedéseket, amelyeket a Guardia Civil emberei követtek el 1912-ben Cuencában és ezzel negatív képet festett a mindmáig létező fegyveres szervről, amelyet a demokrácia idején is tisztelni kell. 1981-ben az esetet tárgyaló bíró végül úgy találta, a kérdés filmpolitikai ügyként kezelendő, ezért abban a haditörvényszék nem kompetens. Addigra már a nemzetközi sajtó is cikkezett a betiltásról, a spanyol városokban tüntetések kezdődtek a szólásszabadság és a rendezőnő védelmében, így bel- és külföldi nyomásra a kormány engedélyezte a film bemutatását 1981-ben. Abban az évben ez a mü érte el a legmagasabb nézőszámot Spanyolországban, nagyrészt a körülötte kialakult botrány miatt. Pilar Miró 1982-ben, a PSOE-kormány alatt filmművészeti föigazgató lett, később az RTVE föigazgatója. A cuencai büntény esetéről megemlékezik minden spanyol filmtörténeti munka legalább egy megjegyzés, de általában több bekezdés erejéig. Az okokat, az ügy részleteit és a következményeket legrészletesebben a rendezőnő életrajza tárgyalja: Galán, Diego: Pilar Miró. Nadie me enseñó a vivir. Barcelona, DeBolsillo, 2007. 117-144.
} 


\section{Az infrastrukturális háttér: a filmstúdiók}

A hivatalosan csak 1942-ben létrejövő, filmgyártásra szakosodott Chamartín részvénytársaság jogelődjének részvényesi juntája 1940-ben rendelkezést hozott, amellyel kifejezte egyöntetű támogatását a Caudillónak és azon szándékát, hogy tevékenységükkel a haza szolgálatába álljanak. A polgárháború előtti lehetőségeket kaotikusnak ítélték, a harcok során a társaság alkalmazottai hősiesen helytálltak a felkelők mellett, a „,örös Kormány hordái” elől megvédték létesítményeiket. Minden stúdiót és berendezést büszkén felajánlottak Franco nemzeti Spanyolországának. ${ }^{349}$ A 40 -es évek elején a filmstúdiók vezető testületeitől számos ehhez hasonló nyilatkozat látott napvilágot.

Az alábbiakban két stúdió, a Cifesa és a Suevia Films tevékenységét vázolom fel, mivel munkájuk szorosan kapcsolódott a rezsim filmpolitikájához, mindenekelőtt az előbbi kapott vezető szerepet. Amerikai mintára már megalakulásuk után elkezdték kiépíteni saját star systemjüket ${ }^{350}$, amelynek tagjaival a nézőket igyekeztek a moziba csábítani. A filmcsillagjaik megjelentek minden társadalmi eseményen, a napilapok és magazinok pletykaés társasági rovatainak állandó szereplőivé váltak. Nevük szorosan kapcsolódott a két stúdióhoz, a spanyol filmgyártás szimpatikus és vonzó arcát adták. ${ }^{351}$

Természetesen más, kisebb filmstúdiók is működtek Spanyolországban a Francokorszak során, volt közöttük, amelyik szintén jelentős müvekkel járult hozzá az állami ideológia fenntartásához és terjesztéséhez (mint a katolikus erények, a tradicionális értékek és a család szentségének védelmét zászlajára tüző Aspa Producciones Cinematográficas), de a Cifesa volt az, amely gyártási politikáját és produkcióit tekintve joggal lenne nevezhető a rezsim filmstúdiójának.

\footnotetext{
${ }^{349}$ García de Dueñas, Jesús: „Chamartín, la orgullosa permanencia” in: García de Dueñas, Jesús - Gorostiza, Jorge (szerk.): Los estudios cinematográficos españoles. Id. mü. 241.

${ }^{350}$ A hollywoodi stúdiórendszerben kialakult star system (az eredeti elnevezés honosodott meg más nyelveken is, így én sem használom a ,sztárrendszer” szót) lényege, hogy a projekteket a közönség által rajongott, idealizált sztárok köré építették fel, akik már jelenlétükkel a moziba csábították a nézőket, a film témája másodlagos volt. Színészek és színésznők, alkalmanként rendezők is tartozhattak ehhez a rendszerhez, amennyiben kellő személyes vagy szakmai vonzerővel rendelkeztek. Ez a glamour általában nem természetükből fakadóan volt jelen, hanem a stúdiók erre szakosodott szakemberei tudatosan építették fel egy kiválasztott személy köré. A 30as évektöl az 50-es évekig létezett a klasszikus amerikai star system. Más országok stúdiói is igyekeztek meghonosítani ezt a szokást saját filmszínészeikre alapozva, ebben legsikeresebbnek az olasz Cinecittà és a spanyol Cifesa volt mondható.

${ }^{351}$ A diktatúra bukása után több korábbi „sztár” (Alfredo Mayo, Francisco Rabal, Fernado Fernán Gómez vagy Fernando Rey) is gyakran kitért rá az interjúkban, hogy csak anyagi okokból és müvészi önmegvalósítás céljából játszottak és próbáltak meg tökéletes, hiteles alakítást nyújtani ezekben a produkciókban.
} 


\section{Cifesa}

A Compañía Industrial Films Españoles, S.A-t, ismertebb nevén Cifesát 1932-ben alakította meg Valenciában a Casanova család. ${ }^{352}$ Közel 20 éven keresztül a legfontosabb filmstúdiónak számított Spanyolországban, leginkább a szuperprodukcióival szerzett hírnevet. Szlogenje: „A sikerek fáklyája”. Az amerikai Columbia stúdióval kötött szerződése alapján a legsikeresebb hollywoodi alkotásokat is ez a cég forgalmazta Spanyolországban, üzletpolitikája, menedzsmentje és produkciói segítségével pedig amerikai stílusú stúdiórendszert igyekezett kialakítani. Az első olyan filmvállalat volt, amely üzleti tervet és forgatási ütemtervet készített, a forgatásokhoz pedig nem épített vagy vásárolt saját stúdiókat, hanem kibérelte a már meglévőket. A Második Köztársaság idején a Cifesa képviselte a konzervatív-jobboldali elveken alapuló filmgyártást, vele szemben állt a liberális értelmiséghez és gazdasági körökhöz kötődő, kisebb jelentőségre szert tevő Filmófono. Vicente Casanova 1935-ben egy újságcikkben kifejezte a náci Németország filmgyártása iránti tiszteletét, csodálta a fejlődését, valamint a közvetített ideológiai üzeneteket. ${ }^{353}$

A Cifesa a köztársaság idején a spanyol vidéken játszódó drámák és españoladák ${ }^{354}$ gyártására specializálódott, majd egyre hangsúlyosabb lett müveiben a konzervatív értékrend. Az általa kiadott Noticiario Cifesa hírlap cikkei alapján a stúdió vezetői feladatuknak tartották, hogy felemeljék a spanyol filmmüvészetet az őt megillető magasságokba, mert a világ legtökéletesebb kultúrájával, természeti adottságaival és történelmével rendelkező civilizáció (vagyis a spanyol) megérdemli, hogy filmmüvészetét tekintve is világelső legyen. Ebben pedig kizárólag a Cifesa segíthet. Október 12-ére, a Faj napjára, valamint a valenciai Fallas idejére hatalmas ünnepségeket, társadalmi eseményeket, bálokat, sportrendezvényeket szerveztek. $^{355}$ A stúdió égisze alól kerülttek ki a 30-as évek legnépszerübb alkotásai, Florián Rey rendező és felesége, Imperio Argentina színésznő zenés-táncos folklórfilmjei. A Francorendszerben a látványos produkciók mellett az emberi / humánus vígjátékok (comedia humana) műfajába tartozó műveket is láthatunk a stúdió profiljában, amelyek lényege, hogy a polgárháború utáni Spanyolországban az addig szegénységben élő ifjak lehetőséget kapnak, hogy kitörjenek a nyomorúságból és megvalósíthassák álmaikat, miközben a szerelem is beköszönt életükbe. A rezsimhez hü rendezők is tettek kirándulásokat ebbe a müfajba, egyik

\footnotetext{
${ }^{352} \mathrm{Az}$ alábbi monográfia feldolgozza a stúdió történetét, mindenekelőtt gazdasági és üzletpolitikai szempontból: Fanés, Félix: Cifesa, la antorcha de los éxitos. Valencia, Institución Alfonso el Magnánimo, 1982. A Cifesáról szóló információk többségét én is innen vettem, kivéve, ahol más forrásra hivatkozom.

${ }^{353}$ Erről lásd: Montero, Julio - Paz, Maria Antonia: La larga sombra de Hitler. El cine nazi en España (19331945). Madrid, Ediciones Cátedra, 2009. 98.

${ }^{354}$ Az españolada müfajáról „A spanyol „nemzeti” film” címủ alfejezetben szólok részletesen.

${ }^{355}$ Fanés, Félix: Cifesa, la antorcha de los éxitos. Id. mủ. 28-29.
} 
fontos darabja az Elbüvölöen bolondok (Deliciosamente tontos, Juan de Orduña, 1943), ahol egy örökség reményében látszatházasságot kötő pár szeret egymásba a játékidő végére.

A polgárháború kitörésekor egy Cifesa-stáb éppen Córdobában forgatott, az általuk használt technikai berendezések és személyzet lett az egyik első, amely a felkelők szolgálatába állt (a CEA stúdió egy forgatócsoportja szintén a „,nemzeti” területen ragadt, ők is felajánlották szolgálataikat a csapatoknak). A stúdióelnök Vicente Casanova már a háború első hónapjaiban egy megállapodást ír alá Sevillában Gonzalo Queipo de Llano tábornokkal, amely értelmében a Cifesát illeti meg a nemzeti filmpropaganda gyártásának elsődleges joga, valamint azonnal szerződéseket köt a stúdió az éppen megalakult Nemzeti Sajtó- és Propagandaügyi Hivatallal. Bár közel húsz propagandacélú dokumentumfilmet és számos filmhíradót is gyártottak a felkelő hadseregnek, a kívánt exkluzivitást nem nyerték el, mindössze ígéretet kaptak arra, hogy ,a leendő új spanyol kormány állni fogja azon filmek költségeit, amelyek azt megérdemlik". 356

A rezsim alatt a filmipart érintő protekcionista intézkedések, valamint a filmgyártást és terjesztést ösztönző állami kedvezmények és támogatások mind a Cifesát hozták előnyös helyzetbe, mivel ez a vállalat volt jelen a legnagyobb százalékban minden területen. Üzletpolitikájához tartozott, hogy a 40-es évek közepéig legtöbb filmjét koprodukcióban forgatta más stúdiókkal, ahol a Cifesa részesedése általában 60-70 \% között mozgott: többségi résztvevőként övé volt a döntő szó, de a gyártási költségek megoszlottak. Szintén sikeres vállalkozás volt, hogy, ismét csak az amerikai mintát követve, áttért a sorozatban történő gyártásra: egy film forgatásához összeállított stábot a következő alkotás készítése során is felhasznált, így minden területen rendelkezésére állt egy már összeszokott szakembergárda. ${ }^{357}$ Kizárólagos szerződéssel kötött magához színészeket, rendezőket, akik megbízható munkatársként teljesítették a feladatot, ugyanakkor a rendezők egyéni látásmódjukat is hozzáadhatták a művekhez. Az elnök Vicente Casanova befolyásos kapcsolatokat épített ki a politika legfelsőbb szintjein kulcspozíciókat elfoglaló személyekkel, a későbbi kormányelnök Luis Carrero Blanco közeli barátjának számított; egészen az 50-es évek közepéig rajtuk keresztül jutottak el Casanovához az arról szóló nem hivatalos értesülések, hogy milyen témájú filmeket látna szívesen a hatalom, melyeket jutalmazna meg nagy valószínűséggel. ${ }^{358}$

A második világháború után továbbra is nagy számban gyártotta a kis költségvetésü, de minőségi melodrámákat és komédiákat, valamint háborús és kalandfilmeket is. Legnagyobb

\footnotetext{
${ }^{356}$ Tranche, Rafael R - Sánchez-Biosca, Vicente: NO-DO. Id. mü. 25-26.

${ }^{357}$ Fanés, Félix: Cifesa, la antorcha de los éxitos. Id. mü. 102-106.

${ }^{358}$ Uo. 165-166.
} 
számban az arisztokrata körökben játszódó romantikus történetek készültek. Legtöbb anyagi és szellemi forrását azonban a stúdió az úgynevezett nemzeti történelmi szuperprodukciókra fordította. Mind technikai, mind müvészi értelemben nagy odafigyeléssel készített filmekröl van szó, amelyeket hasonló profizmussal kivitelezett reklámkampányok segítségével népszerüsítettek. Témájukat tekintve az állam által felmagasztalt, dicsőségesnek tartott történelmi korokban játszódtak, így természetes volt, hogy az állami sajtó is komoly támogatásban részesítette ezeket a produkciókat. Juan de Orduña és Luis Lucia filmrendezők nevéhez füződött a legtöbb ilyen történelmi film, a legfontosabbakról a későbbiekben részletesen is szólok. Közös jellemzőjük, hogy a történelmet a közönség számára megfoghatóvá, élvezhetővé, érthetővé, populárisabbá tették: nem csak történelmi tények és személyek egymás után történő felsorakoztatására törekedtek, hanem a korabeli nézők számára érdekes, érzelmes, helyenként izgalmas forgatókönyveket adaptáltak, eltorzítva és (általában szándékosan) meghamisítva néhány történelmi tényt. Mindegyikben párhuzamosan futott legalább egy politikai és egy szerelmi szál, a cselekmény szövése folyamán pedig változó, hogy éppen melyik kerül előtérbe, és az is, hogy melyik kelti fel inkább a nézők érdeklődését. A rendező Juan de Orduña meggyőződése mindegyikre érvényes: „Mindig is azt vallottam, hogy a történelmi filmek, ahhoz, hogy valóban elviselhetőek legyenek, 20-30\%ban kell megfeleljenek a történelmi tényeknek, 70-80\%-ban pedig inkább a fantázia szüleményei." ${ }^{359}$ Ezzel magyarázható, hogy az españolada és a folklórfilmek jellegzetességei sok ilyen alkotásban feltünnek. Mindezt pedig a rendszer történelem- és nemzetfelfogásának megfelelő ideológiai burokkal vették körül, ahol az elsődleges szempont az egységes, katolikus, spanyol nemzet védelme a kisebbséggel, forradalmárokkal, puccsistákkal és külföldi (nemzetközi) összeesküvőkkel, támadókkal szemben.

A stúdió fénykorában a filmgyártás minden területén jelen kívánt lenni: 1948-ban Cifesa-díjat is alapítottak, amelyet az IIEC-ben végzett legjobb tanulónak ítéltek oda minden évben. Az elsőt Juan Antonio Bardem kapta. ${ }^{360}$

A Cifesa stratégiája kiválóan kielégítette mind a hatalom, mind a közönség igényeit: a fö irányelveknek megfelelően közvetítette az üzeneteket, tette mindezt szórakoztató formában. A hanyatlás okai ugyanehhez a filmtípushoz kötődnek. Ahogyan a különböző müfajok kapcsán számos alkalommal bekövetkezett a világ filmtörténetében, egy bizonyos zsáner csak néhány évig, esetleg évtizedig tudja megőrizni népszerüségét, ezután a közönség

\footnotetext{
${ }^{359}$ Castro, Antonio: El cine español en el banquillo. Valencia, Fernando Torres, 1974. 75.

${ }^{360}$ Bardem, Juan Antonio: Y todavía sigue. Id. mü. 69.
} 
érdeklődését veszíti. ${ }^{361}$ A Cifesa azonban nem volt hajlandó tudomásul venni, hogy változtatnia kell profilján: az egyre költségesebbé váló, de egyre kevesebb nézőt vonzó történelmi filmjei anyagilag nehéz helyzetbe sodorták a stúdiót, és tovább rontotta a helyzetet, hogy alkalmazottaikat több évre szóló, nagy összegü szerződésekkel kötötték magukhoz, valamint a rivális Suevia Films is egyre nagyobb piaci hányadot hódított el. José María García Escudero filmföigazgató első periódusa idején (1951-1952) ráadásul számos támadás érte őket a filmek minősége miatt, és a Barázdák (Surcos, José Antonio Nieves Conde, 1951) Amerika hajnala (Alba de América, Juan de Orduña, 1951) filmek „párharca” kapcsán kirobbant botrány csak fokozta a problémákat. ${ }^{362}$ A könnyedebb hangvételü, de még mindig történelmi témájú és nagy költségvetésű Lola, a faszénárus (Lola la Piconera, Luis Lucia, 1951) volt a stúdió utolsó produkciója, 1956-ra a Cifesa gyártó részlege csődbe ment, a Banco Real a tartozások fejében átvette a stúdió pénzügyi irányítását. A filmforgalmazói tevékenységet még közel egy évtizedig folytatták.

\section{Suevia Films}

A Casanova család stúdiójával ellentétben Cesáreo González - aki producerként 1941től volt jelen a filmvilágban - produkcióival leginkább a szórakoztatásra és a nagy bevételekre koncentrált. A Hispanidad elveit azonban ő maga is felhasználta: filmográfiájában lényeges elemeket tesznek ki a Latin-Amerikával forgatott koprodukciók, illetve az onnan „importált” sztárok, hírességek spanyol filmben történő szerepeltetése. A 40-es évek közepétől egészen a 60-as évekig üzleti szempontból González tekinthető a legsikeresebb filmmogulnak Spanyolországban. Filmjeinek ideológiai üzenete kevésbé volt hangsúlyos, ezért részletesebben nem térek ki munkásságára. ${ }^{363}$ Sikere azonban elvitathatatlan: egy 1965-ös statisztika szerint 233 filmet forgalmazott, ezek közül 130 tisztán spanyol produkció (nagy részük González produceri közremüködésével készült), 29 mexikói és 18 argentin, valamint számos koprodukció. A Suevia Films a világ 108 országában rendelkezett leányvállalattal vagy képviselettel (köztuik olyan távoli helyek, mint Dél-Vietnám, Hong-Kong, Pakisztán és Sierra Leone), ahol a filmterjesztés mellett más spanyol üzleti érdekeket is képviselt a diktatúra éveiben. ${ }^{364}$

\footnotetext{
${ }^{361}$ Leginkább a western, a musical, a háborús és a kosztümös történelmi film rendelkezik ilyen korszakokkal, elsősorban az Amerikai Egyesült Államokban. Mindegyiknek megvolt az aranykora, majd következett egy hanyatló periódus, hogy aztán ismét visszatérjen a népszerủ müfajok közé.

${ }^{362}$ Erről lásd részletesebben a Barázdákkal foglalkozó alfejezetet.

${ }^{363}$ A Suevia Films történetével foglalkozik: Castro de Paz, José Luis - Cerdán, Josetxo (szerk.): Suevia Films Cesáreo González: treinta años de cine español. A Coruña, Centro Galego de Artes da Imaxe, 2005.

${ }^{364}$ Taibo I, Paco Ignacio: Un cine para un imperio. Id. mü. 223-224.
} 
A Cifesa és a Suevia közötti harc az 50-es évek elejétől az utóbbi javára dőlt el. Míg a Casanova-birodalom képtelen volt megújulni, és ragaszkodott a diktatúra ideológiai kiszolgálásához, González vállalata sikeresen kombinálta az eszmét az innovációval és a marketinggel. A Cifesához nagyságrendekkel több állami támogatás érkezett, mint a Sueviához, így az utóbbinak a piacot kellett meghódítania. ${ }^{365}$ A Cifesa bukása után a Suevia lett a legfontosabb, legtöbb érdekeltséggel rendelkező stúdió. A 60-as évek nyitást ösztönző légkörében, José María García Escudero új filmpolitikájának köszönhetően, González exkluzív jogokkal már ideológiailag semleges szovjet filmeket is forgalmazhatott, de csak olyanokat, amelyek cselekménye az 1917-es orosz forradalom előtt játszódott, így García Escudero és González közös erőfeszítései ellenére sem ismerhette meg a spanyol közönség például a Szállnak a darvakat (Летят журавли, Mihail Kalatozov, 1957). Képviselői útján a spanyol filmeket már értékesíthette Moszkvában is. ${ }^{366}$

\section{A folyóirat: Primer Plano}

Ahogyan korábban már említettem, több filmmel foglalkozó folyóirat is napvilágot látott a 40-es években. A polgárháború előtt létezők (Popular Film, Nuestro Cinema, Cinegramas stb.) mind eltüntek, az újak közül elsőként a Radiocinemát hozta létre La Coruñában a felkelő hadsereg 1938-ban; a háború során kiadott számok vezércikkeiben minden alkalommal kiemelik, hogy legfőbb céljuk: a filmet a burgosi kormány propagandaeszközévé tenni, a teljes filmmüvészetet Franco tábornok szolgálatába állítani. A rezsim során kezdetben erőteljesen, majd egyre kevésbé ideologizált filmművészeti folyóirattá vált, egészen 1963-as megszünéséig. További jelentős, a témához illeszkedő folyóiratnak számított a Cámara, az egyházi Film Ideal, valamint a Nemzeti Szórakoztatóipari Szakszervezethez tartozó Espectáculo. Mind közül a Radiocinema és az alább tárgyalt lap volt a legnépszerübb a közönség körében. ${ }^{367}$

Az állami propaganda erőteljes jelenlétét, a filmelméleti, filmművészeti kérdéseket tárgyaló írások minőségét és mennyiségét tekintve az 1940-ben született Primer Plano számított a legfontosabb filmes tárgyú folyóiratnak. Tekinthetjük a francói filmpolitika hivatalos sajtóorgánumának, írásainak hangneme és vezérfonala a diktatúra belpolitikájával és

\footnotetext{
365 Uo. 225.

${ }^{366}$ Gubern, Román - Font, Doménec: Un cine para el cadalso. Id. mü. 115.

367 A népszerüséget alátámasztani számadatokkal nem tudjuk, mert nem volt arról nyilvántartás, hogy mekkora példányszámban jelentek meg ezek a lapok. Annyi bizonyos, hogy a Franco-rendszer folyamán mindvégig a Primer Plano és a Radiocinema volt a hivatkozási alap a filmtörténészek, az értelmiség és a közönség számára a spanyol film területén, és ez ma is így van, amikor erre a korszakra tekintenek vissza.
} 
ideológiai változásaival összhangban folyamatosan módosult. Az alapító Manuel Augusto García Viñolas (egyben a Filmművészet Nemzeti Szakosztálya igazgatója) két éven keresztül maradt a főszerkesztői poszton, ez idő alatt valódi filmművészeti folyóiratot hozott létre, erőteljes ideológiai töltettel; a közremüködők között olyan neveket találunk, mint Pío Baroja, Rafael Sánchez Masas, Eugenio D’Ors, Ernesto Giménez Caballero, Manuel Machado, Wenceslao Fernández-Flórez, Azorín, vagy Eugenio Montes. Az első években számos olyan cikk jelent meg a legfontosabb propagandisták, politikusok és egyházi személyek tollából, amelyek arra keresték a választ, milyen is az igazi nemzeti film. Tudósítottak más országok filmpolitikai rendelkezéseiről is, jelezve, mely részeket kellene átemelni spanyol környezetbe (a világháború alatt Németország, Olaszország és a francia Vichy-kormány intézkedéseit vizsgálták, később ilyen cikkek már csak elvétve fordultak elő). A folyóirat kezdeményezésére és aktív közremüködésével jött létre 1940-ben a Spanyol Filmmüvészeti Kör (Círculo Cinematográfico Español - CIRCE) García Viñolas elnökletével, amely célját tekintve a spanyol filmipar müvészeti, bibliográfiai hátterét szándékozott kimunkálni, lehetőséget biztosítva filmes folyóiratok és könyvek publikálására, valamint konferenciák, szakmai továbbképzések, kiállítások és olyan filmklubok szervezésére, ahol a közönség a hagyományos mozikban nem látható külföldi filmeket is megnézhetett. ${ }^{368} \mathrm{~A}$ CIRCE és a Primer Plano együttesen próbálták meg kialakítani az új spanyol filmkultúrát, ahol egyszerre lehet helye a müvészetnek és az ideológiának.

García Viñolas a Falange egyik kiemelkedő politikusa volt, így a párt filmpolitikai szócsöveként funkcionált a lap első 78 száma, mindvégig megőrizve annak filmművészeti aspektusait is. 1942-ben váltás történt a főszerkesztői poszton, a rezsim elsőszámú filmtörténészének tartott Carlos Fernández Cuenca került vezető pozícióba, a tájékoztatási és idegenforgalmi miniszter Gabriel Arias Salgado pedig a Primer Planót a Nemzeti Sajtó- és Propagandaügyi Hivatal hatáskörébe rendelte. ${ }^{369}$ Ettől kezdve már hivatalosan is a rezsim filmművészeti folyóiratává vált. Az ideológiai írások mellett a filmművészeti témájú cikkek is megjelentek, kiegészülve forgatási tudósításokkal és interjúkkal, amelyek a filmet teljes értékü művészeti és kulturális ágként kezelték. A Fernández Cuencát követő főszerkesztők irányítása alatt sem változott érdemben a lap orientációja, de megjelentek a külföldi tudósítók beszámolói, majd, igazodva az olvasói elvárásokhoz, a filmsztárok életére és megjelenéseire

\footnotetext{
${ }^{368}$ A CIRCE működéséről lásd: Díez Puertas, Emeterio: „El Círculo Cinematográfico Español (1940-1944)” in: Historia y Comunicación Social, No. 13. 2008. 47-62.

${ }^{369}$ Minguet i Battlori, Joan M: „La regeneración del cine como hecho cultural durante el primer franquismo (Manuel Augusto García Viñolas y la etapa inicial de „Primer Plano”)” in: Actas del VI Congreso de la A.E.H.C. Madrid, Academia de las Artes y las Ciencias Cinematográficas de España, 1998. 197-199.
} 
fókuszáló pletykarovatok is. Az 50-es évek végétől a hollywoodi filmmagazinok stílusát másolta, majd 1963-ban megszünt.

$\mathrm{Az}$ értekezés során több helyen is támaszkodom a Primer Plano cikkeire és vezércikkeire, így képet kaphatunk arról is, milyen, a témámhoz illeszkedő írásokat publikált.

Legfontosabb a föszerkesztő García Viñolas vezércikksorozata Kiáltvány a spanyol filmhez címmel, amely az első öt számban jelent meg $^{370}$; ez megmutatja, milyen filmpolitikai célokat tüzött ki maga elé a főszerkesztő, rajta keresztül pedig a Falange és a rezsim. Először a film mint mủvészeti ág kérdését járja körül, és megállapítja, hogy az észak-amerikai világhatalmi felsőbbrendüség részben ennek az új médiumnak köszönhető. Ahhoz, hogy a spanyol filmgyártás felemelkedhessen, mindenekelőtt szükség van a filmipar kiépítésére, az infrastruktúra és az anyagi háttér létrehozására, és csak ezután lehet a film céljairól beszélni. A szerző úgy véli, Spanyolország filmgyártása lemaradásban van a többi országéval szemben, annak megújítása elengedhetetlen az egész spanyol nemzet megújításához. Új szemléletet kell meghonosítani a filmmüvészethez történő viszonyulásban, és ebben a politikának döntő szerepet kell vállalnia. Át kell állni a szisztematikus tervezésre, mert a korábbi spanyol filmpolitikákat az improvizáció és a kalandorság (aventurismo) jellemezték. A művészeti, ipari és elméleti megalapozás után a negyedik részben tér át a főszerkesztő a film mint politikai eszköz kérdésére, idézve Mussolinit: „A film a legerősebb fegyver”. Spanyolországban is szükséges szerinte az állami beavatkozás és kontroll, mert a filmet mindenhol fegyverként kell használni. Ehhez állami hiteleket kell a filmipar rendelkezésére bocsátani, bevonni a magántőkét, valamint mindvégig szem előtt tartani, hogy müvészeti szempontból is kiemelkedő alkotások szülessenek (ez utóbbi kitétel ritkán jelenik meg más szerzők írásaiban, amikor az új nemzeti filmről értekeznek). Záró soraiban megfogalmazza kétségeit, hogy a spanyol nemzeti érzelmeket vajon ki lehet-e fejezni a maguk teljességében a film segítségével; erre a választ másoktól, elsősorban a filmművészektől várja.

A folyóirat későbbi vezércikkeiben a főszerkesztő és a szerzők (általában értelmiségiek) folyamatosan a nemzeti film jelentőségére, szükséges voltára reflektálnak, és azokra a lehetőségekre, művészi, technikai és anyagi természetü problémákra, sürgető és megoldandó kérdésekre, amelyekkel a mozgókép a pillanatnyi állapotokat tekintve rendelkezik.

Általánosságban elmondható, hogy, míg ideológiailag a Szovjetuniót a Franco-rezsim esküdt ellenségének tartotta, addig annak filmművészetét és filmpolitikáját csodálta.

\footnotetext{
${ }^{370}$ García Viñolas, Manuel Augusto: „Manifiesto a la cinematografía española I-V” in: Primer Plano, No. 1. 1940. október 20; No. 2. 1940. október 27; No. 3. 1940. november 3; No. 4. 1940. november 10; No. 5. 1940. november 17 .
} 
Bartolomé Mostaza úgy vélekedett, hogy Eizenstein filmjeinek hatására többen váltak kommunistává, mint bármilyen más propagandának köszönhetően, a szovjet filmmüvészet pedig az egyik legtökéletesebb. Filmpolitikát tekintve az orosz mellett a náci Németországét kell követni, ahol a mozit teljes mértékben az állam és az annak történő feltétlen engedelmesség szolgálatába állították. ${ }^{371}$

Fernández Cuenca főszerkesztői kinevezésével (1942) változik a hangnem, a vezércikkek többsége a spanyol filmmüvészet felsőbbrendüségét hirdeti, amelyet összekapcsol a polgárháború révén elnyert nemzeti függetlenség eszméjével. Az írások szerint nem csak Spanyolország, hanem a spanyol filmkészítés is megmenekült a kommunizmustól. A filmmüvészet a spanyol állam egyik legfontosabb szektorává válik, a cikkekkel ezt igyekeznek alátámasztani. Egyes írások szerint a spanyol mozgókép a létét köszönheti annak, hogy a Nemzeti Mozgalom került hatalomra, mert így válhatott csak valódi mủvészeti ággá; a továbbiakban a celluloid legfőbb feladata, hogy szolgálja a spanyol hazát, elmesélje annak dicsőséges múltját, jelenét és jövőjét, bemutassa kulturális és természeti kincseit. ${ }^{372}$

A Falange ideológusa, Ernesto Giménez Caballero szerint a spanyol filmekben meg kell jeleníteni a nemzeti tradíció és a jövőre vonatkozó álmok minden elemét, Spanyolország géniusza leginkább a mozgóképen keresztuil mutatkozhat meg. Az emberiség Végzetét így ismét Spanyolország uralhatja majd, visszaszerezve azt a hatalmat, amelyet most alsóbbrendü fajok birtokolnak. Mindehhez fejleszteni kell a színészek interpretációs képességét, támogatni a háborús film müfaját, mintául a Faj, a Vörös és fekete (Rojo y negro, Carlos Arévalo, 1942) és Az Alcázarban a helyzet változatlan (Sin novedad en el Alcázar, Augusto Genina, 1940) ${ }^{373}$ szolgálhat, mindig szem elött tartva, hogy Spanyolország az első nemzet volt a világtörténelemben, amely legyőzte a kommunizmust. Erre most lehetőség van, mert a nemzetközi elszigetelődésnek hála nem érkezik be az országba „,a külföldi hülyeség”. Ha lezárul a világháború, a spanyol film fogja képviselni mindazon magasztos értékeket a világban, amelyeket korábban a missziók és a katolikus színház. ${ }^{374}$

A kötelező szinkron tárgyalása kapcsán már utaltunk rá, hogy annak fogadtatása nem volt egyöntetüen pozitív: míg egyesek a castellano nyelv egyeduralma érdekében üdvözölték azt, mások szerint a spanyol filmek elveszítették a külföldi filmekkel szembeni elönyüket azáltal, hogy minden mű spanyol nyelven szólt a közönségéhez. A vitának a Primer Plano hasábjai is helyt adtak, a cenzúrát ellenző szerzők 1943 végétől erőteljesen támadták a

\footnotetext{
${ }^{371}$ Mostaza, Bartolomé: „El cine como propaganda” in: Primer plano, No. 10. 1940. december 22.

372 Cortés Cavanillas, Julián: „Panorama prometedor” in: Primer Plano, No. 109. 1942. november 13.

373 Mindhárom filmet részletesen tárgyalom a későbbiekben.

${ }^{374}$ Giménez Caballero, Ernesto: „España y el cine” in: Primer Plano, No. 100. 1942. október 13.
} 
döntéshozókat; a hangnem helyenként olyan szélsőséges volt, hogy meglepő, hogyan is jelenhetett meg ilyen cikk ebben a korszakban. Egy producer azt is felhozta érvként, hogy a külföldi filmek jobbak, mint a spanyolok, ezért, ha azonos nyelven beszélnek, akkor egyértelmüen a hazai filmgyártás marad alul. ${ }^{375}$ A szinkron ellenzői köré filmrendezők és értelmiségiek csoportosultak, velük a döntéshozók vitatkoztak. 1943 ősze és 1944 tavasza között húsznál is több írás jelent meg ebben a témában, majd 1944 márciusában egy név nélkül publikált cikk lezárta a vitát azzal, hogy a szinkronról döntés született, az érvénybe lépett, így mostantól a legfontosabb feladat, hogy a nemzet érdekében mindenki támogassa annak létezését és gyakorlati működését. ${ }^{376}$

A későbbiekben a Primer Plano hasábjain vezércikkekben és esszékben folyamatosan értekeztek az éppen aktuális kérdésekről, mindvégig kihangsúlyozva a korábban már említett szempontokat: a filmnek az állam szolgálatában kell állnia, miközben szem előtt kell tartania a művészi értékeket is.

\footnotetext{
${ }^{375}$ Ballesteros, Serafín: „Para navegar en un mar de confusiones” in: Primer Plano, No. 172. 1944. január 30.

376 „Síntesis de una polémica” in: Primer Plano, No. 178. 1944. március 12.
} 


\section{A polgárháború filmtermése és a NO-DO}

A két téma egy fejezetben történő tárgyalását az indokolja, hogy mindkettőről bő és rendkívül informatív szakirodalom áll rendelkezésre spanyol nyelven, jelen dolgozat keretein belül nem tudok hozzátenni sok újdonságot. Magyar nyelven azonban még nem foglalkoztak ezekkel a kérdésekkel, és egy Franco-rendszer filmpolitikáját tárgyaló tudományos értekezésben mindenképpen szólni kell ezekről is, így orientációs célból egy-egy alfejezetben összefoglalom az elmúlt húsz évben született irodalom eredményeit, valamint az általam megtekintett releváns alkotások alapján levont következtetéseimet.

\section{A polgárháború}

A spanyol filmtörténetet tárgyaló munkák közül legbővebb bibliográfiája az 1936-39 között zajlott polgárháborúnak van, a témát kimerítő alapossággal tárgyaló monográfiák ${ }^{377}$ részletesen elemzik mindkét oldal filmgyártását, valamint a későbbi évtizedek filmjeinek háború-ábrázolását. Összefoglalásomhoz ezeket a müveket, valamint a megtekintett filmeket vettem alapul.

Mindkét oldalra jellemző, hogy elsősorban filmhíradókat és rövid dokumentumfilmeket gyártottak, játékfilmeket csak elvétve: ezeket inkább importálták, illetve a korábbi években készült müveket vetítették, amennyiben azok tartalmát megfelelőnek ítélték.

Számadatok tekintetében a következő eredményekre jutottak filmtörténészek: a polgárháború éveiben a köztársasági oldalon 360 film készült (313 dokumentumfilm, 10 filmhíradó és 37 játékfilm; ez utóbbi kategória nagyrészt már korábban elkezdett filmek befejezését jelentette), a felkelők oldalán pedig 93 (80 dokumentumfilm, 5 filmhíradó, 8 játékfilm, utóbbi esetben is mindenekelőtt a végső munkálatok elvégzéséről van szó). Külföldi filmek esetében az alábbi adatok állnak rendelkezésre: 66 darab köztársaságiakkal szimpatizáló dokumentumfilm és filmhíradó készült (döntően Nagy-Britannia, Franciaország,

\footnotetext{
${ }^{377}$ A legfontosabb, általam is használt müvek (a historiográfiai fejezetben már hivatkozott monográfiák): Amo García, Alfonso del (szerk.): Catálogo general del cine de la Guerra Civil. Madrid, Cátedra - Filmoteca Española, 1996; Álvarez Berciano, Rosa - Sala Noguer, Ramón: El cine en la zona nacional, 1936-39. Bilbao, Mensajero, 2000; Crusells, Magí: La Guerra Civil española: cine y propaganda. Barcelona, Editorial Ariel, 2000; Fernández Cuenca, Carlos: La guerra de España y el cine. Madrid, Editora Nacional, 1972; Sala Noguer, Ramón: El cine en la España republicana, 1936-39. Bilbao, Mensajero, 1993; Sánchez-Biosca, Vicente: Cine y Guerra Civil Española. Madrid, Alianza Editorial, 2006; Sánchez-Biosca, Vicente: España en armas: El cine de la Guerra Civil Española. Diputación de Valencia, 2007; Sánchez-Biosca, Vicente - Tranche, Rafael R.: El pasado es el destino: Propaganda y cine del bando nacional en la guerra. Madrid, Cátedra, 2011.
} 
a Szovjetunió és az Amerikai Egyesült Államok részvételével), a felkelők mellett 43 alkotás foglalt állást (főleg olasz és német alkotások, a dokumentumfilmek és filmhíradók mellett 7 játékfilm is idesorolható), semleges hangvételü film pedig 29 darab készült (szintén brit, francia és amerikai stúdiókban). ${ }^{378}$

A dolgozatom vizsgálati köre szempontjából kevéssé releváns köztársasági filmkészítés jellemzőire nem térek ki részletesebben, mindössze annyira, amennyire a téma megkívánja. A filmgyártás éppen kialakult infrastrukturális háttere, stúdiói, technikai berendezései és szakemberei szinte kivétel nélkül a köztársasági ellenőrzés alatt álló területekhez kötődtek, a legjelentősebb filmgyártói központ ekkor Barcelona volt. A polgárháború előtt hatalmon lévő Népfrontot alkotó pártok, szervezetek mind saját filmgyártásba kezdtek, amely elsősorban dokumentumfilmek, híradók rögzítését jelentette. A már létező stúdiókat, berendezéseket, majd a vetítőtermeket is kisajátították, államosították. Így elkülöníthető kormányzati, marxista, anarchista, anarchoszindikalista filmkészítés is; ezen belül, minden csoport rendelkezett saját propagandaközponttal. Az operatőrök az elkészült anyagot az adott párt vagy szervezet illetékes testülete előtt bemutatták, majd annak engedélyével kerülhetett bel- és külföldi forgalmazásra. A háborús propaganda szempontjából elsősorban a dokumentumfilmek és híradók forgatása volt elsődleges. Magánkézben lévő produkciós cégek - a kisajátítások miatt - kis mértékben járultak csak hozzá a köztársasági filmgyártáshoz. ${ }^{379}$ A propagandacélú dokumentumfilmek előállításában az anarchista és a kommunista szervezetek filmes szekciói jártak az élen, utóbbiak pedig (mindenekelőtt a Film Popular nevü produkciós és terjesztő vállalat) nagy mennyiségü szovjet játékfilmet is importáltak. Mindezeken felül főleg hollywoodi komédiákat láthattak a köztársasági zónában élő nézők. A Film Popular már alapításakor is jelezte, milyen célokat tart szem előtt: a hiteles forradalmi filmkészítés termékeit akarja bemutatni nézőinek, a dolgozó és harcoló nép előtt meg akarja nyitni az új müvészeti forma kapuit és elhozni Spanyolországba azon antiimperialista és antifasiszta mủveket, amelyek előállításában a Szovjetunió főszerepet játszik. ${ }^{380}$ A háború alatt külföldre távozó Luis Buñuel is aktívan támogatta a köztársasági filmkészítést. $^{381}$

\footnotetext{
${ }^{378}$ Az adatokat közli: Ibáñez Ferradas, María Luisa: „Un inconexo retablo de luz y sombra” in: Amo García, Alfonso del (szerk.): Catálogo general del cine de la Guerra Civil. Id. mü. 31.

${ }^{379}$ Minderröl lásd: Sala Noguer, Ramón: El cine en la España republicana, 1936-39. Id. mü.

${ }^{380}$ Cabeza Rodríguez, José: „Madrid en guerra: un público para la revolución” in: Pelaz, José-Vidal - Rueda, José Carlos (szerk.): Ver cine. Id. mü. 142.

${ }^{381}$ Erről lásd: Crusells, Magí: „La producción de Luis Buñuel a favor de la causa republicana (1936-1939)” in: FilmHistoria Online, Vol. XVI. No. 3. 2006.

Elérhető: $\quad$ http://www.publicacions.ub.edu/bibliotecadigital/cinema/filmhistoria/2006/Ensayo bunuel_1.htm (2012-11-29)
} 
A felkelök oldalán a Serrano Súñer vezette Belügyminisztériumban müködő, már említett Nemzeti Sajtó- és Propagandaügyi Hivatal egyik része volt a Propaganda Főigazgatóság (Dirección General de Propaganda) Dionisio Ridruejo irányításával, ezen belül állt fel a Filmművészet Nemzeti Szakosztálya (Departamento Nacional de Cinematografía) Manuel Augusto García Viñolas vezetésével. A FET y de las JONS Filmszekciójával (Sección Cinematográfica de FET y de las JONS) kiegészülve a nacionalista filmkészítés falangista kézben volt, szegényes infrastruktúráját a Cifesa és a CEA stúdiók a zónában maradt eszközei adták. Az általuk készített filmhíradók és dokumentumfilmek a felkelő csapatok előrenyomulását, győzelmeit és Franco beszédeit, valamint a köztársasági csapatok, a „vörösök” pusztításait örökítették meg.

Számos közös vonás említhető, amely jellemző volt minden, a Nemzeti Mozgalom égisze alatt készült, propagandacélú filmre. Ilyen a képek és a kommentár viszonya. Az erő nem a képekben rejlik, hanem a hozzá füzött kommentárban. Egy város pusztítását megörökítő, vagy a köztársasági csapatokat váltó nemzeti erők megérkezését lefilmező munkák vizuális erejét az adja, hogy közel hozza a nézőt a harc történéseihez, a romboláshoz, halottakhoz, romokhoz. Az azonban nem lenne egyértelmü a verbális csatorna hozzáadása nélkül, hogy éppen mit is látunk: egy nacionalista propagandafilmet, vagy éppen egy köztársaságiak által készített Franco-ellenes mozgóképet. A narrátor nem hagy kétséget afelöl, mit is kell látnunk. Számos esetben előfordult, hogy a különböző oldalon álló csapatok ugyanazt a képsorozatot teljes mértékben ellentétes módon kommentálták, így adva a látottaknak bal- vagy jobboldali értelmezést. Az is gyakori volt, hogy térben és időben egymástól nagy távolságra lévő események felvételeit montírozták össze, és a kommentár segítségével összekapcsolták őket, mintha egyazon helyen és időben készültek volna. A kamera minden helyszínen olyan elemeket, képeket keresett, amelyek kapcsán ellentétbe lehetett állítani az „ellenség” által okozott pusztítást a győzelemre törő csapatok sikereivel. Természetesen a saját oldal bemutatása a „költői túlzás” jegyeit viselte magán: minden felkelő katona az életét kockáztatta, tudatában volt annak, hogy talán soha nem látja viszont szeretteit, de mégis harcolt, mert a Haza ügye mindennél fontosabb volt. Ha ö nem kockáztatja az életét, akkor Spanyolország el fog veszni a „,örösök” kezén. Szintén állandó elem Franco tábornok jelenléte, általában egy harcra vagy kitartásra buzdító beszéd ürügyén.

Az alábbiakban kiemelek néhány olyan jelentős dokumentumfilmet, amelyet alkalmam volt megtekinteni.

A vizcayai front és július 18 (Frente de Vizcaya y 18 de julio, Sección Cinematográfica de FET y de las JONS, 1937) címü dokumentumfilm a falangista propaganda egyik 
kiemelkedő darabja, amely az északi fronton történő előrenyomulást, valamint a köztársaságiak által hátrahagyott pusztítást mutatja be sajátos szemszögböl. A film jól példázza a tipikus jegyeket, az ellenséget minden esetben szélsőséges jelzővel illetik: moszkovita hordák, vörös szeparatisták stb. A felkelök szemében ugyanis mindenki, aki a köztársaság mellett állt, és a baloldal bármelyik szárnyához tartozott, az kommunista, bolsevik, marxista jelzőt kapott. A film bemutatja Guernica pusztulását is. Ez a baszk város vált a spanyol polgárháború eseményeinek szimbólumává: 1937. április 26-án a felkelőket támogató német Kondor-légió és néhány olasz repülőgép lebombázta a települést, becslések szerint 200-300 halottat hagyva maga után, akik főleg az ártatlan civil lakosság köréből kerültek ki. A falangista propaganda azonban megpróbálta a felelősséget másra hárítani: közleményekben, valamint propagandaanyagokban és filmekben (ahogyan a szóban forgó rövidfilmben is) tudatták a lakossággal és a külvilággal, hogy Guernicát nem ők, hanem a visszavonuló kommunisták gyújtották fel, még mielőtt Franco csapatai odaértek volna. Napjainkban, ahogyan már a 40-es években is, számos megdönthetetlen bizonyíték árulkodik arról, hogy valóban légi bombázás történt, és nem gyújtogatás. Érdekes azonban megnézni a bizonyítékokat: a köztársaságiak is készítettek filmfelvételeket, és szinte ugyanazokat a képeket vonultatják fel bizonyítékként, mint a nemzetiek a saját igazuk alátámasztására. Az utókor azonban az előbbieket igazolta, és Guernica úgy vonult be a történelembe, mint a fasiszta-falangista pusztítás legkegyetlenebb epizódja. Említés szintjén érdemes megjegyezni: napjainkban ismét napirendre került a kérdés, ugyanis egyes köztársasági felvételeken is úgy látszik, mintha a házakat alulról gyújtották volna fel, ami persze ellentmond az általánosan elfogadott nézeteknek. Történészek és filmtörténészek, a baszk történelmet, illetve a polgárháborút kutatók a filmfelvételek kielemzésével igyekeznek a kérdést megvitatni. ${ }^{382}$

Számos ehhez hasonló film készült, ezek arról a régióról szóltak, amelyet éppen uralma alá vont a felkelő hadsereg. Mindegyik közös eleme, hogy saját előrenyomulásukat hősies, honvédő tettként állítják be, amellyel megtisztítják a városokat, falvakat a „,vörösöktől”, „kommunistáktól”, „,bolsevik állatoktól”, „zsidó szabadkőművesektől”, „marxista barbároktól”. A köztársaságiak szerintük ugyanis kizárólag pusztítást hagynak maguk után, felrobbantott és felégetett városokat, hidakat és templomokat; a nemzeti csapatokra van szükség ahhoz, hogy Spanyolország lakosságát megvédjék a gátlástalan baloldaliaktól (Guernica lerombolásának nacionalista interpretációja is ezt hivatott igazolni).

\footnotetext{
${ }^{382}$ A kérdésről bővebben: Pablo, Santiago de: Tierra Sin Paz. Guerra Civil, cine y propaganda en el País Vasco. Madrid, Biblioteca Nueva, 2006. A szerző a könyvben részletesen bemutat minden játék- és dokumentumfilmet, amely a polgárháború baszk vonatkozásairól szól, Guernica ellentmondásaival is több helyen foglalkozik.
} 
Nem csak védenek, helyre is állítanak: a filmek bemutatják, hogy a nemzeti erők miként segítenek az otthon nélkül maradt lakosságon, és kezdik meg a házak és templomok újjáépítését. A templom fontos elem: Franco és csapatai nemzetikatolicizmusa, a katolikus vallás fenntartás nélküli védelme a felkelő csoport egyik alapvető ideológiai pontja.

A propaganda egyik kiemelkedő példája a Hadifoglyok (Prisioneros de guerra, Manuel Augusto García Viñolas, 1938) című rövidfilm. Mivel a köztársasági csapatok állítása szerint Franco és serege a hadifoglyokat embertelen körülmények között tartotta, a felkelök cáfolatként ebben a filmben ,játszották el”, milyen humánus bánásmódban részesülnek a foglyul ejtett baloldaliak. Ráadásul a foglyok egy részét meg is tudták téríteni: a köztársasági oldalon harcoló katonákat a fogságban meggyőzték az igazukról, a spanyol nemzeti ügy mellé állították őket. Higiénikus kórházakban ápolták a sebesülteket, valamint munkaterápiát is alkalmaztak: a spanyol hadifogoly annál boldogabb, minél több utat és hidat építhet az eljövendő új Spanyolország lakói számára. ${ }^{383}$ A belföld és a külföld is láthatta ezt.

A spanyol felkelők oldalán álló országok maguk is készítettek a Franco-féle keresztes háborút támogató munkákat. Egyik legnagyobb visszhangot kiváltó és legszélesebb körben ismertté vált dokumentumfilm a Németországban készült Hösi Spanyolország (España heroica, Joaquín Reig Gonzálbes, 1938). Reig saját bevallása szerint azért kezdett a film megírásába, hogy megmutassa, milyen kaotikus állapotok uralkodtak Spanyolországban a felkelést megelőző időszakban, és miért vált szükségessé, hogy a haza védelmében a nemzeti erők megtegyék a megfelelő lépéseket. Legfőbb célja az volt, hogy a köztársaságiak (vagy ahogyan ő nevezi, a „,"örösök”) külföldön terjesztett propagandáit ellensúlyozza. ${ }^{384}$ A film alapját filmhíradókból és dokumentumfilmekből kivágott és összeollózott felvételek adják, amelyek egy részét éppen a köztársaságiak készítették, hogy saját propagandájukat erősítsék vele. Ezeket a felvételeket azonban, sok más baloldali anyaggal együtt, a nemzeti csapatok elkobozták, lefoglalták, vagy éppen ellopták, amikor fokozatosan átvették az uralmat a korábban köztársasági kézen lévő területeken. A már bevált módszert folytatták: új narrációs szöveget igazítottak a régi felvételekhez, így megváltozott a propaganda ideológiai irányultsága. Reig kivágott jeleneteket a polgárháborút megelőző évek játékfilmjeiből, valamint az amerikai filmhíradók bizonyos kiadásaiból is, és ezeket egészítette ki saját felvételekkel. Mindezek kombinációjából született meg az egyik leghatásosabb francóista propagandafilm, amely valójában Berlinben, német filmes szakemberek és társrendezők

\footnotetext{
${ }^{383}$ Crusells, Magí: La Guerra Civil española: cine y propaganda. Id. mü. 83.

384 „El film de la España nacional” Interjú Reiggel, dátum megjelölése nélkül. AGA. Cultura, 21/165-ös doboz
} 
segítéségével állt össze teljes egésszé. ${ }^{385}$ A film bizonyos tekintetben különbözik az előzőektől: bár továbbra is jelen van a „vörösök”, „marxisták” elnevezés, az elsőszámú célpontok már a Nemzetközi Brigádok csapatai ${ }^{386}$. Mindannyiukat kommunistának titulálta a nacionalista propaganda, holott széles spektrumú politikai meggyőződéssel rendelkeztek ezek az önkéntesek. A filmben minden borzalmas tettet nekik és a spanyol kommunistáknak tulajdonítanak. Egy másik újdonság is felfedezhető a filmben: bár a kommentár továbbra sem hagy kétséget afelől, hogy a nézőnek mit kell látnia a filmkockákon, a narrátor most kevésbé hangsúlyos, inkább csak orientál: professzionális filmes tudásról árulkodik az a módszer, ahogyan a felvételeket összevágták, egymáshoz illesztették, így tulajdonképpen a képek már önmagukért beszélnek. A spanyol polgárháború teljes addigi történetének nacionalista interpretációja ez a legfontosabb személyek és csaták szubjektív bemutatásával és értelmezésével.

A spanyol hivatalos filmgyártás Németország és Olaszország segítségével kezdődhetett csak el. ${ }^{387}$ A Filmszakosztálynak átlagosan évente négy dokumentumfilm és két filmhíradó elkészítésére volt anyagi lehetősége, és a személyi feltételek sem voltak éppen a legideálisabbak: mindössze néhány forgatócsoportot tudott csak kiállítani, akik a harci cselekményeket követték Spanyolország egész területén, a felszerelés pedig olyan nehéz volt, hogy lemaradtak a legfontosabb eseményekről. Természetesen mindent, ami az intézmény szárnyai alól került ki, kötelező volt bemutatni a mozikban és vetítőhelyiségekben. A munkák általában ugyanazokat a témákat járták körbe: a felkelő csapatok hősies küzdelme, a náci mintát imitáló tömegrendezvények lefilmezése, és egyes városok bevétele, elfoglalása.

1938-tól már forgalmazásra került a hivatalos Spanyol Filmhíradó (Noticiario Español) is, amely nacionalista szemszögből adott hírt a háború kimeneteléröl. Legfőbb célja nem a hazai lakosság, hanem a külföld tájékoztatása volt: meg akarták nyerni ügyüknek a be nem avatkozás politikáját folytató országokat, megmutatni nekik, hogy a felkelők a jó ügyért harcolnak. Háborús időkben azonban gyakran felmerül egy probléma, mely a Spanyol Filmhíradót is elérte: a nehezen hozzáférhető nyersanyag, valamint a már említett nehézkes forgatási körülmények miatt a hírek már elavultnak számítottak, mire összeálltak egy egységes híradóvá. Összesen 32 számot ért meg, helyét a német UFA Aktualitások, vagy a

\footnotetext{
${ }^{385}$ Crusells, Magí: La Guerra Civil española: cine y propaganda. Id. mü. 80.

386 A Nemzetközi Brigádok a világ számos országából érkeztek spanyol földre, hogy a köztársasági erőket segítsék. Filmgyártásban való megjelenésükről ír: Crusells, Magí: Las Brigadas Internacionales en la pantalla. Universidad de Castilla La Mancha, 2002; a könyv a magyar Pavel Lukacs (Zalka Máté) részvételét is bemutatja a filmhíradókon keresztül az alábbi oldalakon: 216-218.

387 Erről lásd részletesen a „Nemzetközi filmkapcsolatok” fejezet „Olaszország” és „Németország” című alfejezeteit.
} 
Francóval szimpatizáló Fox Movietone filmhíradói vették át, hogy aztán 1942-ben megszülessen a teljes mértékben spanyol állami ellenőrzés alatt álló NO-DO (Noticiarios y Documentales - Filmhíradók és Dokumentumfilmek), amely később a diktatúra szimbólumává válik.

Az amerikai (Fox, Paramount, Universal, Hearst Metrotone News), brit (Pathé Gazette, Universal Talking News) és francia (Pathé Journal, Actualités Movietone Fox, Gaumont Actualités) filmhíradók forgatócsoportjai folyamatosan dolgoztak a háborús zóna mindkét térfelén, és az általuk készített felvételekböl, valamint spanyol operatőröktől vásárolt (vagy más módon megszerzett) anyagokból állították össze a külföldi közönségnek szánt tudósításokat. Semleges álláspontot tükröző értelmezésük szerint itt nem a Jó és a Rossz küzdelméről volt szó, egyszerüen csak két csoport konfliktusáról. Filmhíradók tekintetében kiemelkednek az amerikai Fox Movietone munkái, ugyanakkor a felvételekhez füzött kommentárokon időnként mégis érződik a készítők Franco-szimpátiája. Egyértelmủen csak a német (UFA-Tonwoche, Bavaria-Tonwoche, Deutsche Monatsschau), az olasz (Cinegiornale Luce) és a szovjet (K sovitiyam v Ispanii) filmhíradók foglaltak állást: elöbbi kettő a felkelők, utóbbi a köztársaságiak oldalán. ${ }^{388}$ A szovjet filmesek a felvett anyagot nem csak saját országukban terjesztették, de üzletemberek és kommunista-szimpatizáns befolyásos személyek révén az Amerikai Egyesült Államokba is eljutottak; a spanyol polgárháború eseményeiről az amerikai filmhíradók után a szovjet munkák voltak jelen legnagyobb számban az amerikai társasági eseményeken és magánvetítéseken. ${ }^{389}$

Az ilyen informatív, híradós eszközökkel készített közlések mellett jelentősek voltak a köztársaságiakkal szolidaritást vállaló, jellemzően az antifasiszta dokumentumfilmeket gyártó amerikai Frontier Films által készített művek. ${ }^{390}$ Legfontosabb darabjait az utókor is értékes forrásként kezeli, külföldön a különböző emberi jogi filmfesztiválokon ma is vetítik: a Spanyolország szíve (Heart of Spain, Herbert Kline, Charles Korvin, 1937), a Visszatérés az életbe (Return to Life, Henri Cartier-Bresson, 1938), valamint az Ernest Hemingway és John Dos Passos aktív részvételével készített, mára emblematikus darabbá vált $A$ spanyol föld (The

\footnotetext{
${ }^{388}$ A már többször idézett katalógus tanulmányai az említett filmhíradókra az alábbi oldalakon térnek ki: Amo García, Alfonso del (szerk.): Catálogo general del cine de la Guerra Civil. Id. mü. 29-115. Felsorolás szintjén szól róluk: Crusells, Magí: Las Brigadas Internacionales en la pantalla. Id. mü. 163 és Uö.: La Guerra Civil española: cine y propaganda. Id. mü. 85-86.

389 Erről részletesen: García López, Sonia: „Bolcheviques en América: circulación y migración de imágenes soviéticas de la guerra civil española en Estados Unidos" in: Archivos de la Filmoteca, No. 61. 2009. 78-95.

390 A műveket bemutatja: García López, Sonia: „El cine de Cultural Front y la guerra civil española: Las películas de Frontier Films" in: Juliá, Santos (szerk.): Actas del congreso internacional: La guerra civil española, 1936-1939. Madrid, Sociedad Estatal de Conmemoraciones Culturales, 2008.

Elérhetö: http://www.uv.es/imagengc/articulos/el_cine_del_cultural_front.pdf (2012-12-01)
} 
Spanish Earth, Joris Ivens, 1937) ${ }^{391}$ címü propagandafilm. Szintén kiemelkedő munkaként tartjuk számon a háború alatt készített, eredeti képeket felhasználó, és később azokat újrahasznosító A reményt (Sierra de Teruel - L’espoir, André Malraux, 1945). Mindezek közös jellemzője, hogy az operatőr a harcok alatt, saját életét is kockára téve, a legsúlyosabb összecsapások helyszínén rögzítette kamerájával az eseményeket, valamint feltérképezte a harcok utóhatását, és látleletet adott a társadalomról. A képekhez füzött kommentárokkal és a készítők által szelektált felvételekkel persze a filmek ideológiai töltetet is kaptak: mindegyik a fasiszták pusztításait, Franco és csapatai brutalitását helyezi elötérbe.

A Magyar Világhíradó is készített polgárháborús összeállítást, A vérzö Spanyolország (1937) címü dokumentumfilm a felkelés első hónapjairól ad képet, és kiemeli, hogy a spanyol nép a felkelő csapatok oldalán áll, míg a köztársasági zónában káosz uralkodik. A Világhíradó összefoglalóihoz a németektől és olaszoktól átvett felvételeket használta. ${ }^{392}$

\section{NO-DO}

A NO-DO (Noticiarios y Documentales - Filmhíradók és Dokumentumfilmek) ${ }^{393}$ a Franco-korszak egyik elsőszámú szimbólumává vált, a rezsim mindennapjai ezen keresztuil kerültek kapcsolatba a nézőkkel. A polgárháború alatt, 1938-tól kezdődően már létezett az említett Spanyol Filmhíradó (Noticiario Español), de jelentősége elhanyagolható volt, ugyanis elegendő nyersanyag, professzionális infrastruktúra és technikai személyzet nélkül nem sikerült sem kielégítően informatív, sem friss híranyagot bemutatnia. A naprakész tájékoztatást a külföldről importált, illetve más országok által Spanyolországban forgatott filmhíradók szolgáltatták. A spanyol polgárháborús filmhíradó részben ugyanazt a módszert alkalmazta, mint amit már a dokumentumfilmek esetében is láttunk: az ellenfél felvételeit elkobozva azokat új narrációval, más magyarázattal a saját híradóikban is bemutatták. Szintén gyakran előfordult, hogy a felkelők által végrehajtott pusztítást úgy mutatták be, mintha a köztársaságiak által okozott kárt és romokat látnák a nézők. Megjelenése is rendszertelen volt, néha kéthetente, 1939-től csak havonta állítottak elő új kiadásokat, így az általuk közölt

\footnotetext{
391 A spanyol földet az Amerikai Egyesült Államok Contemporary Historians nevet viselő csoportja támogatta, amelyet a köztársasággal szimpatizáló amerikai írók és hollywoodi körök hoztak létre. Egy korábbi változatban Orson Welles, a későbbi, szélesebb körben ismertté váltban Ernest Hemingway a narrátor.

${ }^{392}$ Pablo, Santiago de: Tierra Sin Paz. Id. mü. 254, 266-267.

${ }^{393}$ A NO-DO történetéről megjelent két rendkívül részletes, informatív mü, amelyek minden felbukkanó témát, személyt, tendenciát és a társadalomra kifejtett hatást részletesen elemeznek. Összefoglalásomban az általam megtekintett filmhíradókon kívül én is ezekre támaszkodom, mindenekelőtt az elsőre, kivéve, ahol más forrást jelölök: Tranche, Rafael R - Sánchez-Biosca, Vicente: NO-DO. El tiempo y la memoria. Madrid, Ediciones Cátedra - Filmoteca Española, 2006 (ezt a 8. kiadást használtam, az első kiadás 2001-re datálódik); Abella, Rafael - Cardona, Gabriel: Los años del NO-DO. Barcelona, Destino, 2008.
} 
információ már a premierkor idejétmúltnak bizonyult. ${ }^{394}$ Mindezek miatt inkább csak összefoglaló propagandafilmekként tekinthetünk rájuk, mintsem információ- és hírközlő médiumként.

A Közoktatási Helyettes Államtitkársághoz tartozó filmhíradót 1943 januárjától kötelező volt minden moziteremben levetíteni a játékfilmek előtt, ugyanakkor tilos volt azon hasonló jellegü alkotások forgalmazása, amelyek nem tartoztak a NO-DO égisze alá. ${ }^{395}$ Feladata, hogy ellássa a spanyol népet minden fontos, a nemzet számára lényeges információval. A Primer Plano folyóiratban a NO-DO igazgatója az alábbiakban jelölte meg filmhíradójuk célját:

„Nemzetünk életének minden nemes tulajdonságát tükröznie kell: politikai, gazdasági, müvészeti, kulturális, tudományos, sport stb. Ugyanezen tulajdonságait, amennyiben lehetséges, az egész világnak. Egyszóval, informálnia, oktatnia, szórakoztatnia kell ... Filmhíradónknak van még egy rendkívül fontos küldetése: a világ legtávolabbi részeire is eljuttassa Spanyolországot. Több millióan, akik nem tudnak rólunk semmit, hamarosan értesülni fognak országunkról, méghozzá folyamatosan. Megismerik eröfeszítéseinket, müvészeti kincseinket, iparunkat, termékeinket, jellemünket és életvitelünket, és a Spanyol Filmhíradó nevetség tárgyává teszi a minket rágalmazó hülyéket, növelve azt a vonzalmat, amelyet azok éreznek irántunk, akik müveltségüknek és tisztességüknek köszönhetöen becsülnek és szeretnek minket. 396

A stábban a korábban Spanyolországban forgató és ott kirendeltséggel is rendelkező német Actualidades UFA és amerikai FOX Movietone szakemberei is közremüködtek, majd helyüket lassan átvették a spanyol dolgozók. Kötelező jellege 1976-ban szünt meg, de 1981-ig készülttek újabb kiadások. A $N O-D O$ a történészek számára nélkülözhetetlen forrást jelent, minden fontosabb nemzeti és nemzetközi esemény megjelenik benne, természetesen a rezsim szemszögéből. Kizárólag a NO-DO forgathatott híranyagot, csak a kötelékébe tartozó tudósítók dolgozhattak belföldön. A filmhíradók folyamatosan visszatérő alakja Francisco Franco, minden egyes kiadásban megjelenik, köré csoportosulnak a hírek. A polgárháború veszteseiről, a legyőzött Spanyolországról nem szóltak a híradók, ők hivatalosan továbbra sem léteztek.

\footnotetext{
394 Tranche, Rafael R - Sánchez-Biosca, Vicente: NO-DO. Id. mü. 188-191.

${ }^{395}$ BOE, 22-XII-1942.

396 „Se crea NO-DO” en: Primer Plano, No. 115. 1942. december 27.
} 
A nézők a filmhíradókon keresztül azt a Spanyolországot látták, amelyet a hatalom láttatni akart. A politikai történések mellett társadalmi és kulturális eseményekről, sportrendezvényekről is tudósított, így információközlő jellege mellett megjelent a szórakoztatás is. Franco alakját leginkább a $N O-D O$,építette fel”: mivel televízió eleinte nem, és később is csak kevés háztartásban volt elérhető ${ }^{397}$, egyedül a mozitermekben vetített filmhíradókon keresztül juthatott el a Caudillo audiovizuális, hús-vér alakban. A rádió sem szolgált hírforrásként, csak a városi, müveltebb, elsősorban a felső középosztályhoz tartozók rendelkeztek készülékkel, és a napi sajtót is főleg ők olvasták. A szerényebb jövedelemmel és alacsonyabb müveltséggel rendelkezők számára a $N O-D O$ volt az egyetlen hírforrás, mivel moziba mindenki járt, aki megengedhette magának a viszonylag olcsónak számító mozijegyet. ${ }^{398}$ Mindenki érthette, még az analfabéta tömegek is. Más diktatúrákra is jellemző módon gondosan megtervezték Franco szerepléseit, a közvetített beszédek és lefilmezett ceremóniák, politikai találkozók egy paternalista, joviális, ugyanakkor fegyelmezett apafigurát tártak a nézők elé, aki éjjel-nappal Spanyolországért dolgozott. 1975-ben a Franco halála (La muerte de Franco) címü különkiadásban négy külön csoportba válogatták össze a korábbi felvételeket, amelyekkel végigkövethették a Caudillo életét: a katonatiszt, a politikus, a fejlesztő és a magánember. Nem találni egyetlen olyan kiadást sem az 50-es évek végéig, ahol a tábornok ne szerepelne legalább egy, de jellemzően több hírben is, a többi tudósítás pedig a rezsim által elért sikereket mutatta be. Még a polgárháború utáni, az önellátást jellemző nélkülöző periódusban is csak a pozitív fejleményekről, kórházak és templomok átadásáról, boldogan mosolygó emberekről számoltak be. A háborús győzelmet, később pedig a rezsimet éltető emberek felvonulása, Franco tömegek általi köszöntése, a harcok és a rendszer különböző évfordulóinak megünneplése, a Generalísimo belföldi utazásai, a mindennapi élet részévé váló helyszínek (gyárak, vásárok, építkezések, új boltok, lakásátadások) megnyitói, az egyház tevékenységei, a különböző emlékművekről és kegyhelyekről (mint az Elesettek Völgye és az El Escorial) szóló tudósítások adták a híradók gerincét, kiegészülve a Nemzeti Mozgalomhoz tartozó társadalmi szervezetek (mint az Ifjúsági Front és a Falange Női Szekciója) rendezvényeinek bemutatásával. A képek a köztársasági erők által okozott pusztítást szembeállították az Új Spanyolország rekonstrukciós munkáival. A második világháború idején a NO-DO aktív tengelybarát propagandát folytatott,

\footnotetext{
${ }^{397}$ A TVE (Televisión Española) 1956. október 28-tól sugároz rendszeresen, de az első években csak szűk vételi körzetben, a Madrid-Barcelona tengelyen. A 60-as évek elejéig inkább csak kísérleti adásnak minősül. A spanyol televíziózás történetéről lásd: Palacio, Manuel: Historia de la televisión en España. Barcelona, Gedisa, 2001.

${ }^{398}$ Sevillano Calero, Francisco: Propaganda y medios de comunicación en el franquismo (1936-1951). Id. mü. 113-115.
} 
a Kék Hadosztályról rendszeresen tudósított, majd egyre erőteljesebb lett a szovjet- és kommunizmus-ellenes anyagok jelenléte. A 60-as évektöl, összhangban a diktatúra más területein is végbemenő nyitással, csökkent mind a propaganda ereje, mind a Caudillo és más irányító szervezetek jelenléte a filmhíradókban.

A híradó igyekezett a nagypolitikában végbement változásokat is visszaadni, de nem részletes tudósításokban, hanem az általános tendenciákat tükrözte. Általában nem tájékoztatott a kormány összetételében bekövetkezett módosulásokról (politikai vitákról pedig soha), egyszerủen csak egyik híradóról a másikra új miniszterek jelentek meg a vásznon. A hozzájuk kapcsolódó megváltozott irányok és hangsúlyok azonban érezhetőek voltak a híradásokban. Míg a polgárháború után még a munkásokat, az egyszerű spanyol népet jelölték meg, mint az új Spanyolország fejlődését elősegítő csoportot, addig az 50-es évektől ez a szerepkör áttevődött magára a Caudillóra: neki köszönhető, hogy az országban végbemegy az iparosodás, az általa átadott új létesítmények viszik előre a nemzetet. ${ }^{399}$ Ezzel párhuzamosan egyre több helyet kapott a $N O-D O$-ban Franco, a magánember: tudósítások a Franco-család nyaralásairól, a Caudillo és Carmen Polo mint nagyszülők, közös játékok a kertben, vadászat a barátokkal stb.

A nézőközönség nem értesülhetett a 40-es években a nemzetközi elszigetelődéshez vezető hivatalos lépésekről sem (mint a diplomáciai kapcsolatok megszakítása, nagykövetek visszahívása), mindez a Spanyolország ellen szőtt nemzetközi összeesküvés részeként jelent csak meg. A baráti gesztusok azonban mindig fontos helyet foglaltak el, elsősorban Argentína, Portugália részesült pozitív elbírálásban, majd 1953-tól az Amerikai Egyesült Államok és számos európai ország is. A külpolitikára is mindig figyeltek - az 1943. január 4én megjelent első számban például Argentína, Anglia és Japán mellett Magyarországról is szólt egy hír, tájékoztatva a spanyol közönséget arról, hogy megkezdődtek az éves magyar katonai sorozások.

1943-tól a NO-DO együttmüködött egyetemek és filmiskolák tanszékeivel, infrastruktúráját és stúdióit a filmes pályára készülő diákok rendelkezésére bocsátotta, ahol gyakorlati idejüket tölthették.

1943 és 1981 között összesen 1966 szám készült, 1945-től kezdődően pedig Imágenes címmel havi tematikus számokat is gyártottak, valamint sport és kulturális különkiadásokat. ${ }^{400}$ 1956-tól az állami televíziónak is adtak át anyagokat. Külföldi kiadásokat is szerkesztettek,

\footnotetext{
${ }^{399}$ Franco szerepének változásáról a NO-DO-ban lásd: Benet, Vicente J.: „Franco, NO-DO y las conquistas de trabajo" in: Archivos de la Filmoteca, No. 42-43. 2002. 30-51.

${ }^{400}$ Az adatokat pontosan közli: Tranche, Rafael R - Sánchez-Biosca, Vicente: NO-DO. Id. mü. 165.
} 
amelyekben a belföldi híradók számára forgatott, Spanyolországról szóló híreket helyeztek el. Ezek célhelye Latin-Amerika volt, de Portugália és Brazília számára portugál nyelvü változatok is születtek. A 60-as évek közepétöl, amikor a televízió már egyre több háztartásban elérhetővé vált, a $N O-D O$ funkciója megváltozott: mivel a nézők többsége már otthonában ülve is hozzájuthatott a hírekhez, a moziban látható filmhíradó inkább szórakoztatói funkciót látott el, nőtt a társadalmi eseményekről és hírességek életéről szóló tudósítások száma, és csökkent - bár nem drasztikusan - az aktuálpolitikai vonatkozású hír.

A filmhíradók gyártásához szükséges alapanyagot eleinte elsősorban Németországból és Olaszországból importálták, csak az 50-es évek második felétől lendült fel a belföldi celluloidgyártás, teljes önellátásra azonban soha nem voltak képesek. A 40-es évek végétől már kép- és híranyagokat is vásároltak külföldről.

A NO-DO dokumentumfilm-gyártó szekciója a hírekhez kapcsolódó kiegészítő müveket állított elő, amelyeket nem volt kötelező müsorra tüzni a mozikban, mert lobbitevékenységükkel megakadályozták ezt a magánkézben lévő konkurens filmstúdiók, akik veszélyben érezték saját dokumentumfilmjeik terjesztését. A $N O-D O$ ezen szekciójának fö feladata, hogy elmagyarázza a „tudatlanok és eltévelyedettek” számára, mi jellemzi az Új Spanyolországot, a külföld számára pedig bemutassa „Spanyolország csodáit, fejlett iparunkat, természeti kincseinket és tudományos felfedezéseinket". ${ }^{401}$ A művészeti témájú dokumentumfilmek egyszerre töltöttek be esztétikai, ismeretterjesztő és propagandisztikus célokat. $^{402}$

\footnotetext{
401 Matud Juristo, Álvaro: „La incorporación del cine documental al proyecto de NO-DO” in: Historia y Comunicación Social, No. 13. 2008. 105-110.

${ }^{402}$ Erről bővebben: Lázaro Sebastián, Francisco Javier: „Situación del documental de arte en la España del franquismo". In: Archivos de la Filmoteca, No. 70. 2012. 151-160.
} 


\section{Nemzetközi filmkapcsolatok}

A Franco-rendszer filmgyártásának nemzetközi kapcsolatai közül négy olyat emelek ki, amelyek a téma szempontból jelentősek voltak. Míg Portugália szerepe technikaigazdasági szempontból értékelődött fel, addig Olaszország és Németország esete alapvető jelentőséggel bírt, mivel a polgárháború kitörésekor a felkelők filmgyártása lényegében tőlük függött, és ezekre az alapokra építkezhetett később az új Spanyolország filmipara. Mindennek már megágyazott a burgosi kormány 1936. október 20-án hozott rendelete, amelynek értelmében az elfoglalt területeken szabadon terjeszthették a német, olasz és portugál sajtótermékeket. ${ }^{403}$ Az Amerikai Egyesült Államokkal, és azon belül Hollywooddal való kapcsolat pedig azt mutatja, hogy a pillanatnyi érdekek és a nemzetközi viszonyrendszer hogyan is módosíthatják a relációkat.

1950 és 1975 között Spanyolország 930 koprodukcióban vett részt partnerként, ez a teljes filmgyártásának 40\%-át tette ki; az egyik szélsőséget 1965 jelentette, amikor a filmtermés $67 \%$-a koprodukció eredménye volt. Az ebben a fejezetben tárgyalt négy országon kívül Franciaország, Argentína, Mexikó és az Egyesült Királyság vett részt ilyen típusú együttmüködésben, míg az összes koprodukció közel 50\%-a Olaszországgal jött létre. ${ }^{404}$

\section{Portugália}

A szomszédos országgal való együttmüködés kevesebb szót érdemel a spanyol filmtörténetírás lapjain, mert közösen forgatott filmjeik sem ideológiai, sem politikai, sem müvészeti szempontból nem voltak jelentősek, a kooperáció mindenekelőtt gazdasági célt szolgált. Az Estado Novo tömegkommunikációs eszközei már a háború kitörésének pillanatában a felkelők oldalára álltak, propagandájuk szerint a Második Köztársaság Moszkva által támogatott nemzetközi forradalmát csak a nemzeti csapatok állíthatták meg. A három fő eszköz közül a sajtó és a rádió töltött be fontosabb szerepet, a film elhalványult ezek mellett. A megkötött egyezmények alapján a koprodukciókat mindig abban az országban kellett forgatni, ahol kedvezőbbek voltak az anyagi és személyi feltételek - mivel ezt a

\footnotetext{
${ }^{403}$ AMAE, R-592, Gabinete Diplomático de Prensa y Propaganda. Informe de la Oficina de Prensa del Cuartel General de Burgos a la Secretaria de Relaciones Exteriores, 20/10/1936.

404 Pardo, Alejandro: „Coproducciones internacionales españolas: ¿estrategia financiera o expresión multicultural?" in: Comunicación y sociedad, Vol. XX. No. 2. 138.
} 
kritériumot általában Spanyolország teljesítette, a közös filmek föleg a spanyoloknak hoztak hasznot, a portugálok ezért a lehető legkevesebb együttmüködést szorgalmazták. ${ }^{405}$

A spanyol polgárháború idején a felkelők mindenekelőtt a lisszaboni laboratóriumok segítségét vették igénybe, ahol a földrajzi közelség miatt egyszerübb és gyorsabb volt előhívni a negatívokat. A spanyol Cifesa és a portugál Lisboa Films között már a harcok idején együttmüködés született e célból, a spanyol cég minden felvételét a portugál stúdióba küldte előhívásra. Elsősorban dokumentumfilmek és filmhíradók készítésében, valamint technikai együttmüködésben volt erős a kapcsolat, de több alkalommal is felmerültek anyagi természetü nézeteltérések a felek között. Szerződésben rögzítették azonban, hogy Portugáliában kizárólag a felkelőket pozitív színben feltüntető felvételeket lehetett forgalmazni, míg a Franco ellenőrzése alatt álló területeken sem mutathattak be olyan müveket, amelyek Salazar rendszeréröl negatív képet festenének. A portugál Nemzeti Propaganda Titkárság (Secretariado de Propaganda Nacional - SPN) egy meghatározott összeget is elkülönített a költségvetésében a spanyol felkelők ügyének megsegítésére, valamint a nemzetközi kommunizmus elleni propagandaanyagok készítésére. Portugál részről jelentősnek mondható a föleg latin-amerikai terjesztésre szánt, a felkelők spanyol fővárosba történő menetelését bemutató Út Madridba (A Caminho de Madrid, Anibal Contreiras, 1936) címü dokumentumfilm; a spanyolok mintegy „,válaszként” elkészítették a Portugália tiszteletére (Homenaje a Portugal, 1936) címü, hivatalos rendezővel nem rendelkező rövidfilmet, amely Salazar rendszerét dicsőíti. A portugál operatőrök által felvett, a felkelés egyik kirobbantójának halálát és temetését megörökítő Sanjurjo tábornok temetése (Funeral do General Sanjurjo, José Nunes das Neves, 1936) képeit megvásárolva és újravágva jött létre az első olyan, az előbbivel azonos címü (El entierro del General Sanjurjo, 1936) spanyol dokumentumfilm, amely már teljes egészében a felkelők filmgyártásához kötődik; Queipo de Llano tábornok ennek sikerén felbuzdulva alakította ki a parancsnoksága alá tartozó Déli Hadsereg Diplomáciai és Polgári Kabinete (Gabinete Civil y Diplomático del Ejército del Sur) keretein belül a filmpropaganda szekciót a már meglévő rádiós propaganda mellé. ${ }^{406} \mathrm{~A}$ spanyol sajtó és a filmpolitika jóval ritkábban említi a portugál együttműködést, mint az olasz és német kooperációt. A korabeli portugál filmpolitika szintén felmutatta a más totalitárius államokból ismert jegyeket, annak ellenére is, hogy filmtörténészek szerint Salazar ellentétben a többi diktátorral - megvetette a filmeket és nem tartotta azokat sem jelentősnek,

\footnotetext{
${ }^{405}$ Pena Rodríguez, Alberto: El gran aliado de Franco. Portugal y la Guerra Civil Española: prensa, radio, cine y propaganda. A Coruña, Edicios do Castro, 1998. 107-109; 425-435.

${ }^{406}$ Uo.
} 
sem társadalomformáló erőnek. ${ }^{407}$ A 40-es években számos koprodukció született a két ország között, de, ahogyan erre már utaltam, témám szempontjából ezek kevéssé relevánsak. ${ }^{408}$

\section{Olaszország}

Mussolini már a spanyol katonai felkelés első pillanataitól segítette a lázadókat felszerelésekkel és technikai szakemberekkel, majd a támogatás még nagyobb méreteket öltött. $^{409}$ A későbbiekben hol nyíltan (1938. októbere: Spanyol-Olasz Filmmüvészeti Egyezmény), hol különböző gyüjtőnevek alatt (pl. kereskedelmi, kulturális megállapodások) jelentős tételként szerepeltek a filmes produktumok. ${ }^{410}$ Mindezek következtében Olaszország a hozzájuk érkezett mozgóképek segítségével tájékozódhatott a felkelők sikereiről, míg Spanyolország az itáliai propagandafilmeket terjesztette; ugyanakkor, az olasz (és német) nyersanyagok segíthettek abban, hogy Franco csapatai is készíthessenek dokumentumfilmeket és híradókat. Elsősorban az olaszok által Salamancában létrehozott USP (Ufficio Stampa e Propaganda) végezte a fent említett feladatokat, kiemelve a kommunisták által Spanyolországban elkövetett „rémtetteket”, az ország területén bekövetkezett rombolást, valamint kifejezték teljes támogatásukat és szimpátiájukat Franco és hadserege iránt. A LUCE filmhíradóinak számos darabja a spanyol polgárháborúra koncentrált, dokumentumfilmjei közül pedig kiemelkedik a Falange történetét megfilmesítő, azt Spanyolország megmentőjeként bemutató Arriba España (1937), valamint a köztársaságiakat pusztítóként, a felkelőket pedig nemzetmentőként ábrázoló Spanyolország egy, nagy, szabad! (¡España una, grande, libre, Giorgio Ferroni - LUCE, 1939), melynek alcíme is összefoglalja álláspontját: $A$ vörös barbárságtól a fasiszta civilizáció gyözelméig (Dalla barbarie rossa al trionfo della civiltá fascista). ${ }^{411}$ Idővel azonban a Caudillo számára világossá vált, hogy az együttműködés a csapataira nézve káros lehet, mert az olasz propaganda a harctéri sikereket részben az itáliai önkéntesek bátorságának és professzionalizmusának tulajdonította. Éppen ezért Spanyolországban a cenzúra elérte az olasz fasiszta propagandafilmeket is, majd a LUCE

\footnotetext{
${ }^{407}$ Erről lásd: López Gallegos, María Silvia: „El control político de Salazar sobre la industria cinematográfica portuguesa” in: Montero, Julio - Rodríguez, Araceli (szerk.): El cine cambia la historia. Id. mü. 177-195.

${ }^{408}$ Erről lásd: Sempere Serrano, Isabel: „La aventura luso-española. Introducción al estudio de la coproducción cinematográfica hispano-lusa de los años cuarenta" in: FilmHistoria Online, Vol. XIII. No. 3. 2003.

Elérhetö:

http://www.publicacions.ub.edu/bibliotecadigital/cinema/filmhistoria/2003/aventura hispano_lusa_1_index.htm (2012-11-22)

${ }^{409}$ Erről lásd: Katona Eszter: Olasz-spanyol kapcsolatok a második világháború éveiben. Szeged, 2007. 13-20.

${ }^{410}$ Diez Puertas, Emeterio: Historia social del cine en España. Id. mü. 103-104.

${ }^{411}$ A LUCE spanyol polgárháborúhoz kötődő filmhíradóíról és dokumentumfilmjeiről lásd: Mazzoccoli, Franco: Film Luce e guerra di Spagna. Torino-Venezia, L'Archivo Nazinale Cinematografico della Resistenza - La Biennale di Venezia, 1976.
} 
filmhíradóit felváltották a saját riportok. A két ország együttműködése a már említett 1938-as filmművészeti egyezménnyel vált hivatalossá, ez pedig a következő főbb pontokra tért ki: offenzív filmek ${ }^{412}$, koprodukciók, olasz filmek Spanyolországban és spanyol filmek Olaszországban történő forgalmazása, vonatkozó törvénykezésről szóló rendelkezések és a forgatásokhoz szükséges nyersanyagellátás. ${ }^{413}$

A polgárháborút követő években Spanyolország filmkészítése még anyagi és infrastrukturális hiánnyal küszködött. Az újonnan létesített filmgyártó vállalatokban markánsan jelen volt az olasz tőke is, a polgárháború idején és a második világháború első éveiben pedig a spanyol forgatócsoportok rendszeres vendégei voltak az olasz filmstúdióknak, ahol gyorsan és professzionális körülmények között folyhatott a munka. Egyik legkiemelkedőbb darabja az együttmüködésnek Az Alcázarban a helyzet változatlan / $A z$ Alcazár ostroma (Sin novedad en el Alcázar / L'assedio dell' Alcazar, Augusto Genina, 1940). 1942 végétől megfordult a helyzet, olasz filmesek nagy csoportokban érkeztek Spanyolországba, ahol olasz-spanyol vegyes tulajdonú vállalatok segítségével, közös tőkéből bérelt stúdiókban forgattak koprodukciókat, illetve tisztán olasz filmeket. ${ }^{414}$

\section{Németország}

Hasonló jelentőséggel bírt a Franco-tábor filmgyártására a másik szélsőjobboldali kormányzás alatt álló állam, Németország támogatása. Spanyolország természetes piacnak tünt a nemzetiszocialista filmipar számára, már a polgárháború előtt is többrétegü kapcsolat állt fenn a két ország között filmgyártás és filmfinanszírozás terén. Spanyol fiókja segítségével az UFA stúdió 1932-ben jelent meg Madridban és a következő évtől kezdődően terjesztésre kínálta fel a katalógusában található filmeket; ettől kezdve nagyságrendekkel megnőtt a Spanyolországban forgalmazott német filmek száma. A spanyol filmes sajtó az UFA stúdióról az egyik legjelentősebb európai filmvállalatként számolt be; míg a konzervatív köztársasági sajtó nem írt arról, hogy milyen ideológiai befolyással bír felette Hitler köre, addig a baloldali orgánumok felhívták erre a figyelmet. A Popular Film című baloldali

\footnotetext{
${ }^{412}$ Az offenzív filmek egy ország olyan alkotásai, amelyek egy másik ország múltját, intézményeit, szokásait sértik, sok esetben szélsőségesen támadó jelleggel; ezek célja a gyártó ország másik nemzettel szemben viseltetett hivatalos politikájának alátámasztása. Az offenzív filmek definícióját az offenzív koprodukciók kapcsán Emeterio Díez Puertas fogalmazta meg alábbi tanulmányában: „Las coproducciones ofensivas” in: Actas del VII Congreso de la A.E.H.C. Madrid, Academia de las Artes y Ciencias Cinematográficas de España, 1999. 167-168.

${ }^{413}$ Diez Puertas, Emeterio: Historia social del cine en España. Id. mü. 109.

${ }^{414}$ Sánchez Salas, Daniel: „A diez mil kilómetros de Hollywood. (La historia de E.C.E.S.A. / Estudios de Aranjuez S.A.)" in: García de Dueñas, Jesús - Gorostiza, Jorge (szerk.): Los estudios cinematográficos españoles. Id. mü. 111-112.
} 
folyóirat folyamatos tájékoztatást adott a német filmpolitika alakulásáról és intézkedéseiket éles kritikával illette. Azt azonban kiemeli minden cikk, hogy tiszteletreméltó Goebbels propagandaminiszter filmmüvészet iránti szeretete, még akkor is, ha azt politikai célra fordítja. 1935 és 1939 között a baloldalhoz kötődő lapokból is eltünik a német filmipar felett gyakorolt politikai-ideológiai megalapozású ítélkezés. ${ }^{415}$

A Goebbels ösztönzésére létrejött Hispano Film Produktion (HFP) 1936-os megalapítása jelölte ki a későbbi német-spanyol filmművészeti együttmüködés sarokpontját. Anyagilag a német Propagandaminisztérium, a Nemzetiszocialista Német Munkáspárt és a spanyol Falange tette lehetővé az új produkciós cég megszületését, amely útjára indította a közös, részben Spanyolországban, részben Berlinben forgatott filmek sorozatát. A későbbiekben a cég Spanyolországba tette át a székhelyét. Szorosan együttmüködött a Cifesa stúdióval, ez utóbbi biztosította a HFP filmjeihez az infrastrukturális hátteret, majd az alkotások terjesztését. ${ }^{416}$ A módszer ugyanaz volt, mint amit korábban Hollywood alkalmazott a hispán országok filmszínházainak meghódítása érdekében a dupla változatokkal: Spanyolországon kívül, saját filmstúdióikban, már eleve spanyol nyelven forgatták a filmet, vagy rögtön készítettek hozzá spanyol szinkront is. A HFP Spanyolországban forgatott filmjeinek munkálataiban német szakemberek is részt vettek, akik közül sokan a munka végeztével Madridban maradtak, és betagozódtak a szakemberhiánnyal küzdő spanyol filmiparba. A két ország közötti együttmüködést 1940-ben egy, az olaszokkal kötött szerződéshez hasonló megállapodás koronázza. ${ }^{417}$ Az olasz LUCE-híradóhoz hasonlóan a német UFA Actualidades filmhíradó is lekerült a mozivásznakról 1943-ban, amikor megszületett a NO-DO. A Spanyolországban készülő UFA híradók főszerkesztője, Joaquín Reig ugyanezt a pozíciót töltötte be az új spanyol filmhíradóban is. A két ország kiemelkedő együttmüködésnek lehetünk tanúi a polgárháborús években. ${ }^{418}$

Németország minden lehetséges eszközzel támogatta a spanyol film fennmaradását és külön a spanyol művészeket is. Miután a Spanyolországban kiemelkedő karriert maga mögött tudó Florián Rey filmrendező 1936-ban politikai és művészeti kérdésekben összekülönbözött köztársasági politikusokkal, hazájából külföldre távozott. Öt és feleségét, Imperio Argentina színésznőt egy több országot érintő körút után Németország szívélyesen fogadta, Hitler személyesen közölte velük, hogy, amíg Spanyolországban nem normalizálódik a helyzet, rendelkezésükre bocsátja a német filmstúdiókat és a technikai személyzetet, így magas

\footnotetext{
${ }^{415}$ Montero, Julio - Paz, Maria Antonia: La larga sombra de Hitler. Id. mü. 59-62; 89-90.

${ }^{416}$ Diez Puertas, Emeterio: Historia social del cine en España. Id. mü. 117-119. és 121.

${ }^{417}$ Uo. 122-131.

${ }^{418}$ Erről lásd részletesebben „A polgárháború” címü alfejezetet.
} 
színvonalon folytathatják munkájukat. Goebbels is biztosította a spanyol filmeseket támogatásáról. Később más, a felkelők ügyét támogató, de otthon a háborús körülmények miatt munkáját folytatni nem tudó filmes csatlakozott hozzájuk. ${ }^{419}$ A két filmes náci vezetőkkel történt találkozásáról, valamint a további tervekről egy Spanyolországba küldött, emelkedett hangú jelentés is részletesen beszámol. ${ }^{420}$ Leni Riefenstahl hosszasan tervezett projektjét, A hegyek aljánt / A mélység birodalmát (Tiefland, 1954) ${ }^{421}$ részben Spanyolországban akarta leforgatni, ezért Hitler elsőszámú filmrendezőnője 1934 és 1944 között többször is Spanyolországba utazott; bár a statiszták és a helyszínek is kiválasztásra kerültek, előbb anyagi problémák, majd a második világháború a németek számára kedvezőtlen alakulása miatt ez a terv meghiúsult, csak pár felvételt sikerült rögzíteni. Végül a mediterrán szereplőket spanyolok helyett a német internálótáborok cigány foglyai alakították, akiket azután Auschwitzba irányítottak. A film nem készült el teljesen, 1954-ben csak részleteit tudták bemutatni. ${ }^{422}$ Riefenstahl az 50 -es évek első felében többször is visszatért Spanyolországba, Madridról, a városok müemlékeiről és Pamplonáról tervezett dokumentumfilmeket (Nap és árnyék, Harci bikák, Madonnák munkacímekkel), de spanyol barátai végül lebeszélték ezek megvalósításáról, mert szerintük a francói cenzúra úgysem engedélyezte volna, hogy szabad kezet kapjon a forgatásokhoz. ${ }^{423}$

Az egymás országába exportált filmek témája kapcsán több olyan pont is felmerült, amelyek miatt a második világháború alatt kevés játékfilm jutott el a baráti országba: míg a német filmpolitika és cenzúra jóval kevésbé volt szigorú olyan jelenetek kapcsán, amelyeket a spanyol megengedhetetlennek tartott (meztelenség, abortusz, eutanázia), addig a spanyol filmekből áradó katolikus hangnem a nácik számára volt zavaró. ${ }^{424}$ Szintén konfliktusforrásra adott okot, hogy a spanyol polgárháború befejezte után, a világháború éveiben a németek egyre inkább szerették volna behajtani a spanyolokon a harcok során nyújtott filmes természetü segítségek (nyersanyag, híranyag) árát. Mivel Franco egyelőre ezt nem tudta teljesíteni, adósságát átmenetileg a német propagandafilmek Latin-Amerikába juttatásával, valamint német üzleti érdekcsoportok spanyol bányászatba történő beengedésével törlesztette.

\footnotetext{
${ }^{419}$ Yraola, Aitor: „Misión españolista”: Los camaradas Florián e Imperio con Hitler y el Dr. Goebbels” in: FilmHistoria, Vol. IX, No. 3. 1999.

Elérhetö: http://www.publicacions.ub.edu/bibliotecadigital/cinema/filmhistoria/art.yraola.pdf (2012-12-01) és „La estrella que deslumbró a Hitler” in: El Mundo, 2003. augusztus 24.

Elérhető: http://www.elmundo.es/elmundo/2003/08/23/cultura/1061601639.html (2012-11-22)

${ }^{420}$ AGA, Presidencia, 51/20891-es doboz, ,Misión Españolista”jelzetü jelentés.

${ }^{421}$ A filmre a magyar nyelvü szakirodalom két különböző címen is szokott hivatkozni.

${ }^{422}$ Az alábbi életrajzi könyv folyamatosan beszámol a film készültének fázisairól, a rendezőnő spanyol útjairól: Bach, Steven: Leni: Leni Riefenstahl élete és munkássága. Budapest, Európa, 2008.

${ }^{423}$ Uo. 418.

${ }^{424}$ Montero, Julio - Paz, Maria Antonia: La larga sombra de Hitler. Id. mü. 181-183.
} 
A megkötött filmmüvészeti szerződések évenkénti újratárgyalásának feltételei is számos vitára adtak okot, mert a felek folyamatosan változtatták igényeiket, elvárásaikat és követeléseiket. $^{425}$

\section{Amerikai Egyesült Államok}

Spanyolország és az USA viszonya a filmkapcsolatok terén tökéletes tükörképét adta a két ország egymás felé irányuló politikájában végbement változásoknak: előbb ideológiai ellenfelek voltak, majd a fokozatos közeledés után fontos szövetségesre találtak a másikban.

Az 1930 óta érvényben lévő hollywoodi Produkciós Kódex általános utasításait követve az erkölcsi, politikai és gazdasági konfliktusok elkerülése érdekében a stúdiók igyekeztek visszafogni a spanyol harcokról szóló filmeket, de ez nem mindig sikerült. Egy alapvető kitétel azonban mindvégig érvényes volt: ezek a filmek nem foglalhatnak nyíltan állást egyik oldal mellett sem, nem derülhet ki, hogy a film készítői melyik csoporttal szimpatizálnak. ${ }^{426}$ Nem volt elsődleges szempont, hogy hitelesnek tünjön legalább a helyszín és a környezet, végül az eredetileg e célból az Egyesült Államokba érkező Luis Buñuel segítségére sem tartottak igényt. ${ }^{427}$ A stúdiók többé-kevésbé betartották a megadott irányelveket, ezt támasztja alá a Paramount stúdió egyik 1938-ban Spanyolországban és az Egyesült Államokban is leközölt fizetett hirdetése, amelyben a stúdió vezetői kinyilvánítják, hogy a barcelonai központjukban dolgozó kollégák köztársasági szimpátiájában nem osztoznak, az ilyen véleménynyilvánításoktól egyértelműen és végérvényesen elhatárolódnak. ${ }^{428}$

A hollywoodi stúdiókhoz kapcsolódó filmesek azonban, ellentétben az intézményekkel, igyekeztek hallatni hangjukat. Jótékonysági gálákat és estélyeket szerveztek, mentőautókat vásároltak és próbáltak meg eljuttatni a köztársasági térfélre, politikai gyűléseken szólaltak fel a spanyol demokrácia védelmében, és ezekhez kapcsolódó szervezeteket alapítottak, vagy csatlakoztak a már létezőkhöz. ${ }^{429}$ Ez utóbbi esetekben már feltűnő volt, hogy a baloldali retorika túlsúlyba került, nem véletlen tehát, hogy az említett eseményeken résztvevő filmesek később az Amerika-ellenes Tevékenységet Vizsgáló Bizottság céltábláivá váltak; a bizottság elé idézett személyektől a szokásos „,Volt Ön valaha tagja a Kommunista Pártnak?” kérdésen

\footnotetext{
${ }^{425}$ Uo. 190-191.

${ }^{426}$ A fő irányelvekről és a szervezet müködéséről lásd: Doherty, Thomas: Hollywood's Censor: Joseph I. Breen and the Production Code Administration. New York, Columbia University Press, 2009.

${ }^{427}$ Buñuel, Luis: Utolsó leheletem. Id. mü. 153.

${ }^{428}$ Langa Nuño, Concha: „Propaganda y evasión: Sevilla, retaguardia de la zona nacional” in: Pelaz, José-Vidal - Rueda, José Carlos (szerk.): Ver cine. Id. mü. 168.

${ }^{429}$ Például: Motion Picture Artists Committee to Aid Republican Spain, North American Committee to Aid Spanish Democracy, American Friends of the Spanish Democracy, Emergency Ambulance Committee stb.
} 
kívül gyakran megkérdezték, hogy „Adományozott Ön pénzt a köztársasági fegyvereseknek Spanyolországban?”430 Leginkább a korábban a nácizmus elől Amerikába menekült német és osztrák filmrendezők kezdtek Franco-ellenes kampányba, például Billy Wilder, Ernst Lubitsch, William Wyler és Fred Zinnemann. ${ }^{431}$ A radikálisan baloldali, kommunistaszimpatizáns csoportok a filmiparban korlátozott számban voltak csak jelen ${ }^{432}$, a fent említett szervezeteknek is mindössze egy százalékát tették ki, viszont a spanyol ügy kérdésében valóban ők voltak a hangadók. ${ }^{433}$ A Produkciós Kódex irányelvei ellenére a polgárháború idején több olyan amerikai film is készült, amely a köztársaságiak pártján állva mutatta be a konfliktust. A második világháború végéig összesen 43 amerikai játékfilmben ${ }^{434}$ említették valamilyen módon a spanyol polgárháborút, 1946 és 1977 között pedig további 16 filmben történt hivatkozás a háborúra vagy a Franco-diktatúrára. ${ }^{435}$ 1988-ban még létezett olyan, amerikai művészeket tömörítő társaság, amely életben tartotta a 30-as évekbeli hollywoodi szolidaritást. $^{436}$ Mindezek alapján megállapítható, hogy Hollywood, mint intézmény, semleges akart maradni a spanyol kérdésben, míg az ott dolgozó filmesek, mint egyének és csoportok, véleményt nyilvánítottak.

Franco a filmpolitika terén egy Hitlertől kölcsönzött módszert is bevezetett: nem csak azokat az amerikai filmeket tiltotta be Spanyolországban, amelyek a polgárháborúval foglalkoztak és szerinte a köztársaságiakkal szimpatizáltak, hanem minden olyan régebbi

\footnotetext{
${ }^{430}$ Pastor Petit, Doménec: Hollywood responde a la Guerra Civil (1936-39). Barcelona, Ediciones de la Tempestad, 1998. 233.

${ }^{431}$ Uo. 278.

${ }^{432}$ A nemzetközi filmtörténet tendenciáit, az azokat alkotó filmesek életművét és témaválasztásait szemlélve megállapítható, hogy a magukat baloldalinak valló forgatókönyvírók, rendezők, kritikusok és teoretikusok témaválasztásukkal gyakran fordultak az elnyomott rétegek felé. Véleményük és szolidaritásuk kifejezéséhez a filmet elsődleges eszközként, mintegy szócsőként és politikai vitairatként használták. Bemutatták az adott ország társadalmának azon szegmenseit, amelyekben - álláspontjuk szerint - a kiszolgáltatott és a kapitalizmus által kizsákmányolt rétegek élnek. A létezö problémákra esetenként megoldást is kínáltak, legtöbbször azonban inkább csak diagnózist állítottak fel. Ha végigtekintünk a történelmen, a 20-as évekbeli szovjet filmektől a francia és olasz filmtörténet különböző vonulatain át a brit munkásosztály mindennapjait ábrázoló művekig (mint Ken Loach filmográfiájának legjelentősebb darabjai) mindez könnyen tetten érhető, az Amerikai Egyesült Államokban azonban napjainkban ez a szemlélet inkább a populista demagógia jelzöt kapja (lásd Oliver Stone vagy Michael Moore filmjeit). A spanyol polgárháború mérföldkővé vált a világ filmeseinek életében: a baloldali eszmékkel azonosuló alkotók újradefiniálták nézeteiket és saját helyüket a nemzetközi alkotói rendszerben.

${ }^{433}$ Rey García, Marta: Stars for Spain: La guerra civil española en los Estados Unidos. A Coruña, Edicios do Castro, 1997. 339.

${ }^{434}$ A legjelentősebbek: Az utolsó vonat Madridból (The Last Train from Madrid, James P. Hogan, 1937), Szerelem tüz alatt (Love under Fire, George Marshall, 1937), Blokád (Blockade, William Dieterle, 1938), Kelj fel, szerelmem (Arise My Love, Mitchell Leisen, 1940) és a Hemingway-regény alapján készült Akiért a harang szól (For Whom the Bell Tolls, Sam Wood, 1943). Utóbbi kivételével egyik sem számít filmmüvészeti szempontból kiemelkedőnek, általában az akkoriban eléggé népszerủ B-kategóriás művek közé sorolhatóak.

${ }^{435}$ A listát közli: Coma, Javier: La Brigada Hollywood. Barcelona, Flor del Viento Ediciones, 2002. 208-220.

${ }^{436}$ A többek között Woody Allen, Gregory Peck, Harry Belafonte, Leonard Bernstein és Norman Mailer nevével fémjelzett Spanish Civil War Historical Society ekkor egy Dávid és Góliát egyenlőtlen harcát ábrázoló szobrot állíttatott Barcelonában a spanyol polgárháború emlékére. Pastor Petit, Doménec: Hollywood responde a la Guerra Civil. Id. mü. 150.
} 
vagy kortárs művet is, amelyhez bármi köze volt a kérdéses offenzív filmekben részt vevő személyeknek; rendezők, forgatókönyvírók, színészek kerültek így tiltólistára. Már nevük említését is kerülni kellett nyilvános fórumokon. A lista változó, gyarapodó, lekerülni nehéz volt róla, felkerülni rá annál könnyebb. Olyan nevekkel találkozhatunk ezeken a spanyol feketelistákon, mint Charlie Chaplin, Joan Crawford, Bette Davis, Bing Crosby, Fredric March, Henry Fonda, Douglas Fairbanks Jr, James Cagney, William Dieterle vagy Lewis Milestone. Szintén felkerült a listákra számos regény- és novellaíró, akik tevékenyen közremüködtek Franco-ellenes dokumentumfilmek forgatásában, akár a helyszínen is; Ernest Hemingway, Upton Sinclair, John Dos Passos neve többször is felmerül. Rajtuk kívül azok is nemkívánatosnak bizonyultak a spanyol sajtóban és kulturális életben, akik az USA-ban alapítói vagy tagjai voltak antifasiszta, a spanyol köztársaság megsegítésére létrejövő segélyszervezeteknek, így például Humphrey Bogart, Lauren Bacall, Spencer Tracy, Claude Rains, Fritz Lang és John Ford. Szintén a spanyol nemzet ellenségévé vált a spanyol köztársasággal nyíltan közösséget vállaló Albert Einstein, Dashiell Hammett, Theodore Dreiser, Thomas Mann és Dorothy Parker is. ${ }^{437}$ Az irántuk érzett gyülöletet egy argentin napilapba írt cikkében egy spanyol tudósító is megfogalmazta. Szerinte „Spanyolország sok mindent megbocsát, de azt soha nem fogja elfelejteni, hogy ezek a zömében zsidó hollywoodiak minden eszközzel a vörös kormányt segítették, meghosszabbítva ezzel annak agóniáját és elodázva a felszabadító csapatok munkájának sikerét”. ${ }^{4} 8$

A filmes feketelista nem spanyol találmány, a náci Németország és a fasiszta Olaszország szintén rendelkezett ilyennel, valamint 1947-től egészen a 60-as évek végéig az Amerikai Egyesült Államokban közel háromszáz filmiparban dolgozót lehetetlenítettek el azzal az indokkal, hogy az illetékes bizottságok feltételezése szerint szimpatizáltak a kommunista eszmékkel. A célkeresztbe helyezett, kommunista-szimpátiával vádolt filmesek elleni egyik fő vád az volt, hogy támogatták a spanyol köztársaságiakat, vagy egyszerüen csak antifasisztának vallották magukat; az Amerika-ellenes Tevékenységet Vizsgáló Bizottság (HUAC) által beidézett filmesek szinte mindegyike megtalálható Franco tiltólistáin is. ${ }^{439}$

Később baráti viszonyba került a spanyol diktatúra és az Amerikai Egyesült Államok, 1949-ben már amerikai élelmiszerekre fordítható hiteleket kapott Spanyolország, 1953-tól hivatalos szerződéseket kötöttek, valamint a HUAC egyik albizottságát irányító Joseph

\footnotetext{
${ }^{437}$ AMAE, R-1724/126-os köteg releváns iratai

${ }^{438}$ Idézi: Álvarez Berciano, Rosa - Sala Noguer, Ramón: El cine en la zona nacional. Id. mü. 46.

${ }^{439}$ Bőséges szakirodalom áll rendelkezésre a hollywoodi „,boszorkányüldözés” témájában. Ezek közül az általam használt források: Freedland, Michael: Hollywood on trial: McCarthysm's War Against the Movies. London, Anova Books, 2007 és Gubern, Román: La caza de brujas en Hollywood. Barcelona, Editorial Anagrama, 1987.
} 
McCarthy szenátor is erőteljesen részt vett a volt spanyol külügyminiszter, Lequerica által kialakított, az USA-t megcélzó spanyolbarát lobbiban. ${ }^{440}$ 1940-41-től, megelőzve több más területet, az USA és Spanyolország küldöttségei folyamatosan írták alá a megállapodásokat és szerződéseket filmimportról és nyersanyagvásárlásról. Hollywood előtt megnyíltak Spanyolország kapui; szuperprodukciókat forgattak Franco meghívására a fasiszta államban, a diktátor különösen Samuel Bronston (eredeti nevén Bronstein, Lev Trockij unokaöccse) orosz származású amerikai producerrel alakított ki jó viszonyt. A 60-as évek elején Spanyolországba helyezték azoknak a filmeknek a forgatását, amelyek felett Bronston bábáskodott, és olyan helyszínekre volt szükség, ahol gond nélkül és olcsón fel lehetett építeni a monumentális díszleteket. ${ }^{441}$ Ezeknél a filmeknél a statiszták elsősorban a spanyol hadsereg tagjai közül kerültek ki, a leendő uralkodó, János Károly gyakran megjelent a forgatásokon, a későbbi demokratikus átmenet kormányfője, Adolfo Suárez pedig statisztaszerepet is vállalt. ${ }^{442}$ Bronston és a rezsim viszonya különösen harmonikusnak volt mondható: az oroszamerikai producer még állami megbízásból is készített propagandaalkotást ${ }^{443}$ a tábornok számára, rajta keresztül pedig számtalan korabeli nemzetközi filmcsillag érkezett Spanyolországba, és élvezte a Caudillo (és a spanyol bulvárlapok) vendégszeretetét.

A spanyol-amerikai együttműködés nem korlátozódott a fenti produkciókra, az 50-es évek második felétől kezdődően számos hollywoodi mű forgott spanyol földön, a déli Almería és környéke pedig valóságos „mini-Hollywooddá” változott az ott készített megszámlálhatatlan mennyiségü westernnek és kosztümös filmnek köszönhetően. Az amerikai stáboknak kötelező volt spanyol személyzetet is alkalmazniuk meghatározott százalékban. Spanyolország számos előnyt tudott nyújtani a külföldi filmeseknek: változatos táj, alacsony áron elérhető stúdiók, technikai berendezések és professzionális tudással rendelkező személyzet, sokoldalú színészek, előnyös állami támogatás és kedvezmények; a tervezett költségvetéshez képest közel 30\%-kal olcsóbb lett így egy produkció. Az amerikaiak mellett később olasz, francia, brit filmesek is megjelentek, akik már a spanyolokkal

\footnotetext{
${ }^{440}$ Gil Pecharromán, Julio: La política exterior del franquismo. Id. mű. 177.

${ }^{441}$ Így született meg az El Cid (El Cid, Anthony Mann, 1961), A Római Birodalom bukása (The Fall of the Roman Empire, Anthony Mann, 1964), a Királyok Királya (King of Kings, Nicholas Ray, 1961), az 55 nap Pekingben (55 Days at Peking, Nicholas Ray, 1963) és A cirkusz világa (Circus World, Henry Hathaway, 1964).

${ }^{442}$ García de Dueñas, Jesús: El Imperio Bronston. Madrid, Ediciones del Imán - Filmoteca de la Generalitat Valenciana, 2000. 255 és 274.

443 Bronston producer a magyar származású Márton Endre filmrendezővel karöltve egy hivatalos propagandafilmet forgatott (bár müvészfilmnek titulálva azt), elsősorban külföldi terjesztés reményében. $A z$ Elesettek Völgye (El Valle de los Caídos, Andrew Marton, 1964) végül csak elvétve került bemutatásra, a hivatalos adatbázisokban nem szerepel, és utólag a stáb is megbánta elkészítését az erőteljesen nacionalista ideológiai töltet miatt. Erről lásd: García de Dueñas, Jesús: El Imperio Bronston. Id. mü. 259-264.
} 
koprodukciókat is készítettek. ${ }^{444}$ Számos, később filmtörténeti mérföldkővé vált nemzetközi szuperprodukció választotta Franco Spanyolországát helyszínül a teljes forgatáshoz, vagy egyes részek rögzítéséhez. ${ }^{445}$ A Caudillo kormányai minden támogatást megadtak a külföldieknek, még olyat is, amelyet spanyol filmeseknek nem. ${ }^{446}$

Bár hivatalosan az USA és Spanyolország az 50-es évek elejéig nem kötöttek szerződéseket egymással, az amerikai filmek importálása folyamatos volt. Az amerikaiak minden diplomáciai kapcsolatukat latba vetették annak érdekében, hogy Franco Spanyolországa növelje a hollywoodi produkciók behozatalát, számos e témában folytatott tárgyalás jegyzőkönyve és levelezés dokumentációja áll rendelkezésre. ${ }^{447}$ Az ábrázolt témák kapcsán is engedékenynek mutatkoztak, amennyiben érdekeik úgy kívánták: a 40-es években a Falange szekciója által egyöntetüen elítélt és behozatalra alkalmatlannak nyilvánított Elfújta a szél például 1950-ben bemutatásra kerülhetett a spanyol mozikban, bármilyen ellenvetés vagy tiltakozás nélkül, amelynek valószínűleg köze volt a gyártó Metro Goldwyn Mayer stúdió amerikai üzleti kérdésekre való jelentős befolyásának. ${ }^{448} 1955$ és 1958 között az Egyesült Államok bojkottálta filmjei Spanyolországba történő exportálását az új spanyol filmvászonkvóta miatt (minden negyedik vetítési napon kizárólag spanyol filmeket tủzhettek müsorra a mozik, ezzel pedig sérültek az amerikaiak üzleti érdekei), de Franco kormánya végül meghátrált, visszavonta ezt a kvótatörvényt, így a hollywoodi produkciók szabadon áramolhattak be az országba. ${ }^{449}$

\footnotetext{
${ }^{444}$ Erről bővebben: Aguilar, Carlos: „El cine en Almería: El paisaje es el mensaje” in: García de Dueñas, Jesús Gorostiza, Jorge (szerk.): Los estudios cinematográficos españoles. Id. mü. 327-342.

445 Néhány példa: Arábiai Lawrence (Lawrence of Arabia, David Lean, 1962), Doktor Zsivágó (Doctor Zhivago, David Lean, 1965), Kleopátra (Cleopatra, Joseph L. Mankiewicz, 1963), Spartacus (Stanley Kubrick, 1960), Patton tábornok (Patton, Franklin J Schaffner, 1970), illetve Sergio Leone és Sergio Corbucci legendás westernfilmjeinek nagy része is Spanyolországban készült.

${ }^{446}$ A spanyol tervekkel szemben kizárólag az említett, 1961-es amerikai El Cid-projektet támogatták, míg a Büszkeség és szenvedély (The Pride and the Passion, Stanley Kramer, 1957) stábja felvételeket készíthetett San Lorenzo de El Escorial monostorának falai között is. A Nagy Katalin orosz cárnőt alakító Bette Davis a John Paul Jones (John Paul Jones, John Farrow, 1959) címü Bronston-produkció forgatásán valóban a madridi Királyi Palota trónszékében foglalhatott helyet. Korabeli spanyol filmeknek ilyenre nem volt lehetöségük. García de Dueñas, Jesús: El Imperio Bronston. Id. mü. 146.

${ }^{447}$ Erről lásd: Díez Puertas, Emeterio: „El acuerdo cinematográfico hispano-norteamericano” in: Secuencias, No. 4. 1996. 9-37; León Aguinaga, Pablo: „El cine norteamericano en España: Las negociaciones para su importación, 1950-1955” in: Hispania, Vol. LXVI. No. 222. 2006. 277-318; León Aguinaga, Pablo: „El comercio cinematográfico como instrumento de la acción norteamericana en España durante la segunda guerra mundial" in: Cuadernos de Historia Contemporánea, Vol. 28. 2006. 303-322.

${ }^{448}$ Gubern, Román - Font, Doménec: Un cine para el cadalso. Id. mü. 58.

${ }^{449}$ Caparrós Lera, José María: „Imágenes de América Latina del siglo XX en el cine de la autarquía” Id. mü. 50.
} 


\section{Néhány reprezentatív film}

\section{A spanyol ,nemzeti” film}

A 20. század elején Spanyolországban tapasztalható identitásválság, kilátástalanság, bizonytalanság és útkeresés érzése, valamint az erre adott reakciók (mint a 98-as Nemzedék írásai ${ }^{450}$ ) egybeestek a film Ibériai-félszigetre érkezésével. A kezdeti lépések azonban még nem sokban különböztek más európai országok kísérletezéseitől, a saját produkciók képtelenek voltak közvetlen diskurzust kialakítani a társadalommal, ugyanis még nem tudták megragadni azokat az elemeket, amelyek a spanyolság jellemzőit, sajátosságait adták. Csak a felszínt láttatták, önmaguk sem határozták meg, hogy mi a spanyol. A külföldi filmesek pedig, mint a Lumière testvérek megbízásából Spanyolországban tartózkodó Alexander Promio, felvételeikkel elsősorban a sztereotip vonásokat erősítették (bikaviadalok, flamenco), kiegészítve azokat a color local néhány elemével (madridi utcaképek, barcelonai kikötő). ${ }^{451}$ Nem volt saját, csak a spanyolokra jellemző filmmüfaj sem, döntően az amerikai és olasz nemzeti zsánereket igazították a hazai viszonyokhoz és a környezethez, felhasználva saját irodalmi vagy történelmi forrásaikat. A spanyol némafilm-korszak legtehetségesebb filmesei közül sokan Olaszországba vagy Franciaországba emigráltak, ahol számos filmművészeti impulzus érhette őket, fejlődhettek és kibontakozhattak, a hangosfilmek megszületésekor pedig már nagyobb számban indultak Hollywood felé, hogy részt vegyenek a már többször említett dupla változatok munkálataiban.

Az egyetlen autentikus próbálkozás az españolada, ami nem egy müfaj, hanem egy típus, leginkább a vígjáték és a zenés film müfaján belül jelenik meg: sztereotípiák halmozása az andalusismo túlhangsúlyozásával, mintha Spanyolország csak az andalúz folklórt jelentené, ezáltal meghamisítva a földrajzi, társadalmi és tradicionális szempontból is sokszínü Spanyolország-képet. Egy idillikus vidéket mutat be, ahol az erkölcs és a tisztelet uralkodik. Eltúlozza a spanyol viselkedést és a szokások ábrázolási módját, kiindulási alapként azonban általában valódi személyeket, földrajzi helyszíneket és élethelyzeteket használ fel. Később a filmiparból az élet más területére is átterjedt az españolada kifejezés, olyan tervekre, megvalósításokra használták, amelyek kezdettől fogva tévúton járnak, torzítanak és túloznak, mintha szándékosan önmaguk ellen dolgoznának. Forrásként spanyol

\footnotetext{
${ }^{450}$ Erről lásd: Csejtei Dezső: „A 98-as nemzedék és a spanyol történelem” Id. mű.

${ }^{451}$ Pérez Perucha, Julio: „Narración de un aciago destino (1896-1930)” in: Gubern, Román (et.al.): Historia del cine español. Id. mü. 23-25.
} 
és külföldi szerzők munkái szolgáltak, ahol a spanyol (andalúz) terület szinte kizárólag banditák és más törvényen kívüliek, cigányok és bikaviadorok élöhelye, egzotikus felhangot adva a régiónak. Állandó jelenléttel bír a tradicionális spanyol tánc, mindenekelőtt a zarzuela, majd a hangosfilm megjelenésével kezdődően a zene is. Prosper Mérimée 1847-ben kiadott Carmen címủ müvétől számíthatjuk az ilyen tipikus jegyek megjelenését, majd ezt fokozza Bizet azonos címü operája az 1875-ös bemutatótól; nem véletlen, hogy amikor a filmgyártásban is szaporodni kezdett az españolada típusú film, alkalmazva a külföldi szerzők elöítéletes ábrázolásmódját, a különféle Carmen-feldolgozások erősen túlsúlyba kerültek: az eredeti, Merimée-féle Carmen figura nem csak az alapjául szolgáló mü filmfeldolgozásaiban szerepelt, de alakja, mint egy „vendégsztár”, feltünt korabeli kalandfilmekben és zenés produkciókban is, ahol alkalmanként útonállóként vagy kocsmai énekesnőként ábrázolták a főhősnőt, megihletve néhány külföldi rendezőt (mint Ernst Lubitsch, Charles Chaplin, Cecil B. DeMille) is, hogy elkészítsék saját Carmen-változatukat. ${ }^{452} \mathrm{Az}$ españolada egészen a Franco-korszak végéig létezett, sokszor koprodukcióban Olaszországgal és olasz rendezők irányításával, az említett toposzokat felhasználva, leginkább az egyértelmủ szórakoztatásra és a mondanivaló nélküli müvekre koncentrálva, még erőteljesebben kihangsúlyozva a machismot. Később sem tűnt el, csak átalakult, bizonyos formájában ma is megtalálható, az andalúz jegyek mellé más régiókra jellemző általánosításokat is belekeverve. A saját identitás felépítése az españoladán kívül klasszikus spanyol irodalmi müvek és színdarabok filmre adaptálásában merült ki.

Primo de Rivera idején (1923-1930) továbbra sem volt egyértelmü, hogy milyen jellemvonások mentén képes önmagát definiálni a spanyol nemzet ${ }^{453}$, de a filmgyártásban beindult egy folyamat, mindenekelőtt a múlt értelmezése és ábrázolása terén. A képkockákon a spanyol összefogás, valamint a külföld iránt táplált ellenséges hangnem elevenedett meg, olyan alakokat, erkölcsi példaképeket és helyzeteket állítva a középpontba, amelyeket követendőnek, mértékadónak véltek a rendezők. A történelmi korokba helyezett cselekményekben ugyanazok az españolada-sajátosságok köszöntek vissza, mint egy évtizeddel korábban, a filmesek próbálták megteremteni a nemzet jellegzeteségeit. ${ }^{454} \mathrm{~A}$ Primo-korszakban a legjelentősebb filmeket gyártó, katolikus és konzervatív beállítottságú Atlántida stúdió 1919-es alapításakor közzétett elvei, retorikáját és szóhasználatát tekintve,

\footnotetext{
${ }^{452}$ Zanger, Anat: Film Remakes as Rituals and Disguise: From Carmen to Ripley. Amsterdam University Press, 2006. 30-31; 46-67.

${ }^{453}$ A korszak politikai-ideológiai leírását adja: Tari Adrienn: A Primo de Rivera-diktatúra közép-kelet-európai politikája (1923-1930). Doktori értekezés. Szeged, 2011. 14-34. Lásd még: Farkas Pálma idézett Fekete legenda ... címü doktori értekezésének vonatkozó részeit.

454 Általános áttekintést ad: Pérez Perucha, Julio: „Narración de un aciago destino” Id. mű. 88-122.
} 
már megelőlegezték azt az álláspontot, amely a Franco-rendszerben jellemezni fogja a nemzetközpontú filmgyártást: „A Társaság a fajunk tradicionális géniuszán fog alapulni, hogy kiváló, sokszínű művészetének terjesztésével hozzájáruljon népünk szellemi felemelkedéséhez, és egyúttal igyekezni fog szorosabbá füzni a testvéri kötelékeket SpanyolAmerikával, valamint a civilizáló kötelékeket Észak-Afrikával". ${ }^{455}$ Mindehhez elsősorban ismét az españoladához, a folklór és a tradíciók bemutatásához, felhasználásához folyamodtak.

Az 1931-től felállt Második Köztársaság idején forgott mozik célja volt, hogy a nézőt elvonatkoztassák a valóságtól, kikapcsolódást nyújtsanak. Ehhez felhasználták a már ismert elemeket és a klasszikus spanyol irodalmi alkotásokat. Kiemelkedő munka A galamb ünnepe (La verbena de la Paloma, Benito Perojo, 1935), egy tíz évvel korábban forgatott José Buchsfilm új feldolgozása a Cifesa filmstúdió gondozásában; az azonos című zarzuelita ${ }^{456}$ adaptációja, ahol a spanyolságot a zene és tánc jelentik. Az egyes filmek témája nem sok különbséget mutatott, általában sablonos történetek és egydimenziós karakterek jellemezték őket.

Már ekkor megjelent az igény, hogy az anyaország és Latin-Amerika között élénk nemzetközi kapcsolatokat alakítsanak ki, és mindezt a filmekre is kiterjesszék. Ennek egyik első lépése az 1931-ben Madridban megrendezett, már említett Hispán-Amerikai Filmművészeti Kongresszus. Itt azonban az összefogás oka elsősorban a hangosfilm megszületése után egyre gyorsabban terjeszkedő észak-amerikai filmek benyomulása volt a közép- és dél-amerikai országokba. A pánhispán jellegü, a spanyol nyelven beszélő művek népszerüsítését és az ehhez szükséges politikai-gazdasági előfeltételek megteremtését célzó tudományos összejövetel nem hozott számottevő eredményt. ${ }^{457}$

A filmpolitika célja Franco számára a nemzeti film megteremtése lett. De hogy mi a nemzeti, azt nem definiálták pontosan. ${ }^{458}$ A nemzeti filmgyártás, bármely ország kapcsán is tekintjük, egy olyan elméleti konstrukció, amely sok szemantikai megközelítést magában foglalhat. Alapesetben egy film nemzeti mivoltát már az meghatározza, hogy az adott ország stábjával, saját anyagi forrásaiból és infrastrukturális háttérével készül, valamint a hivatalos

\footnotetext{
${ }^{455}$ Idézi: Cánovas Belchí, Joaquin T.: „La Atlántida S.A.C.E ...”. Id. mű. 29.

${ }^{456}$ A zarzuela egy hagyományosan spanyol, a 17. századból származó színpadi zenei müfaj, amelyben keveredik a zene, a dal és a próza. A zarzuelita ennek egyfelvonásos, a 19. században népszerüvé váló változata.

457 Gubern, Román: „El cine sonoro (1930-1939)” Id. mű. 130-131.

458 A témáról lásd: Lénárt András: „A spanyol nemzetfelfogás és önazonosság változatai a filmvásznon” in: Mediterrán Világ, 2013. (megjelenés alatt) és Uő: „En busca del concepto del cine nacional español” in: Acta Hispanica, Tomus XVII. 2012. (megjelenés alatt).
} 
nyelven szól a közönséghez. Mindehhez hozzáadódhat, hogy a témának is nemzeti jelleget kell képviselnie: saját történelméböl, jelenkorából, társadalmi és szociális kérdéseiből kell táplálkoznia. Legszélsőségesebb esetben - és a diktatúrák kapcsán erről beszélhetünk - a nemzeti film a fennálló rendszer által egyeduralkodónak bélyegzett ideológiát tükrözi vissza, a hivatalos retorikát alkalmazza.

Ebben a rendkívül tágan értelmezhető kategorizálásban minden alkotó a saját meggyőződése szerint interpretálhatta a nemzeti film fogalmát Spanyolországban is: míg Florián Rey filmrendező szerint a „fajra” jellemző tulajdonságokat, a folklórt, a tradicionális zenét és a legősibb szokásokat kellett bemutatnia (illeszkedve így a 19. századi konzervatív nacionalizmushoz) ${ }^{459}$, addig Juan Antonio Bardem sokkal elvontabban nyúlt a kérdéshez, inkább a különböző emberi jogok gyakorlását lehetővé tevő politikai közösséget tekintette nemzetalkotónak, így a nemzeti film bármi lehet, ami a közösség által jön létre. ${ }^{460}$ A Francokorszakban a filmiparhoz kötődő jelentősebb személyek mind rendelkeztek világos koncepcióval arról, milyen is a nemzeti film. A Primer Plano folyóirat alapítója, García Viñolas szerint a spanyol filmet ugyanúgy meg kell újítani, mint Spanyolországot, mivel minden nemzet a filmjén keresztül tudja kifejezni önmagát a legvilágosabban; Rafael Gil filmrendező úgy vélte, ,,a film egy olyan kollektív művészet, amelyet az egész nép együttesen müvel”, a gyártás színvonalának javításához pedig az szükséges, hogy az egész nemzet egy magasabb intellektuális szintre lépjen; a rezsim egyik állandó rendezője, José Luis Sáenz de Heredia szintén összekötötte egy nemzet kulturális fejlettségét saját filmgyártásának állapotával, és hozzátette, a filmeket nem csak a konkrét filmesek készítik, hanem az egész ország, még az is, aki nem jár moziba, a kollektív nemzeti öntudat formálja a nemzeti filmmüvészetet. ${ }^{461} \mathrm{Az}$ 50-es évek közepén a volt (és egyben leendő) filmművészeti főigazgató, José María García Escudero úgy vélte, 1939-ig nem létezett spanyol film sem anyagi, sem szellemi, sem technikai értelemben. Leginkább egy olyan gyermekhez hasonlította, aki 1929 és 1934 között tette meg az első lépéseit, csak 1939 után kezdett el önállóan járni, de még akkor sem sikerült saját filmipart és politikai filmgyártást kialakítani. Szerinte a mesterkélt alkotások, a semmitmondó castañuelák ${ }^{462}$ és a hiteltelen vallási mủvek árasztották el a vásznakat. ${ }^{463}$ García Escudero minden filmes témájú tanulmányában és

\footnotetext{
${ }^{459}$ Cerón Gómez, Juan Francisco: El cine de Juan Antonio Bardem. Id. mü. 63-64.

${ }^{460}$ Uo.

${ }^{461}$ A véleményeket összegyüjtötte: García Escudero, José María: Cine español. Id. mű. 35-36.

${ }^{462}$ A castañuela (magyarosan: kasztanyetta) egy páros spanyol népi ütőhangszer. Spanyolországban gyakran ugyanezzel a névvel illetik a hangszerrel előadott dallamot, zenei számot, esetenként egy teljes előadást.

${ }_{463}$ García Escudero, José María: La historia en cien palabras del cine español y otros escritos sobre cine. Salamanca, Publicaciones del Cine-club del SEU, 1954. 11-12.
} 
könyvében visszatérő és állandóan megerősödő gondolat, hogy a filmekre a legnagyobb veszélyt nem a cenzúra és a politika jelentik, hanem maga a közönség: a közönség ugyanis alapvetően rossz (el mal público, ahogyan ő nevezi), hozzá nem értő, nem tudja, mire kell figyelni, mit kell látni, érezni; a közönség kiművelése, megnevelése ezért a mindenkori filmpolitika egyik fő feladata, amelynek nem ideológiai, hanem intellektuális alapon kell történnie. ${ }^{464} 1971$-ben egy könyvet is írt a közönség intellektuális neveléséröl és a társadalom filmkulturális müveltségének javításáról. ${ }^{465}$

A Második Köztársaság idején virágzásnak induló filmipart, amely megteremtette a szükséges infrastrukturális hátteret és kitermelte a szükséges szakembergárdát is, a polgárháború szinte teljesen lerombolta. Filmrendezők, forgatókönyvírók, színészek, technikai szakemberek tömegesen hagyták el Spanyolországot, összesen közel kétszázan, a legkedveltebb célhely Mexikó, Argentina és Franciaország volt. A filmes emigráció nagy része betagozódott a befogadó ország filmgyártásába, igyekezett alkalmazni egymást a projektekben, sokan a helyi állampolgárságot is felvették. Segítették öket a már korábban, az 1920-as évek során Latin-Amerikába érkező, a dupla változatok elkészítésében közremüködő spanyol filmesek. Nem készítettek olyan müveket, amelyek nyíltan reflektáltak a spanyol polgárháborúra és az azt követő rendszerre, de gyakori volt a spanyol irodalom és kultúra felhasználása, megjelenítése a dokumentumfilmekben és a játékfilmekben. Az emigráció azonban nem minden esetben volt végleges: a filmezés mellett színházi előadásokban is részt vevő számos színész hivatalosan nem hagyta el országát, hanem társaival együtt az új spanyol kormány által a Hispanidad szellemében támogatott hispán-amerikai turnéra indult, négy-öt év alatt bejárt több országot is, majd visszatért a polgárháború közvetlen utóhatásai miatt már kevésbé kaotikusnak tűnő hazájába. Az is gyakori volt, hogy a turnék keretein belül külföldre indult színészek végül letelepedtek a körút egyik állomásán. Így helyükre Franco Spanyolországában új emberek kerültek; esetenként könnyebben voltak pótolhatóak (színészek, rendezők), máskor viszont nagy nehézségekbe ütközött megfelelő szakembereket találni (forgatókönyvírók, technikai szakemberek). ${ }^{466}$

A polgárháború előtti időszak egyik legnépszerübb típusa fennmaradt a Francokorszakban is: a folklórfilm, mely szerves részét képezte a spanyol nemzeti öntudat építésének. Ez nevezhető a rezsim nem hivatalos filmjének is, szemben a nyíltan ideologikus müvekkel, amelyekről később szólok. Az españolada átmentéséről van szó, ám továbbra is

\footnotetext{
${ }^{464}$ Több helyen is kifejti ezt a véleményét, leghosszabban itt: García Escudero, José María: Cine español. Id. mű. 39-44.

${ }^{465}$ García Escudero, José María: Cine para el año 2000. Madrid, Zero, 1971.

${ }^{466}$ Gubern, Román: Cine español en el exilio. Id. mü. 14-19. és 201.
} 
ellentmondásos eredménnyel: míg a kritika szinte egyöntetủen lenézte a műfajt az egyszerü cselekmény és szegényes megvalósítás miatt, a nézők továbbra is örömmel vették ezeket, belefeledkezhettek a tradicionális spanyol kultúrába és az ismert dalokba. A 20-as és 30-as években feltünt flamenco énekesek és táncosok uralták ezeket a rendkívül népszerü filmeket, kiegészülve a 40-es és 50-es évek új csillagaival: Imperio Argentina, Pastora Imperio, Angelillo, Carmen Amaya, a Rosario és Antonio páros, Antonio Molina és mind közül a leghíresebb, Lola Flores. Florián Rey filmrendező egy 40-es években adott interjúban megfogalmazta, mi a spanyol folklórfilmek egyik fő kulturális feladata - igazolásként pedig a magyar filmművészetet hozta fel: „A spanyol filmnek kötelessége Amerika felé irányítania a közönségét és costumbrista folklórfilmeket készítenie. Ebben leginkább Spanyolország érdekelt; és ha bennük, a külföldiekben él egy legenda Spanyolországról, akkor azt fenn is kell tartani. Igen, uram; barna nők és spanyol zene. Ha Ön megnéz egy magyar filmet, és abban nem lát cigányokat, átverve érzi magát”. 467 Bár törekedtek a rendszer által elképzelt spanyol nemzeti tudatot államilag ösztönzött filmeken keresztül megteremteni, visszatekintve azt mondhatjuk, a közönség körében továbbra is rendkívül népszerü folklórfilmek, a costumbrismót közvetítő españoladák maradtak a spanyolság tudat fö képviselői. ${ }^{468}$

Bár a köztársaság idején is megfigyelhető volt, hogy bizonyos üzleti körök befektettek a filmiparba, a polgárháború után egyre nagyobb számban jelentek meg konzervatív nagytőkések, akik az anyagi hasznot másodlagosnak tartották, szemben azzal a hazafias kötelességgel, hogy segítsenek megteremteni a valódi nemzeti filmgyártást, szembeállítva azt a külföldről érkező, liberális és demokratikus filmpolitikák termékeivel. Ezzel magyarázható, hogy az állam és a magántőke, először Spanyolország történetében, közösen avatkozott be a hazai filmiparba, mind ideológiai, mind anyagi megfontolásból. Mint kiderült, egyes befektetőket mégis az anyagi haszonszerzés motivált. Az állami hozzájárulás olyan mértéküvé vált, hogy a gyártási költségektől elmaradó bevételek által okozott anyagi kárt az állam előbb vissza nem térítendő támogatásokkal, majd a Szakszervezeti Filmhitellel (Crédito Cinematográfico Sindical) térítette meg. Megérte tehát filmbe fektetni: egy statisztika szerint 1941 és 1950 között 193 filmgyártó vállalat létezett (ezek együttesen több mint 400 mủvet

\footnotetext{
${ }^{467} \mathrm{Az}$ idézet több helyen is megtalálható, többek között: Castro, Antón: „Recuerdo de Florián Rey” in: http://antoncastro.blogia.com/2005/050601-recuerdo-de-florian-rey-.php (2012-11-21)

${ }_{468}$ Mályusz Elemér a „népiség”-hez, népi gondolathoz és nemzetfogalomhoz kapcsolódó írásai részben rokoníthatóak ezzel a felfogással. Erről lásd: Romsics Ignác: Clio bűvöletében. Budapest, Osiris Kiadó, 2011. 326-329.
} 
forgattak), de közülük több mindössze egy film készítése kedvéért alakult, majd az állami támogatás felvétele után azonnal el is tünt. ${ }^{469}$

Az alábbiakban olyan alkotásokról szólok, amelyek megtestesítik a Franco-korszak ideológiai mozaikjának egészét vagy egyes darabjait. A legkiemelkedőbb darabokról hosszabban írok, egyéb jelentősebb filmeket rövidebben mutatok be, míg további munkákat csak említés szintjén sorolok fel. Nem törekszem a témához kapcsolódó összes film ismertetésére, célom jellemző példákat állítani. Mindenekelőtt a polgárháborús témájú Keresztes Hadjárat filmekröl (cine de Cruzada), a fegyveres eröket heroizáló eposzokról, a közös ellenségképet kijelölő mozikról, a történelmi papírmasé filmnek (cine de cartón piedra), esetenként köpenyes-kardos filmnek (cine de capa y espada) nevezett, a Spanyol Birodalom és a napóleoni hódítás időszakába visszanyúló alkotásokról és a katolicizmus jegyében született művekről lesz szó, mivel ezek elkészítésében fedezhetjük fel a legerőteljesebb eszmei mondanivalót. Mindegyik a hazafias film (cine patriótico) kategóriájába tartozik. Minden, az állam számára fontos alkotáshoz társult legalább egy, a film szellemiségét tükröző, a nézői elvárásokat már előre meghatározó plakát ${ }^{470}$, amelyet a sajtóban, a filmszínházak falán és hirdetőoszlopokon hetekkel a premier előtt terjeszteni kezdtek. ${ }^{471} \mathrm{Az}$ alkategóriák végén minden esetben törekszem arra, hogy megközelítő becslést adjak az ilyen témában készült alkotások számáról. Mivel hivatalos statisztikák nem készülttek, ezért kizárólag az általam látott filmekre, valamint azon könyvekre és tanulmányokra hagyatkozhatok, amelyek az alkategóriába tartozó filmek egyes darabjait vizsgálták.

A 40-es évek filmpolitikáját jellemző vélemény szerint az új spanyol film feladata ,a falangista ideológia terjesztése, és egy tántoríthatatlanul hispán gyökerü kultúra létrehozása, fenntartani és fejleszteni gazdag szellemi tradícióját, szilárd katolikus hitét és faji sajátosságait”. ${ }^{772}$ A tárgyalt alkotások ezt a meggyőződést voltak hivatottak kiszolgálni, majd fokozatosan halványodni kezdett ez a szemlélet. Közös jellemzőjük, hogy - kevés kivételtől eltekintve - mindet 1939 és 1959 között forgatták. A 60-as évek változó légkörében, ahogyan

\footnotetext{
${ }^{469}$ Castro de Paz, José Luis: Un cinema herido. Id. mü. 26-30.

${ }^{470} \mathrm{Az} 1939$ és 1945 között készült filmplakátokat stílusuk és művészi megjelenítésük szempontjából elemzi, azok dokumentumértékét és készítőit bemutatja: Fernández Mellado, Rebeca: „El cartel de cine español de posguerra (1939-1945): Modelo de tratamiento documental" in: Cuadernos de Documentación Multimedia, No. 18, 2007.

Elérhetö: http://multidoc.rediris.es/cdm/viewarticle.php?id=57 (2012-11-22)

${ }^{471}$ Az értekezés 2. számú Függelékében közlöm a legjelentösebb filmek plakátját.

${ }^{472}$ Idézi: García Seguí, Alfonso: „Cifesa, la antorcha de los éxitos” in: Archivos de la Filmoteca, No. 4. 19891990. 17.
} 
erre majd egy külön fejezetben is kitérek, változtak a filmpolitika prioritásai, az ideológiai mondanivaló, a propagandisztikus hangnem háttérbe szorult a filmmüvészeti szempontokkal szemben. Fontosnak tartom megismételni: a teljes Franco-rendszer során, az olasz és a német diktatúrákhoz hasonlóan, még a rendszer konszolidációs periódusában is, számukat tekintve, kisebbségben voltak a propagandának tekinthető, állami ideológiát tükröző filmek a semleges hangvételü, pusztán szórakoztatói funkciót ellátó munkákkal szemben. Azonban az állami propaganda számára így is rendkívül nagy jelentőséggel bírtak.

\section{Faj-Raza}

A Faj (Raza, José Luis Sáenz de Heredia, 1942) minden szempontból a legfontosabb eredménye a francói filmpolitikának; egyik alkategóriába sem lehet kizárólagosan besorolni, mivel mindegyikhez szervesen kapcsolódik, egyszerre mindegyik legfontosabb alkotása, ezért külön alfejezetet szentelek neki. Kiemelkedő jelentősége miatt indokoltnak tartom az előzményeket és keletkezésének körülményeit is bemutatni.

José Luis Sáenz de Heredia filmrendező a polgárháború kitörésekor még bujkált, attól félt, hogy rokoni kapcsolatai miatt a köztársaságiak kivégzik: nagybátyja Miguel Primo de Rivera volt, unokatestvére pedig José Antonio Primo de Rivera. Majdnem így is történt, egy szocialista fegyveres csoport letartóztatta, de kollégája és politikai meggyőződésbeli különbségeik ellenére barátja, Luis Buñuel közbenjárására szabadon engedték, mivel semmi jelét nem adta annak, hogy a felkelőkkel szimpatizálna. ${ }^{473}$

1941-ben Franco bizalmasa és közvetlen munkatársa, Jesús Fontán egy közvetítőn keresztül kapcsolatba lépett vele, hogy közölje, a Hispanidad Tanácsa egy filmforgatást tervez, amely az El Pardo palota teljes támogatását élvezi. A forgatókönyvet a mindenki számára ismeretlen Jaime de Andrade jegyzi, témája pedig a spanyolok spirituális értékeinek dicsérete. Három lehetséges rendező közül Sáenz de Heredia lett a befutó, Franco személyesen választotta ki őt. Bár akkoriban nem hozták nyilvánosságra hivatalosan, hogy Jaime de Andrade Franco tábornok írói álneve, már közszájon forgott „,a Caudillo filmje” elnevezés. Számos tanácsadó jelen volt a forgatásokon, több korabeli szemtanú, például a főszereplő Alfredo Mayo is állította, hogy gyakran érkezett az El Pardo palotából egy motoros futár instrukciókkal, de maga a Generalísimo egyszer sem jelent meg. A karácsonyra tervezett, számos diplomata és fontos személy körében tartandó nem hivatalos premier előtt Franco a családja, valamint orvosa és közeli barátai társaságában megtekintette a filmet egy

${ }^{473}$ Buñuel, Luis: Utolsó leheletem. Id. mü. 132-133. 
privát vetítésen; a résztvevők szerint többször könnyes lett a szeme, mindenekelőtt annál a jelenetnél, amikor a szerzeteseket kivégzik. Végül dicséretben részesítette a rendezőt. A karácsonyi vetítést hatalmas ováció övezte a díszvendégek részéről, majd 1942 januárjában a madridi Zenepalotában tartották meg a hivatalos premiert, szintén nagy sikerrel. ${ }^{474}$ A napi- és hetilapok közel egy hónapon keresztül állandó promóciót biztosítottak a műnek, a Nemzeti Szórakoztatóipari Szakszervezet pedig az év filmjei közül a Fajt ítélte a legjobbnak, 400 ezer pesetás díjban részesítette, amelyet az alkotók között osztott szét a stúdió. A Velencei Filmfesztiválra is kiküldték, mint Spanyolországot képviselő alkotást.

A filmben elmesélt történet a Franco-korszak ideológiai kollázsának, egyben a Hispanidad eszméjének hủ képviselője. A főszereplők a francói ideális családmodell tagjai: a hős, életét a hazájáért és elveiért feláldozó apa, a családot összetartó és szentként tisztelt anya, valamint a fiatalok, akik mindent katonai, politikai és egyházi hivatásuknak rendelnek alá.

A Caudillo által írt eredeti filmregényben ${ }^{475}$ az eseményleírásokat a szerző elhanyagolta, mindent a párbeszédeknek rendelt alá. Számos helyesírási és nyelvtani hiba található benne, a szereplők keresztnevei pedig helyenként felcserélődnek, egy idős ember unokájára a következő oldalon már a fiaként utalnak - Román Gubern szerint senki sem merte kijavítani a tévedéseket, mert Franco tábornok tollából származnak ${ }^{476}$, de az adaptációt készítő forgatókönyvírók már odafigyeltek. A könyv 1942-ben, a film premierjével egy időben jelent meg nyomtatásban ${ }^{477}$, „Anekdotagyüjtemény egy film forgatókönyvéhez” alcímmel Jaime de Andrade nevén. ${ }^{478}$ 1943-ban már nyomtatásban is megemlíti egy író, hogy a valódi szerző a Caudillo volt, de mindez csak 1964-ben válik hivatalossá, amikor Franco

\footnotetext{
${ }^{474}$ Mindezekről Sáenz de Heredia életrajzírói számolnak be: Vizcaíno Casas, Fernando - Jordán, Ángel A.: De la checa a la meca. Una vida de cine. Barcelona, Editorial Planeta, 1988. 52-58. Az előzetes vetítés részleteiről más művekben is találunk említést. Az El Pardóból érkező utasítások létezését Sáenz de Heredia mindig tagadta, szerinte senki sem szólt bele a munkájába. A rendező karrierjét bemutató legfrissebb életrajz több helyen is ír a forgatásról: Castro de Paz, José Luis: El destino se diculpa: el cine de José Luis Sáenz de Heredia. Valencia, Ediciones de la Filmoteca, 2011.

${ }^{475}$ A mủ leginkább filmregénynek nevezhetö; lapjain látszódik, hogy eleve filmre adaptálás céljából írták, de mégsem forgatókönyv, hiányzik minden olyan instrukció, amely alapján technikai forgatókönyvnek vagy akár szkriptnek minősíthetnénk. Éppen ezért téves az az általánosan idézett megállapítás, hogy Franco a film forgatókönyvírója. A tábornok egy olyan filmregényt írt, amelyet könnyen tudtak forgatókönyvvé fejleszteni Sáenz de Heredia és munkatársai. Hivatalos spanyol megnevezése novela cinematográfica.

${ }^{476}$ Gubern, Román: Raza: un ensueño del general Franco. Madrid, Ediciones 99, 1977. 7. Gubern részletesen elemzi a filmet és forgatását. Szintén sokat ír erröl: Crusells, Magí: La Guerra Civil española: cine y propaganda. Id. mü. 205-216, valamint: Reig Tapia, Alberto: „La autoimagen de Franco: la estética de la raza y el imperio" in: Archivos de la Filmoteca, No. 43-44. 2002-2003. 97-121.

A Franco művészi tevékenységét pozitív színben bemutató Julio Merino, ezzel ellentétben, éppen azt emeli ki, hogy milyen választékos stílusban, gyönyörü irodalmi nyelvezettel íródott a könyv: Merino, Julio: El otro Franco. Id. mü. 99. Nem állapítható meg, hogy kinek van igaza, mivel a publikált könyv már a kiadó által korrigált változat.

${ }^{477}$ Erről hírt ad az alábbi vezércikk: „Raza” in: Primer Plano, No. 86. 1942. június 7.

${ }^{478}$ Andrade, Jaime de: Raza. Anecdotario para el guión de una película. Madrid, Ediciones Numancia, 1942.
} 
kéri felvételét Jaime de Andrade néven a Spanyol Szerzők Társaságába (Sociedad General de Autores de España). ${ }^{479}$

A Faj, keletkezését és történetét tekintve, egyben Franco idealizált önéletrajza is. A szerzőként feltüntetett Andrade nevet a Generalísimo egyik saját felmenőjétől kölcsönözte ${ }^{480}$, a cselekmény minden fontosabb mozzanatának köze van a tábornok múltjához, családjához és elveihez. Nyílt ideológiai üzeneteket és propagandaszövegeket ad szereplői szájába, a mondatokból a hazafias érzés, a spanyol nemzet és a hispán faj magasztalása, a katolicizmus felsőbbrendüsége és az ellenfél becsmérlése sugárzik. Az írás valójában egy dramatizált politikai pamflet, az ebből forgatott film pedig ennek vizualizált változata. Áttekintve a világ propagandafilmjeit, megkockáztatható az a kijelentés, hogy a megvalósított cél és a mondanivaló egyértelműsége szempontjából a diktatúrák propaganda-játékfilmjei közül Sáenz de Heredia müve az egyik legtökéletesebbként értékelhető, a Franco-rezsim ideológiai önmeghatározásának minden eleme megtalálható benne.

A főszereplő, José Churruca feleltethető meg leginkább Francisco Francónak: a nacionalista oldalhoz hủ katonatiszt, aki karrierje során ugyanazokat a fokozatokat járja végig, amit a Caudillo is korábban, valamint olyan sikereket is elér, amelyekre Franco csak vágyott, de soha nem tudta valóra váltani. Az őt alakító Alfredo Mayo a korszak háborús filmjeiben Franco alter ego-jaként funkcionál, személye egybeforrt a hős katonatiszt alakjával. ${ }^{481} \mathrm{Az}$ évszázadokra visszamenően hősi elődöket felmutató galíciai család másodszülöttjeként a család központi alakja. Két fiútestvére és egy lánytestvére van: a köztársaságpárti Pedro (megfeleltethető Ramón Francónak), a Tengerészeti Akadémia elvégzése után az egyház szolgálatába álló Jaime és Isabel, aki egy katonatiszthez megy feleségül. Pedro gyerekkorától kezdve mutatja annak jeleit, hogy torz, romlott, kétszínü személyiség - így nem is meglepetés (a francói szemlélet szerint), hogy baloldali lesz. A család feje, idősebb Pedro a 1898-as kubai háborúban veszíti életét egy hősies csatában (Harsányi Ivánt idézve: „Franco faragott magának egy ízlés szerinti apát" ${ }^{\text {"482 }}$, míg az édesanya, Isabel a mintaanya és mintaasszony. José a polgárháborúban a köztársaságiak fogságába esik, kivégzik, de csodás módon mégis életben marad (ahogyan a valóságban a későbbi Caudillo is felépült egy végzetesnek hitt sebesülésböl), ezután életét a nemzeti ügynek szenteli, csatlakozik Franco tábornok csapataihoz. A harcok során a köztársaságiak a film művészileg egyik legszebben

\footnotetext{
${ }^{479}$ Crusells, Magí: La Guerra Civil española: cine y propaganda. Id. mü. 205.

480 Gubern, Román: Raza. Id. mü. 12.

${ }^{481}$ Mayo a diktatúra bukása után tett nyilatkozataiból úgy tủnik, mintha nem szimpatizált volna a rendszerrel, csak szükségből szolgálta ki azt. Hozzá hasonlóan a legtöbb színész így vallott, nem tudni természetesen, hogy valóban ez-e az igazság.

${ }^{482}$ Ormos Mária - Harsányi Iván: Mussolini - Franco. Budapest, Pannonica Kiadó, 2001. 272.
} 
megkomponált jelenetében agyonlövik a pap Jaimét, a történet végére pedig a baloldali testvér is ,jó útra tér” (erről Pedro a hispán fajról tartott emelkedett hangvételü monológja során kapunk képet), és segédkezik a felkelők egyik kémjének is. A film 1939-ben, a Győzelmi Felvonuláson zárul, amelyen a Caudillo személyesen is részt vesz.

Franco tábornok és José Antonio Primo de Rivera idézetek és falakra, sátrakra kihelyezett képek révén végig jelen vannak a történetben, a szerző így önmagát is beleírta a mübe.

Sáenz de Heredia filmje az alábbi felirattal harangozza be a elkövetkező képsorokat: „A hatalmas spanyol szuperprodukció, melyet A Hispanidad Tanácsa támogat”.

Franco az alapul szolgáló mủ ajánlásában és a bevezetőjében még lényegretörőbben fogalmaz (az alábbi mondatok a filmbe nem kerültek bele, csak a kiadott filmregényben olvashatóak):

„Spanyolország fiataljainak, akik vérükkel megnyitották az utat felemelkedésünk elött. Egy generáció életének jeleneteit fogjátok most átélni, a spanyol Keresztes Hadjárat eddig ismeretlen epizódjait, melyeket a fajunkra jellemző szellemiség és nemesség uralt. Egy nemesi család áll a mü középpontjában, hü képe azon spanyol családoknak, amelyek ellenálltak a materializmus legádázabb rohamainak. Fenséges áldozatok, hösi tettek, a nagyvonalúság jellemzöi és a fennkölt nemesség tettei vonulnak fel szemeitek elött."483

A film minden egyes dialógusa és monológja propagandaüzenet, amely a Francorendszer ideológiájának komponenseit idézi vissza: az ellenfél brutális és embertelen, az ország vesztére tör; a katolicizmus (és az egyház) az emberi lélek és jóság védelmezői, míg a katonalét a legtökéletesebb, legnemesebb hivatás; a család a legszentebb kötelék; a spanyol-amerikai háború a nemzet egyik tragédiája, de akik részt vettek a harcban a spanyol oldalon, mind hősök; a polgárháború pedig a hősök és árulók közti harc. A haza áll mindenek felett: amikor José sógora dezertálni akar, hogy hazamenjen a védelemre szoruló családjához, a főszereplő eltéríti őt ettől egy hazafias beszéddel. Minden tematikus szál a becsület, hüség, kötelesség és büszkeség négyese körül forog, ezeket pedig a katolicizmus fogja össze. José és szülei monológjai a múltról a dicsőséges Spanyolország mozaikjait idézik meg, majd a főszereplő kijelenti : „Isten a spanyol nemzetet szereti legjobban”.

${ }^{483}$ Andrade, Jaime de: Raza. Id. mü. 1. és 4. 
A cím, ismerve a „faj” szó gyakori alkalmazását a rezsim részéről, az új Spanyolország, az igazi hispán nép átfogó elnevezése. Magában foglal mindent, ami a győztesek eszmerendszerében az igazi spanyolságot adja. Jelen esetben, ahogyan a Churruca család feje elmeséli, a hispán faj alapját az almogávar népcsoport adja, belőlük fejlődtek ki az igazi hispánok.

A film bővelkedik olyan jelenetekben, amelyek - a nyílt és tolakodó propaganda mellett - müvészi tekintetben is túlzásba esnek, inkább a giccs kategóriájába tartoznak. Ilyen például a kereszt és sziluettjének állandó megjelenése ${ }^{484}$, vagy a hosszan a kamerába és a mellé meredő szereplők, amint átszellemülten, könnyes szemmel monologizálnak a hispán fajról és a nemzetről.

A Faj megszületése a rezsim és a Hispanidad Tanácsa azon nyílt szándékának eredménye, hogy megteremtsék a hazafias filmek prototípusát, amely egyben legitimálja is az 1936-os felkelést. Már történt egy próbálkozás korábban, de A Baleár cirkálót (El crucero Baleares, Enrique del Campo, 1940), a cenzúra engedélye után, maga a Tengerészeti Minisztérium tiltatta be és zúzatta be minden kópiáját, mert nem érezte eléggé tiszteletteljesnek az alkotást a beillesztett romantikus szál és a könnyedebb hangvétel miatt. Csak a forgatókönyve található meg a Filmarchívumban. A címbeli cirkáló polgárháborús bevetéseit elmesélő történet volt az első, amelyet valóban Spanyolországban forgattak, a korábbiaknak Olaszország adott otthont. ${ }^{485}$ A Faj, ezzel szemben, minden állami és sajtótámogatást megkapott.

A Primer Plano és a Radiocinema folyóiratok a forgatási engedély kiadásától kezdve a vetítések visszhangjáig mindenről tájékoztatták az olvasókat, egyértelmű volt, hogy a legfontosabb spanyol film készül. ${ }^{486}$ A rendezővel, színészekkel és a stáb tagjaival (még a gyártásvezető titkárnőjével is) készített több oldalas, központi helyen található interjúk mindegyike igazolni volt hivatott, hogy a spanyol filmtörténet leggrandiózusabb alkotása jön létre, valamint minden résztvevő élete és karrierje csúcspontjának tartja, hogy megadatott neki a közremüködés lehetősége. Egyesek hosszú monológokban, mások pontokba szedve sorolták fel, miért gondolják, hogy a $F a j$ a spanyol filmmüvészet

\footnotetext{
${ }^{484}$ A film esztétikai szempontú, a giccs témakörére fókuszáló vizsgálata: Yarza, Alejandro: „Las lágrimas petrificadas del general Franco: fascismo y kitsch en Raza de José Luis Sáenz de Heredia" in: Herrera, Javier Martínez-Carazo, Cristina (szerk): Hispanismo y cine. Id. mü. 65-88.

${ }^{485}$ Gubern, Román: 1936-1939: La guerra de España en la pantalla. Id. mü. 88-89.

${ }^{486}$ A Primer Plano 42. száma (1941. április 10.) ad hírt a forgatási engedély kiadásáról. Ettől kezdve szinte minden héten leközöl egy új hírt a forgatás éppen aktuális állapotáról, a színészek szerződtetéséről és a bemutatót megelőző hatalmas várakozásról. A madridi és barcelonai premier kapcsán a díszvendégekről készült fotooösszeállítással és interjúkkal is szolgál: Primer Plano, No. 65. 1942. január 11.
} 
csúcspontja. ${ }^{487}$ A müről készült kritikák pedig a felmagasztalás egy újabb szintjét valósították meg. ${ }^{488}$

A film nemzetközi bemutatásával kapcsolatban Magí Crusells érdekes információkra bukkant a közelmúltban. XII. Pius pápát lenyügözte a Faj által közvetített katolicizmus és fennkölt hangnem, de - tekintettel a Franco-kormány akkori nemzetközi megítélésére - a Szentszék diplomáciai testülete nagykövetén keresztül megkérte a spanyol külügyminisztériumot, hogy ne hozzák nyilvánosságra a pápa pozitív véleményét, sem azt a tényt, hogy a Fajt egyáltalán levetítették a Vatikánban. A német frontra maga a rendező utazott el a Caudillo személyes kérését tolmácsolva, hogy a Kék Hadosztály számára levetíthessék a filmet; a német parancsnokok azonban ezt nem engedélyezték. Németországban sem érdeklődtek iránta, de tíz német film Spanyolországba történő importálásáért cserébe lehetővé tették a bemutatást, ahogyan Olaszországban is, nyolc importengedély fejében. Több európai országba is eljutott a Faj, Svédország és Románia viszont már a bevitelét sem hagyta jóvá, Svájc pedig azonnal betiltotta, mert úgy ítélte meg, hogy ez a propagandafilm olyan reakciókat válthat ki a közönségből, amely megzavarhatja a közrendet. ${ }^{489}$

1950-ben került bemutatásra az Egy Faj szelleme (Espíritu de una Raza, José Luis Sáenz de Heredia), amely valójában nem egy új film, hanem a régi Faj újravágott, újraszinkronizált változata. ${ }^{490}$ A munkálatokból a rendezőt teljes mértékben kihagyták, a $N O-D O$ stábja végezte az új film készítését. A hivatalos indoklás szerint a módosításokat „,a párbeszédek és effektek technikai újraszinkronizálása” miatt kellett beiktatni. Az egyik legfontosabb változtatás az új szinkron: az eredeti színészek helyett az amerikai Metro Goldwyn Mayer stúdió barcelonai szinkronszínészei hallhatóak az új verzióban, egy az egyben az amerikai Elfújta a szél éppen készülő spanyol hangsávjának stábja. A szinkronrendező szerint az indokolta a korrekciókat, hogy ,a tábornok soha nem volt igazán elégedett az előző változattal”. ${ }^{491}$ Teljesen új dialógusok kerültek be, a filmben több helyen

\footnotetext{
${ }^{487}$ Interjú a premier kapcsán a rendezővel, a vezető producerrel, a zeneszerzővel, a színészekkel és a technikai stábtagokkal, összesen közel húsz személlyel a Fajnak szentelt különszámban: Radiocinema, No. 72.1942. január 30 .

${ }_{488}^{A z}$ 1. számú Függelékben eredeti nyelven közlöm az egyik kritika egy részletét.

${ }^{489}$ Constenla, Tereixa: „Pío XII, espectador secreto de 'Raza'” in: El País, 2011. augusztus 21. Elérhető: http://elpais.com/diario/2011/08/21/revistaverano/1313877602_850215.html (2012-11-21)

${ }^{490}$ A filmről készült cenzori jelentésben is jelzik, hogy nem önálló müről, hanem a már létező Faj ,technikai indíttatású javított változatáról” van szó: AGA, Cultura, 36/03379-es doboz, 09689-es köteg.

${ }^{491}$ A második változat létrejöttének körülményeiröl részletesen tájékoztat a 2002-ben a Filmoteca Española gondozásában megjelent Raza DVD-kiadása; a film „Extra” tartalmát a Filmarchívum munkatársai állították össze a fellelhető információkból. Szintén ad erről néhány információt, valamint elemzi a két változat közötti különbségeket: Caparrós Lera, José María: „Camuflaje ideológico del franquismo: Raza (1941-1950),
} 
is jól észrevehető, hogy nem egyezik a szájmozgás a beszédhanggal. Az új verzió alkalmazkodott a hidegháború viszonyaihoz, eltünt belöle minden, ami a fasizmusra és a Falange-ra emlékeztetett, a köszönésként használt előrenyújtott kar, a felvonulások, a szélsőjobboldalt dicsőítő párbeszédek és az Amerika-ellenes megjegyzések és újságcímek. Megjelenik viszont új ellenségként a kommunizmus. A dialógusbeli különbségek közül az egyik tökéletesen illusztrálja ezt a változást. Míg az eredeti filmben az egyik felkelő hadseregre vonatkozó mondat így hangzik: „Mindig megnyerik a csatát az önteltekkel szemben”, addig az Egy Faj szellemében már ezt halljuk: „Mindig megnyerik a csatát a barbár és ateista kommunisták ellen".

Az eredeti Faj 1950-ben, az új verzió megjelenésével párhuzamosan eltünt, többet nem lehetett bemutatni. Egészen 1993-ig úgy hitték, nem maradt hátra példány, de akkor előkerült egy hiányos kópia, majd 1996-ban a német UFA stúdió archívumából egy teljes, spanyol nyelvü változat. ${ }^{492}$ Jorge Herralde a demokratikus átmenetben készült dokumentumfilmje, a Faj: Franco szelleme (Raza: el espíritu de Franco, 1979) korabeli anyagok, még élő közremüködők és azok rokonai (mint Pilar Franco) segítségével próbálta rekonstruálni a forgatás folyamatát.

A Faj valószínüleg nyitódarabja lett volna a hasonló típusú filmeknek, de kimondottan ezt az utat folytató, teljes mértékben a Hispanidad és a Faj szellemében fogant mű nem született több. Ennek okát csak találgatni lehet, vélhetően a filmesek nem mertek ehhez a témához nyúlni, ugyanis nem lehetett versenyezni a Fajjal, minden más csak utánzatnak minősült volna. Létezik pontosan nem dokumentált és nem bizonyítható szóbeszéd arról, hogy Franco és Sáenz de Heredia terveztek egy folytatást a Fajhoz, amely a Kék Hadosztályra koncentrált volna, azonban soha nem készült el, ilyen irányban tett hivatalos lépésekről sem tudunk.

\section{A polgárháború}

A Franco és a spanyol katolikus egyház által is Keresztes Hadjáratnak titulált polgárháborúval kapcsolatos művek a Keresztes Hadjárat filmjei (cine de Cruzada) elnevezést kapták a filmtörténészektől. A polgárháború a Franco-rendszer számára a közelmúlt, inkább a jelen körébe tartozik, ezért nem a történelmi filmek kategóriájában tárgyalom. Közös

manipulación de un film de propaganda política" in: Uö: Estudios sobre el cine español del franquismo. Id. mü. 15-31 és Crusells, Magí: La Guerra Civil española: cine y propaganda. Id. mü. 210-216, valamint Román Gubern már idézett Raza-elemzése.

${ }^{492}$ Berthier, Nancy: „Raza, de Sáenz de Heredia, una <película-acontecimiento>” in: Sánchez-Biosca, Vicente: España en armas. Id. mü. 60. 
jellemzője ezeknek az alkotásoknak, hogy a stáblistán is előkelő helyen hirdetik: a forgatáson magas rangú tisztek, általában alezredesek segédkeztek katonai tanácsadóként, valamint valódi katonák statisztáltak és a hadsereg biztosította a felszerelést is. Többségükben a játékidő egy pontján, általában egy csatára készülve, a szereplők dalra fakadnak a táborban és közösen előadnak egy katonai indulót vagy népszerü spanyol dalt.

A Madridi front (Frente de Madrid, Edgar Neville, 1939) az első játékfilm, amely a polgárháborúról szól. A rendező a mủvet Olaszországban forgatta, két változatot készített különböző főszereplökkel, egy olaszt és egy spanyolt; utóbbiból nem maradt fenn kópia, az olaszból őriz egy példányt az olasz Filmarchívum. ${ }^{493}$ A történet szerint egy felkelő katona a köztársasági zónában teljesít küldetést, de megsérül, így utolsó óráit egy szintén sebesült kormányhű katonával tölti. A polgárháborúban harcoló felek egymás iránt érzett szimpátiájának vagy kibékülésének ábrázolása teljes mértékben elképzelhetetlen volt akkoriban, így Neville-nek meg kellett változtatnia a eredetileg tervezett zárójelenetet, amelyben a két sérült tiszt átöleli egymást. ${ }^{494}$ Ez a kép a nemzeti megbékélés egyik első üzenete lehetett volna, de a cenzori hatóság nem tolerálta. Már a forgatás megkezdése előtt számos figyelmeztetést kapott a rendező, hogy bizonyos jeleneteket ne vegyen fel, mert azok nem tükröznék reálisan a fronton történteket, ezért a cenzúra sem fogja elfogadni az ilyen történelemhamisítást. A rendező úgy véli, éppen ő ábrázolta volna a valóságot azzal, hogy mindkét oldal katonáihoz érző, emberi lényként közelít, és nem csak egyoldalúan a felkelők iránti szimpátiát viszi vászonra. ${ }^{495}$

\section{Az Alcázarban a helyzet változatlan - Sin novedad en el Alcázar}

A Franco-rendszer elsőszámú propagandafilmjeként értékelhető Faj után foglal helyet a sorban a két évvel korábban spanyol-olasz koprodukcióban készült, két hivatalos címmel is rendelkezö Az Alcázarban a helyzet változatlan / Az Alcazár ostroma (Sin novedad en el Alcázar / L’assedio dell' Alcazar, Augusto Genina, 1940). A polgárháború nacionalista interpretációjának és a Keresztes Hadjárat témájának legkiemelkedőbb darabja ez, központi eleme a korabeli háborús propaganda egyik legendává emelt eseménye, amely minden művészeti ágat megihletett, a festészettől a grafikán át a költészetig: a toledói Alcázar erőd

\footnotetext{
${ }^{493}$ Ebből adódóan a filmet én sem láttam, létezéséről az írott források alapján tudok.

${ }^{494}$ AGA, Cultura, 36/04539-es doboz, jelzet nélküli iratköteg

495 Pérez Perucha, Julio: El cinema de Edgar Neville. Valladolid, 27 Semana Internacional de Cine de Valladolid, 1982. 97-99.

Edgar Neville ideológiailag bizonytalannak mondható. A polgárháború előtt a köztársaságiakkal szimpatizált és nyíltan vállalta baloldaliságát, a harcok alatt a felkelők számára forgtatott dokumentumfilmeket, majd a rezsim alatt megpróbált igazodni az éppen aktuális viszonyokhoz, többek között antikommunista propagandát is készített. Mindezek mellett a spanyol filmmüvészet egyik legkiemelkedőbb rendezőjévé vált.
} 
falai közé vonult felkelő csapatokat hetven napon keresztül bombázták a köztársasági erők, majd az afrikai hadsereg érkezésével a kormányerők visszavonultak, az erőd túlélői és halottai pedig a nacionalista mitológia hőseivé váltak. A film ezt az ostromot mutatja be a katonai akadémiaként funkcionáló erődben tartózkodó katonák és civilek szemszögéből. Már a polgárháború utolsó évében is felmerült, hogy az Alcázart központi témaként használva készítsenek egy propagandafilmet, de a személyesen Franco tábornoknak ajánlott, egy újságíró tollából származó forgatókönyv nem került megfilmesítésre, egyes részeit azonban viszontláthatjuk Genina alkotásában. ${ }^{496}$

A forgatás helyszínéül kisebb részben a valódi, de már csak romokban meglévő Alcázar, nagyobb részben az olasz Cinecittà filmstúdió szolgált, ahol felépítették az erőd és a környékbeli utcák élethű mását. A bemutató évében a Velencei Filmfesztiválon elnyerte a legjobb olasz filmnek járó Mussolini-kupát. Két változatban készült el a mű: előbb olaszul, majd spanyolul is felvették a jeleneteket ugyanazokkal a színészekkel, de hangot a helyszínen nem rögzítettek, azokat utószinkronnal adták hozzá. Így a kettős forgatás a színészek szájmozgása és a későbbi szinkron egyezése miatt volt csak fontos. Ahogyan a Faj esetében, úgy az Alcázarról szóló filmből is több verzió készült mind Spanyolországban, mind Olaszországban, mert az évek során többször újravágták és újraszinkronizálták, hogy igazodjon a kül- és belpolitikában beállt változásokhoz, fokozatosan eltávolították belőle a fasizmusra utaló párbeszédeket, dallamokat, karmozdulatokat. ${ }^{497}$

Mindkét ország saját filmjeként kezelte, megemlítve, hogy elkészítésében együttműködtek a másik nemzettel; bár a filmről összeállított spanyol cenzori jelentésben ${ }^{498}$ olasznak jelölik a film származását, az újságok és filmes folyóiratok a spanyol nemzeti filmipar kiemelkedő darabjának nevezték. Az akkori spanyol filmpropaganda leghatásosabb elemévé vált.

Rendezője, az olasz fasizmus egyik legtöbbet foglalkoztatott filmese a premier kapcsán írt spanyol nyelvü, a felkelő fegyvereseket és a háború kimenetelét is magasztaló újságcikkében kifejti, hogy a szovjet Patyomkin páncélosra adott válasznak szánta ezt a müvet, mert, míg Eizenstein filmje a pusztító (destruktív) forradalmat mutatja be, addig az ő filmje az építő (konstruktív) forradalomnak állít emléket. Szerinte a filmtörténetben most

\footnotetext{
${ }^{496}$ Ennek részleteit lásd: Gubern, Román: „A Madrid 682: un proyecto de 1939” in: Archivos de la Filmoteca, No. 35. 2000. 130-141.

${ }^{497}$ Alberich, Ferran: „El rechazo del pasado” in: Archivos de la Filmoteca, No. 35. 2000. 97-107. Alberich tanulmánya több ponton is összehasonlítja az olasz és spanyol változatokat.

A két nyelven íródott forgatókönyveket és a filmet összeveti: Aronica, Daniela: „La génesis de Sin novedad en el Alcázar: estudio comparativo del argumento al guión" in: Archivos de la Filmoteca, No. 35. 2000. 71-95.

${ }^{498}$ AGA, Cultura, 36/03170-es doboz, 02656-os köteg
} 
fordul csak elő másodszor (a Patyomkin esete az első), hogy a világtörténelem alapot szolgáltat egy film elkészítésének. Eizenstein müvét úgy értékeli, mint a bolsevik propaganda bármely írott, a marxizmust népszerüsítő anyagánál fontosabb eszközét. A film jelentős fegyverré válhat annak kezében, aki tudja, hogyan kell azt használni. A rendező végső megállapítása saját alkotásának üzenetéről: „A filmből a spanyol nép szellemisége árad: egy nemes, hősies, ifjú szellemiség. José Antonio Primo de Rivera és Franco tábornok Új Spanyolországának szellemisége ... A haza, a család és a vallás teszik lehetővé az Alcázar csodáját. Bárcsak az új spanyol nemzedékek is megértenék, hogy ezen a három elven alapul a jólétük, jövőjük és nagyságuk.”. 499

Tükrözve a spanyol rezsim politikáját, ahol a Szovjetuniót tekintették az egyik fö (később a legfőbb) ellenfélnek, az abban az időszakban legfontosabb propagandafilmnek számító mü ${ }^{500}$ is egy szovjet alkotással szállt szembe. Hozzá kell tenni, filmművészeti és technikai (de nem ideológiai) szempontból a spanyol filmkritikusok és filmtörténészek már a Franco-korszakban is elismerően szóltak Eizenstein filmjéről, Az akarat diadala mellett a Patyomkin páncélost tartották a legprofesszionálisabban kivitelezett propagandafilmnek. ${ }^{501}$ Természetesen a nézők többsége nem tudta megítélni, hogyan sikerült ez a „,válasz”, mivel az illegális vetítések kivételével sehol nem lehetett megtekinteni a rezsim által tiltott és hatalmas veszélynek tartott szovjet müvet, a nem hivatalos filmklubokban azonban folyamatosan jelen volt.

Már az első felirat jelzi, hogy fontos filmet lát majd a néző: „hatalmas nemzeti szuperprodukció”-nak titulálják alkotói még a stáblista elején. Láthatjuk José Calvo Sotelo Cortesben elmondott, a fasizmust éltető beszédét, majd a haláláról szóló újságcikkek bevágása után a temetésén megjelent hazafiak esküt tesznek, hogy megmentik Spanyolországot. A film alapján úgy tűnhet a néző számára, hogy a szélsőjobboldali politikus halála vezetett a felkeléshez, amelyet az ország visszahódításának (la reconquista del país) nevez egy tábornok. Az Alcázar parancsnoka egyesével végigkérdezi tisztjeit, ki milyen utat tart követendőnek. Mindenki ugyanazt válaszolja: „Követni Francót!”, később pedig általános helyzetértékelésként hangzik el: „Számunkra Spanyolország egyet jelent Franco tábornokkal.” Rádióhírek, újságcikkek, beszélgetések segítségével a felkelő csapatok fontosabb harcairól is értesülünk, és láthatjuk mindkét oldal haditanácsait, taktikai megbeszéléseit. A köztársaságiak

\footnotetext{
${ }^{499}$ Genina, Augusto: „Por qué he realizado <Sin novedad en el Alcázar〉” in: Primer Plano, No. 3, 1940. november 3 .

500 Mivel a Faj csak két évvel később készült és vált a rezsim előtérbe helyezett alkotásává, 1940-ben még az Alcázarról készült müvet jellemezhette ez a titulus.

${ }^{501}$ Mostaza, Bartolomé: „El cine como propaganda” Id. mü.
} 
presztízskérdésként fogják fel, hogy minél hamarabb visszaszerezzék az Alcázart, az elhúzódó harcok pedig súlyosan érintik a morált táborukban. Franco győzelmeinek hírére az erőd falai között örömünnep kezdődik, a katonák, civilek, idősek és kisgyerekek egymást átölelve, könnyes szemmel éneklik az Arccal a nap felé (Cara al Sol) címü falangista himnuszt egy közel másfél perces jelenetben. Kérésükre beengednek hozzájuk egy papot, aki misét celebrál, feloldozást ad mindenkinek a bünei alól, a súlyos sérülteknek utolsó kenetet ad fel, egy haldoklót összead szerelmével, mindenkit megáld, miközben a katonák, a civilek és az apácák könnyezve készülnek a végső ütközetre. A még életben maradtak a végsőkig kitartanak a szétbombázott erőd romjai között is, majd megérkezik Varela tábornok felmentő serege. A győzelmet ismét a falangista himnusz tömeges eléneklésével ünneplik, és amint előjönnek a romok közül a civilek, megérkezik Franco tábornok is, aki átöleli az erőd parancsnokát. A záróképen a katonák és a civil tömeg könnyes szemmel, magasba tartott jobb karral tisztelegnek a Caudillo előtt.

Az itt meghonosodott ellenségábrázolás a későbbi filmekben is visszatér: a köztársaságiak csapata rosszarcú, züllött, alkoholista férfiakból áll, akik az erőd parancsnokát fia megkínzásával és megölésével, egy másik katonát pedig felesége megerőszakolásával és meggyilkolásával akarnak rávenni, adja fel a küzdelmet; ezek az etikátlan és erkölcstelen próbálkozások általában nem érnek célt. Ezzel szemben, az ellentétes oldalak fötisztjei egymással tisztelettel bánnak: az erődbe érkező köztársasági főtiszt és a felkelők helyi parancsnoka kollégaként tekintenek egymásra, és közös jelenetük azt sugallja, a katonai lét mindenek felett áll; bár más oldalon küzdenek, mégis egy „családhoz”, a fegyveres erők családjához tartoznak.

A film egyik érdekessége, hogy a 108. percnél, miközben tart az egyik támadás, külföldi újságok vonatkozó címlapjait vágják be. A francia Le Journal, az olasz Il Messaggero, az amerikai The New York Times és a német B.Z am Mittag mellett ötödikként a Magyarország címü napilap 1936. szeptember 29-ei, reggeli kiadása tünik fel, az alábbi címmel és alcímmel: „Az Alkazár még mindig a nemzetiek kezében van. A madridi kormány újabb fegyvereket és csapatokat küld Toledóba. Az Alkazarra sok tonnányi dinamitot zúdítanak". Miközben a címlapokat mutatják, a tudósítók (feltehetőleg) ezekből olvasnak fel részleteket, melyek alapján úgy tünhet, a nemzetközi sajtó a hős védők mellett áll, míg a köztársaságiakat brutális hordákként írják le.

Szintén megemlítendő egy híres mondat újraértelmezése: a francia Pétain marsalltól származó, de a spanyol kommunista Dolores Ibárruri által híressé-hírhedtté tett „Nem törnek át!” (¡No pasarán!) felkiáltást egy falfirkaként látjuk viszont, a montázstechnika segítségével 
pedig mindez új értelmet nyer: az erőd védői megakadályozzák, hogy a köztársaságiak áttörjenek a falakon.

A megtörtént eseményeket fikciós szálakkal vegyíti, a valóságban is létező szereplök mellett megjelennek kitalált alakok, és nem hiányzik a minden müben, még a propagandafilmekben is szinte kötelező elemként jelen lévő szerelmi szál sem. Ez a játékfilm számított 1940-ben és 41-ben az állami filmpropaganda legtöbbet emlegetett, legtovább játszott, legnagyobb büszkeséggel körülvett filmjének. Bár 1942-ben a Faj még ezt is felülmúlta, ma is a francói filmpolitika és filmpropaganda egyik legfontosabb darabjaként tartjuk számon.

\section{Vörös és fekete - Rojo y negro}

A polgárháború kitörésének első hónapjaiba kalauzol el minket a Vörös és fekete (Rojo y negro, Carlos Arévalo, 1942) címü film, amely a kommunistaellenes propaganda egyik legkifejezőbb, legközvetlenebb, didaktikai szempontból legtökéletesebb darabja. Bár az ellenségképre fókuszál, mégis a polgárháborús filmek között tárgyalom, mert döntően a háború éveiben, a frontvonalakon történt események mögé enged betekintést. Egy, már gyerekkoruktól kezdve egymáshoz vonzódó, később Falange-szimpatizáns lány (Luisa) és kommunista fiú (Miguel) története. Mivel a fiút kizárólag a politika érdekli, eltávolodnak egymástól, a lány pedig igyekszik segíteni falangista barátait, társait és az édesanyját. Miután a baloldaliak (mindannyian a CNT anarchoszindikalista szervezet tagjai) elhurcolják és megerőszakolják Luisát, régen látott szerelme igyekezne segítségére sietni, de már késő: egy mezőn csak a holttestét találja meg sok más kivégzett jobboldali asszony teteme mellett. Miguel ráeszmél, hogy a rossz oldalon áll, kétségbeesésében az öngyilkosság egy egyedi módját választja: rálő egy CNT-feliratú autóra, a benne utazók pedig a nyílt utcán agyonlövik öt.

A filmben az anarchisták és kommunisták által egyaránt használt börtön falán látható sarló és kalapács motívumokat egy kereszt tetejére rajzolták, jelezve, hogy vallás- és egyházellenes csoportról van szó, amely a kommunizmust mindenek elé helyezi. Az utcán a falakon a Népfront, valamint a FE y de las JONS José Antonio Primo de Rivera felszólalását is hirdető választási plakátjait látjuk, utóbbit az egyik első jelenetben Miguel letépi, Luisa rosszallása mellett. A CNT viszont feliratokkal, korabeli graffitikkel csúfítja el az épületeket.

Az elérendő célhoz megfelelő színészválasztás és karakterábrázolás járult. A cenetisták mind antipatikus, már-már hajléktalannak tünő, borostás, ápolatlan és müveletlen személyek, némelyikük szinte fogyatékosnak van beállítva, viselkedésük alapján inkább 
állatias jegyeket mutatnak. Lerészegedve dalolnak a börtönben, miközben társaik ártatlanokat kínoznak a másik szobában. Luisa letartóztatásakor a lakásból az értékes holmit, az aranytárgyakat is elviszik. A köztársasági politikusok egy burleszk-szerü jelenetben tanúbizonyságot tesznek arról, hogy összefüggéstelen és értelmetlen vitákat folytatnak a semmiről. Ezzel szemben a Falange tagjai és a velük szimpatizálók elegáns, müvelt, jóképü férfiak és vonzó asszonyok, még a fogdában is öltönyben, nyakkendőben, ünnepi viseletben fekszenek a földön. Ártatlan és jó szándékú személyek, akik nem értik, miért zárták be őket, de a végsőkig bíznak az emberi jóságban.

A filmben a CNT-hez tartozó, ugyanakkor kommunista jelmondatokat használó szereplő kimondja egy gyülésen: a forradalom lényege, hogy lerombolj mindent, elkobozd a vagyont és törekedj az ellenség teljes megsemmisítésére. A Luisa kivégzése utáni jelenetben pedig az alkotók felhívják a figyelmet a baloldaliak önellentmondására: egy falfeliratot mutatnak, amelyen a halálbüntetés ellen tiltakozik a CNT; éppen az a szervezet, amely ártatlan asszonyokat végez ki.

Carlos Arévalo filmje tökéletesen illusztrálja a diktatúra, mindenekelőtt a Falange szemléletét. Az ellenfél elvetemült, embertelen, ártatlanok életére tör, ezért a felkelés teljesen jogos, a spanyol nemzet érdekében történik, az ország jövője csak így védelmezhető meg. Bár az üzenet egyértelmű, a filmet csak hosszas cenzori procedúra ${ }^{502}$ után sikerült bemutatni, ugyanis a baloldali Miguel a játékidő során egyre szimpatikusabb lesz a néző számára, ő maga is egy jóképü, viszonylag kulturált fiatalember. Ez azonban mégsem volt akkora probléma, mert Miguel végül ,jó útra” tér, rádöbben, hogy eddig a rossz oldalon harcolt.

A Vörös és fekete az egyetlen olyan fikciós játékfilm, amely tisztán a Falange ideológiáját közvetíti (beleértve a szervezet zászlajának színeire utaló ${ }^{503}$ filmcímet is), valamint időrendben az első antimarxista ellenállásra felszólító alkotás. Az igazi spanyol fasiszta film titulust is megkapja a spanyol filmtörténetekben. Többször felcsendül a Arccal a nap felé, a Falange-tag szereplők a párt programjából is idéznek. Díszlettervezőként José María Alfaro, a Falange társalapítója és himnuszuk szövegének társszerzője szerepel a stáblistán, zeneszerzője Juan Tellería, aki ugyancsak a fasiszta indulókhoz kötődik. Arévalónak korábban felajánlották a $F a j$ rendezői székét is, de inkább saját, 1934-ben született forgatókönyvét szerette volna filmre vinni: ez lett a Vörös és fekete. ${ }^{504}$ A siker azonban nem tartott sokáig, egyelöre tisztázatlan okokból a filmet három héttel a premier után

\footnotetext{
${ }^{502}$ AGA, Cultura, 36/03185-ös doboz, 03611-es köteg.

${ }^{503}$ Érdekesség, hogy az anarchoszindikalisták ugyanezeket a színeket használták.

504 Ríos Carratalá, Juan Antonio: El enigma de Carlos Arévalo. Alicante, Biblioteca Virtual Miguel de Cervantes, 2008. Elérhető: http://www.cervantesvirtual.com/obra/el-enigma-de-carlos-arvalo-0/ (2012-11-21)
} 
levették a müsorról és betiltották, csak 1996-ban láthatta újra a közönség, amikor a Filmarchívum munkatársai ünnepélyes keretek között levetítettek egy pár évvel korábban véletlenül előkerült, restaurált kópiát. ${ }^{505}$ Csak találgatni lehet a betiltás okát, egy Arévalóval foglalkozó szerző szerint a vetítésen a rezsim befolyásos katonatisztjei felháborodtak a túlzott mértékủ falangista propagandán, és magát Franco tábornokot sürgették, hogy járjon el a betiltás ügyében. ${ }^{506}$ Más források is úgy vélik, hogy bizonyos döntéshozók túlságosan kockázatosnak ítéltek a második világháború alatt műsoron tartani egy ennyire egyértelműen fasiszta retorikát használó filmet. ${ }^{507}$ A betiltás szó használata tehát ebben az esetben nem feltétlenül helyes, inkább a „müsorról történő levétel” a helytálló.

Technikai szempontból érdekessége a filmnek, hogy az alkalmazott montázsokat és plánokat egyértelmüen a szovjet filmek mintájára készítették, a Patyomkin páncélosból konkrét jeleneteket is átvettek. Ilyen filmtechnikai eszközökkel élnek, többek között, amikor baloldali támadásokról és falangisták inzultálásáról szóló újságkivágásokat és cikkrészleteket montíroznak egymásra. Nem egyedülálló jelenség, a későbbiekben is használatos módszer lesz, hogy az országok a legfőbb ellenségnek kikiáltott nemzet filmesztétikáját alkalmazzák a saját filmkészítésükben.

\section{A Szentély nem adja meg magát - El Santuario no se rinde}

A Szentély nem adja meg magát (El Santuario no se rinde, Arturo Ruiz Castillo, 1949) a részleges amnéziában szenvedő női főszereplő visszaemlékezéseit meséli el flashback jelenetekben. A kiindulópont az Afrikában állomásozó spanyol csapatok felkelésének a híre, majd ennek következményeként a polgárháború kitörése, amelyet eredeti filmhíradófelvételekkel illusztrálnak. A korábbi ábrázolás ismét megjelenik: rosszul öltözött, ápolatlan, civilizálatlan fegyveresek (vagyis a köztársaságiak) zaklatják és végzik ki az öltönyös, ápolt, müvelt spanyol polgárokat (a „nemzetieket”).

A történet szerint a fegyverhez jutó földművesek meggyilkolnak egy konzervatív földbirtokost, majd a lánya, Marisa is veszélybe kerül. A republikánus Luis (Alfredo Mayo alakításában) menti meg a biztos halál elől és a közeli Szentélybe menekíti, amelyet a felkelők mellett harcoló és a fegyveres parasztok elől visszahúzódó Guardia Civil védelmez. A sebesült Luisnak ápolást biztosítanak, aki, látva, hogy a legitim kormány milyen atrocitásokat követ el, fokozatosan a számukra menedéket nyújtó felkelők oldalára áll. Kilenc hónapon

\footnotetext{
505 Gubern, Román: 1936-1939. Id. mü. 100.

${ }^{506}$ Ríos Carratalá, Juan Antonio: El enigma de Carlos Arévalo. Id. mü.

${ }^{507}$ A különböző teóriákat foglalja össze: Elena, Alberto: „¿Quién prohibió Rojo y negro?” in Secuencias, No. 7. 1997. október. 61-78.
} 
keresztül ostromolják a helyet a köztársaságiak és a Nemzetközi Brigádok, a bent lévőket repülőgépekről ledobott élelmiszercsomagokkal látják el Franco csapatai. Végül azonban a védők elbuknak, az utolsó képsorokon a megismert főszereplők brutális lemészárlását láthatjuk, a kegyetlen gyilkolást köztársasági fegyveresek és francia brigadisták követik el. A szentély védői az utolsó pillanatokig kitartanak, ezt támasztja alá egy falon látható felirat is, amelyre a kamera ráközelít: „A Guardia Civil meghal, de meg nem adja magát”. 508

A cselekmény szerkezete sok hasonlóságot mutat az Alcazárban a helyzet változatlan konstrukciójával: az elzárt helyre visszaszorult „,nemzeti” csapatok és a védelmük alatt álló civilek próbálják meg fenntartani az erődöt a kívülről folyamatosan ostromlókkal szemben. Az ellenség nem törődik a bent lévő civilek életével sem, szovjet repülőgépek bombázzák őket. A harcok során kibontakozik két szerelmi szál is, de egyik sem teljesülhet be.

Augusto Genina ostrom-filmjéhez hasonlóan a korábban köztársaság-szimpatizáns Ruiz Castillo műve is megtörtént eseményeken alapul, a Nuestra Señora de la Cabeza Szentély kilenc hónapos ostromát vette alapul, ahol a védelmet ellátó Guardia Civil kapitánya is életét vesztette a harcokban. A film bemutatója kapcsán az egyik kritikus sérelmezte, hogy kevés film készült eddig a nagy spanyol Felszabadító Háborúról (vagyis a polgárháborúról), erre a mulasztásra pedig nincs magyarázat. Éppen ezért nagy öröm szerinte, hogy az alkotók egy ilyen nagyszabású filmet szenteltek a brutális küzdelemnek, az életüket is feláldozó Guardia Civil hőseinek és a szentély védelmét ellátó, mártírhalált halt Cortés kapitánynak. ${ }^{509}$

A film a nemzetközi csapatok és a kommunisták elleni harc, a hazafias ellenállás szimbólumává vált a diktatúra számára. A főszerepet ezúttal is Alfredo Mayo alakítja, aki itt egy összetettebb karaktert formál meg: egy eredetileg republikánus, ám a harcok hatására a felkelők oldalára álló férfi, ezzel bizonyítva, hogy nem mindenki rossz, aki a másik oldalon áll, mert egyes személyek meggyőzhetőek, megtéríthetőek. Román Gubern ebben már a nemzeti megbékélésre, a győztesek és vesztesek közötti párbeszéd megkezdésére utaló jeleket lát, a női főszereplő emlékezetvesztését pedig a felejtésre való felhívásként értékeli. A film premierjét egy, a Guardia Civil tiszteletére rendezett ünnepségen tartották, ezen részt vettek az ostrom túlélői is. ${ }^{510}$

\footnotetext{
${ }^{508}$ A filmben elhangzó mondat az 1815-ös waterlooi csatában elhíresült „A gárda meghal, de meg nem adja magát!” („La garde meurt et ne se rend pas! „) felkiáltás adaptálásaként értelmezhető. A spanyol mondatot Cortés kapitány parancsára írták ki a szentély mellett rögtönözve felállított temető bejárata fölé. Erről lásd: „La Guardia Civil muere pero no se rinde" in: http://www.momentosespañoles.es/contenido.php?recordID=65 (2012-12-04)

${ }^{509}$ Gómez Tello, Luis: „El Santuario no se rinde” in: Primer Plano, No. 480. 1949. december 25.

${ }^{510}$ Gubern, Román: 1936-1939: La guerra de España en la pantalla. Id. mü. 111-112.
} 


\section{A béke sosem jön el - La paz empieza nunca}

A 60-as években változás következett be a filmpolitikában, megkezdődött az enyhe nyitás periódusa. A béke sosem jön el (La paz empieza nunca, León Klimovsky, 1960) azonban agresszív stílusával még visszatérést jelent a korábbi évtizedek filmjeihez. Az alkalmazott eszközök és technikák egy müfajkeveréket állítanak elő: háborús filmként indul, egy film noir elemeket alkalmazó melodrámává alakul, végül a Hollywoodban népszerủvé vált undercover filmek ${ }^{511}$ eszköztárát használva feszült thrillerbe torkollik.

A film a polgárháború kitörésének előzményeitől az 1940-es évek közepéig követi nyomon a föszereplök életét, akik már a harcok elött is a Falange propagandaanyagait terjesztették a kommunistákkal teli közegben. A korábban látott ábrázolási mód ez esetben is megjelenik, a köztársaságiak civilizálatlan csoportok, míg a falangisták kifogástalan úriemberek. A film első fele a háború idején játszódik, tanúi lehetünk a felkelők oldalán harcoló föszereplők csatáinak, sebesüléseinek, megmeneküléseinek és szerelmi kalandjainak. Eredeti filmhíradó-felvételekkel illusztrálja a rendező a korabeli Spanyolországot, a harcok nyomasztó légkörét, valamint az ünneplő tömeget, amely rajongva köszönti a gyözelmet bejelentő Franco tábornokot. A 40-es évek eseményeit, mindenekelőtt a nemzetközi elszigetelődést és a rezsimet támogató felvonulásokat $N O-D O$ felvételek és újságcikkek beemelésével szemlélteti.

Klimovsky filmjének második fele bemutatja, hogy a „nemzeti” oldal nem pihenhet meg, mert továbbra is veszély fenyegeti. A korábbról ismert szereplők egyikét, Lópezt egy jelenleg politikai tisztséget betöltő volt bajtársa beszervezi az ellenállók (maquik) elleni küzdelembe: be kell épülni az Asztúria hegyei között bujkáló fegyveresek közé, folyamatosan jelenteni a helyzetükről, majd segédkezni a likvidálásukban. López a feladatot azért vállalja, mert szerinte a gerillaharc elhúzódása akár egy nemzetközi beavatkozást is kiprovokálhat, annak felszámolásával azonban végre elérhető lenne, hogy többé ne legyen háború a spanyolok között. Ekkor hangzik el az a beszélgetés, amelyböl a film címe is származik: a béke sosem jön el, mindig készenlétben kell állni, mert a haza ellenségei folyamatosan támadásra készülnek. A maquik ábrázolása szintén egyoldalú: kegyetlen hordák, akik élvezetből lőnek agyon gépfegyverrel egy imádkozó papot, nincsen se lelkiismeretük, se bűntudatuk. Az akció sikerrel jár, a maquikat tőrbe csalják és lemészárolják a rezsim fegyveresei. Miközben a többségüket hátba lövik, fennkölt és hazafias dallamok szólnak -

\footnotetext{
${ }^{511}$ Az undercover jelentése beépített: ezekben a filmekben a föszereplő beépül az ellenség táborába (általában egy rendőr a bünözők közé, vagy egy kém / katona a másik csapat soraiba), az állandó lebukás veszélye, valamint az akció kétséges kimenetele pedig folyamatos feszültséget generál a nézőkben.
} 
nem szégyen tehát, hogy a védekezni nem tudó ellenfelet ilyen módon pusztítják el, mert ők mindannyian a haza ellenségei voltak (a béke ellenségei a főszereplö szerint). Az akció végeztével López civilként éli tovább életét Madrid nagyvárosi forgatagában.

A mü megszületése felveti a kérdést, vajon miért készült egy ilyen erőteljes ideológiai töltettel bíró film éppen abban az időben, amikor elötérbe került a nemzeti megbékélésre való törekvés a mozivásznon is. Valószínüsíthető, hogy éppen ezt a tendenciát akarták megtörni, mindenekelőtt a rezsim legkonzervatívabb szárnyával jó viszonyt ápoló Cifesa stúdió. Erre utal, hogy a karrierje során kevés jelentős darabot jegyző, ugyanakkor szinte minden müfajban alkotó León Klimovsky filmrendezö ${ }^{512}$ nem akart falangista filmet forgatni, de a cenzori junta, a Hadügyminisztérium és a Cifesa irányítói átdolgoztatták az Emilio Romero müve alapján írt forgatókönyvet, és végül ezt az új változatot kellett elkészítenie. Mivel a főszerepet játszó színész és a stáb több tagja is antifasiszta meggyőződésű volt, a művet ellentmondásos körülmények között forgatták. Bár az elvárt utasításoknak a kész film megfelelt, annak megtekintése után maga Franco tábornok közölte a rendezővel, hogy, bár a film jó lett, neki valamiért mégsem tetszik. ${ }^{513}$

A Falange és az ideológiailag merev szektor háttérbe szorulása a filmpolitikában is éreztette hatását, az 50-es évek második felétől elenyésző számú, továbbra is ezt a retorikát alkalmazó propagandafilmnek értékelhető alkotás született. A béke sosem jön el a szabályt erősítő kivétel, a rezsim belső változásait túlzásnak, elfogadhatatlannak tartó szekciók egyik utolsó mozgóképes próbálkozásának is tekinthető.

$$
* * * * * * * * * * * * * * *
$$

A fentieken kívül több olyan film említhető, amely a polgárháború francóista interpretációját választotta témájául, legtöbbjük háborús környezetben játszódó melodráma vagy kaland- és háborús film. Ilyen például a Franco légierejében szolgáló pilóták (egyikük ismét Alfredo Mayo alakításában) szerelmi és háborús kalandjait bemutató Repülőraj (Escuadrilla, Antonio Román, 1941). Tekintve, hogy számos olyan film készült a Francorendszer során, amely lényegében nem a polgárháborúról szól, de a cselekmény egy része mégis akkoriban játszódik, bizonytalan az ebbe a kategóriába tartozó filmek száma. A Román

\footnotetext{
${ }^{512}$ León Klimovsky, az 50-es évektöl leginkább Spanyolországban dolgozó, orosz származású argentin rendező (eredetileg fogorvos) szinte minden zsánerben alkotott, inkább tisztes iparosnak tekinthető, mintsem egyedi stílusú vagy látásmódú filmművésznek. Többségében ideológiailag ártalmatlan filmeket készített, pusztán a közepes minőségű szórakoztatást, az anyagi sikert és a szórakozni vágyó közönség igényeit szem előtt tartva, majd a 70-es évektöl alacsony színvonalú horrorfilmek és erotikus darabok készítőjeként lett ismert. Felesége a magyar írónő, Elisabeth Szél volt. Az írónőről lásd: Anderle Ádám: „Elisabeth Szél” in: Tiszatáj, 1994/3. 72-74.

${ }_{513}$ Aguilar, Carlos: „La paz empieza nunca” in: Pérez Perucha, Julio (szerk.): Antología crítica del cine español. Id. mü. 490-491.
} 
Gubern, Magí Crusells, és Alfonso del Amo könyveiben ${ }^{514}$ legalább említés szintjén jelen lévő játékfilmek összesítése alapján úgy gondolom, hogy a 35-40-es szám állhat a legközelebb a valósághoz, de ezek esetében is számtalan az átfedés az általam más kategóriába sorolt filmekkel.

\section{A hadsereg}

A katonai lét nagyszerüségét, a hadsereg és a hazafias cselekedetek felsőbbrendű szerepét a polgárháborús filmek is tökéletesen tükrözik, de szükségesnek tartom egy külön kategória beemelését három olyan film rövid bemutatása miatt, amelyekben nem a polgárháború áll a középpontban, hanem az Ibériai-félszigeten kívül eső területeken szolgáló fegyveresek életébe engednek bepillantást. Fő témáik a hazaszeretet, a heroizmus, mindez valamilyen történelmi vagy háborús környezetbe ágyazva. A hispán faj egysége és felsőbbrendűsége adja a történetek keretét. A polgárháború mellett az afrikai légiósok és a latin-amerikai kontinensen szolgáló katonák között játszódó alkotások mutatták fel ezeket a jellemző jegyeket.

\section{Harka!}

A Vörös és fekete rendezője (Carlos Arévalo) és a Faj főszereplője (Alfredo Mayo) egy évvel az öket rendkívül népszerüvé tevő filmek elött forgatták közösen a Harka ! (¡Harka!, Carlos Arévalo, 1941) című alkotást, amely a 20-as években Marokkóban harcoló spanyol és helyi katonák történetét meséli el. Egy szokványos vonalvezetésű, romantikus szállal is vegyített háborús filmet tár a nézők elé a rendező; leginkább azért érdemel említést, mert az első olyan produkció volt, amely nem polgárháborús környezetbe helyezve mesélt a hadseregről. Összhangban az uralkodó ideológiával, a Marokkóban szolgálatot teljesítő katonák a spanyol haza büszkeségei, a hispán erények képviselői, akik még a szerelmet és a boldog családi életet is feláldozzák a hivatásuk érdekében.

A Harka! indította el azt a filmes vonulatot, amely egy évvel később a következőkben tárgyalt Orduña-művel érte el csúcspontját. A film címe azokra a helyi lakosokra utal, akik európai parancsnokság alatt folytatnak harcot egy másik csoport ellen; ez főleg Algériára és Marokkóra volt jellemző ${ }^{515}$. A filmből képet kapunk arról, hogy a Franco-rendszer milyen véleménnyel volt Afrikáról, mindenekelőtt annak lakosairól: alapvetően alsóbbrendű, de jól

\footnotetext{
${ }^{514}$ Gubern, Román: 1936-1939: La guerra de España en la pantalla. Id. mü; Crusells, Magí: La Guerra Civil española: cine y propaganda. Id. mü; Amo, Alfonso del: Catálogo general del cine de la Guerra Civil. Id. mü. ${ }^{515}$ Erről lásd a Por Tierra, Mar y Aire blog bejegyzéseit: http://www.portierramaryaire.com/foro/viewtopic.php?p=58082 (2012-11-27)
} 
használható (leginkább ki- és felhasználható) népként tekintett rájuk, akiknek szükségük van a felsőbbrendü spanyolok irányítására, hogy hasznos részét képezzék a civilizált világnak. Kivételes esetben jelenik csak meg a „mór ellenség”, az ezekben a művekben felsorakoztatott afrikaiak többsége „mór barát”, ha konfliktusba kerül velük a „nemzeti” Spanyolország, az általában valamilyen kívülről érkező támadásnak, külföldi manipulációnak köszönhető. Az itt tárgyalt műveken kívül ilyenre példa még a Tanger rejtélyei (Los misterios de Tánger, Carlos Fernández Cuenca, 1942) és a Tizenkét órányi élet (Doce horas de vida, Francisco Rovira Beleta, 1948) is; a többi, az afrikai kontinensen játszódó film általában a rezsim civilizációs tevékenységére koncentráló kalandfilm vagy melodráma. ${ }^{516}$

\section{Légió, hozzám! - ¡A mí la Legión!}

A filmcímben olvasható felkiáltás az úgynevezett Légiós Hitvallás (Credo Legionario) negyedik pontjára utal, amely szerint egy bajba került légiós segélykérésére a többiek feltétel nélkül és azonnal a megmentésére sietnek. A Spanyol Légió megalapítója, José Millán-Astray fogalmazta meg a 12 pontból álló hitvallást, amelyet a szervezet tagjai életük során mindig szem előtt kell tartsanak. ${ }^{517}$

A Marokkóban játszódó Cifesa-produkció, a Légió, hozzám! (;A mí la Legión!, Juan de Orduña, 1942) két légiós történetét meséli el, amely során egyiküket megvádolják emberöléssel, a másik pedig kitart barátja ártatlansága mellett, és nyomozni kezd. Végül sikerül őt tisztáznia. Mint kiderül, a megvádolt katona valójában egy távoli (a valóságban nem létező) ország trónörököse, akinek el kellene foglalnia az uralkodói pozíciót. Barátja elkíséri a herceget a királyi palotába, de a spanyolországi „nemzeti felkelés” hírére 1936-ban mindketten visszatérnek az Ibériai-félszigetre, hogy a lázadó csapatokat segítsék.

Az alkotás sokszor túlzásokba eső, helyenként meseszerü cselekménye (mint a távoli ország trónját a spanyol ügyért feladó herceg története) ebben az esetben másodlagos jelentőséggel bír, a lényeg ugyanis nem a háttértörténet, hanem a szereplők viselkedése. A föszereplők mindannyian a legfelsőbb katonai erények megtestesítői, rendíthetetlen, büszke és lovagias hazafiak, akik egész életüket a haza szolgálatára tették fel. A családjuk a Légió, másnak nincs helye az életükben. A jelenetek, a párbeszédek és a monológok a Hispán Faj védelmében szolgáló hadsereg (itt konkrétan a Légió) dicsőítését, felmagasztalását tükrözik, a spanyol fegyveres erők legközvetlenebb propagandáját nyújtják. Számos alkalommal

\footnotetext{
${ }^{516}$ A spanyol filmgyártás észak-afrikai (leginkább marokkói) témával foglalkozó alkotásairól ad összefoglalást: Corrales, Eloy Martín: „El cine español y las guerras de Marruecos (1896-1994)” in: Hispania, Vol. LV/2. No. 190. 1995. 693-708.

517 A Spanyol Légió alapításáról, történetéről, hitvallásáról lásd az alakulat hivatalos honlapját: http://www.lalegion.es/menu.html (2012-11-27)
} 
felhangzik az „Éljen a légió!” felkiáltás. A Faj gyártási évében bemutatott film még Sáenz de Heredia alkotásánál is egyértelmübben és elfogultabban áll ki a katonai értékek mellett. A polgárháborús filmekben is használt módszert követve a hősies tettek, a hazát és az erkölcsöt magasztaló monológok mellett a patriotizmust tükröző indulók adják a zenei aláfestést. A francói ideológia szellemében számos direkt utalást találunk a kommunisták és anarchisták nemzetromboló tevékenységére. Egy, a francói filmpolitika szellemében fogant müvek témái között ritkán felbukkanó elemmel is találkozunk: a bonyodalmak egyik fő okozója egy kapzsi és jellemtelen zsidó karakter. ${ }^{518}$

Alkotói az elkövetkezendő években is bizonyítják, hogy a hazafias filmek mesterei: a föszereplö, ahogyan a Faj és a Harka! esetében is, az utókor által a rezsim színészének nevezett Alfredo Mayo, a Franco-korszak müveinek örök katonatisztje, a film rendezői székébe a később a látványos és hatalmas költségvetésű, hazafias történelmi tablók készítője, Juan de Orduña ült, míg forgatókönyvírója a szintén a hispán múltat visszaidéző filmek rendezőjeként ismertté váló Luis Lucia.

A légiósok egymás iránti feltétlen hüségének és barátságának ábrázolását az utókor máshogy értelmezi: mára elfogadott vélemény, hogy a föszereplők rendkívül közeli viszonya egyértelmủen a kettejük között fennálló homoszexuális kapcsolatra utal, ami annak idején beszédtéma is volt a színészek között, de végül a kérdés nem okozott problémát, mert a légiósok egy olyan felsőbbrendü kasztot képviseltek a társadalomban, ahol talán még ez is megengedhető volt; komoly tanulmányok láttak már napvilágot a szóban forgó film kapcsán abban a kérdésben, hogy a bajtársias önfeláldozás, a mindent felülíró férfibarátság és a saját nemhez való vonzódás közötti határvonal a példás életvitelt folytató katonatisztek esetében elég vékony volt. ${ }^{519}$ Valóban nem egyértelmü, hogy a másság minden formáját teljes mértékben elutasító egyházi és katonai cenzúra miért nem távolíttatott el a filmből néhány

\footnotetext{
${ }^{518}$ Bár a francói retorika gyakran használta az ellenség megjelölésekor a ,judeo” kifejezést, a diktatúrára nem volt jellemző az antiszemitizmus. Rafael de España a rezsim filmjeit áttekintve kizárólag a Jézus történetét Júdás szemszögéből elmesélő Júdás csókját (El beso de Judas, Rafael Gil, 1954) értékeli antiszemita elemeket is felsorakoztató alkotásnak, más filmekben kizárólag utalásként, vagy mellékes körülményként jelenik meg a zsidók negatív ábrázolása. Erről lásd: España, Rafael de: „Antisemitismo en el cine español” in: Film-Historia, Vol. I. No. 2. 1991.

Elérhető: http://www.publicacions.ub.edu/bibliotecadigital/cinema/filmhistoria/ArtRdEspana.pdf (2012-11-27) További példaként említhető a Faj rendezőjének filmje, a Faustina (Faustina, José Luis Sáenz de Heredia, 1957) című szatíra, ahol a gonosz természetfeletti erők és a sátáni küldöttek jelképe a Dávid-csillag; a zsidó szót egyszer sem ejtik ki a filmben, de az ötágú csillagot szimbólumként használó ördögi alakok lesznek a filmben felelősek minden társadalmi felforgatásért a világban (összhangban a Franco-rezsim által terjesztett világméretü judeo-szabadkőmüves-kommunista összeesküvés teóriával).

${ }^{519}$ Egyik ilyen: Navarrete-Galiano Rodríguez, Ramón: „Conceptualización de lo queer en ¡A mí la Legión! Relecturas de la filmografía franquista" in: Icono 14 - Revista de Comunicación y Nuevas Tecnologías, Vol. 9, No. 3. 345-360.

Elérhető: http://www.icono14.net/ojs/index.php/icono14/article/view/17/64 (2012-11-30)
} 
olyan jelenetet és párbeszédet, amely magában hordozza ezt a kétértelmüséget. Napjainkban a Légió, hozzám! címü filmet úgy tartják számon, mint a francói értékeket tükröző egyik legfontosabb propagandafilmet, ugyanakkor nem hivatalosan az első férfiak közötti homoszexuális kapcsolatot bemutató alkotásként is említik. ${ }^{520}$ Más tanulmány az egy évvel korábban készült Harka! katonái közötti bajtársiasságban is felfedezni véli a homoszexualitást. $^{521}$

\section{A Fülöp-szigetek utolsó harcosai - Los últimos de Filipinas}

A megvalósítást tekintve átmenetet képez a történelmi és a polgárháborús filmek között a megtörtént esetet bemutató A Fülöp-szigetek utolsó harcosai (Los últimos de Filipinas, Antonio Román, 1945). Már távol áll a papírmasé filmektől, kivitelezésében a polgárháborús filmekre hasonlít, a történet pedig a századfordulót eleveníti fel: a spanyol-amerikai háború idején a Fülöp-szigeteken kitört felkelést egy Balerben ragadt spanyol katonai alakulat szemszögéből mutatja be. Egyes jeleneteket egy narrátor is kommentál, a látottak hazafias interpretációját nyújtva, mint a „Mindannyian azért tartottak ki, mert a spanyol erény és kötelesség ezt követelte meg" megállapítás. Az igaz történeten alapuló eseményeket fiktív epizódokkal és karakterekkel egészítették ki.

A cselekmény szerint a Fülöp-szigeteken állomásozó katonák látszólag harmonikus kapcsolatot alakítottak ki a helyiekkel, egyikük szerelmi viszonyba is kerül egy filippínó lánnyal. A hirtelen kirobbanó felkelés elől a közel 60 katona egy templomba menekül. Erődítményként kezelik a helyet a védők és a támadók is, előbbiek hosszú ott tartózkodásra rendezkednek be, igyekeznek azt otthonossá tenni. Többször is felcsendülnek spanyol népdalok, amelyeket hol kórusban, hol önállóan énekelnek. A filippínók betörési és a katonák kitörési kísérletei állandóak, kisebb sikereket mindkét fél elér. Közben aláírásra kerül a Párizsi szerződés ${ }^{522}$, amely a narrátor szerint a spanyol történelem egyik legszomorúbb pillanata volt, de erről a templomban lévők eleinte nem tudnak, majd nem hiszik el sem a nem

\footnotetext{
${ }^{520}$ Akkoriban nem volt közbeszéd tárgya az a ma már ismert tény, hogy a film rendezője, egyben a nemzetikatolikus rezsim legtöbbet foglalkoztatott direktora és a dicsőséges hispán múltat a hamarosan tárgyalandó papírmasé filmekben feldolgozó Juan de Orduña is homoszexuális volt; bár a filmrendezők magánélete általában nem képezi tárgyát munkásságuk elemzésének, ez esetben mégis szükséges megemlíteni ezt a részletet, hogy világossá váljon: mivel a diktatúra hivatalosan nem tolerálta a másságot, ezt az információt nem szellőztethette meg egyetlen sajtóorgánum sem, ugyanis a rezsimnek szüksége volt Orduña müvészi tehetségére.

${ }_{521}$ Amador Carretero, Pilar: „La sexualidad en el cine español durante el primer franquismo” in: Fotocinema, No. 1. 2010. 16-19.

Elérés:http://www.revistafotocinema.com/index.php?journal=fotocinema\&page=article\&op=viewFile\&path[]=5 1\&path[]=34 (2012-12-03)

${ }_{522} 1898$. december 10-én írta alá Spanyolország és az Amerikai Egyesült Államok a Párizsi szerződést, ezzel lezárult a spanyol-amerikai háború. A Fülöp-szigetek, Guam és Puerto Rico amerikai fennhatóság alá került.
} 
hivatalos, sem a hivatalos értesítéseket, azokat hamisnak, átverésnek gondolják; nem hihető szerintük, hogy Spanyolország belement volna egy ilyen szégyenletes és a nemzetüket megalázó egyezségbe. Még közel fél éven át kitartanak, a vezérkari utasítást sem tartja megbízhatónak a parancsnok, az érkező tiszteket és fötiszteket csalóknak, imposztoroknak véli. A Madridból küldött napi sajtó híreit olvasva azonban rájönnek, hogy mégis megtörtént a békekötés, kétségbeesve törődnek bele a megváltoztathatatlanba, ezért kivonulnak. Spanyolországba visszatérve hősként ünneplik őket, a parancsnokot kitüntetik, ugyanis bebizonyították, hogy milyen az igazi spanyol hazafi.

Az ellenség által körülvett épületbe zárt hadsereg motívuma a Nincs újdonság az Alcazárban címü filmben már megjelent öt évvel korábban, Antonio Román alkotása pedig ezen felül az amerikai westernfilmekkel is rokonságot mutat a megvalósítást és a történetvezetést tekintve. ${ }^{523}$ A csatajelenetek kompozíciója szintén az amerikai háborús filmekére rímel. Két irodalmi forgatókönyv (Baler erődje és Baler hősei) alapján készült az adaptáció, egy irodalmi, egy katonai és egy vallási tanácsadót is feltüntettek a stáblista fő helyein.

A hazafias hangnem, a „nemzeti Spanyolország” történelemszemléletéhez illeszkedő cselekményvezetés szerint a szerződést aláíró politikusok a spanyol érdekekkel nem törődve, mosolyogva adják el hazájukat, és csak a maroknyi, nemzetéért akár önmagát is feláldozni hajlandó katona becsületes helytállása méltó a tiszteletre. A Franco-rendszer egyik tartóoszlopaként funkcionáló hadsereg tehát, értelmezésük szerint, a múltban és a jelenben is a Haza erényeinek letéteményese, a katonák az utolsó csoport, amely feladja az elvek védelmében folytatott küzdelmet. A film végén mutatott újságcím segítségével a néző is tudja, mit kell gondolnia az ostromról és a kitartó főszereplőkről: „337 napig tartott Baler hőseinek ellenállása"; a későbbiekben a film alapjául szolgáló megtörtént események nacionalista-konzervatív körökben a spanyol nemzeti múlt egyik legdicsőségesebb epizódjának számítottak. ${ }^{524} \mathrm{Az}$ SNE által díjazott és nagy közönségsikert elérő film is megkapta a nemzeti érdek besorolást.

Bár a film igaz történeten alapul, a Franco-rendszer saját szemszögéből meséli el azt. A hazafias és katonai erények és értékek felmagasztalása mellett a pillanatnyi (a 40-es évek

\footnotetext{
${ }^{523}$ Őslakosok, vagy más nemzetek fegyveresei által támadott amerikai katonák és hös hazafiak, akik egy zárt helyen próbálnak kitartani: leginkább az Alamo-erőd ostromát feldolgozó filmek képsorai köszönnek vissza. Antonio Román ismerhetett néhányat a korábbi feldolgozásokból, mivel a western mindig népszerủ volt Spanyolországban, az Alamo-téma pedig már az 1910-es évektől kezdődően visszatérő elem volt a hollywoodi filmekben. Legjelentősebbek, amelyeket Román is láthatott, Az Alamo mártírjai (The Martyrs of the Alamo, Christy Cabanne, 1915) és Az Alamo hösei (Heroes of the Alamo, Harry L. Fraser, 1937).

${ }_{524}$ Esparza, José Javier: „Los últimos de Filipinas: los héroes de Baler” in: El Manifiesto, 2008. június 24. Elérhető: http://www.elmanifiesto.com/articulos.asp?idarticulo=2421 (2012-09-07)
} 
közepét jellemzö) külpolitikai helyzetre is reflektál. Ugyan a spanyolok az 1898-as háborúban az Amerikai Egyesült Államokkal vívták a harcot, a filmben az amerikaiak ábrázolása meglehetősen pozitív, kizárólag az őslakosok az ellenség. Még egy amerikai hadihajó is a spanyolok segítségére siet, őket azonban a filippínók feltartóztatják; mintha Amerika és Spanyolország egy oldalon állt volna ebben a háborúban. Alejandro Pizarroso Quintero úgy véli, a második világháború lezárultával Spanyolország igyekezett elnyerni az USA szimpátiáját, ehhez alkalmazkodott a spanyol-amerikai háború ilyen formában történő ábrázolása, ahol azt az epizódot emelték ki az alkotók, amelyben a két ország között éppen nem állt fenn éles konfliktus. ${ }^{525}$ A film stáblistáján a köszönetnyilvánításban megkülönböztetett hálával fordul a rendező a madridi amerikai nagykövetséghez is. ${ }^{526}$

\section{Az ellenségkép kijelölése}

A kora francóizmus egyik leggyakrabban visszatérő motívuma a lesben álló, az Új Spanyolországra veszélyt jelentő kommunisták és hasonló felforgató erők tevékenysége. Úgy vélték, a nemzet védelmében kellett a potenciális veszélyforrásokat megfigyelés alatt tartani. Ahogyan az ideológiai fejezetben már jeleztem, kommunizmus, anarchizmus és szabadkőművesség lényegében szinonimaként müködtek a Franco-korszak eszmeiségében, ezért minden olyan filmet ebbe a kategóriába helyezek, amely ezzel az ellenségképpel foglalkozik. Sok esetben átfedés található a polgárháborús tematikájú mủvekkel, mivel azok egy részének története nem ér véget 1939-ben, hanem követi szereplői életét az elkövetkezendő években is, néhány alkotást pedig akár mindkét kategóriába besorolhatnánk, mivel a polgárháború tárgyalása együtt jár az ellenség ábrázolásával. Mégis egy külön alfejezetet szentelek ezeknek műveknek, mert többségük a fegyveres konfliktus utáni periódusban játszódik. A kommunizmus-ellenes hangvétel megjelenik minden egyes polgárháborús, egyházi témájú, vagy a hadseregre fókuszáló alkotásban, karöltve az idegengyülölettel (a nem hispán fajhoz tartozók iránti xenofóbia megnyilvánulásai).

A kommunista-ellenes témák és a társadalomba beszivárgó bolsevik ügynökökről szóló filmek a hidegháború kiéleződésével az Amerikai Egyesült Államokban gyakori almüfajjá váltak, ennek kapcsán már szóltam korábban az úgynevezett amerikai paranoia filmekről. Ellentétben az USA-val, Spanyolországban nem alakult ki az idegen megszállásról

\footnotetext{
525 Pizarroso Quintero, Alejandro: „Guerra, Cine e Historia. La guerra de 1898 en el cine” in: Historia y Comunicación Social, No. 3. 1998. 153.

${ }^{526}$ Nem részletezik, hogy konkrétan miért mondanak köszönetet, de valószínüleg a filmben rövid időre felbukkanó amerikai hadihajó, a statiszták, esetleg további tanácsadók közreműködéséért.
} 
szóló művek tudományos-fantasztikus metaforája, ebben az esetben a spanyol hazafiak valódi kommunista ügynökökkel és kémekkel néztek szembe a filmvásznon. Egyesek személyisége ezekben a müvekben azonban még nem teljesen romlott, a folyamat néha visszafordítható, ehhez pedig az szükséges, hogy a főszereplő spanyolok a helyes útra tereljék a megtévedt ellenfelet. Feltűnő, ahogyan azt látni fogjuk, hogy a „pokol” szó több olyan film címében is megtalálható, amely a Szovjetunióba vagy egy másik kommunista országba helyezi cselekményét.

\section{Az örjárat - La patrulla}

Pedro Lazaga filmjeinek közös jellemzője, hogy, bár különböző mértékben, de eltávolodnak az erőteljes propagandavonaltól, a korai és a kései Franco-korszak közti határvonalat képviselik. Ami valódi újdonság müveiben, az a nemzeti megbékélés óhajának jelenléte. A köztársasági oldal, ellentétben a korábbi filmekkel, nem a Gonosz megtestesülése, a felkelők szemében ők is emberek, sőt, honfitársak, akik a történelmi helyzetből fakadóan a harctér másik felére kerültek. Lazaga rendkívül termékeny filmrendező volt, aki szinte minden müfajban alkotott, elsősorban vígjátékai és négy háborús filmje miatt emlékszik rá az utókor. Az alábbiakban tárgyaltakon kívül a maqui-témával, mint törvényen kívüli fegyveres csoportok történetével első ízben foglalkozó Torrepartida (Torrepartida, 1956) és a háborús zónába küldött ifjú papról szóló A végtelen front (El frente infinito, 1956) tartozik a fegyveres konfliktust tárgyaló filmjei sorába.

Az örjárat (La patrulla, 1954) öt föszereplője a felkelők csapatában szolgáló katona, akik egy, a polgárháború vége felé készült közös fotó után megállapodnak abban, hogy tíz évvel később ismét találkozni fognak ugyanazon a helyszínen. A film ezt a tíz évet mutatja be, mi történik a szereplőkkel, hogyan próbálják meg feldolgozni a háborúban történteket és hogyan tudják folytatni életüket. Lesz köztük, aki megcsömörlik és bünözőnek áll, és olyan is, aki a Kék Hadosztályba kerül.

Az őrjárat az egyik első olyan produkció, amely bemutatja, hogy a nacionalista oldalon harcolók közül sem tud mindenki elszámolni a lelkiismeretével, és táborukban sem mindenki feddhetetlen jellem. Az ellenség démonizálása is mérséklődik, a narrátor azonban egyértelművé teszi, hogy a polgárháborúban a kommunizmus ellen folyt a harc. A külpolitika változását a Kék Hadosztályban szolgáló Enrique történetén keresztül láthatjuk, és ez egyben a film egyik legérdekesebb része is. A szovjet fogolytáborban kifüggesztett sarló és kalapács, valamint Lenin-portré folyamatosan szemünk elé idézi, hogy ki és mi a fö ellenfél, egy korábban megvetett nemzet viszont barátivá válik: Enrique egy amerikai repülőgépen 
menekül el a táborból, majd a gép tisztje, ahelyett, hogy a szabályt követve feladná őt a célállomás föparancsnokának Franciaországban, hagyja megszökni, még pénzt is ad neki. A nézők is láthatják, hogy a kommunizmus ellen kizárólag összefogással lehet sikert elérni. A film elsősorban a háború utóhatásaival foglalkozik, leszámítva az első jeleneteket (ahol köztársasági golyók végeznek az egyik ifjú szereplővel) és a Kék Hadosztályban zajló eseményeket.

\section{Nagykövetek a pokolban - Embajadores en el infierno}

A teljes mértékben a Kék Hadosztályra koncentráló Nagykövetek a pokolban (Embajadores en el infierno, José María Forqué, 1956) a francói propaganda terméke, a szovjet kényszermunkatáborba került spanyol önkéntesek szenvedéseit tárja a néző elé, akik két alternatíva közül választhatnak: lemondanak a spanyol állampolgárságról és így esélyt kapnak a szovjet hadseregben történő szolgálatra, vagy spanyol fogolyként a táborban elszenvedik a megalázó bánásmódot. A hazájukhoz mindvégig hű katonák büszkén jelentik ki, hogy azért léptek be a Kék Hadosztályba, mert a kommunizmus ellen akartak harcolni. A fogolytáborban a Genfi egyezmény értelmében elutasítják a kényszermunkában való részvételt, majd egy kirakatperben az átálló spanyol katonák közremüködésével lázadás szítása címén hosszú fogságra ítélik őket. Sztálin halálakor, közel tizenegy évnyi rabság után az állampolgárságukat megtartó spanyolok egy Vöröskereszthez tartozó hajón hazatérhetnek, míg a szovjeteket kiszolgáló spanyoloknak orosz földön kell maradniuk; utóbbiak egyike kétségbeesve próbálna mégis velük tartani, míg a másik, amikor a hajó távolodni kezd, lelkiismeret-furdalása miatt szovjet szolgálati fegyverével öngyilkos lesz. Forqué alkotásában a szovjetek testesítik meg az embertelen és érzéketlen ellenfelet, a hazaárulóvá váló spanyolok pedig megvetést érdemelnek. Az igazi hazafiak azonban nem adják fel, nem hajolnak meg a kényszerítés előtt sem, és a halált is vállalják, hogy hazájukhoz hűek maradjanak. Utóbbi személyiségtípust állította a Franco-rendszer is a nemzeti történelem középpontjába. Az időnként megszólaló narrátor erősíti a patrióta felhangot és a jelenetek alatt kifejti, milyen hősies viselkedésnek, milyen feddhetetlen spanyol magatartásnak vagyunk tanúi. Úton hazafelé a hajón az Arccal a nap felé himnuszt hallgatják vigyázzba állva a hazatérők, majd családtagjaik rádióüzeneteit közvetítik nekik.

A film igaz történeten alapul, 1954 áprilisában érkezett meg Odesszából Barcelona kikötőjébe a Szemiramisz nevü hajó, fedélzetén 229 spanyol katonával, akik a Kék Hadosztály tagjaiként 11 évet raboskodtak a Gulágon. Torcuato Luca de Tena az ABC napilap hasábjain cikksorozatot tett közzé a visszatérők emlékeiből és a velük készített interjúkból, majd 
egyikükre fókuszálva Nagykövet a pokolban címmel $^{527}$ könyvet írt. A filmváltozat elkészítésének rendezői székétől többen visszaléptek, mert a téma kockázatos volt: egyes miniszterek utasítására a Falange motívumait és szólamait erőteljesen ábrázolni kellett volna, miközben, az 50-es évek közepén, a régi falangizmustól eltérő, a nyugati demokráciák felé orientálódó külpolitikát folytatott Spanyolország. Luca de Tena monarchista szemléletet képviselt, és cikkeiben alig utalt a Falange-ra, sőt, a könyvben is csak felszínesen szólt arról, hogy a Kék Hadosztály valójában a német hadsereget segítette. A könyv, majd forgatókönyv szereplőinek nagy része kitalált figura, személyiségjegyeiket a valódi alakok tulajdonságaiból állították össze. Forqué vállalta a rendezői feladatot, és igyekezett egy mindenki számára kielégítő változatot készíteni. A kor egyik legnépszerübb filmjévé vált, mert a rendezőnek sikerült a hazafias szólamok, a spanyolság-tudat, a katolicizmus és az antikommunizmus mellett a történtek drámai oldalát is bemutatnia, a szereplők átélt szenvedéseinek realista ábrázolását. A bemutató előtt azonban betiltották, mert a rezsim nem érezte eléggé hazafiasnak, a rendezőt pedig falangista csoportok hazaárulónak nevezték és több alkalommal megfenyegették. Végül Agustín Muñoz Grandes hadügyminiszter (a Kék Hadosztály volt parancsnoka), José Luis Arrese, a Mozgalom főtitkára, valamint Gabriel Arias Salgado tájékoztatási és idegenforgalmi miniszter megtekintették együtt egy privát vetítésen, és az általuk javasolt két változtatással továbbították engedélyezésre: egészítsék ki a filmet olyan jelenetekkel, ahol a spanyol katonák egyenruháján látszódnak a Falange jelvényei, valamint adjanak hozzá egy mondatot, amelyben a narrátor kijelenti, hogy a Kék Hadosztály tevékenysége valójában a Spanyol Felszabadító Háború folytatása volt. ${ }^{528}$

\section{A hü gyalogság - La fiel infantería}

Az örjárat kapcsán már említettem, hogy Carlos Arévalo rendező a nemzeti megbékélés útján indult el filmjeivel. Ennél is jelentősebb elmozdulást láthatunk $A$ hü gyalogság (La fiel infantería, 1959) címü munkájában. A korábbiakból ismert propagandából és ideológiai töltetből itt szinte semmi sem maradt, látható a gondolkodásban, a múlthoz és a legyőzött ellenfélhez való viszonyulásban bekövetkezett változás. A film első 60 perce egy, a frontról kimenőt kapott felkelő zászlóalj mindennapjait mutatja be, a családdal és menyasszonyokkal történő találkozásokat, tanulmányi vizsgákat, szórakozást, mindezt romantikus, helyenként vígjátéki tónusban. Az egyik szereplő megnősül, a többiek önfeledten élvezik a békés napokat. Bár mindannyian egyenes jellemek, egyikük mégis csal a vizsgáján, amelyhez a

\footnotetext{
${ }^{527}$ Luca de Tena, Torcuato: Embajador en el infierno. Memorias del capitán Palacios: once años de cautiverio en Rusia. Madrid, 1955. A könyvböl máig közel 20 újabb kiadás látott napvilágot Spanyolországban.

${ }^{528}$ Soria, Florentino: José María Forqué. Huesca, Festival de Cine de Huesca, 1992. $42-45$.
} 
többiek asszisztálnak is, nevetségessé téve egy jelenetben mind az egyetemi professzorokat, mind magát az Oktatási Minisztériumot és a kormányrendeleteket. Az alkotás második felében azonban visszavezénylik őket a harctérre, ahol tömény, a korabeli és a mai hollywoodi háborús filmekhez hasonló, tökéletesen megkoreografált, vérben és erőszakban bővelkedő jeleneteket láthatunk. Az egyik első olyan film a Franco-korszakban, amely a szuronyok és golyók behatolását mutató közelképekkel illusztrálja, hogy a háborúban valóban emberi életeket oltanak ki. A film során megkedvelt szimpatikus és jó szándékúnak lefestett nacionalista férfiak a játékidő utolsó 15 percében kegyetlen halált halnak, de a kamera hasonló érzékenységgel mutatja be a republikánus fegyveresek halálát is. A kor elsőrangú színészei alakítják még a legkisebb szerepeket is.

A film záró állóképére írt végső üzenet, egyszersmind ajánlás minden kétséget eloszlat afelől, hogy mi volt a rendező szándéka a filmmel: „Minden spanyolnak, akik ezt a háborút vívták. Bárhol is legyenek most, élők vagy holtak. Tartós békét!” Szintén üzenet-értékü, hogy a cenzori jelentések közül néhány ${ }^{529}$ aggodalmát fejezi ki a békülékeny hangnem és a brutalitás miatt, a Junta azonban mégsem tiltotta be és nem is vágatta ki az említett részeket. A hü gyalogság elnyerte az SNE legjobb filmnek járó kitüntetését is, a mozipénztáraknál kasszasikernek számított, a főszereplők (különösen a vígjátéki szerepekhez szokott Tony Leblanc) pedig valódi sztárstátuszba emelkedtek. A rezsimet támogató filmtörténész, Carlos Fernández Cuenca (egyben a Filmarchívum alapítója, a SNE és számos filmes intézmény és fesztivál igazgatója és a diktatúra legtöbbet foglalkoztatott filmkritikusa) nem csak Spanyolország, de a világ legjobb háborús filmjének nevezi könyvében. ${ }^{530} \mathrm{Az}$ alkotás egyértelműen a nemzeti megbékélés, a győztesek és vesztesek közötti különbségek eltörlése mellett tette le a voksát, és még azt is megengedte magának, hogy szatirikus módon közelítsen az állam életét meghatározó hivatalos intézmények és személyek felé. A film természetesen a felkelők oldalán áll, a néző is velük kell szimpatizáljon, de a másik oldal sem minden körülmények között elpusztítandó ellenség, ahogyan a korábbi alkotásokban. A hivatalos spanyol filmművészetben a nyitás ezzel a filmmel, 1959-ben kezdődött.

\section{Az ászok békére törekszenek - Los ases buscan la paz}

A kultúrpolitikát tárgyaló fejezetben már szóltam róla, hogy az 50-es években, kihasználva a társadalom labdarúgás iránti rajongását, futballisták föszereplésével forgattak népszerü játékfilmeket. A legismertebb Spanyolországhoz kötődő magyarként számon tartott

\footnotetext{
${ }^{529}$ AGA, Cultura, 36/03743-as doboz, 20137-es köteg és 36/03745-ös doboz, 20225-ös köteg

${ }^{530}$ Fernández Cuenca, Carlos: La guerra de España y el cine. Id. mü. 596.
} 
Kubala László föszereplésével készült Az ászok békére törekszenek (Los ases buscan la paz, Arturo Ruiz-Castillo, 1954) nem csak sportfilmként, de ideológiai alkotásként is funkcionált. A Kubala életén alapuló játékfilmben a focista önmagát alakítja, karrierjét és viszontagságait mutatja be a kezdetektől az FC Barcelonában töltött napjaiig. A Spanyolországban forgatott (Budapestet is Madrid utcái és kocsmái ,alakítják”, kombinálva néhány, a magyar fővárosról készült eredeti felvétellel) alkotás spanyol propagandafilmnek is tökéletesen használható: a főszereplőt a magyar kommunista titkosszolgálat folyamatosan nyomás alatt tartja, kémként és besúgóként akarja alkalmazni, ezért családjával és más disszidensekkel együtt kalandos körülmények között elmenekül Magyarországról, elöbb Olaszországba, majd Spanyolországba érkezik. Utóbbi tárt karokkal fogadja, rajonganak érte, és, bár éri őt egy utolsó megkísértés (egy magyar kommunista tiszt felajánlja, hogy büntetlenül hazatérhet szülőhazájába és találkozhat ott élő édesanyjával, amennyiben együttmüködik a magyar hatóságokkal), Kubala hü marad választott hazájához, és így a spanyol nemzet büszkesége lesz.

A film igyekszik minél realistábbnak, valóságosabbnak tünni: körülbelül egyhatodát eredeti futballmérkőzéseken készített felvételek teszik ki, amelyeken Kubala játékát mutatják be; másik hatodát magyar népzene és cigányzene adja, a hozzá kapcsolódó tradicionális táncokkal és dalokkal. A film egésze során pedig folyamatosan szól az ismert magyar témákat cimbalommal és hegedűvel előadott folklórzene. Kubala két fia is szerepel. A budapesti utcákon és kocsmákban magyar feliratok láthatóak, azonban az egyik jelenetben a Kubala kezében lévő újság, amelyről közelképek is készülnek, a korábbi hitelességet romba dönti: rossz helyesírással és hibás nyelvtannal írt, nevetséges végeredményt nyújtó magyar szavak egymás mellé helyezése alkotja az elméletileg magyar nyelven íródott, magyarországi napilapot. Ez persze csak azt a nézőt zavarja, aki tud magyarul; a spanyol közönségnek elég volt annyi, hogy „magyarnak látszó” környezetbe helyezték a történet egy részét.

Az ászok békére törekszenek elhitette a spanyol nézőkkel, hogy a kommunizmus által elnyomott, bolsevik ügynökök uralta Magyarországgal szemben Spanyolország valóságos Paradicsom a menekültek számára; a Franco-rendszer befogadó közegének köszönhető, hogy a spanyol nemzet büszkesége, Ladislao Kubala ki tudta bontakoztatni tehetségét.

Még két olyan filmet szükséges megemlíteni, amely Magyarországot választotta témájául. A Hajnalhasadás (El canto del gallo, Rafael Gil, 1955) ${ }^{531}$ Spanyolországban élő

\footnotetext{
${ }^{531}$ A filmből a történet alapján nem derül ki egyértelműen, hogy kommunista országban járunk. A cselekmény során felsorakoztatott tisztek viselkedése, egyház-ellenessége azonban feltűnően hasonlít arra az ábrázolási módra, amelyet a kommunistákkal kapcsolatban alkalmaztak a spanyol filmesek a 40-es és 50-es években.
} 
magyar emigránsok közremüködésével készült, egy magyar pap viszontagságait és egy bolsevik tisztté vált volt barátjával folytatott, mindkettőjük halálába torkolló párharcát mutatja be, filmnyelvi eszközeivel és nyomasztó légkörével az amerikai film noirokat idézi fel. ${ }^{532} \mathrm{~A}$ Vérrapszódia (Rapsodia de sangre, Antonio Isasi-Isasmendi, 1957) az 1956-os forradalom eseményeit helyezi középpontba, egy budapesti magyar zongorista történetét, szökését és a kommunista erők brutális elnyomását örökíti meg. Mindkét filmre jellemző, hogy sztereotip és sablonos karaktereket felvonultató, teljes mértékben az antikommunista propagandát kiszolgáló mủvek, ahol Magyarország egy sötét, az ott élő emberek számára elviselhetetlen diktatúra képét nyújtja. A magyarok többsége azonban vagy belenyugszik a helyzetbe, vagy együttműködik a rendszerrel; kivételt képez a főszereplő, aki nem adja fel, és a saját, valamint mások érdekében folytatja a kommunisták elleni harcot a maga eszközeivel. Hozzá kell tenni, Magyarország a Hajnalhasadásban egy „egzotikus díszlet”-ként funkcionált: míg a Kubalafilm esetében értelemszerü volt, hogy a futballista hazáját válasszák kiindulópontnak, a Vérrapszódia fó témája (az 56-os forradalom) is behatárolta a helyszínt, a Hajnalhasadás bármely más, szovjet-szatellit államban is játszódhatna, a lényeges elem, hogy egy Szovjetunió által elnyomott térséget mutathassanak be. Ezt a megállapítást igaznak tartom A csend légiójára (La legión del silencio, José Antonio Nieves Conde, José María Forqué, 1956) is, ahol Csehszlovákia adja a hátteret. Mindezt azzal a ténnyel is alátámaszthatjuk, hogy sem a Hajnalhasadás, sem A csend légiója esetében nem lényeges, hogy a cselekmény az adott országokban játszódik, de a filmekben megjelenő újságok, falfeliratok alapján erre a következtetésre jutunk. Magyarország és Csehszlovákia ebben az esetben „felcserélhető” lehetne egymással, mert sem létező személyek, sem történelmi események nem kötik a történéseket a szóban forgó országokhoz.

$* * * * * * * * * * * * * * *$

Az alábbiakban kitérek olyan spanyol antikommunista filmekre, amelyek esetében elégségesnek tartom pár szóban összefoglalni azok tartalmát a címek felsorolása mellett. Rendkívül egyszerü történetvezetésű és sematikus művekről van szó, ahol a romantikus történet, a melodráma és a családi dráma egyik szálát minden esetben a kommunizmusellenesség adja, ezeken keresztül bemutatható, milyen sokszínü módon jelenhetett még meg az ellenség ábrázolása. Ide sorolható, többek között:

\footnotetext{
Magyarországot is csak az alapján tudjuk beazonosítani, hogy több alkalommal is hallunk magyar mondatokat, valamint az utcákon magyar feliratok állnak a boltok bejárata felett.

${ }^{532}$ Spanyolország a Hajnalhasadást akarta benevezni a Velencei Filmfesztiválra, de nem fogadták be, mert a válogatást irányítók véleménye szerint a cselekménye sértő egy külföldi országra, vagyis Magyarországra nézve. Lásd: Gubern, Román: 1936-1939: La guerra de España en la pantalla. Id. mü. 119.
} 
- a Szovjetunióból Spanyolországba menekülő, üldözött oroszok és rajtuk segítő spanyolok témáját feldolgozó Esküvő a pokolban (Boda en el infierno, Antonio Román, 1942), Üldözöttek (Perseguidos, José Luis Gamboa, 1952) és Üldözés Madridban (Persecución en Madrid, Enrique Gómez, 1952);

- a második világháború utóhatásait vizsgáló, a szovjet győzteseket szörnyetegként ábrázoló, és a 40-es évek elejének német-barát alkotásait megidéző Béke (Paz, José Díaz Morales, 1949), ahol a másik győztes hatalmi csoport, a kapitalista Nyugat is negatív színben tünik fel;

- a korábban a köztársaságiak oldalán harcoló, Franciaországba menekülő spanyol katonatisztről szóló Arccal a tenger felében (Rostro al mar, Carlos Serrano de Osma, 1951) a spanyol főszereplő „megtérését” akadályozzák az őt folyamatosan zaklató kommunista ügynökök; ebben az esetben újdonság, hogy a rendező a legyőzött csapatba tartozó főszereplőt szimpatikus vonásokkal ruházza fel, egy lépést téve így a Pedro Lazaga által később kialakított, a békés egymás mellett élést sugalló filmes ösvényen;

- a Német Demokratikus Köztársaságból Spanyolországba érkező, egy merényletet előkészítő kommunista ügynöknő történetét elmesélő Útlevél egy angyalnak (Pasaporte para un ángel, Xavier Setó, 1953), amelyben a lelkiismeret felülkerekedik a kötelességen, és a nő a spanyolok védelmére kel elvtársaival szemben;

- a Tizenöt éve halt meg (Murió hace quince años, Rafael Gil, 1954) képsorain a spanyol polgárháború idején Oroszországba küldött gyerekek egyike visszatér hazájába azzal a céllal, hogy a szovjet hatóságok megbízásából kémkedjen édesapja, a magas rangú spanyol titkosszolgálati tiszt után; a történet folyamán a föszereplö, látva a francói Spanyolország „eredményeit”, édesapja oldalára áll; hasonló témát dolgoz fel az Ami soha nem hal megben (Lo que nunca muere, Julio Salvador, 1954) a szintén a Szovjetunióból hazatérő, kommunistává vált spanyol fiatal története, aki saját testvérével kerül szembe, amikor merényletet kísérel meg a szovjetek megbízásából;

- néhány mű kommunista országokba helyezi a cselekményt: a Vietnámban papokat és apácákat gyilkoló kommunista gerillákról szóló Egy kereszt a pokolban (Una cruz en el infierno, José María Elorrieta, 1954), ahol az egyháziak védelmére kel egy László nevű, tisztázatlan nemzetiségü szökevény, és az NDK-ból az NSZK-ba menekülőket segítő, katolikus önkénteseket bemutató És a poklot választotta ( $Y$ eligió el infierno, César Fernández Ardavín, 1957);

- egyes alkotások Spanyolország második világháborúban elfoglalt semleges álláspontját állítják középpontba (elfeledkezve a „nem hadviselő fél” státuszról): ilyen az egy 
náci kémnő és egy spanyol hajóskapitány szerelmét bemutató, olasz-spanyol koprodukcióban készült Vicente Blasco Ibáñez-adaptáció, a Mare Nostrum (Rafael Gil, 1948), illetve a semlegesség kinyilvánítása mellett humanitárius feladatokat is ellátó spanyol tengerészek története a Semlegességben (Neutralidad, Eusebio Fernández Ardavín, 1949).

A 60-as évektől kezdődően a melodrámák, kalandfilmek, esetenként vígjátékok háttereként továbbra is megjelent a hidegháborús szembenállás, a spanyol társadalomba beszivárgó szovjet ügynökök témája, de halványodott az erőteljesen propagandisztikus jelleg. Ebben is analógia mutatkozik a hollywoodi filmgyártással, ahol ez a tendencia kicsit később, a 60-as évek második felétől figyelhető majd meg.

A polgárháborús filmek esetében már említettem, hogy rendkívül nehéz megbecsülni az abban a témában a Franco-rendszerben készült filmek számát. Ha az ellenségképpel, az Új Spanyolország ellenségeivel foglalkozó filmeket szeretnénk számba venni, akkor a dolgunk szinte lehetetlennek bizonyul. Számos müvet nem lehet ugyanis elkülöníteni egyértelmüen a polgárháborús tematikájú alkotásoktól, valamint ide kellene sorolni azokat is, amelyek alapvetően más cselekménnyel rendelkeznek, de egy történetszál, egy mellékszereplő, vagy egy altéma miatt mégis meg kellene azt említeni. Ha a teljességre törekednénk, nem lenne túlzás azt állítani, hogy a Franco-diktatúrában készült filmek közel $80 \%$-át be kellene ide emelni.

\section{A történelem}

José Enrique Monterde spanyol filmtörténész adatai szerint 1939 és 1950 között megközelítőleg 437 film készült Spanyolországban, ebből 20-nál nem többre alkalmazható az ideologizált „történelmi film” megnevezés ${ }^{533}$. Gyüjtőnevük papírmasé film (cine de cartón piedra), utalva a monumentális díszletek építőanyagára. Leginkább a Cifesa filmjei tartoznak ebbe a kategóriába.

Bár a diktatúrák rendkívül fontosnak tartják a rendszerhü, propagandaként is értékelhető filmalkotások készítését, a mozi legfőbb feladata minden ilyen rendszerben azonban a szórakoztatás, a nézők elszigetelése a valóságtól, legalább a játékidő erejéig. A tisztán ideológiai alapokon nyugvó és azokat direkt módon közvetítő filmek száma így minden totalitárius rendszerben kisebbségben van. Mindazonáltal, a rezsim üzenetét éppen ezek a filmek hordozzák, a legnagyobb állami támogatást és a legfelsőbb szintről érkező promóciót is ezek kapják. Ahogyan az elsőszámú filmművészeti folyóirat, a Primer Plano vezércikke

\footnotetext{
${ }^{533}$ Monterde, José Enrique: „Un modelo de reapropiación nacional” in: Berthier, Nancy - Seguin, Jean Claude: Cine, nación y nacionalidades en España. Id. mü. 90-91.
} 
megfogalmazta 1942-ben, a történelmi filmek müfaja mind közül a legfontosabb, ugyanis ezek döntően hozzájárulnak a nemzeti szellem formálásához. Spanyolország lakosai számára a nemzeti értékek képviselete az első, ezért a filmproducereknek és rendezőknek be kell mutatniuk a belföldnek és a külföldnek egyaránt, milyen dicsőséges utat járt be az ország, amíg elérkezett jelenlegi állapotába. ${ }^{534}$ A már többször említett Manuel García Viñolas testvére, Pío García Viñolas egy évvel korábban, ugyanebben a lapban a spanyol filmmüvészet legnagyobb hiányosságának azt tartotta, hogy nem készít a nemzeti történelmet feldolgozó műveket. ${ }^{535}$ A Radiocinema folyóirat főszerkesztője kifejtette: „Faji Filmet alkotunk, amely bemutatja szépségünket, vallási, hősi és kissé kalandvágyó szellemünket. Egy mély spanyol gyökerekkel rendelkező Filmet. Romancero filmet szilárd klasszikus vonalakkal. Itt vannak hajósaink, szentjeink és költőink élettörténetei. El Cid és Hernán Cortés megérdemelnek egy filmet. És a nagy Izabella királynőnk és Cisneros bíborosunk, Cervantesünk, Lopénk." ${ }^{536}$ Ugyanez az írás a továbbiakban kifejti, hogy a filmből valódi nemzeti fegyvert lehet kovácsolni, ennek segítségével az egész világ megismerheti a spanyol nagyságot, amely példaként szolgálhat mindenki számára. A 40-es évek során a Primer Plano és a Radiocinema számos ilyen témájú cikket és vezércikket jelentetett meg, mindegyik ugyanazt a tézist járja körül: a dicsőséges spanyol múlthoz tartozó események, hősök, szentek történelmi filmeken való megjelenítése szükséges ahhoz, hogy mind a belföld, mind a külföld számára bemutassák, Spanyolország a civilizáció legmagasabb fokát képviseli, a világ történelmének mozgatórugója és elválaszthatatlan része. ${ }^{537}$

A feladat teljesítéséhez számítottak a kellő képzelőerővel, befolyással és profizmussal rendelkező, valamint a hatalomhoz hü rendezök, forgatókönyvírók, díszletmesterek és filmstúdiók (elsősorban a Cifesa, kisebb mértékben a Suevia Films) segítségére.

A részben eredeti forgatókönyveken, részben az Aranykorban vagy később született irodalmi műveken alapuló történelmi filmek készítése nem egyedülálló jelensége a francói Spanyolországnak, Mussolini Olaszországa és Hitler Németországa szintén kedvelt müfajjá tették ezeket. A diktatúrák a történelem sajátos átértelmezésével szimbolikus jelentőséget

\footnotetext{
534 „Necesidad de un cine histórico español” in: Primer Plano, No. 95. 1942. augusztus 9.

535 García Viñolas, Pío: „La escasez de asuntos históricos en nuestra pantalla” in: Primer Plano, No. 17. 1941. február 9.

${ }^{536}$ Romero-Marchent, Joaquín: „Cinema nacional. Comentarios al margen” in: Radiocinema, No. 44. 1940. január 15. 7 .

537 Például: Sainz y Díaz, José: „Hacia un cinema nacional. La misión de la pantalla: distraer y educar” in Radiocinema, No. 50. 1940. április 15; Casares, Francisco: „El cine en función de la historia” in: Primer Plano, No. 66. 1942. február 18; ugyanez a szerző pár hónappal később, az előzőhöz nagyon hasonló címmel és csak kis tartalmi változtatásokkal publikált egy írást egy másik folyóiratban: „El cinema al servicio de la historia” in: Radiocinema, No. 70. 1942. november 3.
} 
adtak a múltnak, a filmet pedig a kiemelkedő irodalmi alkotások adaptálása révén előkelő müvészi magasságokba emelték, így legitimizálták annak propagandaként történő használatát is.

Monterde tanulmányában nyolc fő jellemzőjét nevezi meg ${ }^{538}$ a történelmi müveknek, én ebből az öt legjelentősebbet emelem be:

1. A hős caudillót teszik meg a történet és egyben a spanyol történelem motorjának, aki minden más ember felett áll, személyisége ellentmondásoktól mentes, és bármikor kész feláldozni életét Istenért és a Hazáért. Mindannyian Franco elődeinek tekinthetők.

2. A Haza egysége a kasztíliai hagyományok alapján valósítható csak meg, ezért szükséges megszüntetni mindent, ami ezt az uniformizációt veszélyeztetheti (mint az osztályharc, a katolikustól eltérő vallások, kisnemzeti és regionalista törekvések).

3. A „másik” demonizálása, vagyis állandó ellenségkép kreálása. Ez lehet belső (szeparatisták, demokraták) és külső (kommunisták, ateisták, szabadkőmüvesek) - ennél a pontnál átfedés mutatkozik a tisztán történelmi és a közelmúlt témáival foglalkozó filmek között.

4. A nemzeti múlt szelektív említése: a rezsim számára dicsőségesnek ítélt korok és személyek kiemelése, valamint a szégyellnivalónak tartott idők kihagyása, esetleg meghamisítása. A filmek alapján abszolút pozitív megítélést kap a reconquista periódusa, a Katolikus Királyok egyesítési törekvései („,kifelejtve” a zsidók és moriszkók ellen elkövetett atrocitásokat), Amerika meghódítása és a kereszténység kiterjesztése (nem említve az őslakosok kiirtását), II. Fülöp korszaka (mindenféle utalás nélkül a Habsburg uralkodók idején keletkező problémákra), a Napóleon elleni függetlenségi háború és a latin-amerikai kolóniák elvesztése (elhallgatva a korábbi anyaország túlkapásait).

5. A nép azon tulajdonságát kihasználva, hogy nem ismeri saját nemzeti történelmét, az alkalmazott narrátor és mesélő segítségével bármilyen történelmi tényt és eseményt a saját szándékaiknak megfelelően interpretálhatnak a film készítői, sokszor elferdítve vagy meghamisítva az igazságot.

A továbbiakban olyan alkotásokra térek ki röviden, amelyek több jellemzőt is magukban foglalnak, valamint visszhangjuk, illetve a bemutatásukba és promóciójukba fektetett energia alapján vélelmezhető ${ }^{539}$, hogy a rezsim nagy jelentőséget tulajdonított nekik.

\footnotetext{
${ }^{538}$ Monterde, José Enrique: „Un modelo de reapropiación nacional” Id. mü. 92-93.

${ }^{539}$ A korabeli filmes folyóiratokban fellelhető cikkek és kritikák mennyisége, az ugyanitt elhelyezett hirdetések száma és a fennmaradt plakátok és szóróanyagok mennyisége és minősége (színezettség, szlogenek és méret) alapján juthatunk ilyen következtetésekre. Mindezek tanulmányozására a madridi Filmarchívumban volt lehetőségem.
} 
A Faj kapcsán már előkerült a giccs szó: a történelmi filmek kapcsán Luis Mariano González egy külön könyvet ${ }^{540}$ szentel annak, hogy a fasizmus és a spanyol történelmi filmek esztétikai megközelítésében miért kulcsfogalom a művészi giccs. Dolgozatomban, mivel nem filmművészeti elemzést készítek, nem térek ki erre a témára. Az alábbiakban felsoroltak mellett szintén ide tartozik, többek között, az Ursino hercegnője (La princesa de Ursinos, Luis Lucia, 1947) és a Kasztília bátor asszonya (La leona de Castilla, Juan de Orduña, 1951), illetve a fejezet végén felsorolt későbbi müvek.

\section{Szent királyné - Reina Santa}

A Suevia Films első papírmasé filmje a Szent királyné (Reina Santa, Rafael Gil, 1947), amelyet két nyelven forgattak párhuzamosan: a spanyol mellett portugál változat is készült, így rögtön két nyelvterületen mutathatták be. A Katolikus Egyház által később szentté avatott Aragóniai Izabella (1271-1336) portugál királyné életéről szóló film a címszereplőt a példás életvitel megtestesítőjeként mutatja be, egy vallásos áhítatban élő mintaasszonyt, aki az őt körülvevő viszontagságos körülmények ellenére is tisztességes marad, népéért és családjáért bármit kész feláldozni. A korábban már tárgyalt asszony-kép francói interpretációja hangsúlyos része az alkotásnak. A történet középpontjában egy testvérharc áll: a portugál trónkövetelő Alfonz Kasztília segítségével próbálja megszerezni a hatalmat, ezért testvére, Dionisio király Aragóniában keres szövetségest, majd feleségül akarja venni Izabellát. A lány apja, III. Péter nem akar beleegyezni a frigybe, de Izabella álmot lát, amelyben Isten a házasság megkötésére szólítja fel. Az új királyné egyenes jellemének és vallási buzgalmának köszönhetően a két portugál testvér is békét köt, hatására pedig Portugália egyházi szervezetei és rendjei a szegények és elnyomottak felé fordulnak. A későbbiekben újabb trónviszályok lépnek fel a királyi családon belül, de Izabella közbelépésével minden probléma megoldódik.

A megtörtént eseményeken alapuló film a spanyol szerepvállalást eltúlozza, Gil filmje szerint a portugál belső béke, valamint a szeretet és a szolidaritás elterjedése mind a szomszéd országból érkező királyné miatt történik.

A producer Cesáreo González a Szent királynét használta fel, hogy a spanyol filmgyártás nemzetközi piacokra léphessen. Mivel a Velencei Filmfesztivál akkoriban nem válogatott be spanyol filmeket, González személyesen utazott az olasz városba, táskájában a filmtekercsekkel, hogy meggyőzze a szervezőket, be kell mutatniuk az alkotást. A helyi kommunista körök ellenkampányba kezdtek, de a filmet végül mégis levetítették, és nagy

\footnotetext{
${ }^{540}$ González González, Luis Mariano: Fascismo, kitsch y cine histórico español. Cuenca, Universidad de Castilla-La Mancha, 2009.
} 
sikert aratott (annak ellenére, hogy a bemutatóra a kommunisták felvásároltak közel hatszáz belépőt, hogy megakadályozzák mások részvételét). Ezután az Egyesült Államokba repült, hogy beajánlja a filmet az Oscar-nevezésben illetékes bizottság tagjainak, de itt nem járt eredménnyel. Azonban a Szent királyné mellett tíz másik filmjét sikerült eladnia az amerikai kontinens huszonegy országának, beindítva ezzel a hazafias spanyol filmgyártás latin-amerikai expanzióját, valamint megkezdődtek a szerződéskötések, amelyek alapján hispán-amerikai filmcsillagok érkeztek Spanyolországba koprodukciók készítése céljából. ${ }^{541}$

\section{Szerelmi örület - Locura de amor}

A rezsim egyik legtöbbet foglalkoztatott rendezője Juan de Orduña ${ }^{542}$, egyik legkedveltebb színésznője pedig Aurora Bautista volt, négy filmben is együttmüködtek. A korabeli spanyol star system legfontosabb tagjai voltak, akik mellé a 40-es és 50-es években még több tucatnyian érkeztek. Legjelentősebb közös alkotásuk a Szerelmi örület (Locura de amor, 1948), amely a Katolikus Királyok lányát, Örült Johannát helyezi a középpontba, bemutatva a tébolyához vezető történéseket. A Cifesa égisze alatt készült, már a feliratokban is ,,szuperprodukció”-nak titulált film Johannát áldozatként festi le, aki az őt körülvevő világ manipulációiba és férje hütlenkedéseibe, majd annak halálába őrült bele. Johanna és Szép Fülöp története ebben a feldolgozásban egy romantikus szerelemi történet, amely a sors akaratából csak részben teljesülhet be. Johanna mentális leépülése akkor kezdődik, amikor értesül anyja, Izabella haláláról. Az udvari nemesek hatalmi játszmáinak részévé válik, hogy a főszereplő számára folyamatosan szállítják a híreket férje hütlenkedéseiről, még akkor is, amikor ő már nem akar hallani róluk. Ebbe az összeesküvésbe bekapcsolódik Fülöp egyik szeretője is, így a Spanyol Birodalom destabilizációjában érdekelt személyek közös „eredménye” lesz, hogy Johanna eszét veszti. A filmből nem derül ki egyértelműen, miért is áll érdekében a konspirálóknak a főhősnő őrületbe kergetése: csak jeleket, utalásokat kapunk arra, hogy egyesek külföldi hatalmak érdekeit szolgálják, mások a férjét, Fülöpöt akarják megszabadítani a felesége jelentette korlátoktól, megint mások egyszerűen csak szét akarják zilálni a birodalmat.

A szerelmi őrület a korszak legsikeresebb filmjének számított a spanyol közönség körében. A kritika akkoriban szintén elismerően nyilatkozott róla, azóta inkább túlzottan melodramatikusnak, giccsesnek titulálja. Valószínűleg éppen ez utóbbi tetszett a

\footnotetext{
${ }^{541}$ Taibo I, Paco Ignacio: Un cine para un imperio. Id. mü. 105-107.

${ }^{542}$ A diktatúra utolsó előtti évében egy interjúkötetben Orduña úgy nyilatkozott, hogy a rezsim során soha nem készíthetett olyan filmeket, amilyeneket szeretett volna. A Cifesa stúdió politikai és üzleti érdekei, valamint a cenzúra szigora szerinte nagy mértékben akadályozták a munkáját. Erről lásd: Castro, Antonio: El cine español en el banquillo. Id. mü. 301-302.
} 
közönségnek: olyan tálalásban került eléjük a nemzeti történelem egy darabja, amely a múltat kevésbé ismerök számára is élvezhető, melodrámai elemekkel füszerezve - az ilyen hollywoodi tradíciók alkalmazása jellemző Orduña és Luis Lucia filmjeire. Ebben az esetben a történelmi szál háttérbe szorult a magánéleti téma mögött.

Johanna, összhangban a Franco-rendszer nő-képével, az anyaországot, a spanyol hazát jeleníti meg; María Asunción Gómez elemzése szerint akik az ő vesztét akarják a filmben, azok jelképesen az egész spanyol nemzetet próbálják elpusztítani, a szálakat pedig külföldröl mozgatják. Ez a korszak ugyanis alapvető jelentőségü mind a későbbi spanyol királyság, mind a Franco-rendszer számára: ekkor dől el, hogy a spanyol nemzetállam milyen sorsra jut, a reconquista utáni periódusban megszületik-e az egységes Spanyolország. Johanna és az öt alakító Aurora Bautista feloldódnak egymás személyiségében, mindketten egy mitikus nőalakot jelenítenek meg, aki maga a spanyol nemzet megtestesülése. ${ }^{543}$

Santiago Juan-Navarro tanulmányában osztja az előző véleményt, Johannát ő is a francói spanyol nemzetfelfogás allegóriájaként értelmezi, és úgy véli, nem véletlen, hogy a Szerelmi örület 1947-ben készült (a bemutató 1948-ra csúszott): ugyanebben az évben fogadták el azt a törvényt, amelyben Spanyolország államformáját a monarchiában határozták meg, ahol Franco továbbra is államfő, utódja személyét pedig ő maga fogja kijelölni. JuanNavarro szerint ez a film részét képezte annak a propagandának, amellyel a társadalom számára pozitív képet akartak nyújtani a királyság intézményéről. A Johannát védelmező admirális, valamint a János Károly trónra lépését előkészítő Carrero Blanco figuráját párhuzamba állítja, mint a monarchia védelmezőit. Mindketten az integrista gondolkodás, a konzervatív-tradicionalista életszemlélet hívei, akik védeni igyekeztek hazájukat az idegen országokból érkező liberális hatásoktól. A filmben megjelenő királyok, Fülöp és Károly erőtlen személyiségek, a hatékony kormányzáshoz rászorulnak a politikában is jártas hadsereg támogatására. Továbbá, a szerző szintén hasonlóságot lát a Johannát a külföldi ármánykodások következtében megszálló betegség (az őrület) és a Franco által veszedelmes ragálynak nevezett ideológiai áramlatok (kommunizmus, szeparatizmus, szabadkőművesség, szekularizáció, politikai káosz) között. ${ }^{544}$

\footnotetext{
${ }^{543}$ Gómez, María Asunción: „Mujer, nación y deseo en Locura de amor de Juan de Orduña y Juana la Loca de Vicente Aranda" in: FilmHistoria Online. Vol. XVI, No. 1-2. 2006.

Elérhetö:

http://www.publicacions.ub.edu/bibliotecadigital/cinema/filmhistoria/2006/REVISTAS/Ensayo_MujerNacionDe seo\%20_1.htm (2012-12-04)

544 Juan-Navarro, Santiago: „La Madre Patria enajenada: Locura de amor, de Juan de Orduña, como alegoría nacional” in: Hispania, 88.1. 2005. 206-213.
} 
A filmről írt egyik ismertetőjében a francia Jean-Claude Seguin úgy véli, Johanna alakja a müben a teljes szétforgácsolódás veszélyét is felmutató kontinuitást fejezi ki két dicsőséges spanyol korszak, a Katolikus Királyok és I. (V.) Károly uralkodása között. Ha valóban bekövetkezne a bukás, akkor már Károlynak sem lenne esélye újra felemelni a nemzetet. Ez alapján Seguin párhuzamot von a filmben ábrázolt kor és a 20. századi Spanyolország között, amely szerinte a filmet készítők eredeti szándéka is volt, lévén ismét egy Cifesa produkcióról van szó: a Katolikus Királyok - Örült Johanna periódus a Primo de Rivera - Második Köztársaság időszakának analógiája, a Szép Fülöp - I. Károly ciklus pedig a polgárháború Franco-rendszer ,tükörképe”. ${ }^{545}$ Ugyanez a szerző hívja fel a figyelmet arra, hogy a képi beállítások, a dekoráció és a szereplők elhelyezkedése számos 15. és 16. századi festmény új környezetben történő megjelenítései, mintegy élő képek. ${ }^{546}$

Cenzori szempontból nézve az utókor számára érdekes találgatásokra adott okot a film. Mint a korábbiakban már számos példát hoztam rá, a spanyol és a külföldi alkotások esetében a bizottságok rendkívül aprólékosan szemügyre vették a bemutatásra szánt filmeket, és kivágattak minden olyan jelenetet vagy párbeszédet, amely szerintük az erkölcstelenségnek akár csak a leghalványabb szikráját is tartalmazta. Éppen ezért furcsállja Román Gubern, hogy a Szerelmi örületben benne maradhattak azok a jelenetek, amelyekben Johanna bebalzsamozza férje holttestét, majd gyengéd bánásmódban részesíti azt, és el sem mozdul mellőle, nehogy más nők hozzáérhessenek. Gubern szerint ${ }^{547}$ (és hatására azóta a filmes közbeszéd is így értékeli) a jelenetek még mai szemmel nézve is nekrofil vonásokat mutatnak, valószínűleg csak azért maradhattak benne, mert történelmi és hazafias tartalma miatt Orduña alkotása érinthetetlennek bizonyult. ${ }^{548}$

\section{A napóleoni korszak}

A Franco-rezsim ideológiai rendszerében minden, ami nem illeszkedik a dicsőséges nemzeti múlt kategóriájába, az elítélendő. A Napóleon ellen vívott spanyol függetlenségi háborút (1808-1814) kontextusként használó filmekben is megjelenik már az a két Spanyolország, amely majd a polgárháborúra is jellemző lesz: a francia hatás alatt álló és velük szimpatizáló spanyolok (afrancesados) hazaárulók, gyenge jellemek, a társadalom szégyenei, nemzetüket önös érdekből bármikor feláldoznák; velük szemben állnak a hazafiak,

\footnotetext{
${ }^{545}$ Seguin, Jean-Claude: „Locura de amor” in: Pérez Perucha, Julio (szerk.): Antología crítica del cine español. Id. mü. 230-232.

${ }^{546}$ Uo.

${ }^{547}$ Gubern, Román - Font, Doménec: Un cine para el cadalso. Id. mü. 57-58.

${ }^{548}$ A filmhez kapcsolódó cenzori jelentések valóban nem tartalmaznak semmilyen lényeges módosítási javaslatot. AGA, Cultura, 36/03331-es doboz, 08318-as köteg és 36/03336-os doboz, 08451-es köteg.
} 
akik az idegen hatalom ellen harcolnak. Egyik emblematikus film e témában a Lola, a faszénárus (Lola la Piconera, Luis Lucia, 1951), ahol megszálló, kegyetlen franciák törnek Spanyolországra, ám a nép hősiesen küzd ellenük. Ismerve az ország 20. századi történelmét, a filmben elhangzó mondatok árulásról, spanyolellenes spanyolokról teljes mértékben megfeleltethetőek az 1936-39-es polgárháborús viszonyoknak, mintha ugyanazt a háborút vinné vászonra a rendező, de 130 évvel korábbra datálva. Nem hiányozhat a filmből, jellemzően a korszak filmgyártására, a spanyol folklór elemeinek erőteljes jelenléte sem, valamint a szerelem és az ellenség általi megkísértés. A főszereplők egy része törvényen kívüli bandita (bandolero), de a spanyol haza érdekében cselekednek a megszállók ellen. Ez a film volt az utolsó alkotás a Cifesa stúdió palettáján, és már ez is könnyedebb hangvételü, zenei betétek alkalmazásával. Még hangsúlyosabb a két háború között vont párhuzam a nyolc évvel korábban készült, május 2 -ai ${ }^{549}$ eseményeket feldolgozó $A$ zászlóvivóben ( $E l$ abanderado, Eusebio Fernández Ardavín, 1943): a hazafias érzések és értékek folyamatos kiemelése, a mindent felülíró nacionalizmus, a „¡Viva España!” felkiáltások, a hazáért életuiket is feláldozó katonák, a nép hősies helytállása és a hazaszeretetet megtestesítő jelkép (itt: a hazát jelképező, a hadsereg számára az asszonyok által varrt nemzeti zászló mindhalálig tartó védelme) Franco Spanyolországának értékszemléletét tükrözik vissza. A főszerepben ismét Alfredo Mayo, a korabeli „,nemzeti” filmek állandó főszereplője. A folklorisztikus elemek itt nem találhatóak meg, de a szerelem és az árulás lehetősége igen. Az árulásnak pedig csak két lehetséges végkimenetele lehet: a bünöst kivégzik (mert megérdemli a halált), vagy jó útra tér és a hazafiak oldalára áll. Ez a szemlélet időnként még napjainkban is visszaköszön egyes filmekben. ${ }^{550}$

Hasonlóan egyértelmű a hazafias szólamok egyeduralma Juan de Orduña művében. A Cifesa stúdióban készült, igaz történeten alapuló film, a valódi személyről mintázott Aragóniai Agustina (Agustina de Aragón, Juan de Orduña, 1950) címszereplője egy bátor,

\footnotetext{
549 1808. május 2-án Madridban felkelés kezdődött a megszálló napóleoni csapatok ellen.

550 2008-ban a Madridi Közösség elnökasszonya, Esperanza Aguirre megbízást adott José Luis Garci filmrendezőnek, hogy a május 2-i felkelés kétszázadik évfordulója alkalmából készítsen egy filmet, mintegy tiszteletadásként. A Benito Pérez Galdós Episodios Nacionales címü müvét alapként használó Május vére (Sangre de Mayo, 2008) 15 millió eurós költségvetését a Madridi Közösség állta, szándékuk szerint az utóbbi évtizedek legnagyszabásúbb történelmi filmjét forgatták, valamint rögtön készítettek egy tévésorozat-változatot is. A végeredmény egy olyan mü lett, amely megosztotta mind a kritikusokat, mind a nézőket, sokak szerint túlfütött nacionalizmusával a Franco-korszak hivatalos filmjeivel volt rokonítható. A téma kezelése és a spanyol nemzeti érzés ábrázolása egyfajta „hipernacionalizmust” állított a nézők elé, akik erre már kevéssé voltak kíváncsiak, 2008 legdrágább produkciója az egyik legnagyobb bukást könyvelhette el. Bár a kormányzat és az alkotó is büszke volt a nagy veszteségeket termelő film mondanivalójára, a premier egy időre felszította Spanyolországban a nacionalizmus művészeteken keresztül történő megmutatkozásáról és a politikai megrendelésből közpénzen készült filmek létjogosultságáról szóló vitákat. A filmet támogatók és az azt ellenzők is harcias kampányba kezdtek, mindenekelőtt az interneten és napilapokban.
} 
hazaszerető asszony, aki Napóleon inváziója után az aragóniai csapatok segítségére siet, előbb hírvivőként, majd aktív harcosként a megszálló csapatok ellen vezeti népét Zaragoza ostromában. Bár a fegyvereseket a tisztek vezetik, a történet alapján Agustina hazafias viselkedésének és lelkesítő beszédeinek köszönhető, hogy az emberek nem adják fel, hanem még a betegek, a vakok és a gyerekek is életüket feláldozva harcba vonulnak hazájukért. Szakít a franciákkal lepaktáló szerelmével, aki, látva Agustina állhatatosságát és rendíthetetlen kitartását, végül mégis a saját népe mellé áll. A címszereplő nő ágyúval lő a franciákra, majd hőstetteiért VII. Ferdinánd is kitünteti, kinevezi a spanyol hadsereg tiszteletbeli alhadnagyává, és Spanyolország minden hősének jelképévé emeli.

Agustina hősies helytállásával szemben áll a franciákat és a velük kollaboráló spanyol arisztokrácia egy részét jellemző, már-már groteszkszerü gonoszság és jellemgyengeség. A korábban említett párhuzam itt is müködik, a francia katonákat hasonló módon ábrázolják, mint a polgárháborús filmekben a köztársaságiakat: kegyetlen, embertelen hordák, akik ártatlan civileket, gyerekeket és időseket gyilkolnak. A női főszereplő több alkalommal „gyávák, gyilkosok” felkiáltással fordul feléjük. A film felvonultatja a korabeli színészgárda legnevesebb alakjait, a címszerepben ismét Aurora Bautista. A jól megkoreografált, látványos csatajeleneteket, valamint több száz statisztát alkalmazó alkotás tökéletesen illeszkedett a Cifesa nagyköltségvetésű produkcióinak sorába. Bár a diktatúra filmcenzúrájának egyik alapelve volt, hogy a filmvásznon a meztelenség nem engedhető meg (sem az öncélú, sem az indokolt), ebben az esetben azonban két jelenetben is feltünik egy gyermekét szoptató anya fedetlen keble; valószínü, hogy az anyasághoz kapcsolódó természetes cselekedet miatt voltak megengedőek a cenzorok, mivel egyik jelentésben sem található erre utaló megjegyzés vagy észrevétel. ${ }^{551}$ A mü jól példázza a Franco-korszak egyik fö alapelvét, amely szerint az asszonyok a haza fennmaradásának letéteményesei, nem csak a lakóhelyen, a gyermeknevelésben és a férj támogatásában játszanak főszerepet, de aktívan részt is vesznek a harcokban. Ezeket az asszonyokat a korszak népszerü színésznői jelenítették meg, az említett Bautista mellett a filmekben általában flamenco énekest és táncost alakító Lola Flores is gyakran feltünt.

\footnotetext{
${ }^{551}$ AGA, Cultura, 36/03389-es doboz, 09973-as köteg és 36/03391-es doboz, 10031-es köteg.
} 


\section{Amerika hajnala - Alba de América}

A Faj mellett az Amerika hajnala (Alba de América, Juan de Orduña, 1951) jelenti a Hispán Kultúra Intézete filmes részlegének másik kiemelkedő darabját. ${ }^{552}$ Kolumbusz Kristóf életét mutatja be, a kolostori magánytól az Új Világba érkezéséig. A film válasz volt a brit Kolumbusz Kristófra (Christopher Columbus, David McDonald, 1948), amely Orduña szerint megalázta a spanyol népet és múltat azzal, hogy a Katolikus Királyokat nevetséges alakokként ábrázolta: Ferdinándot Kolumbusz fel is pofozza, Izabella pedig lenézi Spanyolországot és a felfedező utat is. ${ }^{553}$ A spanyol kormány is így gondolta ezt, Franco megbízására Carrero Blanco admirális vette kezébe a film előkészítését, a Hispán Kultúra Intézete pedig pályázatot hirdetett meg az „Amerika felfedezése” téma legtökéletesebb feldolgozására: az Intézet választja ki a forgatókönyvet, hagyja jóvá a rendező személyét és jelöli ki a film történelmi, katonai, egyházi és művészeti tanácsadóit. A forgatókönyv végül ideológiai szempontból olyan tökéletes lett, hogy ma szinte tényként kezelik az akkoriban szárnyra kelt pletykát, amely szerint maga Carrero Blanco írta azt. Minden más aspektusból azonban rendkívül alacsony színvonalúnak tartották azt a hozzáértők: lassan építkező, terjengős, szentimentális és rendkívül unalmas celluloidpazarlásnak. ${ }^{554}$ Rafael de España úgy értékeli a filmet, mint a spanyol gyarmatosítást övező fekete legenda elleni francói mozgóképes harc egyetlen darabját. $^{555}$

A Kolumbuszt útjára bocsátó Kasztíliai Izabella a spanyol nemzet Anyjaként jelenik meg, ő a kiindulópontja a hispán faj birodalomépítő terjeszkedésének. A film értelmezésében nem csak az egységes Spanyolország, hanem Latin-Amerika is a „hispán ősanya” nemzetépítő tevékenységének köszönhető. A felfedezőhöz intézett, pátosszal teli beszédében kifejti, a hit és a nyelv kapcsolja össze a régmúlt és a jelenkor Spanyolországát az új területekkel, ezáltal formálódik a Hispán Birodalom. Izabella a spanyol népről, vallásról, nyelvről, dicső múltról és nemzeti nagyságról szóló monológjaiban a Hispanidad szellemiségét idézi vissza, a francói propagandatézisek lényegretörő összegzései ezek. Míg Aragóniai Ferdinánd szkeptikusan fogadja Kolumbusz vállalkozását, addig Kasztíliai Izabella teljes szívvel támogatja azt; a

\footnotetext{
${ }^{552}$ A Fajt A Hispanidad Tanácsa készítette, ami a Hispán Kultúra Intézetének jogelődje, ezért a két szervezetet ebben az esetben egynek tekintem.

${ }^{553}$ Castro, Antonio: El cine español en el banquillo. Id. mü. 296.

${ }^{554}$ Fanés, Félix: Cifesa, la antorcha de los éxitos. Id. mü. 175-177.

${ }^{555}$ España, Rafael de: „El franquismo combate la <<leyenda negra〉>: Alba de América” in: Romero Campos, David: La Historia a través del cine. Memoria e historia en la España de la posguerra. Universidad del País Vasco, Servicio de Publicaciones, 2010. 65-89. A szerző elemzést ad Kolumbusz Kristóf életének és jellemének azon aspektusairól, amelyek alátámasztják, illetve megcáfolják a fekete legendát, és mindezeket bemutatja a nemzetközi filmmművészet Kolumbuszról szóló alkotásaiban.
} 
felfedezés tehát Kasztíliának köszönhető (támogatva ezzel a Franco-rezsim Kasztíliacentrizmusát). Bár történik utalás olasz származására, a konkvisztádor a filmben eggyé válik a spanyol nemzettel, ő maga is kifejti, hogy hazája már Kasztília. Granada visszahódítását Kolumbusz egy új kezdetként értékeli: Spanyolország már teljes, de a civilizált világ még nem, a távoli földek sokáig vártak arra, hogy egy király és egy zászló alatt egyesülhessenek. Isten Kasztíliát, közvetítőként pedig Kolumbuszt választotta, hogy kapcsolatba léphessen az ismeretlen vidékkel. Az új területek a szabadságért és keresztény hitre térítésért cserébe aranyat, gyöngyöket és füszereket adnak az őket megváltó Kasztíliai Birodalomnak. Ugyanakkor, bár a főszereplő többször is említi, hogy milyen gazdagság várja a felfedezőket az Újvilágban, a spanyolok minden alkalommal egyértelművé teszik: őket nem a kincsek, nem az anyagi dolgok vonzzák, kizárólag civilizációs és evangelizációs missziót akarnak teljesíteni. Később a felfedező is felismeri, hogy küldetésének legfőbb célja a lelkek védelme és a kereszténység terjesztése.

A hódítással párhuzamosan zajlik a visszahódítás: több látványos jelenetben a kasztíliai fegyveresek területeket foglalnak vissza a móroktól, egy ilyen hősies küzdelemben maga Kolumbusz is részt vesz.

A spanyolok Újvilágba érkezése a film szerint Isten akaratából történik, az expedíció legfőbb feladata és egyben érdeme, hogy civilizálja az ott élő barbárokat és terjessze a kereszténység tanait. Ezzel történelmi küldetését teljesíti a hispán nép. Az Amerika hajnalában két karaktert találunk csak, akik egyértelműen negatív színben tűnnek fel és útját akarják állni a hispán birodalom kiépülésének: egy mórokat segítő zsidó uzsorás és egy jellemtelen francia, akik rá akarják venni Kolumbuszt, hogy inkább nekik dolgozzon. A felfedező azonban csak a spanyol királyi párral hajlandó együttmüködni, mert szerinte egy ilyen rendkívüli küldetést kizárólag a kiemelkedő birodalom támogathat.

A filmben a kitűzött cél beteljesül, Kolumbusz eléri a távoli vidéket, küldetését siker koronázza. Orduña itt zárja le a történetet, így nem szembesíti nézőit az ezt követő eseményekkel, a föld kirablásával és az őslakosok leigázásával. Illeszkedve a Hispanidad elvéhez, Amerika felfedezésével civilizálás és evangelizáció történt, kizárólag pozitív eredményekkel. A szereplők kifejtik, testvérként bánnak az itt élő népekkel, és mindenkit egyesítenek egy közös vallás, egy közös nyelv és egy közös végzet nevében. A film egésze a Franco-rendszer által megfogalmazott hispán birodalmi akarat filmvászonra adaptálása, a nemzetikatolicizmus, a kasztíliai hagyományok és a hispán faj civilizáló és messianisztikus missziójának dicsérete. A filmelmélethez és filmelemzésekhez kevéssé értő nézők számára is egyértelmű lehet, hogy az 1492-ben játszódó film allegóriája a Franco-rendszer önmagáról 
alkotott és sugárzott képének. ${ }^{556}$ Kolumbusz a Caudillo számára hivatkozási alap is volt: 1948-ban a rábidai kolostorban, ahol a felfedező utolsó éjszakáját töltötte, mielőtt Palos de Moguerből útnak indult volna, Franco egy ünnepélyes ceremónia keretében önmagának adományozta a Kasztília admirálisa címet. Paul Preston szerint a tábornok ezzel is jelezte, hogy ő a 20. század Kolumbusza. ${ }^{557}$

A korabeli kritikák és a premierről tudósító cikkek megemlítették, hogy a film kiemelkedő politikai jelentőséggel bír, ugyanis bemutatja a Spanyolország és Latin-Amerika között fennálló szoros kapcsolat kiindulási pontját; arról azonban hallgattak, mi a véleményük a film tartalmi részéről. A film premierje után kitört botrányt, amely az akkori filmmüvészeti főigazgató lemondásához vezetett, egy másik fejezetben tárgyalom részletesen, mert az jobban meghatározta egy másik film sorsát. ${ }^{558}$ A közönséget azonban nem elsősorban ez a botrány tántorította el a filmtől, hanem az, hogy ráunt a történelmi eposzokra. Hatalmas anyagi bukást hozott a mü, és ez a Cifesa stúdiót is magával rántotta.

Négy évvel korábban a Suevia Films is elkészítette saját, amerikai expedícióval foglalkozó művét, a La Nao Capitanat (Florián Rey, 1947). A címben szereplő hajó útját, a fedélzeti kalandokat és szerelmi viszonyokat elmesélő film a 17. században játszódik, alapjául Ricardo Baroja regénye szolgált. Az Indiákon új életet kezdő spanyolok társadalmi körképet adnak a korabeli Spanyolországról, mindannyian Kasztília és a kereszténység nevében vállalkoznak az útra. Mindössze egyetlen negatív karaktert láthatunk, egy potyautasként rejtőzködő moriszkót, aki egy keresztény lány szerelmére vágyik. A hajó utasainak, minden osztálybeli különbségük ellenére, össze kell fogniuk, amikor kalóztámadás éri őket. A francói nemzetfelfogás tuikörképének is tekinthető az epizód: csak a kasztíliaiak egységével győzhető le az ellenség. Összességében egy kevéssé jelentős, indokolatlanul hosszú film lett az eredmény, amelyet a Cifesa papírmasé produkcióival ellentétben jórészt ismeretlen színészekkel és kis költségvetésből forgattak (a tengert egy pillanatra sem látni, a fedélzet egy stúdióban felállított díszlet).

\footnotetext{
556 Santiago Juan-Navarro az Amerika hajnaláról írott, részletes elemzéssel egybekötött tanulmányában alátámasztja ezt a jelenetek és a párbeszédek vizsgálatával. Lásd: Juan-Navarro, Santiago: „El cine como alegoría nacional: La construcción del estado franquista en Alba de América, de Juan de Orduña" in: FilmHistoria Online, Vol. XII, No. 1-2. 2002.

Elérés: http://www.publicacions.ub.edu/bibliotecadigital/cinema/filmhistoria/2002/AlbadeAmerica.htm (201211-29)

${ }^{557}$ Preston, Paul: Juan Carlos. Id. mü. 152.

558 Összegezve: a filmművészeti főigazgató nem engedte, hogy odaítéljék a filmnek a nemzeti érdek titulust, mert alacsony színvonalúnak találta az alkotást, helyette egy erőteljesen rendszerkritikus film kapta azt. Erről lásd részletesebben a „Barázdák” címü alfejezet utolsó bekezdéseit.
} 
Bár Amerika felfedezése és az Újvilággal való szoros kötelékek a francói történelemszemlélet gerincét alkották, mégis elenyésző számú film készült ilyen témában. Rafael de España hívja fel a figyelmet arra, hogy sem Cortés, sem Pizarro nem jelenik meg a korszak alkotásaiban, mindössze Vasco Núñez de Balboának szenteltek egyet, A Csendesóceán hóditóit (Los conquistadores del Pacífico, José María Elorrieta, 1963), azt is a nyitás periódusában és különösebb kritikai és nézői visszhang nélkül. A filmtörténész szerint ennek az lehetett a legfőbb oka, hogy a Franco-rendszer filmjeinek elsődleges külföldi piaca LatinAmerika volt, az ott élök pedig valószínüleg nem értettek egyet abban egyhangúlag, hogy kizárólag a spanyol missziós és hódító törekvéseknek köszönhető a jelenlegi hispán-amerikai civilizáció. Mivel a Hispanidad szellemisége éppen ezt hirdette, az ideológiai célokat (a Hispanidad elveinek elterjesztése) ez esetben alárendelték a gazdasági céloknak (minél nagyobb bevétel a spanyol filmek számára). ${ }^{559}$

$* * * * * * * * * * * * * * *$

A papírmasé filmek kora az 50-es évek közepén már leáldozóban volt, ennek okairól a Cifesa stúdiót tárgyaló alfejezetben részletesebben is szóltam. A szóban forgó évtizedben történt még néhány próbálkozás, amelyről nem mondható el, hogy teljes bukás lett volna, mérsékelt közönség- és kritikai sikert arattak, valamint egyre kevésbé volt érezhető rajtuk az az ideológiai töltet, ami az ebbe az almüfajba tartozó müveket korábban jellemezte. A II. Fülöp féltestvérét, Juan de Austriát középpontba állító Jeromín (Luis Lucia, 1953) még a birodalmi Spanyolországot éltető filmek sorozatába illeszkedik, míg a Hová mész, XII. Alfonz? (¿Dónde vas, Alfonso XII?, Luis César Amadori, 1958) és folytatása, a Hová mész, te szomorú ember? (¿Dónde vas, triste de ti?, Alfonso Balcazar, 1960) már inkább a romantikára, illetve a lélekrajzra helyezi a hangsúlyt, és egyéni drámaként mutatja be XII. Alfonz életét, szerelmeit és halálát.

Luis Mariano González González filmesztétikai elemzése, José Enrique Monterde tanulmánya ${ }^{560}$, az ezekben nem szereplő, de általunk idetartozónak vélt művek, valamint a nem a papírmasé kategóriába sorolható, de szintén történelmi témát feldolgozó alkotások alapján úgy vélem, a Franco-korszakban megközelítőleg 60 olyan történelmi film készült, ahol a cselekményválasztás és történetkezelés összhangban állt a rendszer ideológiájával.

\footnotetext{
${ }^{559}$ España, Rafael de: „El franquismo combate la <<leyenda negra >». Id. mü. 65-66.

${ }^{560}$ González González, Luis Mariano: Fascismo, kitsch y cine histórico español. Id. mü; Monterde, José Enrique: „Un modelo de reapropiación nacional” Id. mü.
} 


\section{A katolicizmus}

Az egyházi cenzúráról és a papság filmhez történő viszonyulásáról már esett szó a korábbiakban.

A korszak egyik legtöbbet foglalkoztatott forgatókönyvírója Vicente Escrivá, a vallási témájú filmek állandó résztvevője és az Aspa P.C. katolikus filmstúdió alapítója volt. Egy filmrendezőkkel foglalkozó lexikon így jellemezte őt és a korszak vallási vonatkozású filmjeit: „Ö az opportunista prototípusa, aki az éppen divatos témát használja fel, hogy a népszerü témából nyereséget kovácsoljon magának. Papokról, apácákról, csodákról és nemzetikatolicizmusról szóló filmjei a pszeudovallásos művek legvilágosabb fokmérői, melyek tele vannak hatásvadászattal és jó szándékkal, de nélkülözik a legminimálisabb mélységet is, kizárólag a jegypénztárakra koncentrálnak, a legszomorúbb és leggyengédebb szentimentalizmus mủvelői". ${ }^{561}$ A bensőséges hangvételű katolikus filmek írója a 70-es évektől erotikus filmekre specializálódik.

A Propagandisták Nemzeti Katolikus Szövetsége (Asociación Católica Nacional de Propagandistas - ACN de P) alkotta a rezsim legvallásosabb szekcióját, és meg volt róla győződve, hogy a kommunista fenyegetés és a társadalom szétforgácsolódása nagyon is létező veszély. Hasonlóan az aktív szerepet vállaló vallási szervezetekhez, számukra is kulcskérdés volt, hogy befolyásukat kiterjesszék minden kommunikációs eszközre, legyen az a sajtó, mozi, rádió vagy televízió. A társaság már a polgárháború alatt aktivizálódott, hogy a médiumok cenzúrázásával kivívhassák a lelkek feletti győzelmet, megkoronázva ezzel Franco csatatéri sikereit, majd a háború után elérkezett az idő, hogy „,a film erejét felhasználják Isten és a Haza szolgálatára”. ${ }^{562}$ Éppen ezért ők maguk kezdtek filmtervek anyagi támogatásába, mert fennállt a veszélye, hogy ,a külföldről országunkat elöntő filmáradat sohasem fogja országunk érzéseinek és szokásainak nyelvét beszélni”. ${ }^{563} \mathrm{Az}$ ACN de P és a Katolikus Akció (Acción Católica) más csoportosulásai így filmkészítő tevékenységbe kezdtek és felismerték, hogy gazdasági haszonra is szert tehetnek; ehhez kapcsolódóan határozatot is hoztak, hogy tehetősebb híveiket arra buzdítsák: fektessenek be tőkét, amellyel egy hatalmas nemzetikatolikus filmgyártó vállalat létrehozását támogatják. Az 1940-es évek második felében viszont nyilvánvalóvá vált számukra, hogy nem lesz egyszerü egy, a gyártástól a

\footnotetext{
${ }^{561}$ Pérez Gómez, Ángel A. - Martínez Montalbán, José L.: Cine español 1951-1978: diccionario de directores. Bilbao, Mensajero D.L., 1979. 74-75.

${ }^{562}$ Montero, Mercedes: „Cine para la cohesión social durante el primer franquismo” in: Pelaz, José-Vidal és Rueda, José Carlos (szerk.): Ver cine. Id. mü. 177-178.

${ }^{563}$ Uo. 180 .
} 
terjesztésig minden mozzanatot felölelő céget felépíteni, ezért inkább más vállalatokon keresztül igyekeztek érvényre juttatni befolyásukat. ${ }^{564}$ Az Aspa P.C. és az Ariel társaság szorosan kötődött a katolikus szervezetekhez, míg a Procusa, a Filmayer és az Exhibidores Unidos az Opus Dei irányítása alá tartozott. ${ }^{565} \mathrm{Az}$ 1956-ban alapított Valladolidi Vallási Filmhét (Semana de Cine Religioso de Valladolid) biztosította, hogy a szakmához és a nézőkhöz is eljussanak a hazai és a nemzetközi filmgyártás vallási darabjai. ${ }^{566}$

A katolicizmus szellemében fogant filmek egy része szentek és apostolok életét mutatja be, míg más csoportja a vallás és az egyház által jó útra terelt emberek történetét meséli el.

\section{Félnótás - Balarrasa}

Az Aspa P.C. katolikus filmstúdió első produkciója a Félnótás (Balarrasa, José Antonio Nieves Conde, 1950). A főszereplő Javier (becenevén Félnótás) napjait a polgárháborús harcok során leginkább a szórakozás, a szerencsejátékok és az élvhajhászat teszik ki. Egy este önmaga helyett egy társát küldi őrjáratba, akit halálos lövés ér, miközben Javier a társaival kártyázik. A Félnótás a történteket isteni figyelmeztetésként fogja fel, és ez megváltoztatja szemléletét, hozzáállását. Úgy dönt, hogy életét mostantól a világ és az emberiség megsegítésének szenteli, ezért a katolikus egyház kötelékébe lép és szeminaristának áll. Tanulmányai során a maximumra törekszik, szorgalmával és tudásával kiemelkedik a társai közül. Képzése végén mentora hazaküldi, hogy családja és barátai körében is próbálja meg elfogadtatni új életét, valamint szembenézzen a múltjával. Otthon egy ideig hitetlenkedve fogadják az új Javiert, aki segítségére siet a rászorulóknak és megpróbálja jó útra terelni a környezetét is. Saját családját is igyekszik megmenteni a romlástól, többek között illegális tevékenységbe keveredett testvéreit és szerencsejáték-függő édesapját. Nagyrészt ez sikerül is, kivéve egyik lánytestvérét, aki a karjai közt hal meg egy gyónás után. Miután elrendezi otthoni ügyeit, pappá szentelik; az ünnepi eseményen a film minden fontosabb, pozitív mellékszereplője megjelenik, kezet csókol Javiernek, aki korábban mindannyiuk életét jobbá tette valamilyen módon. A felszentelés után elbúcsúzik családjától, barátaitól és misszionáriusként külföldre megy. A film első és utolsó jelenete Alaszkában játszódik, ahol Javier egyházi szolgálatot teljesít, és egy fagyos vidéken reked; a cselekmény egy innen kiinduló visszaemlékezés. Az utolsó képen a főszereplő belenyugszik sorsába, felajánlja életét Istennek, és megbékélve várja a halált.

\footnotetext{
${ }^{564}$ Heredero, Carlos F.: Las huellas del tiempo. Id. mü. 78-82.

${ }^{565}$ López, Juan - Aramis, Enrique: „Religiosidad en el cine español en la década de los cincuenta” in: Zainak. Cuadernos de Antropología-Etnografía. No. 28. 2006. 314.

${ }_{566}$ Ma Valladolidi Nemzetközi Filmhét (Semana Internacional de Cine de Valladolid - SEMINCI) néven müködik nagy sikerrel.
} 
A Franco-rezsim számára a hadsereg és a katolikus egyház két alapvető intézmény volt, a diktatúra tartópillérei. Előbbi fegyveres, utóbbi lelki-erkölcsi szempontból legitimálta az új Spanyolországot. A Vicente Escrivá forgatókönyve alapján készült film a két témát vegyíti, bemutatja, hogy a két szervezet között könnyü az átjárás, aki a polgárháborúban a „nemzetiek” oldalán harcolt, békeidőben az egyház szolgálatában fejtheti ki hazafias tevékenységét. A spanyol társadalom tisztelettel és bizalommal viseltetett a papok iránt: Javier új életét és tevékenységét - az első meglepődés után - támogatással fogadja környezete, régi harcostársai is segítik öt elérendő céljai megvalósításában. Ahogyan a katolikus témájú filmekben általában, a vallás mellett itt is lényeges szerepet játszik egy másik elem, a család, mint a legalapvetőbb, legfontosabb értelme a létezésnek. Javier testvérei továbbra is azt az életmódot folytatják, amit régebben ő, ezért a címszereplő morális és családi kötelességének érzi, hogy megváltoztassa az életüket.

A Félnótásban megjelenik egy olyan téma is, amely nem volt gyakori a rezsim ideológiai filmgyártásában: a bünözés. A negatív szereplő, Santos illegális üzelmeihez a föhős testvéreit használja, cserébe anyagilag támogatja a családot. A főszereplő az ellene folytatott harcban, bár többször is lehetősége nyílna rá, nem alkalmaz közvetlen erőszakot, mindent a hite szerint old meg - ez azonban nem tartja vissza attól, hogy trükkökkel, esetleg más személyek által alkalmazott erőszakkal rendezze a helyzetet. A film indoklást talál arra, hogy a katolikus erkölcs és a szükséges nyers erő között megtalálja a középutat, mert - a mü érvelése szerint - a társadalom bizonyos szegmenseiben még jelen van a romlottság, ez ellen pedig fel kell venni a harcot, bármilyen eszköz is szükséges hozzá. Matt Losada tanulmánya szerint a Félnótás ezzel intézményesíti az állam által alkalmazott katolikus erőszakot. ${ }^{567}$ Nieves Conde, bár a rezsim rendezőjének tartják, a Félnótásban és az 1951-es (általam egy külön alfejezetben tárgyalt) Barázdákban is bemutatja, hogy a francói társadalom nem tökéletes. Előbbi filmjében a vallás és az erkölcs még részleges megoldást hoz, utóbbiban már rendkívül negatív és pesszimista az összkép.

\section{Fátima asszonya - La Señora de Fátima}

A Fátima asszonya (La Señora de Fátima, Rafael Gil, 1951) szintén az Aspa P.C. gondozásában született: a Fatimai Szűz 1917-ben megjelenik egy portugál falu három lakosa előtt és intelmeket intéz hozzájuk. Bár megígérik, hogy senkinek sem szólnak erről, mégis mesélnek a jelenésről. A lakók nem hisznek nekik, a kommunista-szimpátiájú

\footnotetext{
567 Losada, Matt: „The Rebranding of Francoism's Originary Violence in José Antonio Nieves Conde's Balarrasa" in: Romance Notes, Vol. 51, No. 2. 2011. 247-265.
} 
képviselőtestület perbe fogja őket, kiközösítik és bántalmazzák is a szélhámosnak vélt fiatalokat. Portugália-szerte híre megy a történteknek, majd a Szűz az általa megígért napon újra megjelenik, ezúttal már több ezer ember szeme láttára, hogy csodákat tegyen. Az áldásnak így mindenki részesévé válhat.

Bár elsősorban vallási filmről van szó, a történetben megjelenik a fennálló ideológia egy másik eleme is: a megjelenő Szűz a film egy pontján kijelenti, hogy a Földön terjedő gonoszságért Oroszország a felelős, feltett szándéka, hogy elpusztítsa a katolikus vallást; utóbbi egyik földi célja Oroszország megtérítése kell legyen. A városvezetés azért akarja minden eszközzel elhallgattatni a fiatalokat, mert szerinte a csoda híre gátolja a marxizmus terjedését.

Rafael Gil filmjével nemzetközi tendenciához csatlakozott, a lourdes-i jelenés a filmművészet több alkotóját is megihlette a 40-es és 50-es években. A Fátima asszonya cselekményvezetésében számos hasonlóságot mutat a közel tíz évvel korábban bemutatott amerikai Bernadette dalával (The Song of Bernadette, Henry King, 1943), majd - szintén az Egyesült Államokban - egy évvel később elkészítették a Miasszonyunk Fatima csodáját (The Miracle of Our Lady Fatima, John Brahm, 1952); ezek közül King változata bekerült a nemzetközi filmtörténet kiemelkedő darabjai közé is, de Brahm filmjét az utókor kevésbé tartja számon, Gil művére pedig elsősorban Spanyolországban emlékeznek.

Hat évvel később Luis García Berlanga elkészíti hasonló témájú filmjét, Csütörtöki csodák (Los jueves, milagro, 1957) címmel, ami részben azonos alaphelyzetet vázol fel, de szatirikus hangvétellel. A cenzúra drasztikus változtatásokra kényszerítette a rendezőt a vallásról és a csodákról szóló párbeszédekben ${ }^{568}$, a forgatáson a vallási téma miatt állandóan jelen lévő pap-cenzor közel kétszáz oldalnyi megjegyzést füzött az eredeti forgatókönyvhöz, végül pedig Berlanga engedélye nélkül az Opus Dei egyik rendezője, Jorge Grau kivágott és megváltoztatott számos jelenetet. ${ }^{569}$ Bár a film cselekménye a sok beavatkozás miatt zavaros lett, Berlanga pedig szívből gyülölte a kész alkotást, a végeredményből még most is egyértelműen látszik, hogy a film célja az egyház, a vallás és a fanatizált társadalom kritizálása, kifigurázása volt.

\section{Marcelino, kenyér és bor - Marcelino pan y vino}

Vajda László (Ladislao Vajda) filmrendező egy viszonylag sikeres magyarországi karrier után előbb Olaszországban, majd Spanyolországban próbált a helyi filmgyártás

\footnotetext{
${ }^{568}$ AGA, Cultura, 36/03593-as doboz, 15750-es köteg.

${ }^{569}$ Gómez Rufo, Antonio: Berlanga. Confidencias de un cineasta, Madrid, Ediciones JC, 2000. 76.
} 
részesévé válni ${ }^{570}$; utóbbi esetben mindezt sikerrel tette, 1952-ben megkapta a Katolikus Izabella Rend kitüntetését, 1954-ben pedig a spanyol állampolgárságot is. Ettől kezdve Vajdát már nem Spanyolországban dolgozó magyar emigráns filmrendezőként tartják számon, hanem spanyol alkotóként. Húsz filmet forgatott Spanyolországban, néhányat ezek közül koprodukcióban más országokkal. Kezdetben olyan projekteket kapott, melyek tematikája sok hasonlóságot mutatott a magyar munkáival. A későbbiekben több müfajban is kipróbálta magát, a melodrámáktól egészen a bünügyi filmekig, és gyakran müködött együtt két másik Spanyolországban dolgozó magyar emigránssal, Gerely Fülöp producerrel és László András forgatókönyvíróval. Az 1950-es évek elejéig készült müveiben kitapintható az olasz neorealizmus és más európai filmes áramlatok hatása.

Sohasem készített nyíltan propagandisztikus célokat szolgáló filmet, de megpróbált illeszkedni a fő témákhoz. Leghivatalosabb, „leghazafiasabb” filmje a Spanyol körút (Ronda española, 1952), amely a Falange Női Szekciója kórus- és tánccsoportjának egy utazását mutatja be játékfilmes keretek között; kapcsolódási pontja Vajda filmjének az ideológiához az a történetszál, amelyben a külföldi ügynökök által irányított emigráns sejtek bombamerényletet terveznek a Női Szekció előadása idejére. A rendező, bár filmjének forgatókönyvírói Falange-szimpatizánsok voltak, kerüli annak említését, hogy kommunisták lennének a merénylők vagy azok felbujtói.

Karrierjének csúcspontjához 1955-ben ért a Marcelino, kenyér és borral (Marcelino pan $y$ vino, 1955). ${ }^{571}$ A film kivételt képez Vajda addigi filmjeivel szemben, ez ugyanis egy több szempontból is kiemelkedő darab, messze nem csak igazodás a hasonló zsánerü filmekhez, vagy a közkedvelt témák ismételgetése, másolása (ami Vajdánál előfordult korábban és a későbbiekben is). Kapcsolódik a gyermekfilm vonulatához, amely akkoriban nagy népszerüségre tett szert, a vallási téma pedig az egész történetet átöleli. Ezek nem gyermekeknek szóló mủvek voltak, hanem az egész család számára kikapcsolódást nyújtó munkák, amelyek végkifejlete általában morálisan igazolható. Egyfajta példabeszédek a hispán ember „jóságáról” és a gyermeki ártatlanságról. A főszerepben mindig egy csodagyerek (niño prodigio), aki általában angyali hangon énekel (ez alól éppen Marcelino a kivétel), a zenei betétek a cselekmény szerves részeivé válnak. Vajda ezt a müfajt teremtette

\footnotetext{
570 A Spanyolországba érkezett magyar filmesekröl ad összegzést: Anderle Ádám: A magyar-spanyol kapcsolatok ezer éve. Id. mü. 135-136.

Vajda László nemzetközi karrierjéről magyar nyelven lásd: Lénárt András: „Mussolini ellensége, Franco kegyeltje. Vajda László" in: Ferwagner Péter Ákos - Kalmár Zoltán (szerk.): Az átmenet egyensúlya. Budapest, Áron Kiadó, 2010. 92-99.

571 A filmről magyar nyelven lásd: Lénárt András: „Spanyol-magyar katolicizmus a filmvásznon” in: Egyházfórum, 2010/6, 25-26.
} 
újjá a szóban forgó darabbal. Címszereplővé megtette Pablito Calvót, aki Marcelino megformálásával szupersztár lett Spanyolországban, még évekig hasonló munkákban tünt fel. Minden adott volt ahhoz, hogy a film hatalmas sikert arasson, és ez be is következett: nemcsak Spanyolországban váltotta be a hozzá füzött reményeket, de ez lett a korszak külföldön is legnépszerübb spanyol filmje. Spanyolországban ez a siker tette Vajdát az egyik elsőszámú rendezővé, a Marcelino... pedig ma is minden generáció által ismert alkotás, mindenekelőtt az idősebb korosztály számára, amely ma is meghatározó filmélményeként tartja számon.

Egy 1952-ben íródott könyvet alapul véve, valamint már a középkorban is ismert történetek és legendák vegyítésével született meg a film. Egy kasztíliai kolostorban élő szerzetesrend befogadja a csecsemő korában magára hagyott Marcelinót. A papok nevelik fel, igyekeznek megválaszolni az élet legfontosabb kérdéseit, és közben akarva-akaratlanul asszisztálnak gyermeki csínytevéseihez is. A kisfiú azonban felcseperedve szeretne többet tudni származásáról, a legnagyobb vágya, hogy megismerje édesanyját. Az egyháziak tiltása ellenére felmegy a padlásra, ahol egy olyan Krisztus-szoborra talál, amely életre kel. Az Úr fia kapcsolatba lép Marcelinóval, ismétlődő beszélgetéseik során Jézus örökérvényü bölcsességekkel ajándékozza meg a fiút, ő pedig ezt azzal viszonozza, hogy titokban kenyeret és bort visz neki. A gyermek vágya, hogy halott édesanyjával találkozzon. Krisztus, hálából Marcelino jóságáért, teljesíti a kérést: magával viszi őt az édesanyjához a Mennybe. A szerzetesek ezzel akkor szembesülnek, amikor rátalálnak Marcelino élettelen testére a szobor mellett.

Az árva gyermek témája állandó jelenléttel bír a klasszikus irodalomban. Szülők nélkül saját identitásának megkérdőjelezésére van kárhoztatva, a tradicionális társadalmi alapegységen (család) kívül rekedt, így valakinek gondoskodnia kell róla. Igazodva a korabeli francói felfogáshoz, természetszerüleg lép a képbe az egyház. A katolikus eszményképhez és a spanyol politikai hatalom felfogásához is maradéktalanul igazodnak Vajda filmjének főbb üzenetei, melyek akár a film kulcsfogalmaiként is megfogalmazhatóak: gyermeki ártatlanság, a katolikus egyház kegye, isteni beavatkozás az ember életébe, az anyai szeretetre való sóvárgás. A kisfiú olyannyira megszállottja a szülő iránti vágynak, hogy Krisztus teremtőjével is meg akar ismerkedni. A szobor megelevenedésével Marcelino Istennel is kapcsolatba kerül, isteni csodaként értelmezhető, hogy a keresztre feszített szobor kommunikálni kezd egy halandóval, valamint magával viszi lelkét a Túlvilágra. A „szobor” és a gyermek viszonya előbb barátivá, majd családiassá válik, Krisztusban Marcelino egy számára addig ismeretlen apafigurára lel. 
A későbbiekben Pablito Calvóval még két filmben müködött együtt a rendezö: $A$ torreádor / Jacinto bácsikám (Mi tío Jacinto, 1956) ${ }^{572}$ és az Egy angyal szállt le Brooklynban (Un ángel pasó por Brooklyn, 1957) Olaszországgal készült koprodukciók. Marcelino hatása, hogy ellepték a spanyol vásznakat az olyan gyermeksztárok (Pablito mellett Joselito, Marisol, Sara Montiel), akik ábrázolásuk szerint tiszta lelkűek, ártatlanok, angyali hangon énekelnek, és az egész társadalom rajonghat értük. Általában árvák vagy számkivetettek, szegény sorból származnak, de a katolikus vallás, az egyház és a (saját vagy örökbefogadó) család révén elnyerik méltó jutalmukat.

$* * * * * * * * * * * * * * *$

Az Aspa P.C. további produkciói központi témája szintén a vallás, a szentek élete és a csodás jelenések, az 50-es évek folyamán ezek a filmek adták a legnépszerűbb vallási történeteket. A stúdió és a forgatókönyvíró (Vicente Escrivá) mellett közös elem a film rendezője (Rafael Gil) is. Ilyen volt az Isten és a kiszolgáltatottak megsegítése érdekében énekesnői karrierjét feláldozó, élete végéig apácaként szolgáló Rettenthetetlen nővér (Sor Intrépida, Rafael Gil, 1952) címszereplőjének bemutatása, a vidéki bányászokat ért igazságtalanságok ellen fellépő papról szóló Isten háborúja (La guerra de Dios, Rafael Gil, 1953) és a Jézus történetét Júdás szemszögéböl elmesélő, egyetlen nyíltan antiszemita alkotásként értékelhető Júdás csókja (El beso de Judas, Rafael Gil, 1954). Más katolikus szellemiséget képviselő stúdiók műhelyéből került ki az 1939-ben a köztársasági zónában kivégzett és ezzel mártírrá vált terueli püspök halálát megfilmesítő Közel az éghez (Cerca del cielo, Domingo Viladomat, Mariano Pombo, 1952), a mexikói gyermekkórus spanyolországi utazásáról és santiagói zarándoklatáról szóló A dicsőség csarnoka (El pórtico de la gloria, Rafael J Silva, 1953) vagy a madridi lakosok és a Három Királyok találkozását bemutató fantázia, A béke hírnökei (Mensajeros de paz, José María Elorrieta, 1957). Több katolikus tematikájú film besorolható más kategóriába is, mint a már említett Hajnalhasadás vagy A végtelen front: előbbiben a kommunista Magyarországon kerül életveszélybe, valamint hitéleti és lelkiismereti válságba egy pap, utóbbiban egy lelkész a háborús időket próbálja meg túlélni. Az általam ismert filmek, valamint López Juan felsorolása ${ }^{573}$ alapján úgy becsülöm, 1942 és 1962 között közel ötven olyan film készült Spanyolországban, amelynek központi története vagy egy fontos szála vallási témát érint.

\footnotetext{
572 Magyarországon két címen ismert.

${ }^{573}$ A szerző a vallási filmeket a karizma és lelkiség szempontjából vizsgálja: Aramis Enrique López Juan: „Religiosidad en el cine español en la década de los cincuenta” Id. mü.
} 


\section{Ellenzéki reakciók}

Az 50-es évek közepétől egyre nagyobb számban jelentek meg a rendszerrel elégedetlen társadalmi csoportok, akik korábban csak nem hivatalos fórumokon osztották meg nézeteiket a társadalommal, most azonban már nyíltan kiálltak véleményük mellett. Összefoglalóan elmondható, hogy mindenekelőtt a munkások, az egyetemi diákság, a lakóközösségek, a szolidaritási szervezetek, a pacifisták és a feministák szerveztek tiltakozó mozgalmakat a nagyvárosokban; ezek közül az első kettő keltett nagyobb visszhangot belföldön és külföldön egyaránt. A 40-es évek végétől állandó témává vált a filmesek között az elégedetlenség: újságcikkekben, konferenciákon nyilvánították ki nemtetszésüket a spanyol filmgyártás jelenlegi állapotával kapcsolatban. Leghangosabb szószólójuk, a nyíltan kommunista nézeteket valló Juan Antonio Bardem megvetett mindent, ami a korabeli spanyol filmmüvészetre jellemző, cikksorozatban ostorozta a hatalmat és az azzal együttmüködő, illetve ellene semmit sem tevő filmeseket, követelte a cenzúra és a kötelező szinkron eltörlését, nemzetellenesnek nevezte az aktuális nemzeti filmet, és ajánlásokat tett a filmgyártás megújítása érdekében. Véleményét és cikkeinek konklúzióit összefoglaló általános elemzése ${ }^{574}$ adta meg az alapot az 1955-ben a Salamancai Egyetem filmklubja szervezésében megrendezett Salamancai Beszélgetéseknek, ahol a filmvilág és a filmpolitika kiemelkedő alakjai, a rezsim emberei is részt vettek, többek között a volt és egyben jövendőbeli filmmüvészeti főigazgató, José María García Escudero. Bardem elhíresült kijelentésével a többség egyetértett:

„a spanyol film politikailag hatástalan, társadalmilag hamis, iparilag angolkóros, intellektuálisan igen csekély értékü, esztétikailag értéktelen."

A pillanatnyi állapotot fenntarthatatlannak ítélték, pozitív változásokat követeltek. Bardem azt is hozzátette, hogy a spanyol filmnek külföldi példákat figyelembe véve kell megújulnia: a szovjet filmgyártás, az olasz neorealizmus, a francia intellektuális filmkészítés és néhány amerikai kívülálló, mint Charles Chaplin legyenek a referenciapontok. ${ }^{576} \mathrm{~A}$ konferencia nagy érdeme, hogy először a rezsim történetében egy közös ügy (filmgyártás) miatt összeült, és hatalmas sajtóvisszhang mellett, nyilvánosan vitázott egymással minden

\footnotetext{
${ }^{574}$ Bardem, Juan Antonio: „Informe sobre la situación actual de nuestra cinematografía” in: Objetivo, No. 6. 1955. június. 7-8.

${ }^{575}$ A kijelentést szinte minden spanyol filmtörténettel foglalkozó mű megemlíti, magyarra is lefordították egy cikkben: Todero Frigyes: „Furkósbot és mézesmadzag” Id. mü. 28. Magam is Todero fordítását használom.

${ }^{576}$ Cerón Gómez, Juan Francisco: El cine de Juan Antonio Bardem. Id. mü. 50-51.
} 
politikai oldalhoz tartozó filmmủvész. Többen állítják, hogy a Franco-rendszerben ez volt az első kongresszus, ahol a megnyitón nem hangzott el a Caudillót dicsőítő hivatalos felszólalás, és abban is első, hogy a diktatúra ellen állást foglaló személyek nyíltan kifejthették véleményüket. ${ }^{577} \mathrm{~A}$ beszélgetések eredményeit García Escudero részben hasznosítani tudta politikájában, de évtizedekkel később többen is úgy értékelték, Salamancában túlságosan is kritikusan fogalmaztak, indokolatlan volt elítélni a teljes filmszakmát. ${ }^{578}$

Az IIEC utódjának számító Hivatalos Filmiskolában (Escuela Oficial de Cine - EOC) oktatók és diákok szinte mindannyian a fennálló rendszer ellen foglaltak állást, müködésüket azonban nem korlátozták. Ennek legfőbb oka az lehetett, hogy a rezsim a legkisebb rosszként fogta fel létezésüket: amíg nemtetszésüket tanórákon, előadásokon és kísérleti filmeken keresztül fejezik ki, addig legalább nem mennek az utcára tiltakozni. A résztvevők szerint ők szervezték meg a második hivatalos sztrájkot is a Franco-diktatúra történetében (az első az 1951-es barcelonai villamossztrájk volt). ${ }^{579}$

A beszélgetések egyik résztvevőjével, Juan Antonio Bardemmel kapcsolatos az egyik nagy visszhangot keltett nemzetközi Franco-ellenes tiltakozás is. A Fö utca (Calle Mayor, 1956) forgatása közben a rendezőt 1956. február 11-én letartóztatták Palenciában, és egy madridi fegyházba vitték, mintegy reakcióként a két nappal korábban a Madridi Egyetemen kirobbant incidensre, amely halálos áldozattal is járt. Bardem bủne az volt, hogy szabadon véleményt nyilvánított az ügyben, ezen felül köztudott volt kommunista-szimpátiája is. Az

\footnotetext{
${ }^{577}$ Lásd a Basilio Martín Patino filmrendezővel készült beszélgetést: Julián, Óscar de (szerk.): De Salamanca a ninguna parte. Diálogos sobre el Nuevo Cine Español. Salamanca, Junta de Castilla y León, 2002. 18-19.

${ }^{578}$ Erröl lásd az alábbi kötetet, ahol a Salamancai Beszélgetések negyvenedik évfordulója alkalmából több résztvevő (többek között José María García Escudero, Juan Antonio Bardem, Basilio Martín Patino) visszatekint a konferenciára és annak következményeire: Conesa, Maite (szerk.): El cine español, desde Salamanca (1955/1995). Salamanca, Junta de Castilla y León, 1995. Pérez Bastías és Barahona tényszerü adatokkal és konkrét filmekre való hivatkozással is megcáfolják Bardem és társai állításait: Pérez Bastías, Luis - Alonso Barahona, Fernando: Las mentiras sobre el cine español. Id. mü. 15-25.

Luis García Berlanga filmrendező nem csak kritikával illette, de meg is bánta az ott elhangzott dolgok egy részét. Mindenekelött azzal nem értett egyet utólag, hogy az összegyült filmesek az akkori spanyol filmgyártás teljes egészét elítélendőnek tartották, az azt kiszolgáló infrastruktúra „eltemetésére” és a teljes spanyol filmmüvészeti tradíció újragondolására szólítottak fel. Bardem és a résztvevők többsége megvetette a Francorendszer hű kiszolgálójának tartott Cifesa stúdiót, holott Berlanga szerint éppen ez rendelkezett megfelelő technikai és személyzeti háttérrel ahhoz, hogy a spanyol filmművészet értékeset tudjon alkotni. Másik tévedésnek Berlanga az olasz neorealizmushoz való fordulást tarja. Nem tagadja, hogy Zavattini, de Sica, és Rossellini nagy hatással voltak az akkori spanyol filmes nemzedékre, viszont Berlanga szerint, ami müködött Olaszországban (utcán forgatott felvételek a stúdiók mesterséges környezete helyett), azt nem kellett volna Spanyolországban is alkalmazni. Mégis kimentek a spanyol filmesek az utcára, és hagyták, hogy a viszonylag profi eszközökkel rendelkező filmstúdiók tönkremenjenek. Azt is szemére veti Berlanga a kongresszus résztvevőinek, hogy kizárólag a fiatal filmesekre koncentráltak, nekik akartak lehetőségeket és támogatást szervezni, pedig egy ország filmművészetét minden pillanatban több generáció együttes jelenléte és müködése formálja. Erről lásd: Gómez Rufo, Antonio: Berlanga. Contra el poder y la gloria. Madrid, Ediciones Temas de Hoy, 1990. 161-170.

${ }_{579}$ Mario Camus, José Luis Borau és Basilio Martín Patino filmrendezők, a Salamancai Beszélgetések résztvevőinek véleménye: Julián, Óscar de (szerk.): De Salamanca a ninguna parte. Id. mü. 31-34.
} 
európai, mindenekelőtt a francia és az olasz értelmiség és művészvilág nemzetközi tiltakozó megmozdulásokat és sajtókampányokat szervezett az akkorra már világszerte elismert alkotó szabadon bocsátásáért, a főszereplő Betsy Blair ${ }^{580}$ pedig megtagadta, hogy más rendezővel folytassák a munkát. Bardem a diktatúra hivatalosan nem létező ellenzékének szimbólumává vált Európában, és minden jel arra mutat, hogy a rezsim meghátrált: két hét múlva indoklás nélkül ejtették ellene a vádakat. ${ }^{581}$

1960-ban felállt a Spanyol Filmrendezők Szakszervezeti Tömörülése (Agrupación Sindical de Directores-Realizadores Españoles de Cinematografía - ASDREC), amely a hivatalos SNE filmes szakszervezettől függetlenül müködött, de a tagok kettős tagsággal rendelkeztek (mivel a SNE-be kötelező volt belépni). Az elkövetkezendő években folyamatosak voltak a belső, politikai indíttatású harcok az ASDREC-en belül. ${ }^{582}$

A rendszerrel egyet nem értő, önmagukat disszidens filmeseknek nevező csoport a diktatúra keretein belül emelte fel a szavát a hatalom ellen. Elsősorban a dráma és a szatíra müfaja látszott a legalkalmasabbnak arra, hogy filmnyelvi eszközökkel mondják el azt, amit más módon, mindenekelőtt a politikai helyzet miatt, nem tudtak megtenni. A spanyol filmesek az 1950-es évektől kezdődően egyre inkább elmerültek az ilyen típusú rendszerkritikákban, a cenzorok pedig igyekeztek támadási felületet keresni. A szigor azonban valamelyest enyhült a 40-es évekhez képest, mert azt hitték, optimálisan müködik már az öncenzúra az alkotóknál. Az ilyen filmek egy részét a hatalom is támogatta, mert eleinte nem talált bennük kivetnivalót, vagy úgy érezték, a megfelelő cenzúrával kordában tartható ez a folyamat. Többször is előfordult azonban, hogy igen nagy botrányt váltott ki egyik-másik alkotás a felsőbb körökben, és felmerült a totális betiltás lehetősége is, de a nemzetközi nyomás hatására mégsem tehették ezt meg, mert egy nyitottabbnak, demokratikusabbnak mutatkozó ország nem tüntethetett el nyomtalanul olyan müvészeti produktumokat, amelyek világszerte nagy visszhangot keltettek. Így történhetett, hogy a legkiemelkedőbb, államilag is támogatott filmek sok esetben éles társadalom- és rendszerkritikát fogalmaztak meg. ${ }^{583}$

\footnotetext{
580 Betsy Blair kommunista-szimpátiája ismert volt világszerte, Hollywoodban feketelistára is került baloldali megnyilvánulásai miatt, ezért az 50-es évek második felétől döntően európai filmekben dolgozott. A spanyol rezsim a színésznő politikai nézetei ellenére megengedte, hogy Bardem foglalkoztassa, mert a külföldi színészek szerepeltetése növelte az esélyét annak, hogy a filmet külföldre is el tudják adni. Így lett a Calabuch (Luis García Berlanga, 1956) föszereplöje a brit Edmund Gwenn, illetve A hóhér (El verdugo, Luis García Berlanga, 1963) föhőse az olasz Nino Manfredi.

${ }^{581}$ Cerón Gómez, Juan Francisco: El cine de Juan Antonio Bardem. Id. mü. 136-137.

${ }^{582}$ Bardem, Juan Antonio: $Y$ todavía sigue. Id. mü. 149-157.

${ }^{583}$ Az 50-es évek második felétől kezdve a spanyol filmmüvészet szempontjából kiemelkedő alkotások születtek. Központi témámhoz, a Franco-rendszer ideológiáját tükröző filmpolitikához azonban nem kapcsolódnak szervesen, ezért nem szólok róluk részletesen, csak a legfontosabb címeket említem: Egy biciklista halála (Muerte de un ciclista, Juan Antonio Bardem, 1955), Fö utca (Calle Mayor, Juan Antonio Bardem, 1956), A
} 
Az alábbiakban két olyan filmről szólok, amelyek az ilyen problémás kategóriába tartoznak, egyszersmind az 50-es évek spanyol filmmüvészetének mesteri darabjai is.

\section{Barázdák - Surcos}

Az 1951-ben mozikba került Barázdák (Surcos, José Antonio Nieves Conde) a társadalmi dráma müfajába sorolható, és a rendszerellenesnek mondható filmek talán első és legkifejezőbb példáját ismerhetjük fel benne. Valamint hozzá füződik a rezsim egyik, korábban már többször említett, legnagyobb filmes botránya is. Annak az általános, filmszakmai körökben, valamint helyenként még a vezetés szintjén is megjelenő vágynak a terméke, hogy a spanyol film újat mutasson, kapcsolódjon az Olaszországból kiindult európai neorealista áramlatokhoz. A filmművészek számára ugyanis egyre inkább fojtogatóvá vált a légkör, a cenzúra által beszűkített önkifejezési módok, és szerettek volna olyan darabokat létrehozni, ahol a jelenkor Spanyolországának társadalmát reálisan mutathatják be, méghozzá széles körü közönség előtt. Mind a Filmművészeti Cenzúra Legfelsőbb Juntája, mind a mozgóképes és más kulturális ügyeket is hatáskörükbe vonó minisztériumok és szakosztályok adósak maradtak egy olyan normarendszer kidolgozásával, amely egyértelmüen megszabta volna, mit szabad és mit nem. A bátrabb rendezők és producerek tehát kísérletezgetni kezdtek, vajon milyen messzire mehetnek el.

A magyar származású Gerely Fülöp produceri felügyelete alatt készült Barázdák története szerint egy vidéken élő szegény földműves család a jobb élet reményében a nagyvárosba, Madridba költözik, de semmi sem úgy alakul, ahogyan azt tervezték. Kénytelenek elmerülni a megalázó munkák, a csempészet, a lopás és a prostitúció világában, a végkifejlet azonban bukást, lelki megnyomorodást és halált rejt magában. Végül úgy döntenek, hogy inkább visszatérnek falujukba, a nyomorba, mert ott legalább meg tudják őrizni méltóságukat a legnagyobb szenvedések közepette is.

Olyan élethelyzeteket és szituációkat tártak a képek a korabeli nézők elé, amelyekkel nap mint nap szembesültek. Ha nem is ismertek teljesen önmagukra a film főszereplőiben, környezetükben biztosan találtak olyan személyeket, akik hasonló megpróbáltatásokon mentek keresztuil. A film bemutatja az 50-es évek spanyol társadalmának minden rétegét, problémáit, a mindennapi élet ellentmondásait, a „nemzeti” Spanyolország teljes szociális

lakásocska (El pisito, Marco Ferreri, 1958), A csavargók (Los golfos, Carlos Saura, 1960), Az autócska (El cochecito, Marco Ferreri, 1960), Akik nem mentünk a háborúba (Los que no fuimos a la guerra, Julio Diamante, 1961), Viridiana (Luis Buñuel, 1961), Banditasirató (Llanto por un bandido, Carlos Saura, 1964), A vadászat (La caza, Carlos Saura, 1965). 
kudarcát. Ami mindebben újdonság: bár ennek a világnak a létezéséről mindenki tudott, de a negatívumairól, vagyis magukról a tényekről beszélni nem volt szabad, mindezt ilyen autentikusan ábrázolni pedig még annyira sem. A boltban alig lehet valamit kapni, az alapvető élelmiszereken kívül minden luxuscikknek számít, viszont az üzlet hátsó helyiségei a csempészek számára kitűnő elosztóhelyként funkcionálnak. A kocsma és a kávézó pedig nem a kikapcsolódást szolgálják, hanem a munkanélküli madridiak találkozóhelyei, akik így olyan benyomást keltenek, mintha tétlenül várnának egy talán soha el nem érkező lehetőségre. Az idősebb és a középkorú generációnak szinte reménytelen az élete, a fiatalok számára az illegális tevékenység lehetne az egyetlen kiút, amennyiben morálisan el tudják azt viselni. A főszereplő család egyes tagjai átmenetileg fel is adják elveiket, és törvénytelen módszerekhez folyamodnak. Ez az egyik legfontosabb eleme a filmnek: mivel a tökéletes spanyol társadalomban csak a kártékony elemek (akkori értelmezésben: bolsevik, szabadkőműves, kommunista stb.) mérgezik a társadalmat törvénybe ütköző cselekedeteikkel, mindez mélységesen elítélendő. A tolvaj, a csaló és a prostituált tehát azért vetemednek ezekre a bünökre, mert eleve romlott lelkek. Nieves Conde alkotásában azonban a főszereplök leginkább sajnálatra méltó áldozatoknak tünnek, akik csak a túlélés érdekében kényszerülnek ilyen tettekre. Mindez azt sugallja, hogy a társadalom igazságtalan, és még mélyebbre taszítja a már eddig is a legnyomorultabb viszonyok között élőket. A film egyik elemzője szerint a legnagyobb kontraszt a Barázdák és a többi korabeli film között az, hogy elöször mutatja be, az elszegényedett rétegek tagjai nem vállalnak szolidaritást egymással, hagyják, hogy a másik egyre inkább elveszítse lába alól a talajt. Nem segítik társaikat, egyesek még ki is használják a védteleneket. $^{584}$

Azzal, hogy a film végén visszatérnek szülőföldjükre, a rendező egyértelmü üzenetet közvetít: nincs remény a kilábalásra, önerőből, tisztességes módon nem lehet előbbre jutni. A szereplők végül feladják a reménytelen próbálkozásokat, beletörődnek sorsukba, és hazatérnek. Az előzetesen eltervezett finálé még ennél is keserübb volt: az eredeti változatban az egyik főszereplő lány Madridban marad, hogy továbbra is prostitúcióval keresse kenyerét, míg a városból megkeseredetten távozó család összefut egy másik, szintén vidékről származó famíliával, akik láthatóan hasonló reményekkel érkeznek ide, mint annak idején ők tették. A történet tehát végtelenített, az ördögi körből a spanyol társadalom alsóbb rétegében élők nem tudnak szabadulni. A cenzúra azonban ezt a konklúziót már nem engedélyezte ${ }^{585}$, az új

\footnotetext{
${ }^{584}$ Zumalde Arregi, Imanol: „Surcos” in: Pérez Perucha, Julio (szerk.): Antología crítica del cine español. Id. mü. 295.

${ }^{585}$ AGA, Cultura, 36/03410-es doboz, 10634-es köteg és 36/03415-ös doboz, 10774-es köteg.
} 
befejezésben az egész család elhagyja a szenvedés színhelyét, és nem jön helyettük utánpótlás.

A forgatás helyszínei is nagyban hozzájárultak ahhoz, hogy igazán realista képet adott a film. A többszobás, mégis kicsinek tetsző lakásban nagy család nyomorog, az életük egybefonódik a hasonló helyzetben lévő szomszédokéval. Az egyre nagyobb terhet jelentő lakásprobléma a későbbiekben sok kiemelkedő spanyol filmben is feltűnt, ez adta a központi problémáját A bérlö (El inquilino, José Antonio Nieves Conde, 1957) és A lakásocska (El pisito, Marco Ferreri, 1959) címü müveknek, de hangsúlyozottan jelent meg $A z$ a boldog párban (Esa pareja feliz, Juan Antonio Bardem és Luis García Berlanga, 1953) és A hóhérban (El verdugo, Luis García Berlanga, 1963) is.

Már a szinopszis alapján felmerülhet a kérdés, hogy miért engedték egyáltalán leforgatni ezt a társadalomkritikát. Az új színház- és filmművészeti főigazgatónak, José María García Escuderónak köszönhetően a filmesek a társadalom és annak problémái felé fordulhattak. Nieves Conde müve jelentette a kezdetét a spanyol neorealizmusnak, ennek nyomát követték a későbbi, hasonló stílusú munkák is. A közönség és a kritika egy része, látva a Barázdákat, egyenesen kommunistáknak, vörösöknek titulálta a készítőket, miközben a rendező és a cselekményért felelős személyek is a spanyol Falange Párt szimpatizánsai, egyesek a tagjai is voltak. Rendelkeztek azonban bizonyos müvészeti és társadalmi érzékenységgel is, ezt próbálták meg érvényesíteni a rezsimben. A Falange azon szárnyát képviselték, amely egyre elégedetlenebb volt a francói szociálpolitikával, és egy új, jobban átgondolt utat látott kívánatosnak, továbbra is ragaszkodva a Nemzeti Mozgalom alapelveihez. $^{586}$ García Escudero elérte, hogy a legnagyobb anyagi támogatást kapja a Barázdák az állam részéről, a bemutatót is úgy harangozták be, mint az év spanyol filmjének premierjét. Ez a döntése hatalmas vitákat váltott ki még a legmagasabb kormányzati körökben is, a katolikus egyház egyes képviselői szerint pedig a film „mélységesen erkölcstelen, feltétlenül be kell tiltani végérvényesen" ${ }^{~} 587$; ugyanakkor, számos befolyásos pap védelmébe vette annak társadalmi mondanivalóját, többek szerint maga Franco is megnézte, és nem látott benne kivetnivalót. ${ }^{588}$ Egyértelmű volt azonban, hogy a mű rendkívül kritikus hangnemet ütött meg a rendszerrel szemben.

A filmművészeti főigazgató a Barázdáknak adományozta a legfontosabb, nemzeti érdek titulust, vagyis valóban az év filmje lett, miközben Franco személyes kedvencét, a Hispanidad

\footnotetext{
${ }^{586}$ Zumalde Arregi, Imanol: „Surcos” Id. mü. 296.

${ }^{587}$ AGA, Cultura, 36/03415-ös doboz, 10774-es köteg.

${ }^{588}$ García Escudero, José María: La primera apertura. Id. mü. 25.
} 
értékeit tükröző, Amerika felfedezéséről szóló Amerika hajnalát nyilvánosan bírálta, müvészeti és történelmi szempontból rossznak és elhibázottnak minősítette, valamint kijelentette, hogy a Filmművészeti Főigazgatóság nem hiteltelenítheti magát azzal, hogy ezt a filmet kebelére öleli. ${ }^{589}$ Ez a két tett jelentette a politikus vesztét. Mivel az igazgató szinte mindenkivel szembekerült a döntése miatt, jobbnak látta, ha lemond. Utódja azonnal korrigálta García Escudero „tévedését”, így az Amerika hajnala is megkapta a nemzeti érdek kitüntető címet. ${ }^{590}$

A Barázdákat a főigazgató még lemondása előtt spanyol versenyfilmnek ajánlotta a Cannes-i Filmfesztiválra. Paradox módon tehát úgy tünhetett a külföld számára, hogy egy olyan, a spanyol állam által ajánlott és patronált film jelent meg így a nemzetközi porondon, amely bemutatja a spanyol társadalom negatívumait, a mindennapok tragédiáit és az elviselhetetlen életet, vagyis a francóizmus csődjét. Belföldön is részesült szakmai elismerésekben, a Filmírók Köre és más filmes szindikátus is számos díjjal tüntette ki, de minden esetben kihangsúlyozva, hogy az elismerés filmmüvészeti indíttatású. Az utókor is tiszteletben tartja: egy rangos filmes szaklap 1995-ben, a legnevesebb spanyol filmrendezök, forgatókönyvírók, színművészek és kritikusok körében végzett közvélemény-kutatása ${ }^{591}$ szerint a Barázdák minden idők tizenharmadik legjobb spanyol filmje, megosztott helyezésben Luis Buñuel Tristana (Tristana, 1970) címủ alkotásával.

\section{Isten hozta, Mr. Marshall! - ¡Bienvenido, Míster Marshall!}

A kérdéskör másik kiemelkedő filmje könnyedebb müfajhoz tartozik.

Luis Buñuellel ellentétben a nyíltan kommunista eszméket valló Juan Antonio Bardem és az önmagát mindennel elégedetlennek és örök lázadónak tartó Luis García Berlanga ${ }^{592}$ Spanyolországban maradtak, és megpróbálták túlélni a mindenható cenzúrát. Eközben politikai nézeteik miatt állandó üldöztetésnek voltak kitéve, de a nemzetközileg egyre nagyobb hírnévre szert tett alkotók túlságosan ismertek volt ahhoz, hogy a demokratizálódás álcáját magára öltő Spanyolország végérvényesen megszabadulhasson tőlük.

\footnotetext{
${ }^{589}$ García Escudero, José María: Mis siete vidas. De las brigadas anarquistas a juez del 23-F. Editorial Planeta, Barcelona, 1995. 231.

${ }^{590}$ AGA, Cultura, 36/03420-as doboz, 10932-es köteg.

${ }^{591}$ Tébar, Juan - Torres Dulce, Eduardo: „Cien españoles y el cine español. Encuesta.” in: Nickel Odeon, 1995/1, 15-35.

${ }^{592}$ Berlangának politikai meggyőződéseinél fontosabb volt a pillanatnyi helyzet. Bár gyülölte a fasizmust, mégis jelentkezett önkéntesnek a Kék Hadosztályba. Ennek - saját bevallása szerint - négy, egymástól teljesen eltérő oka volt: remélte, hogy így enyhíteni tud a börtönben ülő republikánus édesapjára kirótt halálbüntetésen; imponálni akart ezzel egy lánynak; fütötte a kalandvágy; legjobb barátai között volt több falangista is, és ő velük akart tartani. Erről lásd: Perales, Francisco: Luis García Berlanga. Madrid, Ediciones Cátedra, 1997. 20-22.
} 
A disszidens filmeseket tömörítő UNINCI filmstúdió megbízta Bardemet és Berlangát, hogy készítsenek egy filmet számukra: választhattak, hogy egy falusi környezetben játszódó drámát hoznak tető alá, vagy inkább könnyedebb müfajban forgatnak. Miután utóbbi mellett döntöttek, a stúdió a korszak népszerü szubzsánere, a folklórfilm címkéje alatt képzelte el a produkciót, és három kritériumot szabott: legyen szórakoztató, játszódjon Andalúziában, egyik főszereplője pedig legyen a népszerü énekesnő, Lolita Sevilla. ${ }^{593}$ Bardem és Berlanga együtt írták meg 1952-ben az Isten hozta, Mr. Marshall! (;Bienvenido, Míster Marshall!) címü forgatókönyvet, amelyet Berlanga már egyedül rendezett meg, mivel társa anyagi természetű nézeteltérések miatt megvált a produkciótól. Sem a forgatókönyv előzetes, sem a leforgatott film utólagos cenzori átvizsgálása ${ }^{594}$ során nem nyilvánították ki egyértelműen a hatóságok, hogy negatív képet fest a film Spanyolországról.

A film kiindulási pontja a Marshall-terv. A második világháború után Európa több országa részesült az amerikai segélyben, mindenekelőtt az USA-ból érkező áruk formájában. Spanyolország azonban kimaradt, ugyanis a világháború alatt előbb semleges álláspontot képviselt, majd a „nem hadviselő fél” státuszába helyezkedett, miközben nyíltan kifejezte szimpátiáját a tengelyhatalmak iránt. 1950-től a spanyolok viszont már Amerika-barát politikát és propagandát folytattak, 1953-ban pedig katonai és gazdasági egyezményeket is kötöttek. Az Amerikai Egyesült Államok tehát partnerként viszonyult hozzájuk.

Ahogyan a Barázdák esetében is nyilvánvaló volt, úgy a Mr. Marshall ... kapcsán is elmondható, hogy már a vázlatos cselekmény is elörevetítette a film kritikai hangnemét. A történet szerint egy kis spanyol faluban elterjed a híre, hogy a Marshall-segélyt osztó amerikai bizottság ellátogat hozzájuk. A lakosok, élükön a szenilis és félsüket polgármesterrel, a kis település teljes átformálásába kezdenek, hogy minden úgy nézzen ki, mint egy tipikus andalúz falu, ahogyan az valószínűleg az amerikaiak képzeletében él (miközben valójában az ország középső része, egy kasztíliai sivatagos terület a helyszín). Az éppen ott tartózkodó híres énekesnő részvételével megkezdődik a nagy átalakítás, andalúz ruhákat bérelnek, az utcákat és épületeket átépítik, feldíszítik. A falu teljesen eladósodik, de biztosak benne, hogy a bizottság érkeztével majd dolláreső hullik a településre, és ebből a hatalmas összegből minden szükségletüket és vágyálmukat kielégíthetik. Hosszú listákat írnak kívánságaikról, miket fognak kérni az amerikaiaktól, mire fordítják majd a kapott pénzt. A film ennek a várakozásnak és vágyakozásnak a története, hogyan készül az átverés, miközben a

\footnotetext{
${ }^{593}$ Perales, Francisco: Luis García Berlanga. Id. mü. 207.

${ }^{594}$ Forgatási engedély kiadása a forgatókönyv alapján kisebb ellenvetésekkel és figyelmeztetésekkel: $A G A$, Cultura, 36/04731-es doboz, , ;Bienvenido, Míster Marshall! forgatási engedély. Cenzori jelentés: AGA, Cultura, 36/03447-es doboz, 11602-es köteg.
} 
filmszalagon megelevenednek a nép álmai is. A vágyott gazdagság helyébe azonban csalódottság lép, amikor az amerikai konvoj megérkezik, és megállás nélkül áthalad a falun. A lakosok pénz és remény nélkül szemlélik a távolodó kocsikat.

Aki jól ismerte a korabeli Spanyolországot, könnyen észrevehette, hogy a kis falu álmai és vágyai - kisebb dimenzióban - az egész ország álmainak és vágyainak kivetülését foglalták magukban: a reményt, hogy a politikai konjunktúra idején amerikai dollárok hozzák meg a fejlődést. A film bemutatja ironikus, helyenként groteszk stílusban az elmaradottságot, a hatóságok teljes inkompetenciáját, a túléléshez és a célok eléréséhez szükséges trükköket. Az elméletileg fejlődésnek induló országban éppen a lakosok számára nem világos, vajon tényleg pozitív irányban haladnak-e. Kitünően jellemzi az állapotokat a film egyik jelenete: amikor az illetékes kormányzati tisztviselő arról győzködi a polgármestert, hogy tartson majd egy beszédet az erkélyről az amerikaiak számára a falu mezőgazdaságáról, állattenyésztéséről és iparáról, az elöljáró zavarodottan, de ártatlan szemekkel kérdez vissza: „Milyen iparról?”. A beszélgetés mindkettőjük számára megnyugtatóan zárul: mivel úgyis csak angolul tudnak a látogatók, teljesen mindegy, mi is hangzik el a spanyol nyelvü szónoklatban.

Sok lakos nem tud elég gyorsan reagálni az új viszonyokra: nem is olyan régen még Amerika-ellenes és náci-szimpatizáns nép voltak ők, most pedig Amerika-barát, demokráciára törekvő nemzetként mutatják magukat. A kis falu így válik az új Spanyolország kirakatfalujává. Az ábrázolás szerint az ország tele van a fejlődést és a közállapotokat érintő ellentmondásokkal, valamint az Amerika-barátság is gúny tárgyát képezi.

A álomjelenetekben tárulnak elénk a falu lakóinak reményei, ábrándjai, azonban ezek az USA-ra nézve hátrányosak. Az álmok megkomponálása minden esetben egy klasszikus müfajt idéz meg, az amerikai westerntől a kalandfilmeken át egészen a sportfilmekig. Ezekben a szekvenciákban világos utalásokat kapunk az indiánok kiirtására, a Ku-KluxKlánra, az Amerika-ellenes Tevékenységet Vizsgáló Bizottságra, valamint az amerikaiak hamis ígérgetéseire. Az eredeti szándék szerint még ennél is több álom került volna az anyagba, de erről végül lemondtak, részben időhiány miatt, részben pedig azért, mert az előzetes cenzori értékelés során figyelmeztették őket, hogy az Értékelő és Cenzori Junta kivágja ezeket, ha tényleg benne maradnak a végleges változatban. ${ }^{595}$

A szereplők a tipikus spanyol személyeket és élethelyzeteket, reakciókat jelenítik meg, ugyanakkor szembetűnő, hogy eléggé sematikusra rajzolták a figurákat: mintha a spanyolok

\footnotetext{
${ }^{595}$ Matellano García, Víctor: Bienvenido, Míster Marshall: De la anécdota al cine con un pequeño pueblo castellano. La Comarca, Colmenar Viejo, 1997. 32-33. A már idézett cenzori jelentés is utal erre: AGA, Cultura, 36/03447-es doboz, 11602-es köteg.
} 
mindegyike egy viszonylag müveletlen, gyakran egészen infantilis, könnyen befolyásolható, egydimenziós karakter lenne, akikkel bármit meg lehet tenni. Néhány adott szituáció pedig könnyen összefüggésbe hozható a valósággal is. Az egyik kulcsjelenetben a polgármester önismétlésekkel teli és értelmetlen szófüzérekből összeállított, erkélyről tartott beszéde egyértelmü utalás Francisco Franco tábornok hazafias előadásaira, amelyekben a magasztos hangvételü felszín alatt valójában nincsen semmi lényegi mondanivaló. Miután az amerikaiak cserbenhagyják öket, a falusiak beletörődnek a megváltoztathatatlan helyzetbe, hogy semmi sem lett jobb, és valószínüleg ezután sem lesz az. Hans-Jörg Neuschafer szerint az „Isten hozta Mr. Marshall! kritikával illeti egyfelöl a nagyság delíriumát és a spanyolok önimádatát, másfelől az amerikaiak önzetlensége iránt táplált mesebeli reményeket." ${ }^{596}$ Minden ország fia, aki csak felvonul a filmben, nemzete legnegatívabb tulajdonságaival van jelen.

Hogy a film miért csak kisebb cenzori beavatkozásokat szenvedett el, azt csak találgatni lehet. Egyesek szerint a folklór jegyében született alkotásban a cenzorok nem érzékelték a Spanyolországot érő kritikákat olyan súlyosnak, az amerikaiakat célzó támadásokat pedig kifejezetten örömmel fogadták, hiszen még mindig élt bennük a nemzetük iránt érzett túlzott nacionalizmus, és minden xenofób megnyilvánulást elfogadhatónak találtak (még akkor is, ha a világpolitika azóta már máshogyan alakult), valamint továbbra is fütötte őket a bosszúvágy, amiért kihagyták őket a Marshall-tervből. Mások szerint a cenzori juntában helyet foglalók felismertek minden rendszerellenes elemet, de ők maguk is jól szórakoztak rajta, egyfajta önkritikát gyakoroltak azzal, hogy nem vágatták ki a problémásabb jeleneteket és dialógusokat. 597

A spanyol filmmüvészeti bizottság ezt a filmet nevezte a Cannes-i Filmfesztiválra, ahol különdíjban részesült. A fesztivál zsürijében helyet foglaló Edward G. Robinson amerikai színész azonban felfedezte benne a hazáját érintő kritikákat, és azt különösen rosszul fogadta, hogy az egyik jelenetben egy amerikai zászló az eső miatt a patakba hull. Mivel Robinsont éppen akkoriban nyomás alá helyezte az Amerika-ellenes Tevékenységet Vizsgáló Bizottság, igyekezett túlkompenzálni, így több fórumon kikelt a film Amerika-gyalázása ellen. A film promóciója gyanánt hamis amerikai bankjegyek lepték el Cannes utcáit, amelyeken George Washington arcképe helyett a film föszereplöi néztek vissza az emberekre. Berlanga és a film producere rendőrségi kihallgatáson voltak kénytelenek magyarázkodni. ${ }^{598}$

\footnotetext{
${ }^{596}$ Neuschafer, Hans-Jörg: Adiós a la España eterna. Id. mü. 202.

${ }^{597}$ Uo. 34.

${ }^{598}$ Perales, Francisco: Luis García Berlanga. Id. mü. 210-211.
} 
A spanyol közönség körében a film nagy tetszést aratott, de a premier és a cannes-i visszhang után már a kormányzat számára is egyértelmü volt, hogy a film Spanyolországképe nem igazán pozitív, az éppen baráttá vált USA-t pedig erőteljesen gúnyolják az alkotók. A fesztiválsiker után azonban a nemzetközi hírnév miatt már nem tehettek semmit, így nemcsak, hogy nem szenvedett el a film szankciókat, hanem tetemes összegü utólagos állami támogatással is honorálták, megteremtve ezzel a lehetőséget a rendezőnek, hogy folytassa hasonlóan kritikus témákkal teletűzdelt karrierjét.

Az Isten hozta, Mr. Marshall! mindmáig talán az egyik leghíresebb spanyol film, igazi nemzeti kincsként tartják számon (az említett rangsorban ${ }^{599}$ a kilencedik helyet foglalja el). Egyszersmind az első spanyol film, amely ilyen széleskörü nemzetközi hírnevet szerzett.

$$
* * * * * * * * * * * * * * *
$$

A Barázdák és az Isten hozta, Mr. Marshall! sikerének a filmpolitikára nézve több hozadéka is volt. A filmesek bátrabbak lettek, és újabbnál újabb kiskapukat kezdtek keresni. Általában sikerrel vették az akadályokat. Éppen ezért, az állam igyekezett ismét megerősíteni a cenzúrát. Az 50-es évek második felében tüzetesebben vizsgálták át már a forgatókönyvek előzetes változatait is.

Ez a sajátos rendszerellenes hangvétel Bardemnek és Berlangának köszönhetően az elkövetkezendő években tovább erősödött. Mindennek tetőpontját a már tárgyalt 1955-ös Salamancai Beszélgetések elnevezésű rendezvény jelentette. Bár a spanyol filmcenzúra a továbbiakban is erőteljes maradt, a rendezők jó érzékkel manővereztek a rájuk kényszerített akadályok között. Az igazi áttörés 1962-ben jött el, amikor visszatért a Színház- és Filmmủvészeti Főigazgatóság élére José María García Escudero, hozzá és Manuel Fraga Iribarnéhoz $^{600}$ füződik az apertura, a nyitás periódusa a 60-as években - a társadalomban kettejüket nevezték a valódi aperturistáknak.

\footnotetext{
${ }^{599}$ Tébar, Juan - Torres Dulce, Eduardo: „Cien españoles y el cine español. Encuesta.” Id. mü. 15-35.

${ }^{600}$ Fraga Iribarnéról magyarul lásd: Anderle Ádám: „Diktatúrából demokráciába. Manuel Fraga Iribarne” in: Uő: Történelmi minták és utak. Esszék Spanyolországról és Latin-Amerikáról. Szeged, 2009. 41-48.
} 


\section{A hatvanas évek változásai}

„Salamanca szelleme” (,el espíritu de Salamanca”), ahogyan a konferencia elkövetkezendő évekre gyakorolt hatását nevezik a filmtörténészek, érezhetően ott lebegett a döntéshozók feje felett. Az Opus Dei csoport által az 50-es évek végén beindított Első Fejlesztési Terv, valamint a diktatúra azon szándéka, hogy nyitottabbnak, demokratikusabbnak mutatkozzon a külvilág felé, érzékeltette hatását az ország mozgóképgyártásában is. Ebben az új periódusban a mozi új szerepkörhöz jutott: tanúsítania kellett, hogy Spanyolország felkarolja és támogatja a fiatal és tehetséges művészeket, és ebben a tekintetben a Spanyol Állam teljes egészében megegyezik más, demokratikus berendezkedésü hatalmakkal. Azt is célul tüzték ki, hogy az ország nemzetközi presztízsét emelendő, olyan filmeket bocsátanak exportra, amelyek esélyesek lehetnek nemzetközi filmfesztiválokon. Ahogyan a gazdasági élet területén is megindult egy bizonyos nyitás, és vonzóvá próbálták tenni az országot a külföldi tőke számára, úgy a filmgyártás területén is megjelentek más országok, elsősorban az Egyesült Államok, és olyan szférákba is lehetőségük volt beszivárogni, amelyeket korábban kizárólag hazai befektetők és szakemberek számára tartottak fenn. Egyik legszemléletesebb példa erre a már említett amerikai Samuel Bronston filmproducer spanyolországi tevékenysége.

A Salamancai Beszélgetések kiemelkedő résztvevője, a spanyol filmélet egyik legaktívabb alakítója, teoretikusa és kritikusa, José María García Escudero ${ }^{601}$ 1962-ben másodszor is elfoglalhatta a Színház- és Filmművészeti Főigazgatóság vezető pozícióját a Tájékoztatási és Idegenforgalmi Minisztérium élére helyezett Manuel Fraga Iribarnénak köszönhetően; kettejük között közeli barátság és problémamentes együttműködés alakult ki. A

\footnotetext{
${ }^{601}$ José María García Escudero kulturális pozíciója mellett a Cortes jogászaként, vizsgálóbíróként, történészként és újságíróként is tevékenykedett. A spanyol konzervativizmusról, Cánovas de Castillóról, Spanyolország társadalomtörténetéröl, a Franco-korszakról, a keresztény gondolkodásról, politikatörténetről, egyháztörténetről írott monográfiáit a történészek ma is alapművekként tartják számon. Az Arriba és a Ya folyóiratok állandó publicistája volt, a hírhedt Matesa-ügyben, valamint az 1981. február 23-ai Tejero-féle puccskísérlet után öt jelölték ki a vádemelési szakasz egyik vizsgálóbírójának. Haláláig Spanyolországban minden politikai oldal által köztiszteletben tartott személyiség volt.

Legfontosabb, nem filmes témájú művei: De Cánovas a la República. Madrid, Ediciones Rialp, 1951; Crítica de la restauracion liberal en España. Madrid, Ateneo, 1952; Historia política de las dos Españas. Madrid, Editora Nacional, 1976; A vueltas con las dos Españas. Madrid, Biblioteca de Autores Cristianos, 1979; El pensamiento de Ángel Herrera: antología política y social. Madrid, Biblioteca de Autores Cristianos, 1987; Los españoles de la conciliación. Madrid, Espasa Calpe, 1987; Historia política de la época de Franco. Madrid, Ed. Rialp, 1987; Los cristianos, la iglesia y la política. Fundación Universitaria San Pablo, Madrid, 1993.

García Escudero munkásságáról részletesen lásd az alábbi tanulmányt: Lénárt András: „Un hombre de la apertura franquista. García Escudero” in: Acta Scientiarum Socialium XXX. Kaposvár, 2009. 37-48.
} 
miniszter García Escuderót az ugyanebben az évben írt könyve, a Cine español ${ }^{602}$ alapján kérte fel a pozíció betöltésére, mert úgy vélte, az abban összegzett tapasztalatai és véleménye kiváló filmpolitikai programtervnek bizonyulhatnak. ${ }^{603}$ Escudero ismerős volt a francói filmgyártás berkeiben, az 50-es években egyszer már betöltötte ezt a tisztséget, salamancai részvételének köszönhetően pedig tisztában volt a spanyol filmgyártás problémáival, ismerte az előttük álló kihívásokat. Luis García Berlanga filmrendező egyenesen ,,a mi emberünk”nek nevezte, aki mindenekelőtt az értékeket tartotta szem előtt, a minőségi filmgyártást szorgalmazta, és erősen hatott rá a francia újhullámos rendezők munkássága. ${ }^{604}$

García Escudero tisztában volt azzal, hogy milyen nehézségekkel áll szemben. A spanyol film 1962-es helyzete véleménye szerint megegyezett az 1952-essel, és szilárd elhatározása volt, hogy tenni kell valamit. Ahogyan a 70-es években publikált személyes naplójában írta: „,...a problémák olyan sebességgel jelentkeznek, hogy levegőt venni sincs idő. Egy új parancsot vezetek be: csináld a dolgokat rosszul, de gyorsan. Még mindig jobb, mintha nem csinálsz semmit”. ${ }^{605}$ Az új határozatok viszonylag gyorsan hatályba léptek, de korántsem haladt rossz irányba a filmpolitika.

Az új föigazgató legfontosabb intézkedéseit két rendelet jelentette, amelyek alapjaiban változtatták meg a vezetés filmgyártáshoz való hozzáállását: az 1963-as cenzúrára, valamint az 1964-es új protekcionista filmpolitikára vonatkozó rendeletekről van szó.

García Escudero nem ellenezte a cenzúrát, több alkalommal is hangoztatta, hogy az egyik legfontosabb eszköznek tartja, amellyel a művészeteket fejleszteni lehet. A politikai cenzúra helyett azonban kizárólag erkölcsi cenzúrát tartott vállalhatónak. Szerinte ez a módszer csak valódi veszélyek elhárítására alkalmazható, de ha mindössze potenciális konfliktusokat akarnak vele elkerülni, akkor nem használható, mert így csak sematikus és sablonos filmek születnének. A cenzúra segítségével pedig a közönség nevelhető is, de nem ideológiai, hanem morális és kulturális kiművelést kell célul kitüzni. ${ }^{606}$ Elítélte és nevetségesnek tartotta az olyan, általában az egyházi cenzortól származó indoklásokat, mint a többször is előforduló „Személy szerint elfogadhatónak tartom, de a katolikus erkölcs alapján

\footnotetext{
${ }^{602}$ García Escudero, José María: Cine español. Id. mü.

${ }^{603}$ Fragának eleinte az oktatási tárcát szánták. Amikor felkínálták neki a Tájékoztatási és Idegenforgalmi Minisztériumot, csak azzal a feltétellel fogadta el a kinevezést, ha maga mellé veheti a vejét, valamint a színházés filmművészeti ügyeket García Escuderónak adhatja. Erről utóbbi az önéletrajzában számol be: García Escudero, José María: Mis siete vidas. De las brigadas anarquistas a juez del 23-F. Editorial Planeta, Barcelona, 1995. 247.

${ }^{604}$ Gómez Rufo, Antonio: Berlanga. Contra el poder y la gloria. Id. mü. 169.

${ }^{605}$ García Escudero, José María: La primera apertura. Id. mü 37-38.

${ }^{606}$ Uő.: Cine español. Id. mü. 45-47 és Uő.: Vamos a hablar de cine. Madrid, Salvat Editores - Alianza Editorial, 1970. 43-44.
} 
mégsem”, vagy a valóságot teljesen figyelmen kívül hagyó és általa álszenteskedésnek minősített „Ilyen helyzetek sajnos léteznek, de ezt azért be kell tiltani” érveléseket. Ezek szerinte nem az evangéliumon, hanem a félreértelmezett kereszténydemokrácián alapultak. ${ }^{607}$ Több alkalommal kérdöre vonták és fel is jelentették őt püspökök a szerintük túlzottan liberálissá vált cenzúra miatt. ${ }^{608}$ Személyes naplójában gúnyos hangvételben jegyzi meg, hogy az egyházi cenzor által is ellenvetés nélkül bemutatásra engedélyezett amerikai A Biblia (The Bible: In the Beginning..., John Huston, 1966) láttán vajon a szentéletü asszonyok megbotránkoznak-e Ádám és Éva ruhátlan jelenetein a Paradicsomban, vagy a Sárát kihívóan simogató Ábrahám viselkedésén. ${ }^{609}$

Az általa kidolgoztatott Filmcenzúra Normái lefektették az alapokat, amelyeknek megfelelően hármas kontrollt lehetett gyakorolni a filmek felett: politikai, erkölcsi és vallási cenzúrát. A rendeletnek megfelelően a filmkészítők számára már világos volt, mihez kell tartaniuk magukat, mit lehet és mit nem lehet ábrázolni (tilos volt például bármiféle negatív megjelenítése az államnak és az egyháznak, a prostitúció, házasságtörés, öngyilkosság nyílt ábrázolása, stb.), viszont a „mit lehet” kategórián belül is megjelent a „hogyan”. Ugyanakkor, a nyitás is megfigyelhető volt: a 60-as évek filmjeiben már többet lehetett mutatni, és egyfajta társadalom- és rendszerkritika is megjelenhetett, amennyiben az átvitt értelemben, metaforikusan került bemutatásra. Az előző igazgatók által betiltott vagy betiltatott filmeket García Escudero újraértékeltette, és azok közel 80\%-ának bemutatását végül engedélyezte, mert szerinte a cenzorok indoklása nevetséges volt. ${ }^{610}$ Megnyitotta az utat az ideológiailag semleges szovjet és kelet-európai filmek előtt (ebben segítségére volt a Suevia stúdió) ${ }^{611}$, ennek köszönhetően jutott el Spanyolországba a szovjet Grigori Kozintsev két klasszikusa, a Don Quijote (Дон Кихот, 1959) és a Hamlet (Гамлет, 1964). ${ }^{612}$ Amit pedig továbbra sem engedtek bemutatni, a spanyolok azt is látni akarták: valóságos filmturizmus indult meg a közeli francia Perpignanba és Biarritzba, hogy láthassák az otthon betiltott vagy cenzúrázott filmek vágatlan változatát. Erre a célra francia vállalkozók külön a spanyol vendégek számára üzemeltetett mozikat tartottak fenn, ahol spanyol szinkronnal nézhették meg a filmeket. ${ }^{613}$

\footnotetext{
${ }^{607}$ Idézi: Uő.: La primera apertura. Id. mü. 55.

${ }^{608}$ Uö.: Mis siete vidas. Id. mü. 263.

${ }^{609}$ Uő.: La primera apertura. Id. mü. 232.

${ }^{610}$ Interjú García Escuderóval: Julián, Óscar de (szerk.): De Salamanca a ninguna parte. Id. mü. 72.

${ }^{611}$ Gubern, Román - Font, Doménec: Un cine para el cadalso. Id. mü. 115.

${ }^{612}$ A spanyol társadalom számára szimbolikus jelentőségü volt és a régi cenzúra hanyatlását jelentette az a rövid jelenet, amelyben Elke Sommer színésznő bikiniben tünt fel a Palma-öböl (Bahía de Palma, Juan Bosch, 1962) címü filmben; ilyen képet korábban nem lehetett látni a mozikban, ezért igazi áttörésként értékelték a nézők, a falvakból és vidéki városokból külön buszjáratokkal zarándokoltak a spanyolok Madridba, hogy megnézhessék a filmet. Eslava Galán, Juan: Coitus interruptus. Id. mü. 323.

${ }^{613}$ Uo. 362.
} 
A cenzúra továbbra is nyújtott érdekességeket: A piszkos tizenkettő (The Dirty Dozen, Robert Aldrich, 1967) címü amerikai film spanyol forgalmazásában egy eredetileg Victor Frankóra keresztelt karakter vezetéknevét Frankie-re kellett változtatni, mivel a történet során pszichopata vonásokat mutatott fel , és így nem viselhette a Caudillo nevét. ${ }^{614}$

A hivatalos cenzúra mellett azonban a 60-as évektől létezett egy nem hivatalos cenzúra is, amelyet az illegálisan tevékenykedő pártok és csoportok javasoltak, esetleg kényszerítettek rá a hozzájuk kötődő filmesekre. Carlos Saura szerint mindenekelőtt a kommunista párt élt ezzel az eszközzel, az egyik legaktívabb „föld alatti cenzor” Jorge Semprún volt, aki világos utasításokkal érkezett Moszkvából arra nézve, milyen típusú filmet kell előállítani. ${ }^{615} \mathrm{~A}$ kommunista propaganda nyíltan nem jelenhetett meg, leginkább a társadalmi és egzisztenciális problémák ábrázolásában merült ez ki.

A hazai film védelme érdekében García Escudero új kategorizációt vezetett be: megkülönböztetett kereskedelmi célzatú (mai szóhasználattal élve „kommersz”) és művészi filmeket. A támogatás elsősorban attól függött, hogy a film költségvetésének mekkora részét sikerült visszatermelnie a mozipénztáraknál. A nemzeti érdek titulust különleges érdekre nevezték át, és csak azok a filmek kaphatták meg (a nagyobb százaléknyi támogatással együtt), amelyek politikai, morális, társadalmi, oktatási, vagy művészeti szempontból rendkívül fontosnak bizonyultak az állam számára. ${ }^{616}$ Ösztönözte a koprodukciók készítését, ügyelve arra, hogy Spanyolország ne csak díszletként funkcionáljon, hanem értékes filmmüvészeti részvétellel legyen jelen. Szerinte a legjobb a tisztán nemzeti filmgyártás lenne, de anyagi okokból szükséges az együttmüködés. Osztotta Nieves Conde filmrendező véleményét: a koprodukció „két szegény összefogása, hogy az egyiket kevésbé szegénnyé tegyék". 617

A fenti intézkedések mellett különös figyelmet fordított a filmgyártás ösztönzésére, más európai országok tapasztalatainak felhasználására, egy finanszírozást zökkenőmentessé tevő Filmmüvészeti Védelmi Alap (Fondo de Protección Cinematográfica) létrehozására, az állami televízió feladatköreinek meghatározására, a fiatal filmesek támogatására és az ifjúsági filmek nagyobb számban történő gyártására. A filmkészítők már több szervezettől, sokféle kritérium alapján juthattak hitelekhez és támogatásokhoz, megtörve ezzel azt a trendet, hogy

\footnotetext{
${ }^{614}$ Mota, Jesús: „Criminales en la guerra” in: Doce del Patíbulo (a filmhez mellékelt kiadvány, Gregorio Belnichá írásaival). Editorial El País, S. L., 2005. 55.

${ }^{615}$ Julián, Óscar de (szerk.): De Salamanca a ninguna parte. Id. mü. 76.

${ }^{616}$ Caparrós Lera, José María: Historia Crítica del Cine Español. Id. mü. 125.

${ }^{617}$ García Escudero, José María: Cine español. Id. mü. 99-100.
} 
döntően állami támogatástól függjön egy-egy produkció jövője ${ }^{618}$ (a rendszerhez hü magánszemélyek, az illetékesek jóváhagyása mellett, eddig is beszállhattak egy-egy film gyártásába). Ezen új rendelkezések ,termelték ki” az Új Spanyol Film (Nuevo Cine Español) elnevezésü filmes generációt, akik már a frissen lefektetett kritériumoknak megfelelően, az új szempontok és lehetőségek figyelembevételével láthattak munkához. Carlos Saura szerint a filmmüvészeti főigazgató tevékenysége elengedhetetlen volt: „Úgy gondolom, García Escudero többet tett a spanyol filmért, mint bárki más ... García Escudero időszakát elemezve látható lesz, hogy nélküle tehetetlenek lettünk volna. Azokban a pillanatokban változtatásokat bevezetni a spanyol filmbe nagy kockázatot jelentett, és ő megtette". ${ }^{619}$ Már mandátumának első évében mozikba kerülhetett a Különböző (Diferente, Luis María Delgado, 1962) címü film, amely először mutatta be egyértelműen egy homoszexuális férfi és a társadalom közötti ellentéteket. García Escudero nevéhez füződik a müvész- és kísérleti mozik (cine de arte y ensayo) megalapítása és gyors ütemü elterjesztése is azzal a céllal, hogy a nagyközönséget kiszolgáló mozitermeken kívül kerülhessenek bemutatásra a mélyebb mondanivalót tartalmazó, valódi művészeti értékkel bíró, inkább film- és műértő szemeknek szánt alkotások, méghozzá a lehető legkevesebb cenzori beavatkozással. Az első ilyen termet 1967 júliusában avatták fel Barcelonában, müsorra tüzve Roman Polanski Iszonyatát (Repulsion, 1965). ${ }^{620}$ A film vetítése és a terem müködése is sikeres volt, így az elkövetkezendő hónapokban és években minden jelentősebb spanyol városban több ilyen profilú mozi is nyílt, kiegészítve ezzel az 1964 és 1969 között szinte megduplázódó filmklubok (132-ről 244-re) rendszerét. ${ }^{621}$ Ettől a pillanattól kezdve már elenyésző volt azon filmek száma, amelyeket legális vagy illegális úton ne láthatott volna a spanyol közönség. García Escudero önéletrajza szerint ő volt az első spanyol politikus, aki 1965-ben elfogadhatta a Szovjetunió meghívását is, és köszöntőt mondhatott a Moszkvai Filmfesztiválon a helyi Kommunista Párt küldöttei elött. $^{622}$

A részleges liberalizáció mellett alkalmanként ismét a filmpropagandához folyamodtak. Amikor a franciák a már meglévő felvételekből összeállították az egyértelműen a köztársaságiakkal szimpatizáló, később Oscar-díjra is jelölt Meghalni Madridbant (Mourir à Madrid, Frédéric Rossif, 1963), a Franco-kormány elkészítette mintegy „válaszként” a Meghalni Spanyolországbant (Morir en España, Mariano Ozores, 1965). Előbbi egy politikai

\footnotetext{
${ }^{618}$ Torreiro, Casimiro: “¿Una dictadura liberal?” in: Gubern, Román (és mások): Historia del cine español. Id. mü. 305-307.

${ }^{619}$ García Escudero, José María: La primera apertura. Id. mü. 19.

${ }^{620}$ Uő.: La primera apertura. Id. mü. 248 és 252.

${ }^{621}$ Hernández-Marcos, José Luis - Ruíz Butron, Eduardo A: Historia de los Cine Clubs en España. Id. mü. 100.

${ }^{622}$ García Escudero, José María: Mis siete vidas. Id. mü. 330.
} 
vitairat a felkelök ellen, utóbbi a nagyközönségnek szánt, könnyebben befogadható munka. A francia alkotás húsz órányi német, brit, szovjet, amerikai és francia archívumokban tárolt, a spanyol polgárháborúról készült felvételből montírozta össze a végeredményt, a fegyveres összecsapást a legyőzöttek szemszögéböl mutatta be; a spanyol mü nyelvezete visszatérést jelentett a 40-es évek agresszív propagandájához, a Falange retorikáját és ideológiáját idézte vissza, áradt belöle az ellenfél iránti gyülölet és megvetés, készítői a háborút és az azt kiváltó okokat a felkelők aspektusából jelenítették meg. A spanyol közönség a francia dokumentumfilmet nem láthatta 1978-ig. ${ }^{623}$

A spanyol film fellendülésének és az egyértelmủ nyitásnak ugyanaz vetett véget, mint a Franco-rendszer egészét tekintve a hasonló kezdeményezéseknek: megkeményedett a merev, mozdulatlan bunker csoport, amely túlzásnak tartotta a liberalizációt. 1967 őszén Franco felmenti García Escuderót ${ }^{624}$, majd kormányzati költségcsökkentésre hivatkozva számos államtitkárságot és főigazgatóságot megszüntetnek, így a filmmel foglalkozót is. Egy évvel később ismét felállítják, méghozzá nagyobb apparátussal, teljesen új személyekkel a vezetésben. A volt föigazgató azonban könyveiben és publikált naplójában sem tér ki részletesen a történtekre.

García Escudero intézkedéseinek hatása, mintegy hivatkozási alapként és követendő példaként, a rezsim bukásáig fennmaradt. Az utolsó években hozott, gyakran egymásnak ellentmondó határozatok, a kis teljesítményü stúdiók megsokszorozódása és a filmiparban dolgozó személyek tanácstalansága kisebb dimenzióban tükrözték mindazt, ami az agonizáló diktatúra magasabb szintjein történt. A Franco-rendszer bukása után, az átmenet időszakának éveiben még sokáig kellett várni, hogy a spanyol filmpolitika ismét hozzáértő kezekbe kerüljön, olyanok hozzák a döntéseket, akik többsíkú szempontrendszert vesznek tekintetbe.

A 60-as évek filmművészetének, filmpolitikájának, az egyszerre jelen lévő nyitásnak és a továbbra is meglévő szigorú irányításnak, a társadalom és a politika pillanatnyi állapotának kitűnő összegzése A hóhér (El verdugo, Luis García Berlanga, 1963), amely témáját és megvalósítását tekintve az egész Franco-rendszer kritikájaként is értelmezhető, mintegy mozgóképes összefoglalása a diktatúra ellentmondásainak. Általánosan elfogadott tény, hogy a spanyol filmtörténet legfontosabb alkotásáról van szó, éppen ezért disszertációm záró alfejezetét ennek a münek szentelem.

\footnotetext{
${ }^{623}$ A két változat közötti különbségeket részletesen bemutatja: Gubern, Román: 1936-1939: La guerra de España en la pantalla. Id. mü. 132-134; 148-149; ezt kiegészíti: Crusells, Magí: La Guerra Civil española: cine y propaganda. Id. mü. 107-132.

${ }^{624}$ BOE, 15-XII-1967.
} 


\section{A hóhér - El Verdugo}

Addigi filmjei kapcsán így szólt a rendezőről Franco tábornok: „Berlanga rosszabb, mint egy kommunista. Ö egy rossz spanyol”. ${ }^{625}$ Indoklást nem hozott fel, csak sejteni lehet, hogy az Isten hozta, Mr Marshall! és a Csütörtöki csodák szatirikus-élcelődő hangneme alapján juthatott erre a következtetésre.

A spanyol filmtörténetben az utolsó osztrák-magyarnak ${ }^{626}$ nevezett Luis García Berlanga korábbi sikereinek betetőzése volt az 1963-as év, ekkor készült el A hóhér. Valamelyest rokonítható Bacsó Péter A tanú (1969) című filmjével: mindkét filmet az adott nemzet elsőszámú klasszikusaként tartják számon manapság, még a fiatalabb generációk is nagy százalékban ismerik. A közbeszédben ma is előkelő helyet foglalnak el a dialógusokból származó idézetek, egysoros bölcsességek. A főszereplők, José Luis Rodríguez és Pelikán József kálváriája egy olyan politikai berendezkedés viszonyai között zajlik, amelyben éppen a főhős, a leginkább érintett személy nem érti, mi történik körülötte. Egyszerüen gondolkodó emberek, akik szeretnének kimaradni a hatalmi játszmákból, csak túlélni akarnak. A bemutatás időpontjában (A hóhér esetében 1964, A tanúnál tíz évvel a forgatás után, 1979) a szóban forgó nemzetek változáson mennek keresztül, legalábbis a kifelé mutatott kép szerint: Spanyolország a zárkózott, önellátó, keményvonalas időszakból az aperturista periódusba lép át, míg Magyarország a Kádár-rendszert a lehető legegyértelmübben szeretné megkülönböztetni a Rákosi-korszaktól. A két filmről már a premier időszakában is érezhető volt, hogy valami különleges értéket képviselnek, azóta pedig saját országukban az adott időszak jelképévé, kulturális ikonjává váltak.

A hóhér cselekménye a spanyol kisember hányattatásait tükrözi vissza. Egy kivégzés után a temetkezési vállalatnak dolgozó José Luis kapcsolatba kerül a hóhér Amadeóval és lányával, Carmennel. A két fiatal viszonyt kezd egymással, és amikor az öregúr erről értesül, nincs más választásuk, mint házasságra lépni. Ezzel a főszereplő lemond eredeti tervéről is, amely szerint Németországba vándorolna ki, hogy ott új életet kezdhessen. A gyermekáldás is hamarosan eljön. Hatalmas problémával találják szemben magukat, amikor kiderül, hogy Amadeo nyugdíjba vonulásával a neki kiutalt szolgálati lakást is elveszítik, ezért apa és

\footnotetext{
${ }^{625}$ Idézi: Taibo I, Paco Ignacio: Un cine para un imperio. Id. mü. 260.

${ }^{626}$ Berlanga egyik védjegyévé vált, hogy minden egyes filmjében megemlíti valamilyen kontextusban az Osztrák-Magyar Monarchiát, még akkor is, ha a cselekmény egyáltalán nem indokolja azt. A rendező soha nem adott erre világos magyarázatot, a filmtörténészek sem tudnak semmit ennek okáról. Amikor Berlanga 2010-ben elhunyt, a spanyol sajtóban több olyan cikket is közöltek, amelyek címükben utalást tettek erre: "Uno de los más grandes, tan grande como el Imperio Austro-húngaro...”; "El poeta del imperio austrohúngaro...”; "Berlanga, el último emperador austrohúngaro..."; "El Imperio Austrohúngaro está de luto" (érdekesség, hogy a monarchia neve szinte minden címben eltérő helyesírással szerepelt).
} 
leánya hosszas győzködése után José Luis elvállalja apósa megüresedő pozícióját. Mindezt úgy, hogy irtózik ettől a szakmától, és abban reménykedik, hogy senkit sem ítélnek halálra, így neki sem kell majd gyakorolnia a hivatását. Napjai állandó félelemben telnek, rettegve olvassa a bünügyi híreket, nehogy valakit elítéljenek, esetenként ő maga avatkozik közbe utcai veszekedéseknél, hogy így megakadályozza egy potenciális emberölés elkövetését. De elérkezik a pillanat, amikor nem menekülhet, Palma de Mallorcán végre kell hajtania egy ítéletet. Börtönőrök vonszolják el a kétségbeesve tiltakozó José Luist a kivégzés helyszínéig, ahol nincs más választása, mint teljesíteni a kötelességét. Egy lelkileg meggyötört fiatalember távozik Mallorca szigetéről. A végső párbeszéd José Luis és Amadeo között jelzi, mire számíthat a jövőben. „Soha többé nem teszem ezt meg, soha többé!”, mondja a fiatal hóhér. Apósa válasza: „Én is ezt mondtam az első alkalommal.”

A halálbüntetés kérdése természetesen kényes téma volt a korabeli Spanyolországban, Berlanga ellenezte az ilyen ítéleteket. ${ }^{627}$ Egy ügyvéd barátja megtörtént esete szolgált számára ösztönzésül, hogy elkészítse ezt a filmet ${ }^{628}$; ez a történet és a halálbüntetés elleni negatív érzései együttesen sarkallták arra, hogy megszülessen a film.

A hóhér első ránézésre szimplán a halálbüntetés elleni vád- és gúnyirat, ám ennél sokkal mélyebb jelentést hordoz magában. Berlanga müve egy látlelet a 60-as évek Spanyolországának társadalmáról, amely nem tud megnyílni. A nagypolitika meghirdette a apertúrát, de az emberek nem képesek alkalmazkodni, mert a régi korlátok továbbra is fennállnak: a nyitni akaró társadalom képtelen megnyílni, az elnyomott embertömegben az egyén szabadsága oly mértékben megkérdőjeleződik, hogy nem lehet ura a saját tetteinek. ${ }^{629}$ Nem csak a kivégzett egyén a diktatúra áldozata, hanem az is, aki életben marad.

Míg José Luis számára kínszenvedés a várakozás és az ítéletvégrehajtás, addig Amadeo a világ legtermészetesebb dolgaként tekint egy ilyen kivégzésre, rutinból cselekszik, és még Carmen számára sem teljesen világos, miért is kell rettegni ettől a feladattól. Egyértelmü: a társadalmat hozzászoktatták az ilyen formában megjelenő legális emberöléshez, szerves részévé vált az életnek, így inkább az kelt feltűnést és nemtetszést, ha valaki ódzkodik az élet törvény által kikényszerített kioltásától.

\footnotetext{
${ }^{627}$ Bevallotta, önzésből állt ezen az állásponton, ugyanis nem tudta elviselni azt a gondolatot, hogy egyszer talán ő is így végezheti, akár valóban elkövetett valamit, akár nem. A lehetőség, hogy őt valaha is halálra ítélhetik, megrémítette. Gómez Rufo, Antonio: Berlanga. Contra el poder y la gloria. Id. mü. 297.

${ }^{628}$ A jogász részt vett egy kivégzésen, ahol a hóhér jobban rettegett, mint az elkövető, nyugtatóinjekciót kellett neki beadni, hogy lecsillapodjon, és elvégezze feladatát a parancs szerint. Perales, Francisco: Luis García Berlanga. Id. mü. 250.

${ }^{629}$ Filmnyelvi eszközökkel ezt a folyamatot írja le Luis Buñuel klasszikusa, Az öldöklö angyal (El ángel exterminador, 1962) is.
} 
Berlanga és forgatókönyvírója, Rafael Azcona egy konkrét téma kapcsán a teljes társadalmi közeg elé állítanak (görbe) tükröt, így válik a cselekmény az egyén és a rendszer közötti párharc terepévé, felszínre kerülnek a rezsim legellentmondásosabb, legkegyetlenebb intézkedései és az általuk létrehozott fojtogató atmoszféra. Az sem gyakori más filmeseknél, hogy két olyan ellentétes fogalmat, mint a halál és a humor, ilyen tökéletesen tud párba állítani. A halálbüntetés mellett a teljes politikai és társadalmi berendezkedés is Berlangáék célpontja lett a filmben. Az elviselhetetlen és átláthatatlan bürokrácia megkeseríti a polgárok életét, semmit sem tudnak elintézni úgy, ahogyan azt szeretnék, mert minden felett az inkompetens bürokraták uralkodnak. Úgy tünik, mintha a fejlődés útjában is ők állnának. A katolikus egyház képmutatását pedig jól példázza az a jelent, amelyben egy alsóbb osztályba tartozó szerelmespár nem érdemli meg azt a pompát az esküvője során, amit az előkelőbbek.

A film tehát egyértelműen kritikusan közelíti meg a politikai és a társadalmi állapotokat, de az említett enyhülésnek, valamint García Escudero filmpolitikájának köszönhetően a közönség megtekinthette a filmet a mozikban.

A cenzori hatóság és Fraga Iribarne személyes utasítására tizennégy helyen avatkoztak be a mübe, összesen 4,31 percnyi anyagot vágtak ki belőle a két fö cenzori véleményezés során. ${ }^{630}$ A filmművészeti főigazgató szerint ez szükséges volt, mert a kérdéses jelenetek túlságosan provokatívak voltak, úgy biztosan nem mutathatták volna be a filmet. García Escudero szerint az alkotás egységén ez nem módosított érdemben és inkább azon kellene elgondolkozni, hogy más időkben, más személyekkel a döntéshozói pozícióban vajon milyen sorsa lett volna a filmnek. ${ }^{631}$ Berlanga azonban nem így gondolta, szerinte a cenzúra alapvetően megváltoztatta a film struktúráját. Mindennek hangot is adott, méghozzá nemzetközi sajtóorgánumokban, ahol többek között negatív képet festett az ország általános filmpolitikájáról. Egy firenzei napilapnak például azt nyilatkozta: „Az érték az a rezsim értéke. Aki nem alkalmazkodik, az nem remélhet túl sokat". 632

A hóhér igazán a nemzetközi környezetben lett népszerü, ugyanis a Velencei Filmfesztivál versenyfilmjeit válogató bizottságot lenyügözte Berlanga munkája, és felkérték, hogy nevezze be az alkotását. Ennek már a filmmüvészeti föigazgató sem örült, mivel a rendszerellenes hangvétel egyértelmü volt. Érezte, hogy amit belföldön még viszonylagos kontroll alatt tudott tartani, azt külföldön már nem tudja befolyásolni. A botrány pedig valóban kitört. A római spanyol nagykövet, a falangista Alfredo Sánchez Bella (korábban a

\footnotetext{
${ }^{630}$ AGA, Cultura. 36/03999-es doboz, 28221-es köteg és 36/04054-es doboz, 30306-os köteg.

${ }^{631}$ García Escudero, José María: Una política para el cine español. Madrid, Editora Nacional, 1967. 57.

${ }^{632}$ Idézi: García Escudero, José María: Una política para el cine español. Id. mü. 57.
} 
Hispán Kultúra Intézetének igazgatója) felháborodott a film velencei bemutatásán, és nem nyugodott addig, amíg bel- és külpolitikai vihart nem kavart. 1963 augusztusában egy igen terjedelmes levelet küldött a spanyol külügyminiszternek, amelyben részletesen kifejtette a problémát. Az alábbiakban összefoglalom a levél tartalmát, mert ez kiválóan mutatja, hogyan reagált egy fontos pozíciót betöltő diplomata erre a filmművészeti kritikára, méghozzá a nyitás periódusában. ${ }^{633}$

A nagykövet csak hallomásból ismerte a rövid szinopszist, magát az alkotást nem látta még, de már ez is elég volt ahhoz, hogy véleményt alkosson róla. Szerinte Spanyolország rossz hírét kelti a munka, rágalmazza a spanyol demokráciát, és a fekete humor tovább súlyosbítja a helyzetet. García Escuderót is Rómába hívatta, hogy együtt találjanak megoldást erre a problémára, ami nem lehet más, mint a film visszavonása. Ám a föigazgató úgy vélte, ezt nem tehetik meg, mivel spanyol-olasz koprodukcióról volt szó, és a másik fél nem egyezne bele, valamint ezzel veszélybe sodornák a két ország közötti, hosszú távra kötött filmmüvészeti szerződéseket is. A sajtó pedig még nagyobb botrányt keltene az ügyből (ekkorra már folyamatosan cikkeztek az olasz és más európai lapok a spanyol diplomaták kétségbeesett próbálkozásairól, hogy A hóhért el tudják lehetetleníteni). Miután Berlanga és producere, Nazario Belmar levetítették a filmet Sánchez Bellának, a nagykövet a korábbinál is hisztérikusabban reagált, a Spanyolország és társadalma ellen valaha is készített legelképesztőbb és legfelháborítóbb politikai pamfletnek minősítette, amelyben egy csepp humort sem talált. A diplomata és a rendező hosszas ideológiai vitába bocsátkoztak a halálbüntetés céljáról és természetéről, a társadalom erkölcsi állapotáról, valamint a külföld felé sugárzott Spanyolország-képről. Sánchez Bella nem értette, hogyan juthatott át a film a cenzori hatóság szigorán. Ezután arra a következtetésre jutott, hogy egy elöre eltervezett akcióról van szó, a film a szocialista realizmus legvérmesebb hagyományait követi abból a célból, hogy egyértelmű kommunista propagandát fejtsen ki. Elkészítésében szerinte számos bolsevik vett részt, akik úgy manipulálták Berlangát, hogy a rendező tulajdonképpen észre sem vette, milyen munkát tett le az asztalra. Belmar producer pedig a nagykövet szerint alapvetően jó és Franco-hü ember, de jellemgyenge és gyáva, már nem mer visszakozni, teljesen a filmesek befolyása alá került. García Escudero végeredményben csak átverés áldozata lett, őt nem szabad hibáztatni a történtekért. Ezek után Sánchez Bella tovább szövi az elméletét, amelynek végeredménye, hogy egy olasz-spanyol, egészen a legfelsőbb körökig érő nemzetközi kommunista-szabadkőmüves összeesküvés eredménye a film és annak velencei

\footnotetext{
${ }^{633}$ A levelet teljes terjedelmében közli: Gubern, Román - Font, Doménec: Un cine para el cadalso. Id. mü. 131138.
} 
bemutatója is. A küszöbön álló botrány ellensúlyozására azt javasolja, adjanak ki közleményeket, amelyek szerint a film cselekménye csak a képzelet szüleménye, az íróknak túl élénk a fantáziája, de látható, hogy Spanyolországban igazi demokrácia uralkodik, hiszen engednek bemutatni egy ilyen merő fikciót is. Ugyanakkor figyelmezteti külügyminiszterét: a jövőben nem szabad engedni, hogy felforgató elemek filmet és színházat készítsenek, könyveket írjanak, vagy bármiféle kulturális terméket állítsanak elő, meg kell tőlük tagadni a támogatást, mert ők a haza esküdt ellenségei.

Érdemes megjegyezni: amikor a politikai nyitásban főszerepet játszó Manuel Fraga Iribarnét 1969-ben eltávolítják a Tájékoztatási és Idegenforgalmi Minisztérium éléről, helyére éppen az említett volt római nagykövetet, Alfredo Sánchez Bellát nevezik ki, aki ismét keményebb szigort vezet be, vezetői stílusának egyes elemei idézett levelének hangneméhez lesznek hasonlóak.

A Spanyolországban ekkor lezajlott események is hozzájárultak a reakciókhoz. Nem sokkal a premier előtt végeztetett ki Franco három embert, a kommunista Julián Grimau-t, valamint az anarchista Francisco Granados Matát és Joaquín Delgadót, nagy nemzetközi visszhangot és tiltakozási hullámot kiváltva. A történtek miatt a Generalísimóra a külföldi sajtó „,a hóhér” gúnynevet akasztotta. Mindez a film bemutatója előtt történt, az áthallások, a sok véletlen többeknek szemet szúrt.

A végeredmény azonban nem lett olyan súlyos, mint amilyennek várták. Néhány olasz újságcikk kivételével A hóhért senki sem kezelte egyértelműen Franco-ellenes filmként, így a botrány tulajdonképpen ki is merült a nagykövet említett tiltakozásában. Ez viszont igen nagy nyilvánosságot kapott, az általa írt levelet pedig a mai napig a 60-as évek Spanyolországának egyik jellegzetes kordokumentumaként tartják számon. A film a Velencei Filmfesztiválon elnyerte a Filmkritikusok Nemzetközi Szövetsége díját, hatalmas kritikai és közönségsikert aratott, és ezzel igazi nemzetközi visszhangot kapott. Spanyolországban is örömmel fogadta a közönség $A$ hóhért, de nem sokáig maradt müsoron, a legtöbb mozi néhány hét után - felsőbb utasításra - felfüggesztette a vetítéseket. Csak a legmerevebb francói körök ítélték el, valamint János Károly későbbi uralkodó felesége, Zsófia hercegnő is, aki egy lisszaboni spanyol filmfesztiválon tekintette meg a filmet, és felháborodott a szerinte arcátlan Francoellenes hangvételen. ${ }^{634}$ Jelentős díjakban részesült belföldön is, főleg a szakmai szervezetek és a kritikusok jóvoltából.

\footnotetext{
${ }^{634}$ García Escudero: La primera apertura. Id. mű. 92.
} 
Berlangát a továbbiakban még a korábbiaknál is nagyobb fenntartásokkal kezelték, következő filmjéig négy évet kellett várnia, és azt is csak Argentína segítségével tudta megvalósítani. A hóhér utáni munkáinak többsége sem a közönség, sem a kritika részéről nem talált kedvező fogadtatásra, csak a 70-es évek végén és a 80-as évek elején készített, a demokratikus átmenetben talaját vesztett spanyol arisztokráciát szatirikus eszközökkel ábrázoló Nemzetinek nevezett trilógiával ${ }^{635}$ talált újra önmagára. Ez a három film visszaidézi Berlanga korai filmjeit, amikor a társadalom és a politikai elit képviselöit is maró gúny céltáblájává tette; a trilógia elkészítésében olyan történészek és politikusok segédkeztek neki, mint Javier Tusell, Ricardo de la Cierva és Marcelino Oreja. ${ }^{636}$

A hóhért az utókor nagy tiszteletben tartja; a már többször idézett reprezentatív közvélemény-kutatás ${ }^{637}$ szerint Berlanga mestermüve minden idők legtökéletesebb spanyol filmje, az alkotó pedig, maga mögé utasítva összes kollégáját, a legjobb rendező titulussal büszkélkedhet a rangsorban.

\footnotetext{
635 Nemzeti vadászat (La escopeta nacional, 1978), Nemzeti örökség (Patrimonio nacional, 1981), Nemzeti vagyon (Nacional III, 1982).

${ }^{636}$ Gómez Rufo, Antonio: Berlanga. Contra el poder y la gloria. Id. mü. 361-362.

${ }^{637}$ Tébar, Juan - Torres Dulce, Eduardo: „Cien españoles y el cine español. Encuesta.” Id. mü. 15-35.
} 


\section{Összegzés}

A nemzetközi tudományos életben Marc Ferro és Pierre Sorlin által megteremtett, Spanyolországban elsősorban Román Gubern és José María Caparrós Lera által képviselt, a történelem és a film kapcsolatával foglalkozó tudományterület Magyarországon még nem kapta meg az öt megillető figyelmet. Egy diktatúra ideológiai önmeghatározása, céljainak népszerüsítése és terjesztése a filmvásznon keresztül könnyen eljuthat a bel- és külföldi közönséghez, a filmek így referenciapontok is lehetnek az adott korszakot kutató történész számára. A spanyol Franco-diktatúrát ilyen szempontból vizsgáló értekezésem ezt a célt szolgáló esettanulmány.

A dolgozat elkészítéséhez használt primer források mennyisége a korábbiaknál átfogóbb képet ad a Franco-diktatúra filmpolitikájáról. A konkrét filmeken kívül az Archivo General de la Administraciónban található jelentések és levelezések, a Külügyminisztériumi Levéltár eddig kevéssé kutatott, spanyol filmekhez kapcsolódó iratanyaga, a korabeli publikációk, ismeretterjesztő anyagok és folyóiratok cikkei, valamint a korszak filmpolitikai életében meghatározó szerepet betöltő személyek írásai és visszaemlékezései hiteles forrásokként szolgáltak ahhoz, hogy a központi téma lényeges részleteit több szempontból is megvizsgálhassam. Kiegészítésként a témához kapcsolódó, Spanyolországban publikált szakirodalom releváns darabjait is felhasználtam.

Disszertációmban Francisco Franco tábornok filmpolitikáját nemzetközi környezetben vizsgáltam. Lenin, Sztálin, Mussolini és Hitler is kitüntetett figyelmet szenteltek a film tömegeket befolyásoló erejének, a források alapján azonban megállapítható, hogy a diktátorok közül Franco használta fel azt leghangsúlyosabban, mint a társadalomra döntő hatást gyakorló egyik elsődleges propagandaformát. A Caudillo és bizalmasai mindezt tudatosan megtervezett módon vitték véghez, megteremtették az ehhez szükséges intézményi hátteret is. A minisztériumok, főosztályok és cenzori testületek mellett a korabeli spanyol politikai és kulturális élet kiemelkedő alakjai is részeseivé váltak annak a folyamatnak, amelynek során a mozgókép főszerepet kapott a rezsim mindennapjaiban: előadásaikkal, újságcikkeikkel, elemzéseikkel és kulturális tevékenységükkel a filmet értékes művészeti formaként kezelték. A kezdeti teljes elutasítás után a katolikus egyház is védelmébe vette azt.

A kiemelt kormányzati figyelem ellenére nem beszélhetünk egységes filmpolitikáról a Franco-rendszerben. A diktatúra évtizedei során, mindenekelött a 60-as években, olyan politikusok kerültek kulcspozíciókba, akik a nyitás jegyében enyhítettek a szigoron. Egyes 
alkotók és filmrendezők, szembeszállva a cenzúra-bizottságokkal, már az 50-es években is lépéseket tettek a nemzeti megbékélés irányába, a disszidens filmesek pedig ettől az évtizedtől kezdve egyre nyíltabban fejthették ki véleményüket alkotásaikon keresztül nemzetközi környezetben is.

A disszertáció lapjain tágyalt filmek szubjektív válogatás eredményeként kerültek vizsgálatra: a diktatúrában forgatott, az állami ideológiához és propagandához igazodó, azt kiszolgáló művek közül saját döntésem alapján véltem úgy, hogy a kutatási téma megfelelő példái lesznek ezek a darabok. A legföbb témák és müfajok mindegyikéből a reprezentatívnak gondolt müvek szerepelnek a dolgozatban, minden esetben politikai és ideológiai megközelítéssel.

A nagy múlttal rendelkező spanyol filmtörténetírás az általam tárgyalt kérdések egy-egy szegmensét monográfiákban és tanulmánykötetekben tárgyalja, a diktatúrát meghatározó ideológiát és annak közvetlen és közvetett megjelenését a filmpolitikában, a filmiparban, valamint az alkotások teljes csoportját tekintve összefoglaló és kiértékelő jelleggel eddig kevéssé vizsgálták. Értekezésemmel kísérletet tettem arra, hogy egy ilyen típusú munkát készítsek. 


\section{Felhasznált források}

Filmográfia

\section{A témához kapcsolódó spanyol filmek a tárgyalt korszakból (1936-1975) kronológiai sorrendben}

1936 - Madrid védelmében (En Defensa de Madrid, Alianza de Intelectuales para la Defensa de la Cultura)

1936 - Portugália tiszteletére (Homenaje a Portugal)

1936 - Sanjurjo tábornok temetése (El entierro del General Sanjurjo, José Nunes das Neves)

1937 - A vizcayai front és július 18 (Frente de Vizcaya y 18 de julio, Sección Cinematográfica de FET y de las JONS)

1938 - Hadifoglyok (Prisioneros de guerra, Manuel Augusto García Viñolas)

1939 - Jelen! José Antonio Primo de Rivera temetésén (;Presente! En el enterramiento de José Antonio Primo de Rivera, Departamento Nacional de Cinematografía)

1939 - Jön már a kíséret (Ya viene el cortejo, Juan de Orduña)

1939 - Madridi front (Frente de Madrid, Edgar Neville)

1940 - A Baleár cirkáló (El crucero Baleares, Enrique del Campo)

1940 - Az Alcázarban a helyzet változatlan / Az Alcazár ostroma (Sin novedad en el Alcázar / L'assedio dell' Alcazar, Augusto Genina)

1941 - Harka! (;Harka!, Carlos Arévalo)

1941 - Repülöraj (Escuadrilla, Antonio Román)

1942 - Esküvő a pokolban (Boda en el infierno, Antonio Román)

1942 - Faj (Raza, José Luis Sáenz de Heredia)

1942 - Légió, hozzám! (¡A mí la Legión!, Juan de Orduña)

1942 - Tanger rejtélyei (Los misterios de Tánger, Carlos Fernández Cuenca)

1942 - Vörös és fekete (Rojo y negro, Carlos Arévalo)

1943 - A zászlóvivö (El abanderado, Eusebio Fernández Ardavín)

1943 - Bajnokok! (;Campeones!!, Ramón Torrado)

1943 - Elbüvölöen bolondok (Deliciosamente tontos, Juan de Orduña)

1945 - A Fülöp-szigetek utolsó harcosai (Los últimos de Filipinas, Antonio Román)

1947 - La Nao Capitana (La Nao Capitana, Florián Rey)

1947 - Szent királyné (Reina Santa, Rafael Gil)

1947 - Ursino hercegnője (La princesa de Ursinos, Luis Lucia)

1948 - Mare Nostrum (Mare Nostrum, Rafael Gil)

1948 - Szerelmi örület (Locura de amor, Juan de Orduña) 
1948 - Tizenkét órányi élet (Doce horas de vida, Francisco Rovira Beleta)

1949 - A Szentély nem adja meg magát (El Santuario no se rinde, Arturo Ruiz Castillo)

1949 - Béke (Paz, José Díaz Morales)

1949 - Semlegesség (Neutralidad, Eusebio Fernández Ardavín)

1950 - Aragóniai Agustina (Agustina de Aragón, Juan de Orduña)

1950 - Egy Faj szelleme (Espíritu de una Raza, José Luis Sáenz de Heredia)

1950 - Félnótás (Balarrasa, José Antonio Nieves Conde)

1951 - Amerika hajnala (Alba de América, Juan de Orduña)

1951 - Arccal a tenger felé (Rostro al mar, Carlos Serrano de Osma)

1951 - Barázdák (Surcos, José Antonio Nieves Conde)

1951 - Fátima asszonya (La Señora de Fátima, Rafael Gil)

1951 - Kasztília bátor asszonya (La leona de Castilla, Juan de Orduña)

1951 - Lola, a faszénárus (Lola la Piconera, Luis Lucia)

1952 - A Júdás (El Judas, Ignacio F. Iquino)

1952 - Közel az éghez (Cerca del cielo, Domingo Viladomat, Mariano Pombo)

1952 - Rettenthetetlen növér (Sor Intrépida, Rafael Gil)

1952 - Spanyol körút (Ronda española, Ladislao Vajda)

1952 - Üldözés Madridban (Persecución en Madrid, Enrique Gómez)

1952 - Üldözöttek (Perseguidos, José Luis Gamboa)

1953 - A dicsőség csarnoka (El pórtico de la gloria, Rafael J Silva)

1953 - Az a boldog pár (Esa pareja feliz, Juan Antonio Bardem, Luis García Berlanga)

1953 - Isten háborúja (La guerra de Dios, Rafael Gil)

1953 - Jeromín (Jeromín, Luis Lucia)

1953 - Útlevél egy angyalnak (Pasaporte para un ángel, Xavier Setó)

1954 - Ami soha nem hal meg (Lo que nunca muere, Julio Salvador)

1954 - Az ászok békére törekszenek (Los ases buscan la paz, Arturo Ruiz-Castillo)

1954 - Az örjárat (La patrulla, Pedro Lazaga)

1954 - Egy kereszt a pokolban (Una cruz en el infierno, José María Elorrieta)

1954 - Júdás csókja (El beso de Judas, Rafael Gil)

1954 - Kellemes húsvétot (Felices Pascuas, Juan Antonio Bardem)

1954 - Tizenegy pár futballcipö (Once pares de botas, Francisco Rovira Beleta)

1954 - Tizenöt éve halt meg (Murió hace quince años, Rafael Gil)

1955 - Egy biciklista halála (Muerte de un ciclista, Juan Antonio Bardem)

1955 - Hajnalhasadás (El canto del gallo, Rafael Gil)

1955 - Marcelino, kenyér és bor (Marcelino pan y vino, Ladislao Vajda) 
1956 - A csend légiója (La legión del silencio, José Antonio Nieves Conde, José María Forqué)

1956 - A jelenség (El fenómeno, José María Elorrieta)

1956 - A torreádor / Jacinto bácsikám (Mi tío Jacinto, Ladislao Vajda)

1956 - A végtelen front (El frente infinito, Pedro Lazaga)

1956 - Calabuch (Calabuch, Luis García Berlanga)

1956 - Fö utca (Calle Mayor, Juan Antonio Bardem)

1956 - Nagykövetek a pokolban (Embajadores en el infierno, José María Forqué)

1956 - Nászút (Viaje de novios, León Klimovsky)

1956 - Torrepartida (Torrepartida, Pedro Lazaga)

1957 - A béke hírnökei (Mensajeros de paz, José María Elorrieta)

1957 - A bérlö (El inquilino, José Antonio Nieves Conde)

1957 - A bosszú (La venganza, Juan Antonio Bardem)

1957 - Csütörtöki csodák (Los jueves, milagro, Luis García Berlanga)

1957 - Egy angyal szállt le Brooklynban (Un ángel pasó por Brooklyn, Ladislao Vajda)

1957 - És a poklot választotta (Y eligió el infierno, César Fernández Ardavín)

1957 - Faustina (Faustina, José Luis Sáenz de Heredia)

1957 - Vérrapszódia (Rapsodia de sangre, Antonio Isasi-Isasmendi)

1958 - A lakásocska (El pisito, Marco Ferreri)

1958 - Az angyal a csúcson van (El ángel está en la cumbre, Jesús Pascual)

1958 - Hová mész, XII. Alfonz? (¿Dónde vas, Alfonso XII?, Luis César Amadori)

1959 - A hü gyalogság (La fiel infantería, Carlos Arévalo)

1960 - A béke sosem jön el (La paz empieza nunca, León Klimovsky)

1960 - A csavargók (Los golfos, Carlos Saura)

1960 - Az autócska (El cochecito, Marco Ferreri)

1960 - Hová mész, te szomorú ember? (¿Dónde vas, triste de ti?, Alfonso Balcazar)

1961 - Akik nem mentünk a háborúba (Los que no fuimos a la guerra, Julio Diamante)

1961 - Viridiana (Viridiana, Luis Buñuel)

1962 - Különbözö (Diferente, Luis María Delgado)

1962 - Palma-öböl (Bahía de Palma, Juan Bosch)

1963 - A Csendes-óceán hódítói (Los conquistadores del Pacífico, José María Elorrieta)

1963 - A hóhér (El verdugo, Luis García Berlanga)

1964 - Banditasirató (Llanto por un bandido, Carlos Saura)

1964 - Franco, ez az ember (Franco, ese hombre, José Luis Sáenz de Heredia)

1965 - A vadászat (La caza, Carlos Saura) 
1965 - Meghalni Spanyolországban (Morir en España, Mariano Ozores)

1970 - Drakula gróf (El conde Drácula, Jesús Franco)

1970 - Tristana (Tristana, Luis Buñuel)

1971 - Dalok egy háború utánra (Canciones para después de una guerra, Basilio Martín Patino)

1973 - Caudillo (Caudillo, Basilio Martín Patino)

\section{Más nemzetiségü, a téma szempontjából releváns filmek kronológiai sorrendben}

1915 - Egy nemzet születése /Amerika höskora (The Birth of a Nation, D. W. Griffith)

1920 - Dr. Caligari (Das Kabinett des Doktor Caligari, Rober Wiene)

1924 - A sztrájk (Стачка, Szergej Mihajlovics Eizentein)

1925 - Patyomkin páncélos (Броненосеи Потёмкин, Szergej Mihajlovics Eizenstein)

1928 - Október (Октябрь, Szergej Mihajlovics Eizenstein)

1931 - Drakula (Dracula, Tod Browning)

1931 - Drakula (Drácula, George Melford)

1935 - Az akarat diadala (Triumph des Willens, Leni Riefenstahl)

1935 - Az asszony ördög (The Devil is a Woman, Josef von Sternberg)

1936 - Sanjurjo tábornok temetése (Funeral do General Sanjurjo, José Nunes das Neves)

1936 - Út Madridba (A Caminho de Madrid, Anibal Contreiras)

1937 - Arriba España (LUCE)

1937 - A spanyol föld (The Spanish Earth, Joris Ivens)

1937 - A vérző Spanyolország (Magyar Világhíradó)

1937 - Az utolsó vonat Madridból (The Last Train from Madrid, James P. Hogan)

1937 - Spanyolország szíve (Heart of Spain, Herbert Kline, Charles Korvin)

1937 - Szerelem tüz alatt (Love under Fire, George Marshall)

1938 - Blokád (Blockade, William Dieterle)

1938 - Hösi Spanyolország (España heroica, Joaquín Reig Gonzálbes)

1938 - Visszatérés az életbe (Return to Life, Henri Cartier-Bresson)

1939 - Elfújta a szél (Gone with the Wind, Victor Fleming, George Cukor, Sam Wood)

1939 - Spanyolország egy, nagy, szabad! A vörös barbárságtól a fasiszta civilizáció gyözelméig (;España una, grande, libre! Dalla barbarie rossa al trionfo della civiltá fascista.

Giorgio Ferroni - LUCE)

1940 - A diktátor (The Great Dictator, Charles Chaplin)

1940 - A zsidó Süss (Jud Sïß, Veit Harlan)

1940 - Kelj fel, szerelmem (Arise My Love, Mitchell Leisen) 
1942 - Casablanca (Casablanca, Kertész Mihály)

1943 - Akiért a harang szól (For Whom the Bell Tolls, Sam Wood)

1945 - A remény (Sierra de Teruel - L'espoir, André Malraux)

1946 - Gilda (Gilda, Charles Vidor)

1948 - Kolumbusz Kristóf (Christopher Columbus, David McDonald)

1951 - Egy amerikai Párizsban (An American in Paris, Vincente Minnelli)

1951 - Pekingi expressz (Peking Express, William Dieterle)

1953 - A palást (The Robe, Henry Koster)

1953 - Mogambo (Mogambo, John Ford)

1954 - A hegyek alján / A mélység birodalma (Tiefland, Leni Riefenstahl)

1954 - Rómeo és Júlia (Romeo and Juliet, Renato Castellani)

1956 - Kereslek téged (Ich suche Dich, O.W. Fischer)

1957 - Büszkeség és szenvedély (The Pride and the Passion, Stanley Kramer)

1957 - Szállnak a darvak (Летят журавли, Mihalil Kalatozov)

1959 - Don Quijote (Дон Kuхот, Grigori Kozintsev)

1959 - John Paul Jones (John Paul Jones, John Farrow)

1960 - Spartacus (Spartacus, Stanley Kubrick)

1961 - El Cid (El Cid, Anthony Mann)

1961 - Királyok Királya (King of Kings, Nicholas Ray)

1962 - Arábiai Lawrence (Lawrence of Arabia, David Lean)

1963 - Kleopátra (Cleopatra, Joseph L. Mankiewicz)

1963 - Meghalni Madridban (Mourir à Madrid, Frédéric Rossif)

1963 - 55 nap Pekingben (55 Days at Peking, Nicholas Ray)

1964 - A cirkusz világa (Circus World, Henry Hathaway)

1964 - A Római Birodalom bukása (The Fall of the Roman Empire, Anthony Mann)

1964 - Az Elesettek Völgye (El Valle de los Caídos, Andrew Marton)

1964 - Hamlet (Гамлет, Grigori Kozintsev)

1965 - Doktor Zsivágó (Doctor Zhivago, David Lean)

1965 - Iszonyat (Repulsion, Roman Polanski)

1966 - A Biblia (The Bible: In the Beginning..., John Huston)

1967 - A piszkos tizenkettö (The Dirty Dozen, Robert Aldrich)

1969 - A tanú (Bacsó Péter)

1970 - Patton tábornok (Patton, Franklin J Schaffner)

1982 - Gandhi (Gandhi, Richard Attenborough) 


\section{További hivatkozott spanyol filmek és televíziós sorozatok kronológiai sorrendben}

1920-as évek - A gyóntató (El confesor, Ramón és Ricardo de Baños)

1920-as évek - A ministráns (El ministro, Ramón és Ricardo de Baños)

1920-as évek - Hölgyek rendelöje (Consultorio de señoras, Ramón és Ricardo de Baños)

1926 - A nö, aki rosszul ment férjhez (La malcasada, Francisco Gómez Hidalgo)

1927 - Május másodika (El dos de mayo, José Buchs)

1929 - Andalúziai kutya (Un chien andalou, Luis Buñuel)

1932 - Föld, kenyér nélkül (Las Hurdes - Tierra sin pan, Luis Buñuel)

1935 - A galamb ünnepe (La verbena de la Paloma, Benito Perojo)

1978 - Nemzeti vadászat (La escopeta nacional, Luis García Berlanga)

1979 - Faj: Franco szelleme (Raza: el espíritu de Franco, Jorge Herralde)

1980 - A cuencai büntény (El crimen de Cuenca, Pilar Miró)

1980 - ... És a harmadik évben feltámadt (... Y al tercer año, resucitó, Rafael Gil)

1981 - Nemzeti örökség (Patrimonio nacional, Luis García Berlanga)

1982 - Nemzeti vagyon (Nacional III, Luis García Berlanga)

1986 - Dragon Rapide (Dragon Rapide, Jaime Camino)

1988 - Várj rám az égben (Espérame en el cielo, Antonio Mercero)

2001-töl - Meséld el, hogyan történt (Cuéntame cómo pasó, TV-sorozat)

2005 - 2012 - Szeretni zavaros idökben (Amar en tiempos revueltos, TV-sorozat)

2008 - Május vére (Sangre de Mayo, José Luis Garci)

2008 - November 20: Franco utolsó napjai (20-N: los últimos días de Franco, Roberto Bodegas)

2009-tö1 - Vörös sas (Águila roja, TV-sorozat)

2011 - Budapest angyala (El ángel de Budapest, Luis Oliveros)

\section{További hivatkozott más nemzetiségü filmek és televíziós sorozatok kronológiai sorrendben}

1915 - Az Alamo mártírjai (The Martyrs of the Alamo, Christy Cabanne)

1937 - Az Alamo hösei (Heroes of the Alamo, Harry L. Fraser)

1941 - Lady Hamilton (That Hamilton Woman, Alexander Korda)

1941 - Vaskorona (La corona di ferro, Alessandro Blasetti)

1943 - Bernadette dala (The Song of Bernadette, Henry King)

1948 - A vasfüggöny (The Iron Curtain, William A. Wellman)

1949 - A vörös Duna (The Red Danube, George Sidney) 
1952 - A fiam, John (My Son John, Leo McCarey)

1952 - Miasszonyunk Fatima csodája (The Miracle of Our Lady Fatima, John Brahm)

1953 - Földönkívüli jövevények (It Came from Outer Space, Jack Arnold)

1953 - Hódítók a Marsról (Invaders from Mars, William Cameron Menzies)

1956 - A testrablók támadása (Invasion of the Body Snatchers, Don Siegel)

1958 - A budapesti rém (The Beast of Budapest, Harmon Jones)

1962 - Az öldöklö angyal (El ángel exterminador, Luis Buñuel)

1963 - Zapruder Film (Zapruder Film, Abraham Zapruder)

1966-1969 - Star Trek - Ürszekerek (Star Trek, TV-sorozat)

1970 - M.A.S.H. (M.A.S.H., Robert Altman)

1972-1983 - M.A.S.H. (M.A.S.H., TV-sorozat)

1979 - Apokalipszis most (Apocalypse Now, Francis Ford Coppola)

1985 - Mussolini és én, Galeazzo Ciano (Mussolini and I, Alberto Negrin)

1986 - A szakasz (Platoon, Oliver Stone)

1987-1994 - Star Trek: Az új nemzedék (Star Trek: The Next Generation, TV-sorozat)

1988-1991 - China Beach (China Beach, TV-sorozat)

1989 - A háború áldozatai (Casualties of War, Brian DePalma)

1989 - Született július 4-én (Born on the Fourth of July, Oliver Stone)

1991 - A legbelsőbb körök (The Inner Circle, Andrej Koncsalovszkij)

2001 - Az elit alakulat (Band of Brothers, TV-sorozat)

2004 - A bukás (Der Untergang, Oliver Hirschbiegel)

2004 - A normandiai partraszálláshoz vezetö út (Ike: Countdown to D-Day, Robert Harmon)

2005 - Irak (Over There, TV-sorozat)

2006 - Levelek Iwo Dzsimáról (Letters from Iwo Jima, Clint Eastwood)

2007-2010 - Tudorok (The Tudors, TV-sorozat)

2008 - Che - A gerilla (Che: Part Two, Steven Soderbergh)

2008 - Che - Az argentin (Che: Part One, Steven Soderbergh)

2008 - Gyilkos megszállás (Generation Kill, TV-sorozat)

2010 - A hös alakulat (The Pacific, TV-sorozat)

2011-től - Borgiák (The Borgias, TV-sorozat) 


\section{Levéltári források}

\section{- Archivo del Ministerio de Asuntos Exteriores (AMAE)}

R-11626-os köteg, 23-as számú jelentés

R-10208/66; „Funciones políticas de la Dirección General de Relaciones Culturales”, $2 / \mathrm{II} / 1959$

R-592, Gabinete Diplomático de Prensa y Propaganda. Informe de la Oficina de Prensa del Cuartel General de Burgos a la Secretaria de Relaciones Exteriores, 20/10/1936.

R-1724/126-os köteg

\section{- Archivo General de la Administración (AGA)}

$\underline{\text { Cultura }}$

21/165-ös doboz

36/03170-es doboz, 02656-os köteg

36/03185-ös doboz, 03611-es köteg

36/03331-es doboz, 08318-as köteg

36/03336-os doboz, 08451-es köteg

36/03389-es doboz, 09973-as köteg

36/03391-es doboz, 10031-es köteg

36/03410-es doboz, 10634-es köteg

36/03415-ös doboz, 10774-es köteg

36/03420-as doboz, 10932-es köteg

36/03437-es doboz, 11370-es köteg

36/03447-es doboz, 11602-es köteg

36/03475-ös doboz, 12359-es köteg

36/03489-es doboz, 12723-as köteg

36/03500-ás doboz, 13015-ös köteg

36/03535-ös doboz, 13868-as köteg

36/03570-es doboz, 14899-es köteg

36/03593-as doboz, 15750-es köteg

36/03621-es doboz, 16675-ös köteg

36/03743-as doboz, 20137-es köteg

36/03745-ös doboz, 20225-ös köteg

36/03835-ös doboz, 22650-es köteg

36/03999-es doboz, 28221-es köteg

36/04054-es doboz, 30306-os köteg

36/04539-es doboz

36/04731-es doboz

36/05261-es doboz, 87854-es köteg

Presidencia

51/20891-es doboz

\section{Boletín Oficial del Estado (BOE)}

24-IV-1938; 5-XI-1938; 18-II-1939; 30-VII-1939; 21-X-1939; 25-II-1940; 2-III-1940; 7-XII1940; 26-XI-1942; 22-XII-1942; 31-VII-1943; 23-VI-1944; 11-X-1947; 31-III-1952; 05-IX1957; 19-III-1966; 15-XII-1967; 24-II-1976; 12-IV-1977 


\section{A tárgyalt időszakban megjelent könyvek és a kapcsolódó személyek irásai, önéletrajzai, naplói}

Andrade, Jaime de: Raza. Anecdotario para el guión de una película. Madrid, Numancia, 1942.

Azorín: El cine y el momento. Madrid, Biblioteca Nueva, 1953.

Azorín: El efímero cine. Madrid, Afrodisio Aguado, 1955.

Cabero, Juan Antonio: Historia de la cinematografía española (1896-1948). Madrid, Gráficas Cinema, 1949.

Castro, Antonio: El cine español en el banquillo. Valencia, Fernando Torres, 1974.

El cine español. Madrid, Oficina Informativa Española, 1949.

El cine y los católicos. Madrid, Editorial Aldecoa, 1941.

García Escudero, José María: Cine español. Madrid, Ediciones Rialp, 1962.

García Escudero, José María: Cine para el año 2000. Madrid, Zero, 1971.

García Escudero, José María: La historia en cien palabras del cine español y otros escritos sobre cine. Salamanca, Publicaciones del Cine-club del SEU, 1954.

García Escudero, José María: La primera apertura. Diario de un director general. Barcelona, Editorial Planeta, 1978.

García Escudero, José María: Mis siete vidas. De las brigadas anarquistas a juez del 23-F. Editorial Planeta, Barcelona, 1995.

García Escudero, José María: Una política para el cine español. Madrid, Editora Nacional, 1967.

García Escudero, José María: Vamos a hablar de cine. Madrid, Salvat Editores - Alianza Editorial, 1970.

García Maroto, Eduardo: Aventuras y desventuras del cine español. Barcelona, Plaza \& Janes Editores, 1988.

Giménez Caballero, Ernesto: Amor a México (a través de su cine). Madrid, Seminario de Problemas Hispanoamericanos, 1948.

Méndez-Leite, Fernando: Historia del cine español. Madrid, Ediciones Rialp, 1965.

\section{A tárgyalt idöszakban megjelent folyóirat- és újságcikkek}

„A propósito de un cine latino” in: Primer Plano, No. 19. 1941. április 13.

Ballesteros, Serafín: „Para navegar en un mar de confusiones” in: Primer Plano, No. 172. 1944. január 30.

Bardem, Juan Antonio: „Informe sobre la situación actual de nuestra cinematografía” in: Objetivo, No. 6. 1955. június. 7-8.

Casares, Francisco: „El cine en función de la historia” in: Primer Plano, No. 66. 1942. február 18. 
Casares, Francisco: „El cinema al servicio de la historia” in: Radiocinema, No. 70. 1942. november 3 .

Centeno, Félix: „El cine español en América” in: Primer Plano, No. 102. 1942. szeptember 27.

„Contra el doblaje de las películas” in: Primer Plano, No. 154. 1943. október 26.

Cortés Cavanillas, Julián: „Panorama prometedor” in: Primer Plano, No. 109. 1942. november 13 .

„Entrevistas sobre Raza” in: Radiocinema, No. 72. 1942. január 30.

„Estreno de Raza” in: Primer Plano, No. 65. 1942. január 11.

„Expediente de rodaje para Raza” in: Primer Plano, No. 42. 1941. április 10.

García Viñolas, Manuel Augusto: „Manifiesto a la cinematografía española I-V” in: Primer Plano, No. 1. 1940. október 20; No. 2. 1940. október 27; No. 3. 1940. november 3; No. 4. 1940. november 10; No. 5. 1940. november 17.

García Viñolas, Pío: „La escasez de asuntos históricos en nuestra pantalla” in: Primer Plano, No. 17. 1941. február 9.

Genina, Augusto: „Por qué he realizado <Sin novedad en el Alcázar>” in: Primer Plano, No. 3. 1940. november 3 .

Giménez Caballero, Ernesto: „España y el cine” in: Primer Plano, No. 100. 1942. október 13.

Gómez Tello, Luis: „El Santuario no se rinde” in: Primer Plano, No. 480. 1949. december 25.

„La censura cinematográfica, tema palpitante” in: Espectáculo, No. 50. 1951. május. 2-3.

„Los académicos españoles y el cine” en: Primer Plano, No. 1. 1940. október 20.

Mostaza, Bartolomé: „El cine como propaganda” in: Primer plano, No. 10. 1940. december 22.

„Necesidad de un cine histórico español” in: Primer Plano, No. 95.1942 augusztus 9.

„Raza” in: Primer Plano, No. 86. 1942. június 7.

Romero-Marchent, Joaquín: „Cinema nacional. Comentarios al margen” in: Radiocinema, No. 44. 1940. január 15.

Sainz y Díaz, José: „Hacia un cinema nacional. La misión de la pantalla: distraer y educar” in Radiocinema, No. 50. 1940. április 15.

Santos, Mateo: „Resurrección de Don Quijote” in: Film Popular, No. 291. 1932. március 10.

„Se crea NO-DO” en: Primer Plano, No. 115. 1942. december 27.

„Síntesis de una polémica” in: Primer Plano, No. 178. 1944. március 12. 


\section{Felhasznált irodalom}

\section{Könyvek és monográfiák spanyol film és filmtörténet témában}

Abella, Rafael - Cardona, Gabriel: Los años del NO-DO. Barcelona, Destino, 2008.

Álvarez Berciano, Rosa - Sala Noguer, Ramón: El cine en la zona nacional, 1936-39. Bilbao, Mensajero, 2000.

Amo García, Alfonso del (szerk.): Catálogo general del cine de la Guerra Civil. Madrid, Cátedra - Filmoteca Española, 1996.

Bardem, Juan Antonio: Y todavía sigue. Memorias de un hombre de cine. Barcelona, Ediciones B, 2002.

Berthier, Nancy - Seguin, Jean Claude: Cine, nación y nacionalidades en España. Madrid, Casa de Velázquez, 2007.

Buñuel, Luis: Utolsó leheletem. Budapest, L’Harmattan, 2006.

Camino Gutiérrez Lanza, María del: Traducción y censura de textos cinematográficos en la España de Franco: Doblaje y subtitulado inglés-español (1951-1975). Universidad de León, Secretariado de Publicaciones, 2000.

Caparrós Lera, José María: Arte y política en el cine de la República (1931-1939). Barcelona, Universidad de Barcelona, 1981.

Caparrós Lera, José María: Cine Español. Una historia por autonomías, Vols. I-II (szerk.). Barcelona, PPU, 1996-1998.

Caparrós Lera, José María: El cine español bajo el régimen de Franco, 1936-1975. Barcelona, Edicions de la Universitat de Barcelona, 1983.

Caparrós Lera, José María: El cine español de la democracia. Barcelona, Anthropos, 1992.

Caparrós Lera, José María: El cine político visto después del franquismo. Barcelona, Dopesa, 1978.

Caparrós Lera, José María: El cine republicano español, 1931-1939. Barcelona, Dopesa, 1977.

Caparrós Lera, José María: Estudios sobre el cine español del franquismo (1941-1964). Valladolid, Fancy Ediciones, 2000.

Caparrós Lera, José María: Historia crítica del cine español. Barcelona, Ariel, 1999.

Caparrós Lera, José María: Historia del cine español. Madrid, T \& B, 2007.

Caparrós Lera, José María - Crusells, Magí - Mamblona, Ricard: 100 documentales para explicar historia. Madrid, Alianza Editorial, 2010.

Caparrós Lera, José María - Crusells, Magí: Cinema en temps de guerra, exili i repressió. Barcelona, Memorial Democrátic, D.L. 2010.

Caparrós Lera, José María - Crusells, Magí - España, Rafael de: Las grandes películas del cine español. Madrid, Ediciones JC, 2007.

Caparrós Lera, José María - España, Rafael de: The Spanish Cinema: A Historical Approach. Barcelona, Centre for Cinematic Research "Film-Historia", 1987. 
Castro de Paz, José Luis: El destino se diculpa: el cine de José Luis Sáenz de Heredia. Valencia, Ediciones de la Filmoteca, 2011.

Castro de Paz, José Luis: Un cinema herido. Los turbios años cuarenta en el cine español (1939-1950). Barcelona, Paidós, 2002.

Castro de Paz, José Luis (és mások, szerk.): La nueva memoria. Historia(s) del cine español, (1939-2000). A Coruña, Vía Láctea Editorial, 2005.

Castro de Paz, José Luis - Cerdán, Josetxo (szerk.): Suevia Films - Cesáreo González: treinta años de cine español. A Coruña, Centro Galego de Artes da Imaxe, 2005.

Cerón Gómez, Juan Francisco: El cine de Juan Antonio Bardem. Universidad de Murcia Primavera Cinematográfica de Lorca, 1998.

Coma, Javier: La Brigada Hollywood. Barcelona, Flor del Viento Ediciones, 2002.

Conesa, Maite (szerk.): El cine español, desde Salamanca (1955/1995). Salamanca, Junta de Castilla y León, 1995.

Crusells, Magí: Cine y Guerra Civil Española: imágenes para la memoria. Madrid, Ediciones JC, 2006.

Crusells, Magí: La Guerra Civil española: cine y propaganda. Barcelona, Editorial Ariel, 2000.

Crusells, Magí: Las Brigadas Internacionales en la pantalla. Universidad de Castilla La Mancha, 2002.

Delgado Casado, Juan: La bibliografía cinematográfica española. Madrid, Arco/libros, 1993.

Diez Puertas, Emeterio: Historia social del cine en España. Editorial Fundamentos, Madrid, 2003.

España, Rafael de: De la Mancha a la pantalla. Aventuras cinematográficas del ingenioso hidalgo. Barcelona, Publicacions i Edicions UB, 2007.

España, Rafael de: Directory of Spanish and Portugese Film-Makers and Films. Westport, Greenwood, 1994.

Fanés, Félix: Cifesa, la antorcha de los éxitos. Valencia, Institución Alfonso el Magnánimo, 1982.

Fernández Cuenca, Carlos: La guerra de España y el cine. Madrid, Editora Nacional, 1972.

Font, Doménec: Del azul al verde. Barcelona, Editorial Avance, 1976.

Galán, Diego: Pilar Miró. Nadie me enseñó a vivir. Barcelona, DeBolsillo, 2007.

García de Dueñas, Jesús: El Imperio Bronston. Madrid, Ediciones del Imán - Filmoteca de la Generalitat Valenciana, 2000.

García de Dueñas, Jesús - Gorostiza, Jorge (szerk.): Los estudios cinematográficos españoles. Madrid, Academia de las Artes y las Ciencias Cinematográficas de España. 2001.

García Rodrigo, Jesús - Rodríguez Martínez, Fran: El cine que nos dejó ver Franco. Toledo, Junta de Comunidades de Castilla-La Mancha, 2005.

Gil, Alberto: La censura cinematográfica en España. Barcelona, Ediciones B, 2009.

Gómez Bermúdez de Castro, Ramiro: Evolución de la producción cinematográfica española (con especial estudio del periodo 1975-1985). Doktori értekezés. Madrid, Universidad 
Complutense de Madrid, Facultad de Ciencias de la Información, Departamento de Comunicación Audiovisual, 1989.

Gómez Rufo, Antonio: Berlanga. Confidencias de un cineasta, Madrid, Ediciones JC, 2000.

Gómez Rufo, Antonio: Berlanga. Contra el poder y la gloria. Madrid, Ediciones Temas de Hoy, 1990.

González Ballesteros, Teodoro: Aspectos jurídicos de la censura cinematográfica en España. Madrid, Editorial de la Universidad Complutense, 1981.

González González, Luis Mariano: Fascismo, kitsch y cine histórico español. Cuenca, Universidad de Castilla-La Mancha, 2009.

Guarner, José Luis: 30 años de cine en España. Barcelona, Editorial Kairós, 1971.

Gubern, Román: Carlos Saura. Festival Iberoamericano de Cine de Huelva, 1979.

Gubern, Román: Cine contemporáneo. Barcelona, Salvat, 1974.

Gubern, Román: Cine español en el exilio. Barcelona, Editorial Lumen, 1976.

Gubern, Román: El cine sonoro en la II República (1929-1936). Barcelona, Lumen, 1977.

Gubern, Román: Historia del cine. Barcelona, Ed. Danae, 1969.

Gubern, Román: La censura. Función política y ordenamiento jurídico bajo el franquismo (1936-1975). Barcelona, Ediciones Península, 1981.

Gubern, Román: 1936-39: La guerra de España en la pantalla. Madrid, Filmoteca Española, 1986.

Gubern, Román: Proyector de luna. La Generación del 27 y el cine. Barcelona, Anagrama, 1999.

Gubern, Román: Raza: un ensueño del general Franco. Madrid, Ediciones 99, 1977.

Gubern, Román (szerk.): Un siglo de cine español. Madrid, Academia de las Artes y las Ciencias Cinematográficas de España, 1997.

Gubern, Román: Val de Omar, cinemista. Granada, Diputación Provincial de Granada, 2004.

Gubern, Román - Font, Doménec: Un cine para el cadalso. Barcelona, Editorial Euros, 1975.

Gubern, Román - Hammond, Paul: Los años rojos de Luis Buñuel. Madrid, Editorial Cátedra, 2009.

Heredero, Carlos F.: Las huellas del tiempo. Cine español 1951-1961. Valencia/Madrid, Filmoteca Valenciana/Filmoteca Española, 1993.

Hernández-Marcos, José Luis - Ruíz Butron, Eduardo A: Historia de los Cine Clubs en España. Madrid, Ministerio de Cultura, Dirección General de Cinematografía, 1978.

Herrera, Javier - Martínez-Carazo, Cristina (szerk): Hispanismo y cine. Madrid - Frankfurt am Main, Iberoamericana - Vervuert, 2007.

Julián, Óscar de (szerk.): De Salamanca a ninguna parte. Diálogos sobre el Nuevo Cine Español. Salamanca, Junta de Castilla y León, 2002.

Lorenzo Benavente, Juan Bonifacio: Asturias y el cine. Gijón, Mases Ediciones, 1984.

Llorente Hernández, Ángel: Arte e ideología en el franquismo (1936-1951). Madrid, Visor, 1995. 
Martínez-Bretón, Juan Antonio: Libertad de expresión cinematográfica durante la II República Española. Madrid, Editorial Fragua, 2000.

Martínez-Carazo, Cristina: Bibliografía cine español. Alicante, Biblioteca Virtual Miguel de Cervantes, 2008.

Elérhető: http://www.cervantesvirtual.com/obra/bibliografia-cine-espanol--0/ (2012-11-20)

Matellano García, Víctor: Bienvenido, Míster Marshall: De la anécdota al cine con un pequẽ̃o pueblo castellano. La Comarca, Colmenar Viejo, 1997.

Mazzoccoli, Franco: Film Luce e guerra di Spagna. Torino-Venezia, L'Archivo Nazinale Cinematografico della Resistenza - La Biennale di Venezia, 1976.

Montero, Julio - Paz, Maria Antonia: La larga sombra de Hitler. El cine nazi en España (1933-1945). Madrid, Ediciones Cátedra, 2009.

Neuschafer, Hans-Jörg: Adiós a la España eterna. Madrid - Barcelona, Ministerio de Asuntos Exteriores - Editorial Anthropos, 1994.

Pablo, Santiago de: Tierra Sin Paz. Guerra Civil, cine y propaganda en el País Vasco. Madrid, Biblioteca Nueva, 2006.

Palacio, Manuel: Historia de la televisión en España. Barcelona, Gedisa, 2001.

Pastor Petit, Doménec: Hollywood responde a la Guerra Civil (1936-39). Barcelona, Ediciones de la Tempestad, 1998.

Payán, Miguel Juan: La historia de España a través del cine. Madrid, Cacitel, 2007.

Pena Rodríguez, Alberto: El gran aliado de Franco. Portugal y la Guerra Civil Española: prensa, radio, cine y propaganda. A Coruña, Edicios do Castro, 1998.

Perales, Francisco: Luis García Berlanga. Madrid, Ediciones Cátedra, 1997.

Pérez Bastías, Luis - Alonso Barahona, Fernando: Las mentiras sobre el cine español. Barcelona, Royal Books, 1995.

Pérez Perucha, Julio (szerk.): Antología crítica del cine español, 1906-1995. Flor en la sombra. Madrid, Ediciones Cátedra - Filmoteca Española. 1997.

Pérez Perucha, Julio: El cinema de Edgar Neville. Valladolid, 27 Semana Internacional de Cine de Valladolid, 1982.

Pérez Gómez, Ángel A. - Martínez Montalbán, José L.: Cine español 1951-1978: diccionario de directores. Bilbao, Mensajero D.L., 1979.

Rey García, Marta: Stars for Spain: La guerra civil española en los Estados Unidos. A Coruña, Edicios do Castro, 1997.

Sala Noguer, Ramón: El cine en la España republicana, 1936-39. Bilbao, Mensajero, 1993.

Salvador Marañón, Alicia: De ¡Bienvenido, Mr. Marshall! a Viridiana. Historia de UNINCI, una productora cinematográfica española bajo el franquismo. Pozuelo de Alarcón, Egeda, 2006.

Sánchez-Biosca, Vicente: Cine y Guerra Civil Española. Madrid, Alianza Editorial, 2006.

Sánchez-Biosca, Vicente: España en armas: El cine de la Guerra Civil Española. Diputación de Valencia, 2007.

Sánchez-Biosca, Vicente - Tranche, Rafael R.: El pasado es el destino: Propaganda y cine del bando nacional en la guerra. Madrid, Cátedra, 2011. 
Soria, Florentino: José María Forqué. Huesca, Festival de Cine de Huesca, 1992.

Taibo I, Paco Ignacio: Un cine para un imperio. Madrid, Oberon, 2002.

Tranche, Rafael R - Sánchez-Biosca, Vicente: NO-DO. El tiempo y la memoria. Madrid, Ediciones Cátedra - Filmoteca Española, 2006.

Utrera Macías, Rafael: Modernismo y 98 frente a Cinematógrafo. Sevilla, Secretariado de Publicaciones de la Universidad, 1981.

Vizcaíno Casas, Fernando: Historia y anécdota del cine español. Madrid, Adra, 1976.

Vizcaíno Casas, Fernando - Jordán, Ángel A.: De la checa a la meca. Una vida de cine. Barcelona, Editorial Planeta, 1988.

\section{Tanulmányok és könyvfejezetek spanyol film és filmtörténet témában}

Afinoguénova, Eugenia: „La censura cinematográfica en el territorio nacional durante la Guerra Civil y la consolidación del <Nuevo Estado〉" in: Herrera, Javier - Martínez-Carazo, Cristina (szerk): Hispanismo y cine. Madrid - Frankfurt am Main, Iberoamericana - Vervuert, 2007.

Aguilar, Carlos: „El cine en Almería: El paisaje es el mensaje” in: García de Dueñas, Jesús Gorostiza, Jorge (szerk.): Los estudios cinematográficos españoles. Id. mü.

Alberich, Ferran: „El rechazo del pasado” in: Archivos de la Filmoteca, No. 35. 2000.

Amador Carretero, Pilar: „La sexualidad en el cine español durante el primer franquismo” in: Fotocinema, No. 1. 2010.

Elérés:

http://www.revistafotocinema.com/index.php?journal=fotocinema\&page=article\&op=viewFil e\&path[]=51\&path[]=34 (2012-12-03)

Aprea, Gustavo: „¿Existe un cine totalitario?” in: Block de Behar, Lisa - Rinesi, Eduardo (szerk.): Cine y totalitarismo. Buenos Aires, La Crujía Ediciones, 2007.

Aronica, Daniela: „La génesis de Sin novedad en el Alcázar: estudio comparativo del argumento al guión" in: Archivos de la Filmoteca, No. 35. 2000.

Ballesteros, Isolina: „Mujer y nación en el cine español de posguerra” in: Herrera, Javier Martínez-Carazo, Cristina (szerk): Hispanismo y cine. Id. mü.

Benet, Vicente J.: „Franco, NO-DO y las conquistas de trabajo” in: Archivos de la Filmoteca, No. 42-43, 2002.

Berthier, Nancy: „Raza, de Sáenz de Heredia, una <película-acontecimiento>” in: SánchezBiosca, Vicente: España en armas. Id. mü.

Bikácsy Gergely: „Lábadozók (A spanyol film Franco után. Négy évtized)” in: Filmvilág, 1982/01.

Bonafoux, Corinne: „Los católicos franceses ante el cine: ensayo de una historia del público católico" in: Montero, Julio - Rodríguez, Araceli (szerk.): El cine cambia la historia. Id. mü. 
Borau, José Luis: „Certamen Cinematográfico Hispanoamericano” in: Borau, José Luis Heredero, Carlos F. (szerk.): Diccionario del cine español. Madrid, Alianza Editorial Academia de las Artes y las Ciencias Cinematográficas de España, 1998.

Borrat, Héctor: „Los múltiples recursos del poder para implantar censuras” in: Bezunarten, D. - Canga Laregui, J. (szerk.): Los límites de la información política. Universidad del País Vasco, San Sebastián, 1989.

Cabeza Rodríguez, José: „Madrid en guerra: un público para la revolución” in: Pelaz, JoséVidal - Rueda, José Carlos (szerk.): Ver cine. Id. mü.

Cánovas Belchí, Joaquin T.: „La Atlántida S.A.C.E. y otros estudios madrileños en los años veinte" in: García de Dueñas, Jesús - Gorostiza, Jorge (szerk.): Los estudios cinematográficos españoles. Id. mü.

Caparrós Lera, José María: „Camuflaje ideológico del franquismo: Raza (1941-1950), manipulación de un film de propaganda política" in: Uö: Estudios sobre el cine español del franquismo. Id. mü.

Caparrós Lera, José María: „El cine como documento histórico” in: Paz Rebollo, María Antonia - Montero Díaz, Julio (szerk.) Historia y Cine: Realidad, ficción y propaganda. Madrid, Editorial Complutense, 1995.

Caparrós Lera, José María: „Imágenes de América Latina del siglo XX en el cine de la autarquía" in: Uő: Estudios sobre el cine español del franquismo. Id. mü.

Corrales, Eloy Martín: „El cine español y las guerras de Marruecos (1896-1994)” in: Hispania, Vol. LV/2. No. 190. 1995.

Crusells, Magí: „La producción de Luis Buñuel a favor de la causa republicana (1936-1939)” in: FilmHistoria Online, Vol. XVI. No. 3. 2006.

Elérhető:

http://www.publicacions.ub.edu/bibliotecadigital/cinema/filmhistoria/2006/Ensayo_bunuel_1. htm (2012-11-29)

Dés Mihály: „Spanyolország messzire van (A spanyol film Franco nélkül)” in: Filmvilág, 1985/07.

Díez Puertas, Emeterio: „El acuerdo cinematográfico hispano-norteamericano” in: Secuencias, No. 4. 1996.

Díez Puertas, Emeterio: „El Círculo Cinematográfico Español (1940-1944)” in: Historia y Comunicación Social, No. 13. 2008.

Díez Puertas, Emeterio: „La censura cinematográfica en las colonias españolas” in: FilmHistoria, Vol. IX, No. 3. 1999.

Elérhető: http://www.publicacions.ub.edu/bibliotecadigital/cinema/filmhistoria/art.diez.pdf (2012-11-22)

Díez Puertas, Emeterio: „Las coproducciones ofensivas” in: Actas del VII Congreso de la A.E.H.C. Madrid, Academia de las Artes y Ciencias Cinematográficas de España, 1999.

Elena, Alberto: „¿Quién prohibió Rojo y negro?” in Secuencias, No. 7. 1997. október.

España, Rafael de: „Antisemitismo en el cine español” in: Film-Historia, Vol. I. No. 2. 1991.

Elérhető:

http://www.publicacions.ub.edu/bibliotecadigital/cinema/filmhistoria/ArtRdEspana.pdf (2012-11-27) 
España, Rafael de: „El franquismo combate la <<leyenda negra >>: Alba de América” in: Romero Campos, David: La Historia a través del cine. Memoria e historia en la España de la posguerra. Universidad del País Vasco, Servicio de Publicaciones, 2010.

España, Rafael de: „Franco después de Franco” in: Film-Historia, Vol V, No. 2-3, 1995.

Elérhető: http://www.publicacions.ub.es/bibliotecadigital/cinema/filmhistoria/Art.Rafael.pdf (2012-12-01)

Fernández Mellado, Rebeca: „El cartel de cine español de posguerra (1939-1945): Modelo de tratamiento documental" in: Cuadernos de Documentación Multimedia, No. 18, 2007.

Elérhetö: http://multidoc.rediris.es/cdm/viewarticle.php?id=57 (2012-11-22)

García de Dueñas, Jesús: „Chamartín, la orgullosa permanencia” in: García de Dueñas, Jesús Gorostiza, Jorge (szerk.): Los estudios cinematográficos españoles. Id. mü.

García López, Sonia: „Bolcheviques en América: circulación y migración de imágenes soviéticas de la guerra civil española en Estados Unidos" in: Archivos de la Filmoteca, No. 61. 2009.

García López, Sonia: „El cine de Cultural Front y la guerra civil española: Las películas de Frontier Films" in: Juliá, Santos (szerk.): Actas del congreso internacional: La guerra civil española, 1936-1939. Madrid, Sociedad Estatal de Conmemoraciones Culturales, 2008.

Elérhetö: http://www.uv.es/imagengc/articulos/el_cine_del_cultural_front.pdf (2012-12-01)

García Seguí, Alfonso: „Cifesa, la antorcha de los éxitos” in: Archivos de la Filmoteca, No. 4. 1989-1990.

Gómez Alonso, Rafael: „Diagonal: Una segunda vida para los estudios Lepanto” in: García de Dueñas, Jesús - Gorostiza, Jorge (szerk.): Los estudios cinematográficos españoles. Id. mü.

Gómez, María Asunción: „Mujer, nación y deseo en Locura de amor de Juan de Orduña y Juana la Loca de Vicente Aranda" in: FilmHistoria Online, Vol. XVI, No. 1-2. 2006.

Elérhető:

http://www.publicacions.ub.edu/bibliotecadigital/cinema/filmhistoria/2006/REVISTAS/Ensay o_MujerNacionDeseo\%20_1.htm (2012-12-04)

Gubern, Román: „A Madrid 682: un proyecto de 1939” in: Archivos de la Filmoteca, No. 35. 2000 .

Gubern, Román: „El cine sonoro (1930-1939)” in: Gubern, Román (és mások): Historia del cine español. Madrid, Cátedra, 2009.

Juan-Navarro, Santiago: „El cine como alegoría nacional: La construcción del estado franquista en Alba de América, de Juan de Orduña" in: FilmHistoria Online, Vol. XII, No. 12. 2002. Elérhető:

http://www.publicacions.ub.edu/bibliotecadigital/cinema/filmhistoria/2002/AlbadeAmerica.ht $\underline{\text { m }}$ (2012-11-29)

Juan-Navarro, Santiago: „La Madre Patria enajenada: Locura de amor, de Juan de Orduña, como alegoría nacional" in: Hispania, 88.1. 2005.

Langa Nuño, Concha: „Propaganda y evasión: Sevilla, retaguardia de la zona nacional” in: Pelaz, José-Vidal - Rueda, José Carlos (szerk.): Ver cine. Id. mü.

Lázaro Sebastián, Francisco Javier: „Situación del documental de arte en la España del franquismo". In: Archivos de la Filmoteca, No. 70. 2012.

León Aguinaga, Pablo: „El cine norteamericano en España: Las negociaciones para su importación, 1950-1955” in: Hispania, Vol. LXVI. No. 222. 2006. 
León Aguinaga, Pablo: „El comercio cinematográfico como instrumento de la acción norteamericana en España durante la segunda guerra mundial" in: Cuadernos de Historia Contemporánea, Vol. 28. 2006.

López, Juan - Aramis, Enrique: „Religiosidad en el cine español en la década de los cincuenta" in: Zainak. Cuadernos de Antropología-Etnografía, No. 28. 2006.

López Gallegos, María Silvia: „El control político de Salazar sobre la industria cinematográfica portuguesa" in: Montero, Julio - Rodríguez, Araceli (szerk.): El cine cambia la historia. Id. mü.

Losada, Matt: „The Rebranding of Francoism's Originary Violence in José Antonio Nieves Conde's Balarrasa" in: Romance Notes, Vol. 51, No. 2. 2011.

Llorente Hernández, Ángel: „La construcción de un mito. La imagen de Franco en las artes plásticas en el primer franquismo (1936-1945)" in: Archivos de la Filmoteca, No. 43-44. 2002-2003.

Martínez, Amparo: „Aragón” in: Caparrós Lera, José María (szerk.): Cine Español. Una historia por autonomías, Vol.1. Id. mü.

Matud Juristo, Álvaro: „La incorporación del cine documental al proyecto de NO-DO” in: Historia y Comunicación Social, No. 13. 2008.

Minguet i Battlori, Joan M: „La regeneración del cine como hecho cultural durante el primer franquismo (Manuel Augusto García Viñolas y la etapa inicial de „Primer Plano”)” in: Actas del VI Congreso de la A.E.H.C. Madrid, Academia de las Artes y las Ciencias Cinematográficas de España, 1998.

Monterde, José Enrique: „El cine de la autarquía”. in: Gubern, Román (és mások): Historia del cine español. Id. mü.

Monterde, José Enrique: „Un modelo de reapropiación nacional” in: Berthier, Nancy Seguin, Jean Claude: Cine, nación y nacionalidades en España. Id. mű.

Montero, Julio - Paz, María Antonia: „Ir al cine en España en el primer tercio del siglo XX” in: Pelaz, José-Vidal - Rueda, José Carlos (szerk.): Ver cine. Los públicos cinematográficos en el siglo XX. Madrid, Ediciones Rialp, 2002.

Montero, Mercedes: „Cine para la cohesión social durante el primer franquismo” in: Pelaz, José-Vidal és Rueda, José Carlos (szerk.): Ver cine. Id. mü.

Mota, Jesús: „Criminales en la guerra” in: Doce del Patíbulo (a filmhez mellékelt kiadvány, Gregorio Belnichá írásaival). Editorial El País, S. L., 2005.

Navarrete-Galiano Rodríguez, Ramón: „Conceptualización de lo queer en ¡A mí la Legión! Relecturas de la filmografía franquista" in: Icono 14 - Revista de Comunicación y Nuevas Tecnologías, Vol. 9, No. 3.

Elérhető: http://www.icono14.net/ojs/index.php/icono14/article/view/17/64 (2012-11-30)

Pardo, Alejandro: „Coproducciones internacionales españolas: ¿estrategia financiera o expresión multicultural?" in: Comunicación y sociedad, Vol. XX. No. 2.

Pérez Perucha, Julio: „Narración de un aciago destino (1896-1930)” in: Gubern, Román (et.al.): Historia del cine español. Id. mü.

Pingree, Geoffrey B.: „Franco and the filmmakers: critical myths, transparent realities” in: Film-Historia, Vol. V, No. 2-3. 1995. 
Elérhető:

http://www.publicacions.ub.es/bibliotecadigital/cinema/filmhistoria/Art.\%20pingree.pdf (2012-12-01)

Pizarroso Quintero, Alejandro: „Guerra, Cine e Historia. La guerra de 1898 en el cine” in: Historia y Comunicación Social, No. 3. 1998.

Reig Tapia, Alberto: „La autoimagen de Franco: la estética de la raza y el imperio” in: Archivos de la Filmoteca, No. 43-44. 2002-2003.

Ripoll, Xavier: „Cataluña” in: Caparrós Lera, José María (szerk.): Cine Español. Una historia por autonomías, Vol.1. Id. mü.

Sánchez-Biosca, Vicente: „El ausente, ¡Presente!: el carisma cinematográfico de José Antonio Primo de Rivera, entre líder y santo" in: Archivos de la Filmoteca, No. 46. 2004.

Sánchez Salas, Daniel: „A diez mil kilómetros de Hollywood. (La historia de E.C.E.S.A. I Estudios de Aranjuez S.A.)" in: García de Dueñas, Jesús - Gorostiza, Jorge (szerk.): Los estudios cinematográficos españoles. Id. mü.

Seguin, Jean-Claude: „Locura de amor” in: Pérez Perucha, Julio (szerk.): Antología crítica del cine español. Id. mü.

Sempere Serrano, Isabel: „La aventura luso-española. Introducción al estudio de la coproducción cinematográfica hispano-lusa de los años cuarenta" in: FilmHistoria Online, Vol. XIII. No. 3. 2003.

Elérhetö:http://www.publicacions.ub.edu/bibliotecadigital/cinema/filmhistoria/2003/aventura hispano_lusa_1_index.htm (2012-11-22)

Tanner Gábor: „Filmtörvény Spanyolországban” in: Filmvilág, 2001/07.

Tanner Gábor: „Mondd, hogy félsz (A spanyol thriller)” in: Filmvilág, 1997/08.

Tanner Gábor: „Torreádorsirató” in: Filmvilág, 2000/11.

Todero Frigyes: „Furkósbot és mézesmadzag (A spanyol film a Franco-rendszerben. Négy évtized)" in: Filmvilág, 1981/12.

Torreiro, Casimiro: “Una dictadura liberal?” in: Gubern, Román (és mások): Historia del cine español. Id. mü.

Tranche, Rafael R.: „CEA: Los intereses creados” in: García de Dueñas, Jesús - Gorostiza, Jorge (szerk.): Los estudios cinematográficos españoles. Id. mü.

Yarza, Alejandro: „Las lágrimas petrificadas del general Franco: fascismo y kitsch en Raza de José Luis Sáenz de Heredia" in: Herrera, Javier - Martínez-Carazo, Cristina (szerk): Hispanismo y cine. Id. mü.

Yraola, Aitor: „Misión españolista”: Los camaradas Florián e Imperio con Hitler y el Dr. Goebbels" in: Film-Historia, Vol. IX, No. 3. 1999.

Elérhetö: http://www.publicacions.ub.edu/bibliotecadigital/cinema/filmhistoria/art.yraola.pdf (2012-12-01)

Zumalde Arregi, Imanol: „Surcos” in: Pérez Perucha, Julio (szerk.): Antología crítica del cine español. Id. mü. 


\section{Folyóirat-, újság- és online cikkek spanyol film és filmtörténet témában}

Castro, Antón: „Recuerdo de Florián Rey”

Elérhetö: http://antoncastro.blogia.com/2005/050601-recuerdo-de-florian-rey-.php (2012-1121)

Constenla, Tereixa: „Pío XII, espectador secreto de 'Raza” in: El País, 2011. augusztus 21.

Elérhető: $\quad$ http://elpais.com/diario/2011/08/21/revistaverano/1313877602_850215.html (2011-11-21)

„'El ángel de Budapest', la película española más vista en televisión en 2011”

Elérhetö: http://www.europapress.es/chance/tv/noticia-angel-budapest-pelicula-espanola-masvista-television-2011-20120103183718.html (2011-11-21)

„Entrevista a Fernando Fernán Gómez” in: Nickel Odeon, No. 9. 1997.

Esparza, José Javier: „Los últimos de Filipinas: los héroes de Baler” in: El Manifiesto, 2008. június 24.

Elérhető: http://www.elmanifiesto.com/articulos.asp?idarticulo=2421 (2012-09-07)

Geli, Carles: „Sesión de tarde con Franco” in: El País, 2011. augusztus 21.

Elérhetö: $\quad$ http://elpais.com/diario/2011/08/21/revistaverano/1313877601_850215.html (2012-11-21)

„La estrella que deslumbró a Hitler” in: El Mundo, 2003. augusztus 24.

Elérhető: http://www.elmundo.es/elmundo/2003/08/23/cultura/1061601639.html (2012-1122)

Ríos Carratalá, Juan Antonio: El enigma de Carlos Arévalo. Alicante, Biblioteca Virtual Miguel de Cervantes, 2008.

Elérhetö: http://www.cervantesvirtual.com/obra/el-enigma-de-carlos-arvalo-0/ (2012-11-21)

Rodrigo Mora, Félix: „Tierra sin pan, ¿obra artística surrealista o panfleto liberalproletarista?"

Elérhető: http://felixrodrigomora.net/Tierra\%20sin\%20panII.pdf (2012-11-22)

Tébar, Juan - Torres Dulce, Eduardo: „Cien españoles y el cine español. Encuesta.” in: Nickel Odeon, 1995/1.

\section{Spanyol politika, történelem, kultúra és társadalom témájú könyvek, monográfiák, tanulmányok, könyvfejezetek és cikkek}

Abella, Rafael: La vida cotidiana bajo el régimen de Franco. Madrid, Ediciones Temas de Hoy, 1996.

Alvar, Carlos - Mainer, José Carlos - Navarro, Rosa: A spanyol irodalom rövid története. Budapest, Nemzeti Tankönyvkiadó, 2002.

Anales azorinianos. Fundación Cultural de la Caja de Ahorros del Mediterráneo, 1983-2007.

Anderle Ádám: A magyar-spanyol kapcsolatok ezer éve. Szeged, Szegedi Egyetemi Kiadó Juhász Gyula Felsőoktatási Kiadó, 2005. 
Anderle Ádám: „Diktatúrából demokráciába. Manuel Fraga Iribarne” in: Uő: Történelmi minták és utak. Esszék Spanyolországról és Latin-Amerikáról. Szeged, 2009.

Anderle Ádám: Megosztott Hispánia. Budapest, Kossuth Könyvkiadó, 1985.

Boor, Jakim: Masonería. Madrid, 1952.

Elérhetö: http://es.scribd.com/doc/8111216/Jakim-Boor-Franco-Masoneria (2012-11-21)

Calleja, José María: El Valle de los Caídos. Madrid, Editorial Espasa Calpe, 2009.

Castro, Américo: España en su historia. Buenos Aires, 1948.

Csejtei Dezső: „A 98-as nemzedék és a spanyol történelem” in: Aetas, 1998/4.

Delgado Gómez-Escalonilla, Lorenzo: Imperio de papel: acción cultural y política exterior durante el primer franquismo. Madrid, Consejo Superior de Investigaciones Científicas, 1992.

Eiroa San Francisco, Matilde: „Las fuentes doctrinales: pensamiento y lenguaje de la represión sistemática (1936-1948)" in: Aróstegui, Julio (szerk.): Franco: La represión como sistema. Barcelona, Flor del Viento Ediciones, 2012.

Eiroa de San Francisco, Matilde - Carrera Álvarez, Pilar: España, voz en off. Teoría y praxis de la prensa española en el contexto de la Guerra Fría. Valencia, Editorial Tirant lo Blanch, 2008.

Eslava Galán, Juan: Coitus interruptus. La represión sexual y sus heroicos alivios en la españa franquista. Barcelona, Editorial Planeta, 1997.

Esparza, José Javier: El terror rojo en España. Madrid, Ed. ALTERA, 2007.

Esparza, José Javier: Juicio a Franco. Madrid, LibrosLibres, 2011.

Farkas Pálma: Fekete legenda, hispanoamericanismo és az Egyesült Államok Miguel Primo de Rivera diktatúrája idején (1923-1930). Doktori értekezés. Szeged, 2012.

Franco Bahamonde, Francisco: Marruecos, diario de una bandera. Madrid, Pueyo, 1922.

Elérhetö: http://es.scribd.com/doc/37918004/Diario-de-una-Bandera (2012. 11. 21.)

Fusi, Juan Pablo: Franco: Autoritarismo y poder personal. Madrid, El País, 1985.

Fusi, Juan Pablo: „La cultura” in: García Delgado, José Luis (szerk.): Franquismo. El juicio de la historia. Madrid, Ediciones Temas de Hoy, 2005.

Fusi, Juan Pablo: „Para escribir la biografía de Franco” in: Claves de Razón práctica, 27/1992.

Gil Pecharromán, Julio: La política exterior del franquismo (1939-1975). Barcelona, Flor del Viento Ediciones, 2008.

Gil Serrano, Rafael: Nueva visión de la Hispanidad. Buenos Aires, Espasa-Calpe, 1938.

Giménez Caballero, Ernesto: Genio de España. Exaltaciones a una resurrección nacional y del mundo. Madrid, Ediciones La Gaceta Literaria, 1932.

Gómez, Luis: „Españolizar ya lo hizo Franco ... y fracasó” in: El País, 2012. október 14. Elérhető:

http://sociedad.elpais.com/sociedad/2012/10/14/vidayartes/1350243756_004204.html (2012-11-21)

González Duro, Enrique: El miedo en la posguerra. Madrid, Oberon, 2003.

González Duro, Enrique: Los psiquiatras de Franco: los rojos no estaban locos. Barcelona, Ediciones Península, 2008. 
Harsányi Iván: „A spanyol politikai konzervativizmus a 20. században” in: Uö: $A$ félperifériától a centrum felé. Spanyolország és Portugália a „hosszú 19.” és még hosszabb 20. században. Pécs, Publikon Kiadó, 2011.

Harsányi Iván: A Franco-diktatúra születése. Budapest, Kossuth Könyvkiadó, 1988.

Harsányi Iván: „Meggyőződés vagy kötelességteljesítés. Ángel Sanz Briz szerepe az üldözött magyar zsidók életében (1944)" in: Anderle Ádám (szerk.): Zsidóság a hispán világban. Szeged, SZTE Hispanisztika Tanszék, 2004.

Juan-Navarro, Santiago: „Una sola fe, una sola lengua: La Hispanidad como coartada ideológica en el pensamiento reaccionario español” in: Hispania, 89.2. 2006.

Katona Eszter: Olasz-spanyol kapcsolatok a második világháború éveiben. Szeged, 2007.

Kiss Tamás Zoltán: „Csend! Csend, ha mondom! Csend! A spanyol színház a Francokorszakban (1936-1945)" in: Lengyel György (szerk.): Színház és diktatúra a 20. században. Budapest, Corvina Kiadó - Országos Színháztörténeti Múzeum és Intézet, 2011.

„La Guardia Civil muere pero no se rinde”

Elérhetö: http://www.momentosespañoles.es/contenido.php?recordID=65 $\quad$ (2012-12-04)

La Legión Española: http://www.lalegion.es/menu.html (2012-11-27)

Lénárt András: „Az Elesettek Völgye” in: Egyenlítő, 2012/5.

Los XXVI puntos del estado español.

Elérhetö: http://www.generalisimofranco.com/descargas/26\%20puntos.pdf (2012-11-21)

Luca de Tena, Torcuato: Embajador en el infierno. Memorias del capitán Palacios: once años de cautiverio en Rusia. Madrid, 1955.

Maeztu, Ramiro de: Defensa de la Hispanidad. Madrid, 1934.

Elérhetö: http://guardiadelahispanidad.files.wordpress.com/2009/09/defensa-de-lahispanidad.pdf (2012-11-21)

Maeztu, Ramiro de: „La Hispanidad” in: Acción Española, 1/I, 1931.

Elérhető: http://www.filosofia.org/hem/193/acc/e01008.htm (2012-11-21)

Malefakis, Edward: „La dictadura de Franco en una perspectiva comparada” in: García Delgado , José Luis (szerk.): Franquismo. El juicio de la historia. Madrid, Ediciones Temas de Hoy, 2005.

Martín Gaite, Carmen: Usos amorosos en la posguerra española. Barcelona, Anagrama, 1987.

Merino, Julio: El otro Franco. El Franco intelectual y el Franco de la República. Madrid, Albor Libros, 2010.

Montero, Mercedes: Cultura y comunicación al servicio del régimen, Historia de la ACN de P entre 1945 y 1959. Ediciones Universidad de Navarra, 2001.

Moradiellos, Enrique: La España de Franco (1939-1975). Política y sociedad. Madrid, Editorial Síntesis, 2000.

Museo del Juego: http://www.museodeljuego.org/contenidos.asp?menu_id=133

(2012.11.21.)

Ormos Mária - Harsányi Iván: Mussolini - Franco. Budapest, Pannonica Kiadó, 2001.

Payne, Stanley G.: Franco. El pérfil de la historia. Madrid, Alianza, 1992. 
Payne, Stanley G.: The Franco Regime. 1936-1975. Madison - London, The University of Wisconsin Press, 1987.

Pérez Herrero, Pedro - Tabanera, Nuria (szerk.): España / América Latina: Un siglo de políticas culturales. Madrid, AIETI/Síntesis-OEI, 1993.

Posztós Ildikó Piroska: „A spanyol Tóth Tihamér-jelenség” in: Magyar Egyháztörténeti Vázlatok, 2006/3-4.

Preston, Paul: Juan Carlos. El Rey de un pueblo. Barcelona, Debolsillo, 2004.

Rodríguez, Joaquín: „Libros en llamas, ideas ignífugas” in: Los futuros del libro.

Elérés: http://www.madrimasd.org/blogs/futurosdellibro/2008/05/14/91803 (2012-11-21)

Rodríguez de Lecea, Teresa (és mások): La Institución Libre de Enseñanza. Madrid, Información y Revistas S.A., 1985.

Rodríguez Jiménez, José Luis: Historia de la Falange Española de la JONS. Madrid, Alianza Editorial, 2000.

Sánchez Albornoz, Claudio: España: un enigma histórico. Buenos Aires. 1957.

Sánchez Soler, Mariano: Los Franco, S.A. Madrid, Oberon - Grupo Anaya, 2003.

Sevillano Calero, Francisco: Propaganda y medios de comunicación en el franquismo (19361951). Alicante, Universidad de Alicante, 1998.

Solís Krause, Rubén: La cultura de Eros. Antología ilustrada del libertinaje. Barcelona, Robinbook, 2007.

Solís Ruiz, José: Pensamiento político de Franco. Vols. I-II. Madrid, Ediciones del Movimiento, 1975.

Tari Adrienn: A Primo de Rivera diktatúra közép-kelet-európai politikája (1923-1930). Doktori értekezés. Szeged, 2011.

Tejada, Luis Alonso: La represión sexual en la España de Franco. Barcelona, Caralt, 1977.

Vallejo Nájera, Antonio: Eugenesia de la Hispanidad y regeneración de la Raza. Burgos, 1938.

Vallejo Nájera, Antonio: Política racial del Nuevo Estado. San Sebastián, Editorial Española, 1938.

Vázquez Montalbán, Manuel: Los demonios familiares de Franco. Barcelona, Random House Mondadori, 2004.

Virágh Anna: „A független Spanyol-Amerika és a Hispanidad eszméje” in: Anderle Ádám (szerk.): Latin-Amerika: A függetlenség útjai. Szeged, 2012.

Virágh Anna: „Európa és a spanyol identitás Ernesto Giménez Caballero történelemszemléletében” in: Ferwagner Péter Ákos - Kalmár Zoltán (szerk.): Az átmenet egyensúlya. Szilágyi István 60 éves. Budapest, Áron Kiadó, 2010.

\section{Egyéb hivatkozott könyvek, monográfiák, tanulmányok és cikkek}

Allen, Robert C - Gomery, Douglas: Film history. Theory and Practice. McGraw-Hill, 1985. Almodóvar, Pedro: Patty Diphusa. Budapest, Palatinus, 2006. 
Alsina Thevenet, Homero: El libro de la censura cinematográfica. Barcelona, Editorial Lumen, 1977.

Anderle Ádám: „Elisabeth Szél” in: Tiszatáj, 1994/3.

Anderson, Benedict: Imagined Communities: Reflections on the Origin and Spread of Nationalism. London-New York, Verso, 1991.

Andrew, Dudley: The Major Film Theories: An Introduction. Oxford University Press, 1976.

Arendt, Hannah: The Human Condition. Chicago, University of Chicago Press, 1958.

Aristarco, Guido: Il cinema fascista: il prima e il dopo. Edizioni Dedalo, Bari, 1996.

Arnone, Karen: The Cinema under Mussolini

Elérhetö: http://ccat.sas.upenn.edu/italians/resources/Amiciprize/1996/mussolini.html (201211-21)

Arnold, Brandon: „Realism, Formalism and Classicism” in Les Cahiers du East Hollywood Cinema

Elérhető: $\quad$ http://filmhistory.wordpress.com/2007/08/31/realism-formalism-and-classicism/ (2012-11-20)

Bach, Steven: Leni: Leni Riefenstahl élete és munkássága. Budapest, Európa, 2008.

Bakos Ferenc: Idegen szavak és kifejezések szótára (9. kiadás). Budapest, Akadémiai Kiadó, 1989.

Balogh Gyöngyi - Gyürey Vera - Honffy Pál: A magyar játékfilm története a kezdetektöl 1990-ig. Budapest, Müszaki Könyvkiadó, 2004.

Bartels, Ulrike: Die Wochenschau Im Dritten Reich: Entwicklung Und Funktion Eines Massenmediums Unter Besonderer. Frankfurt am Main - Berlin - Bern - Brüsszel - New York - Oxford - Wien, Peter Lang, 2004

Bazin, André: Qu'est-ce que le cinéma ? Éditions du Cerf, Collection "Septième Art", 19581962. ( magyarul: Bazin, André: Mi a film? Budapest, Osiris Kiadó, 2002.)

Bergan, Ronald: Sergei Eisenstein: A Life in Conflict. Boston, Overlook, 1999.

Berkes Ildikó: Az orosz-szovjet film: a szovjet filmmüvészet mint a Szovjetunió tükre. Budapest, Uránusz, 2008.

Berkes Ildikó - Nemes Károly: A filmmüvészet fejlődési vonala. Budapest, Uránusz, 2011.

Berkes Ildikó - Nemes Károly: A japán film világa. Budapest, Magyar Filmintézet, 1997.

Berkes Ildikó - Nemes károly: A kelet-európai filmmüvészet. Budapest, Uránusz, 2007.

Berkes Ildikó - Nemes Károly: A német filmmüvészet története. Budapest, Uránusz, 2006.

Bernstein, Matthew (szerk.): Controlling Hollywood: Censorship and Regulation in the Studio Era. Rutger, Rutgers University Press, 1999.

Bikácsy Gergely: Bolond Pierrot moziba megy. A francia film ötven éve. Budapest, Héttorony - Budapest Film, 1992.

Bikácsy Gergely: Buñuel-napló. Budapest, Osiris Kiadó, 1997.

Bíró Yvette: A hetedik müvészet. A film formanyelve, a film drámaisága. Budapest, Századvég, 1994. 
Black, Gregory D.: Hollywood Censored: Morality Codes, Catholics and the Movies. Cambridge University Press, 1996.

Buñuel, Luis: Odalenn [forgatókönyv]. Szeged, Szukits Kiadó, 2001.

Buñuel, Luis: Az andalúziai kutyától Az öldöklö angyalig - Forgatókönyek 1. Budapest, L'Harmattan, 2006.

Buñuel, Luis: Az Egy szobalány naplójától a Tristanáig - Forgatókönyek 2. Budapest, L"Harmattan, 2008.

Byrd, Cathy - Richmond, Susan (szerk.): Potentially Harmful: The Art of American Censorship. Athens, The University of Georgia Press, 2006.

Camarero, Gloria - Heras, Beatriz de las - Cruz, Vanessa de: Una ventana indiscreta. La historia desde el cine. Madrid, Ediciones JC, 2008.

Canudo, Ricciotto: A hetedik müvészet esztétikája. Budapest, MFI, 1961.

Castells, Manuel: Comunicación y poder. Madrid, Alianza Editorial, 2009.

Chiarini, Luigi: El cine, quinto poder. Madrid, Taurus, 1963.

Child, Ben: „Nazi 3D films from 1936 discovered” in The Guardian, 2011. február 16.

Elérhető: http://www.guardian.co.uk/film/2011/feb/16/nazi-3d-films-discovered (2012-1121)

Cristian Réka Mónika - Dragon Zoltán: Encounters of the Filmic Kind: Guidebook to Film Theories. Szeged, JATE Press, 2008.

Damasio, Antonio R.: The Feeling of What Happens, Body and Emotion in the Making of Consciousness. New York, Harcourt Brace \& Company, 1999.

Dobai Péter - Pintér Judit - Szkárosi Endre: „Szenvedély és ideológia. Dialógus Pier Paolo Pasoliniröl" in: Filmvilág, 2010/12.

Doherty, Thomas: Hollywood's Censor: Joseph I. Breen and the Production Code Administration. New York, Columbia University Press, 2009.

Domenach, Jean-Marie: La propagande politique. Párizs, Presses Universitaires de France, 1950.

Elsaesser, Thomas: A német úffilm. Budapest, Palatinus Kiadó, 2004.

España, Rafael de: El cine de Goebbels. Barcelona, Editorial Ariel, 2002.

Evans, Gary: John Grierson: Trailblazer of Documentary Film. Montréal, Dundurn, 2005.

Ferro, Marc: Cinéma et Historie. Paris, 1977.

Ferro, Marc: Historia Contemporánea y Cine. Barcelona, Editorial Ariel, 2000.

Fielding, Raymond: The American Newsreel: A Complete History, 1911-1967. Jefferson, McFarland \& Company, 2006.

Garcia Escudero, José María: A vueltas con las dos Españas. Madrid, Biblioteca de Autores Cristianos, 1979.

Garcia Escudero, José María: Crítica de la restauracion liberal en España. Madrid, Ateneo, 1952.

Garcia Escudero, José María: De Cánovas a la República. Madrid, Ediciones Rialp, 1951. 
Garcia Escudero, José María: El pensamiento de Ángel Herrera: antología política y social. Madrid, Biblioteca de Autores Cristianos, 1987.

Garcia Escudero, José María: Historia política de la época de Franco. Madrid, Ed. Rialp, 1987.

Garcia Escudero, José María: Historia política de las dos Españas. Madrid, Editora Nacional, 1976.

Garcia Escudero, José María: Los cristianos, la iglesia y la política. Madrid, Fundación Universitaria San Pablo, 1993.

Garcia Escudero, José María: Los españoles de la conciliación. Madrid, Espasa Calpe, 1987.

Geertz, Clifford: „Ideology as a cultural system” in: Apter, David Ernest (szerk.): Ideology and Discontent. New York, The Free Press of Glencoe, 1964.

Elérhető: http://xroads.virginia.edu/ DRBR/geertz.html (2012-12-04)

Gerő András: Képzelt történelem. Budapest, Eötvös Kiadó - PolArt Kiadó, 2004.

Gervai András: A tanúk: film - történelem. Budapest, Saxum, 2004.

Gervai András: Fedőneve: „szocializmus” - Müvészek, ügynökök, titkosszolgák. Pécs, Jelenkor, 2010.

Gomery, Douglas: Shared Pleasures: A History of Movie Presentation in the United States. Madison, The University of Wisconsin Press, 1992.

Gregor, Ulrich - Patalas, Enno: A film világtörténete. Budapest, Gondolat, 1966.

Győri Zsolt (szerk.): Fejezetek a brit film történetéből. Eger, Líceum Kiadó, 2010.

Gyürey Vera - Lencsó László - Veress József (szerk.): A magyar filmtörténet képeskönyve. Budapest, Osiris Kiadó, 2003.

Hahner Péter: „Rick háborúba megy (A Casablanca és a politika)” in: Filmvilág, 2012/09.

Heinzlmeier, Adolf: Nachkriegsfilm und Nazifilm. Anmerkungen zu einem deutschen Thema. Frankfurt am Main, Frankfurter Bund für Volksbildung, 1988.

Hollós Adrienne: Carlos Saura. Budapest, Magyar Filmtudományi Intézet és Filmarchívum, 1983.

Hughes, William: „The evaluation of film as evidence” in: Smith, Paul: The Historian and Film. Cambridge University Press, 1976.

Hughes-Warrington, Marnie: History Goes to the Movies: Studying History on Film. Abingdon, Routledge, 2007.

Jackson, Martin A.: „Film as a Source Material: Some Preliminary Notes Toward a Methodology" in: The Journal of Interdisciplinary History, Vol. IV. 1973. 73-80.

Jakab György: „Tükör vagy ecset? Avagy történelem a filmen, film a történelemórán” Elérhető: http://www.tte.hu/toertenelemtanitas/toertenelemtanarok-orszagoskonferenciaja/6740-tukor-vagy-ecset (2012-11-29)

Jarvie, Ian: Towards of Sociology of the Cinema: A Comparative Essay on the Structure and Functioning of a Major Entertainment Industry. London, Routledge \& Paul Kegan, 1970.

Jeff, Leonard L. - Simmons, Jerold L. The Dame in the Kimono: Hollywood, Censorship, and the Production Code. The University Press of Kentucky, 2001. 
Jowett, Garth - O'Donnell, Victoria: Propaganda and Persuasion. London, Sage Publications, 1986.

Kelecsényi László: Vászonszerelem - A magyar hangosfilm krónikája 1931-töl napjainkig. Budapest, Noran Kiadó, 2007.

Kelecsényi László: Álmodozók és megszállottak.Bevezetés a magyar filmtörténetbe. Budapest, L'Harmattan, 2010.

Kenez, Peter: Cinema and Soviet Society from the Revolution to the Death of Stalin. London, I.B. Tauris, 2001.

Kovács András Bálint: A film szerint a világ: tanulmányok. Budapest, Palatinus, 2002.

Kovács András Bálint: A modern film irányzatai: Az európai müvészfilm 1950-1980. Budapest, Palatinus, 2005.

Kracauer, Siegfried: From Caligari to Hitler. A Psychological History of the German Film. New York, Princeton University Press / London, Dennis Dobson Ltd, 1947. (magyarul: Caligaritól Hitlerig: a német film pszichológiai története. Budapest, Magyar Filmintézet, 1993.)

Kreimeier, Klaus: The UFA Story: A History of Germany's Greatest Film Company, 19181945. Berkeley - Los Angeles - London, University of California Press, 1999.

„Lady Hamilton” in: Imágenes, 2008/12.

Lagny, Michele: De l'Histoire du Cinema. Méthode historique et historie du cinema. Párizs, A Colin, 1992.

Lasswell, Harold D.: Propaganda Technique in World War I. New York, Knopf, 1927. (későbbi, szélesebb körben, és általam is ismert kiadás: MIT Press, 1971.)

Lasswell, Harold D - Lerner, Daniel - Speirer, Hans (szerk.): Propaganda and Communication in World History, Vols. I-III, Honolulu, 1979-1980.

Le Bon, Gustave: A tömegek lélektana. Budapest, Hatágú Síp Alapítvány, 1993.

Lengyel László: „Tömegpropaganda és buborékpolitika” in: Mozgó Világ, 2006/1.

Lévai Csaba: „Hollywood és az Amerikai Egyesült Államok történelmi küldetése Mel Gibson A hazafi címü filmjének tükrében" in: Tóth Zsófia Anna - Vajda Zoltán (szerk): Amerikanisztika és vizualitás. Metszéspontok az információs társadalom horizontján. Szeged, Americana eBooks, 2012.

Lizzani, Carlo: Az olasz film története. Budapest, Gondolat, 1981.

Magyar Bálint: A magyar némafilm története. Budapest, Palatinus, 2003.

Magyar Bálint: Az amerikai film. Budapest, Gondolat Kiadó, 1974.

Magyar Larousse (Bakos Ferenc és Szávai János főszerk.). Akadémiai Kiadó, Budapest, 1991.

Murai András: Film és kollektív emlékezet. Magyar múltfilmek a rendszerváltozás után. Szombathely, Savaria University Press, 2008.

Nemes Károly: A nyugati filmmüvészet konfliktusa. Budapest, Kossuth Kiadó, 1971.

Nemes Károly: Luis Buñuel. Budapest, Magyar Filmtudományi Intézet és Filmarchívum, 1979. 
Nemeskürty István: A képpé varázsolt idö: a magyar film története és helye az egyetemes kultúrában, párhuzamos kitekintéssel a világ filmmüvészetére. Budapest, Magvető Kiadó, 1984.

Ormos Mária: Hitler élete és kora, Budapest, Pannonica Kiadó, 2003.

Ormos Mária: Nácizmus - fasizmus. Budapest, Magvető Kiadó. 1987.

Ormos Mária: Van-e történelem? elöadás, Mindentudás Egyeteme, 2003.

Elérhető: http://mindentudas.hu/elodasok-cikkek/item/49-van-e-történelem?.html (2012-1120)

Paris, Mike: „La industria británica de cine y el problema de la descolonización” in: Montero, Julio - Rodríguez, Araceli (szerk.): El cine cambia la historia. Madrid, Ediciones Rialp, 2005.

XI. Pius: Divini Redemptoris kezdetü enciklika

Elérhetö: http://www.vatican.va/holy_father/pius_xi/encyclicals/documents/hf_p-

xi_enc_19031937_divini-redemptoris_en.html (2011-11-21)

Por Tierra, Mar y Aire blog: http://www.portierramaryaire.com/foro/viewtopic.php? $\mathrm{p}=58082$ (2012-11-27)

Ricci, Steven: Cinema and Facism. Italian Film and Society, 1922-1943. University of California, 2008.

Richards, Jeffrey - Aldgate, Anthony: Best of British: Cinema and Society from 1930 to Present. London, I.B. Tauris, 1999.

Rodríguez González, Félix: „Eufemismo y propaganda política” in: Revista Alicantina de Estudios Ingleses 1. 1988.

Romsics Ignác: Clio büvöletében. Budapest, Osiris Kiadó, 2011.

Rosenstone, Robert A. : History on Film / Film on History. London, Pearson Education Ltd, 2006.

Rosenstone, Robert A (szerk.).: Revisioning History. Film and the Construction of a New Past. Princeton, Princeton University Press, 1995.

Rosenstone, Robert A.: Visions of the Past. The Challenge of Film to Our Idea of History. Cambridge, Harvard University Press, 1995.

Rosselli, Alessandro: Amikor a Cinecittà magyarul beszélt. Szegedi Tudományegyetem, 2005.

Salmi, Hannu: „Film as Historical Narrative” in: Film-Historia, Vol. V, No. 1. 1995.

Elérhető: http://www.publicacions.ub.es/bibliotecadigital/cinema/filmhistoria/Art.Salmi.pdf (2012-11-29)

Sand, Shlomo: Le XX siécle á l'écran. Seuil, 2004.

Sárközy Réka: Elbeszélt múltjaink. A magyar történelmi dokumentumfilm útja. Budapest, 1956-os Intézet - L’Harmattan Kiadó, 2011.

Schulte-Sasse, Linda: Entertaining the Third Reich: Illusions of Wholeness in Nazi Cinema. Duke University Press, 1998.

Shafik, Viola: Arab Cinema: History and Cultural Identity. Cairo, American University in Cairo Press, 2007.

Shiel, Mark - Fitzmaurice, Tony: Cinema and the City: Film and Urban Societies in a Global Context. Oxford, Blackwell Publishers, 2009. 
Smith, Paul (szerk.): The Historian and Film. Cambridge University Press, 1976.

Sorlin, Pierre: European Cinemas, European Societies, 1939-1990. London, Routledge, 1991.

Sorlin, Pierre: Sociologie du Cinéma. Párizs, Aubier Montaigne, 1977.

Sorlin, Pierre: The Films in History. Restaging the Past. Oxford, Basil Blackwell, 1980.

Stam, Robert: Film Theory. An Introduction. Oxford, Blackwell Publishers, 2000.

Stark, Werner: The Sociology of Knowledge. London, Routledge, 2001.

Storey, John: Cultural Theory and Popular Culture. An Introduction. London, Longman, 2009.

Strauss, Frédéric (szerk.): Pedro Almodóvar. Budapest, Osiris Kiadó, 2005.

Szabó Z. Pál: Lázadás a halál ellen. Salvador Dalí, Luis Buñuel: Andalúziai kutya. Budapest, Áron Kiadó, 2003.

Szélpál Lívia: „Sommersby, avagy Martin Guerre visszatérése a történelem és film kapcsolatának tükrében" in: Aetas, 2010/3.

Taylor, Richard: The Politics of the Soviet Cinema, 1917-1929. Cambridge University Press, 1982.

Taylor, Richard - Christie, Ian (szerk.): The Film Factory: Russian and Soviet Cinema in Documents 1896-1939. New York, Routledge, 2002.

Tegel, Susan: Nazis and the Cinema. Hambledon Continuum, 2008.

Thomson, Oliver: Mass Persuasion in History: a Historical Analysis of the Development of Propaganda Techniques. Edinburgh, Paul Harris Publishing, 1977.

Thompson, Kristin - Bordwell, David: A film története. Budapest, Palatinus, 2007.

Varga Anna: Az 1910-es évek orosz némafilm-kultúrája. Budapest, L’Harmattan, 2011.

Varga Balázs: „Türéshatár. Filmművészet és cenzúrapolitika a hatvanas években” in: Kisantal Tamás - Menyhért Anna (szerk.): Müvészet és hatalom - A Kádár-korszak müvészete. Budapest, József Attila Kör - L’Harmattan, 2005. 116-138

Zaller, John: The Nature and Origins of Mass Opinion. Cambridge, Cambridge University Press, 1992.

Zalán Vince: „Kisvárosi víkendek. Ivan Passer másfél cseh filmje - 1. rész” in: Filmvilág, 2010/10. 32-35.

Zanger, Anat: Film Remakes as Rituals and Disguise: From Carmen to Ripley. Amsterdam University Press, 2006. 


\section{A szerző témához kapcsolódó publikációi}

„A spanyol nemzetfelfogás és önazonosság változatai a filmvásznon” in: Mediterrán Világ, 2013. (megjelenés alatt)

„En busca del concepto del cine nacional español” in: Acta Hispanica, Tomus XVII. 2012. (megjelenés alatt)

„Spanyol Hollywood. Samuel Bronston tündöklése és bukása” in: Filmvilág, 2012/05. 33-35.

„Hollywood és a spanyol fasizmus” in: Vajda Zoltán - Tóth Zsófia Anna (szerk): Amerikanisztika és vizualitás. Metszéspontok az információs társadalom horizontján. Szeged, Americana eBooks, 2012.

Elérhetö: http://ebooks.americanaejournal.hu/books/amerikanisztika-es-vizualitas/

„Teoría y práctica del cine "nacional” en la Guerra Civil Española” in: Acta Hispanica, Tomus XVI. 2011. 123-132.

„A rezsim (ön)kritikája: rendszerellenes spanyol filmek a Franco-korszakban” in: Mediterrán Világ, 17. sz., 2011. 73-84.

„Propaganda és cenzúra: spanyol filmpolitika a Franco-korszakban” in: Tóth Zsófia Anna (szerk.): A varázsgyürütöl az interkonfesszionális kommunikációig. Információtudományi metszéspontok bölcsészeti megközelitésben. Szeged, Primaware, 2011. 137-143.

Elérhető: http://otodikalprogram.huminf.uszeged.hu/sites/default/files/Konyvek/TZsA_ebookInftud\%20a\%20bolcseszetben_szerk.pdf

„A hóhér. Filmművészeti rendszerkritika a spanyol Franco-korszakban” in: Ezredvég, 2011/5. 116-123.

„La concepción histórica de Franco y su reflejo en el cine oficial del régimen” in: Mediterrán tanulmányok XX. Szeged, 2011.71-81.

„Spanyol-magyar katolicizmus a filmvásznon” in: Egyházfórum, 2010/6, 25-26.

„A film mint történeti forrás” in: Aetas, 2010/3. 159-171.

„Mussolini ellensége, Franco kegyeltje. Vajda László” in: Ferwagner Péter Ákos - Kalmár Zoltán (szerk.): Az átmenet egyensúlya. Budapest, Áron Kiadó, 2010. 92-99.

„A diktátor és a film. Bevezetés a XX. század történelmét meghatározó diktátorok filmpolitikájába" in: Bölcsészmühely 2008, Szeged, 2009. 91-100.

„Un hombre de la apertura franquista. García Escudero” in: Acta Scientiarum Socialium XXX. Kaposvár, 2009. 37-48.

„László Vajda, l' ungherese internazionale” in: Quaderni Vergeriani V, Trieszt, 2009. 207217.

„A film, mint a legfontosabb mủvészet Franco tábornok számára” in: Ezredvég, 2009/11. 7182.

„Politika és útkeresés a 70-es évek spanyol filmmüvészetében” in: Mediterrán Világ, 12. sz., 2009. 91-104.

„Bases y conceptos de la política cinematográfica de Franco” in: Acta Scientiarum Socialium XXVII. Kaposvár, 2008. 37-48. 


\section{Függelék 1 - A Faj kritikája}

Részlet a Faj (Raza, José Luis Sáenz de Heredia, 1942) egyik kritikájából.

Todavía queda en el camino que va de la retina al corazón, el reflejo de la emoción vivida frente a la gran película española $<<R a z a \gg$. Yo bien sé que la misión de la crítica es juzgar las cosas con sujeción a los princípios científicos 0 a las reglas del arte. Pero $<<$ Raza $\gg$, que es arte, ciencia e Historia, encarna virtudes esencialmente españolas que culminan en el amor, en el sacrificio, en hechos heroicos que nos ofrecen una visión exacta del genio español. Por eso, en $<<$ Raza $>$ tenemos que relegar a segundo término los valores técnicos para detener nuestra devoción frente a los símbolos.

La idea inicial de $<<$ Raza $>$, debida a $<<$ Jaime de Andrade $>$, parte de una inteligencia con clara visión de nuestra Historia y de nuestro temperamento que no es racial en lo biológico, sino en aquellas acciones capaces de definir un modo de ser y pensar o de responder a la voz suprema de la Patria. Perfilada por los asesores histórico-literarios, la idea va tomando forma expresiva, hasta ser traducida en imágenes por José Luis Sáenz de Heredia.

Trafalgar, Cuba y nuestra gloriosa Cruzada forman los tres puntos esenciales sobre los que están latentes las virtudes de una raza que ha convertido en páginas de gloria sus más deseperadas situaciones, hizo victorias de sus derrotas y forjó grandezas de su dolor. Todos los matices del genio español están representados a través de las dos generaciones descendientes del héroe de Trafalgar y que forman la imaginaria familia de Churruca. La raza con sus sacrificios, con sus devociones, con sus preferencias, con el vibrar de las fibras del patriotismo dispuesta siempre a vencer por imperativo de su genuino valor moral.

Grandiosa concepción de la gallardía española. Visión exacta de un pueblo que arranca fuerzas de sus flaquezas, porque en su alma conserva encendida la llama inextinguible de la raza.

Técnicamente, <<Raza > es la película española mejor lograda. Su realizador José Luis Sáenz de Heredia, inteligente observador de las sensibilidades y de las formas, ha reunido destacadas figuras de nuestra escena para acoplar un conjunto que diera la medida exacta de lo estético.

Este acierto inicial se mantiene en actitud progresiva a lo largo del film, en el que la cámara, la fotografía, la decoración y la música juegan a la armonía hábilmente dirigidos.

El ambiente de las distintas épocas, la caracterización de los personajes y el medio en que se desenvuelven, demuestran la realidad de ese gran director que es José Luis Sáenz de Heredia, quien anota en su haber uno de sus mejores triunfos.

Son las estampas de nuestra guerra de liberación, el fusilamiento de los Hermanos de San Juan de Dios, fotogramas reveladores de un espíritu analítico profundo, de un sentido netamente cristiano, puesto de relieve en aquel perdón que el Prior otorga a sus verdugos, mientras el Sol cubre de reflejos de amanecer los pasos de los que sacrifican su vida en aras de la Fe.

Desde el primer fotograma hasta el último, $<$ Raza $>$ supone una lección de cine puro explicada por sus artífices, al frente de los cuales figura como Jefe de Producción D. Luis Días Amado.

Nuestros fervorosos elogios alcanzan desde su director hasta el más modesto colaborador, pasando por ese maravilloso conjunto de intérpretes que se superan en su propia labor para ofrecernos la más perfecta encarnación de los personajes ...

Radiocinema, No. 72, 1942. január 30. 


\section{Függelék 2 - Plakátok}

A disszertáció során tárgyalt fontosabb filmek korabeli plakátjai*

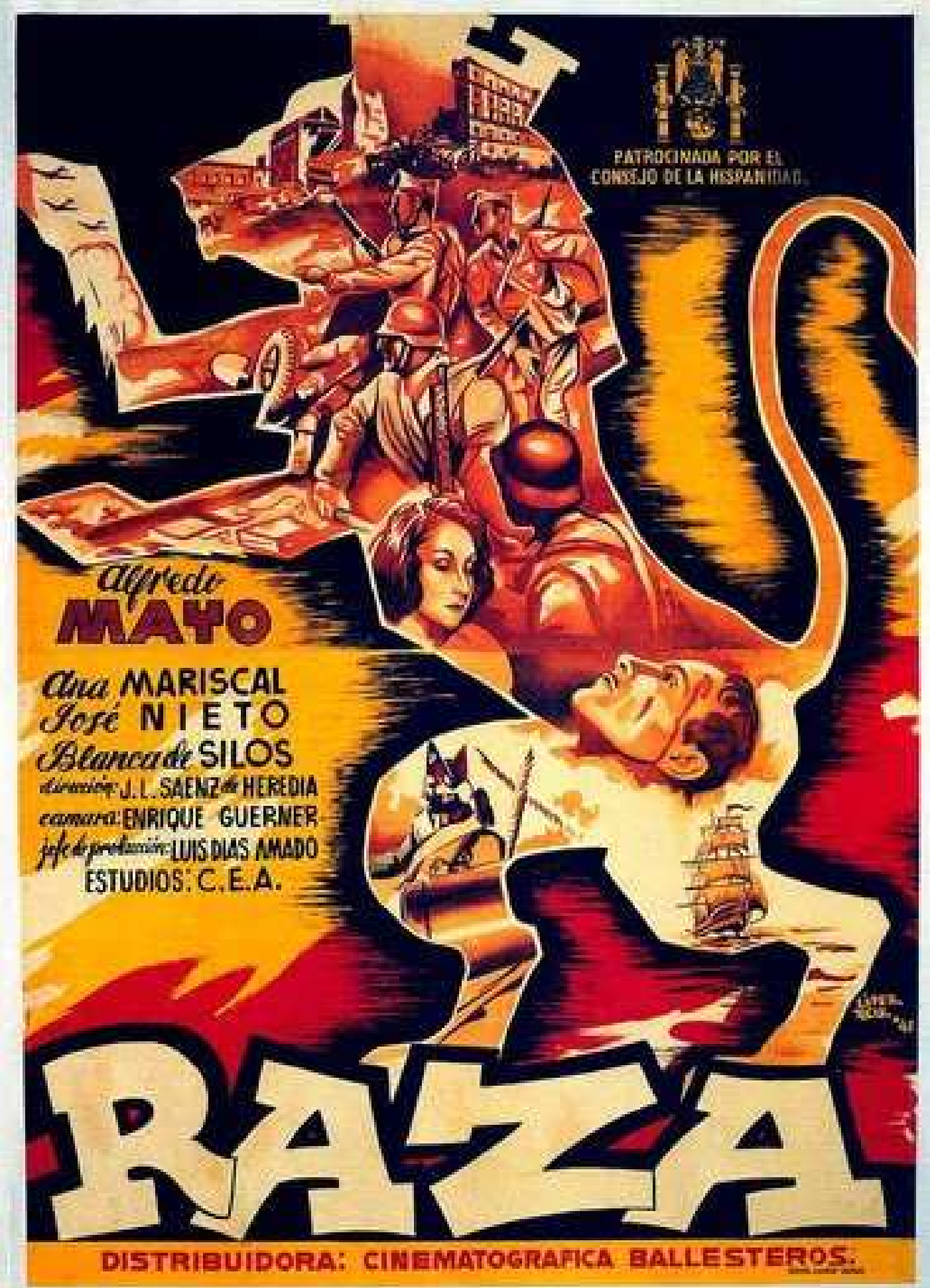

\footnotetext{
* A plakátok forrásai internetes oldalak, elsősorban a http://www.cartelespeliculas.com/wp/
}

$(2012-12-28)$ honlap. Minden esetben igyekeztem a legjobb minőségü, de korhü képet kiválasztani. 

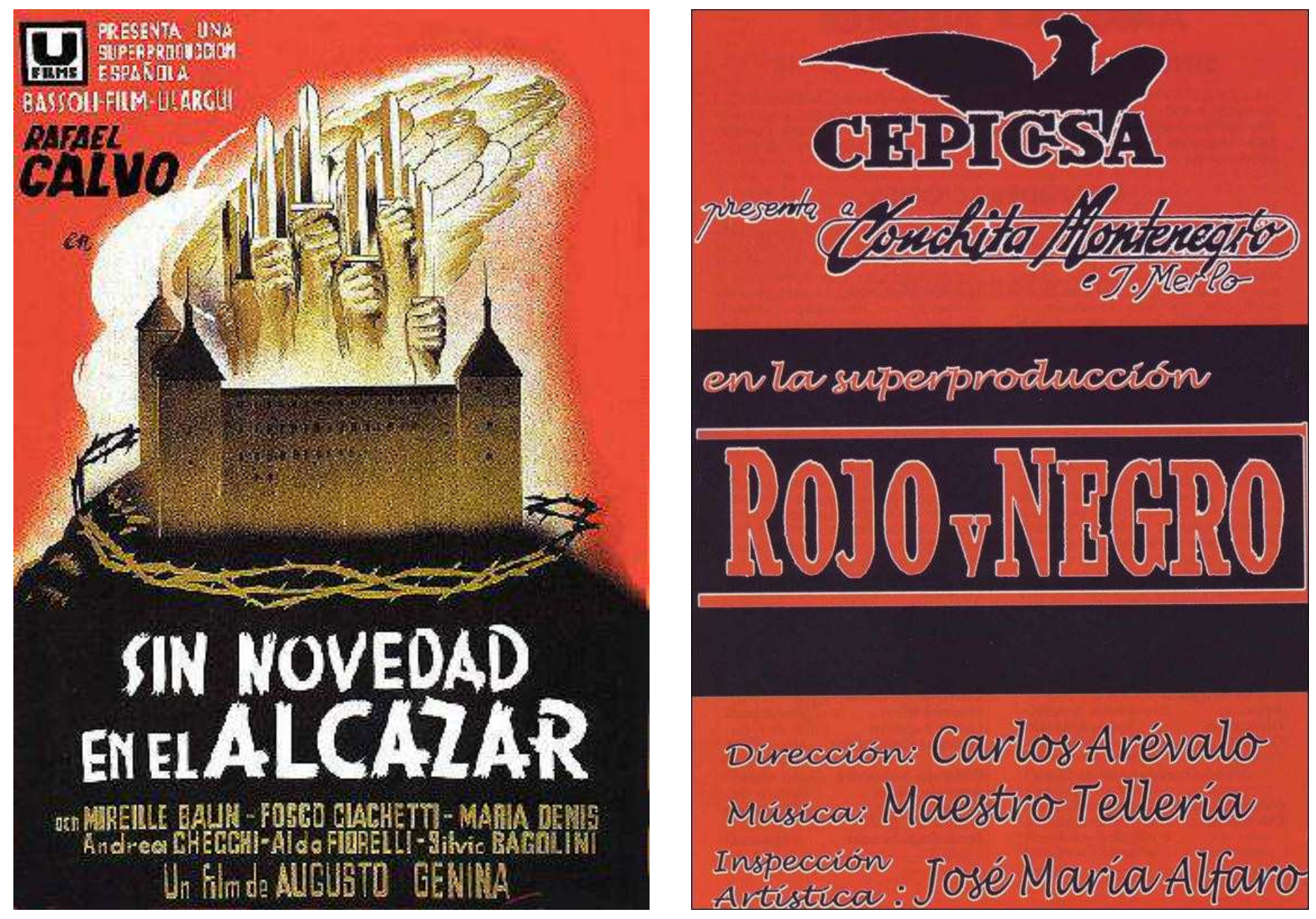

en ta supperporotuccion
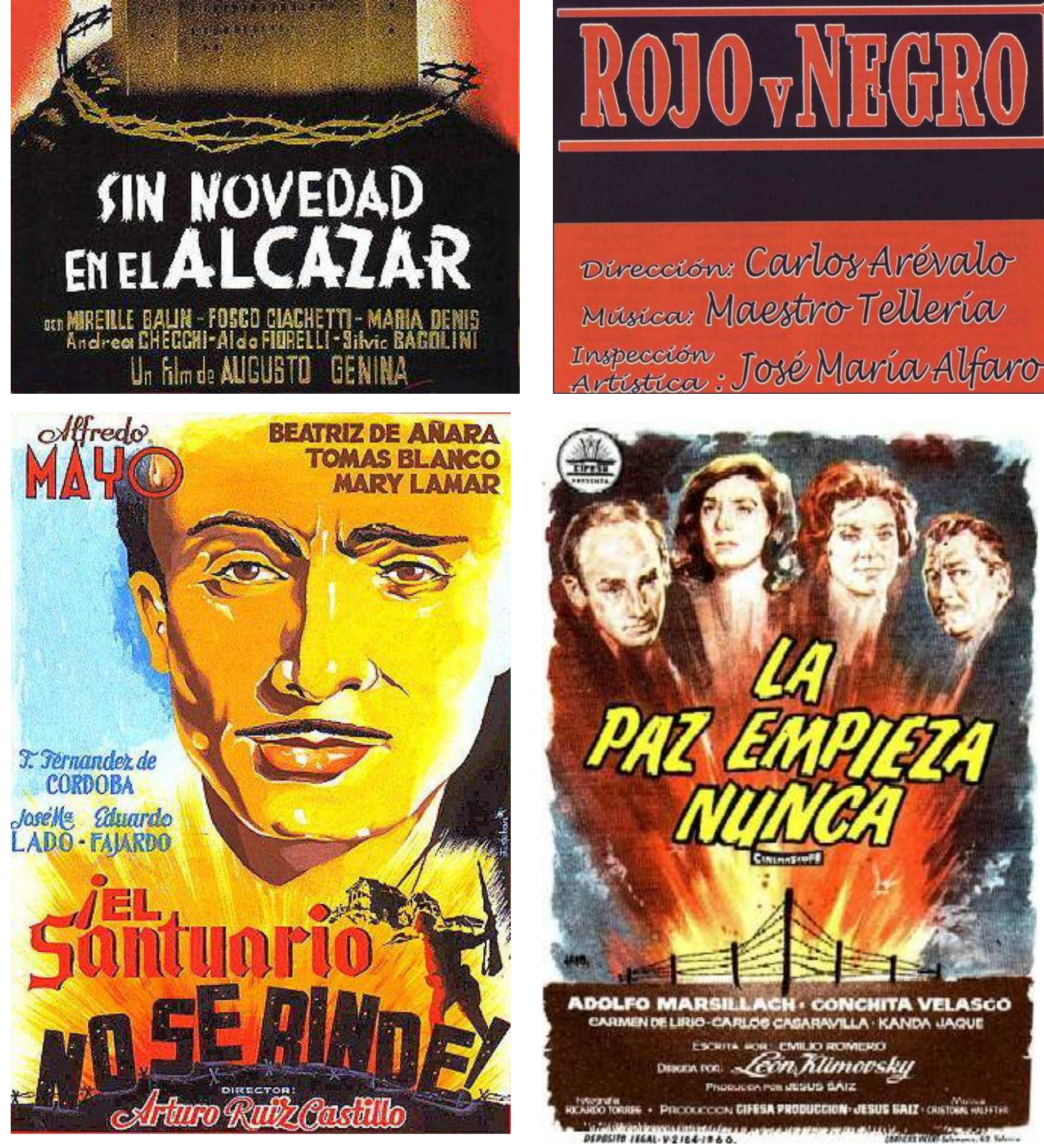

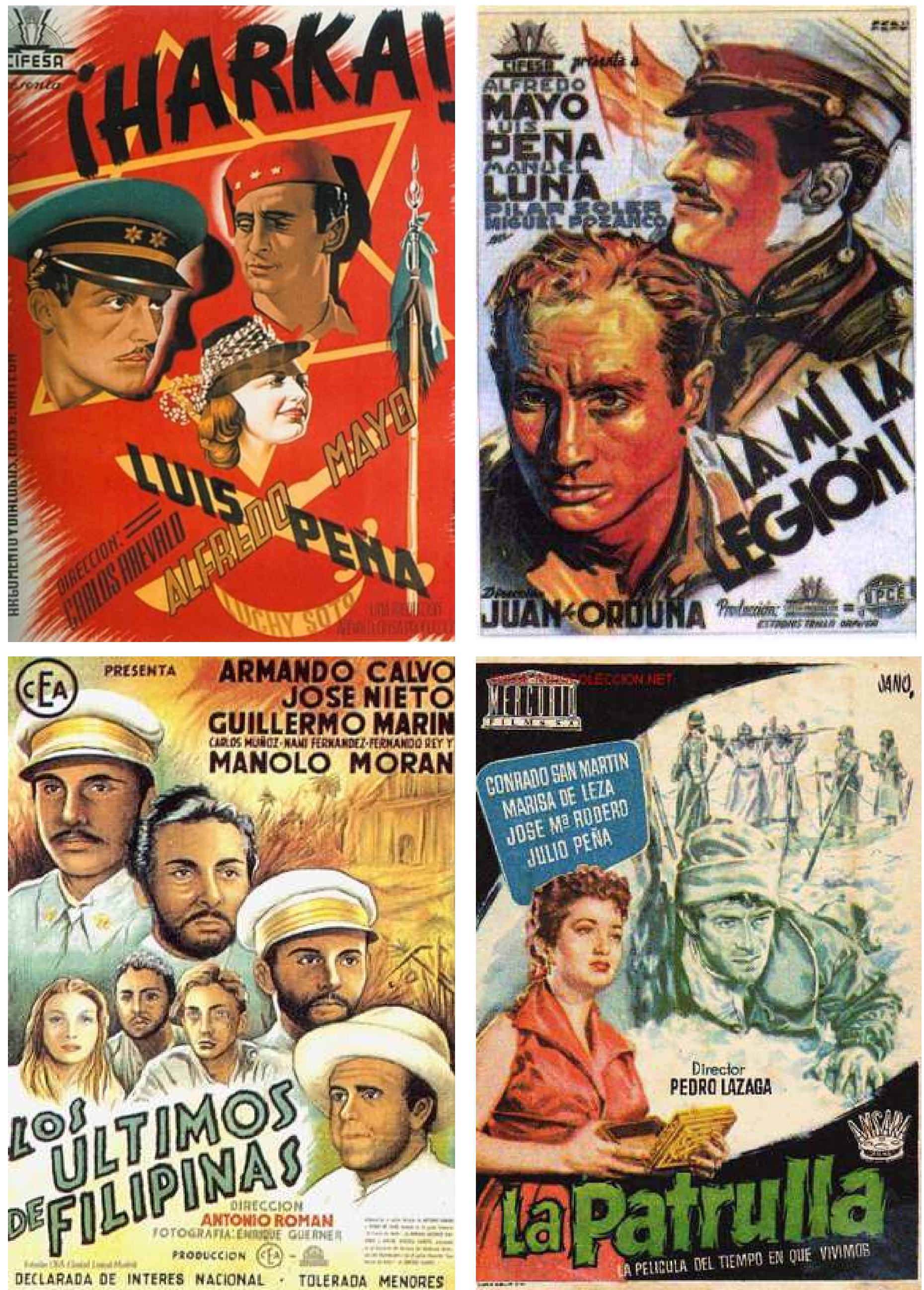

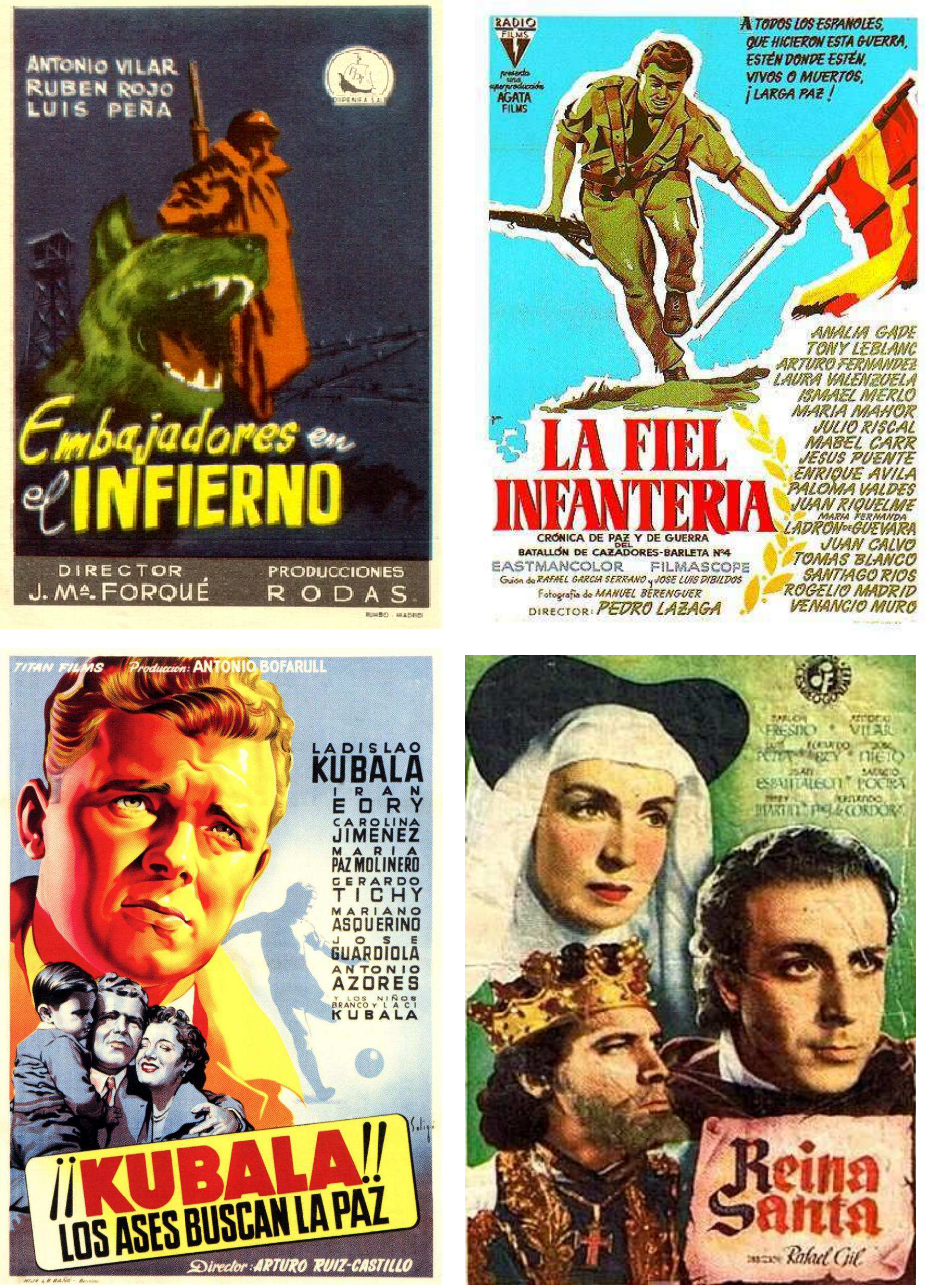

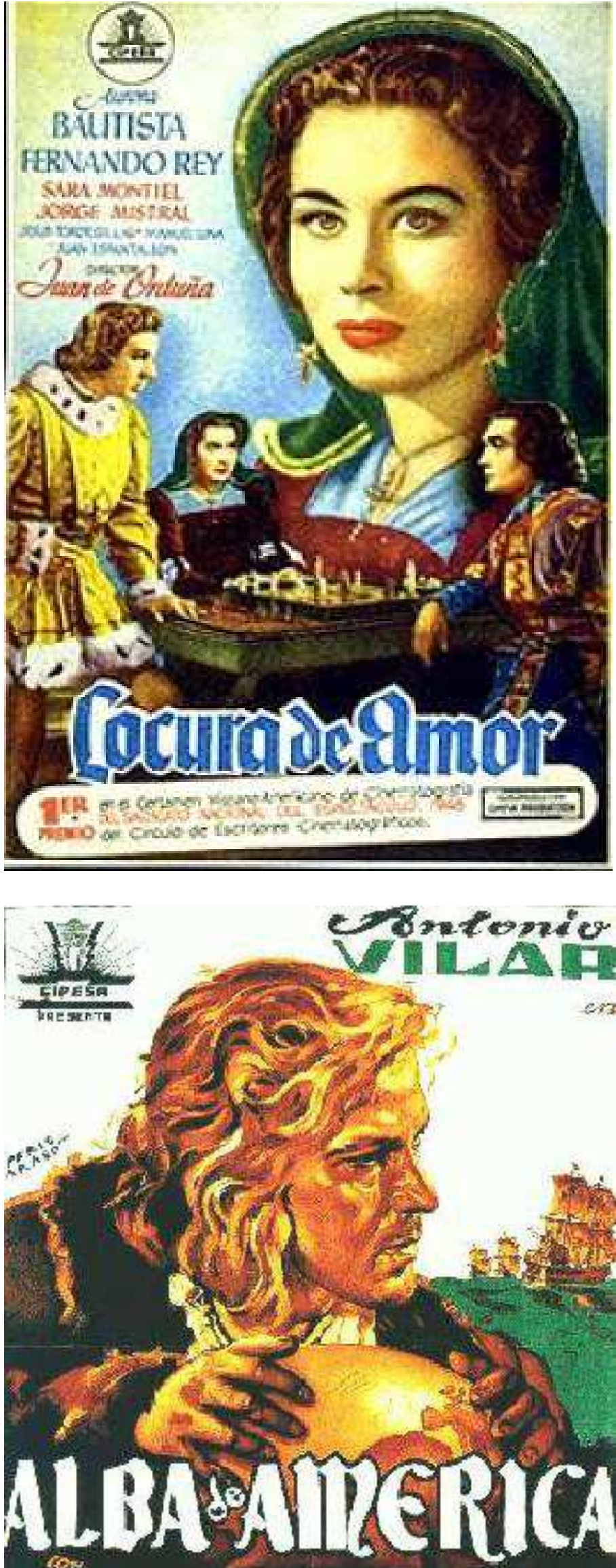

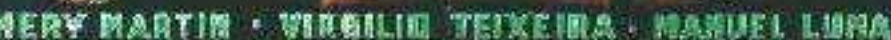

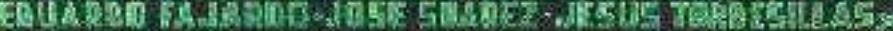

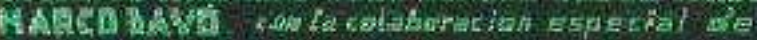

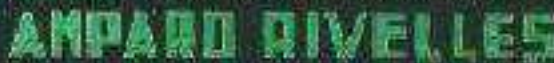

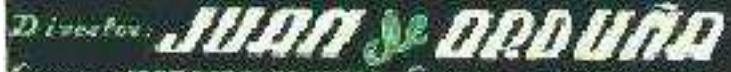

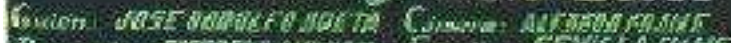

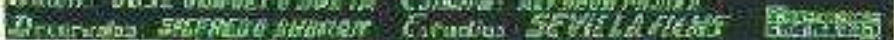
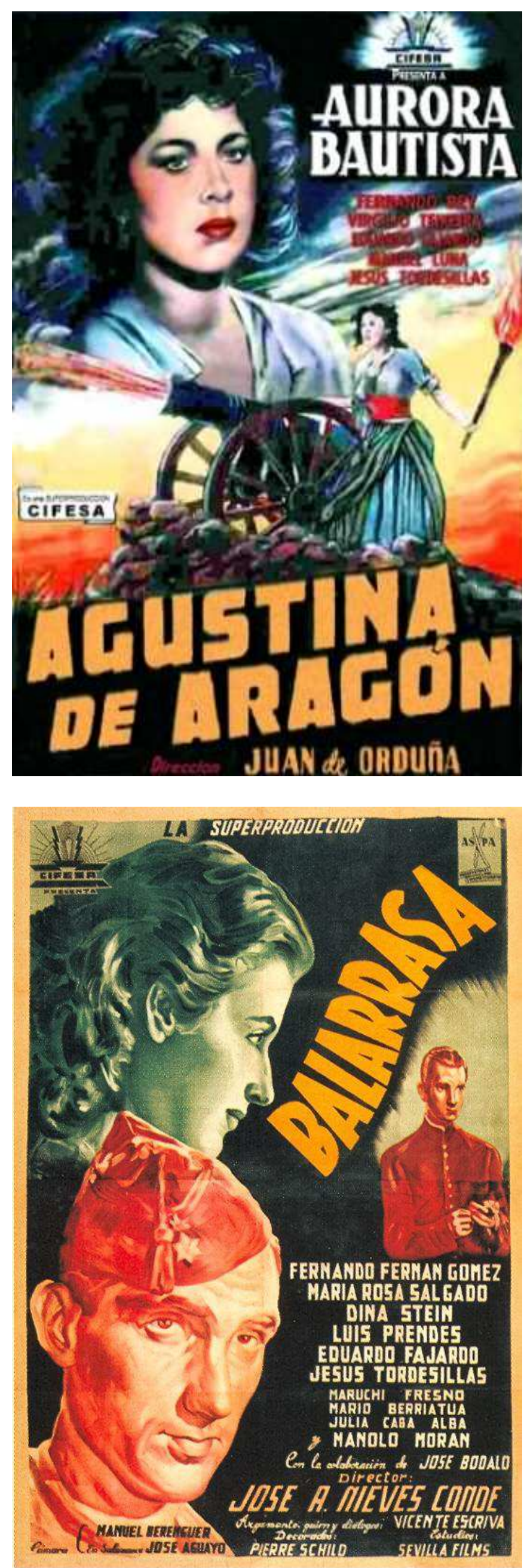

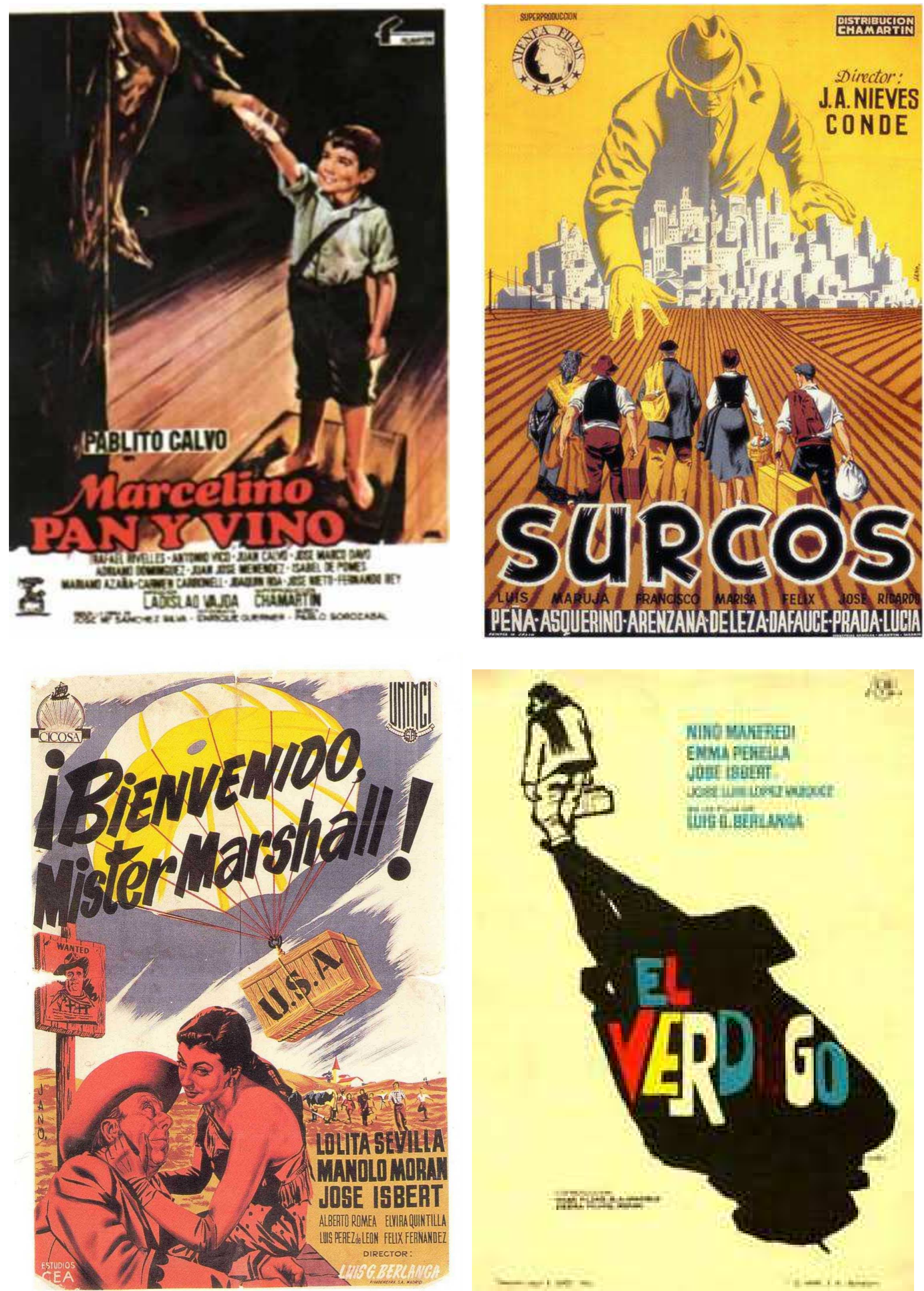